ES/ESH/69

\title{
Oak Ridge Reservation Annual Site Environmental Report for 1995
}

\author{
Project director \\ L. V. Hamilton \\ Project coordinator \\ D. C. West \\ Technical coordinators \\ L. W. McMahon \\ Oak Ridge Y-12 Plant \\ L. V. Hamilton \\ Oak Ridge National Laboratory \\ L. G. Shipe \\ Oak Ridge K-25 Site \\ Environmental compliance \\ J. G. Rogers \\ Coordinating editor \\ W. S. Koncinski
}

Date Published: September 1996

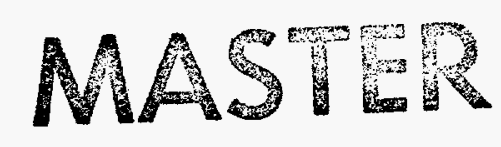

Prepared by

Oak Ridge National Laboratory

P.O. Box 2008, Oak Ridge, TN 37831-6285

Managed by Lockheed Martin Energy Research Corp.

for the U.S. Department of Energy under Contract No. DE-AC05-96OR22464

and by

the Oak Ridge Y-12 Plant and the Oak Ridge K-25 Site

P.O. Box 2008, Oak Ridge, TN 37831-6285

Managed by Lockheed Martin Energy Systems, Inc.

for the U.S. Department of Energy under Contract No. DE-AC05-84OR21400 


\section{DISCLAIMER}

Portions of this document may be illegible in electronic image products. Images are produced from the best available original document. 


\section{Contents}

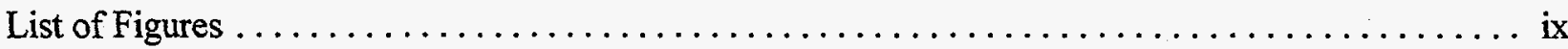

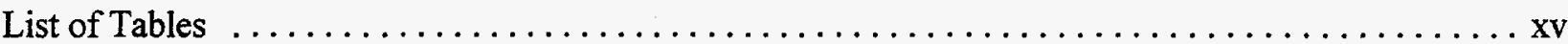

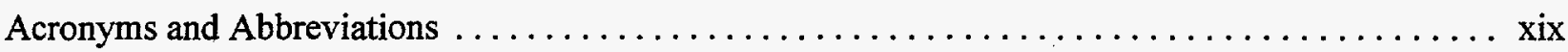

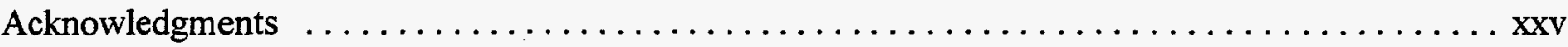

1. SITE AND OPERATIONS OVERVIEW $\ldots \ldots \ldots \ldots \ldots \ldots \ldots \ldots \ldots \ldots \ldots \ldots \ldots \ldots \ldots \ldots \ldots \ldots$

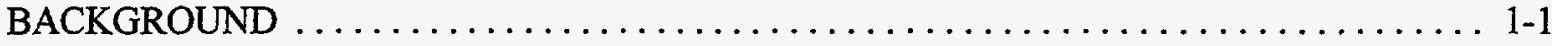

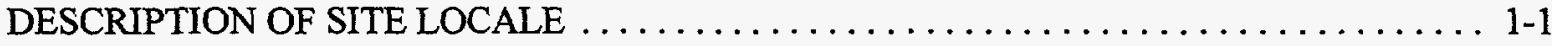

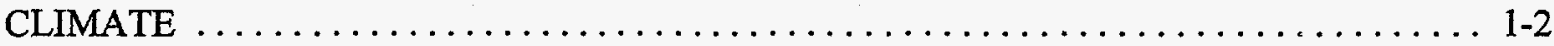

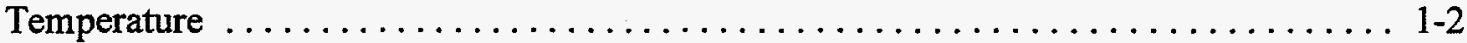

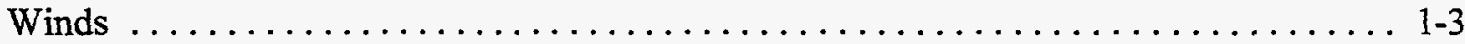

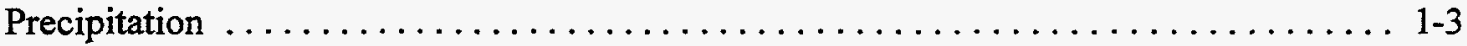

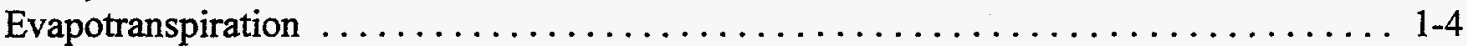

DESCRIPTION OF SITE, FACILITIES, AND OPERATIONS $\ldots \ldots \ldots \ldots \ldots \ldots \ldots \ldots \ldots 1-4$

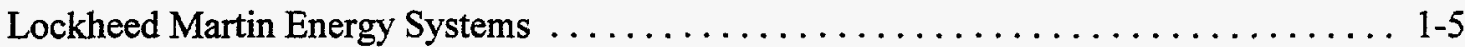

Oak Ridge $\mathrm{Y}-12$ Plant . . . . . . . . . . . . . . . . . . . . . . .

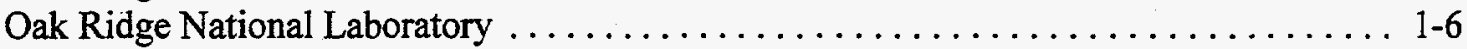

Oak Ridge K-25 Site . ........................... 1-7

Oak Ridge Institute for Science and Education $\ldots \ldots \ldots \ldots \ldots \ldots \ldots \ldots \ldots \ldots \ldots$

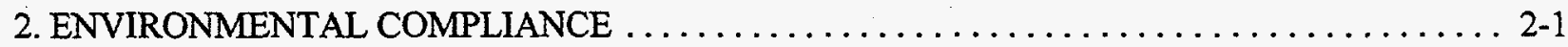

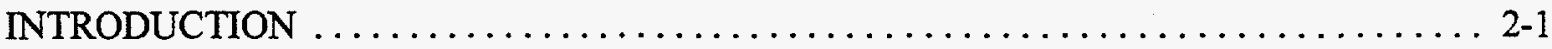

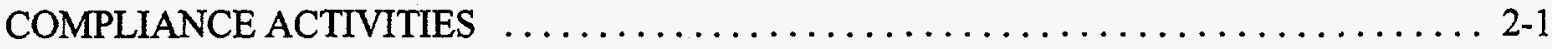

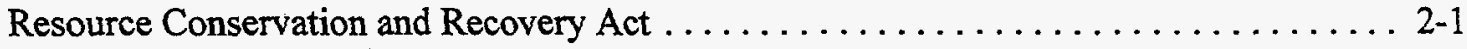

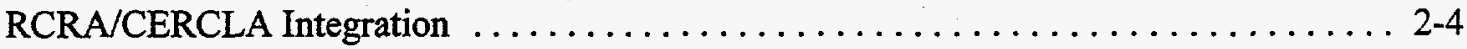

Comprehensive Environmental Response, Compensation, and Liability Act . . . . . 2-5

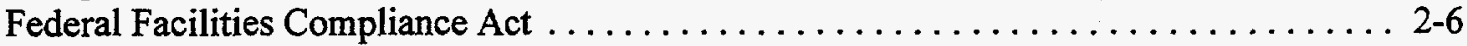

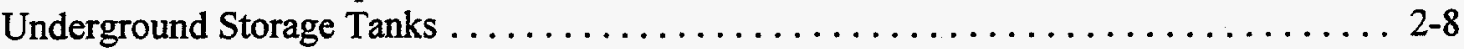

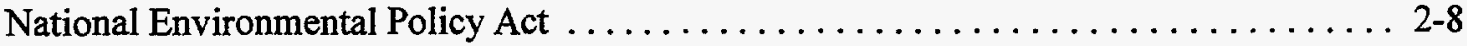

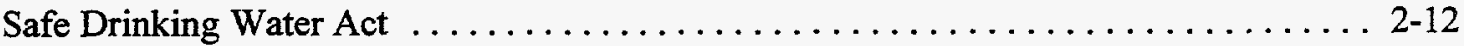

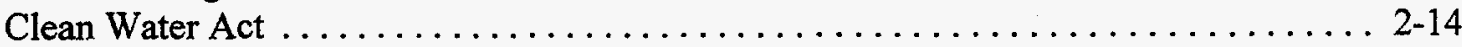

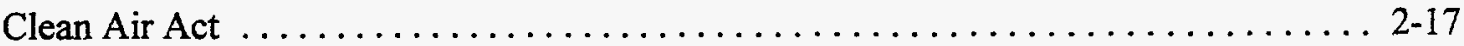

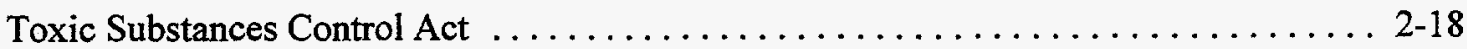

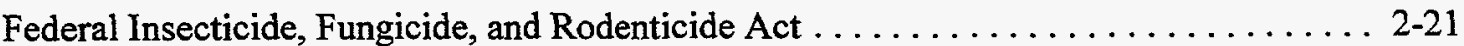

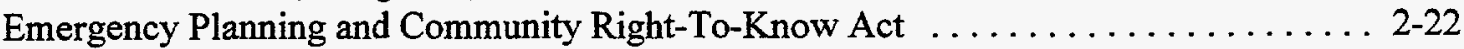

Environmental Occurrences ................................. 2-22

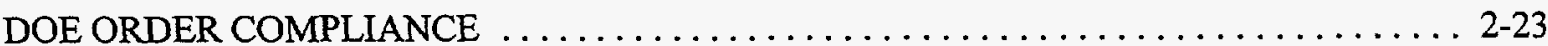

DOE Order 5400.1, General Environmental Protection Program ............ 2-24

DOE Order 5400.5, Radiation Protection of the Public and the Environment . . . . 2-26

DOE Order $5820.2 \mathrm{~A}$, Radioactive Waste Management $\ldots \ldots \ldots \ldots \ldots \ldots \ldots \ldots \ldots \ldots$ 
APPRAISALS AND SURVEILLANCES OF ENVIRONMENTAL PROGRAMS $\ldots \ldots \ldots 2-26$

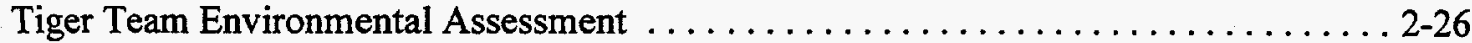

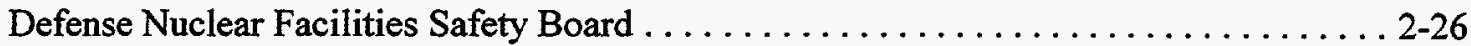

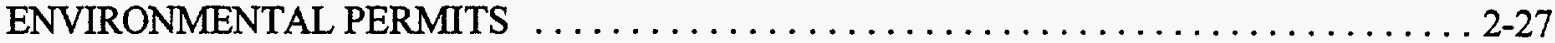

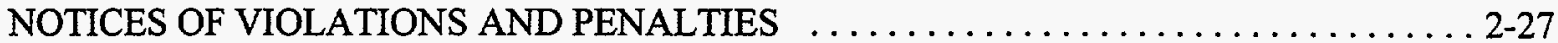

CURRENT ISSUES . . . . . . . . . . . . . . . . . . . . . . . . . . . . . 2-29

Actions Filed by Friends of the Earth, Inc. . . . . . . . . . . . . . . . 2-29

Hazardous/Toxic Waste Off-Site Shipment Moratorium ............... 2-30

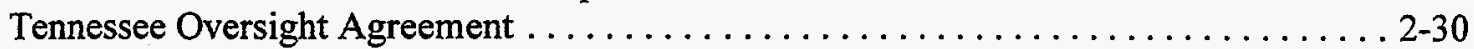

3. ENVIRONMENTAL MANAGEMENT PROGRAM $\ldots \ldots \ldots \ldots \ldots \ldots \ldots \ldots \ldots \ldots \ldots \ldots \ldots \ldots$

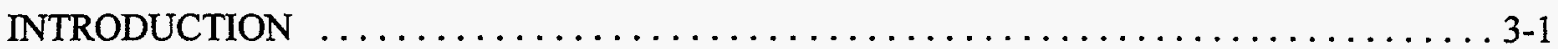

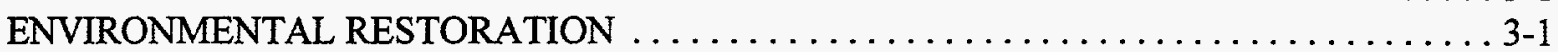

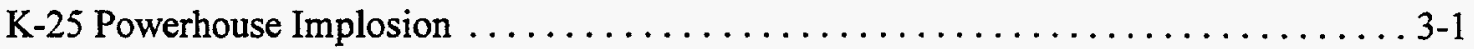

A Decision Is Reached for Lower Watts Bar Reservoir . . . . . . . . . . . . . 3-1

DOE Submits Record of Decision for Remediation of Lower East Fork

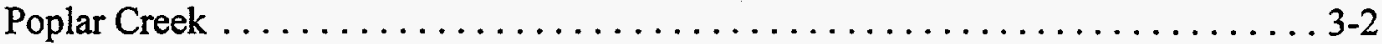

DECONTAMINATION AND DECOMMISSIONING $\ldots \ldots \ldots \ldots \ldots \ldots \ldots \ldots \ldots \ldots \ldots \ldots \ldots$

Variable Dose Rate Irradiation Facility Dismantled $\ldots \ldots \ldots \ldots \ldots \ldots \ldots \ldots \ldots \ldots \ldots$

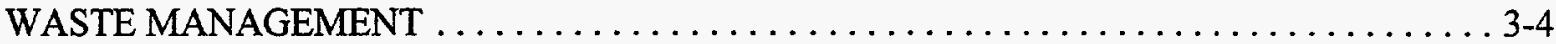

TDEC Issues an Order for Mixed-Waste Treatment and Storage $\ldots \ldots \ldots \ldots \ldots \ldots \ldots .4$

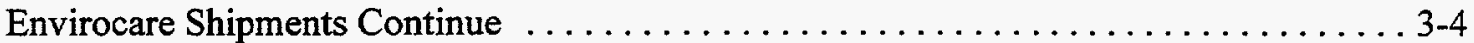

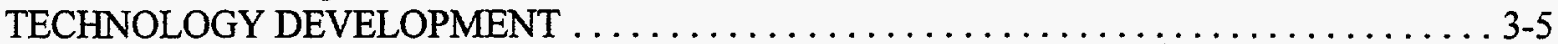

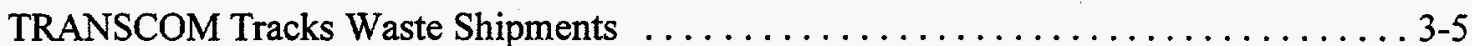

Interim Waste Management Facility Refines Tumulus Disposal Technique . . . . . . . 3-5

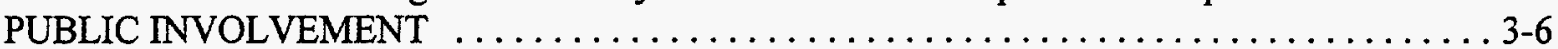

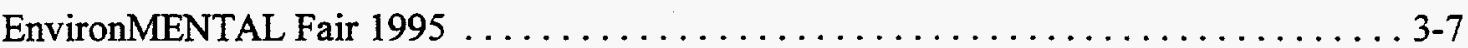

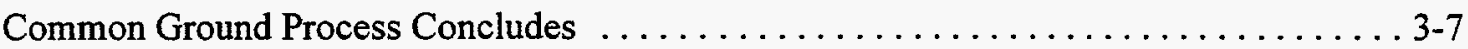

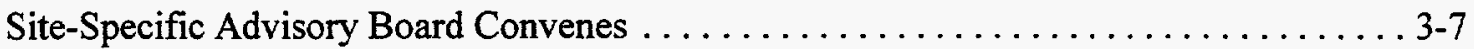

Some Web Sites and a New Toll-Free Number $\ldots \ldots \ldots \ldots \ldots \ldots \ldots \ldots \ldots \ldots \ldots$

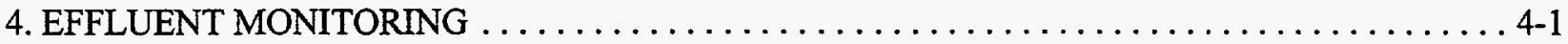

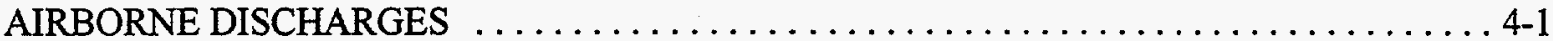

Y-12 Plant Radiological Airborne Effluent Monitoring $\ldots \ldots \ldots \ldots \ldots \ldots \ldots \ldots$ 4-2

ORNL Radiological Airborne Effluent Monitoring $\ldots \ldots \ldots \ldots \ldots \ldots \ldots \ldots \ldots \ldots$. 2

K-25 Site Radiological Airborne Effluent Monitoring $\ldots \ldots \ldots \ldots \ldots \ldots \ldots \ldots \ldots$

Y-12 Plant Nonradiological Airborne Emissions Monitoring $\ldots \ldots \ldots \ldots \ldots \ldots \ldots .7$

ORNL Nonradiological Airborne Emissions Monitoring $\ldots \ldots \ldots \ldots \ldots \ldots \ldots \ldots$ 4-10

K-25 Site Nonradiological Airborne Emissions Monitoring $\ldots \ldots \ldots \ldots \ldots \ldots \ldots$ 4-12

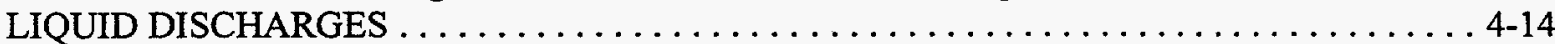

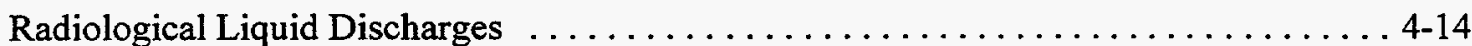

Nonradiological Liquid Discharges . . . . . . . . . . . . . . . . . . . . . 4-22

TOXICITY CONTROL AND MONITORING PROGRAM . . . . . . . . . . . . . . 4-48

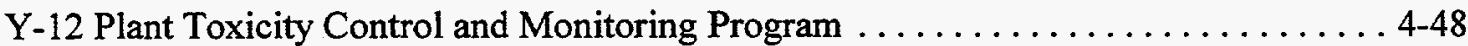

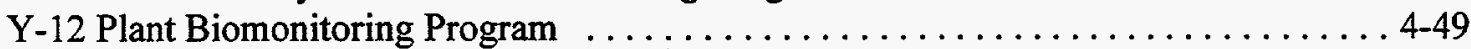

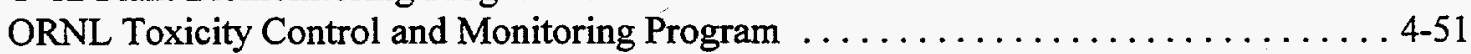

K-25 Site Toxicity Control and Monitoring Program ................ $4-55$

BIOLOGICAL MONITORING AND ABATEMENT PROGRAM $\ldots \ldots \ldots \ldots \ldots \ldots \ldots .4-56$

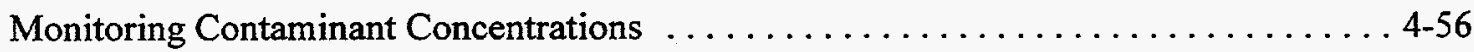

Toxicity of Lithium Discharges to Oak Ridge Stream Is Mitigated by Sodium . . . . 4-60 
Reduction of Aqueous Mercury Inputs to East Fork Poplar Creek Is Slow To Produce a Corresponding Decrease in Mercury Bioaccumulation in Fish . . . . . . . . . 4-60

Sources of Contamination to Stream Biota Are Identified and Evaluated ......... 4-61

Fish Communities in Mitchell Branch Are Recovering Following Remedial Actions .. . 4-61

Cessation of Fly Ash Discharges to McCoy Branch Leads to Recovery of the Benthic Macroinvertebrate Community ..................... 4-62

5. ENVIRONMENTAL SURVEILLANCE $\ldots \ldots \ldots \ldots \ldots \ldots \ldots \ldots \ldots \ldots \ldots \ldots \ldots \ldots$

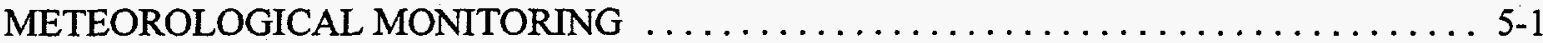

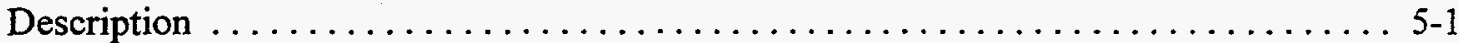

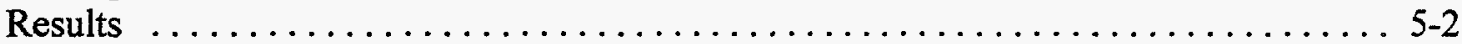

EXTERNAL GAMMA RADIATION MONITORING $\ldots \ldots \ldots \ldots \ldots \ldots \ldots \ldots \ldots \ldots . \ldots \ldots$

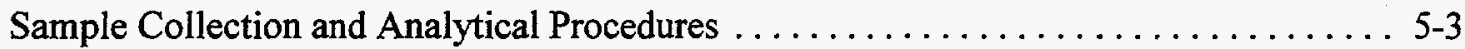

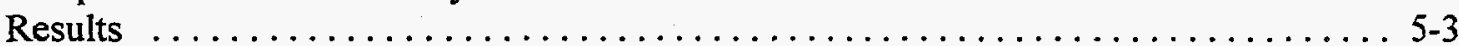

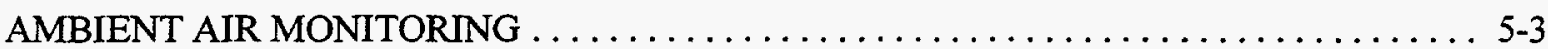

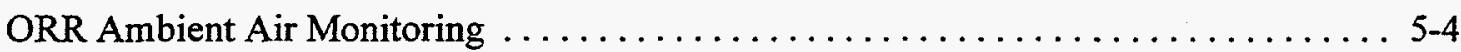

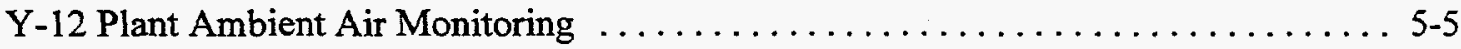

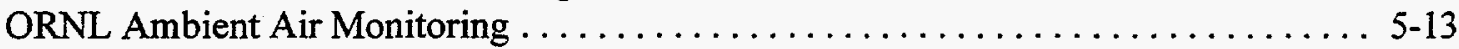

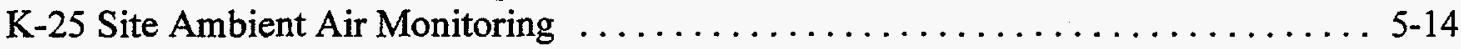

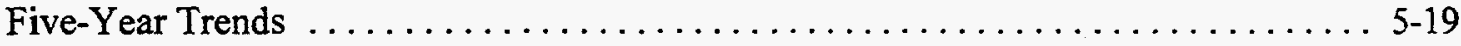

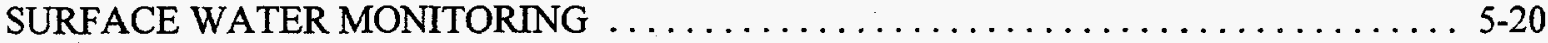

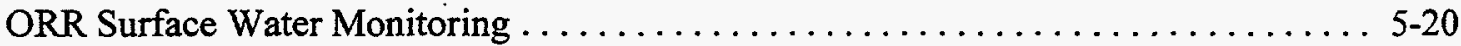

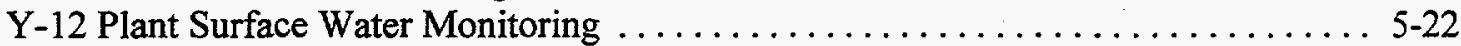

ORNL Reference Surface Water Monitoring .................... 5-24

ORNL Radiological Liquid Effluent Monitoring Program under the EMP $\ldots \ldots \ldots \ldots$ 5-25

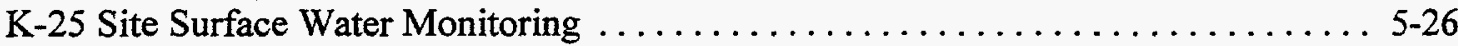

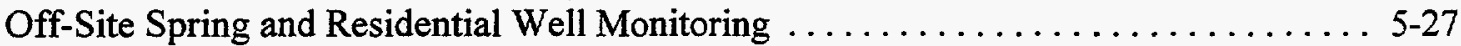

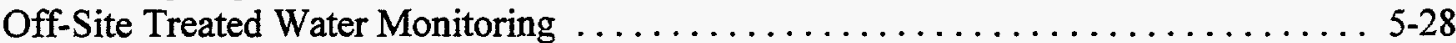

SOIL ........................................... 5-29

SEDIMENT ........................................ $5-29$

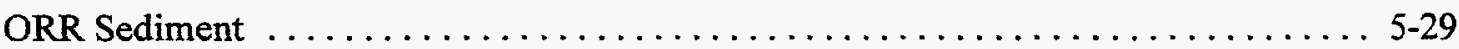

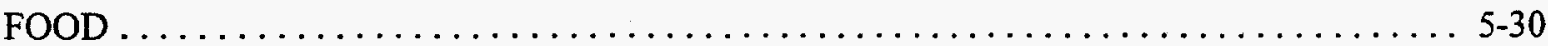

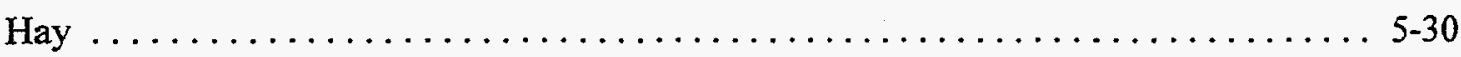

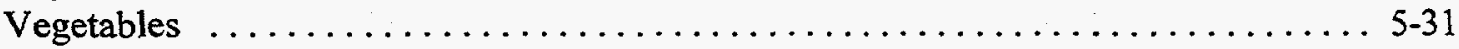

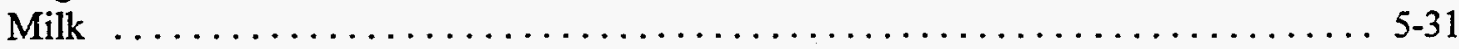

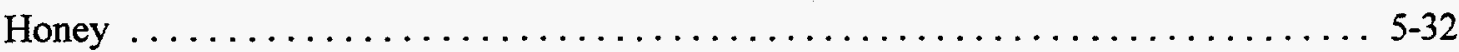

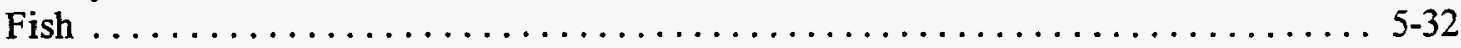

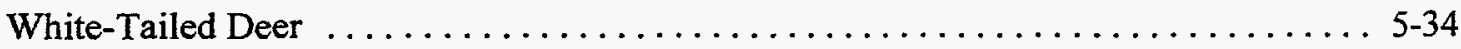

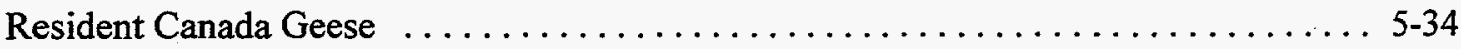

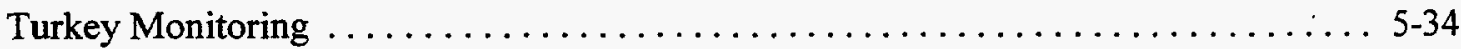

6. DOSE . . . . . . . . .

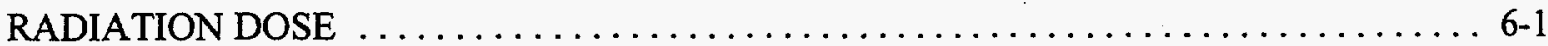

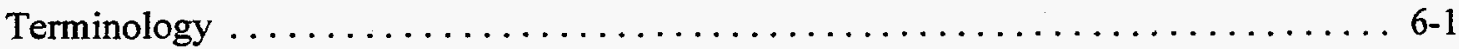

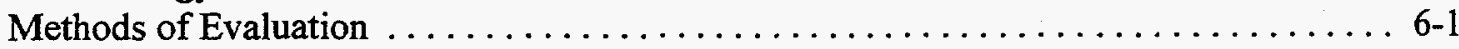

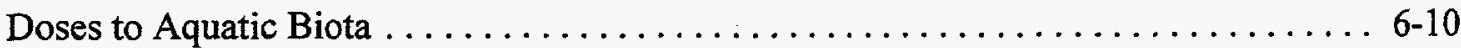

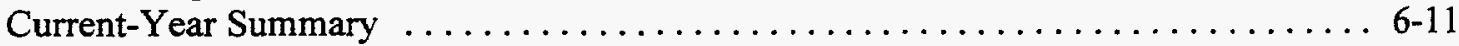

Five-Year Trends . . . . . . . . . . .

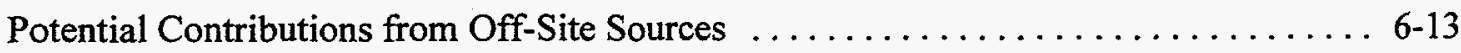

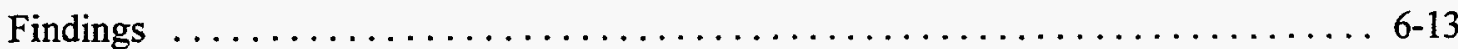

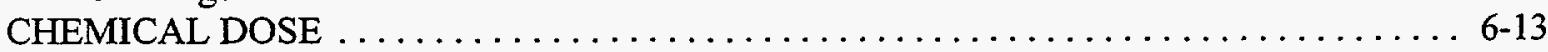




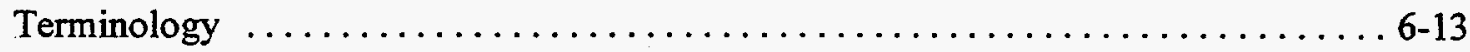

Methods of Evaluation $\ldots \ldots \ldots \ldots \ldots \ldots \ldots \ldots \ldots \ldots \ldots \ldots \ldots \ldots \ldots \ldots \ldots \ldots \ldots \ldots, 14$

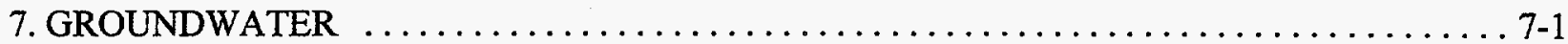

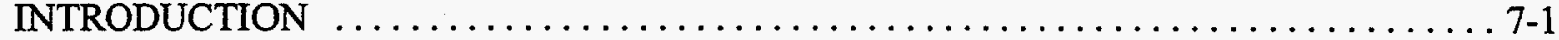

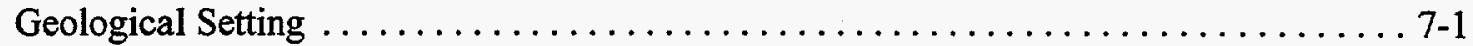

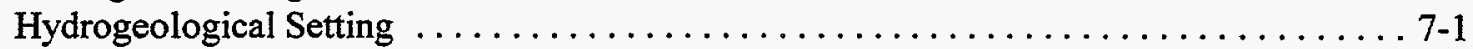

Groundwater Flow ............................... $7-5$

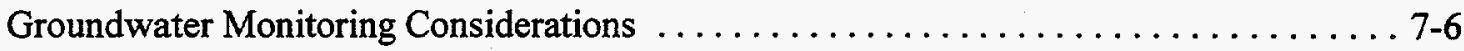

Off-Site Spring and Residential Well Monitoring $\ldots \ldots \ldots \ldots \ldots \ldots \ldots \ldots \ldots \ldots \ldots$

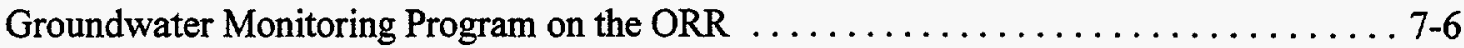

GROUNDWATER MONITORING AT THE Y-12 PLANT $\ldots \ldots \ldots \ldots \ldots \ldots \ldots \ldots .7-6$

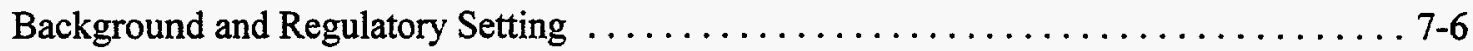

Hydrogeologic Setting and Summary of Groundwater Quality ............ 7-9

1995 Well Installation and Plugging and Abandonment Activities . . . . . . . . 7-10

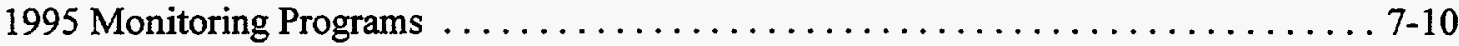

Y-12 Plant Groundwater Quality . . . . . . . . . . . . . .

GROUNDWATER MONITORING AT THE OAK RIDGE

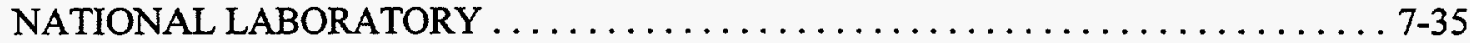

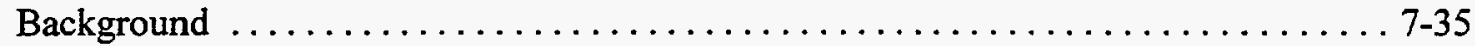

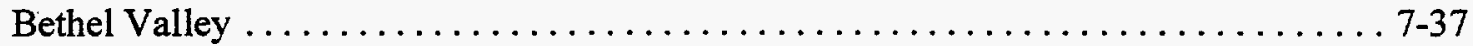

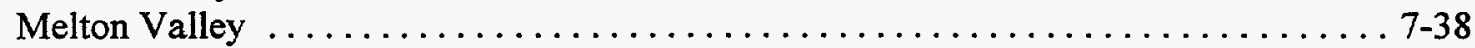

1995 Groundwater Quality Well Installation, Development,

and Sampling Activities ......................... $7-41$

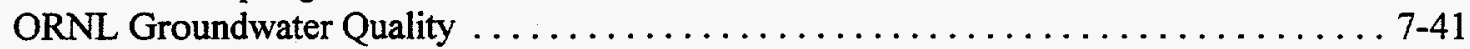

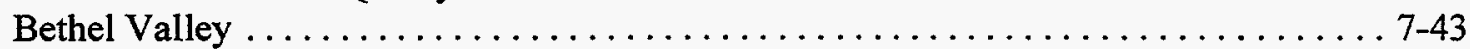

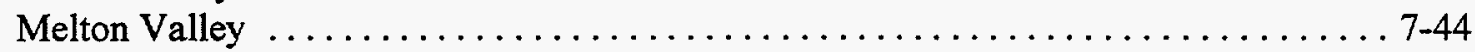

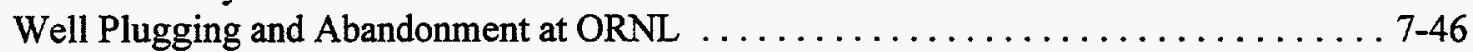

GROUNDWATER MONTTORING AT THE K-25 SITE $\ldots \ldots \ldots \ldots \ldots \ldots \ldots \ldots \ldots \ldots 7-47$

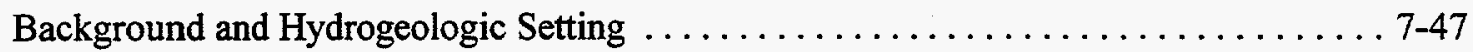

Waste Area Groupings . . . . . . . . . . . . . . . . .

1995 Well Installation and Plugging and Abandonment Activities . . . . . . . . . 7-50

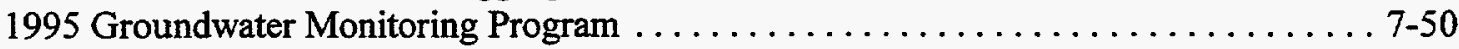

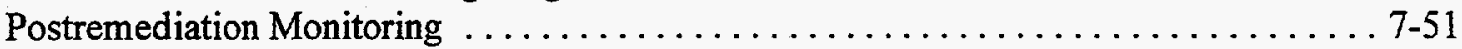

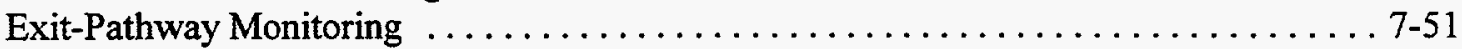

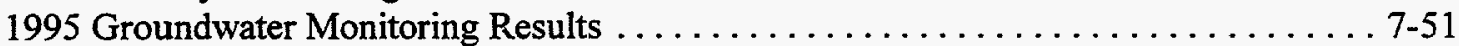

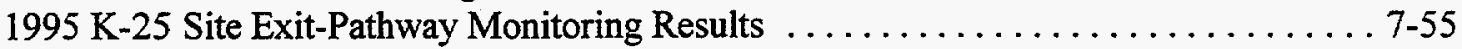

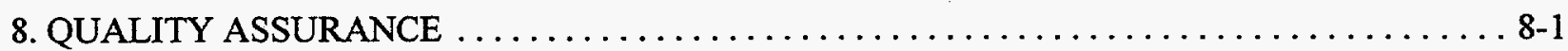

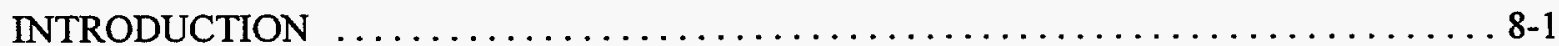

FIELD SAMPLING QUALITY ASSURANCE $\ldots \ldots \ldots \ldots \ldots \ldots \ldots \ldots \ldots \ldots \ldots \ldots \ldots$.

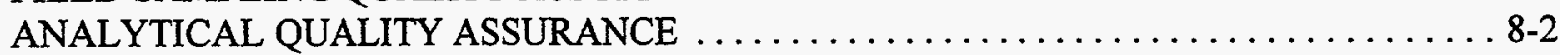

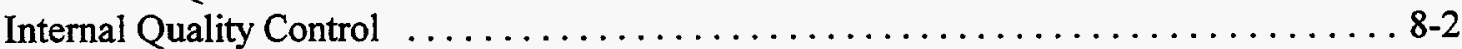

External Quality Control ..........................

DATA MANAGEMENT, VERIFICATION, AND VALIDATION $\ldots \ldots \ldots \ldots \ldots \ldots \ldots .8$

Appendix A. Radiation $\ldots \ldots \ldots \ldots \ldots \ldots \ldots \ldots \ldots \ldots \ldots \ldots \ldots \ldots \ldots \ldots \ldots \ldots \ldots \ldots \ldots \ldots$

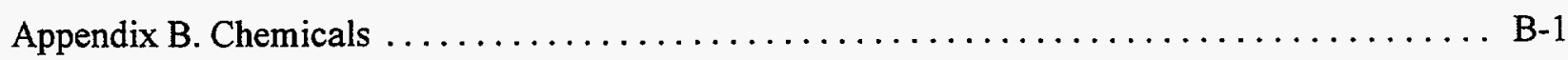




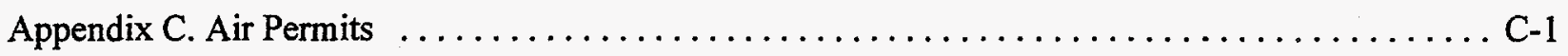

Appendix D. Drinking Water Standards $\ldots \ldots \ldots \ldots \ldots \ldots \ldots \ldots \ldots \ldots \ldots \ldots \ldots \ldots \ldots \ldots \ldots \ldots \ldots$

Appendix E. Underground Storage Tank Data $\ldots \ldots \ldots \ldots \ldots \ldots \ldots \ldots \ldots \ldots \ldots \ldots \ldots \ldots \ldots \ldots$

Appendix F. NPDES Noncompliances $\ldots \ldots \ldots \ldots \ldots \ldots \ldots \ldots \ldots \ldots \ldots \ldots \ldots \ldots \ldots \ldots \ldots \ldots \ldots \ldots$

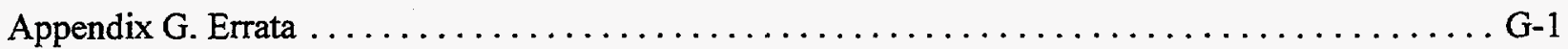

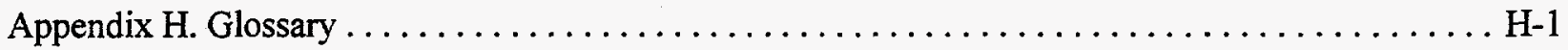

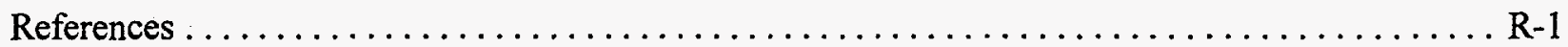




\section{Figures}

Figure

Page

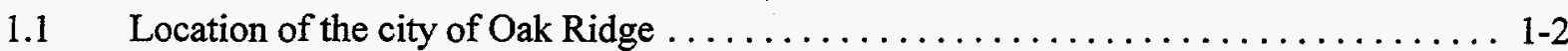

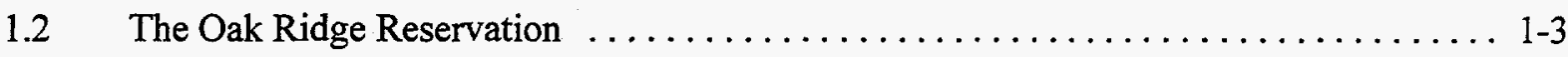

1.3 The ten-county region surrounding the Oak Ridge Reservation $\ldots \ldots \ldots \ldots \ldots \ldots \ldots$

1.4 Locations and populations of towns nearest to the Oak Ridge Reservation $\ldots \ldots \ldots$ 1-4

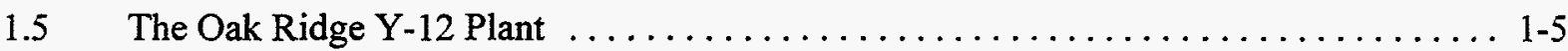

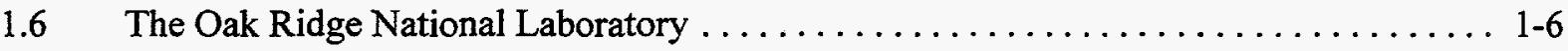

1.7 The Oak Ridge $\mathrm{K}-25$ Site $\ldots \ldots \ldots \ldots \ldots \ldots \ldots \ldots \ldots \ldots \ldots \ldots \ldots \ldots \ldots \ldots$

$2.1 \quad$ Five-year summary of NPDES noncompliances $\ldots \ldots \ldots \ldots \ldots \ldots \ldots \ldots \ldots \ldots \ldots$

3.1 The framework of the K-25 Powerhouse was demolished as part of DOE's

Environmental Restoration Incentive Project program . . . . . . . . . . . . 3-2

3.2 The Clinch River flows past the ORR en route to Kingston, where it merges with the

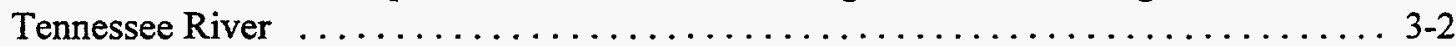

3.3 The ROD for Lower East Fork Poplar Creek calls for excavating the Bruner's

Center site along the Oak Ridge Turnpike and the NOAA site along Illinois Avenue . . 3-3

3.4 Workers at Envirocare of Utah, Inc., prepare to pour clean concrete in the void spaces between drums, to seal the drums in the lined disposal cell $\ldots \ldots \ldots \ldots \ldots \ldots \ldots . . \ldots \ldots$

3.5 Waste vaults are stacked on reinforced concrete pads at ORNL's Interim Waste

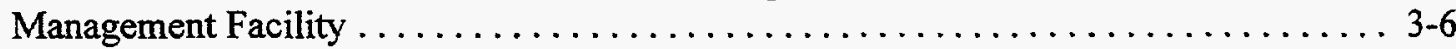

3.6 A concerned citizen comments on the plan proposed for the cleanup of the Lower East Fork Poplar Creek floodplain $\ldots \ldots \ldots \ldots \ldots \ldots \ldots \ldots \ldots \ldots \ldots \ldots \ldots \ldots \ldots \ldots .7$

3.7 Students at the EnvironMENTAL Fair are introduced to "the World of Leaves" . . . . 3-7

4.1 Total curies of uranium discharged from the $\mathrm{Y}-12$ Plant to the atmosphere, 1990-95 .. 4-3

4.2 Total kilograms of uranium discharged from the Y-12 Plant to the atmosphere, 1990-95

4.3 Locations of major stacks (rad emission points) at ORNL $\ldots \ldots \ldots \ldots \ldots \ldots \ldots \ldots$

4.4 Total discharges of ${ }^{3} \mathrm{H}$ from ORNL to the atmosphere, $1991-95 \ldots \ldots \ldots \ldots \ldots .4$ 


\section{Oak Ridge Reservation}

4.5 Total discharges of ${ }^{131} \mathrm{I}$ from ORNL to the atmosphere, $1991-95 \ldots \ldots \ldots \ldots \ldots .7$

4.6 K-25 Site active point sources of airborne radioactivity $\ldots \ldots \ldots \ldots \ldots \ldots \ldots \ldots$ 4-8

4.7 Total curies of uranium discharged from the K-25 Site to the atmosphere, 1991-95 . . . 4-9

4.8 Total kilograms of uranium discharged from the K-25 Site to the atmosphere, 1991-95 . 4-9

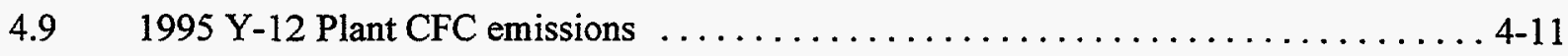

4.10 Surface water and sanitary sewer radiological sampling locations at the Y-12 Plant .. 4-16

4.11 Concentrations of ${ }^{238} \mathrm{U}$ at the Y-12 Plant Outfall 501, January 1989 through

December 1995 ..................................... 4-17

4.12 Five-year trend of $\mathrm{Y}-12$ Plant release of uranium to surface water $\ldots \ldots \ldots \ldots \ldots .4-17$

4.13 Five-year trend of total uranium discharges from the Y-12 Plant Sanitary Sewer . . . . 4-18

4.14 ORNL surface water, NPDES, and reference sampling locations $\ldots \ldots \ldots \ldots \ldots$ 4-19

4.15 Radionuclides at ORNL sampling sites having average concentrations greater

than $5 \%$ of the relevant derived concentration guides in $1995 \ldots \ldots \ldots \ldots \ldots \ldots$. 49

4.16 Cobalt-60 discharges at White Oak Dam, $1992-95 \ldots \ldots \ldots \ldots \ldots \ldots \ldots \ldots \ldots$

4.17 Cesium-137 discharges at White Oak Dam, 1992-95 .............. 4-20

4.18 Gross alpha discharges at White Oak Dam, $1992-95 \ldots \ldots \ldots \ldots \ldots \ldots \ldots \ldots$ 4-20

4.19 Gross beta discharges at White Oak Dam, $1992-95 \ldots \ldots \ldots \ldots \ldots \ldots \ldots \ldots$ 4-20

4.20 Total radioactive strontium discharges at White Oak Dam, $1992-95 \ldots \ldots \ldots \ldots \ldots$ 4-20

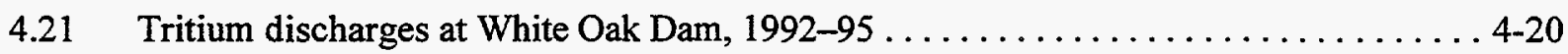

4.22 K-25 Site NPDES major outfalls and Category I storm drain outfalls $\ldots \ldots \ldots \ldots .4-21$

4.23 Five-year trend of uranium releases to surface waters from the K-25 Site . . . . . 4-22

4.24 Percentage of DCG for uranium isotopes from $\mathrm{K}-1407-\mathrm{J} \ldots \ldots \ldots \ldots \ldots \ldots \ldots \ldots 4-22$

4.25 ORNL NPDES compliance status comparison and sources of noncompliances,

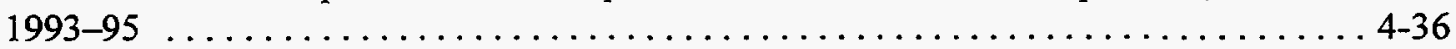

4.26 ORNL sampling locations for mercury in water $\ldots \ldots \ldots \ldots \ldots \ldots \ldots \ldots \ldots \ldots$

4.27 ORNL sampling locations for mercury in sediment $\ldots \ldots \ldots \ldots \ldots \ldots \ldots \ldots \ldots$ 
4.28 ORNL sampling locations for polychlorinated biphenyls $\ldots \ldots \ldots \ldots \ldots \ldots \ldots$. $\ldots 44$

4.29 Sampling locations for polychlorinated biphenyls in the greater ORNL area . . . . 4 4-44

4.30 K-25 Site NPDES compliance history by source of noncompliance . . . . . . . 4-45

4.31 Average concentrations ( \pm standard error) of mercury (in micrograms per gram)

in sunfish collected from November 1994 to March 1995 at sites on the ORR . . . . . 4-57

4.32 Average concentrations ( \pm standard error) of PCBs (in micrograms per gram)

in sunfish collected from November 1994 to March 1995 at sites on the ORR . . . . . 4-58

5.1 The ORR meteorological monitoring network $\ldots \ldots \ldots \ldots \ldots \ldots \ldots \ldots \ldots \ldots$

5.2 External gamma radiation monitoring locations on the ORR $\ldots \ldots \ldots \ldots \ldots \ldots \ldots$

5.3 Location of ORR perimeter air monitoring stations $\ldots \ldots \ldots \ldots \ldots \ldots \ldots \ldots \ldots$

5.4 Locations of ambient air monitoring stations at the $\mathrm{Y}-12$ Plant $\ldots \ldots \ldots \ldots \ldots \ldots$

5.5 Time trends in mercury vapor concentrations for the four active airborne mercury monitoring sites at the Y-12 Plant (1986 through 1995) . . . . . . . 5-12

5.6 Locations of ambient air monitoring stations at ORNL $\ldots \ldots \ldots \ldots \ldots \ldots \ldots \ldots$

5.7 Locations of ambient air monitoring stations at the $\mathrm{K}-25$ Site $\ldots \ldots \ldots \ldots \ldots \ldots$

5.8 Five-year total suspended particulate results at the K-25 Site $\ldots \ldots \ldots \ldots \ldots \ldots \ldots$-17

5.9 Five-year PM10 results at the K-25 Site $\ldots \ldots \ldots \ldots \ldots \ldots \ldots \ldots \ldots \ldots \ldots \ldots \ldots \ldots \ldots \ldots$

5.10 Ambient air monitoring 5-year trend results at the $\mathrm{K}-25$ Site $\ldots \ldots \ldots \ldots \ldots \ldots$

5.11 Ambient air monitoring 5-year trend results for uranium at the K-25 Site $\ldots \ldots \ldots 5-20$

5.12 Locations of ORR surface water sampling stations $\ldots \ldots \ldots \ldots \ldots \ldots \ldots \ldots \ldots .21$

5.13 Locations of $\mathrm{Y}-12$ Plant surface water sampling stations $\ldots \ldots \ldots \ldots \ldots \ldots \ldots$-23

5.14 Operating Surface Water Hydrological Information Support System

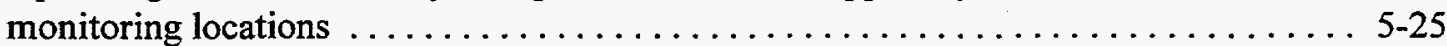

5.15 Monitoring locations for surface water at the K-25 Site $\ldots \ldots \ldots \ldots \ldots \ldots \ldots \ldots$

5.16 Percentage of DCGs for K-25 Site surface water monitoring locations $\ldots \ldots \ldots \ldots$ 5-27

5.17 Sampling locations for off-site treated water $\ldots \ldots \ldots \ldots \ldots \ldots \ldots \ldots \ldots \ldots .28$

5.18 ORR environmental monitoring plan sediment sampling locations $\ldots \ldots \ldots \ldots \ldots \ldots 5-29$ 


\section{Oak Ridge Reservation}

5.19 Hay sampling locations on the ORR $\ldots \ldots \ldots \ldots \ldots \ldots \ldots \ldots \ldots \ldots \ldots \ldots \ldots \ldots \ldots \ldots \ldots \ldots$

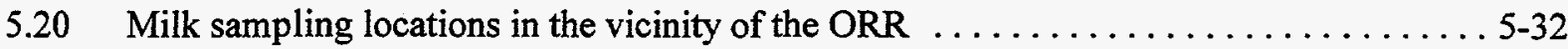

5.21 Fish sampling locations along the Clinch River $\ldots \ldots \ldots \ldots \ldots \ldots \ldots \ldots \ldots \ldots \ldots \ldots \ldots$

7.1 Vertical relationships of flow zones of the ORR: estimated thicknesses, water flux,

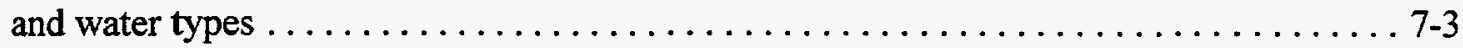

7.2 The Knox Aquifer and the aquitards on the Oak Ridge Reservation . . . . . . . . . 7-4

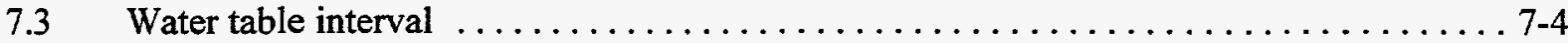

7.4 Y-12 Plant inactive regulated units, study areas, and active facilities for which

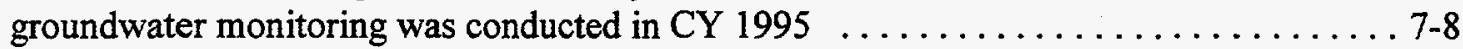

7.5 Hydrogeologic regimes at the $\mathrm{Y}-12$ Plant $\ldots \ldots \ldots \ldots \ldots \ldots \ldots \ldots \ldots \ldots \ldots \ldots$

7.6 Locations of ORR perimeter surveillance wells and multiport monitoring wells specified in the Environmental Monitoring Plan $\ldots \ldots \ldots \ldots \ldots \ldots \ldots \ldots \ldots \ldots \ldots \ldots \ldots$

7.7 Locations of waste management sites and monitoring wells sampled during 1995 in the Upper East Fork Poplar Creek Hydrogeologic Regime . . . . . . . . . . . . . 7-14

$7.8 \quad$ Nitrate $($ as $\mathrm{N})$ observed in groundwater at the $\mathrm{Y}-12$ Plant $\ldots \ldots \ldots \ldots \ldots \ldots \ldots \ldots \ldots$

7.9 Quarterly volatile organic compound concentrations in groundwater in selected wells

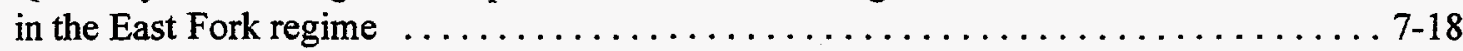

7.10 Quarterly volatile organic compound concentrations in selected wells near

New Hope Pond and exit-pathway wells $\ldots \ldots \ldots \ldots \ldots \ldots \ldots \ldots \ldots \ldots \ldots \ldots \ldots \ldots \ldots \ldots \ldots \ldots .18$

7.11 VOC concentrations in Maynardville Limestone, at depths between 200 and $500 \mathrm{ft} \ldots .7-19$

7.12 Summed volatile organic compounds in groundwater at the Y-12 Plant $\ldots \ldots \ldots 7-20$

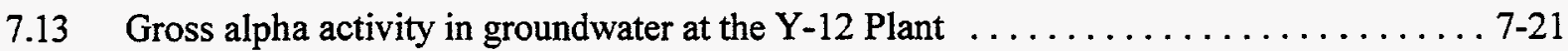

7.14 Gross beta activity in groundwater at the $\mathrm{Y}-12$ Plant $\ldots \ldots \ldots \ldots \ldots \ldots \ldots \ldots \ldots \ldots \ldots \ldots$

7.15 Locations of waste management sites and monitoring wells sampled during 1995

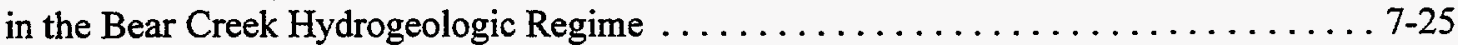

7.16 Surface water and spring stations sampled during 1995 in the Bear Creek

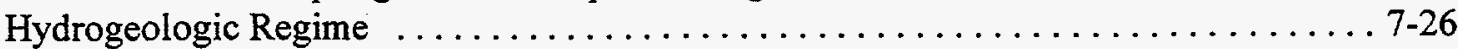

7.17 Concentrations of selected contaminants in exit-pathway monitoring wells GW-725, GW-704, and GW-684 in the Bear Creek Hydrogeologic Regime $7-28$ 
7.18 Locations of waste management sites and monitoring wells sampled during 1995 in the Chestnut Ridge Hydrogeologic Regime

7.19 Locations of ORNL waste area groupings (WAGs) $\ldots \ldots \ldots \ldots \ldots \ldots \ldots \ldots$

7.20 Groundwater exit pathways on the Oak Ridge Reservation that are likely to be

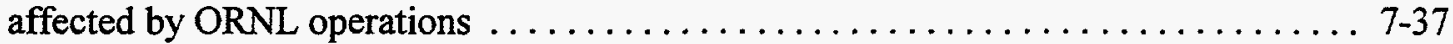

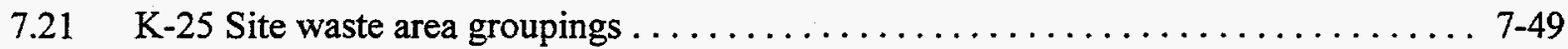

7.22 Background and exit-pathway monitoring well locations at the K-25 Site $\ldots \ldots \ldots 7-52$

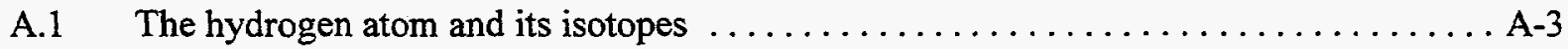

A.2 Examples of radiation pathways $\ldots \ldots \ldots \ldots \ldots \ldots \ldots \ldots \ldots \ldots \ldots \ldots \ldots \ldots \ldots \ldots \ldots$ 
-

-

- 


\section{Tables}

Table

$2.1 \quad$ RCRA and CERCLA corrective action processes $\ldots \ldots \ldots \ldots \ldots \ldots \ldots \ldots \ldots \ldots \ldots \ldots$

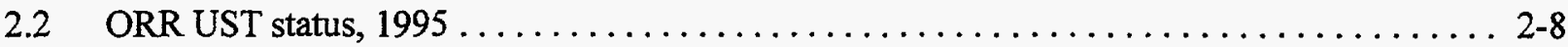

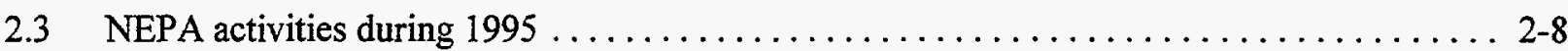

2.4 Animal species of concern reported from the Oak Ridge Reservation $\ldots \ldots \ldots \ldots \ldots$ 2-12

2.5 Plant species found on the Oak Ridge Reservation and listed by state of

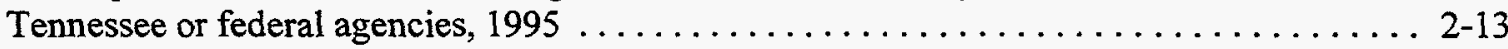

2.6 EPCRA (SARA Title III) compliance by site for the ORR $\ldots \ldots \ldots \ldots \ldots \ldots \ldots \ldots \ldots 2-22$

2.7 EPCRA Section 313 toxic chemical release summary for the ORR $\ldots \ldots \ldots \ldots \ldots \ldots 23$

2.8 Results of selected Oak Ridge Reservation recycling activities for the past 5 years . . . 2-25

2.9 Summary of environmental audits and assessments conducted at the $\mathrm{Y}-12$ Plant, $1995 \ldots 2-27$

2.10. Summary of environmental audits and assessments conducted at ORNL, $1995 \ldots \ldots \ldots 2-27$

2.11 Summary of environmental audits and assessments conducted at the K-25 Site, $1995 \ldots 2-28$

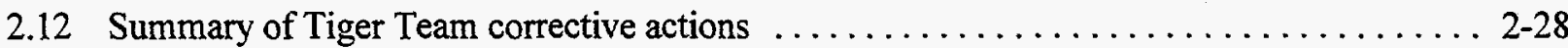

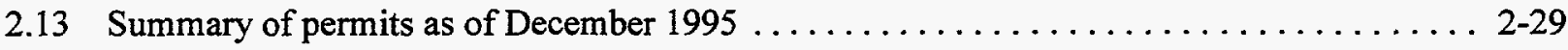

$4.1 \quad$ Y-12 Plant airborne uranium emission estimates, $1995 \ldots \ldots \ldots \ldots \ldots \ldots \ldots \ldots \ldots$

4.2 Major sources of radiological airborne emissions at ORNL, 1995 (in curies) ....... 4-6

$4.3 \quad$ K-25 Site radionuclide air emission totals, 1995 (in curies) $\ldots \ldots \ldots \ldots \ldots \ldots \ldots \ldots$

$4.4 \quad$ Y-12 Plant nonradiological airborne emissions, $1995 \ldots \ldots \ldots \ldots \ldots \ldots \ldots \ldots \ldots$. $\ldots \ldots$

4.5 ORNL nonradiological airborne emissions, $1995 \ldots \ldots \ldots \ldots \ldots \ldots \ldots \ldots \ldots \ldots \ldots$

4.6 Allowable emissions of criteria pollutants from the K-25 Site, $1992-95 \ldots \ldots \ldots \ldots \ldots$. . . . .

4.7 Actual emissions of criteria pollutants from the K-25 Site, $1995 \ldots \ldots \ldots \ldots \ldots \ldots \ldots$

4.8 Estimated K-25 Site emissions of ozone-depleting substances, $1995 \ldots \ldots \ldots \ldots \ldots \ldots$. . .

4.9 Estimated air emissions from the K-1501 Steam Plant at the K-25 Site, $1995 \ldots \ldots \ldots$. . 4-14

4.10 Estimated air emissions from the TSCA Incinerator at the K-25 Site, $1995 \ldots \ldots \ldots$. . . 14 
4.11 Summary of Y-12 Plant radiological monitoring plan sample requirements $\ldots \ldots \ldots \ldots$ 4-16

4.12 Release of uranium from the Y-12 Plant to the off-site environment

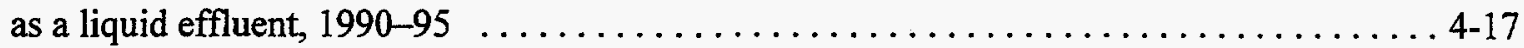

4.13 Y-12 Plant Discharge Point SS6, Sanitary Sewer Station 61995 radiological summary . . . 4-18

4.14 Radionuclides discharged to off-site surface waters from the K-25 Site, $1995 \ldots \ldots \ldots$. . 4-22

4.15 NPDES compliance monitoring requirements and record for the Y-12 Plant,

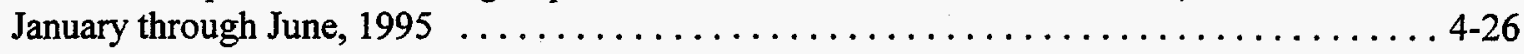

4.16 NPDES compliance monitoring requirements and record for the Y-12 Plant,

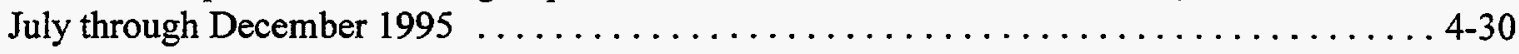

4.17 Surface water analytical results of polychlorinated biphenyls monitoring

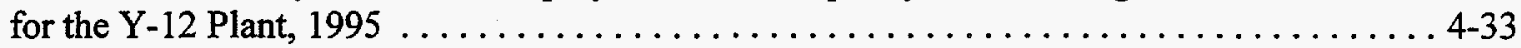

4.18 Y-12 Plant Discharge Point SS6, Sanitary Sewer Station SS-6 nonradiological

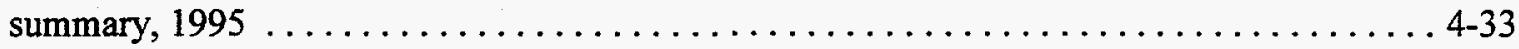

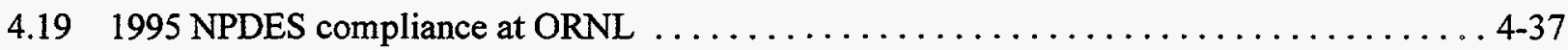

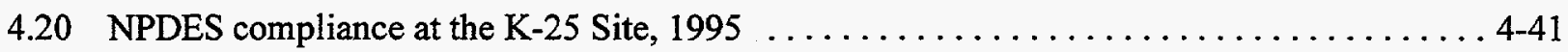

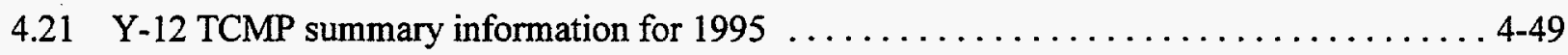

4.22 Y-12 Plant Biomonitoring Program summary information for wastewater treatment

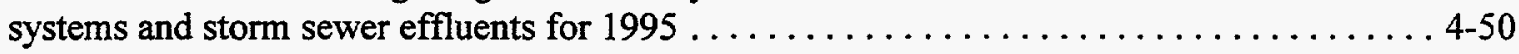

4.23 Y-12 Plant Biomonitoring Program summary information for Outfall 201 for $1995 \ldots$. . . 4-51

4.241995 toxicity test results of ORNL wastewaters and ambient water $\ldots \ldots \ldots \ldots \ldots \ldots$. 52

4.25 1995 average water quality parameters measured during toxicity tests of ORNL

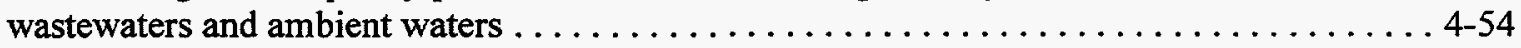

4.26 $1995 \mathrm{~K}-25$ Site NPDES Permit Number TN 0002950 toxicity tests results $\ldots \ldots \ldots . .4-56$

$4.271995 \mathrm{~K}-25$ Site average water quality parameters measured during toxicity tests

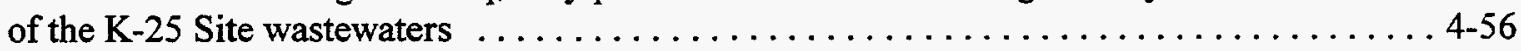

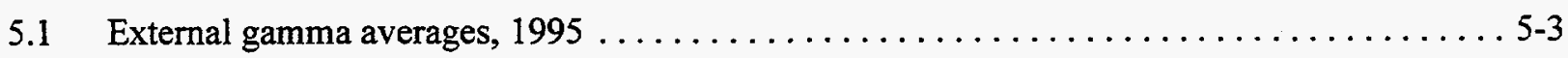

5.2 ORR environmental surveillance multimedia summarized by station $\ldots \ldots \ldots \ldots \ldots \ldots$

5.3 ORR environmental surveillance multimedia by media $\ldots \ldots \ldots \ldots \ldots \ldots \ldots \ldots \ldots$

5.4 Uranium concentrations in ambient air on the ORR $\ldots \ldots \ldots \ldots \ldots \ldots \ldots \ldots \ldots \ldots$ 


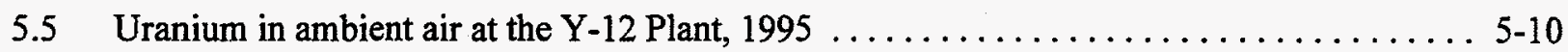

5.61995 results of the $\mathrm{Y}-12$ Plant ambient air mercury monitoring program $\ldots \ldots \ldots \ldots .11$

5.7 Radionuclide concentrations measured at ORNL perimeter air monitoring stations,

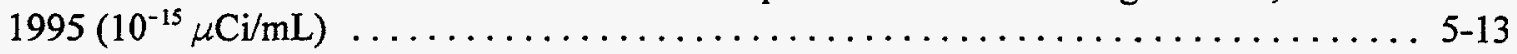

5.8 Summary of ambient air pollutants measured at the K-25 Site, $1995 \ldots \ldots \ldots \ldots \ldots$. . . . .

5.9 Total suspended particulates in ambient air at the K-25 Site, $1995 \ldots \ldots \ldots \ldots \ldots$

5.10 PM10 particulates in ambient air at the K-25 Site, $1995 \ldots \ldots \ldots \ldots \ldots \ldots \ldots \ldots$

5.11 Lead concentrations in ambient air at the K-25 Site, $1995 \ldots \ldots \ldots \ldots \ldots \ldots \ldots \ldots$

5.12 HAP carcinogen metals in ambient air at the K-25 Site, $1995 \ldots \ldots \ldots \ldots \ldots \ldots \ldots$

5.13 Uranium in ambient air at the K-25 Site, $1995 \ldots \ldots \ldots \ldots \ldots \ldots \ldots \ldots \ldots \ldots \ldots$

5.14 Surface water sampling measurements exceeding Tennessee water quality criteria

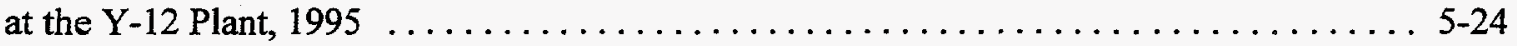

5.15 Concentrations of total radioactive strontium $\left({ }^{89} \mathrm{Sr}+{ }^{90} \mathrm{Sr}\right)$ in raw milk, $1995(\mathrm{pCi} / \mathrm{L}) \ldots \ldots 5-32$

5.16 Significant radiological results for honey sampled from hives on the ORR, $1995 \ldots \ldots \ldots 5-33$

6.1 Monitored and sampled release point parameters and receptor locations

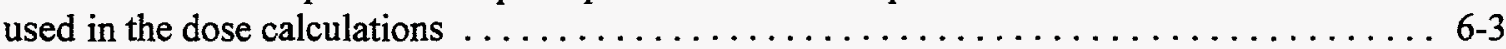

6.2 Calculated radiation doses to maximally exposed off-site individuals from airborne

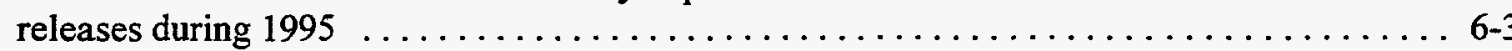

6.3 Calculated collective EDEs from airborne releases during $1995 \ldots \ldots \ldots \ldots \ldots \ldots \ldots 6$

6.4 Potential maximum individual EDEs from use of off-site waters (mrem) $\ldots \ldots \ldots \ldots .6$

6.5 Average EDEs from ingesting vegetables grown at ORR

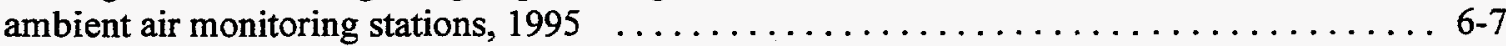

$6.6 \quad 1995$ total dose rate for aquatic organisms $(\mathrm{rad} /$ day $) \ldots \ldots \ldots \ldots \ldots \ldots \ldots \ldots \ldots \ldots$

6.7 Summary of estimated effective dose equivalents to an adult during 1995 at locations

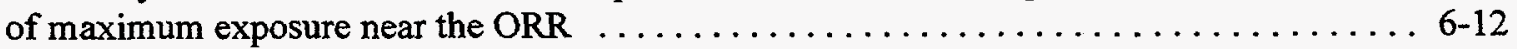

6.8 Trends in total effective dose equivalent for selected pathways $\ldots \ldots \ldots \ldots \ldots \ldots \ldots \ldots 6-12$

6.9 Chemical reference doses and slope factors used in drinking water and fish intake analysis $\ldots \ldots \ldots \ldots \ldots \ldots \ldots \ldots \ldots \ldots \ldots \ldots \ldots \ldots \ldots \ldots \ldots \ldots .14$

6.101995 chemical hazard quotients and I/CDI for drinking water $\ldots \ldots \ldots \ldots \ldots \ldots \ldots 6-15$ 
6.111995 chemical hazard quotients (HQs) for metals and estimated dose/chronic daily intake (I/CDIs) for carcinogens in fish $\ldots \ldots \ldots \ldots \ldots \ldots \ldots \ldots \ldots \ldots \ldots \ldots \ldots \ldots \ldots \ldots .16$

7.1 Summary of the comprehensive groundwater monitoring program at the Y-12 Plant, 1995

7.2 Regulatory status and operational history of waste management units and underground storage tanks included in the 1995 Comprehensive Groundwater Monitoring Program; Upper East Fork Poplar Creek Hydrogeologic Regime . . . . . . . . . . . . . . 7-15

7.3 Regulatory status and operational history of waste management units included in the 1995 Comprehensive Groundwater Monitoring Program;

Bear Creek Hydrogeologic Regime

7.4 Regulatory status and operational history of waste management units included in the 1995 Comprehensive Groundwater Monitoring Program;

Chestnut Ridge Hydrogeologic Regime

7.5 Annual average summed volatile organic compound (VOC) concentrations in groundwater

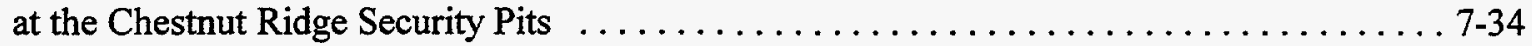

7.6 Summary of the groundwater surveillance program at ORNL, $1995 \ldots \ldots \ldots \ldots \ldots \ldots 7-42$

7.7 Summary of the plant perimeter surveillance program at ORNL, $1995 \ldots \ldots \ldots \ldots \ldots \ldots 7-43$

8.1 QA/QC results for the Oak Ridge Reservation, $1995 \ldots \ldots \ldots \ldots \ldots \ldots \ldots \ldots \ldots \ldots$

A.1 Radionuclide nomenclature $\ldots \ldots \ldots \ldots \ldots \ldots \ldots \ldots \ldots \ldots \ldots \ldots \ldots \ldots \ldots$

A.2 Comparison and description of various dose levels $\ldots \ldots \ldots \ldots \ldots \ldots \ldots \ldots \ldots \ldots$

C.1 Air permits at the $\mathrm{Y}-12$ Plant $\ldots \ldots \ldots \ldots \ldots \ldots \ldots \ldots \ldots \ldots \ldots \ldots \ldots \ldots \ldots \ldots \ldots \ldots$

C.2 ORNL air pollution emission sources permitted with the Tennessee Department of

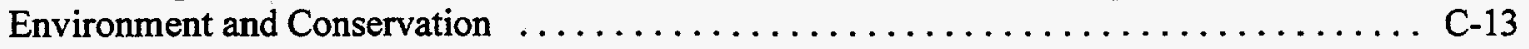

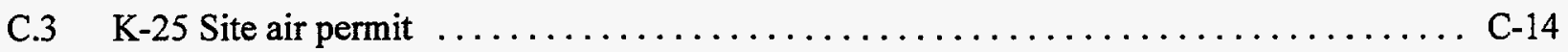

D.1 Reference standards for radionuclides in water $(\mathrm{pCi} / \mathrm{L}) \ldots \ldots \ldots \ldots \ldots \ldots \ldots \ldots$

D.2 Reference standards for chemicals and metals in water $\ldots \ldots \ldots \ldots \ldots \ldots \ldots \ldots \ldots$

E.1 Underground storage tanks (USTs) at the $\mathrm{Y}-12$ Plant $\ldots \ldots \ldots \ldots \ldots \ldots \ldots \ldots$

F.1 Summary of $\mathrm{Y}-12$ Plant NPDES excursions, $1995 \ldots \ldots \ldots \ldots \ldots \ldots \ldots \ldots \ldots$

F.2 Summary of ORNL NPDES Excursions, $1995 \ldots \ldots \ldots \ldots \ldots \ldots \ldots \ldots \ldots \ldots$

F.3 Summary of K-25 Site NPDES noncompliance, $1995 \ldots \ldots \ldots \ldots \ldots \ldots \ldots \ldots \ldots$ 


\section{Acronyms and Abbreviations}

\begin{tabular}{|c|c|}
\hline ACGIH & American Conference of Governmental Industrial Hygienists \\
\hline AEC & Atomic Energy Commission \\
\hline AIHA & American Industrial Hygiene Association \\
\hline ALARA & as low as reasonably achievable \\
\hline ARAP & Aquatic Resources Alteration Permit \\
\hline ARAR & applicable or relevant and appropriate requirement \\
\hline ASER & Annual Site Environmental Report \\
\hline ATSDR & Agency for Toxic Substances and Disease Registry \\
\hline BCK & Bear Creek kilometer \\
\hline BCV & Bear Creek Valley \\
\hline BMAP & Biological Monitoring and Abatement Program \\
\hline BOD & biological oxygen demand \\
\hline $\mathrm{CA}$ & characterization area \\
\hline CAA & Clean Air Act \\
\hline $\mathrm{CDI}$ & chronic daily intake \\
\hline CEQ & Council on Environmental Quality \\
\hline CERCLA & Comprehensive Environmental Response, Compensation, and Liability Act \\
\hline CET & Center for Environmental Technology \\
\hline CFC & chlorofluorocarbon \\
\hline CLP & Contract Laboratory Program \\
\hline $\mathrm{CMC}$ & criterion maximum concentration \\
\hline CMTS & Central Mercury Treatment System \\
\hline CNF & Central Neutralization Facility \\
\hline CRADA & cooperative research and development agreement \\
\hline CRK & Clinch River kilometer \\
\hline CRMP & cultural resource management plan \\
\hline CWA & Clean Water Act \\
\hline CWG & citizens' working group \\
\hline CWSA & Containerized Waste Storage Area \\
\hline CWM & Center for Waste Management \\
\hline CY & calendar year \\
\hline CYRTF & Coal Yard Runoff Treatment Facility \\
\hline D\&D & decontamination and decommissioning \\
\hline DAC & derived air concentration \\
\hline DCF & dose conversion factor \\
\hline DCG & derived concentration guide \\
\hline DEUSS & Discharge of Enriched Uranium to the Sanitary Sewer \\
\hline DNAPL & dense nonaqueous phase liquid \\
\hline DNFSB & Defense Nuclear Facilities Safety Board \\
\hline DOE & U.S. Department of Energy \\
\hline DOE-HQ & U.S. Department of Energy Headquarters \\
\hline DOE-ORO & U.S. Department of Energy Oak Ridge Operations Office \\
\hline DWS & drinking water standard \\
\hline EA & environmental assessment \\
\hline EDE & effective dose equivalent \\
\hline EESSMS & East End Sanitary Sewer Monitoring Station \\
\hline
\end{tabular}




\begin{tabular}{|c|c|}
\hline EFK & East Fork Poplar Creek kilometer \\
\hline EFPC & East Fork Poplar Creek \\
\hline ELPAT & Environmental Lead Proficiency Analytical Testing Program \\
\hline EML & Environmental Measurements Laboratory \\
\hline EMP & Environmental Monitoring Plan for the Oak Ridge Reservation \\
\hline Energy Systems & $\begin{array}{l}\text { Lockheed Martin Energy Systems, Inc. (formerly Martin Marietta Energy } \\
\text { Systems, Inc.) }\end{array}$ \\
\hline EPA & U.S. Environmental Protection Agency \\
\hline EPA-HQ & U.S. Environmental Protection Agency Headquarters \\
\hline EPCRA & Emergency Planning and Community Right-To-Know Act \\
\hline EPIP & Environmental Protection Program Implementation Plan \\
\hline EPT & Ephemeroptera, Plecoptera, and Trichoptera \\
\hline ER & environmental restoration \\
\hline ES\&H & environment, safety, and health \\
\hline ESD & Environmental Sciences Division (ORNL) \\
\hline FDA & U.S. Food and Drug Administration \\
\hline FFA & federal facilities agreement \\
\hline FFCA & federal facilities compliance agreement \\
\hline FFEO & Federal Facilities Enforcement Office \\
\hline FIFRA & Federal Insecticide, Fungicide, and Rodenticide Act \\
\hline FONSI & finding of no significant impact \\
\hline FY & fiscal year \\
\hline GIS & geographic information system \\
\hline GWPP & Groundwater Protection Program \\
\hline GWPS & groundwater protection standard \\
\hline GWTF & groundwater treatment facility \\
\hline HAP & Hazardous Air Pollutant \\
\hline HAZWRAP & Hazardous Waste Remedial Action Program \\
\hline HEPA & high-efficiency particulate air \\
\hline HiVal & High Investment Value \\
\hline HQ & hazard quotient \\
\hline HSWA & Hazardous and Solid Waste Amendments to RCRA (1984) \\
\hline I/CDI & intake (estimated dose)/calculated daily intake \\
\hline ICP-MS & inductively coupled plasma mass spectrometry \\
\hline ICRP & International Commission on Radiological Protection \\
\hline IHgTU & Interim Mercury Treatment Unit \\
\hline IRIS & Integrated Risk Information System \\
\hline ISV & In-Situ Vitrification \\
\hline IWC & in-stream waste concentration \\
\hline IWMF & Interim Waste Management Facility \\
\hline K-25 Site & the Oak Ridge K-25 Site \\
\hline LDR & land disposal restriction \\
\hline LLLW & liquid low-level (radioactive) waste \\
\hline LLW & low-level (radioactive) waste \\
\hline LMER & Lockheed Martin Energy Research Corporation \\
\hline LMES & Lockheed Martin Energy Systems \\
\hline LQAP & Laboratory Quality Assurance Plan \\
\hline MACT & maximum achievable control technology \\
\hline
\end{tabular}




\begin{tabular}{|c|c|}
\hline MAPEP & Mixed Analyte Performance Evaluation Program \\
\hline $\mathrm{MCL}$ & maximum contaminant level \\
\hline MEK & Melton Branch kilometer \\
\hline Mgd & million gallons per day \\
\hline MIK & Mitchell Branch kilometer \\
\hline MSRE & Molten Salt Reactor Experiment \\
\hline NEPA & National Environmental Policy Act \\
\hline NESHAP & National Emission Standards for Hazardous Air Pollutants \\
\hline NHPA & National Historic Preservation Act \\
\hline NIST & National Institute of Standards and Technology \\
\hline NOAA & National Oceanic and Atmospheric Administration \\
\hline NOEC & no-observed-effect concentration \\
\hline NOEL & no-observed-effect level \\
\hline NON & notice of noncompliance \\
\hline NOV & notice of violation \\
\hline NPDES & National Pollutant Discharge Elimination System \\
\hline NPL & National Priorities List \\
\hline NRWTF & Nonradiological Wastewater Treatment Facility \\
\hline NRC & Nuclear Regulatory Commission \\
\hline OHF & Old Hydrofracture Facility \\
\hline ORAU & Oak Ridge Associated Universities \\
\hline OREIS & Oak Ridge Environmental Information System \\
\hline ORISE & Oak Ridge Institute for Science and Education \\
\hline ORNL & Oak Ridge National Laboratory \\
\hline ORR & Oak Ridge Reservation \\
\hline ORR-PCB-FFCA & $\begin{array}{l}\text { Oak Ridge Reservation Polychlorinated Biphenyl Federal Facilities } \\
\text { Compliance Agreement }\end{array}$ \\
\hline OU & operable unit \\
\hline PAM & perimeter air monitoring (station) \\
\hline PA/SI & preliminary assessment/site investigation \\
\hline PAT & Proficiency Analytical Testing \\
\hline PCB & polychlorinated biphenyl \\
\hline PCK & Poplar Creek kilometer \\
\hline PET & Proficiency Environmental Testing \\
\hline PIDAS & Perimeter Intrusion Detection Assessment System \\
\hline PM10 & particulate matter less than 10 microns in diameter \\
\hline POTW & publicly owned treatment works \\
\hline PWMP & Pond Waste Management Project \\
\hline QA & quality assurance \\
\hline QA/QC & quality assurance/quality control \\
\hline QC & quality control \\
\hline R\&D & research and development \\
\hline Rad-NESHAP & Rad-National Emission Standards for Hazardous Air Pollutants \\
\hline RAM & remote air monitoring \\
\hline RCRA & Resource Conservation and Recovery Act \\
\hline $\mathrm{RCW}$ & recirculating cooling water \\
\hline RFA & RCRA Facility Assessment \\
\hline RfD & reference dose \\
\hline
\end{tabular}




\begin{tabular}{|c|c|}
\hline RI & remedial investigation \\
\hline RI/FS & remedial investigation/feasibility study \\
\hline RMPE & Reduction of Mercury in Plant Effluent \\
\hline ROD & record of decision \\
\hline ROI & return on investment \\
\hline RQ & reportable quantity \\
\hline SARA & Superfund Amendments and Reauthorization Act \\
\hline SDWA & Safe Drinking Water Act \\
\hline SF & slope factor \\
\hline SHPO & Tennessee state historic preservation officer \\
\hline SMCL & secondary maximum contaminant level \\
\hline SOP & standard operating procedure \\
\hline SPCC & Spill Prevention Control and Countermeasures Plan \\
\hline S/RIDs & Standards/Requirements Identification Documents \\
\hline STP & Site Treatment Plan \\
\hline STP & Sewage Treatment Plant \\
\hline SWDF & solid waste disposal facilities \\
\hline SWHISS & Surface Water Hydrological Information Support System \\
\hline SWM & solid waste management \\
\hline SWMU & solid waste management unit \\
\hline SWPPP & Storm Water Pollution Prevention Program \\
\hline SWSA & solid waste storage area \\
\hline TCMP & Toxicity Control and Monitoring Program \\
\hline TDEC & Tennessee Department of Environment and Conservation \\
\hline TDEC/DOE-OD & Tennessee Department of Environment and Conservation/DOE Oversight Division \\
\hline T\&E & threatened and endangered \\
\hline TEMA & Tennessee Emergency Management Agency \\
\hline TLD & thermoluminescent dosimeter \\
\hline TOA & Tennessee Oversight Agreement \\
\hline TPF & Transuranic Processing Facility \\
\hline TRANSCOM & U.S. Transportation Command \\
\hline TRC & total residual chlorine \\
\hline TRK & Tennessee River kilometer \\
\hline TRU & transuranic \\
\hline TSCA & Toxic Substances Control Act \\
\hline TSD & treatment, storage, and disposal \\
\hline TSO & Technical Subcontracting Office \\
\hline TSP & total suspended particulates \\
\hline TVA & Tennessee Valley Authority \\
\hline TWQC & Tennessee General Water Quality Criteria \\
\hline TWRA & Tennessee Wildlife Resources Agency \\
\hline UE & uranium enrichment \\
\hline UE-PCB-FFCA & $\begin{array}{l}\text { Uranium Enrichment Polychlorinated Biphenyl Federal Facilities } \\
\text { Compliance Agreement }\end{array}$ \\
\hline UE-TSCA-FFCA & $\begin{array}{l}\text { Uranium Enrichment Toxic Substances Control Act Federal Facilities } \\
\text { Compliance Agreement }\end{array}$ \\
\hline UEFPC & Upper East Fork Poplar Creek \\
\hline USEC & United States Enrichment Corporation \\
\hline
\end{tabular}




$\begin{array}{ll}\text { UST } & \text { underground storage tank } \\ \text { UV } & \text { ultraviolet } \\ \text { VDRIF } & \text { Variable Dose Rate Irradiation Facility } \\ \text { VOC } & \text { volatile organic compound } \\ \text { WAG } & \text { waste area grouping } \\ \text { WQS } & \text { water quality standard } \\ \text { WCK } & \text { White Oak Creek kilometer } \\ \text { WETF } & \text { West End Treatment Facility } \\ \text { WIPP } & \text { Waste Isolation Pilot Plant } \\ \text { WMP } & \text { waste management program } \\ \text { WOC } & \text { White Oak Creek } \\ \text { WOD } & \text { White Oak Dam } \\ \text { WOL } & \text { White Oak Lake } \\ \text { Y-12 Plant } & \text { the Oak Ridge Y-12 Plant }\end{array}$


-

-

- 


\section{Acknowledgments}

The authors wish to recognize everyone who participated in the publication of the annual site environmental report for this year. Although we cannot name everyone who participated, we'd like to mention a few names in particular.

Doug Aho

Steve Baloga

Bill Barre

Don Bohrman

Darryl Bonner

Mark Burris

Stephanie Byrge

Wayne Carlton

Laura Cunningham

Sharon Davison

Stan Duke

Jim Eaton

Ron Evans

Henry Fellers

Steve Foster
Joanne Gideon

Jan Gilbert

Jim Grimes

Clarence Hill

Roxanna Hinzman

Wade Hollinger

Mona Johnson

Robert Johnson

Rodney Kingrea

Sandi Lyttle

Cathy McCoy

Jeff Murphy

Paula Plont

Sheila Poligone

Tony Poole
Stacey Rathke

Ernest Ryan

Melinda Salmons

Ron Sharp

Johnny Skinner

Pam Stevens

Kelly Stroud

Charlie Valentine

Lenny Vaughn

Robert Ward

Jennifer Webb

Mick Wiest

Joe Wolfe

Mic Woltman

Gary Worley 


\title{
1. Site and Operations Overview
}

L. V. Hamilton, L. W. McMahon, and L. G. Shipe

\begin{abstract}
The Department of Energy currently oversees activities on the Oak Ridge Reservation, a government-owned, contractor-operated facility. The three sites that compose the reservation (the Y-12 Plant, Oak Ridge National Laboratory, and the K-25 Site) were established in the early 1940 s as part of the Manhattan Project, a secret undertaking that produced the materials for the first atomic bombs. The reservation's role has evolved over the years, and it continues to adapt to meet the changing defense and energy needs of the United States. Both the work carried out for the war effort and subsequent research, development, and production activities have produced (and continue to produce) radiological and hazardous wastes.
\end{abstract}

\section{BACKGROUND}

This document contains a summary of environmental monitoring activities on the Oak Ridge Reservation (ORR) and its surroundings and is required for the U.S. Department of Energy (DOE) facilities. The monitoring and documentation criteria are described within the requirements of DOE Order 5400.1, General Environmental Protection Program. The results summarized in this report are based on the data collected during 1995 and compiled in Environmental Monitoring on the ORR: 1995 Results (Energy Systems 1995). Both books are available on request from Oak Ridge National Laboratory (ORNL) Laboratory Records, P.O. Box 2008, Oak Ridge, TN 37831-6285. Some of the data are also available on the Oak Ridge Environmental Information System (OREIS) to those who have a Lockheed Martin Energy Systems user identification. For more information, visit the OREIS home page on the World-Wide Web (http://www-internal.ornl.gov/-oreis/ oreishome.html).

To the extent possible, this document follows the Environmental Monitoring Plan for the Oak Ridge Reservation (EMP) (DOE 1995), the authorization and requirement for which are also contained in DOE Order 5400.1. The plan outlines the goals of environmental monitoring for the reservation and its facilities. The plan has been approved by the manager of the U.S.
Department of Energy Oak Ridge Operations Office (DOE-ORO).

Environmental monitoring on the ORR consists of two major activities: effluent monitoring and environmental surveillance.

Effluent monitoring is the collection and analysis of samples or measurements of liquid, gaseous, or airborne effluents to characterize and quantify contaminants and process stream characteristics; assess radiation and chemical exposures to members of the public; and demonstrate compliance with applicable standards.

Environmental surveillance is the collection and analysis of samples of air, water, soil, foodstuffs, biota, and other media from the site and its environs and the measurement of external radiation to demonstrate compliance with applicable standards, assessing radiation and chemical exposures to members of the public, and assessing effects (if any) on the local environment.

\section{DESCRIPTION OF SITE LOCALE}

The city of Oak Ridge lies in a valley between the Cumberland and Blue Ridge mountain ranges and is bordered on two sides by the Clinch River. The Cumberland Mountains are $16 \mathrm{~km}$ (10 miles) to the northwest; the Blue Ridge Mountains, which include the Great 


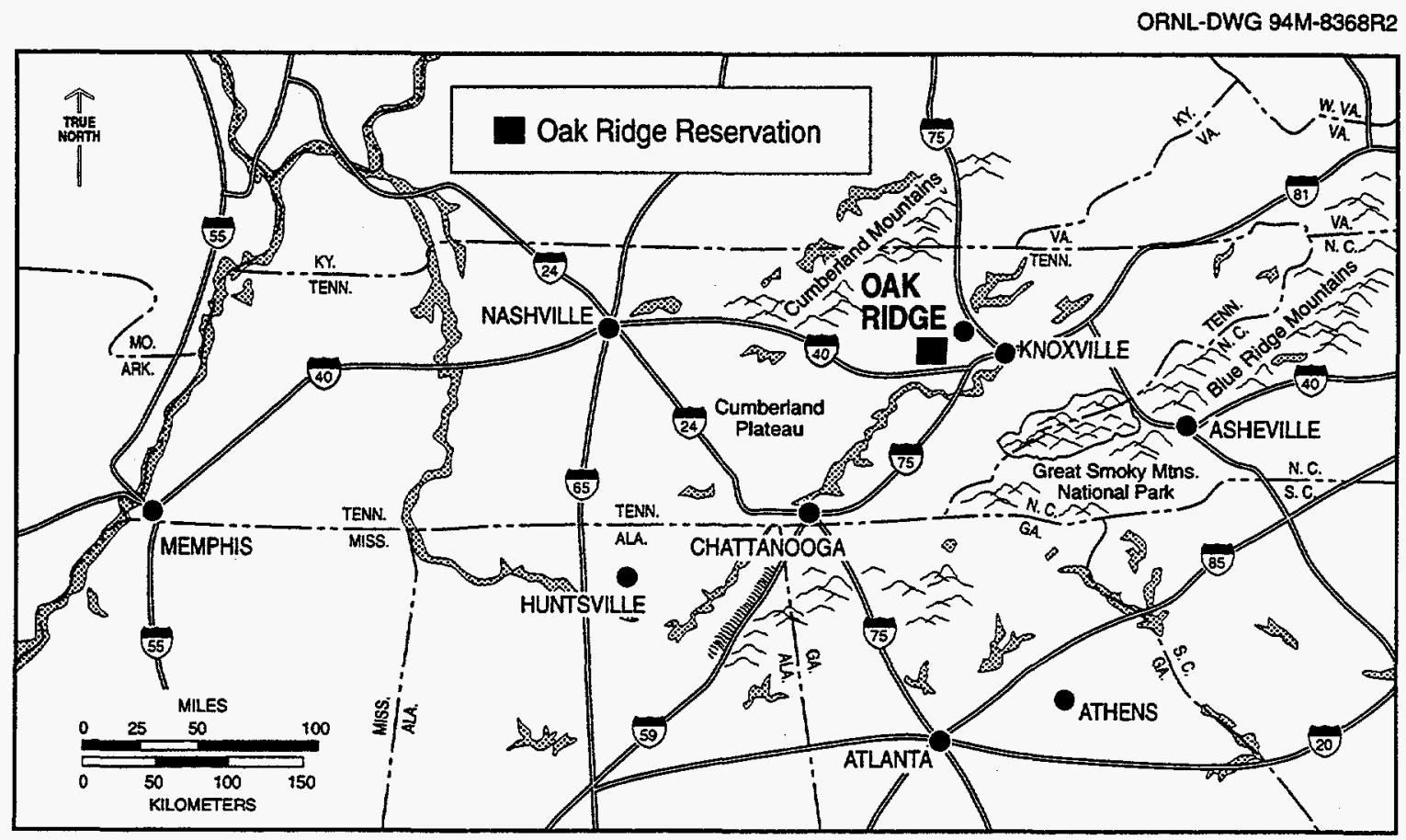

Fig. 1.1. Location of the city of Oak Ridge.

Smoky Mountains National Park, are 51 km (32 miles) to the southeast (Fig. 1.1).

The ORR lies within the corporate limits of the city of Oak Ridge and encompasses all of the contiguous land owned by DOE in the Oak Ridge area. The residential section of Oak Ridge forms the northern boundary of the reservation. The Tennessee Valley Authority's (TVA's) Melton Hill and Watts Bar reservoirs on the Clinch and Tennessee rivers form the southern and western boundaries (Fig. 1.2).

The population of the ten-county region is 717,880 , with $5 \%$ of its labor force employed on the ORR (Fig. 1.3). Other towns in close proximity to the reservation are Oliver Springs, Clinton, Lenoir City, Farragut, Kingston, and Harriman (Fig. 1.4). Knoxville, the major metropolitan area nearest Oak Ridge, is located about $40 \mathrm{~km}$ ( 25 miles) to the east and has a population of about 165,000 (1990 census). Except for the city of Oak Ridge, the land within $8 \mathrm{~km}$ of the ORR is predominantly rural and is used primarily for residences, small farms, and cattle pasture. Fishing, boating, water skiing, and swimming are popular recreational activities in the area.

\section{CLIMATE}

The climate of the region may be broadly classified as humid continental. The Cumberland Mountains to the northwest help to shield the region from cold air masses that frequently penetrate far south over the plains and prairies in the central United States during the winter months. During the summer, tropical air masses from the south provide warm and humid conditions that often produce thunderstorms; however, anticyclonic circulation around high-pressure systems centered in the western Gulf of Mexico can bring dry air from the southwestern United States into the region, leading to occasional periods of drought.

\section{Temperature}

The mean annual temperature for the Oak Ridge area is $14.4^{\circ} \mathrm{C}\left(58^{\circ} \mathrm{F}\right)$ (Webster and Bradley 1988). The coldest month is usually January, with temperatures averaging about $3.3^{\circ} \mathrm{C}$ $\left(38^{\circ} \mathrm{F}\right)$ but occasionally dipping as low as $-31^{\circ} \mathrm{C}$ $\left(-24^{\circ} \mathrm{F}\right)$.

July is typically the hottest month of the year, with temperatures averaging $25^{\circ} \mathrm{C}\left(77^{\circ} \mathrm{F}\right)$ 


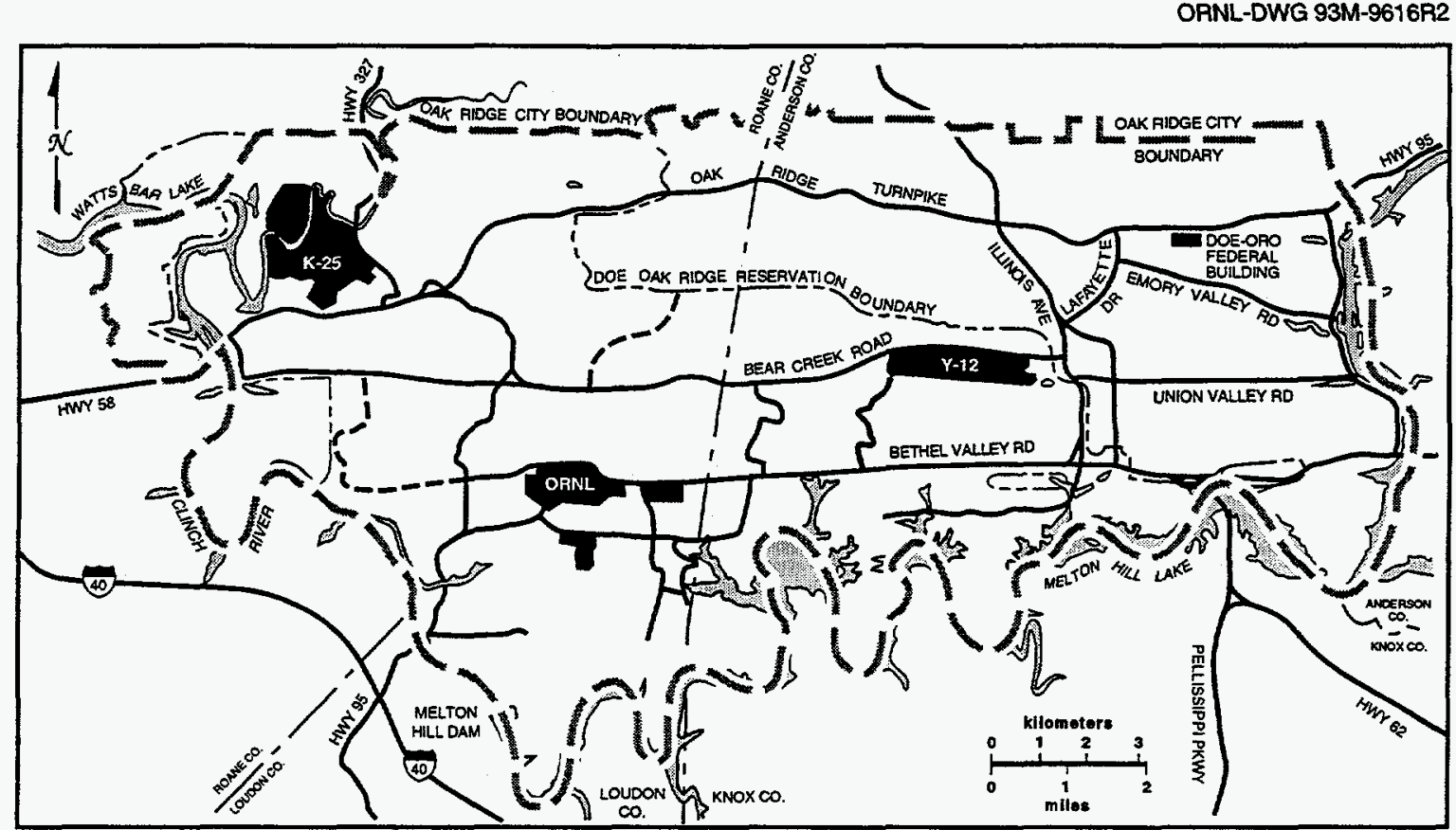

Fig. 1.2. The Oak Ridge Reservation.

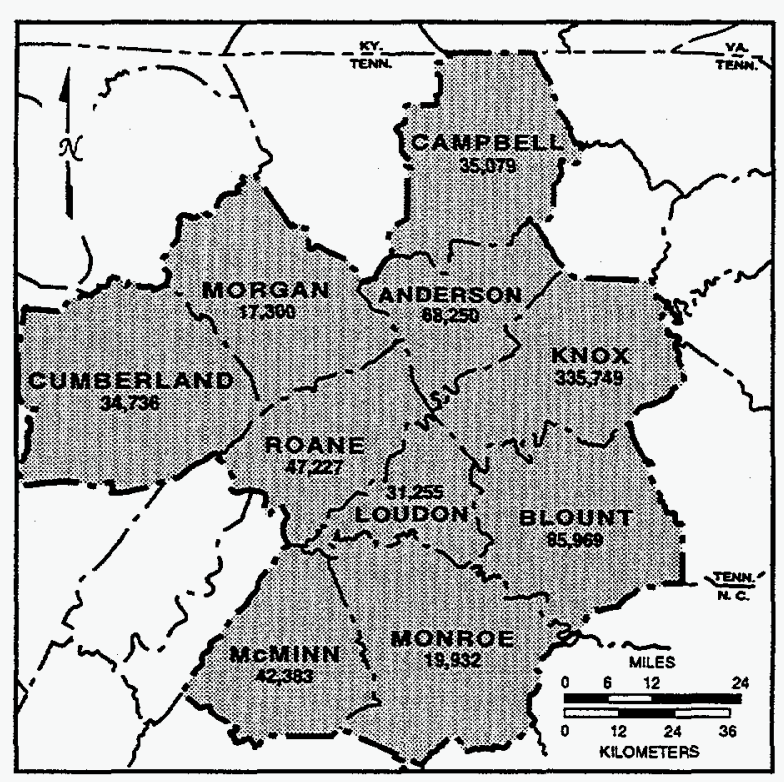

Fig. 1.3. The ten-county region surrounding the Oak Ridge Reservation. (Population figures based on the 1990 U.S. census.)

but occasionally peaking at over $37.8^{\circ} \mathrm{C}\left(100^{\circ} \mathrm{F}\right)$. In the course of a year, the difference between maximum and minimum daily temperatures averages $12^{\circ} \mathrm{C}\left(22^{\circ} \mathrm{F}\right)$.

\section{Winds}

Winds in the Oak Ridge area are controlled in large part by the valley-and-ridge topography. Prevailing winds are either up-valley (northeasterly) daytime winds or down-valley (southwesterly) nighttime winds. Wind speeds are less than $11.9 \mathrm{~km} / \mathrm{hour}$ ( $7.4 \mathrm{mph}) 75 \%$ of the time; tornadoes and winds exceeding $30 \mathrm{~km} /$ hour (18.5 mph) are rare.

Air stagnation is relatively common in eastern Tennessee (about twice as common as in western Tennessee, for example). An average of about two multiple-day air stagnation episodes occurs annually in eastern Tennessee, to cover an average of about 8 days per year. August, September, and October are the most likely months for air stagnation episodes.

\section{Precipitation}

The 40-year annual average precipitation is $137 \mathrm{~cm}$ (53.9 in.), including about $26 \mathrm{~cm}$ (10.4 in.) of snowfall. Precipitation in 1995 was $116.9 \mathrm{~cm}$ ( 48.7 in.), about $12.9 \mathrm{~cm}$ (5.1 in.) below the annual average. Precipitation in the region is greatest in the summer months (June through August), largely because of thunderstorm 
ORNL-DWG 87M-7054R4

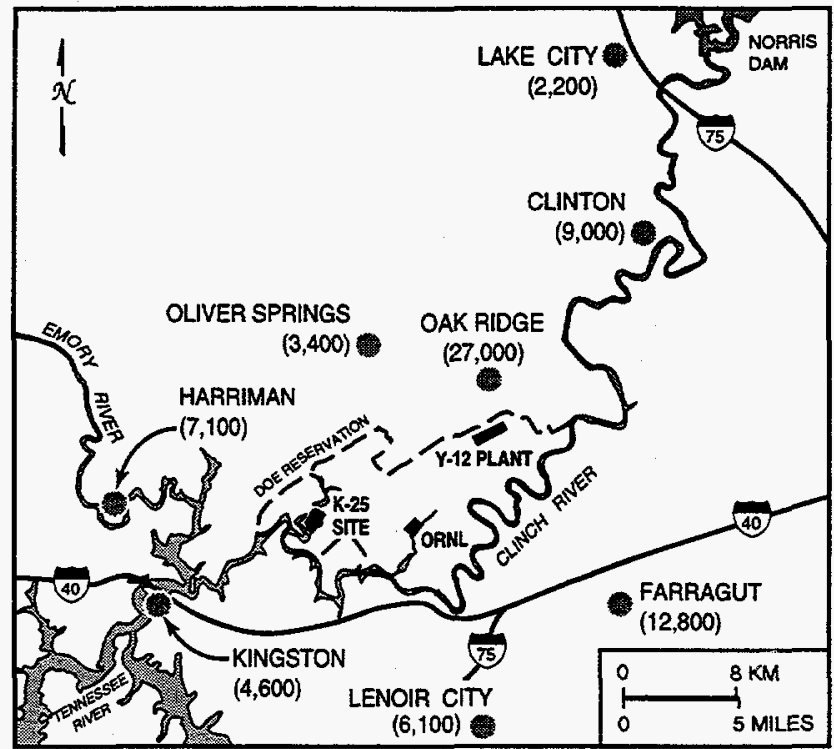

Fig. 1.4. Locations and populations of towns nearest to the Oak Ridge Reservation. (Population figures based on the 1990 U.S. census.)

activity. The driest periods generally occur during the fall months, when high-pressure systems are most frequent.

\section{Evapotranspiration}

Regionally, annual evapotranspiration has been estimated to range from 81 to $89 \mathrm{~cm}$ (32 to 35 in.), or 60 to $65 \%$ of rainfall (Farnsworth et al. 1982). Evapotranspiration in the Oak Ridge area is 74 to $76 \mathrm{~cm}$ (29 to $30 \mathrm{in}$.), or 55 to $56 \%$ of annual precipitation (TVA 1972, Moore 1988, and Hatcher et al. 1989). Evapotranspiration is greatest in association with the growing season, which in the vicinity of the ORP, is 220 days, from mid-March through mid October. During this period, evapotranspiration often exceeds the rate of precipitation, resulting in soil moisture deficits.

\section{DESCRIPTION OF SITE, FACILITIES, AND DPERATIONS}

The facilities on the ORR began operating in 1943 as part of the secret World War II Manhattan Project, producing components for the first nuclear weapons. The ORR continues to be a government-owned, contractor-operated facility, although the nature of the work has changed. The primary missions of the three sites have evolved during the past 50 years and continue to adapt to meet the changing defense and energy needs of the United States.

The reservation contains three major DOE installations: the Oak Ridge Y-12 Plant (Y-12 Plant), ORNL, and the Oak Ridge $\mathrm{K}-25$ Site (K-25 Site). The DOE buildings and structures located on the reservation but outside the major sites consist of the Oak Ridge Institute for Science and Education (ORISE) Scarboro Operations Site, Clark Center Recreational Park, the Central Training Facility, and the Transportation Safeguards maintenance facility.

The off-reservation DOE buildings and structures consist of the Federal Office Building, Office of Scientific and Technical Information, most of the ORISE offices and laboratories, the Atmospheric Turbulence and Diffusion Division of the Air Resources Laboratory [National Oceanic and Atmospheric Administration (NOAA)], the American Museum of Science and Energy, the Lockheed Martin Energy Systems (formerly Martin Marietta Energy Systems) administrative support office buildings, and the former museum building. In addition to

\section{1-4 Site and Operations Overview}




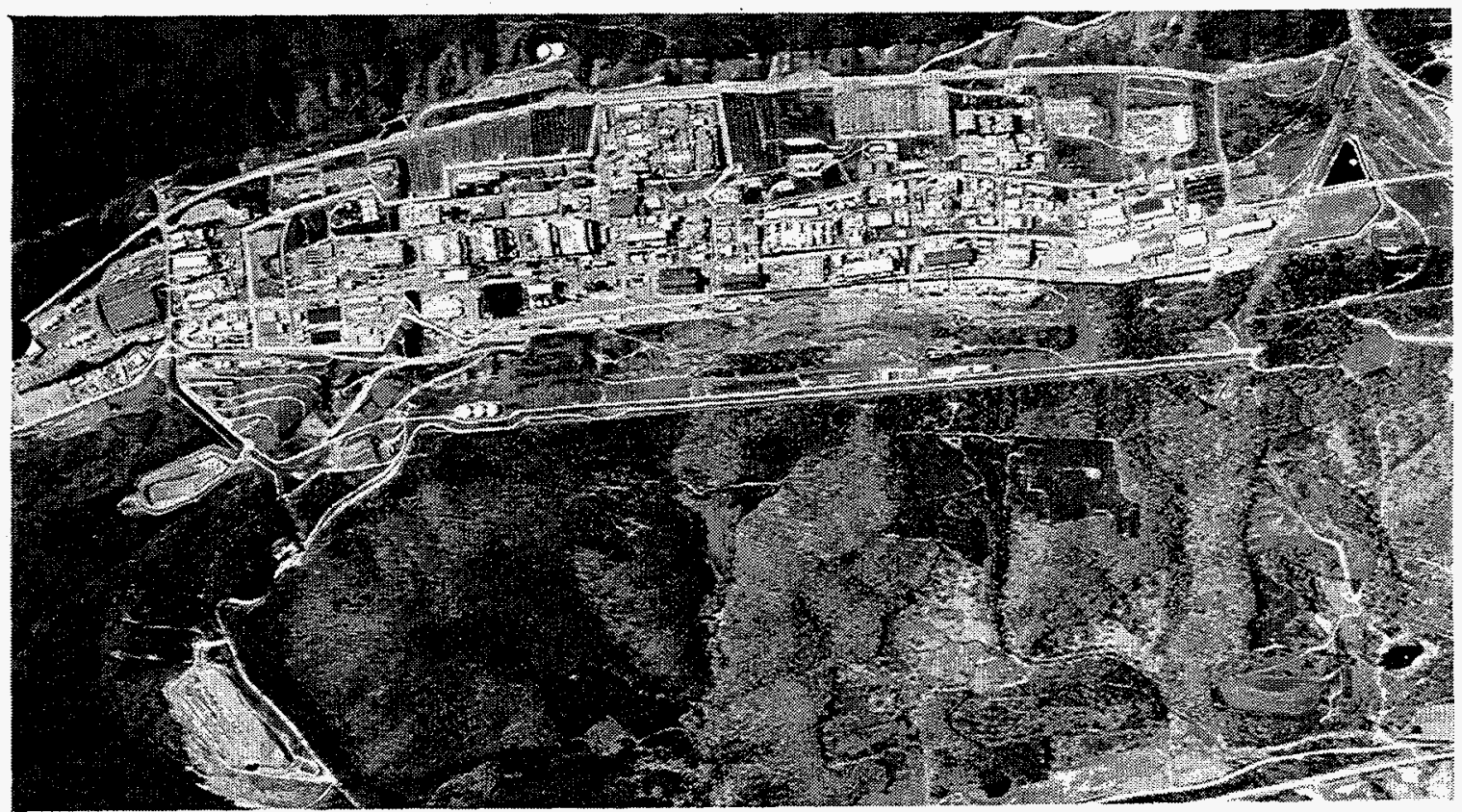

Fig. 1.5. The Oak Ridge Y-12 Plant.

government-owned property, there are numerous leased buildings housing about $7 \%$ of the government and contractor work force.

\section{Lockheed Martin Energy Systems}

On March 15, 1995, Lockheed and Martin Marietta completed a merger to create the Lockheed Martin Corporation. Following the merger, Martin Marietta Energy Systems, Inc., the prime contractor for the ORR, was renamed Lockheed Martin Energy Systems, Inc., (Energy Systems). In late 1995 Lockheed Martin Corporation organized into several business sectors, each of which focused on a particular aspect of the company's business. As a result the Energy and Environment Sector was formed. All of the company's DOE business became part of the sector.

On August 15, 1995, Lockheed Martin Corporation announced that ORNL would no longer be operated as part of the contract with the Y-12 Plant and the K-25 Site under Energy Systems. Instead, Lockheed Martin Energy Research Corporation (LMER) would be formed with the sole mission of operating ORNL for
DOE. On December 6, 1995, a contract was signed with DOE, effective January 1, 1996, that transferred the responsibility for operating ORNL from Energy Systems to the newly formed Lockheed Martin Energy Research Corporation.

During 1995 Energy Systems managed the Y-12 Plant, ORNL, and the K-25 Site as well as most of the other properties on the 14,049-ha $(34,700$-acre) reservation. In addition, it manages programs at both the Paducah, Kentucky, facility and the Portsmouth plant in Piketon, Ohio. Energy Systems carries out energy research and development (R\&D), production of enriched uranium and weapons components, and other goals of national importance.

For more information, visit the Energy Systems home page on the World-Wide Web (http://www.ornl.gov/mmes.html).

\section{Oak Ridge Y-12 Plant}

Until 1992 the primary mission of the Y-12 Plant was the production and fabrication of nuclear weapon components (Fig. 1.5). Activities associated with these functions included production of lithium compounds, 


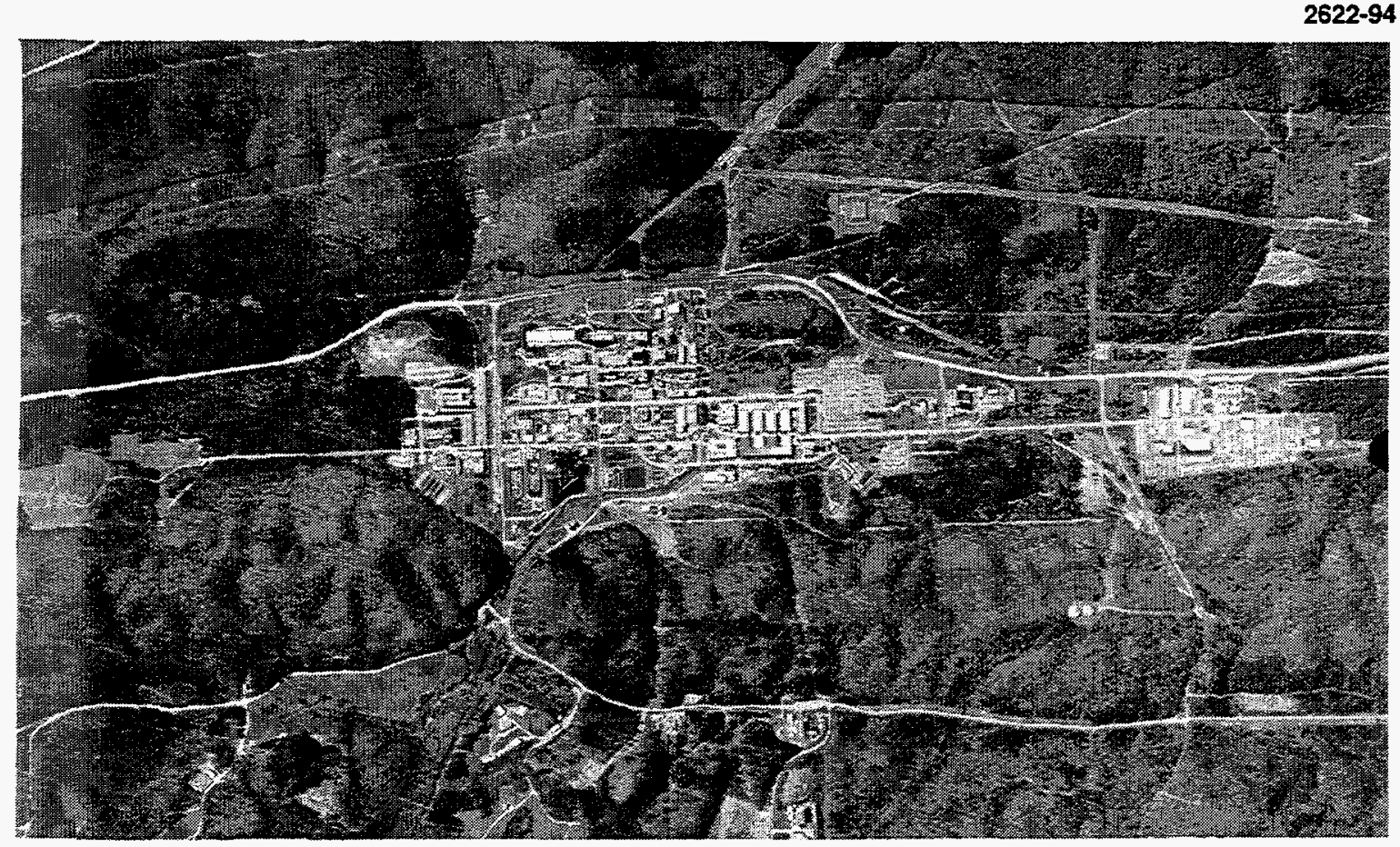

Fig. 1.6. The Oak Ridge National Laboratory.

recovery of enriched uranium from scrap material, and fabrication of uranium and other materials into finished parts. Fabrication operations included vacuum casting, arc melting, powder compaction, rolling, forming, heat treating, machining, inspection, and testing.

Current assignments in the $\mathrm{Y}-12$ Plant Defense Programs include dismantling nuclear. weapon components retumed from the national arsenal, serving as the nation's storehouse of special nuclear materials, and providing special production support to DOE programs. Another mission of long standing is the support of other federal agencies through the Work for Others Program. The technology transfer mission has as its goals to apply unique expertise, initially developed for highly specialized military purposes, to a wide range of manufacturing problems to support the capabilities of the U.S. industrial base. The all-inclusive expertise at the Y-12 Plant includes proceeding from concept, through detailed design and specification, to building prototypes and configuring integrated manufacturing processes.

The Oak Ridge Centers for Manufacturing Technology, located on the Y-12 Plant site, applies skills, capabilities, and facilities developed during the 50-year history of the Oak Ridge complex to a variety of peacetime missions. Major programs exist at the Y-12 Plant in metrology (measurement science), machine tool technology, technology applications, manufacturing operations, and gear and thread technology. Manufacturers nationwide can access information and services at the Y-12 Plant through a toll-free telephone service (1-800-356-4USA) that is a direct link to scientists, engineers, and other technical experts in the full range of manufacturing technologies.

For more information, visit the Y-12 Plant home page on the World-Wide Web (http://www.oml.gov/mmes-www/general/ OverviewY12.html).

\section{Oak Ridge National Laboratory}

ORNL, located toward the west end of Melton and Bethel valleys, is a large, multipurpose research laboratory, the primary mission of which is to expand knowledge, both basic and applied, in areas related to energy and the environment (Fig. 1.6). ORNL's facilities include a high-flux nuclear research reactor, 


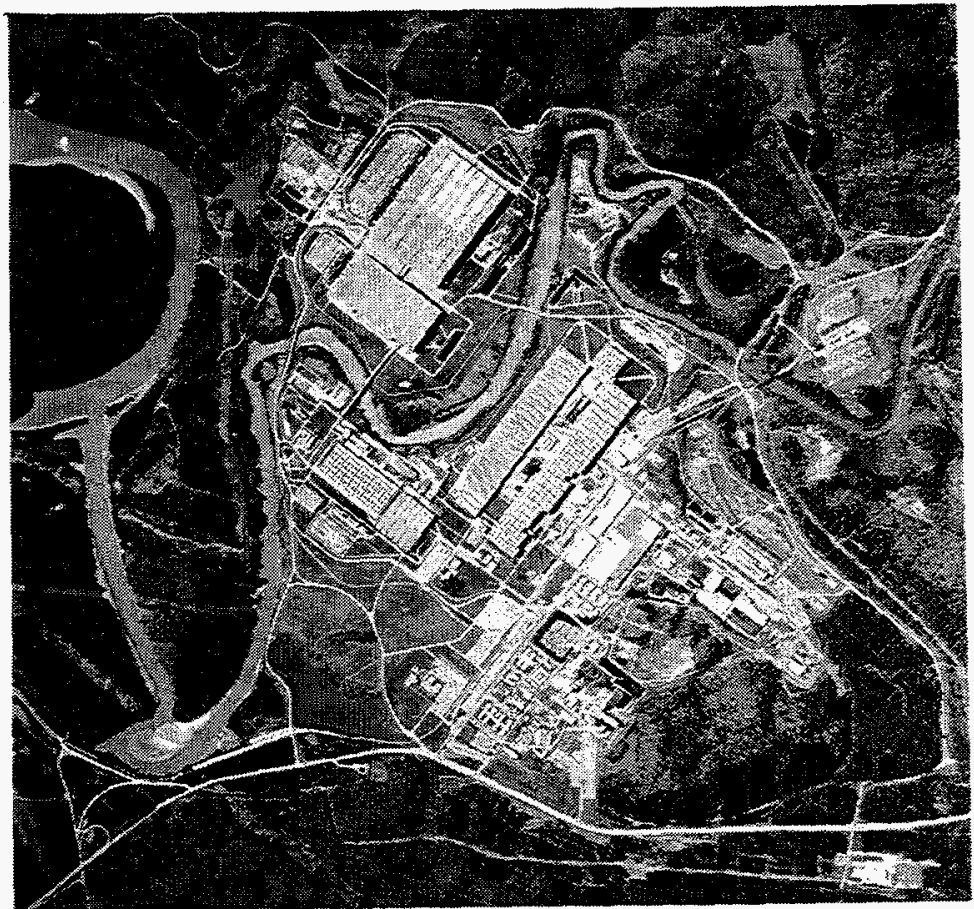

Fig. 1.7. The Oak Ridge K-25 Site.

chemical pilot plants, research laboratories, radioisotope production laboratories, accelerators, fusion test devices, and support facilities. In addition to the main ORNL complex, the Oak Ridge National Environmental Research Park is managed by ORNL.

For more information, visit the ORNL home page on the World-Wide Web (http://www.oml.gov).

\section{Oak Ridge K-25 Site}

The K-25 Site, formerly known as the Oak Ridge Gaseous Diffusion Plant, began operations in 1945 as part of the Manhattan Project (Fig. 1.7). The original mission was to separate the uranium-235 isotope for use in atomic weapons. In December 1987, DOE permanently shut down the gaseous diffusion processes, and the site was placed on the list of facilities slated for decontamination and decommissioning (D\&D).

Specific missions include management of the Toxic Substances Control Act (TSCA) Incinerator, which treats waste through thermal destruction, using a rotary kiln. In 1991, it became the first PCB-mixed-waste incinerator in the United States. Other missions include support of risk-based cleanup programs for all contaminated facilities and natural resources, safe and compliant waste management, development and demonstration of innovative environmental technologies, support of the Hazardous Waste Remedial Action Program (HAZWRAP), and provision of cost-effective support and services to $\mathrm{K}-25$ Site users.

The K-25 Site serves as home of DOE's centers for demonstration of advanced environmental technologies, $D \& D$, and waste management. The Demonstration Center for Environment and Waste Management Technology is bringing industry to a significant portion of the ORR by defederalizing the $\mathrm{K}-25$ Site. This privitization of land and facilities for economic development will attract new technical companies to the area for demonstration and certification of their effectiveness and access to the Oak Ridge scientific, technical, and manufacturing expertise. Several of the uniquely equipped laboratories 
and fabrication facilities at the K-25 Site will be leased by private companies.

For more information, visit the K-25 Site home page on the World-Wide Web (http://www.oml.gov/mmes-www/ERWM/ erwmout.html).

\section{Oak Ridge Institute for Science and Education}

ORISE is managed for DOE by Oak Ridge Associated Universities (ORAU), a nonprofit consortium of 89 colleges and universities. ORISE includes 65 ha (162 acres) on the southeastern border of the ORR that from the late 1940s to the mid-1980s was part of an agricultural experiment station owned by the federal government and, until 1981, was operated by The University of Tennessee.

The ORISE Scarboro Operations Site (formerly the South Campus) currently occupies about 65 ha (162 acres) and lies immediately southeast of the intersection of Bethel Valley Road and Pumphouse Road. It houses some of the offices and laboratories of one of ORISE's operating divisions, the Chemical Safety Building, and other support structures, and the site is being developed for other productive uses. ORISE received the DOE Pollution Prevention Award in 1994 for work in transforming three lagoons on the Scarboro Site into functional wetlands for the degradation of hazardous wastes into harmless constituents.

The Freels Bend tract, about 101 ha (250 acres) on the northeastern edge of Freels Bend abutting Melton Hill Lake, was transferred from ORISE to ORNL in late 1995 after removal of the six cobalt- 60 sources (total of $2200 \mathrm{Ci}$ ) from the Variable Dose Rate Irradiation Facility (VDRIF) by a private contractor for recycling.

For more information, visit the ORAU/ORISE home page on the World-Wide Web (http://www.orau.gov). 


\title{
2. Environmental Compliance
}

\begin{abstract}
It is the policy of the U.S Department of Energy Oak Ridge Operations Office to conduct its operations in compliance with federal, state, and local environmental protection laws, regulations, compliance agreements and decrees, settlement agreements, executive orders, DOE orders, and best management practices. The Department of Energy and its contractors make every effort to conduct operations in compliance with the letter and intent of applicable environmental statutes. The protection of the public, personnel, and the environment is of paramount importance.
\end{abstract}

\section{INTRODUCTION}

The ORR includes three sites managed for DOE by Lockheed Martin Energy Systems, Inc., a DOE prime contractor. The three sites include the Y-12 Plant, ORNL, and the K-25 Site. One tract on the ORR, the Scarboro Operations Site, is managed by ORISE. Johnson Controls World Services, Inc., serves as a DOE prime contractor for operation of the Oak Ridge water plant and for the maintenance and repair of construction equipment, automobiles, and trucks.

DOE's operations on the reservation are required to be in conformance with environmental criteria established by a number of federal and state statutes and regulations, executive orders, DOE orders, and compliance and settlement agreements.

Principal among the regulating agencies are the U.S. Environmental Protection Agency (EPA) and Tennessee Department of Environment and Conservation (TDEC). These agencies issue permits, review compliance reports, participate in joint monitoring programs, inspect facilities and operations, and oversee compliance with applicable regulations.

When ongoing self-assessments of compliance status identify environmental issues, the issues are discussed with the regulatory agencies in an effort to ensure that compliance with all environmental regulations will be attained. In the following sections, compliance status for the ORR sites with regard to major environmental statutes and DOE orders is summarized by topic.

\section{COMPLIANCE ACTIVITIES}

\section{Resource Conservation and Recovery Act}

The Resource Conservation and Recovery Act (RCRA) was passed in 1976 to address management of the country's huge volume of solid waste. The law requires that EPA regulate the management of hazardous waste, which includes waste solvents, batteries, and many other substances deemed potentially harmful to human health and to the environment. RCRA also regulates underground storage tanks (USTs) used for the storage of petroleum and hazardous substances.

Subtitle C of RCRA controls all aspects of the management of hazardous waste, from the point of generation to treatment, storage, and disposal (TSD). Hazardous waste generators must follow specific requirements for handling these wastes.

The Y-12 Plant, ORNL, and the K-25 Site are large-quantity generators. Each generate both RCRA hazardous waste and RCRA hazardous waste mixed with radionuclides (mixed waste). The hazardous and/or mixed wastes are accumulated by individual generators at locations referred to as satellite accumulation areas or 90-day accumulation areas, as appropriate, where they are picked up by waste management personnel and transported to a treatment, storage, or disposal facility. At the end of 1995, the Y-12 Plant had about 285 generator accumulation areas for hazardous or mixed waste, ORNL 
had about 350 , and the K-25 Site maintained 338 generator accumulation areas.

ORISE is classified under RCRA as a "conditionally exempt small-quantity generator." Its site accumulation area is located in the Chemical Safety Building on the Scarboro Operations Site.

The Central Training Facility, Bear Creek Valley Road, is also classified as a "conditionally exempt small-quantity generator." The Transportation Safeguards Division Garage, at present, is a small quantity generator. However, because of recycling efforts and product replacements, the reduction of hazardous waste generation at this facility should allow its reclassification to a "conditionally exempt small-quantity generator."

RCRA requires that owners and operators of hazardous waste management facilities have operating and/or postclosure care permits. The Y-12 Plant is registered as a large-quantity generator and a TSD facility under EPA ID Number TN3890090001. Most of the units at the Y-12 Plant are being operated under operating permits; however, several units still operate under interim-status regulations in accordance with a Part A permit application, the most recent version of which was approved in July 1991. Amended Part A permit applications were submitted to TDEC in December 1991, August 1993, July 1994, and September 1995 but have not yet been acted on. Six RCRA Part B permit applications have been submitted for 20 active storage and treatment units listed on the Part A permit application. Three of these Part B applications have been approved and issued as RCRA operating permits. The first permit (TNHW-032) was issued by the TDEC on September 30,1994, for the tank storage units, which include the following:

- the Building 9811-1 Tank Storage Unit (OD-7), in the western end of the Y-12 Plant;

- the Waste Oil/Solvent Storage Unit (OD-9), on Old Bear Creek Road; and

- the Liquid Organic Solvent Storage Unit (OD-10), in the Bear Creek Burial Grounds.
Permit TNHW-083 was issued by TDEC on September 28, 1995, for the container storage units, which include the following:

- Building 9201-4 Container Storage Unit,

- Building 9720-9 Container Storage Unit,

- Building 9720-25 Container Storage Unit,

- Building 9720-31 Container Storage Unit,

- Building 9720-58 Container Storage Unit,

- Building 9811-1 Container Storage Unit, and

- the Containerized Waste Storage Area (CWSA).

Three Class 1 permit modifications were submitted to the TDEC in 1995 for Permit TNHW-032. These modifications included updating the contingency plan, changing the name of the company to Lockheed Martin Energy Systems, Inc., updating maps and figures, and minor modifications to the language used in the permit. A Class 1a permit modification request was submitted in 1995 changing the inspection checklists and logs. This modification request was also approved by the TDEC in 1995.

Permit TNHW-084 was also issued by TDEC on September 28, 1995, for the production-associated units, which include the following:

- Building 9206,

- Building 9212,

- Building 9720-12, and

- the Cyanide Treatment and Storage Unit.

Five units at the Y-12 Plant remain as interim-status units. Eight wastewater treatment units operate in accordance with permit-by-rule regulations.

RCRA postclosure permit applications for the Y-12 Plant Kerr Hollow Quarry and New Hope Pond site were submitted to TDEC during 1995. (See the "RCRA/CERCLA Integration" section for additional information.)

ORNL is registered as a large-quantity generator and a TSD facility under EPA ID Number TN1890090003. Two additional ORNL facilities, the Walker Branch Watershed Laboratory and the White Oak Creek Embayment, were operated 
as small-quantity generators under EPA

ID Numbers TN8981800008 and TN8891800007

in previous years; however, in 1995 they did not generate any hazardous wastes.

ORNL's most recent Part A revision, dated August 9, 1995, included 36 units. During 1995, 25 units operated as interim-status or permitted units, and another 11 units were proposed (new construction). Construction began on three new storage units: 7668 for mixed wastes, 7883 for transuranic (TRU) mixed wastes, and 7572 for CH-TRU storage. On May 30, 1995, TDEC issued a RCRA permit (TNHW-010A) for eight units $(7507,7507 \mathrm{~W}, 7651,7653,7654,7668$, $7669,7934)$. Building 7652 continues to operate under the 1986 RCRA permit (TN1890090003 and HWSA-TN001). Tank 7830A received a RCRA permit on October 15, 1992 (TNHW-027).

Seven Class 1 permit modifications were submitted to TDEC in 1995: changing the name of the company from Martin Marietta Energy Systems, Inc., to LMES in three permits, adding newly listed wastes in three permits, and updating the waste analysis plan for the Tank 7830A permit. A Class 1a permit modification request was submitted in 1995 covering the leasing of 1000 acres of the ORR to the East Tennessee Economic Council. TDEC approved and issued the modification, but the modification was appealed by DOE and Energy Systems. The appeal is still pending. Class 2 modifications will be initiated in early 1996 for incorporating newly listed wastes in three permits.

The K-25 Site has received four RCRA permits. The $\mathrm{K}-1435 \mathrm{TSCA}$ Incinerator is a hazardous waste treatment unit operating under a RCRA permit (TNHW-15) issued byTDEC on September 28, 1987. Issuance of a revised RCRA permit based on trial burn results was received in December 1995. A second permit is for storage of waste at the incinerator. Two other permits cover storage in the former process building vaults.

1995 modifications to the K-25 Site RCRA permits included an update of contingency plan information, changes to the map of the site boundaries and portals, revisions to personnel training sections, removal of waste piles that had not been used to store waste, and submittal of as-built drawings and calculations for newly constructed units. In addition, modifications to permit management of newly listed wastes were submitted.

\section{RCRA Assessments, Closures, and Corrective Measures}

The Hazardous and Solid Waste Amendments (HSWA) to RCRA, passed in 1984, require any facility seeking a RCRA permit to identify, investigate, and (if necessary), clean up all former and current solid waste management units (SWMUs). The HSWA permit for the ORR was issued as an attachment to the RCRA permit for Building 7652 at ORNL. The HSWA permit addresses past, present, and future releases of hazardous constituents to the environment. Many HSWA permit requirements have now been integrated into the ORR federal facilities agreement (FFA). (See the "RCRAVCERCLA Integration" section for details.)

At the Y-12 Plant, 24 RCRA units have been certified closed by TDEC since the mid-1980s. Additional RCRA units requiring closure at the Y-12 Plant include the 9409-5 Tank Storage Unit, the northern section of the Interim Drum Yard, and the Uranium Treatment Unit. Regulatory approval of the closure plans for these units has been received, and closure has been initiated for each of these units. Closure of these units should be completed in CY 1996.

At ORNL, solid waste storage area SWSA 6 is currently undergoing RCRA/Comprehensive Environmental Response, Compensation, and Liability Act (CERCLA) closure. The revised closure plan for SWSA 6 was resubmitted to TDEC and EPA for formal review in July 1995. The revision focuses on the integration of CERCLA remediation processes while still addressing the RCRA closure requirements. On October 13, 1995, TDEC approved the Closure Plan for New Hydrofracture Surface Facility (Building 7860). Closure of the facility is nearing completion, and certification is expected by mid-1996. RCRA-mandated corrective actions continue under the CERCLA process. 
Table 2.1. RCRA and CERCLA corrective action processes

\begin{tabular}{|c|c|c|}
\hline RCRA & CERCLA & Purpose \\
\hline RCRA Facility Assessment & $\begin{array}{l}\text { Preliminary Assessment/Site Investiga- } \\
\text { tion }\end{array}$ & $\begin{array}{l}\text { Identify releases needing further investiga- } \\
\text { tions. }\end{array}$ \\
\hline RCRA Facility Investigation & Remedial Investigation & $\begin{array}{l}\text { Characterize nature, extent, and rate of con- } \\
\text { taminant releases. }\end{array}$ \\
\hline Corrective Measures Study & Feasibility Study & Evaluate and select remedy. \\
\hline $\begin{array}{l}\text { Corrective Measures Implementa- } \\
\text { tion }\end{array}$ & Remedial Design/Remedial Action & Design and implement chosen remedy. \\
\hline
\end{tabular}

Closure of the New Hydrofracture Surface Facilities, Building 7860 , is pending final approval of the closure plan. RCRA-mandated corrective actions continue under the CERCLA/FFA process.

At the K-25 Site, closure of the K-1413 unit was completed, and certification of closure was submitted to TDEC in July 1995.

\section{Land Disposal Restrictions}

The 1984 RCRA amendments established land disposal restrictions (LDRs), which prohibit the land disposal of untreated hazardous wastes. The amendments require that all untreated wastes meet treatment standards before land disposal or that they be disposed of in a land disposal unit from which there will be no migration of hazardous constituents for as long as the waste remains hazardous. These restrictions also prohibit storage of restricted hazardous or mixed waste except as necessary to facilitate recovery, treatment, or disposal.

Currently, with the exception of a few organic mixed wastes, the same restrictions apply to mixed wastes, which are composed of a mixture of radioactive and hazardous wastes. In June 1992, negotiation was completed on a federal facilities compliance agreement (FFCA) to resolve the compliance issue of storing restricted waste for a period longer than is necessary to facilitate recovery, treatment, or disposal. The agreement contained a compliance schedule for submittal of strategies and plans for treatment of the backlog of restricted waste through a variety of treatment options. Since then, the Federal Facilities Compliance Act has been passed by Congress to address the extended storage of mixed waste by DOE through agreement with host states. A Tennessee commissioner's order signed on September 26, 1995, culminated negotiations between DOE and the state and established a schedule for treatment and disposal of DOE's mixed waste at Oak Ridge Facilities.

\section{RCRA/CERCLA Integration}

The CERCLA and RCRA corrective action processes are similar. Each process has four steps with similar purposes (Table 2.1).

EPA, DOE, and TDEC have negotiated the ORR FFA to ensure that the environmental impacts associated with past and present activities at the ORR are thoroughly investigated and that appropriate remedial actions or corrective measures are taken as necessary to protect human health and the environment. This agreement established a procedural framework and schedule for developing, implementing, and monitoring response actions on the ORR in accordance with CERCLA. The ORR FFA is also intended to integrate the corrective action processes of RCRA and CERCLA.

For example, in April 1993, DOE, TDEC, and Energy Systems signed an agreed order regarding the RCRA postclosure permit for the S-3 Site at the Y-12 Plant, formally agreeing to proceed with CERCLA as the lead regulatory program and with RCRA as an applicable or relevant and appropriate requirement, to the extent that postclosure maintenance and care of former interim-status units will be conducted in compliance with the terms of RCRA postclosure permits. Groundwater monitoring will be integrated with CERCLA programs, and corrective actions will be deferred to CERCLA. Reporting of groundwater monitoring-data will 
comply with RCRA postclosure permit conditions as well as CERCLA requirements. The RCRA postclosure permit for units located in the Bear Creek Hydrogeologic Regime was modified effective September 12, 1995. This regime-wide permit now includes all units closed under RCRA in the western end of Bear Creek Valley (BCV).

TDEC issued a Class 3 modification to the Chestnut Ridge Hydrogeologic Regime RCRA postclosure permit effective September 19, 1995, and issued the final Chestnut Ridge Security Pits modification to the Chestnut Ridge Hydrogeologic Regime RCRA postclosure permit on March 8, 1996. The site is now under RCRA corrective-action monitoring and postclosure care and maintenance. In addition, TDEC issued the draft Kerr Hollow Quarry modification to the Chestnut Ridge Hydrogeologic Regime RCRA postclosure permit on March 26, 1996. Public notice of the proposed action and comment period was posted on March 29, 1996.

\section{Comprehensive Environmental Response, Compensation, and Liability Act}

CERCLA, also known as Superfund, was passed in 1980 and was amended in 1986 with passage of the Superfund Amendments and Reauthorization Act (SARA). Unlike the other basic regulatory programs summarized in this chapter [such as RCRA or the Clean Water Act (CWA)], CERCLA is a process to respond to environmental problems using other environmental laws and standards to guide the response action. Under CERCLA, abandoned or uncontrolled hazardous waste sites where a release has occurred or may occur are investigated, and a site is remediated if it poses significant risk to health or the environment. CERCLA requires that EPA place sites needing CERCLA response on the National Priorities List (NPL). The ORR was placed on the NPL in December 1989. In September 1995 DOE issued a revision to the Oak Ridge Reservation Site Management Plan for the Environmental Restoration Program (DOE 1995). The plan represents the DOE approach to satisfying the requirements of CERCLA under the FFA and completing the remediation of the ORR.

More than 200 potentially contaminated units have been identified at the Y-12 Plant, resulting from past operations and waste management practices. Many of these sites have been grouped into operable units (OUs) based on priority, common assessment, or potential remedial actions.

Field sampling activities were completed in the Bear Creek Hydrogeologic Regime during 1995 , and work was initiated on the remedial investigation and feasibility study reports. The draft remedial investigation report is scheduled to be issued for regulatory review in the fall of 1996.

A proposed plan and record of decision for Chestnut Ridge OU 2 were issued during 1995. The remedial action will include stabilizing an earthen dam that retains coal ash slurry generated at the Y-12 Plant, repair of the dam spillway, and relocation of a wetland that will be disrupted during construction.

CERCLA activities continued at ORNL during 1995. The postconstruction report for the waste area grouping (WAG) 5 Seep C and D removal action was completed and submitted to the regulators. Both seep collection and treatment systems continue to remove strontium-90 from groundwater emanating from WAG 5 at the designed treatment efficiency. The construction related to the WAG 1 , Corehole 8 Removal Action Project was completed during 1995, and collection of groundwater contaminated with strontium- 90 was initiated. The Gunite and Associated Tank CERCLA Treatability Study continued during the year. Two incentive task order projects involving CERCLA actions were initiated in 1995: Demolition of the Waste Evaporator Building (Building 3506) and the WAG 4 Seeps 4 and 6 Grouting Project. Planning was initiated concerning potential incentive task order projects to include the Gunite and Associated Tanks and the WAG 1 Surface Impoundments OU remedial investigation/feasibility study (RI/FS).

The Molten Salt Reactor Experiment (MSRE) removal action-Phase 1 was initiated and completed. Planning for future CERCLA 
actions continued for the MSRE. The WAG 5 remedial investigation was completed in 1995. CERCLA/RCRA integration at WAG 5 North was attempted with the submittal to TDEC of a revised closure plan for SWSA 6. In 1995 Environmental Restoration submitted a revision to the 1988 RCRA Closure Plan for SWSA 6 that proposed an integration of RCRA closure and CERCLA remedial action requirements. As of this writing, no response has been received from the TDEC. Plans to submit a WAG 6 postclosure permit application to TDEC were put on hold per TDEC's request. Background monitoring under the WAG 6 Environmental Monitoring Plan was completed during 1995 and routine monitoring was initiated. Planning continued and field work was initiated during the year with respect to the WAG 7 In Situ Vitrification Project.

There are approximately 190 potentially contaminated units at the K-25 Site, grouped into 12 areas of contamination, including groundwater. 1995 CERCLA activities involved the following actions:

- $\mathrm{K}-1070 \mathrm{C} / \mathrm{D}$ Feasibility Study (the eastern edge of the K-25 Site, composed of a 22-acre burial ground, three storage areas, and the K-1414 UST site);

- K-1070 SW31 Perennial Spring Remedial Action (downgradient of the $\mathrm{K}-1070 \mathrm{C} / \mathrm{D}$ Burial Ground);

- K-901-A Holding Pond and K-1007-P1 Pond Remedial Evaluation;

- K-25 Groundwater Unit, about 1200 acres, bounded on the south by Tennessee Highway 58 , on the east by Blair Road, on the north by Black Oak Ridge, and on the west by the Clinch River;

- K-1070-A Contaminated Burial Ground Remedial Investigation;

- K-25 Auxiliary Facilities (K-725, 724, 1131, 1410, and 1031) Assessment; and

- K-1407-B and K-1407-C Pond Remediation.

Contaminated water collected from the SW31 spring was transported to the Y-12 Plant's Groundwater Treatment Facility. Activity began in January 1994 as Phase I of the CERCLA remedial action. Phase II began in early 1995 and involves upgrading the K-25 Site Central Neutralization Facility (CNF) to treat the water. Completion of this project is anticipated during calendar year 1996.

The K-1407-B Holding Pond and K-1407-C Retention Basin were RCRA interim-status units until 1994, when closure plans for these units were approved, granting clean closure. Closure certification was received from TDEC in June 1994, and remediation began in July 1994. Remedial construction was completed in January 1995, when both units were filled and capped. These sites are now regulated exclusively by CERCLA.

The K-1070 C/D Burial Ground Feasibility Study was initiated during 1995 , with the completion scheduled for spring of 1996. Remediation is anticipated for the spring of 1997.

The K-25 Auxiliary Facilities Assessment commenced activities during the fall of 1995. The removal action is scheduled to commence in 1997 and consists of the demolition and removal of five buildings.

The K-901-A Holding Pond and K-1007-P1 Pond Remedial Evaluation was performed in 1995; the Remedial Site Evaluation Report for the K-901-A Holding Pond at the Oak Ridge K-25 Site, Oak Ridge, Tennessee (SAIC 1995) was published in September 1995 and updated in February 1996 (SAIC 1996a). It is anticipated that an Engineering Evaluation/Cost Analysis will be published addressing the contaminated silt in September 1996, with construction beginning in fiscal year (FY) 1997.

\section{Federal Facilities Compliance Act}

The Federal Facilities Compliance Act was signed on October 6, 1992, to bring federal facilities (including those under DOE) into full compliance with RCRA. The act waives the government's sovereign immunity, allowing fines and penalties to be imposed for RCRA violations at DOE facilities. In addition, the act requires that DOE facilities provide comprehensive data to EPA and state regulatory agencies on mixed-waste inventories, treatment capacities, and treatment plans for each site. The act

\section{2-6 Environmental Compliance}


ensures that the public will be informed of waste-treatment options and encourages active public participation in the decisions affecting federal facilities. TDEC is the authorized regulatory agency under the act for the DOE facilities in the state of Tennessee.

Site treatment plans are required for facilities at which DOE generates or stores mixed waste. The purpose of the proposed site treatment plan is to identify to TDEC the proposed options (treatment method, facility, and schedule) for treating mixed waste at the ORR. For some waste types, these options include continued waste characterization for treatment, development, and/or modification of treatment technologies. The proposed site treatment plan is also being provided to the EPA pursuant to the requirements contained in the ORR LDR FFCA and the Federal Facilities Compliance Act. To the extent possible, the proposed site treatment plan designates specific facilities for the treatment of mixed waste and proposes schedules as set forth in the Federal Facilities Compliance Act. If it is not possible to designate facilities or to adhere to schedules, the proposed site treatment plan provides schedules for alternative activities, such as waste characterization and technology assessment. The main treatment strategies are as follows:

- Existing and modified on-site facilities will be used to treat mixed waste when possible.

- Off-site DOE capacity will be used when available and appropriate.

- When available and technically appropriate (based on risk, cost, and schedule), commercial-sector resources will be used to treat mixed wastes. Waste types targeted for commercial treatment include inorganic sludges and soils.

- The minimum set of new on-site facilities will be built to treat those wastes for which commercial treatment is unavailable or unsuccessful.

- TRU mixed wastes will be treated only as necessary to meet the waste acceptance criteria of the Waste Isolation Pilot Plant (WIPP) in New Mexico.
The plan calls for mixed low-level waste on the ORR to be treated by a combination of commercial treatment capabilities and existing and modified on-site treatment facilities. Mixed TRU waste streams on the ORR, composed of both contact and remote-handled wastes, will be treated in the proposed Transuranic Processing Facility (TPF) only as necessary to meet the waste acceptance criteria for disposal at the WIPP. Nine existing on-site facilities will be used to treat inventoried mixed waste. Construction of one new major on-site facility (the TPF) is proposed for the ORR, as described in the plan. The final configuration of new on-site facilities for mixed low-level (radioactive) waste (LLW) streams will depend on the extent to which commercial resources are available.

The proposed site treatment plan was issued to TDEC on April 4, 1995. TDEC has reviewed and modified the proposed plan in accordance with Section 3021(b) 2 of RCRA. TDEC has issued a commissioner's order (effective October 1, 1995) which requires compliance with the approved plan.

The Site Treatment Plan (STP) provides overall schedules, milestones, and target dates for achieving compliance with LDR; a general framework for the establishment and review of milestones; and other provisions for implementing the STP that are enforceable under the commissioner's order.

Semiannual progress reports will document the quantity of LDR mixed waste in storage at the end of the previous 6-month period and the estimated quantity to be placed in storage for the next 5 fiscal years. Descriptions will be provided of (1) the progress for treatment of each waste stream during the previous 6-month period and (2) new treatment development. Additionally, the progress report will provide information such as addition or deletion of waste streams, funding activities, any changes in waste form or code, and any technology or capacity needs.

Annual updates of the STP may contain requests for approval of changes. The requests may include, as appropriate, (1) proposed revisions or conditionally approved revisions, (2) proposed new milestones, and (3) other changes to overall schedule. 
Table 2.2. ORR UST status, 1995

\begin{tabular}{lccc}
\hline & Y-12 Plant & ORNL & K-25 Site \\
\hline Active/in service & 4 & 10 & 5 \\
Closed & 40 & 42 & 12 \\
Hazardous substance & $3^{a}$ & 0 & $5^{b}$ \\
Upgraded & 0 & 3 & 0 \\
Known or suspected sites & 0 & 0 & 16 \\
Total & 47 & 55 & 38 \\
\hline
\end{tabular}

\footnotetext{
${ }^{a}$ Two USTs are deferred because they are regulated by the Atomic Energy Act of 1954. The third is a permanently closed methanol UST.

${ }^{b}$ Four USTs, one of which has been closed, were used to store natural gas odorant and are regulated under the Pipeline Safety Act. The fifth UST, designed as a spill-overfiow tank, has never been placed into service.
}

The STP will terminate when there is no longer any LDR mixed waste being stored on the $O R R$, regardless of when it was generated. In the absence of an STP, LDR mixed-waste storage would be in violation of RCRA Section 3004(j).

\section{Underground Storage Tanks}

UST Program personnel ensure that all active tank and piping systems are in compliance with applicable performance requirements (Subtitle I). These requirements apply to hardware and equipment installed for leak detection, corrosion protection, and spill/overfill prevention. New UST systems (installed after December 22, 1988) must have these features incorporated at the time of installation. Existing UST systems (installed before December 22, 1988) must be upgraded, either by replacement or retrofit, to meet these same performance requirements. UST systems that are not in compliance and will not be upgraded by December 22, 1998, must be permanently closed. Depending on the confirmation of a release, a UST closure can necessitate an environmental assessment of a particular site and a subsequent corrective action.

UST compliance also requires that a certain amount of documentation be maintained in the form of tank tightness records, tank repairs, and/or inventory control records. General operating requirements are outlined in the regulations and are incorporated into the applicable Energy Systems operating procedures. Table 2.2 presents the status of USTs on the ORR.

\section{National Environmental Policy Act}

The National Environmental Policy Act (NEPA) provides a means to evaluate the potential environmental impact of proposed federal activities and to examine alternatives to those actions. Table 2.3 notes the types of NEPA activities conducted at the ORR during 1995.

Energy Systems operates under a procedure that establishes administrative controls and provides requirements for project reviews and compliance with NEPA. Provisions apply (1) to the review of each proposed project, activity, or facility for its potential to result in significant impacts to the environment and

Table 2.3. NEPA activities during 1995

\begin{tabular}{lcccc}
\hline \multicolumn{1}{c}{ Types of NEPA documentation } & Y-12 Plant & ORNL & K-25 Site & ORISE \\
\hline Categorical exclusion (CX) recommendation & 1 & $20^{a}$ & 7 & 7 \\
CX granted & 1 & 6 & 7 & 51 \\
Approved under general CX documents & 50 & 30 & 0 \\
Environmental assessment & 2 & 7 & 0 \\
Special environmental analysis & 0 & 0 & 0 \\
Programmatic environmental assessment & 0 & 0 & 0 \\
Supplement analysis & 0 & $1^{b}$ & 0 \\
Environmental impact statement & 0 & 0 & 0 \\
Supplemental environmental impact statement & 0 & 0 & 0 \\
Programmatic environmental impact statement & 0 & $1^{c}$ & \\
\hline${ }^{a}$ Includes the submission of 14 revised five-site generic CXs that have not yet been approved by DOE-ORO. \\
${ }^{b}$ Prepared for Energy Systems Waste Management Organization (ESWMO). \\
${ }^{c}$ Coordinated review of draft Waste Management (WM) preliminary environmental impact statement for ESWMO.
\end{tabular}


(2) to the recommendation based on technical information of the appropriate level of NEPA documentation. The NEPA review process results in the preparation of NEPA documents and supporting information. Federal, state, and local environmental regulations and DOE orders applicable to the environmental resource areas must be considered when preparing NEPA documents. These environmental resource areas include air, surface water, groundwater, terrestrial and aquatic ecology, threatened and endangered species, land use, and environmentally sensitive areas. Environmentally sensitive areas include floodplains, wetlands, prime farm land, habitats for threatened and endangered species, historic properties, and archaeological sites. Each ORR site NEPA program also maintains compliance with NEPA through the use of its site-level administrative and operational procedures. These procedures assist in establishing effective and responsive communications with program managers and project engineers with the goal of establishing NEPA as a key consideration in the formative stages of project planning.

The Y-12 Plant received two approved environmental assessments (EAs): for the Interim Storage of Enriched Uranium Above Historical Level Project and the Hydrogen Fluoride Supply System for Building 9212 Project. These EAs were approved by issuance of "findings of no significant impact (FONSI)."

ORNL has prepared or supported the preparation of seven environmental assessments. Four of these have been approved and a FONSI issued. They include (1) Construction and Operation of Transuranic and Transuranic Mixed Waste Retrievable Storage Facilities, (2) Management of Spent Nuclear Fuel on the Oak Ridge Reservation, (3) Melton Valley Storage Tanks Capacity Increase Project, and (4) Lease of Parcel ED-1 of the ORR by the East Tennessee Council. The remaining three are in various stages of review and/or preparation. They include (1) Class III/IV Solid Low-Level Waste Storage Area 7; (2) Construction and Operation of the Center for Biological Sciences, Buildings 1010, 1011, and 1012; and (3) Proposed Changes to the Sanitary Sludge Land Application Program on the ORR.
National Historic Preservation Act

Section 106 of the National Historic Preservation Act (NHPA) requires that federal agencies to take into account the effects of their undertakings on properties included in or eligible for inclusion in the National Register of Historic Places (National Register). To comply with Section 106 of the NHPA, and its implementing regulations at $36 \mathrm{CFR} 800, \mathrm{DOE}-\mathrm{ORO}$ has seen to the ratification of a programmatic agreement among DOE-ORO, the Tennessee state historic preservation officer (SHPO), and the Advisory Council on Historic Preservation concerning management of historical and cultural properties on the ORR. The programmatic agreement, ratified on May 6,1994, outlines DOE-ORO's plan for the management of cultural and historical properties on the ORR. The programmatic agreement stipulates that DOE-ORO will prepare a cultural resource management plan (CRMP) for the ORR and will provide a draft of the CRMP to the Tennessee SHPO and Advisory Council on Historic Preservation within 24 months of the ratification of the agreement. The agreement also stipulates that DOE-ORO will conduct surveys to identify significant historical properties within the ORR. A draft outline of the CRMP has been completed and is currently being reviewed for submission to the SHPO.

Compliance with NHPA at ORNL, the Y-12 Plant, and the K-25 Site is achieved and maintained in conjunction with NEPA compliance. The scope of proposed actions is reviewed in accordance with the programmatic agreement and, if warranted, consultation is initiated with the SHPO and the Advisory Council on Historic Preservation, and the appropriate level of documentation is prepared and submitted. Because the programmatic agreement has improved project review efficiency and has caused a reduction in the number of projects requiring concurrence from SHPO and the advisory council, ORNL, the K-25 Site, and Y-12 Plant experienced a sharp decline in the number of archaeological/historical reviews required for submittal to the SHPO and the council; four reviews were prepared for submittal in 1995. 
A survey of the Y-12 Plant to identify sites eligible for the National Register was completed in 1995. In addition, the Y-12 Plant site archaeological survey is under way, scheduled for completion in 1996. Final reports for both surveys are expected by the end of 1996. ORR-wide surveys to identify and evaluate pre-World-War II structures and known archaeological sites for eligibility in the National Register were completed in 1995. Survey results will be incorporated into the CRMP.

A historical consultant acceptable to the Tennessee SHPO was contracted to conduct a survey of all ORISE structures in order to comply with the NHPA. Section 106 of the NHPA requires federal agencies to coordinate with the state and allow the SHPO to review proposed demolition projects and other activities adversely affecting existing structures. During the past 3 years, ORISE removed 40 surplus structures (some requiring decontamination) from the ORR. Two properties, the Freels Cabin and the Atmospheric Turbulence Diffusion Laboratory, were identified as previously included in the National Register of Historic Places (National Register). Management responsibilities for the Freels Cabin have since been transferred to LMER.

\section{Protection of Wetlands}

Executive Order 11990 (issued in 1977) was established to mitigate adverse effects to wetlands caused by destruction or modification of wetlands and to avoid new construction in wetlands wherever possible. Protective buffer zones and application of best management practices are required for activities on the ORR. Avoidance of these effects is ensured through implementation of the sensitive-resource analysis conducted as part of the NEPA review process. Coordination with the U.S. Army Corps of Engineers and TVA is necessary for activities in waters of the United States, which include wetlands and floodplains. This is also true for the state and waters of the state. Generally, this coordination results in permits from the Corps of Engineers, TVA, and/or the state.
The ORR implements protection of wetlands through the site NEPA program offices in accordance with 10 CFR 1022 , "Floodplain/Wetlands Environmental Review Requirements." Each of the sites has surveys for the presence of wetlands, and surveys are conducted on a project or program as-needed basis. Wetland surveys and delineations have been conducted on about 14,000 acres $(5,668 \mathrm{ha})$ of the 34,500 acres $(13,968 \mathrm{ha})$ that compose the reservation. About 800 acres ( $324 \mathrm{ha}$ ) of wetlands have been identified in the areas in which surveys have been conducted. Surveys for the remaining 20,500 acres $(8,300 \mathrm{ha})$ are planned to be conducted only as needed.

TDEC develops a regulatory position on impacted wetlands that includes mitigation; any affected wetlands must be replaced in area and function by newly constructed wetlands.

The Y-12 Plant has conducted two surveys of its wetlands resources. Identification and Characterization of Wetlands in the Bear Creek Watershed (Energy Systems 1993a) was completed in October 1993, and a wetland survey of selected areas in the Y-12 area of responsibility was completed in October 1994. The first report surveys the Y-12 Plant and surrounding areas; the second report surveys additional areas for which environmental restoration (ER) activities are planned.

The Y-12 Plant practices wetlands protection by requiring protective buffer zones and other best management practices whenever activities are proposed that may introduce a potential environmental impact. Wetlands protection, documentation, and reporting requirements are administered through the NEPA review and documentation process according to 10 CFR 1022.

In 1995 TDEC approved a wetlands mitigation plan for First Creek at ORNL in conjunction with a sediment-removal project on Melton Branch. The implementation date for the plan is March 1996. A wetlands survey of ORNL areas will be completed and published in 1996.

A partial wetlands survey for areas within the K-25 Site area of responsibility was conducted during the summer of 1994. 
Not all areas within the K-25 Site area of responsibility have been surveyed for wetlands, and it is likely that additional locations will be classified as wetlands. The wetlands that have been identified are protected by various best management practices.

\section{Floodplains Management}

Executive Order 11988 (issued in 1977) was established to require federal agencies to avoid to the extent possible adverse impacts associated with the occupancy and modification of floodplains and to avoid direct or indirect support of floodplain development wherever there is a practicable alternative. Agencies must determine whether a floodplain is present that may be affected by an action, assess the impacts on such, and consider alternatives to the action. The executive order requires that provisions for early public review and measures for minimizing harm be included in any plans for actions that might occur in the floodplain. Floodplain assessments and the associated notices of involvement and statement of findings are prepared in accordance with 10 CFR 1022, as part of the NEPA review and documentation process.

\section{Plant and Animal Species of Concern}

Good stewardship as well as state and federal laws dictate that animal and plant species of concern be considered when a proposed project has the potential to alter their habitat or otherwise harm them. At the federal level, such species are classified as endangered, threatened, or species of concern; at the state level, species are considered endangered, threatened, or special concern (plants)/in-need-of-management (animals). All such species are termed threatened and endangered (T\&E) species in this report

\section{Threatened and Endangered Animals}

Listed animal species known to be currently present on the reservation (excluding the Clinch River bordering the reservation) are given along with their status in Table 2.4. Other listed species may also be present, although they have not been observed recently. These include several species of mollusks (such as the spiny riversnail), amphibians (such as the hellbender), birds (such as Bachman's sparrow), and mammals (such as the smoky shrew). In particular, the reservation has not been sampled extensively for the several listed bat and amphibian species that may be present. The only federally listed animal species that have been recently observed (the gray bat, bald eagle, and peregrine falcon) are represented by one to several migratory or transient individuals rather than by permanent residents, although this situation may change as these species continue to recover. Similarly, several state-listed bird species, such as the anhinga, olive-sided flycatcher, sandhill crane, double-crested cormorant, and little blue heron are currently uncommon migrants or visitors to the reservation. Others, such as the cerulean warbler, northern harrier, great egret, and yellow-bellied sapsucker, are common migrants or winter residents that do not nest on the reservation.

\section{Threatened and Endangered Plants}

No federally listed plant species are currently known to occur on the ORR. Twenty-four plant species currently known to occur on the ORR are listed by the state of Tennessee, including the fen orchid, pink lady's slipper, and Canada lily (Table 2.5). Four species (spreading false foxglove, Appalachian bugbane, tall larkspur, and butternut) have been under review for listing at the federal level and were listed under the formerly used " $\mathrm{C} 2$ " candidate designation. Current information is insufficient to determine whether these species may be appropriate for federal listing.

Whorled mountain mint is found on the ORR, but its taxonomy is uncertain. A species of Pycnathemum, it is believed to be either Pycnathemum verticillatum or Pycnathemum torrei. If the presence of either were confirmed, it would be listed by the state. Two additional species listed by the state, Lilium michiganense and Carex oxylepis (var. pubescens), were identified in the past on the ORR; however, they have not been found in recent years. Several state-listed plant species currently found on 
Table 2.4. Animal species of concern reported from the Oak Ridge Reservation ${ }^{a}$

\begin{tabular}{|c|c|c|c|}
\hline \multirow[t]{2}{*}{ Species } & \multirow[t]{2}{*}{ Common name } & \multicolumn{2}{|c|}{ Legal status $^{b}$} \\
\hline & & Federal & State \\
\hline \multicolumn{4}{|c|}{ Fish } \\
\hline Phoxinus tennesseensis & Tennessee dace & & NM \\
\hline \multicolumn{4}{|c|}{ Amphibians and reptiles } \\
\hline Hemidactylium scutatum & Four-toed salamander & & NM \\
\hline \multicolumn{4}{|c|}{ Birds } \\
\hline Haliaeetus leucocephalus & Bald eagle & $\mathbf{T}$ & $T$ \\
\hline Falco peregrinus & Peregrine falcon & $\mathbf{T}$ & $\mathrm{E}$. \\
\hline Dendroica cerulea & Cerulean warbler & $\mathrm{C}$ & \\
\hline Pandion haliaetus & Osprey & & $\mathrm{T}$ \\
\hline Ammodramus savannarum & Grasshopper sparrow & & NM \\
\hline Accipiter striatus & Sharp-shinned hawk & & NM \\
\hline Accipiter cooperii & Cooper's hawk & & NM \\
\hline Circus cyaneus & Northem harrier & & NM \\
\hline Anhinga anhinga & Anhinga & & NM \\
\hline Casmerodius alba & Great egret & & NM \\
\hline Leucophoyx thula & Snowy egret & & NM \\
\hline Contopus borealis & Olive-sided flycatcher & & NM \\
\hline Grus canadensis & Sandhill crane & & NM \\
\hline Lanium ludovicianus & Loggerhead shrike & & NM \\
\hline Phalacrocorax auritus & Double-breasted cormorant & & NM \\
\hline Sphyrapicus varius & Yellow-bellied sapsucker & & NM \\
\hline Egretta caerulea & Little blue heron & & NM \\
\hline \multicolumn{4}{|c|}{ Mammals } \\
\hline Myotis grisescens & Gray bat & $E$ & $\mathrm{E}$ \\
\hline Sorex longirostris & Southeastern shrew & & NM \\
\hline
\end{tabular}

adjacent lands may be present on the ORR as well, although they have not been located.

\section{Environmental Justice}

On February 11, 1994, President Clinton promulgated Executive Order 12898, "Federal Actions To Address Environmental Justice in Minority Populations and Low-Income Populations." The executive order requires that federal actions not have the effect of excluding, denying, or discriminating on the basis of race, color, national origin, or income level. DOE and Energy Systems are continuing to work with EPA and other stakeholders to ensure that environmental justice issues are addressed when federal actions are taken on the ORR.

\section{Safe Drinking Water Act}

The Safe Drinking Water Act (SDWA) of 1974 is an environmental statute for the protection of drinking-water sources. The act requires EPA to establish primary drinking water regulations for contaminants that may cause adverse public health effects. Although many of the requirements of the SDWA apply to public water supply systems, Section 1447 states that each federal agency having jurisdiction over a federally owned or maintained public water system must comply with all federal, state, and local requirements regarding the provision of safe drinking water. Because the systems that supply drinking water to the ORR are DOE-owned, the requirements of Section 1447 apply. A second provision of the SDWA requires individual states 
Table 2.5. Plant species found on the Oak Ridge Reservation and listed by state of Tennessee or federal agencies, $1995^{a}$

\begin{tabular}{|c|c|c|c|}
\hline Species & Common name & Habitat on the ORR & Status \\
\hline Aureolaria patula & Spreading false-foxglove & River bluff & $b, c$ \\
\hline Carex gravida & Heavy sedge & Varied & $d$ \\
\hline Carex howei & Howe sedge & Wetland & $\boldsymbol{e}$ \\
\hline Cimicifuga rubifolia & Appalachian bugbane & River slope & $b, e$ \\
\hline Cypripedium acaule & Pink lady-slipper & Dry to rich woods & $f$ \\
\hline Delphinium exaltatum & Tall larkspur & Barrens and woods & $b, c$ \\
\hline Diervilla lonicera & Northern bush-honeysuckle & River bluff & $e$ \\
\hline Draba ramosissima & Branching whitlow-grass & Limestone cliff & $f$ \\
\hline Elodia nuttalii & Nuttall waterweed & Pond, embayment & $f$ \\
\hline Fothergilla major & Mountain witch-alder & Woods & $e$ \\
\hline Hydrastis canadensis & Golden seal & Rich woods & $e$ \\
\hline Juglans cinerea & Butternut & Slope near stream & $b, e$ \\
\hline Juncus brachycephalus & Small-head rush & Wetland & $f$ \\
\hline Lillium canadense & Canada lily & Moist woods & $e$ \\
\hline Liparis loeselli & Fen orchid & Forested wetland & $c$ \\
\hline Panax quinquifolius & Ginseng & Rich woods & $e$ \\
\hline Platanthera flava (var. herbiola) & Tuberculed rein-orchid & Forested wetland & $e$ \\
\hline Platanthera peramoena & Purple fringeless orchid & Wet meadow & $e$ \\
\hline Pycnanthemum verticillatum & Whorled Mountain-mint & Barrens, wet meadows & $c$ \\
\hline Rhynchospora colorata & White-topped sedge & Rocky edge of pond & $f$ \\
\hline Ruellia purshiana & Pursh's wild-petunia & Dry, open woods & $f$ \\
\hline Saxifraga careyana & Carey saxifrage & River bluff, sinkhole & $f$ \\
\hline Scirpus fluviatilis & River bulrush & Wetland & $f$ \\
\hline Spiranthes lucida & Shining ladies'-tresses & Wetland & $e$ \\
\hline Spiranthes ovalis & Lesser ladies'-tresses & Moist to dry woods & $f$ \\
\hline Viola tripartita (var. tripartita) & Three-parted violet & Rocky woods & $f$ \\
\hline
\end{tabular}

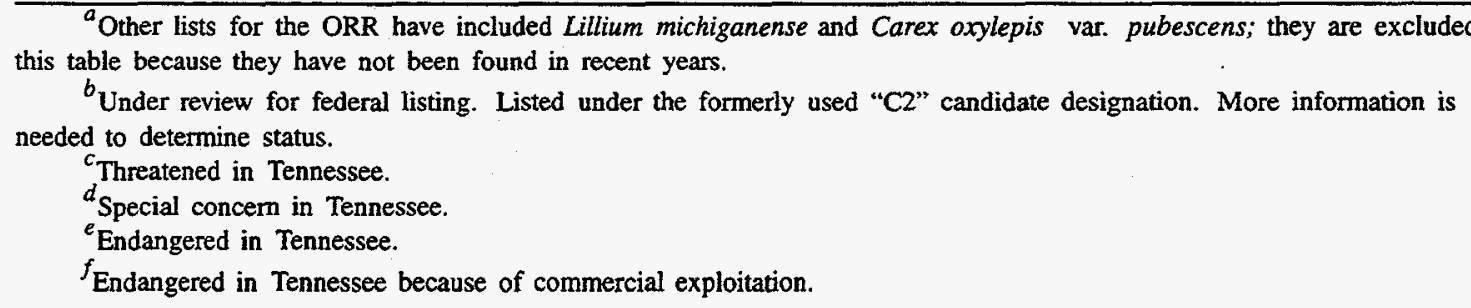

to establish programs to prevent contamination of underground sources of drinking water by underground injection of hazardous waste.

Potable water for the city of Oak Ridge, the Y-12 Plant, and ORNL is received from a DOE-owned water-treatment facility located northeast of the Y-12 Plant and currently managed by Johnson Controls World Services, Inc. Both ORNL and the Y-12 Plant are designated as non-transient, non-community water-distribution systems by the TDEC Division of Water Supply and are subject to the Tennessee Regulations for Public Water Systems and Drinking Water Quality, Chapter 1200-5-1. Under the TDEC regulations, distribution systems that do not perform water treatment can use the records sent to the state by the water treatment facility from which water is received to meet applicable compliance requirements. In 1995, the DOE water treatment plant met all of the Tennessee radiological and nonradiological standards.

ORNL's water system, which is sampled and analyzed annually, met the lead and copper action-level standards during the last 4 years.

The K-1515 Sanitary Water Plant provides drinking water for the K-25 Site and for an industrial park located on Bear Creek Road south of the site. The DOE-owned facility is classified as a non-transient, non-community water-supply system by TDEC and is subject to state regulations. The plant is in compliance with 

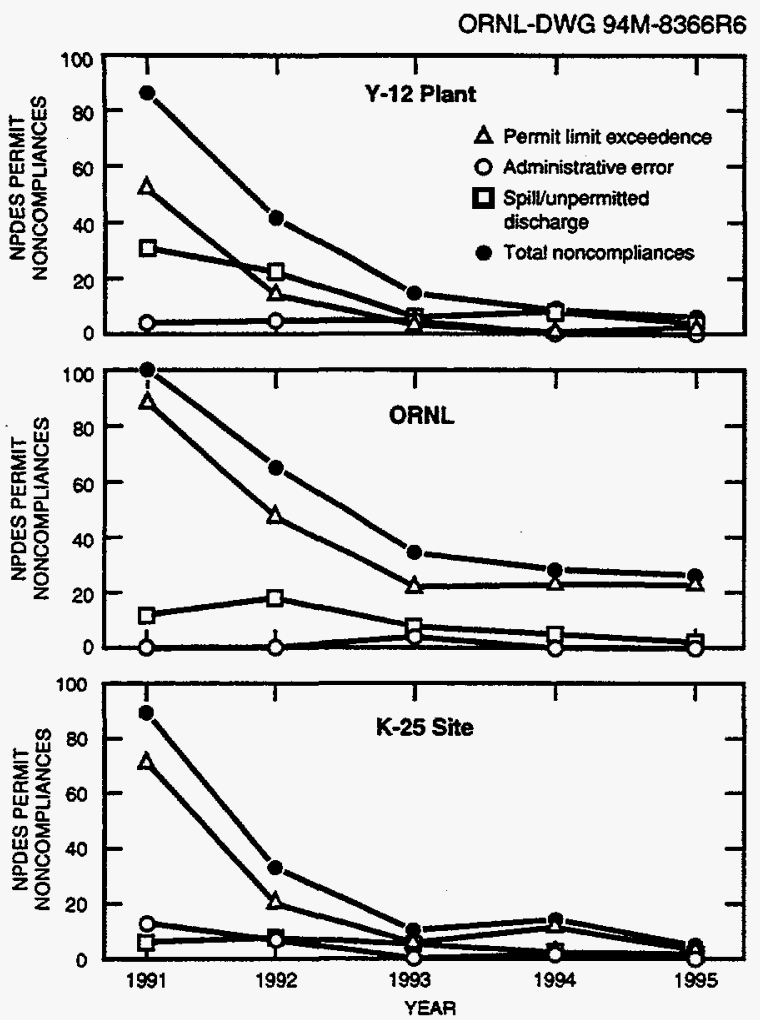

Fig. 2.1. Five-year summary of NPDES noncompliances.

the drinking-water quality standards; monthly and quarterly testing for required constituents is carried out and reported to TDEC. Requirements of the lead and copper rule have been met, and the plant has been granted approval to reduce monitoring for these constituents to once per year.

A cross-contamination control program implemented at the Y-12 Plant, ORNL, and the $\mathrm{K}-25$ Site prevents and eliminates cross-connects of sanitary water with process water and utilizes back-flow prevention devices and an engineering review and permitting process. As part of the program, an inventory of installed back-flow prevention devices is maintained, and inspection and maintenance of the devices are conducted in accordance with regulatory requirements.

\section{Clean Water Act}

The CWA was originally enacted as the Water Pollution Control Act in 1948, then later established as the Federal Water Pollution Control Act in 1972. Since that time the CWA has been subject to two major amendments. The objective of the CWA is to restore and maintain the chemical, physical, and biological integrity of the nation's waters. With continued amendments, the CWA has established a comprehensive federal and state program to protect the nation's waters from pollutants. A third round of amendments is being considered by Congress.

\section{National Pollutant Discharge Elimination System}

One of the strategies developed to achieve the goals of the CWA was the establishment by the EPA of specific pollutant limits that are allowed to be discharged to waters of the United States by municipal sewage treatment plants and industrial facilities. In 1972, the EPA established the National Pollutant Discharge Elimination System (NPDES) permitting program to regulate compliance with these pollutant limitations. The program was designed to protect surface waters by limiting effluent discharges into streams, reservoirs, wetlands, and other surface waters.

The Y-12 Plant NPDES permit encompasses approximately 100 active point-source discharges requiring compliance monitoring that resulted in about 10,000 laboratory analyses in 1995, in addition to numerous field observations. The number of outfalls continues to decline as they are consolidated or eliminated. Although releases that exceed the NPDES permit levels and spills to the environment occur, considerable progress was made in 1995 to minimize such releases and their effect on receiving streams. Monitoring of discharges demonstrates that the Y-12 Plant has achieved an NPDES permit compliance rate of more than 99\%; biological monitoring programs conducted on nearby surface streams provide evidence of the ecological recovery of the streams. At the Y-12 Plant there were 6 NPDES noncompliances in 1995, compared with 11 in 1994 (Fig. 2.1). Only two of the noncompliances during 1995 were because of events that exceeded the wastewater discharge limits.

The ORNL NPDES permit, issued in 1986, lists 161 point-source discharges that require compliance monitoring. Approximately 100 of

\section{2-14 Environmental Compliance}


these are storm drains, roof drains, and parking lot drains. Runoff from storm and parking lot drains has resulted in NPDES permit effluent limits for oil and grease and total suspended solids being exceeded. Progress continues toward minimizing or eliminating these noncompliances (Fig. 2.1). Compliance was determined by approximately 18,000 laboratory analyses and measurements in 1995 in addition to numerous field observations by ORNL field technicians. The NPDES permit limit compliance rate for all discharge points for 1995 was greater than $99 \%$. About $80 \%$ of ORNL's permit noncompliances for 1995 were for suspended solids in storm water runoff.

The K-25 Site NPDES permit includes five major outfalls and 137 storm drain outfalls. One storm drain outfall was removed from the permit during 1995, and five storm drain outfalls were added. From about 35,000 NPDES laboratory and field measurements completed in 1995, only 5 noncompliances occurred (compared with 16 in 1994), indicating a compliance rate of more than 99\% (Fig. 2.1).

\section{Status of NPDES Permits}

TDEC issued a new NPDES permit for the Y-12 Plant on April 28, 1995; it became effective on July 1 . The previous Y-12 Plant NPDES permit (TN0002968) expired on May 23, 1990. The plant continued to operate through the first half of 1995 under the expired permit pending issuance of a new permit by TDEC, as provided in Tennessee Regulation 1200-4-1.05(5)(b). In May, the Y-12 Plant appealed two provisions of the permit: the biomonitoring limitations placed on East Fork Poplar Creek (EFPC) Outfall Point 201 and the mercury limitations at Monitoring Station 17. These limits are stayed while resolution of both issues is being sought by personnel from the Y-12 Plant and TDEC. The new permit addresses revisions that were in the renewal application, such as some previously unlisted miscellaneous outfalls. In addition, it requires that storm water characterizations be made at selected monitoring locations in accordance with the Y-12 Plant Storm Water Pollution Prevention Plan, which was submitted to TDEC during 1995. Other documents submitted to TDEC in accordance to the new NPDES permit include the revised Radiological Monitoring Plan, the Biological Monitoring and Abatement Program (BMAP) Plan, and a report on the analysis of fecal coliform bacteria levels at selected storm water monitoring points.

ORNL is currently operating under NPDES Permit 0002941 , issued by TDEC and EPA Region 4 on April 1, 1986. The permit expired on March 31, 1991. An application for renewal was submitted to TDEC on September 28, 1990. ORNL submitted a separate, individual NPDES storm water application in October 1992. Negotiations toward a new permit were initiated in 1993 and were continued in 1994 and 1995. It is anticipated that a new permit will be issued in the fourth quarter of 1996.

The K-25 Site is operating under NPDES Permit TN0002950, issued with an effective date of October 1, 1992. A major permit modification became effective June 1, 1995. As required by the permit, a Storm Water Pollution Prevention Plan was completed by October 1993. This plan (1) identifies areas having the potential to discharge pollutants to the receiving waters, (2) includes a pollutant control strategy to identify actions to minimize discharges of pollutants, and (3) outlines the development of annual sampling and analysis plans. Sampling as outlined in the FY 1995 Storm Water Pollution Prevention Sampling and Analysis Plan was initiated during the fourth quarter of 1994 and was completed in 1995. An evaluation of FY 1995 results was used to determine the scope of the FY 1996 Storm Water Pollution Prevention Sampling and Analysis Plan.

\section{Sanitary Wastewater}

The CWA includes pretreatment regulations for publicly owned treatment works (POTW). Sanitary wastewater for the Y-12 Plant is discharged to the city of Oak Ridge under an industrial and commercial user permit. The city of Oak Ridge staff performed their annual sanitary sewer compliance inspection on March 14, 1995, and October 16, 1995. No deficiencies of the Y-12 Plant Sanitary Sewer 
Compliance Program were noted during the inspections.

During 1995 the Y-12 Plant experienced violations of the current discharge permit. Samples obtained at the compliance point for the Y-12 Plant exceeded permit limits for oil and grease, iron, cyanide, copper, mercury, and lead. All of these incidents occurred as a result of maintenance and construction activities involving the sanitary sewer system at the Y-12 Plant. The Y-12 Plant sanitary sewer system is more than 50 years old and has received only minor maintenance upkeep during this period; therefore, it needs major rehabilitation. A multimillion dollar sanitary sewer upgrade project has been initiated and is currently in the design stage. Construction activities are expected to begin in early FY 1997 and last through FY 1998.

The city of Oak Ridge has delayed issuance of a new discharge permit for the Y-12 Plant until the state of Tennessee issues an NPDES permit for the Oak Ridge Wastewater Treatment Plant. The current discharge permit for the Y-12 Plant has been extended through January 1997.

Sanitary sewer radiological sample results at the Y-12 Plant are routinely reviewed to ensure compliance with DOE Order 5400.5. As sample results are received they are compared with the derived concentration guides (DCGs) listed in the order. No radiological parameter that is monitored (including uranium) has exceeded a DCG. Typically, the results are three orders of magnitude below DCG limits.

At ORNL, sanitary wastewater is collected, treated, and discharged separately from other liquid wastewater streams through an on-site package sewage treatment plant. Wastewater discharged into this system is regulated by means of internally administered waste acceptance criteria based on the plant's NPDES operating permit parameters. Wastewater streams currently processed through the plant include sanitary sewage from facilities in Bethel and Melton valleys, area runoff of rainwater that infiltrates the system, and point sources such as biodegradable laboratory wastes and biodegradable scintillation fluids. The effluent stream from the sewage treatment plant is ultimately discharged into White Oak Creek (WOC) through an NPDES-permitted outfall (X-01). Infiltration into the system and the discharge from the on-site laundry has, at times, caused the sludge generated during the treatment process to become slightly radioactive. As a result, the sludge is treated as solid LLW and is disposed of in ORNL SWSAs. ORNL has received funding and is carrying out comprehensive upgrades of its sanitary sewage system. Upgrades include sealing the collection system to prevent infiltration of contaminated groundwater and surface water and redirecting contaminated discharges from the laundry to appropriate alternative treatment facilities.

$\mathrm{K}-25$ Site domestic wastewater is treated at the K-1203 Sewage Treatment Plant and discharged pursuant to the NPDES permit. A sewer use ordinance and an influent surveillance program are in effect to ensure that effluent from the K-1203 sewage treatment plant continues to meet all NPDES permit limits. The sewer lines are currently being relined and repaired to reduce rainwater infiltration. The project is scheduled to be completed during 1996.

\section{Aquatic Resources Protection}

The U.S. Army Corps of Engineers, TVA, and TDEC conduct permitting programs for projects and activities with the potential to affect aquatic resources, including navigable waters, surface waters (including tributaries), and wetlands. These are the Corps of Engineers Section 404 dredge-and-fill permits, TDEC Aquatic Resources Alteration Permits (ARAPs), and TVA 26a approvals. (See "Environmental Permits" section for ARAP permits.)

\section{Oil Pollution Prevention}

Section 311 of the CWA regulates the discharges of oils or petroleum products to waters of the United States and requires the development and implementation of a Spill Prevention Control and Countermeasures Plan (SPCC) to minimize the potential for oil discharges. Currently, each facility implements a site-specific SPCC plan. This section was then significantly amended by the Oil Pollution Act of 1990, which has as its

\section{2-16 Environmental Compliance}


primary objective the improvement of responses to oil spills.

The Oil Pollution Act requires certain facilities to prepare and implement a facility response plan for responding to a worst-case discharge of oil. The K-25 Site is subject to the requirements for preparing such a plan because of its oil storage capacity and location. An updated plan was submitted to the EPA on February 17, 1995. The plan includes designation of response personnel, description of response equipment, identification of the worst-case discharge scenario and associated response actions, personnel training requirements, testing and inspection requirements, and other oil spill-prevention and response measures. No facility response plan was required for the Y-12 Plant or ORNL.

\section{Clean Air Act}

Authority for enforcement of the Clean Air Act (CAA) is shared between TDEC for nonradioactive emission sources and EPA for radioactive emission sources. EPA also enforces rules issued pursuant to the $1990 \mathrm{CAA}$ Amendment, Title VI-Stratospheric Ozone Protection.

\section{General CAA Compliance}

CAA compliance is an integral part of the TDEC air permit program, in which all three ORR facilities participate. Each site complies with all federal air regulations in addition to any air-permit conditions. Hoods at ORISE facilities are exempt from permitting requirements under the ORR laboratory equipment exemption and TDEC approval for exempt sources that handle negligible quantities of carcinogens and radiological materials.

The CAA program staff routinely participate in both inspections and internal audits to identify areas for improvement in the operation of air sources as required by regulation or permit condition. Major sources are appropriately permitted, and documentation of compliance is developed. A number of minor sources that are exempt from permitting requirements under state of Tennessee rules are documented for internal purposes as well. All major emission sources are permitted by TDEC and are operating in compliance with those permits. The programs for permitting, compliance inspection, and documentation of compliance are in place.

\section{Compliance with 1990 CAA Amendments}

An increasing number of the new CAA amendment rules have application at all three ORR facilities. Regarding Title VI-Stratospheric Ozone Protection, compliance activities have included compliance with the final refrigerant-recycling rules that require the purchase and use of certified refrigerant recovery and recycling equipment. EPA granted a provision that allows removal of leaking refrigerant systems instead of retrofitting or replacing them, as had been required. The EPA provision came in response to comments from DOE-ORO concerning EPA rules. This additional provision to the refrigerant-leak repair rules will allow avoiding unnecessary repairs to equipment. Compliance requirements for refrigeration-system and motor vehicle air-conditioner maintenance are being met. Recommendations were made for refrigeration-system replacements or performing the necessary modifications to plant refrigeration equipment to accommodate the production ban on ozone-depleting chemicals.

Under Title III-Hazardous Air Pollutants (HAPs), the major emphasis in 1995 has been on determining the applicability of final rules that have been promulgated by EPA to date. HAP emission inventories continue for the purposes of Title V permit applications.

Under Title V permits, each ORR facility has conducted source identification programs. This information will form the basis for Title $V$ permit applications that will be submitted in 1996 and 1997. A comprehensive Title V Permit for each ORR facility will replace the individual source permits that are currently active at each facility. 


\section{National Emission Standards for Hazardous Air Pollutants for Radionuclides}

Compliance with the Rad-National Emission Standards for Hazardous Air Pollutants (Rad-NESHAP) dose limit of $10 \mathrm{mrem} /$ year to the maximum exposed individual of the public was demonstrated by modeling emissions from major and minor point sources during periods of operation. The annual off-site dose to the most-exposed member of the public for the ORR was $0.5 \mathrm{mrem}$ in 1995, which is below the Rad-NESHAP compliance limit of $10 \mathrm{mrem}$.

Continuous emissions monitoring is performed at the K-25 TSCA Incinerator, at four major stacks and two minor stacks at ORNL, and at exhaust stacks serving uranium-processing areas at the Y-12 Plant. As of January 1, 1995, the Y-12 Plant had a total of 68 stacks, of which 63 were active and 5 were temporarily shut down. During 1995, five additional stacks were put into temporary shutdown. Thus, during the course of the year, 63 stacks were monitored, and there were 58 stacks being monitored at the end of 1995. Grab samples and other EPA-approved estimation techniques are used on remaining minor emission points, grouped area sources, and fugitive emissions. All three facilities met the emission and test procedures of 40 CFR 61 , Subpart $\mathrm{H}$.

\section{NESHAP for Asbestos}

The ORR facilities have numerous buildings and equipment that contain asbestos materials. The compliance program for asbestos management includes demolition and renovation inspections, identification, monitoring, abatement, and disposal of asbestos materials. One asbestos release of a reportable quantity was identified at the K-25 Site in 1995. The release occurred when $4.95 \mathrm{lb}$ of asbestos dropped from an inactive steam line to the ground. No reportable quantities were reported at the Y-12 Plant or ORNL.

\section{Other NESHAPs}

The Y-12 Plant is subject to a NESHAP rule for machining beryllium. The Y-12 Plant currently monitors four stacks that serve beryllium machining and handling areas to demonstrate compliance with the $10 \mathrm{~g} /$ day emission limit. In 1995, measured stack emission rates at the Y-12 Plant were less than $0.005 \mathrm{~g} /$ day. The total emitted for 1995 was $<1 \mathrm{~g}$. The K-25 Site TSCA Incinerator is also subject to the NESHAP rule for incinerators that process beryllium. The current permitted emission limit for beryllium is $<1 \mathrm{~g} /$ day, which is well below the NESHAP limit of $10 \mathrm{~g} /$ day. EPA is currently developing other NESHAP standards, pursuant to the CAA amendments of 1990. These standards will be evaluated as they are proposed and promulgated.

\section{State-Issued Air Permits}

The Y-12 Plant has 56 active air permits covering 334 air emission points. There are 166 documented exempt minor sources and 284 exempt minor emission points.

At the close of 1995, 31 permitted air emission sources were in operation at ORNL. During the year, permit maintenance activities included exemption of one source, a new permit for one source, permit renewal for four sources, and construction permit applications submitted for three sources. In addition, an internal surveillance of all permitted sources was conducted and TDEC conducted compliance inspections.

There were 160 active air sources at the K-25 Site at the end of 1995 . The total includes 29 sources covered by 10 TDEC air operating permits and 131 sources that are exempt from permitting requirements. Three proposed sources were covered under permits to construct.

\section{Toxic Substances Control Act}

TSCA regulates the manufacture, processing, distribution in commerce, use, and disposal of chemical substances and mixtures that may present an unreasonable risk of injury to human health or the environment. TSCA gives 
EPA comprehensive authority to identify and control chemical substances manufactured, processed, distributed in commerce, and used within the United States. EPA imposes strict information-gathering requirements of both new and existing chemical substances. The statute is also unique in that it imposes specific requirements related to individual chemical substances, including polychlorinated biphenyls (PCBs).

Compliance with the act is ensured through the activities of the TSCA Task Team and the PCB Task Team. The TSCA Task Team addresses all aspects of TSCA compliance except matters related to PCBs, which are addressed by the PCB Task Team. Both teams are composed of members of K-25 Site, Y-12 Plant, and ORNL.

\section{Polychlorinated Biphyenyls}

TSCA specifically banned the manufacture, processing, and distribution in commerce of PCBs but authorized the continued use of some existing PCBs and PCB equipment. TSCA also imposed marking, storage, and disposal requirements for PCBs. 40 CFR 761 is the codified regulation mandated by TSCA and regulated by EPA. The state of Tennessee restricts PCBs from disposal in landfills and classifies PCBs as special wastes under the Tennessee solid waste regulations. A special waste exemption is required from the state of Tennessee to dispose of PCBs in landfills. Additionally, $\mathrm{PCB}$ discharges into waterways are restricted by the state-regulated CWA and NPDES programs.

\section{Authorized and Unauthorized Uses}

In the 50-year history of ORR facilities, a variety of $\mathrm{PCB}$ systems and equipment have been in service. Many of the systems and equipment were industry standards, and their continued use was authorized under the 1979 PCB regulations. Systems that were authorized include transformers, capacitors, other electrical-distribution equipment, heat-transfer systems, and hydraulic systems. The vast majority of PCBs have been phased out at ORR. The small amount of PCBs remaining in service in PCB light ballasts are being replaced by non-PCB ballasts during the course of normal maintenance. A few transformers containing $\mathrm{PCBs}$ remain in service, but they are either being retrofitted by replacing $\mathrm{PCB}$ fluid with non-PCB dielectric fluid to reduce the $\mathrm{PCB}$ concentration to below regulated limits, or they are being removed from service altogether.

PCB regulations promulgated in 1979 (40 CFR 761) did not anticipate the use of PCBs in many of the applications for which they were employed. As a result, uses not specifically authorized present compliance issues under TSCA. Such uses include PCBs incorporated into gasket materials, metal-working lathes, and other oil- or grease-lubricated equipment, electrical wire and other insulation materials, corrosion-resistant coatings and paints, and plastics. Such unauthorized uses of PCBs are occasionally found in building materials, lubricants, and non-electrical systems during the course of ORR decommissioning and decontamination activities. The most notable of these unauthorized uses of PCBs are PCB-impregnated gaskets in the gaseous diffusion process motor ventilation systems at the K-25 Site. These gaskets are addressed under the Uranium Enrichment Polychlorinated Biphenyl Federal Facilities Compliance Agreement (UE-PCB-FFCA) between EPA and DOE. Other unauthorized uses are to be included in the Oak Ridge Reservation Polychlorinated Biphenyl Federal Facilities Compliance Agreement (ORR-PCB-FFCA) currently being negotiated with EPA Region 4.

\section{Compliance Agreements}

In addition to unauthorized uses, a variety of PCB compliance issues at the ORR are being addressed in the ORR-PCB-FFCA negotiations: PCB spills, storage and disposal, remediation of hydraulic and heat-transfer systems, decontamination of equipment, management of PCBs in the laboratory, and others. A final draft of the agreement was routed for concurrence within both DOE and EPA at both the headquarters level and within ORO and EPA Region 4. Generally, the draft 
agreement has been well received. The language of the final draft is undergoing some fine tuning based on comments from U.S. Environmental Protection Agency Headquarters (EPA-HQ), U.S. Department of Energy Headquarters (DOE-HQ), and the EPA Region 4 Office of Regional Counsel. Once the final adjustments are made to the language of the agreement, it will be sent for signatures to the DOE-ORO manager and the EPA Region 4 Administrator.

The predecessor to the ORR-PCB-FFCA is the Uranium Enrichment Toxic Substances Control Act Federal Facilities Compliance Agreement (UE-TSCA-FFCA), which was signed February 20,1992. This agreement between DOE-HQ and EPA-HQ provides a vehicle for resolution of PCB issues at the Portsmouth, Ohio, and Paducah, Kentucky, uranium enrichment UE facilities and at the former K-25 UE facility in Oak Ridge. In July 1993 the Portsmouth and Paducah UE facilities were leased from DOE by the United States Enrichment Corporation (USEC). USEC, created by the Energy Policy Act of 1992, is a wholly owned enterprise of the U.S. government, independent of DOE. The terms of the lease specify that responsibility for $\mathrm{PCB}$ regulatory compliance is retained by $\mathrm{DOE}$ for these two facilities.

EPA-HQ agreed to continue the UE-TSCA-FFCA with DOE for the Portsmouth and Paducah facilities but directed EPA Region 4 to enter into an agreement with DOE-ORO that would include the $\mathrm{K}-25$ Site as well as the Y-12 Plant and ORNL. The UE-TSCA-FFCA continues in force for the K-25 Site until the ORR-PCB-FFCA is completed. Administration of the UE-TSCA-FFCA has been assigned to the EPA Federal Facilities Enforcement Office (FFEO), Office of Enforcement and Compliance Assurance at EPA-HQ. Periodic progress meetings are held between $\mathrm{DOE}$ and EPA FFEO. Several proposals to advance efforts under the UE-TSCA-FFCA have been proposed by DOE-HQ and accepted by EPA-HQ.

In a separate effort, DOE-HQ, the Department of the Navy and EPA-HQ are pursuing a national FFCA, which would cover solely the issue of storage of PCB wastes at DOE facilities for periods longer than 1 year.
The agreement would cover all DOE facilities nationwide but would not address particular issues as does the UE-TSCA-FFCA, or as will the ORR-PCB-FFCA. ORR will be a party to this national agreement until the signing of the ORR-PCB-FFCA. The national agreement was signed by DOE-HQ and the navy, but the EPA General Counsel has requested minor changes before it recommends signing the agreement. It is anticipated that this agreement will be signed in the near future.

\section{Historic PCB Spills}

Various locations within the facilities where $\mathrm{PCB}$ equipment was used have been identified as sites of historic PCB contamination. These sites resulted from PCB spills occurring throughout the history of the reservation, many of which occurred before regulation. K-25 Site historic PCB spill sites are addressed in the UE-PCB-FFCA and are to receive cleanup or remediation as required by the agreement. Spill sites at the Y-12 Plant and ORNL will be addressed in the UE-PCB-FFCA.

Progress is being made through ongoing cleanup efforts for remediation of these sites. Several historic spill sites and some historically contaminated equipment have been decontaminated at the ORR through use of innovative cleanup technologies. ORNL and the Y-12 Plant have undertaken R\&D projects to develop alternative cleanup technologies. These projects are approved under TSCA by EPA Region 4.

\section{Storage and Disposal of Radioactive PCB Wastes}

The $\mathrm{PCB}$ regulations require that $\mathrm{PCB}$ wastes be disposed of within 1 year of being removed from service. Because of a lack of available disposal methods for radioactive PCB wastes, these wastes are stored at the K-25 Site, Y-12 Plant, and ORNL for periods exceeding 1 year. The UE-PCB-FFCA allows the K-25 Site to store such wastes generated by the K-25 Site for periods exceeding 1 year. Radioactive PCB wastes older than 1 year generated by other DOE 
facilities, particularly the Y-12 Plant and ORNL, are also stored at the K-25 Site.

In February 1993, DOE submitted an updated list of PCB compliance issues to EPA Region 4 for consideration in developing the ORR-PCB-FFCA. Among these was a request to extend the current ORR-PCB-FFCA allowance to store radioactive $\mathrm{PCB}$ wastes for periods exceeding 1 year to all such wastes stored by the three ORR facilities. In addition to the lack of available disposal methods, concern over the potential for even small amounts of radioactive waste to be shipped off site for disposal has prompted DOE to mandate a self-imposed moratorium on the shipment of waste for off-site disposal pending development of procedures to ensure that no radioactive material is shipped. The K-25 Site TSCA Incinerator is the only facility in the nation permitted to incinerate RCRA/PCB/radioactive waste.

Various difficulties arise in meeting the storage requirements of the PCB regulations because of the unique character and large volume of PCB wastes generated on the ORR. One of the most significant difficulties is the necessity of storing some radioactive PCB wastes in specifically shaped containers because of criticality safety concerns and in areas not meeting PCB regulatory secondary containment requirements. Another storage concern is that large items, such as ventilation duct systems, cannot be placed into containers. Storage concerns of this nature are addressed under the UE -PCB-FFCA and the proposed ORR-PCB-FFCA.

\section{K-25 Site TSCA Incinerator PCB Disposal Approval}

The K-25 Site TSCA Incinerator is currently operating under an extension of EPA Region 4 approval granted on March 20, 1989. This extension is based on submittal of a reapplication for PCB disposal approval filed with EPA Region 4 on December 20,1991, which was within the time frame allowed for reapplication. Minor amendments, updates, and corrections to the reapplication identified by DOE have been made in the interim and have been submitted to EPA. EPA Region 4 has been making some minor progress toward renewal of the PCB incineration approval, but reapproval is not anticipated until late 1997 or 1998 . The renewal application is being coordinated with the TDEC renewal of the hazardous waste incineration permit to better facilitate public participation.

\section{PCB Research and Development Permits}

EPA Region 4 has granted ORNL authorization to conduct $R \& D$ projects on stabilization/solidification techniques, base-catalyzed/reductive-catalyzed procedures, and a microorganism-catalyzed procedure for the treatment of PCB-contaminated materials. Currently active research projects include the reductive-catalyzed work in the ORNL Environmental Sciences Division and the microorganism-catalyzed work in the ORNL Chemical Technology Division. Upon submittal of a formal R\&D application and EPA Region 4 concurrence, additional work in the Environmental Sciences Division using a chemical dechlorination technique will start. These research projects as well as proposed projects may provide a route for DOE to meet the requirements of the ORR-PCB-FFCA between EPA and DOE.

\section{Federal Insecticide, Fungicide, and Rodenticide Act}

The Federal Insecticide, Fungicide, and Rodenticide Act (FIFRA) governs the sale and use of pesticides and requires that all pesticide products be registered by EPA before they may be sold. The regulations for the application, storage, and disposal of pesticides are presented in 40 CFR 150-189.

The Y-12 Plant, the K-25 Site, and ORNL maintain procedures for the storage, application, and disposition of pesticides. Individuals responsible for the application of FIFRA materials are certified by the Tennessee Department of Agriculture. If a pesticide can be used according to directions without unreasonable adverse effects on the environment 
Table 2.6. EPCRA (SARA Title III) compliance by site for the ORR

Y-12 Plant ORNL K-25 Site
302-303, planning notification
In compliance In compliance In compliance
304, extremely hazardous substance release notification
In compliance In compliance In compliance
$311-312$, material safety data sheet/chemical inventory
In compliance In compliance In compliance
313, toxic chemical release reporting ${ }^{b}$
In compliance In compliance In compliance
a Requires that Local Emergency Planning Committee
and State Emergency Response Commision be notified of
EPCRA-related planning.
$b$ Addresses reporting to state and local authorities of
off-site releases.
$c_{\text {Requires that either material safety data sheets (MSDSs) }}$
or lists of hazardous chemical for which MSDSs are required
be provided to state and local authorities for emergency
planning.
$d_{\text {Requires that releases of toxic chemicals be reported }}$
annually to EPA and the state.

or applicator (i.e., if no special training is required), it is classified for general use. A pesticide that can harm the environment or injure the applicator even when being used according to directions is classified for restricted use. No restricted-use pesticide products are used at the K-25 Site or at ORNL. Safrotin ${ }^{\circledR}$, used for the control of cockroaches, is the only restricted-use pesticide stored and used both at the Y-12 Plant and ORNL. To date, no purchases of this restricted-use material have been made since August 1993, and efforts for substitution are under way at the Y-12 Plant. An inventory of pesticide products is maintained for use at each facility. It is site policy to store, apply, and dispose of these products in a manner that ensures full compliance with FIFRA requirements.

\section{Emergency Planning and Community Right-To-Know Act}

The Emergency Planning and Community Right-To-Know Act (EPCRA), also referred to as SARA Title III, requires reporting of emergency planning information, hazardous chemical inventories, and environmental releases to federal, state, and local authorities. The ongoing requirements of EPCRA are contained in Sections 302, 303, 304, 311, 312, and 313 (Table 2.6).

The ORR had 21 releases subject to Section 304 notification requirements during 1995. The Section 311 lists are updated frequently and are provided to the appropriate officials. The Section 312 inventories for 1995 identified 62 hazardous chemicals, documented their locations, and summarized the hazards associated with them. Of these Section 312 chemicals, 43 were located at the Y-12 Plant, 30 at ORNL, and 17 at the K-25 Site.

Under Section 313, five toxic chemicals were reported for 1995. Release data for 1994 and 1995 are summarized in Table 2.7. Compared with 1994 releases, there was a $40 \%$ reduction in total reportable toxic-chemical releases in 1995.

\section{Environmental Occurrences}

CERCLA requires notification of the National Response Center if a nonpermitted release of a reportable quantity (RQ) or more of a hazardous substance (including radionuclides) is released to the environment within a 24-hour period. The CWA requires that the National Response Center be notified if an oil spill causes a sheen on navigable waters, such as rivers, lakes, or streams. When notified, the National Response Center alerts federal, state, and local regulatory emergency organizations so they can determine whether government response is appropriate.

During 1995, Y-12 Plant staff reported 14 CERCLA RQ releases to federal and state agencies. All were ethylene glycol (antifreeze) releases within the Y-12 Plant, predominantly caused by government vehicles with either overfilled radiators or ruptured radiator hoses. On July 12 , 1995, EPA raised the reportable threshold for ethylene glycol from 1 pound to 5,000 pounds. Because all of the antifreeze releases were considerably below the new threshold value, the reporting burden has been greatly reduced. 
Table 2.7. EPCRA Section 313 toxic chemical release summary for the ORR

\begin{tabular}{|c|c|c|c|c|c|}
\hline \multirow[t]{2}{*}{ Chemical } & \multirow[t]{2}{*}{ Year } & \multicolumn{4}{|c|}{ Quantity (lb) } \\
\hline & & Y-12 Plant ${ }^{a}$ & ORNL & K-25 Site & Total \\
\hline \multirow[t]{2}{*}{ Methanol } & 1994 & 39,000 & 367 & 7 & 39,374 \\
\hline & 1995 & 36,300 & 272 & 14 & 36,586 \\
\hline \multirow[t]{2}{*}{ Hydrochloric acid } & 1994 & 1,031 & 202 & 81 & 1,314 \\
\hline & 1995 & 1,170 & 81 & 69 & 1,320 \\
\hline \multirow[t]{2}{*}{ Lead } & 1994 & $b$ & $b$ & $b$ & $b$ \\
\hline & 1995 & 14 & 5,948 & 19 & 5,981 \\
\hline \multirow[t]{2}{*}{ Nitric acid } & 1994 & 32,300 & 43 & 0 & 32,343 \\
\hline & 1995 & 222 & 1 & 0 & 223 \\
\hline \multirow[t]{2}{*}{ Sulfuric acid } & 1994 & $0^{c}$ & $0^{c}$ & $0^{c}$ & $0^{c}$ \\
\hline & 1995 & $0^{c}$ & $0^{c}$ & $0^{c}$ & $0^{c}$ \\
\hline \multirow[t]{2}{*}{ Total } & 1994 & 72,331 & 612 & 88 & 73,031 \\
\hline & 1995 & 37,706 & 6,302 & 102 & 44,110 \\
\hline
\end{tabular}

The National Response Center and the Tennessee Emergency Management Agency (TEMA) were also notified of two incidents that involved oil sheens observed on EFPC.

During 1995 ORNL reported one incident involving an oil sheen on Melton Hill Lake. NRC and TEMA were notified.

In 1995 two releases occurred at the K-25 Site that required notification of the National Response Center or TEMA. These included the discovery of asbestos-containing material on the ground and the presence of an oil sheen on Mitchell Branch.

\section{DOE ORDER COMPLIANCE}

In 1995 DOE implemented Standards/Requirements Identification Documents (S/RIDs), which include all federal, state, and local requirements applicable to the Y-12 Plant, $\mathrm{K}-25$ Site, and ORNL. The S/RIDs include mandatory contractor requirements from the DOE orders of primary interest to the Defense Nuclear Facilities Safety Board (DNFSB). The
S/RIDs covering all environment-, safety-, and health-related activities were included in the DOE contracts for Energy Systems and LMER in October 1995 and January 1996, respectively. This change established the S/RIDs as the contractual set of environment, safety, and health (ES\&H) requirements rather than DOE orders.

An effort is planned for 1996 by LMES to incorporate new ES\&H orders and rules into the S/RIDs as they are issued. The S/RIDs will also be evaluated to determine the cost benefit of individual requirements. If the requirements do not result in added value in the protection of ES\&H, or if they do not apply to current operations, they may be deleted from the S/RIDs system if approved by DOE. Thus, the S/RIDs system is designed to reflect changing regulatory and operational conditions.

In 1996 LMER and DOE will undergo the "Necessary and Sufficient" process for ES\&H. Standards identified during this process will replace the S/RIDs for ORNL. 


\section{DOE Order 5400.1, General Environmental Protection Program}

DOE Order 5400.1 establishes environmental protection program requirements, authorities, and responsibilities for DOE operations to ensure compliance with applicable federal, state, and local environmental protection laws and regulations, executive orders, and internal DOE policies. The order specifically defines the mandatory environmental protection standards (including those imposed by federal and state statutes), establishes reporting of environmental occurrences and periodic routine significant environmental protection information, and provides requirements and guidance for environmental monitoring programs. Implementation of the order is provided by specific program plans, as detailed in Chapter III of the order. The internal environmental protection programs mandate the creation of several environmental reports.

Reports include the 5-year plan required by Office of Management and Budget Circular A-106, the Annual Site Environmental Report, and reports of significant nonroutine releases of hazardous substances consistent with DOE Order 5000.3B, "Occurrence Reporting and Processing of Operations Information." An Environmental Protection Program Implementation Plan (EPIP) is required and is updated annually. The document serves to define specific environmental objectives, including the means and schedules for accomplishment during the year. The EPIPs for the Y-12 Plant and the K-25 Site were reissued in November 1995. In agreement with the ORNL DOE contracting officer's representative, the ORNL EPIP will be revised, if required, to reflect new contractual obligations.

An environmental monitoring plan is to be prepared, reviewed annually, and updated every 3 years or as needed. The Environmental Monitoring Plan for the ORR was released by DOE in September 1992. The plan provides a single point of reference for the effluent monitoring and environmental surveillance programs of the Y-12 Plant, ORNL, the
K-25 Site, and ORR areas outside specific facility boundaries. The annual review identified the need to update the plan. A revised document was issued as a controlled document in May 1995. The three ORR sites are in compliance with DOE Order 5400.1. Selected requirements demonstrating compliance follow.

\section{Pollution Prevention/Waste Minimization}

The fundamental ORR Pollution Prevention function is to implement projects that result in the creation of less waste. This fundamental function is supported by three ancillary activities: (1) providing technical assistance (identifying and justifying opportunities for projects);

(2) developing the overall program (awareness activities, planning, budgeting, reporting); and (3) administering the program (interfacing and communicating with site generator organizations, DOE, and outside organizations).

A central Pollution Prevention Information Management System has been created to integrate and synthesize information collected from tracking systems which have been developed at all three sites to track pollution prevention progress. Pollution prevention councils have been established at all three sites, with representation from each of the site organizations. The councils exchange information to promote pollution prevention activities. Responsibilities within the divisions at each site include the development of pollution prevention goals and implementation of programs and activities necessary to reduce both the amount and the toxicity of waste and environmental pollutants, communication of Energy Systems pollution prevention goals, documentation and communication of progress made toward implementation, and promotion of employee awareness.

During 1995, a great deal of effort was spent to identify pollution prevention opportunities and implement pollution prevention projects. Several source-reduction and recycling projects were completed. Projects include facility-specific activities as well as programmatic activities. Table 2.8 summarizes the results of selected 
Table 2.8. Results of selected Oak Ridge Reservation recycling activities for the past 5 years

\begin{tabular}{|c|c|c|c|c|c|}
\hline \multirow[t]{2}{*}{ Material } & \multicolumn{5}{|c|}{ Quantity (tons) } \\
\hline & 1991 & 1992 & 1993 & 1994 & 1995 \\
\hline Aluminum cans & 15.7 & 24.8 & 28.7 & 25.3 & 24 \\
\hline Cardboard & 85.5 & 315.4 & 428.5 & 354.6 & 241.9 \\
\hline Paper & 302.4 & 552.8 & 786.6 & 734.4 & $906.2^{a}$ \\
\hline Ash & $b$ & $b$ & $b$ & $b$ & $15,294.7$ \\
\hline Toner cartridges & $b$ & $b$ & $b$ & $b$ & 10.5 \\
\hline
\end{tabular}

recycling activities on the ORR during the past 5 years.

Three mechanisms have been developed and employed to fund pollution prevention implementation projects. Project proposals are submitted to the pollution prevention program. The proposals are evaluated and submitted to one of three funding avenues: (1) DOE hazard quotient (HQ)-funded high return on investment (ROI), (2) the reservation-funded High Investment Value (HiVal) System, or (3) the site-funded generator set-aside program. The generator set-aside fund is the newest funding mechanism; it taxes generated waste. The tax is accumulated for funding implementation projects.

\section{Groundwater}

The hydrogeologic system at the Y-12 Plant has been divided into three hydrogeologic regimes based on topography and surface water and groundwater flow patterns. An exit-pathway well network, as required by DOE Order 5400.1, has been completed to monitor flow from each hydrogeologic regime at Y-12 Plant. Water quality data from the exit-pathway wells at the east end of the Y-12 Plant indicate the volatile organic compounds (VOCs) carbon tetrachloride and tetrachlorethane, common industrial solvents previously used in large quantities at the Y-12 Plant, are being transported off the ORR through the Maynardville Limestone at depths of 100 to $300 \mathrm{ft}$. Property owners in the area have been notified and have been provided with a status report. Investigations during 1994 confirmed that no drinking water wells are in the affected area. A remedial investigation of the off-site plume is being conducted under CERCLA.

Additional well installation and groundwater monitoring activities continued through 1994 in support of the Y-12 Plant UST Program and of the construction and permitting of new industrial landfills to serve the reservation.

Exit-pathway monitoring was initiated at ORNL in 1993. The program monitors groundwater and streams at four general locations that are thought to be likely exit pathways for ORNL groundwater. The ORNL WAG perimeter monitoring network includes perimeter wells at ten WAGs.

Exit-pathway monitoring at the K-25 Site is conducted at locations where groundwater flowing from relatively large areas converges before discharging to surface water locations. The exit-pathway monitoring of groundwater quality in both the unconsolidated zone and the bedrock is supported by surface water monitoring at three convergence points. During 1995 groundwater samples from the eight-well perimeter groundwater surveillance network were collected under wet-season (February to April) and dry-season (September to October) conditions. Micropurging and low-flow sampling procedures were used.

An off-site residential drinking water quality monitoring program has been conducted since 1989. The objective of the program is to document water quality from groundwater sources near the ORR and to monitor the potential impact of DOE-ORO operations on the quality of these groundwater sources. Currently, 
sixteen wells and three springs are included in the program; these sites were selected on the basis of their proximity to the ORR and a representative distribution of sources from the different geologic formations of the area. The wells are sampled semiannually, and results are provided in individual reports to the well owners. In past years, no contaminant movement to these off-site locations has been indicated, and the results from sampling in 1995 continue to support this.

The 1995 annual TDEC RCRA groundwater compliance evaluation inspections were conducted in January and December at the Y-12 Plant and in October at ORNL. No findings or recommendations were issued as a result of the inspections.

\section{DOE Order 5400.5, Radiation Protection of the Public and the Environment}

DOE Order 5400.5 provides guidance and establishes radiation protection standards and central practices designed to protect the public and the environment against undue risk from DOE operations. This order requires that no member of the public receive an effective dose equivalent (EDE) in a year greater than 100 mrem via all pathways and that no member of the public receive a radiation dose equivalent greater than $10 \mathrm{mrem}$ in a year from airborne emissions. In addition, dose limits imposed by other federal regulations (40 CFR Parts 61, 191, and 192 and 10 CFR Parts 60 and 72) must be met. The primary dose limit is expressed as an EDE, which requires the weighted summation of doses to specified organs of the body. Monitoring of effluents released to the environment is required to ensure that radiation doses to the public are as low as reasonably achievable (ALARA) and are consistent with prescribed dose standards.

\section{DOE Order 5820.2A, Radioactive Waste Management}

DOE Order 5820.2A establishes the policies and minimum requirements for managing $O R R$ radioactive wastes and the radioactive component of mixed wastes. The order requires that each DOE site prepare a waste management plan for radioactive waste generation, TSD operations. In previous years each site had prepared its own waste management plan. These plans have now been consolidated into one document, The Oak Ridge Reservation Waste Management Plan (Energy Systems 1995b).

ORNL manages TRU waste and LLW. Radioactive waste management activities at both the K-25 Site and Y-12 Plant are primarily related to LLW. Although material contaminated with TRU elements exists on the K-25 Site, the concentrations are less than the limits for TRU waste.

\section{APPRAISALS AND SURVEILLANCES OF ENVIRONMENTAL PROGRAMS}

Numerous appraisals, surveillances, and audits of the ORR environmental activities occurred during 1995 (see Tables 2.9, 2.10, and 2.11). These tables do not include internal Energy Systems and Lockheed Martin corporate assessments.

\section{Tiger Team Environmental Assessment}

Table 2.12 provides a summary of the status of corrective actions from the Tiger Team assessments.

\section{Defense Nuclear Facilities Safety Board}

In September 1994, during a DNFSB tour of a storage building in 9204-2E, a discrepancy with specific stipulations of the criticality safety approval for storage of fissile material in that area was identified. As a result, a number of operations at the Y-12 Plant were curtailed. However, environmental management operations (compliance monitoring, reporting, and oversight) have continued operations, and there have been no environmental impacts as a result of the stand-down. Work continues at the Y-12 Plant 
Annual Site Environmental Report

Table 2.9. Summary of environmental audits and assessments conducted at the Y-12 Plant, 1995

\begin{tabular}{lllc}
\hline \multicolumn{1}{c}{ Date } & \multicolumn{1}{c}{ Reviewer } & \multicolumn{1}{c}{ Subject } & Issues \\
\hline $1 / 10-11$ & TDEC & Groundwater RCRA Compliance Evaluation Inspection & 0 \\
$1 / 26-2 / 7$ & DOE & Y-12 Plant drain survey program surveillance & 1 \\
$3 / 14$ & City of Oak Ridge & Sanitary Sewer compliance inspection & 0 \\
$9 / 12-10 / 9$ & DOE & Y-12 Plant Site Office monthly report & 2 \\
$10 / 16$ & City of Oak Ridge & Sanitary Sewer compliance inspection & 0 \\
$11 / 28-1 / 9 / 96$ & DOE & Surveillance of Clean Air Act construction permits & 0 \\
$12 / 5-7$ & TDEC & NPDES compliance evaluation inspection & 0 \\
$12 / 7-8$ & TDEC & RCRA Operations and Maintenance Inspection-groundwater & 0 \\
\hline
\end{tabular}

Table 2.10. Summary of environmental audits and assessments conducted at ORNL, 1995

\begin{tabular}{llll}
\hline \multicolumn{1}{c}{ Date } & Reviewer & \multicolumn{1}{c}{ Subject } & Issues \\
\hline $2 / 1$ & TDEC & Permitted emission sources & 0 \\
$3 / 23-24$ & TDEC/DOE-O & Permitted emission sources & \\
$6 / 19$ & TDEC/DOE-O & Investigation of steam plant emissions & 0 \\
$7 / 5$ & TDEC & Inspection of sediment removal from White Oak Creek and Melton Branch weirs & 1 \\
$10 / 10$ & TDEC/DOE-O & Opacity evaluation at 7603 oil-fired boiler & 0 \\
$10 / 23$ & TDEC/DOE-O & Inspection of lead shop with respect to air permit requirements & 0 \\
$11 / 14-16$ & TDEC/DOE-O & Inspection of NPDES compliance sampling & 0 \\
\hline
\end{tabular}

to respond to recommendations from the board concerning formality of operations.

\section{ENVIRONMENTAL PERMITS}

Table 2.13 contains a summary of environmental permits for the three ORR sites.

\section{NOTICES OF VIOLATIONS AND PENALTIES}

One new notice of violation (NOV) was received by the Y-12 Plant on November 14, 1995. The NOV was from the city of Oak Ridge for releases that exceed permit levels into the sanitary sewer.

DOE received two notices of noncompliance (NONs) from TDEC in 1995 for violations of its NPDES Permit at ORNL. One NON was received March 29 for iron and total-suspended-solids excursions. A second was received July 31 for fecal coliform and total-suspended-solids excursions. On December 13, 1995, ORNL received an NOV from the Division of Water Pollution Control for a wetland alteration that occurred adjacent to Mitchell Branch during the Pine Beetle Reforestation Project.

The K-25 Site received one NOV for two noncompliances at the K-1203 sewage treatment 
Table 2.11. Summary of environmental audits and assessments conducted at the K-25 Site, 1995

\begin{tabular}{|c|c|c|c|}
\hline Date & Reviewer & Subject & Issues \\
\hline $1 / 26-27$ & TDEC & Annual air inspection & 0 \\
\hline $2 / 6$ & TDEC & Inspection of the K-1417 Drum Storage Yard & 0 \\
\hline $3 / 17$ & TDEC/DOE-O & Visible emissions evaluation of TSCA Incinerator & 0 \\
\hline $3 / 27-28$ & TDEC & Annual RCRA Inspection & 0 \\
\hline $5 / 24$ & TDEC/DOE-O & Follow-up to annual RCRA inspection & 0 \\
\hline $5 / 25$ & TDEC/DOE-O & Inspection of waste identified in TDEC RCRA inspection & 0 \\
\hline $6 / 26$ & TDEC & Observe air performance test & 0 \\
\hline $7 / 6$ & TDEC & Observe active and proposed ARAP sites & 0 \\
\hline $7 / 19$ & TDEC & Inspect cooling tower and power house demolition project asbestos abatement & 0 \\
\hline $9 / 18-19$ & TDEC & Annual RCRA inspection & 0 \\
\hline $9 / 21-22$ & TDEC & RCRA inspection of TSCA Incinerator & 0 \\
\hline $11 / 29-12 / 1$ & TDEC/DOE-O & Annual NPDES Compliance Evaluation Inspection & 0 \\
\hline
\end{tabular}

Table 2.12. Summary of Tiger Team corrective actions

\begin{tabular}{lccc}
\hline \multicolumn{1}{c}{ Date of review } & Site & $\begin{array}{c}\text { Environmental } \\
\text { findings }\end{array}$ & Status \\
\hline $\begin{array}{l}\text { 6/89 } \\
\text { (follow-up visit) }\end{array}$ & Y-12 Plant & 62 & $\begin{array}{l}59 \text { have been closed (52 of these } 59 \text { have been verified } \\
\text { closed by DOE); } 3 \text { remain open. }\end{array}$ \\
$10 / 22-11 / 30 / 90$ & ORNL & 69 & $\begin{array}{l}53 \text { have been closed; } 45 \text { of these } 53 \text { have been verified } \\
\text { as closed by DOE; } 16 \text { remain open. }\end{array}$ \\
& K-25 Site & 102 & 70 have been closed; 32 remain open. \\
\hline
\end{tabular}

\footnotetext{
${ }^{a} \mathrm{DOE}$ reviews closures, but verification of closure is not required.
}

facility. The noncompliances occurred by exceeding effluent limitations for biochemical oxygen demand and total residual chlorine. On February 16 the total residual chlorine value for the sewage treatment plant was reported at $0.53 \mathrm{mg} / \mathrm{L}$, which exceeded the daily maximum permit limit of $0.24 \mathrm{mg} / \mathrm{L}$. A review of operators' logs and procedures revealed that operations were conducted in accordance with the procedures. Additionally, the sewage treatment plant is equipped with an in-line continuous chlorine monitor. The maximum total residual chlorine concentration recorded on that day was $0.12 \mathrm{mg} / \mathrm{L}$, which is well within permit limits. On February 22 the biological oxygen demand (BOD) result of $31.9 \mathrm{mg} / \mathrm{L}$ exceeded the daily maximum permit limit of $20 \mathrm{mg} / \mathrm{L}$. Site activities were examined, as were the raw materials and resultant wastes that could possibly have influenced the BOD. No activities out of the routine were being conducted before the event.

\section{2-28 Environmental Compliance}


Table 2.13. Summary of permits as of December 1995

\begin{tabular}{|c|c|c|c|}
\hline & Y-12 Plant & ORNL & K-25 Site \\
\hline \multicolumn{4}{|c|}{ Resource Conservation and Recovery Act } \\
\hline Part B Permit & $3^{a}$ & 3 & 4 \\
\hline Part $B$ applications in process & $3^{b}$ & 2 & 0 \\
\hline Postclosure & $2^{c}$ & 1 & 0 \\
\hline Permit-by-rule units & 10 & $173^{c}$ & 92 \\
\hline Solid waste landfills & $5^{d}$ & 0 & 0 \\
\hline Annual petroleum UST facility certificate & 2 & 1 & 1 \\
\hline \multicolumn{4}{|c|}{ Clean Water Act } \\
\hline NPDES & $1^{e}$ & 1 & 1 \\
\hline Storm water & $\mathfrak{1}^{f}$ & $0^{g}$ & $1^{f}$ \\
\hline $\begin{array}{l}\text { Aquatic resource alteration/U.S. Army Corps of } \\
\text { Engineers } 404 \text { permits }\end{array}$ & 1 & 3 & 7 \\
\hline General storm water construction & $2^{h}$ & 0 & 3 \\
\hline \multicolumn{4}{|c|}{ Clean Air Act } \\
\hline Operating air & 56 & 31 & 10 \\
\hline Construction & 0 & 0 & 3 \\
\hline Prevention of significant deterioration & 0 & 0 & 0 \\
\hline \multicolumn{4}{|c|}{ Sanitary Sewer } \\
\hline Sanitary sewer & 1 & 0 & 0 \\
\hline
\end{tabular}

Toxic Substances Control Act

TSCA Incinerator

R\&D for alternative disposal methods

$\begin{array}{lll}0 & 0 & 1 \\ 1 & 3 & 0\end{array}$

\footnotetext{
${ }^{a}$ Three permits have been issued, representing 14 active units.

${ }^{b}$ Three applications are under review by TDEC, representing 6 active units.

${ }^{c}$ Two permits have been issued representing units closed under RCRA in Bear Creek Hydrogeologic Regime and Chestnut Ridge Hydrogeologic Regime. One additional permit (for the Upper East Fork Poplar Creek Regime) is pending as of publication of this report.

${ }^{d}$ Three landfills are operational, one (Spoil Area 1) is inactive and is in the RI/FS process under CERCLA; and one (Landfill VII) is constructed but not operational as of December 1995.

${ }^{e}$ Issued $4 / 28 / 95$ and effective $7 / 1 / 95$. TDEC has incorporated requirements for stormwater into individual NPDES permits.

${ }^{f}$ TDEC has incorporated into individual NPDES permits.

${ }^{8}$ TDEC has incorporated into a draft NPDES permit.

${ }^{h}$ Notice of intent that accesses a general NPDES permit. Two notices of intent remain on file for construction at Landfill V, VII, and for tree maintenance on tributary 7 at the Walk-in-Pits closure.
}

\section{CURRENT ISSUES}

\section{Actions Filed by Friends of the Earth, Inc.}

On January 17, 1992, Friends of the Earth, Inc., a nonprofit corporation, filed a lawsuit against Admiral James D. Watkins (then Secretary of Energy) and DOE in the U.S. District Court for the Eastern District of Tennessee, Northern Division. The suit alleges that $\mathrm{DOE}$ is violating the terms and conditions of its NPDES permits for the Y-12 Plant, ORNL, and the K-25 Site. Specifically, the complaint alleges that discharges of certain quantities of 
various pollutants into tributaries of the Clinch River that have their sources at the Y-12 Plant, ORNL, and the K-25 Site have exceeded (and are exceeding) the allowable discharge limits established by the NPDES permits. The suit seeks to force DOE to comply in all respects with its NPDES permits, declaratory judgments, and the award of various other costs.

Friends of the Earth made a request for production of documents, which were provided by $\mathrm{DOE}$. The complaint was amended to add another environmental group and several individuals as plaintiffs to the lawsuit. Friends of the Earth took depositions in August 1993, and toured the facility with their expert witness in October 1993.

In October 1992, Friends of the Earth filed a motion for summary judgment with the court. In January 1993 DOE and the U.S. Department of Justice filed a cross-motion for denial of summary judgment. A hearing was held in Federal District Court in Knoxville, Tennessee, in May 1993. At that time, the court ordered the parties to prepare charts or tables summarizing the parties' positions regarding the number and extent of the alleged violations of the NPDES permits and the corrective actions taken, planned, or requested. The parties have complied with this order. Oral arguments on the issues were held in March 1995, in Knoxville. At the time of this writing, a decision has not been issued by the court.

\section{Hazardous/Toxic Waste Off-Site Shipment Moratorium}

In May 1991, a moratorium on the off-site shipment (to non-DOE sites) of PCB and RCRA hazardous waste was implemented throughout the DOE complex, including the DOE sites located on the ORR. The purpose of the moratorium is twofold: (1) to ensure that hazardous/toxic wastes shipped from DOE facilities to commercial treatment, storage, or disposal facilities do not have bulk (volume) radioactive contamination as a result of $\mathrm{DOE}$ operations and (2) to ensure that the wastes do not have surface contamination exceeding DOE Order 5400.5 criteria unless the receiving facility is specifically licensed to manage radioactive waste. The moratorium for a given site will remain in effect until the site receives approval from DOE to resume off-site shipments using site-specific procedures that have been reviewed and approved by DOE.

In October 1993, the K-25 Site received a partial lifting of the moratorium for wastes composed of solid materials that do not have the potential for bulk contamination. The $\mathrm{K}-25$ Site moratorium continues to remain in effect for hazardous/toxic wastes that are not solid materials (because of the potential for bulk contamination) until such time as DOE develops generic criteria for bulk contamination release. Off-site shipments of solid, hazardous/toxic wastes resumed at the K-25 Site following DOE's issuance of the partial lifting.

The moratorium at the Y-12 Plant was fully lifted by DOE in January 1994. The Y-12 Plant resumed off-site shipment activities for hazardous/toxic wastes following the lifting of the site moratorium.

In November 1994, ORNL received a partial lifting of the moratorium for wastes composed of solid materials that do not have the potential for bulk contamination. The ORNL moratorium continues to remain in effect for hazardous/toxic wastes that are not solid materials (because of the potential for bulk contamination) until such time as DOE develops generic criteria for bulk contamination release. ORNL resumed activities for the off-site shipment of solid, hazardous/toxic wastes following DOE's issuance of the partial lifting.

\section{Tennessee Oversight Agreement}

On May 13, 1991, the state of Tennessee and DOE entered into a 5-year monitoring and oversight agreement in which DOE agreed to provide the state financial and technical support for an "independent monitoring and oversight" of DOE activities on the ORR. Activities that are conducted under the agreement include oversight of DOE's environmental monitoring, waste management, $E R$, and emergency management programs. The agreement is intended to assure Tennessee citizens that their health, safety, and 
environment are being protected by DOE's ongoing programs and new commitments specified in the agreement. The agreement may be extended beyond 5 years or amended as necessary to address federal, state, or local community issues that may arise.

TDEC is the lead Tennessee state agency for implementation of the agreement. TDEC has established the Tennessee Department of Environment and Conservation/DOE Oversight Division (TDEC/DOE-OD), located in the city of Oak Ridge. TDEC has entered into contracts with various state and local agencies to support oversight activities. Contracts have been signed with Tennessee Wildlife Resources Agency (TWRA) for fish and wildlife monitoring activities, with TEMA for emergency management support, and with the Local Oversight Committee for assistance in achieving a better public understanding of the issues and activities on the ORR.

A DOE-Tennessee Oversight Agreement (TOA) steering committee composed of site and major program representatives has been established to coordinate implementation of the TOA and to promote consistency in its implementation across the ORR. Energy Systems, LMER, and other selected DOE prime contractors have established internal organizations, including the designation of TOA coordinators to facilitate implementation of the agreement.

To date, a variety of activities have been conducted under the agreement. DOE has provided security clearances and training necessary for state employees to gain access to the sites. Environmental data and documents pertaining to the environmental management, $\mathrm{ER}$, and emergency management programs are being provided or made available to the state for their review. TDEC/DOE-OD routinely visits the three DOE sites to attend formal meetings and briefings, to conduct walk throughs of buildings and grounds, or to conduct observations of site operations to assess compliance with environmental regulations. During CY 1995, TDEC/DOE-OD continued its Facility Survey Program by conducting 34 walk-through assessments of buildings on the ORR. The goal of this program is to provide an independent evaluation of the conditions of facilities on the ORR which can be used to support risk assessment.

TDEC/DOE-OD has also initiated an environmental monitoring and sampling program. In December 1994, TDECIDOE-OD made its CY 1995 Environmental Monitoring Plan available to DOE. The plan addressed the state's intentions in the areas of sampling, site audits and inspections, review of sampling and analysis of data generated by DOE, review of plans, and oversight. Through these activities, the state intends to characterize and monitor chemical and radiological emissions in the air, water, and soil both on and off the ORR. Of particular note of CY 1995 activities, in the second quarter TDEC/DOE-OD initiated an environmental thermoluminescent dosimeter (TLD) program. TLDs were placed at various locations at each site on the ORR and are replaced on a quarterly basis. On April 1, 1996, TDEC/DOE-OD published an environmental monitoring report of its CY-1995 activities.

In May 1995, the state and DOE began discussion on a 5-year renewal of the current agreement. It is expected that the new agreement will be signed in CY 1996. 


\title{
3. Environmental Management Program
}

\begin{abstract}
The Oak Ridge Environmental Management Program has four primary components. Environmental restoration studies environmental contamination and proposes cleanup solutions. Decontamination and decommissioning removes bulk contaminants and contaminated equipment from process buildings no longer in use. Waste management treats, stores, and disposes of waste generated from Department of Energy operations and cleanup work. Technology development creates new technologies or modifies existing technologies to solve environmental problems. Public involvement in decision-making is also an integral part of the Environmental Management Program.
\end{abstract}

\section{INTRODUCTION}

For nearly half a century, one of the primary missions of DOE and its predecessor agencies was the production of nuclear weapons for the nation's defense. Production of materials for nuclear weapons, which began on the ORR in 1943, as part of the secret World War II Manhattan Project, also produced radioactive and hazardous wastes. In 1989 the reservation was placed on EPA's National Priorities List (NPL), which names waste sites across the country most in need of cleanup.

Once the reservation was added to the NPL, cleanup became subject to the process specified in CERCLA, more commonly known as Superfund. This law requires federal agencies and private-sector companies to investigate and remedy abandoned or uncontrolled hazardous waste sites where a release has occurred or may occur. It also requires public involvement to ensure that citizens are informed of and are involved in making cleanup decisions.

In 1990 DOE-HQ established the Office of Environmental Management, making DOE-ORO responsible for cleanup of the reservation, with Energy Systems serving as its managing and operating contractor. The following sections highlight some of the environmental management projects that were addressed in 1995.

\section{ENVIRONMENTAL RESTORATION}

\section{K-25 Powerhouse Implosion}

On September 9, 1995, the K-25 Powerhouse was demolished. Explosives were used to implode the steel structure after most of the brick and masonry walls had been removed. The facility was built in 1945 in support of the Manhattan Project and later was used for offices, laboratories, and storage. The Powerhouse demolition was part of DOE's Environmental Restoration Incentive Project program, a new contracting method that promotes faster, more cost-effective cleanups without compromising safety (Fig. 3.1). The scope of this project included decontamination and demolition of 14 of the 22 structures located in the Powerhouse area.

\section{A Decision Is Reached for Lower Watts Bar Reservoir}

In 1995 DOE completed an environmental investigation of Lower Watts Bar Reservoir downstream from Kingston (Fig. 3.2). Copies of DOE's findings were made available to the public, and stakeholders meetings were held in Oak Ridge, Kingston, and Spring City. The public had the opportunity to comment on the DOE findings between March 24 and April 28, 1995. Results of the survey showed that risks from contaminants in the reservoir are very low. Therefore, DOE recommended that no action be taken to remove the contaminants. 
Y-12 PHOTO 318023

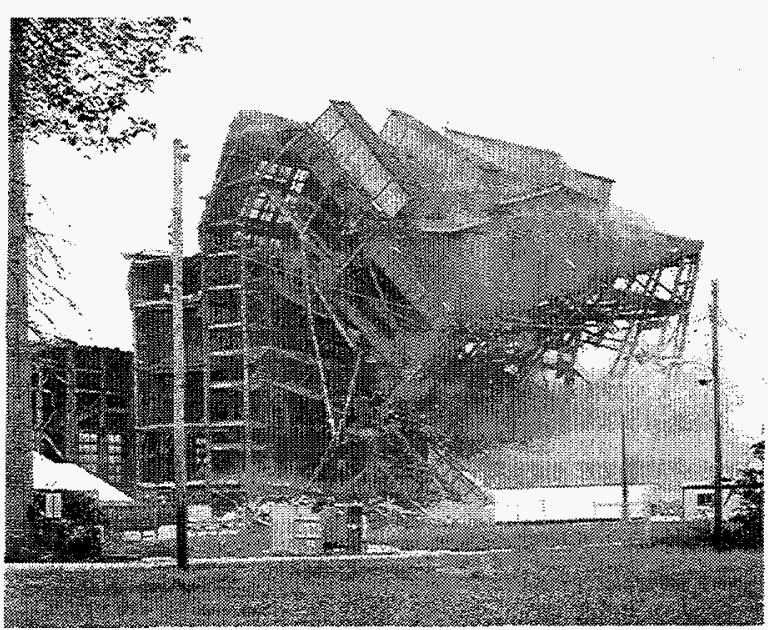

Fig. 3.1. The framework of the K-25 Powerhouse was demolished as part of DOE's Environmental Restoration Incentive Project program.

ORNL-DWG 96M-4861

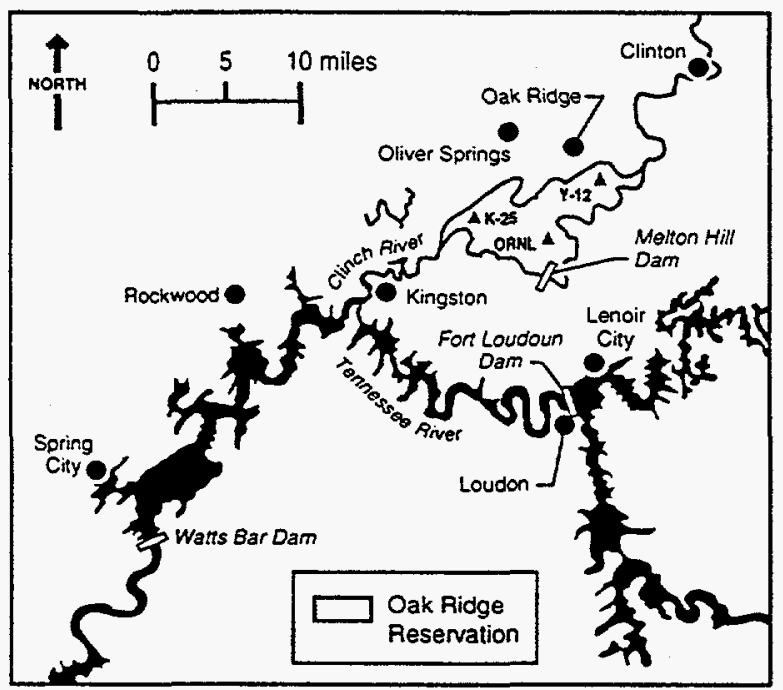

Fig. 3.2. The Clinch River flows past the ORR en route to Kingston, where it merges with the Tennessee River. The Lower Watts Bar Reservoir extends from Kingston south to Watts Bar Dam, south of Spring City.

Polychlorinated biphenyls (PCBs) and radioactive cesium are the contaminants of greatest concern in the reservoir. PCBs are cancer-causing industrial chemicals that accumulate in the flesh of fish. Their presence in Lower Watts Bar Reservoir can be attributed in part to DOE activities, although their use was once widespread, and they are also found in waters upstream of the ORR. Most of the cesium contamination resulted from DOE activities that took place 40 years ago. Small but detectable amounts are buried in deep-water sediment of the reservoir.

DOE and its regulators (EPA and TDEC) have signed the Lower Watts Bar Reservoir Record of Decision (ROD). The ROD includes comments received during the public comment period and calls for institutional controls, such as fishing advisories and control of dredging activities, to limit exposure to contaminants in fish and sediments. DOE will continue monitoring conditions in the reservoir for at least another 5 years, at which time DOE, EPA, and TDEC will determine whether further monitoring is needed.

\section{DOE Submits Record of Decision for Remediation of Lower East Fork Poplar Creek}

On June 1, 1995, DOE delivered its ROD for Lower East Fork Poplar Creek to EPA and TDEC for approval. DOE also held a public meeting on June 8 to explain the ROD to the public. The ROD documents DOE's plan for the removal of mercury contamination from floodplain soil along the creek (Fig. 3.3). The contamination was released inadvertently into the creek from the Y-12 Plant during the 1950s, where for many years mercury was used in production processes.

The planned remediation involves removal of contaminated soil until the level of mercury (measured in parts per million) is reduced and is no longer a threat to human health. To determine a safe level, DOE considered the types of mercury compounds present as well as the quantity. The threat posed by mercury to human health, and the health of other organisms, depends on how readily the mercury is taken into the body; some forms of mercury, such the elemental metal and mercuric sulfide, are less easily absorbed than mercuric chloride. By identifying the amounts and types of mercury present, DOE was able to determine a "percent bioavailablity factor," from which it could estimate a safe parts-per-million concentration for

\section{3-2 Environmental Management Program}




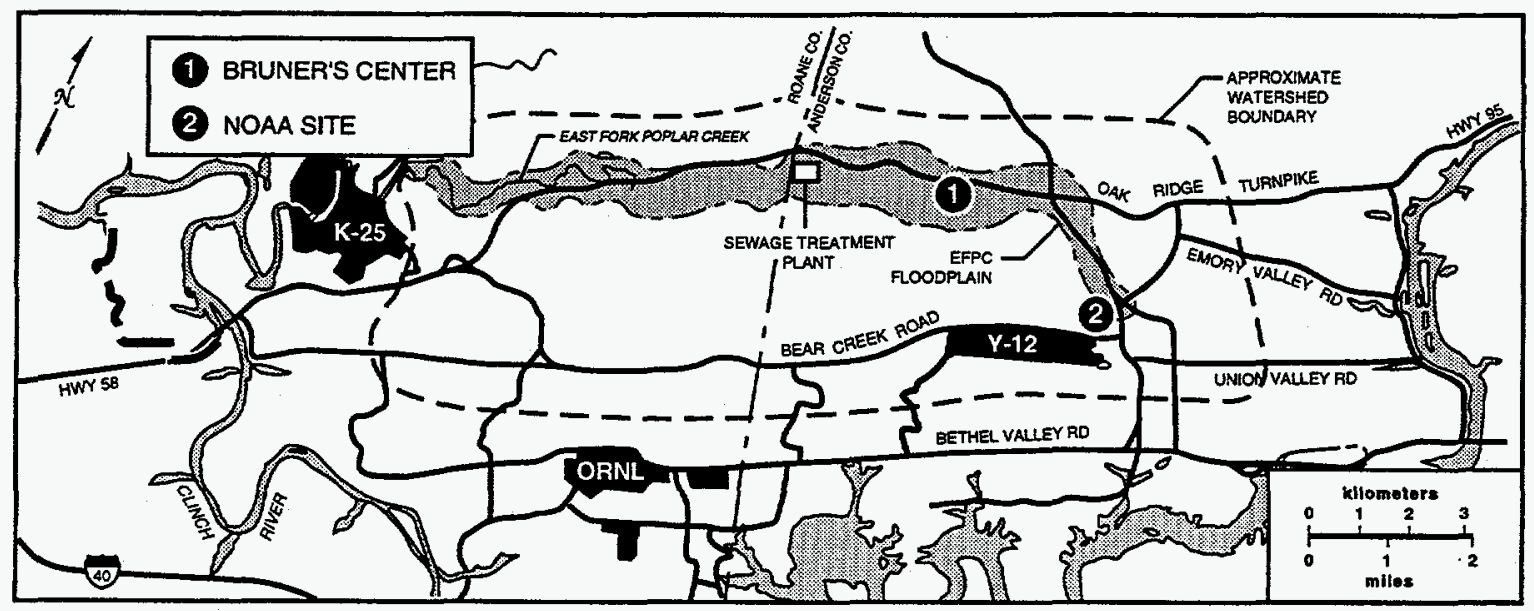

Fig. 3.3. The ROD for Lower East Fork Poplar Creek calls for excavating the Bruner's Center site along the Oak Ridge Turnpike and the NOAA site along Illinois Avenue.

the Lower East Fork Poplar Creek floodplain soil. Its findings were corroborated by EPA, TDEC, and the Agency for Toxic Substances and Disease Registry (ATSDR), which is part of the Centers for Disease Control.

DOE's planning was also tempered by public opinion. On January 26, 1995, DOE held a public meeting to announce a proposed plan for removal of the mercury. The plan was the result of a remedial investigation that had begun in 1990. DOE received 90 responses from the public, 50 at the meeting and 40 more during the comment period, which lasted until February 22. It was the most responses ever generated from a proposed remedial action in Oak Ridge. Many of the comments expressed concerns that the proposed excavations would harm the floodplain ecology, which in spite of the mercury, is thriving. Following the announcement of a revised cleanup level, DOE held another comment period, from June 14 to July 14 .

Actions to be taken include the removal of all floodplain soil containing mercury concentrations above $400 \mathrm{ppm}$, thus reducing the threat to human health while minimizing the impact on the local ecology. The creek will continue to be monitored to determine the effectiveness of the project. The soil will be taken to a permitted landfill on the Y-12 Plant, and the excavated sites will be back-filled with clean soil. At a cost of about $\$ 30$ million, the project will allow unrestricted future land use. All documentation, including public comments and the ATSDR report, pertaining to the Lower East Fork Poplar Creek Floodplain remediation project are available at the DOE Information Resource Center, 105 Broadway Avenue, Oak Ridge.

\section{DECONTAMINATION AND DECOMMISSIONING}

\section{Variable Dose Rate Irradiation Facility Dismantled}

The Variable Dose Rate Irradiation Facility (VDRIF), located on the ORR, has been dismantled. During the 1960s and 1970s, VDRIF had served as state-of-the-art radiation-exposure research facility. It contributed significantly to experiments in radiobotany, pathology, soil chemistry and plant nutrition, genetics, and animal physiology. In 1995 its cobalt-60 sources were removed, thus ending the long useful service of VDRIF.

Research into the effects of radioactive fallout began in Oak Ridge in 1948, following the weapons testing at Alamogordo, New Mexico. The Atomic Energy Commission set aside a portion of the ORR as an agricultural research station to be operated jointly with the

Environmental Management Program 
University of Tennessee. Its purpose was to study responses of plants and animals to external radiation, uses of radioisotopes in agricultural research, and transport of radionuclides in food chains. During the 1950s the open-air Low Dose Irradiation Facility was constructed to study the effects of whole-body gamma radiation on large animals.

The desire to conduct experiments at higher dose rates led to the building of VDRIF. Funding for construction was authorized by the Atomic Energy Commission (AEC). ORNL, the Y-12 Plant, and the University of Tennessee collaborated to supply the design and materials.

The VDRIF is an enclosed structure containing an entrance maze, a control room, and an irradiation room. Each of the six cobalt-60 radiation sources contained 3631 -cm-diam. wafers within stainless steel, lead-shielded tubes. The activity of the wafers increased exponentially from top to bottom to provide variable dose rates, and each source could be raised or lowered independently of the others from shielded wells. In June 1967 the activity of each source, $452 \mathrm{Tbq}$ $(4.52 \mathrm{E}+14 \mathrm{~Bq}$ or $1.2 \mathrm{E}+16 \mathrm{pCi})$ contributed to an initial maximum exposure of about $70 \mathrm{R} / \mathrm{min}$ at the exposure stations.

The Agricultural Research Laboratory (renamed the "Comparative Animal Research Laboratory" in 1975) became the responsibility of ORAU in 1981. The VDRIF sources were last used in May 1984; the sources were sealed and the lifting mechanisms were removed in 1991. In 1995 a company under contract to ORAU on behalf of DOE transported the sources to California for recycling. The VDRIF structure is currently vacant and is available for other uses.

\section{WASTE MANAGEMENT}

\section{TDEC Issues an Order for Mixed-Waste Treatment and Storage}

In September 1995 the commissioner of TDEC issued an order to DOE that specifies a schedule for the treatment and disposal of mixed waste originating from the three ORR sites. In early April 1995 DOE submitted to
TDEC a proposed treatment plan for all mixed wastes on the ORR. The development of the plan encouraged stakeholder involvement, which in addition to general stakeholder meetings included three workshops for local individuals interested in waste treatment. The state order modifies the proposed site treatment plan.

Mixed waste is a mixture of hazardous chemical waste and transuranic radioactive waste components. DOE was required to submit a mixed-waste treatment plan under RCRA as amended by the Federal Facilities Compliance Act of 1992. The Act requires that hazardous components of mixed waste be treated before disposal.

The final order details a timetable for treatment of the wastes, includes schedules for additional characterization of some wastes when it is required to support planning for treatment, and takes into account funding availability. It will be reviewed annually to consider changing technologies and funding levels. The order is available in the DOE Public Reading Room at 55 Jefferson Circle, off the turnpike in Oak Ridge.

\section{Envirocare Shipments Continue}

Shipments are continuing from the K-25 Site to Envirocare of Utah, Inc. Since August of 1994 more than 20,592 drums ( 264 box cars) have been shipped to the Envirocare facility, located 80 miles (about $129 \mathrm{~km}$ ) west of Salt Lake City. Wastes shipped from the K-25 Site include material dredged from two ponds as well as ash from the TSCA Incinerator.

Envirocare is the only commercial facility in the United States licensed to dispose of mixed waste once it has been treated to stabilize the hazardous components. After the box cars arrive at Envirocare, the drums are unloaded, are tested to ensure that they meet waste acceptance criteria, and are placed in a lined disposal cell. When the cell is filled, steel box lids are placed around the drums, forming a boundary (Fig. 3.4). Clean concrete is then poured over the drums to fill void spaces between them. Once filled completely, the cell is capped with clean soil. 


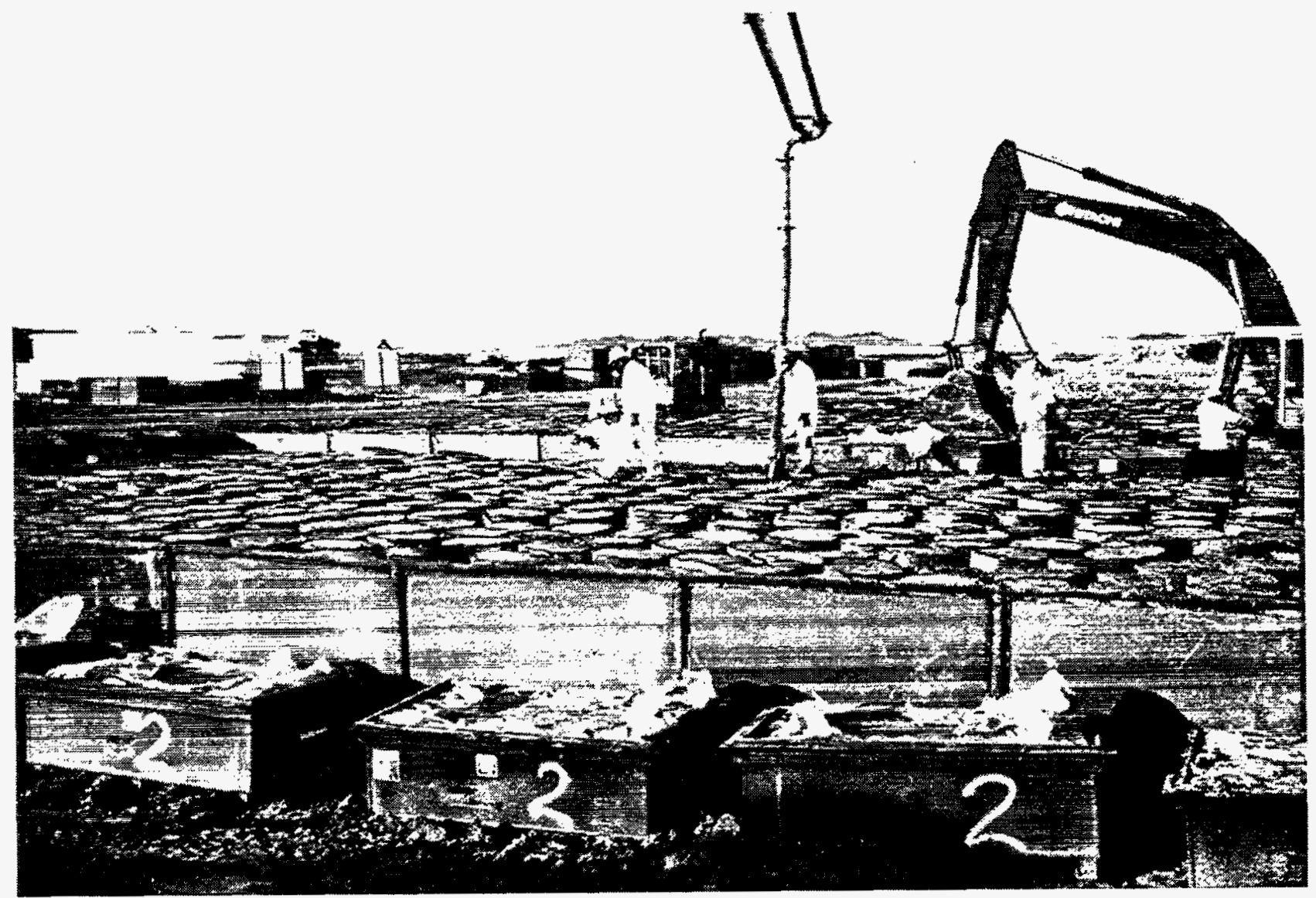

Fig. 3.4. Workers at Envirocare of Utah, Inc., prepare to pour clean concrete in the void spaces between drums and to seal the drums in the lined disposal cell. Once the drums have been sealed in the lined disposal cell with clean concrete, the area is capped with clean soil.

\section{TECHNOLOGY DEVELOPMENT \\ TRANSCOM Tracks Waste Shipments}

The U.S. Transportation Command (TRANSCOM) is part of DOE's Transportation Information Network, which uses a satellite positioning and reporting system to track highway shipments of waste and spent nuclear fuel. After vehicle information is transmitted to a satellite receiving station, it is relayed to the TRANSCOM Control Center in Oak Ridge, located at 3 Main Street. Authorized users can gain access to the information from their personal computers.

\section{Interim Waste Management Facility Refines Tumulus Disposal Technique}

At the ORNL Interim Waste Management Facility (IWMF) DOE applies "tumulus" disposal technology to ensure that LLW stays isolated from the environment. Developed by the French nuclear industry, tumulus disposal involves placing compacted LLW in metal boxes, sealing the boxes, and placing them inside concrete vaults. The vaults are stacked three-high on an engineered concrete pad that has been reinforced with layers of sand and gravel and with plastic and fabric liners. Impervious liners and soil are placed over completed stacks, making an earthen

Environmental Management Program 
'TNYO te spuod pareuruejuos

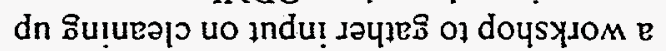

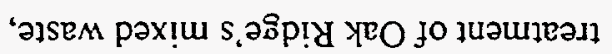

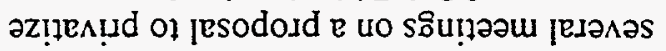

'sô!ıวaน

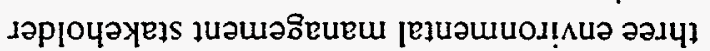

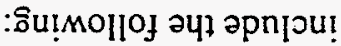

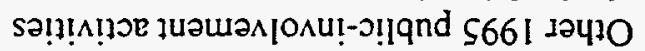

`66I ว1ए U!

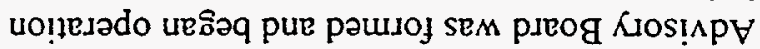

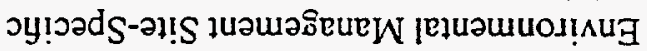

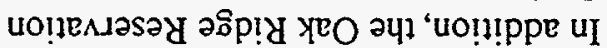
' ( $9^{\prime} \varepsilon$ '.

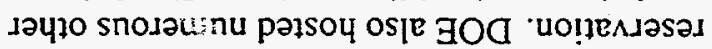

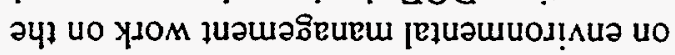

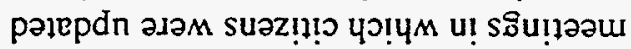

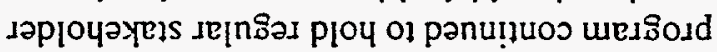

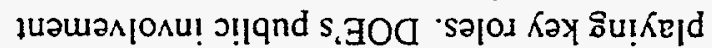

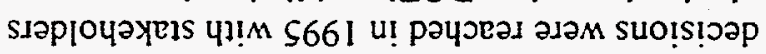

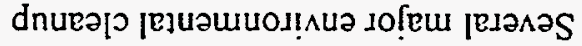

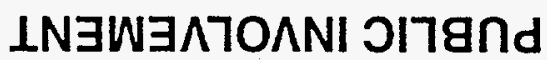

$\cdot\left(\varsigma \varepsilon \cdot 8 \cdot \frac{0}{1 ! 4}\right)$

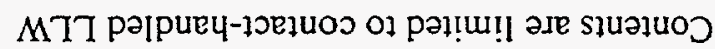

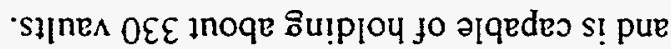

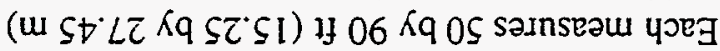

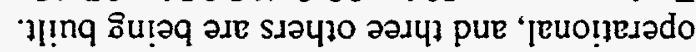

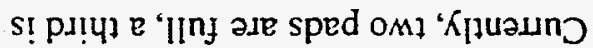

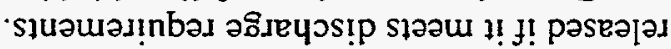

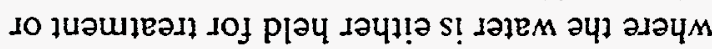

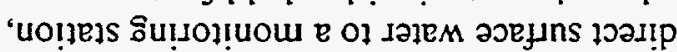

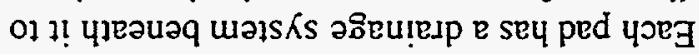

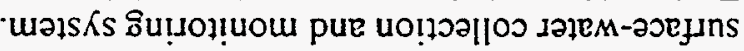

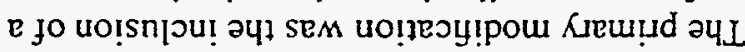

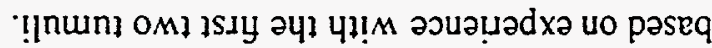
'pəy!pou SEM uô!səp ә4L ‘ I66I u! l!!nq SEM ped

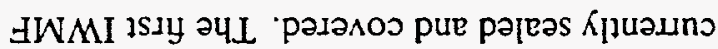
aje Качl : 661 l!

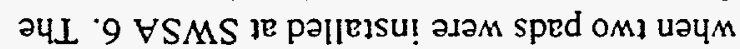
'886I U! 7NAO Ie uxôa jesods!p snjnunL

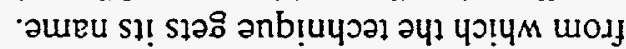

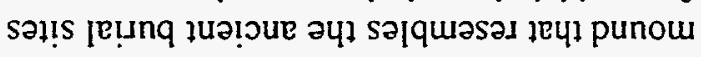

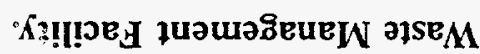

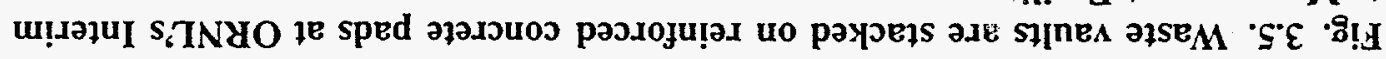

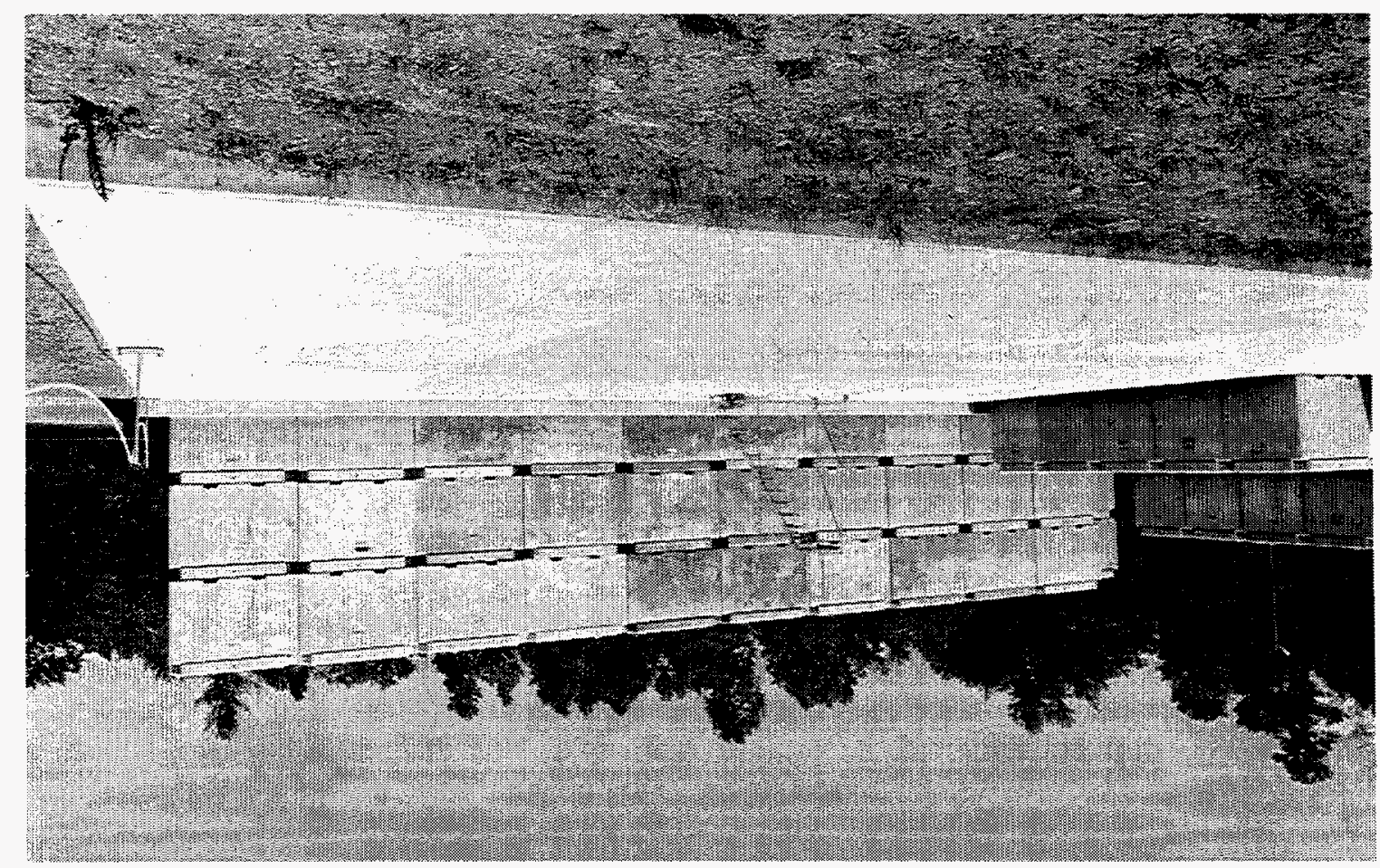



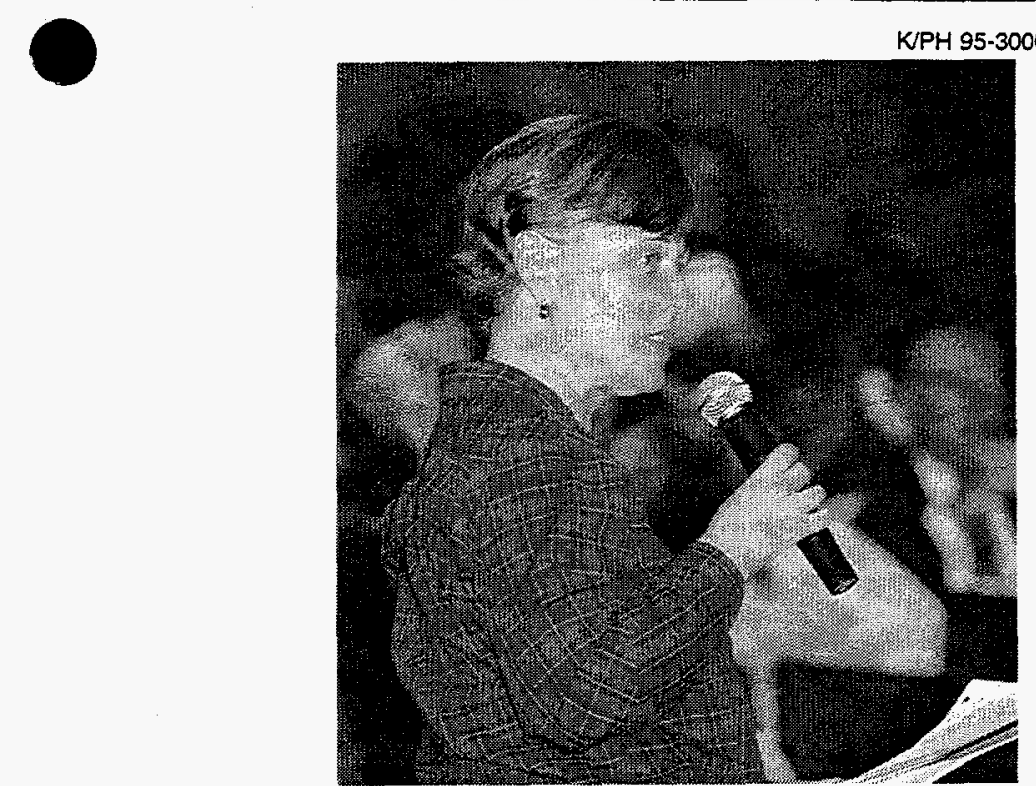

Fig. 3.6. A concerned citizen comments on the plan proposed for the cleanup of the Lower East Fork Poplar Creek floodplain.

ORNL PHOTO $3572-96$

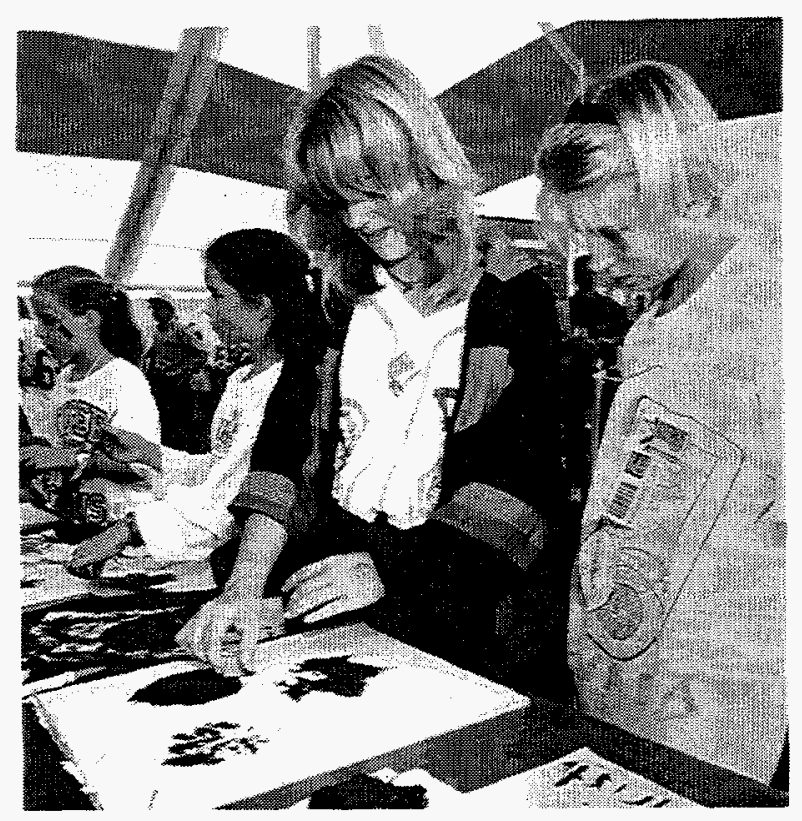

Fig. 3.7. Students at the EnvironMENTAL Fair are introduced to "the World of Leaves."

- a public comment period on the Chestnut Ridge Filled Coal Ash Pond Proposed Plan,

- a public workshop on the Baseline Environmental Management Report,
- a public workshop on the Molten Salt

Reactor Experiment remedial action program at ORNL,

- a video conference on the Draft Waste Management Programmatic Environmental Impact Statement, and

- a meeting with members of the Merriwater Homepark Association concerning testing of groundwater in their neighborhood.

\section{EnvironMENTAL Fair 1995}

DOE held its fourth annual EnvironMENTAL Fair on October 10. More than 2000 sixth-graders from 27 area schools had fun while learning what we can all do to make the world a cleaner place (Fig. 3.7).

\section{Common Ground Process Concludes}

A process that began in 1994 to involve all affected stakeholders in land-use planning at the ORR concluded in late 1995. More than 350 stakeholders participated in the Common Ground Process, including citizens who live and work in the surrounding region, local government leaders, union leaders, opinion leaders, regulators, and senior management from DOE and Energy Systems.

Conclusions reached in the final Common Ground report will be used to aid in reaching cleanup decisions and in strategic planning for overall land use. The overall vision specifies that the site should serve as an integrated science, education, and technology complex operated in partnership with the private sector. Under this scenario, the reservation would be managed by the federal government as a single parcel. The final report also recommends a comprehensive planning process, led by a group of federal, state, and local interests, to work through land-use decisions.

\section{Site-Specific Advisory Board Convenes}

In September 1995 the Oak Ridge Environmental Management Site-Specific 
Advisory Board held its first meeting. The board was established to advise DOE on environmental management issues, including recommendations for cleanup levels, technology development, and long-term waste management issues.

The group includes 17 citizen members from communities affected by cleanup decisions and three nonvoting members from DOE, TDEC, and EPA Region 4. The board co-hosted with DOE two workshops on DOE's Prioritization List for Fiscal Year 1998.

\section{Some Web Sites and a New Toll-Free Number}

You can get the latest information on environmental cleanup and waste management in Oak Ridge, including the Public Involvement Calendar, at the following web addresses:

- http://www.doe.gov reaches the national DOE Web site;
- http://www.em.doe.gov takes you to the national DOE Environmental Management Web site;

- http://www.ornl.gov provides access to all ORNL home pages, plus home pages for the Y-12 Plant, the K-25 Site, ORAU, Energy Systems, and other sites of local interest; and

- http://www.ornl.gov/doe/oro/home.html reaches the DOE Oak Ridge Operations Web site.

Stakeholders outside the local calling area may reach the Environmental Management Community Relations Office by calling toll-free: 1-800-382-6938. 


\title{
4. Effluent Monitoring
}

S. Baloga, E. T. Collins, S. G. Cortelyou, L. V. Hamilton, K. G. Hanzelka, J. M. Loar, D. M. Maguire, H. B. McElhoe, M. J. Peterson, R. A. Rich, E. M. Schilling, I. D. Shelton, R. S. Sherles, L. R. Shugart, G. R. Southworth, M. M. Stevens, and P. T. Stevens

\begin{abstract}
Effluent monitoring is a major activity on the ORR. Effluent monitoring is the collection and analysis of samples or measurements of liquid and gaseous effluents to determine and quantify contaminants and process-stream characteristics, assess any chemical or radiological exposures to members of the public, and demonstrate compliance with applicable standards.
\end{abstract}

\section{AIRBORNE DISCHARGES}

Airborne discharges from DOE Oak Ridge facilities, both radioactive and nonradioactive, are subject to regulations issued by EPA, the TDEC Air Pollution Control Board, and DOE orders. Radioactive emissions are regulated by EPA Region IV under the CAA, NESHAP, 40 CFR 61, Subpart H. (See Appendix A for a list of radionuclides and their radioactive half-lives.) Nonradioactive emissions are regulated under the rules of the TDEC Division of Air Pollution Control.

The NESHAP regulations limit the amount of annual radioactive exposure or dose to the nearest or most affected member of the public. In December 1989, the NESHAP regulations were reissued. Negotiations between EPA and DOE were initiated to bring the ORR into full compliance with the new regulations. As a result of those negotiations, an FFCA was signed in May 1992 by the DOE-ORO manager and was implemented at the ORR facilities. The ORR fulfilled all of its FFCA commitments and came into compliance with the regulations by December 1992. On March 26, 1993, EPA Region IV certified that DOE-ORO had completed all actions required by the FFCA and is considered to be in compliance with the radionuclide NESHAP regulations. An updated Rad-NESHAP Compliance Plan was sent to EPA Region 4 in May 1994.

DOE requirements for airbome emissions are established in DOE Order 5400.1, DOE
Order 5400.5, 40 CFR 61 Subpart H, and the Environmental Regulatory Guide for Radiological Effluent Monitoring and Environmental Surveillance (DOE 1991). The criteria in NESHAP regulations and DOE orders define major effluent sources as emission points that have the potential to discharge radionuclides in quantities that could cause an EDE of $0.1 \mathrm{mrem} / \mathrm{year}$ or greater to a member of the public. Potential emissions are calculated for a source by assuming the loss of pollution control equipment while the source is otherwise operating normally.

Each ORR facility has a comprehensive air pollution control and monitoring program to ensure that airborne discharges meet regulatory requirements and do not adversely affect ambient air quality. Air pollution controls at the three Oak Ridge facilities include exhaust gas scrubbers, baghouses, and exhaust filtration systems designed to remove airborne pollution from exhaust gases before their release to the atmosphere. Process modifications and material substitutions are also made to minimize air emissions. In addition, administrative control plays a role in regulating emissions. Each installation has developed an emissions inventory program that includes stack sampling as necessary to determine the amounts of pollutants that are not removed by the air pollution control equipment. 


\section{Y-12 Plant Radiological Airborne Effluent Monitoring}

The release of radiological contaminants, primarily uranium, into the atmosphere at the Y-12 Plant occurs almost exclusively as a result of plant production, maintenance, and waste management activities. NESHAP regulations for radionuclides require continuous emission sampling of major sources; (a "major source" is considered to be any emission point that potentially can contribute $>0.1 \mathrm{mrem} /$ year EDE to an off-site individual). During 1995, 55 of the Y-12 Plant's 68 stacks were judged to be major sources. Five of these sources were not operational in 1995 because of work in progress on process and stack modifications. Twenty-one of the stacks having the greatest potential to emit significant amounts of uranium are equipped with alarmed breakthrough detectors, which alert operations personnel to process-upset conditions or to a decline in filtration-system efficiencies, allowing them to investigate and correct the problem before a significant release occurs.

As of January 1, 1995, the Y-12 Plant had a total of 68 stacks, 63 of which were active and 5 were temporarily shut down. During 1995 five additional stacks were placed into temporary shutdown. Thus, during the course of the year 63 stacks were monitored, and there were 58 stacks being monitored at the end of 1995.

Radionuclides other than uranium are handled in millicurie quantities as part of ORNL and Y-12 Plant laboratory activities at facilities within the boundary of the Y-12 Plant. The releases from these activities are minimal, however, and have negligible impact on the total Y-12 Plant dose. Emissions from unmonitored process and laboratory exhausts, categorized as minor emission sources, are estimated according to EPA -approved calculation methods. Emissions from room ventilation systems are estimated from health physics data collected on airborne radioactivity concentrations in the work areas. Areas where the monthly average concentration exceeded $10 \%$ of the DOE derived air concentration (DAC) worker protection guidelines were included in the annual emission estimate.

\section{Sample Collection and Analytical Procedure}

Uranium stack losses were measured continuously on 63 process exhaust stacks in 1995. Particulate matter (including uranium) was filtered from the stack sample; filters at each location were changed routinely, from one to five times per week, and analyzed for total uranium. In addition, the sampling probes and tubing were removed quarterly and washed with nitric acid; the washing was analyzed for total uranium. At the end of the year, the probe-wash data were included in the final calculations in determining total emissions from each stack.

In 1995, 62 emission points were identified from unmonitored radiological processes and laboratories. In addition, one ventilation area from a building that houses depleted uranium operations was identified from health physics data, where one or more average monthly concentration exceeded $10 \%$ of the DAC. For the area, the annual average concentration is used, with design ventilation rates, to arrive at the annual emission estimate. No areas from buildings that house enriched uranium operations met these criteria.

\section{Results}

An estimated $0.02 \mathrm{Ci}(6.5 \mathrm{~kg})$ of uranium was released into the atmosphere in 1995 as a result of Y-12 Plant activities (Table 4.1). The specific activity of enriched uranium is much greater than that of depleted uranium, and about $86 \%$ of the curie release was composed of emissions of enriched uranium particulate, even though only $4 \%$ of the total mass of uranium released was enriched material (Figs. 4.1 and 4.2).

\section{ORNL Radiological Airborne Effluent Monitoring}

Airborne discharges at ORNL consist primarily of ventilation air from radioactively contaminated or potentially contaminated areas, 
Table 4.1. Y-12 Plant airborne uranium emission estimates, 1995

\begin{tabular}{|c|c|c|}
\hline \multirow[t]{2}{*}{ Source of emissions } & \multicolumn{2}{|c|}{ Quantity emitted } \\
\hline & $\mathrm{Ci}^{a}$ & $\mathbf{k g}$ \\
\hline \multicolumn{3}{|c|}{ Enriched uranium } \\
\hline Process exhaust (monitored) & 0.017 & 0.26 \\
\hline $\begin{array}{l}\text { Process and laboratory exhaust } \\
\text { (unmonitored) }\end{array}$ & 0.0002 & 0.0025 \\
\hline Room exhaust (from health physics data) & 0.00 & 0.00 \\
\hline \multicolumn{3}{|c|}{ Depleted uranium } \\
\hline Process exhaust (monitored) & 0.0009 & 1.7 \\
\hline $\begin{array}{l}\text { Process and laboratory exhaust } \\
\text { (unmonitored) }\end{array}$ & 0.0021 & 4.0 \\
\hline Room exhaust (from health physics data) & 0.00027 & 0.5 \\
\hline Total & 0.02 & 6.5 \\
\hline
\end{tabular}

${ }^{a} 1 \mathrm{Ci}=3.7 \mathrm{E}+10 \mathrm{~Bq}$.

ORNL-DWG 93M-7051R2

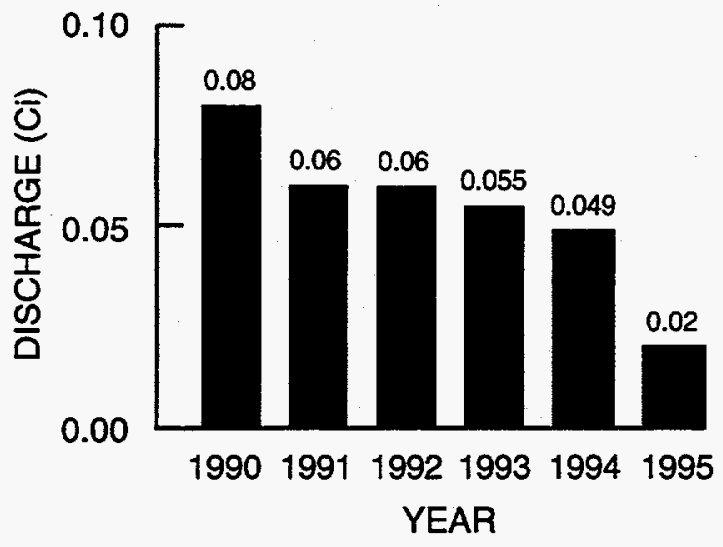

Fig. 4.1. Total curies of uranium discharged from the Y-12 Plant to the atmosphere, 1990-95.

vents from tanks and processes, and ventilation for reactor facilities. Typically, radioactively contaminated and potentially contaminated airborne emissions are treated, then filtered with high-efficiency particulate air (HEPA) and/or charcoal filters before discharge to ensure that any radioactivity released is as little as possible.

Airborne discharges are unique because of the wide variety of research activities performed at ORNL. Radiological gaseous emissions from ORNL typically consist of solid particulates, adsorbable gases (e.g., iodine), tritium, and nonadsorbable gases. The major radiological emission point sources for ORNL consist of

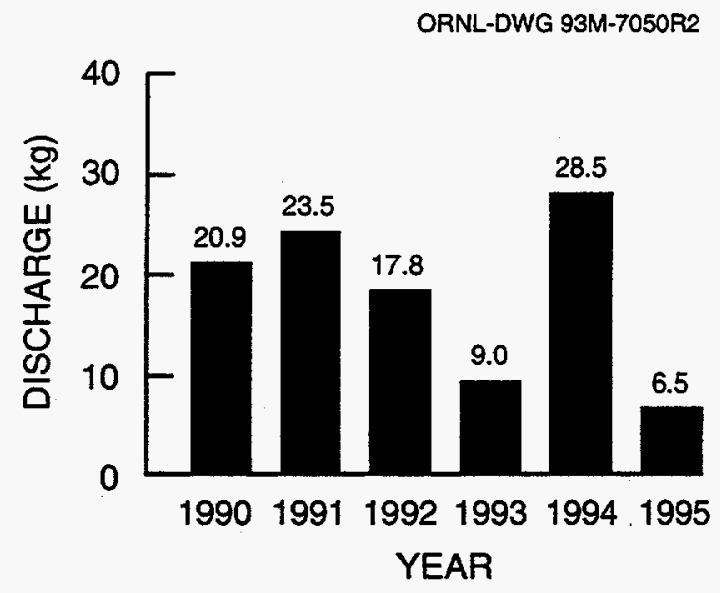

Fig. 4.2. Total kilograms of uranium discharged from the Y-12 Plant to the atmosphere, 1990-95.

the following four stacks located in Bethel and Melton valleys (Fig. 4.3):

- 2026 High Radiation Level Analytical Laboratory;

- 3020 Radiochemical Processing Plant;

- 3039 , central off-gas and scrubber system, which includes 3500 and 4500 areas cell ventilation system, isotope solid state ventilation system, and 3025 and 3026 areas cell ventilation system; and

- 7911 Melton Valley complex (HFIR and REDC). 


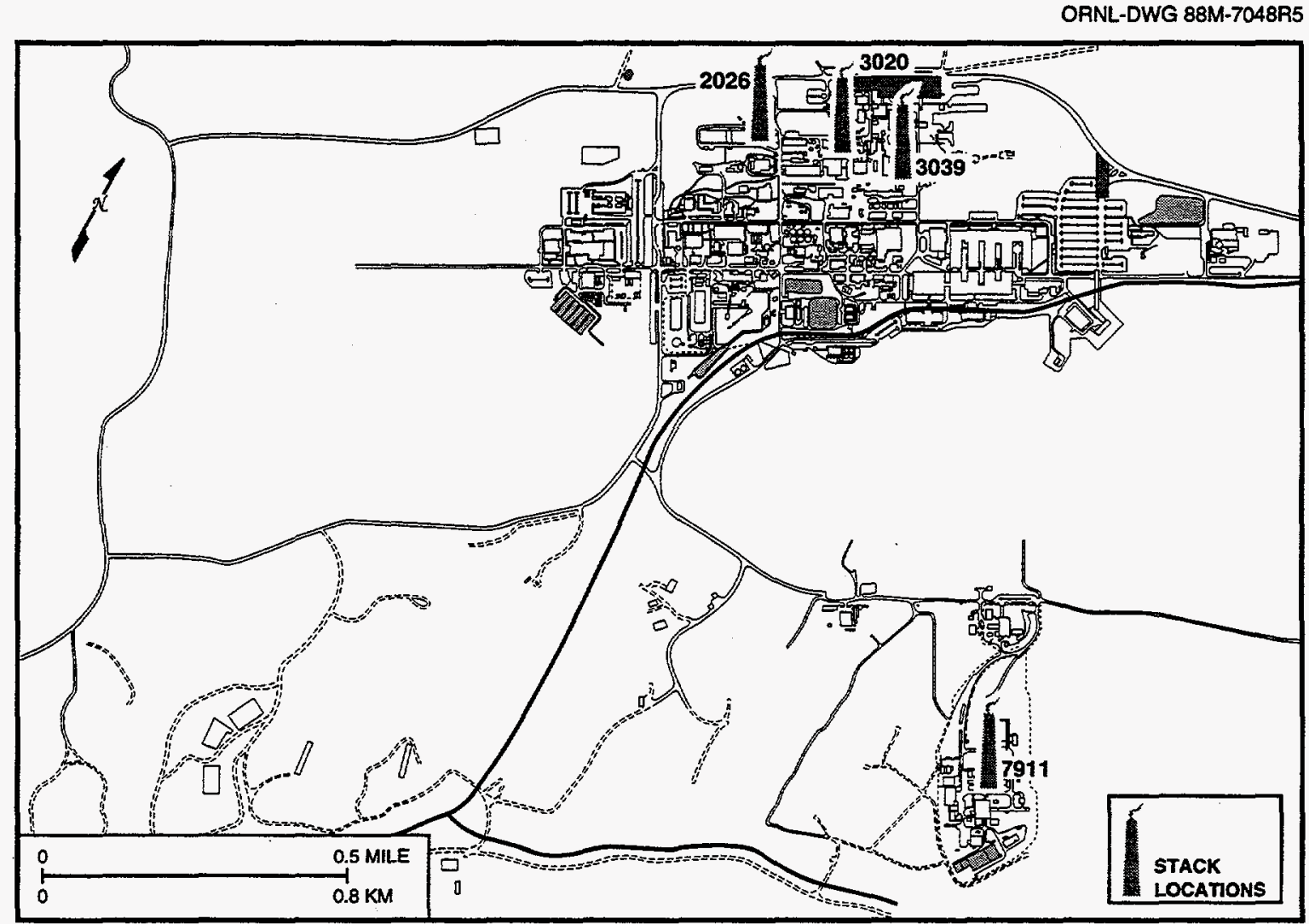

Fig. 4.3. Locations of major stacks (rad emission points) at ORNL.

Each stack and vent was assessed for its potential to discharge regulated air pollutant emissions. Those with no potential for regulated air pollutant emissions, such as steam vents, do not require any further documentation. The first phase of the stack and vent survey focused primarily on radioactive emission sources. These sources are updated annually. In 1995, there were 18 minor point/group sources, and emission calculations/estimates were made for each of these sources.

\section{Sample Collection and Analytical Procedure}

Each of the four major point sources is equipped with a variety of surveillance instrumentation, including radiation alarms, near-real-time monitors, and continuous sample collectors. Only data resulting from analysis of the continuous samples are used in this report because the other equipment does not provide data of sufficient accuracy and precision to support the quantitation of emission source terms.

All ORNL in-stack source sampling systems comply with American National Standards Institute N 13.1 (1969, R-1982) criteria. The sampling systems generally consist of a multipoint in-stack sampling probe, sample transport line, a particulate filter, activated charcoal cartridges, a silica-gel cartridge (if required), flow measurement and totalizing instruments, a sampling pump, and a return line to the stack. In addition to that instrumentation, the system at Stack 7911 includes a high-purity germanium detector with a NOMAD analyzer, which allows continuous isotopic identification and quantification of radioactive noble gases present in the effluent stream. To ensure that all radioactive particulates are accounted for, end-of-the-year samples are collected and analyzed by cleaning the in-stack sampling probes. This program requires annual removal, inspection, and cleaning of sample probes.

\section{4-4 Effluent Monitoring}


Velocity profiles are performed following the criteria in EPA Method 2. This profiling ensures that the continuous samplers are sampling at acceptable isokinetic conditions and are obtaining accurate stack flow data for subsequent emission-rate calculations. An annual leak-check program is carried out to verify the integrity of the sample transport system, including the sample components.

In addition to the major sources, ORNL has a number of minor sources that have the potential to emit radionuclides to the atmosphere. Minor sources are composed of any ventilation systems or components such as vents, lab hoods, room exhausts, and stacks that do not meet the criteria for a major source but are located in or vent from a radiological control area. A variety of methods were used to determine the emissions from the various minor sources. All methods used for minor source emission calculations complied with criteria agreed upon by EPA and/or included in the NESHAP Compliance Plan for the ORR. These minor sources are evaluated on a 1- to 3-year basis, depending on the source type. All emissions, both major and minor, are compiled annually to determine the overall ORNL source term and associated dose.

\section{Results}

The 1995 radioactive airborne emissions data for ORNL included more than 45 isotopes. The charcoal cartridges, particulate filters, and silica gel traps were collected weekly. The use of charcoal cartridges is a standard method for capturing and quantifying radioactive iodines in airborne emissions. Gamma spectrometric analysis of the charcoal samples quantifies the adsorbable gases. Analysis was performed weekly. Particulate filters were held for 8 days prior to a weekly gross alpha and gross beta analysis to minimize the contribution from short-lived isotopes such as ${ }^{220} \mathrm{Rn}$ and its daughter products. At Stack 7911, a weekly gamma scan was conducted to better detect short-lived gamma isotopes. The weekly filters were then composited quarterly and analyzed for alpha-, beta-, and gamma-emitting isotopes. Compositing provides a better opportunity for quantification of these low-concentration isotopes. At the end of the year, each sample probe was rinsed, and the rinsate was collected and submitted to the laboratory for isotopic analysis identical to that of the particulate filter. The data from the charcoal cartridges, silica gel, probe wash, and the quarterly filter composites were compiled to give the annual emissions for each major source and some minor sources.

Annual radioactive airborne emissions for major sources are presented in Table 4.2. All data presented were determined to be significantly different from zero at the $95 \%$ confidence level. Any number not statistically different from zero was not included in the emission calculation. Historical trends for ${ }^{3} \mathrm{H}$ and ${ }^{131} \mathrm{I}$ are presented in Figs. 4.4 and 4.5, respectively.

The tritium emissions for 1995 are approximately 200 curies. The primary contributor was off-gas from the Tritium Facility, even though it has been inoperative since 1989. Emissions from the central off-gas system, Stack 3039, were highest in 1991 (16,000 Ci); emissions have decreased sharply since then (Fig. 4.4). The ${ }^{131}$ I emission for 1995 are 0.16 curies, which is higher than the past years (Fig. 4.5). The emissions are attributable to operations that exhaust through Stack 7911.

\section{K-25 Site Radiological Airborne Effluent Monitoring}

Locations of airborne radioactivity point sources at the K-25 Site are shown in Fig. 4.6. These locations include both individual point sources and grouped point sources such as laboratory hoods. Radioactive emissions data were determined from either EPA-approved sampling results or EPA-approved calculation methods.

\section{Sample Collection and Analytical Procedure}

Routine emission estimates from the TSCA Incinerator were generated from the continuous stack sampling system. The TSCA Incinerator is the only major radionuclide emission source at 
Table 4.2. Major sources of radiological airborne emissions at ORNL, 1995 (in curies) ${ }^{a}$

\begin{tabular}{|c|c|c|c|c|}
\hline \multirow[t]{2}{*}{ Isotope } & \multicolumn{4}{|c|}{ Stack } \\
\hline & 2026 & 3020 & 3039 & 7911 \\
\hline${ }^{3} \mathrm{H}$ & $4.1 \mathrm{E}-01$ & & $2.4 E+01$ & 4.7E+01 \\
\hline${ }^{7} \mathrm{Be}$ & $3.2 \mathrm{E}-08$ & $2.7 \mathrm{E}-07$ & $5.2 \mathrm{E}-05$ & $8.1 \mathrm{E}-04$ \\
\hline${ }^{40} \mathrm{~K}$ & $3.8 \mathrm{E}-07$ & $4.5 \mathrm{E}-07$ & $2.5 \mathrm{E}-06$ & \\
\hline${ }^{41} \mathrm{Ar}$ & & & & 1.7E+03 \\
\hline${ }^{60} \mathrm{Co}$ & $2.4 \mathrm{E}-08$ & $1.9 \mathrm{E}-07$ & $1.8 \mathrm{E}-05$ & \\
\hline${ }^{85} \mathrm{Kr}$ & & & & $9.1 \mathrm{E}+00$ \\
\hline${ }^{85 m^{m}} \mathrm{Kr}$ & & & & 9.7E+00 \\
\hline${ }^{87} \mathrm{KI}$ & & & & $1.4 \mathrm{E}+01$ \\
\hline${ }^{88} \mathrm{Kr}$ & & & & $5.0 \mathrm{E}+00$ \\
\hline${ }^{89} \mathrm{Kr}$ & & & & $1.9 \mathrm{E}-01$ \\
\hline${ }^{90} \mathrm{Sr}$ & $5.3 E-06$ & $4.8 \mathrm{E}-07$ & $4.8 E-05$ & $1.9 \mathrm{E}-05$ \\
\hline${ }^{129} I$ & & & & $2.1 \mathrm{E}-0 \mathrm{~S}$ \\
\hline${ }^{131} I$ & $2.1 E-05$ & & $3.7 \mathrm{E}-05$ & $1.6 \mathrm{E}-01$ \\
\hline${ }^{132} I$ & & & & $4.7 \mathrm{E}-02$ \\
\hline${ }^{133} \mathbf{I}$ & $8.8 \mathrm{E}-06$ & $5.5 \mathrm{E}-06$ & $5.7 \mathrm{E}-04$ & $6.5 \mathrm{E}-01$ \\
\hline${ }^{135} I$ & $1.2 \mathrm{E}-04$ & $2.1 E-04$ & $1.2 \mathrm{E}-03$ & $1.8 \mathrm{E}+00$ \\
\hline${ }^{131 m} \mathrm{Xe}$ & & & & $6.4 \mathrm{E}+00$ \\
\hline${ }^{133} \mathrm{Xe}$ & & & & $1.2 \mathrm{E}-01$ \\
\hline${ }^{133 m} \mathrm{Xe}$ & & & & $6.2 \mathrm{E}-01$ \\
\hline${ }^{135} \mathrm{Xe}$ & $8.5 E-07$ & $1.7 \mathrm{E}-06$ & $6.8 \mathrm{E}-05$ & $9.4 \mathrm{E}+01$ \\
\hline${ }^{135 m} \mathrm{Xe}$ & & & & $3.8 \mathrm{E}+02$ \\
\hline${ }^{137} \mathrm{Xe}$ & & & & $5.0 \mathrm{E}+01$ \\
\hline${ }^{138} \mathrm{Xe}$ & & & & $2.7 \mathrm{E}+02$ \\
\hline${ }^{134} \mathrm{Cs}$ & & & & $8.8 \mathrm{E}-07$ \\
\hline${ }_{137}^{137} \mathrm{Cs}$ & $2.8 \mathrm{E}-05$ & $1.2 \mathrm{E}-06$ & $1.9 \mathrm{E}-04$ & $3.8 \mathrm{E}-05$ \\
\hline${ }^{138} \mathrm{Cs}$ & & & & $9.1 \mathrm{E}+02$ \\
\hline${ }^{137 m} \mathrm{Ba}$ & $2.8 \mathrm{E}-05$ & $1.2 \mathrm{E}-06$ & $1.9 E-04$ & $3.8 \mathrm{E}-05$ \\
\hline${ }^{140} \mathrm{Ba}$ & & & & $5.8 \mathrm{E}-05$ \\
\hline${ }^{75} \mathrm{Se}$ & $1.9 E-06$ & & & \\
\hline${ }^{191}$ Os & & $1.9 \mathrm{E}-05$ & $1.4 \mathrm{E}-01$ & \\
\hline${ }^{212} \mathrm{~Pb}$ & $2.2 \mathrm{E}-01$ & $3.6 \mathrm{E}-01$ & $1.1 \mathrm{E}+00$ & $3.7 \mathrm{E}-01$ \\
\hline${ }^{228} \mathrm{Th}$ & $1.1 \mathrm{E}-07$ & $2.9 \mathrm{E}-08$ & $1.2 \mathrm{E}-07$ & $8.3 \mathrm{E}-08$ \\
\hline${ }^{230} \mathrm{Th}$ & $4.7 \mathrm{E}-08$ & $3.8 \mathrm{E}-08$ & $1.7 \mathrm{E}-07$ & $1.4 \mathrm{E}-07$ \\
\hline${ }^{232} \mathrm{Th}$ & $1.9 \mathrm{E}-08$ & $2.8 \mathrm{E}-08$ & $8.9 \mathrm{E}-08$ & $7.3 \mathrm{E}-08$ \\
\hline${ }^{234} \mathrm{U}$ & $3.5 \mathrm{E}-06$ & $5.6 \mathrm{E}-08$ & $1.4 \mathrm{E}-05$ & $8.8 \mathrm{E}-06$ \\
\hline${ }^{235} \mathrm{U}$ & $7.7 \mathrm{E}-09$ & $1.4 \mathrm{E}-09$ & $1.0 \mathrm{E}-08$ & \\
\hline${ }^{238} \mathrm{U}$ & $1.6 \mathrm{E}-07$ & $2.6 \mathrm{E}-08$ & $5.8 \mathrm{E}-08$ & $4.8 \mathrm{E}-08$ \\
\hline${ }^{238} \mathrm{Pu}$ & $7.8 \mathrm{E}-07$ & $5.4 \mathrm{E}-09$ & $6.6 \mathrm{E}-06$ & \\
\hline${ }^{239} \mathrm{Pu}$ & $2.4 \mathrm{E}-06$ & $5.5 \mathrm{E}-08$ & $1.1 \mathrm{E}-05$ & $1.2 \mathrm{E}-08$ \\
\hline${ }^{241} \mathrm{Am}$ & $1.5 \mathrm{E}-06$ & $6.6 \mathrm{E}-08$ & $6.5 \mathrm{E}-06$ & $1.5 \mathrm{E}-07$ \\
\hline${ }^{244} \mathrm{Cm}$ & $2.5 \mathrm{E}-05$ & $2.7 \mathrm{E}-08$ & $1.0 \mathrm{E}-04$ & $5.8 \mathrm{E}-07$ \\
\hline
\end{tabular}

$$
{ }^{a} 1 \mathrm{Ci}=3.7 \mathrm{E}+10 \mathrm{~Bq} .
$$

the K-25 Site and is therefore the only stack that is continuously monitored. Estimates of TSCA Incinerator emissions were based on monthly composites of weekly stack samples.

Various techniques were used to generate all other radiological point source emissions. Representative grab sample techniques were used to generate emission estimates for the K-1015 Laundry. Material balance calculations were used to generate emission estimates for the $\mathrm{K}-1004-\mathrm{A}$ through $\mathrm{D}$ laboratories. The remaining active sources were calculated using surrogate sample techniques as described in the EPA-approved NESHAP compliance plan, or from emission factors specified in 40 CFR 61, Appendix D. Both techniques are conservative methods of estimating emissions based on the physical form 


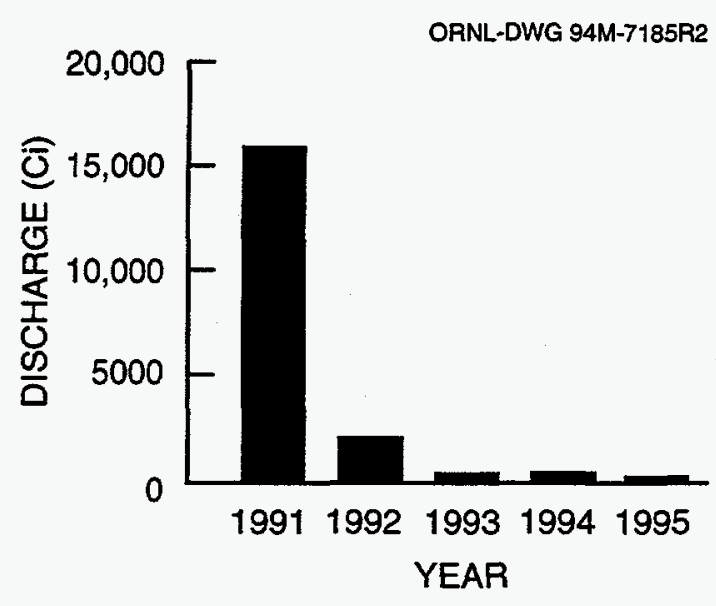

Fig. 4.4. Total discharges of ${ }^{3} \mathrm{H}$ from ORNL to the atmosphere, 1991-95.

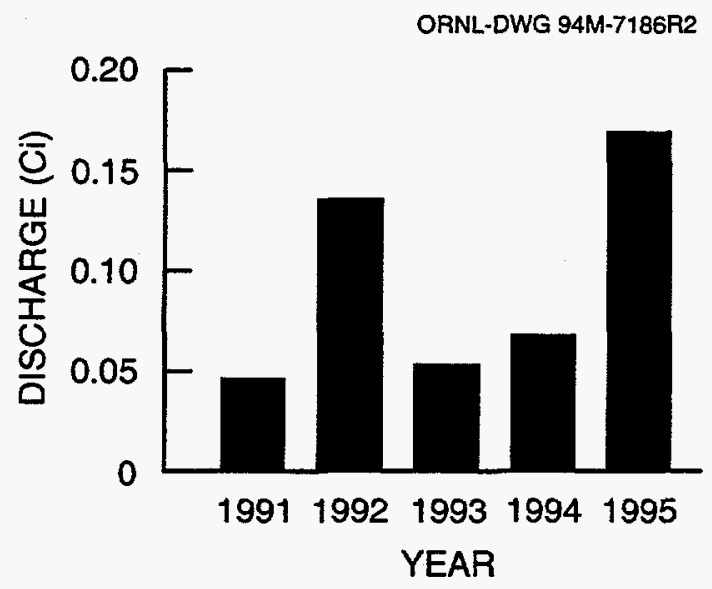

Fig. 4.5. Total discharges of ${ }^{131} I$ from ORNL to the atmosphere, 1991-95.

of the radionuclides and the maximum operating temperature of the process.

Three new minor point sources were approved for operation in 1995: (1) a container-processing facility located in K-1423 to wash potentially contaminated empty drums and to operate in conjunction with a drum crusher, (2) a HEPA vacuum-cleaning facility located in K-1310-DC for servicing vacuums containing potentially contaminated debris, and (3) the K-1037 metal-cutting activities in a HEPA-filtered room to cut up a radiologically contaminated transport cart and associated equipment. K-1423 and K-1310-DC did not initiate operations in 1995.

The following minor sources were inactive during 1995: the K-304-5 Deposit Removal
Project activities to mechanically remove radiological materials from the interior of cascade components and the $\mathrm{K}-1420$ valve shop. The Pond Waste Management Project (PWMP) drum crusher and dry material repackaging project, and the K-31/33 cascade equipment removal project minor sources completed work in 1994 and discontinued operations.

\section{Results}

K-25 Site 1995 radionuclide emissions from the TSCA Incinerator and minor emission sources are shown in Table 4.3. Additionally, Figs. 4.7 and 4.8 show a comparison of the total 1995 discharges of uranium with those of previous years. The total kilograms emitted has increased due to the incineration of a larger quantity of low-level waste at the TSCA Incinerator. As shown in Fig. 4.7, the annual total of curies emitted is similar to the total in 1994 because of the lower specific activity of the uranium isotopes emitted.

\section{Y-12 Plant Nonradiological Airborne Emissions Monitoring}

The release of nonradiological contaminants into the atmosphere at the Y-12 Plant occurs as a result of plant production, maintenance, and waste management operations and of steam generation. Most process operations are served by ventilation systems that remove air contaminants from the workplace. TDEC has issued 55 air permits that cover 335 of these emission sources. The allowable level of air pollutant emissions from permitted and exempt emission sources in 1995 was approximately 27,345 tons per year of regulated pollutants. The actual emissions are much lower than the allowable amount; however, major sources are required to pay their annual emission fee based on allowable emissions until the issuance of the major source operating permit. Therefore, the annual emission fee is based on the sum of allowable air emissions of all regulated pollutants at the Y-12 Plant as defined in Chapter 1200-3-26 of the TDEC regulations. 


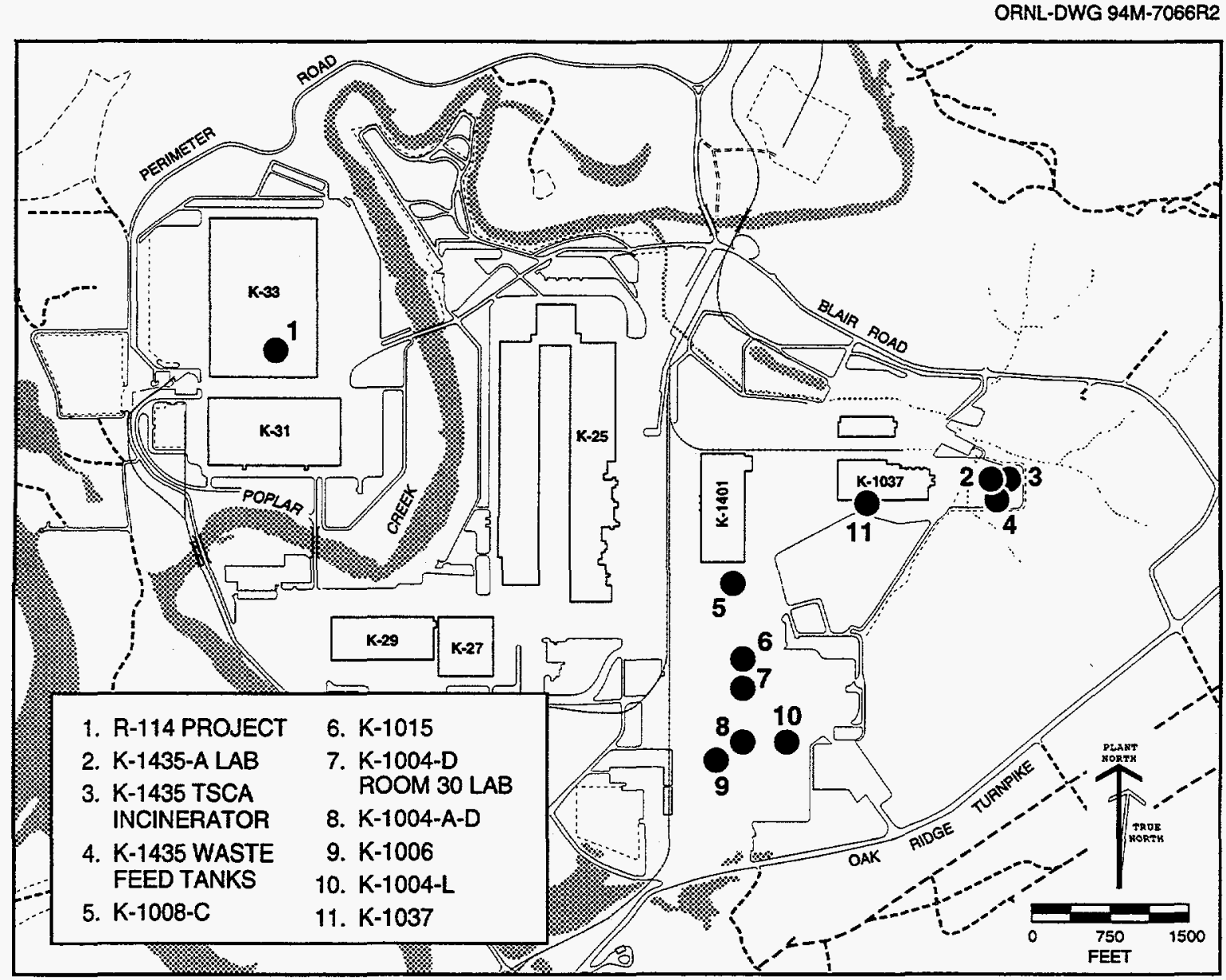

Fig. 4.6. K-25 Site active point sources of airborne radioactivity.

The Y-12 Plant annual emission fee was calculated by TDEC personnel based on 9,499 tons per year of allowable emission of regulated pollutants, with an annual emission fee of $\$ 61,982.45$, as defined in TDEC regulations, Chapter 1200-3-26-.02(9)(i). In calculating the annual emission fee, Schedule III of Chapter 26 was used, where the adjusted emissions equal the total emissions minus carbon monoxide and exempt emissions, and a 4,000-ton cap for $\mathrm{SO}_{2}$ and $\mathrm{NO}_{x}$. The emission fee rate is based on $\$ 18.55$ per ton of regulated pollutant allowable emissions. In addition, the Y-12 Plant received a prorated credit for annual emission fees paid during the FYs 1993/1994 and $1994 / 1995$ in the amount of $\$ 114,224$ pursuant to Rule 1200-3-26-.02(9)(i). When the major source operating permit is issued, the emission fee rate will increase to $\$ 32.20$ per ton of regulated pollutant.
The level of pollutant emissions is expected to decline in the future because of the changing mission of the Y-12 Plant and downsizing of production areas. More than $90 \%$ of the pollutants are attributed to the operation of the Y-12 Steam Plant; however, as a best management practice, Y-12 Plant personnel also monitor emissions from four areas that process beryllium.

In anticipation of permitting requirements and implementation of maximum achievable control technology (MACT) standards under Title V of the CAA amendments, an effort is under way to improve the stack and vent survey, criteria pollutant emission inventory, and hazardous air pollutant emission inventory. A draft of the Oak Ridge Y-12 Plant Title V permit application is expected to be prepared in 1996.

Planning for compliance with anticipated and newly issued requirements under Title VI 
Table 4.3. K-25 Site radionuclide air emission totals, 1995 (in curies) $^{a}$

\begin{tabular}{ccc}
\hline Radionuclide & TSCA Incinerator & Minor sources \\
\hline${ }^{3} \mathrm{H}$ & & $2.38 \mathrm{E}-05$ \\
${ }^{14} \mathrm{C}$ & & $3.14 \mathrm{E}-07$ \\
${ }^{40} \mathrm{~K}$ & $1.14 \mathrm{E}-02$ & $2.71 \mathrm{E}-07$ \\
${ }^{57} \mathrm{Co}$ & & $1.81 \mathrm{E}-08$ \\
${ }^{99} \mathrm{Tc}$ & $9.96 \mathrm{E}-03$ & $2.60 \mathrm{E}-05$ \\
${ }^{131} \mathrm{I}$ & & $2.69 \mathrm{E}-07$ \\
${ }^{137} \mathrm{Cs}$ & $8.48 \mathrm{E}-05$ & $1.90 \mathrm{E}-07$ \\
${ }^{237} \mathrm{~Np}$ & $9.65 \mathrm{E}-07$ & $2.55 \mathrm{E}-07$ \\
${ }^{238} \mathrm{Pu}$ & $3.60 \mathrm{E}-06$ & $1.36 \mathrm{E}-07$ \\
${ }^{239} \mathrm{Pu}$ & $9.17 \mathrm{E}-07$ & $1.06 \mathrm{E}-07$ \\
${ }^{228} \mathrm{Th}$ & $7.35 \mathrm{E}-07$ & $5.15 \mathrm{E}-07$ \\
${ }^{230} \mathrm{Th}$ & $8.54 \mathrm{E}-06$ & $9.09 \mathrm{E}-07$ \\
${ }^{232} \mathrm{Th}$ & $4.16 \mathrm{E}-07$ & $4.69 \mathrm{E}-08$ \\
${ }^{234} \mathrm{Th}$ & $2.31 \mathrm{E}-02$ & $3.83 \mathrm{E}-05$ \\
${ }^{234 m} \mathrm{~Pa}$ & $1.21 \mathrm{E}-01$ & $1.04 \mathrm{E}-04$ \\
${ }^{234} \mathrm{U}$ & $1.17 \mathrm{E}-03$ & $5.71 \mathrm{E}-05$ \\
${ }^{235} \mathrm{U}$ & $2.00 \mathrm{E}-06$ & $2.43 \mathrm{E}-06$ \\
${ }^{238} \mathrm{U}$ & $5.37 \mathrm{E}-03$ & $8.58 \mathrm{E}-05$ \\
Totals & $1.72 \mathrm{E}-01$ & $3.40 \mathrm{E}-04$ \\
\hline${ }^{a} 1 \mathrm{Ci}=3.7 \mathrm{E}+10 \mathrm{~Bq}$. & \\
${ }^{b} \mathrm{Negative} \mathrm{values} \mathrm{are} \mathrm{not} \mathrm{included.}$ & &
\end{tabular}

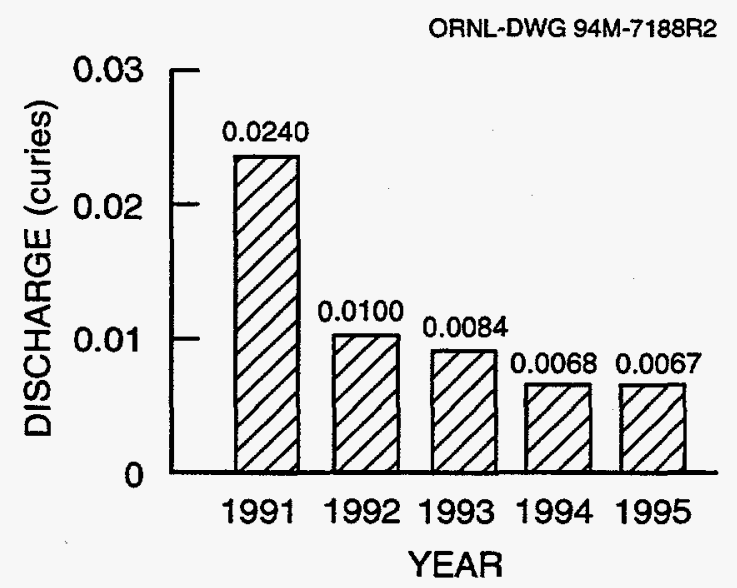

Fig. 4.7. Total curies of uranium discharged from the K-25 Site to the atmosphere, 1991-95.

of the CAA amendments is a major effort. In accordance with the Y-12 Plant CAA implementation plan, a stratospheric ozone protection plan has been issued to outline actions necessary to comply with the new limitations on the release of ozone-depleting chemicals and with the 1995 production ban on these chemicals. The Y-12 Plant Environmental Management Department personnel and refrigeration maintenance personnel successfully implemented
ORNL-DWG 94M-7187R3

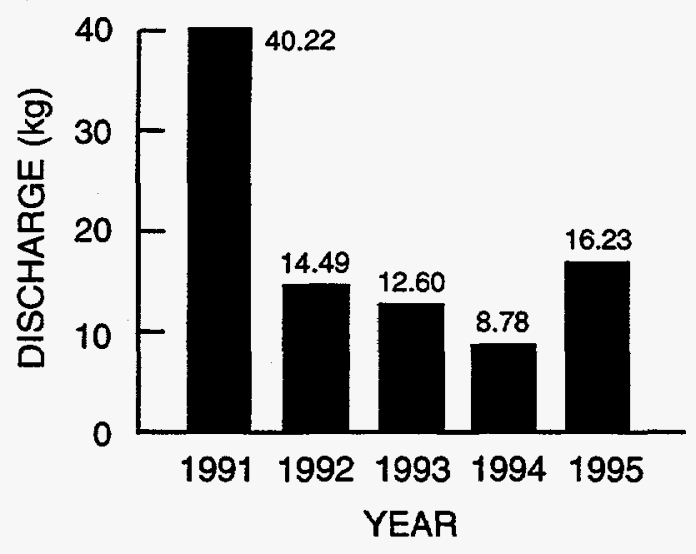

Fig. 4.8. Total kilograms of uranium discharged from the K-25 Site to the atmosphere, 1991-95.

work practices required to minimize releases of ozone-depleting refrigerants to the atmosphere. Requirements for refrigeration-system and motor-vehicle air-conditioner maintenance compliance are being met. To accommodate the production ban on ozone-depleting chemicals, studies are proceeding to find suitable replacements, and plant refrigeration equipment is being modified as needed. The Retrofit Heating, Ventilation, and Air 
Conditioning and Chillers for Ozone Protection project, currently in conceptual design, will eliminate the use of chlorofluorocarbon (CFC) refrigerants in chillers, direct expansion air conditioners, and process coolers, either by replacement with new equipment that operates on "ozone-friendly" refrigerants or by retrofit of existing equipment with new components to operate on "ozone-friendly" refrigerants.

\section{Sample Collection and Analytical Procedure}

The two Y-12 Steam Plant exhaust stacks are each equipped with Lear Siegler RM41 opacity monitoring systems. Under the current operating permit, the opacity monitoring systems are required to be fully operational for at least 95\% of the operational time of the monitored units during each month of a calendar quarter.

Currently, four exhaust stacks that serve beryllium processing areas are sampled continuously by extracting a portion of the stack gas and filtering out particulate matter. The samples are then analyzed for beryllium, and emission rates are calculated.

\section{Results}

The east and west Y-12 Steam Plant stack opacity monitors were each operational more than $99 \%$ of the time in 1995 . Both systems were taken out of service for annual calibration/recertification and for a plant-wide power outage. The calibration/recertification was performed by a subcontractor in April. A single 6-min period of excess emissions from the east stack occurred on January 20, 1995. This excess emission resulted from a malfunction of a defective microswitch on Number 3 Baghouse that caused the bypass to open. There were four 6-min periods of excess emissions, which occurred on July 13 and August 7 and 12 , 1995. Two 6-min periods of excess emissions that occurred on July 13 from the east stack resulted from start-up of fans on Boiler 3 after overhaul. Two 6-min periods of excess emissions that occurred on August 7 and 12 from the west stack resulted from taking Boilers 1 and 2 out of service and putting the baghouse into cleaning cycle. In addition, there were two 6-min periods of excess emissions, which occurred on November 5 and 21, 1995. One 6-min period of excess emissions occurred on November 5 from the east stack when a pipe from the feeder to the pulverizer was occluded with coal, thus extinguishing the fire in the boiler. One 6-min period of excess emissions occurred on November 21 from the west stack as a result of a plantwide power outage. Quarterly excess opacity reports of the operational status of the Y-12 Steam Plant are submitted to personnel at TDEC within 30 days after the end of each calendar quarter to comply with Condition 10 of the current air permit. The annual opacity calibration error test reports were submitted to TDEC in July 1995.

Beryllium stack sampling results indicated that $<1 \mathrm{~g}$ of beryllium was released during 1995; most readings on the filters were less than the plant laboratory detectable level. Thus, emission rates of beryllium are well below the NESHAP limit of $10 \mathrm{~g} /$ day. Emissions of other materials have been estimated and are provided in Table 4.4. The TDEC annual inspection, conducted in July 1995, found no noncompliances.

The Y-12 Plant has reduced CFC emissions by more than $91 \%$ since 1992 , and improvements are continuing (Fig. 4.9). The efforts of Y-12 Plant management and personnel to minimize emissions of ozone-depleting substances earned the Y-122 Plant a White House "Closing the Circle" Award for waste prevention in 1995. The Y-12 Plant was one of 18 organizations to receive the award, which recognizes outstanding achievements in federal waste prevention, recycling, and affirmative procurement.

\section{ORNL Nonradiological Airborne Emissions Monitoring}

ORNL operates 31 permitted air emission sources. Most of these sources are small-scale activities and result in very low emission rates. TDEC air permits for ORNL sources do not require stack sampling or monitoring; however, an opacity monitor is used at the steam plant to

\section{4-10 Effluent Monitoring}


Table 4.4. Y-12 Plant nonradiological airborne emissions, 1995

\begin{tabular}{|c|c|c|c|c|}
\hline \multirow[t]{2}{*}{ Chemical } & \multicolumn{2}{|c|}{ Quantity released } & \multirow{2}{*}{$\begin{array}{c}\text { Major release } \\
\text { source }\end{array}$} & \multirow[t]{2}{*}{ Basis of estimate } \\
\hline & $\mathbf{l b}$ & kg & & \\
\hline \multicolumn{5}{|c|}{ SARA 313 chemicals $^{a}$} \\
\hline Hydrochloric acid & 1,170 & 532 & Chemical processing aid & Engineering calculation \\
\hline Lead & 11 & 5 & Stack emission & $\begin{array}{l}\text { Engineering calculations based } \\
\text { on emission facts }\end{array}$ \\
\hline Methanol & 35,000 & 15,910 & Cleaning/cooling & Engineering calculation \\
\hline Nitric acid & 200 & 91 & Chemical processing aid & Engineering calculation \\
\hline
\end{tabular}

Freon 11

Freon 12

Freon 22

Particulates

$\mathrm{SO}_{x}$

Carbon monoxide

Volatile organic compounds $\mathrm{NO}_{x}$

400

Other large-inventory chemicals ${ }^{b}$

$\begin{array}{ll}181 & \text { Refrigerant } \\ 110 & \text { Refrigerant } \\ 350 & \text { Refrigerant }\end{array}$

Quarterly report
Quarterly report
Quarterly report

Steam plant emissions (all calculated emissions) ${ }^{c}$

$$
30,853 \quad 14,024 \text { Stack emission }
$$

$6,392,261 \quad 2,905,573 \quad$ Stack emission

53,901

24,500

6,181

2,810

Stack emission

$2,998,106$

$1,362,77$

Stack emission

Stack emission

\begin{abstract}
Engineering calculations based on emission factors Engineering calculations based on emission factors Engineering calculations based on emission factors Engineering calculations based on emission factors Engineering calculations based on emission factors
\end{abstract}

\footnotetext{
${ }^{a}$ Superfund Amendments and Reauthorization Act, Title III, Section 313.

${ }^{b}$ Fugitive emissions.

${ }^{c}$ Point-source emissions.
}

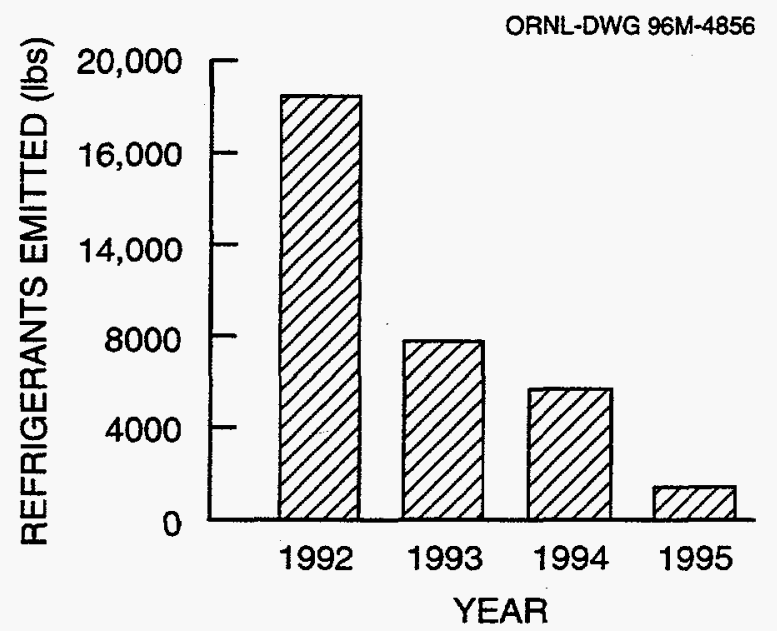

Fig. 4.9. 1995 Y-12 Plant CFC emissions.

ensure compliance with visible emissions. The steam plant and two small oil-fired boilers are the largest emission sources at ORNL and account for $98 \%$ of all allowable emissions.

In 1995, ORNL paid $\$ 101,150$ in annual emission fees to TDEC; it is estimated that ORNL will pay approximately $\$ 100,000$ in annual emission fees in 1996. These fees are based on allowable emissions (actual emissions are lower than allowable emissions). In early 1995, TDEC inspected all permitted emission sources to ensure compliance; no noncompliances were noted.

ORNL is currently preparing the permit application that will be required under the Title $\mathrm{V}$ permit program. It is anticipated that this application will be due to TDEC in the summer of 1997. To facilitate the preparation of this application, an existing survey of all emission points at ORNL was updated. This survey located all emission points and evaluated 
Table 4.5. ORNL nonradiological airborne emissions, 1995

\begin{tabular}{|c|c|c|c|c|}
\hline \multirow[t]{2}{*}{ Chemical } & \multicolumn{2}{|c|}{ Quantity released } & \multirow{2}{*}{$\begin{array}{c}\text { Major release } \\
\text { source }\end{array}$} & \multirow[t]{2}{*}{ Basis of estimate } \\
\hline & $\mathbf{l b}$ & kg & & \\
\hline Particulates & 16,953 & 7,706 & Stack emission & $\begin{array}{l}\text { Engineering calculations based } \\
\text { on emission factors }\end{array}$ \\
\hline $\mathrm{SO}_{x}$ & $2,440,718$ & $1,093,053$ & Stack emission & $\begin{array}{l}\text { Engineering calculations based } \\
\text { on emission factors }\end{array}$ \\
\hline Carbon monoxide & 138,972 & 63,169 & Stack emission & $\begin{array}{l}\text { Engineering calculations based } \\
\text { on emission factors }\end{array}$ \\
\hline $\begin{array}{l}\text { Volatile organic } \\
\text { compounds }\end{array}$ & 2,053 & 933 & Stack emission & $\begin{array}{l}\text { Engineering calculations based } \\
\text { on emission factors }\end{array}$ \\
\hline $\mathrm{NO}_{x}$ & 440,758 & 200,344 & Stack emission & $\begin{array}{l}\text { Engineering calculations based } \\
\text { on emission factors }\end{array}$ \\
\hline
\end{tabular}

their compliance status. Survey results provided information regarding small sources that are currently exempt from air permit requirements. The survey will also assist with compliance efforts that may be required under Title III, Hazardous Air Pollutants.

Actions have been implemented to comply with the prohibition against releasing ozone-depleting substances under Title VI. Also, service requirements for refrigeration systems (including motor vehicle air conditioners), technician certification requirements, and labeling requirements, have been implemented. ORNL has taken actions to phase out the use of Class I ozone-depleting substances. The most significant challenge is the replacement or retrofitting of large chiller systems that require Class I refrigerants.

\section{Results}

The opacity monitor at the steam plant operated without incident during 1995 . No opacity exceedences of permit limits were noted. Emissions of other materials have been estimated and are provided in Table 4.5.

\section{K-25 Site Nonradiological Airborne Emissions Monitoring}

The CAA provides the basis for protecting air quality and regulating air pollution. The TDEC Division of Air Pollution Control has been delegated the authority by EPA to implement and enforce the sections of the CAA related to nonradiological air emissions in the state of Tennessee. Title $\mathrm{V}$ of the CAA amendments of 1990 will require the K-25 Site to submit a new permit application package to TDEC for all sources in operation. The K-25 Site is one of the many sources that will submit applications early in the Title V Program as a participant in TDEC's early volunteer program. Preparation for the new permit application includes an air emissions inventory of allowable and actual emissions from the K-25 Site. To verify the annual air emission fee assessment, which is based on the K-25 Site's allowable limits for air pollutants, an inventory of potential emissions from the permitted sources at the K-25 Site is updated annually. Table 4.6 shows the allowable emissions of criteria pollutants from the K-25 Site for the past 3 years. An inventory of actual emissions from all permitted sources in operation at the K-25 Site was completed in 1995 . Table 4.7 shows actual emissions from the K-25 Site.

Title VI of the CAA amendments addresses stratospheric ozone protection. This section provides a number of regulations to phase out the production and to eliminate the intentional release of ozone-depleting substances to the atmosphere. Ozone-depleting substances have been used at the K-25 Site, primarily as refrigerants in gaseous diffusion processes and for office comfort cooling. Because the K-25 Site is no longer involved in UE, its stockpile of process refrigerants was shipped in 1993 to the operational gaseous diffusion plants in 
Table 4.6. Allowable emissions of criteria pollutants from the K-25 Site, 1992-95

\begin{tabular}{lrrrr}
\hline \multirow{1}{*}{ Pollutant } & \multicolumn{4}{c}{$\begin{array}{c}\text { Allowable emissions } \\
\text { (tons/year) }\end{array}$} \\
\cline { 2 - 5 } & $\mathbf{1 9 9 2}$ & $\mathbf{1 9 9 3}$ & $\mathbf{1 9 9 4}$ & $\mathbf{1 9 9 5}$ \\
\hline Particulate matter & 172 & $\mathbf{1 8 0}$ & 141 & 296 \\
Volatile organic compounds & 262 & 166 & 153 & 167 \\
Sulfur dioxide & 429 & 429 & 429 & 428 \\
Nitrogen oxides & 226 & 226 & 226 & 224 \\
Carbon monoxide & 157 & 157 & 157 & 157 \\
Miscellaneous & 291 & 291 & 145 & 149 \\
$\quad$ Total & 1537 & 1449 & 1251 & 1421 \\
\hline
\end{tabular}

Table 4.7. Actual emissions of criteria pollutants from the K-25 Site, 1995

\begin{tabular}{lc}
\hline \multicolumn{1}{c}{ Pollutant } & $\begin{array}{c}\text { Estimated emissions } \\
\text { (tons/year) }\end{array}$ \\
\hline Particulate matter & 3.42 \\
Volatile organic compounds & 2.03 \\
Sulfur dioxide. & 3.05 \\
Nitrogen oxides & 25.22 \\
Carbon monoxide & 24.71 \\
\hline
\end{tabular}

Table 4.8. Estimated K-25 Site emissions of ozone-depleting substances, 1995

\begin{tabular}{lc}
\hline $\begin{array}{c}\text { Ozone-depleting } \\
\text { substance }\end{array}$ & $\begin{array}{c}\text { Estimated emissions } \\
\text { (lb/year) }\end{array}$ \\
\hline R-12 & 65 \\
R-22 & 1058 \\
R-114 & 0 \\
\hline
\end{tabular}

Portsmouth, Ohio, and Paducah, Kentucky, for reuse. Purging of the residual CFC-114 from process equipment continued until February 1995. Releases of CFC-114 for 1995 are shown in Table 4.8. The K-25 Site has eliminated the use of CFC-114 and there will be no future atmospheric emissions of this ozone-depleting substance (also reflected in Table 4.8).

Additional refrigeration equipment service practices were implemented in 1993 in response to the refrigerant recycling and emissions reduction rule. This rule focused on record keeping, a leak repair program for equipment with refrigerant capacity of $50 \mathrm{lb}$ or more, and a safe equipment/refrigerant disposal program.
EPA regulations also require maintenance personnel to recover and recycle refrigerants used in air-conditioning/refrigeration equipment. It also requires that these personnel be trained and certified on the use of approved refrigerant recovery equipment and be certified through the EPA certification program for refrigerant recycling and emissions reduction.

As a result of a well-implemented and focused Ozone-Depleting Substances Program, emissions from air-conditioning/refrigeration equipment have been greatly reduced. It should be noted that the main contributor to the release of R-22 was a 45-year-old air-conditioning system that is being replaced in 1996. 
Table 4.9. Estimated air emissions from the

K-1501 Steam Plant at the K-25 Site, 1995

\begin{tabular}{lrcc}
\hline \multicolumn{1}{c}{ Pollutant } & \multicolumn{2}{c}{$\begin{array}{c}\text { Emissions } \\
\text { (tons/year) }\end{array}$} & $\begin{array}{c}\text { Percentage } \\
\text { of } \\
\text { allowable }\end{array}$ \\
\cline { 2 - 3 } & Estimated & Allowable & \\
\hline Particulate matter & 3.42 & 143 & 2.4 \\
Sulfur dioxide & 3.05 & 390 & 0.8 \\
Nitrogen oxides & 25.22 & 204 & 12.4 \\
Volatile organic compounds & 2.03 & 9 & 22.6 \\
Carbon monoxide & 24.71 & 138 & 17.9 \\
\hline
\end{tabular}

Table 4.10. Estimated air emissions from the TSCA Incinerator at the K-25 Site, 1995

\begin{tabular}{llll}
\hline Pollutant & \multicolumn{2}{c}{$\begin{array}{c}\text { Emissions } \\
\text { (tons/year) }\end{array}$} & $\begin{array}{c}\text { Percentage of } \\
\text { allowable }\end{array}$ \\
\cline { 2 - 3 } & Estimated & Allowable & \\
\hline Lead & 0.00066 & 0.575 & 0.11 \\
Beryllium & 0.00000185 & 0.00037 & 0.5 \\
Mercury & 0.00129 & 0.088 & 1.47 \\
Fluorine & 0.000085 & 2.63 & 0.003 \\
Chlorine & 0.017 & 16.12 & 0.11 \\
Sulfur & 0.167 & 38.54 & 0.48 \\
Particulate & 0.096 & 13.14 & 0.14 \\
\hline
\end{tabular}

\section{Results}

The major sources of criteria air pollutants at the K-25 Site are the four steam-generating units in operation at the K-1501 Steam Plant. These units use natural gas as their primary fuel source, with No. 2 fuel oil used as backup during curtailment of natural gas supplies. Table 4.9 presents the estimated and allowable emissions from the steam plant for 1995.

The TSCA Incinerator is also a major source of air emissions from the K-25 Site. Emissions from the incinerator are controlled by extensive exhaust-gas treatment. Estimated emissions from the incinerator are significantly less than the permitted allowable emissions (Table 4.10).

\section{LIQUID DISCHARGES}

\section{Radiological Liquid Discharges}

DOE Order 5400.1 requires that effluent monitoring be conducted at all DOE sites. DOE
Order 5400.5 sets annual dose standards to members of the public, as a consequence of routine DOE operations, of 100 mrem through all exposure pathways and 4 mrem from the drinking water pathway. Effluent monitoring results are a major component in the determination of compliance with these dose standards.

DOE Order 5400.5 also established DCGs for radionuclides in water. (See Appendix A for a list of radionuclides and their half-lives.) The DCG is the concentration of a given radionuclide for one exposure pathway (e.g., drinking water) that would result in an EDE of 100 mrem $(1 \mathrm{mSv})$ per year to reference man, as defined by International Commission on Radiological Protection (ICRP) publication 23 (ICRP 1975). The consumption of water is assumed to be $730 \mathrm{~L} /$ year at the DCG level. DCGs were calculated using methodologies consistent with recommendations found in ICRP publications 26 (ICRP 1977) and 30 (ICRP 1978). DCGs are used as reference concentrations for conducting environmental protection programs at DOE sites, 
as screening values for considering best available technology for treatment of liquid effluents, and for making dose comparisons. Radiological data are determined as percentages of the DCG for a given isotope. In the event that a sum of the percentages of the DCGs for each location ever exceeds $100 \%$, an analysis of the best available technology to reduce the sum of the percentages of the DCGs to less than $100 \%$ would be required as specified in DOE Order 5400.5.

\section{Y-12 Plant Radiological Summary}

\section{Regulatory Requirements}

At the Y-12 Plant, radiological monitoring of effluents and surface waters is also a component of the NPDES permit (TN002968). The permit, issued in 1995, required that the Y-12 Plant reevaluate the radiological monitoring plan and that it submit results from the monitoring program quarterly, as an addendum to the NPDES Discharge Monitoring Report. There were no discharge limits set by the new NPDES permit for radionuclides; the requirement is only to monitor and report. The Radiological Monitoring Plan for the Y-12 Plant: Surface Water (Energy Systems 1995) was revised and reissued to better characterize the radiological components of plant effluents and to reflect changes in plant operations. The monitoring program was designed to monitor effluent at three types of locations: (1) treatment facilities, (2) other point and area source discharges, and

(3) in-stream locations. The revised monitoring plan, fully implemented in 1995, incorporates new monitoring locations, revisions to the parameter list (such as the addition of gamma scans), and the proposed requirements of 10 CFR 834.

The following parameters are monitored routinely under the plan:

- alpha and beta activity,

- americium $\left({ }^{241} \mathrm{Am}\right)$,

- neptunium $\left({ }^{237} \mathrm{~Np}\right)$,

- plutonium $\left({ }^{238} \mathrm{Pu}\right.$ and $\left.{ }^{239 / 240} \mathrm{Pu}\right)$,

- $\operatorname{radium}\left({ }^{226} \mathrm{Ra}\right.$ and $\left.{ }^{228} \mathrm{Ra}\right)$,

- strontium $\left({ }^{90} \mathrm{Sr}\right)$,
- technetium $\left({ }^{99} \mathrm{Tc}\right)$,

- thorium $\left({ }^{228} \mathrm{Th},{ }^{230} \mathrm{Th},{ }^{232} \mathrm{Th},{ }^{234} \mathrm{Th}\right.$, and total thorium),

- $\quad \operatorname{tritium}\left({ }^{3} \mathrm{H}\right)$, and

- uranium $\left({ }^{234} \mathrm{U},{ }^{235} \mathrm{U},{ }^{236} \mathrm{U},{ }^{238} \mathrm{U}\right.$, total uranium, and percentage of ${ }^{235} \mathrm{U}$ ).

The revised plan also requires that a gamma scan be performed routinely for 1 year. The resultant data will be reviewed to determine the applicability of this measurement.

In addition, the Y-12 Plant is permitted to discharge domestic wastewater to the city of Oak Ridge Sewage Treatment Plant STP under Industrial and Commercial User Waste Water Discharge Permit No. 1-91. Radiological monitoring of this discharge is also conducted and is reported to the city of Oak Ridge. The following parameters are monitored routinely:

- alpha, beta, and gamma activity;

- plutonium $\left({ }^{238} \mathrm{Pu}\right.$ and $\left.{ }^{239 / 240} \mathrm{Pu}\right)$; and

- uranium $\left({ }^{234} \mathrm{U},{ }^{235} \mathrm{U},{ }^{236} \mathrm{U},{ }^{238} \mathrm{U}\right.$, total uranium, and percentage of ${ }^{235} \mathrm{U}$ ).

\section{Results}

Radiological monitoring plan sampling locations are noted in Fig. 4.10. Table 4.11 identifies the monitored locations, the frequency of monitoring, and the sum of DCG percentages for radionuclides measured in 1995. Radiological data for all locations were well below the allowable DCGs. The highest summed percentage of DCGs was from the in-stream location at Bear Creek kilometer (BCK) 11.97. Uranium $\left({ }^{234} \mathrm{U}\right.$ and $\left.{ }^{238} \mathrm{U}\right)$ and ${ }^{237} \mathrm{~Np}$ were the major contributors of radioactivity there, contributing $7.0,11.0$, and $3.7 \%$, respectively, to the total $21.7 \%$ of the sum of the percentages of the DCGs. Minor contributors account for the remaining $0.3 \%$.

The Central Pollution Control Facility (Outfall 501) is the only treatment facility that has exceeded maximum allowable DCGs in the past; however, improvements in the treatment process have resulted in effluent data consistently well below DCGs. This 


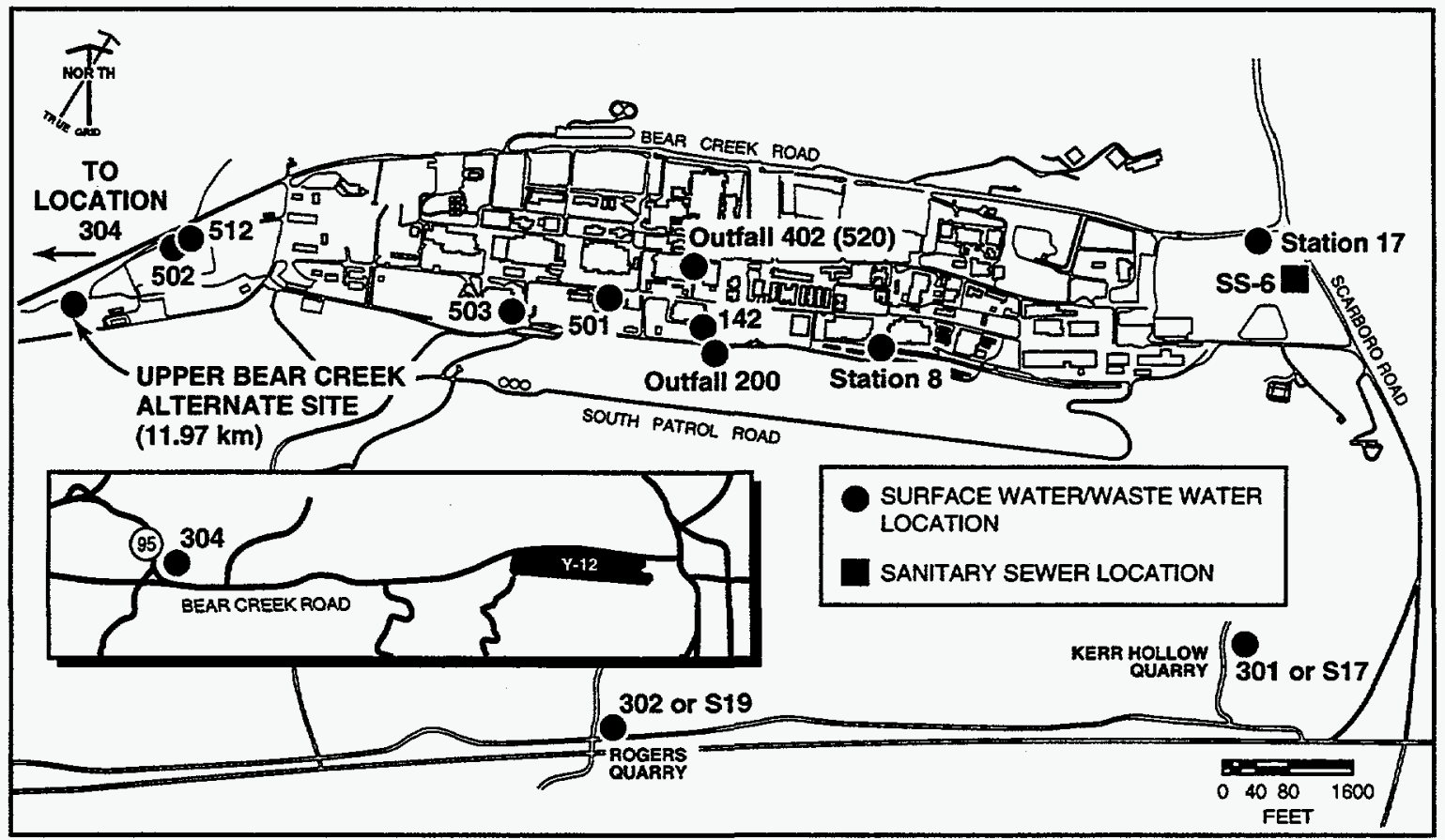

Fig. 4.10. Surface water and sanitary sewer radiological sampling locations at the Y-12 Plant.

Table 4.11. Summary of Y-12 Plant radiological monitoring plan sample requirements

\begin{tabular}{|c|c|c|c|c|}
\hline $\begin{array}{c}\text { Outfall } \\
\text { No. }\end{array}$ & Location & $\begin{array}{l}\text { Sample } \\
\text { frequency }\end{array}$ & Sample type & $\begin{array}{c}\text { Sum of DCG } \\
\text { percentage }\end{array}$ \\
\hline \multicolumn{5}{|c|}{ Y-12 Plant wastewater treatment facilities } \\
\hline 501 & Central Pollution Control Facility & 1/week & Composite during batch operation & -0.24 \\
\hline 502 & West End Treatment Facility & $1 /$ week & 24-hour composite & 0.28 \\
\hline 503 & Steam Plant Wastewater Treatment Facility & $1 /$ week & 24-hour composite & No flow \\
\hline 512 & Groundwater Treatment Facility & $1 /$ week & 24-hour composite & 0.93 \\
\hline $402(520)^{a}$ & Steam Condensate & $1 /$ week & Grab & No flow \\
\hline \multicolumn{5}{|c|}{ Other Y-12 Plant point and area source discharges } \\
\hline 142 & Isotope Separation Process & $1 /$ month & 24-hour composite & No flow \\
\hline $301(S 17)^{a}$ & Kerr Hollow Quarry & $1 /$ month & 24-hour composite & -1.2 \\
\hline $302(\mathrm{~S} 19)^{a}$ & Rogers Quarry & $1 /$ month & 24-hour composite & -0.059 \\
\hline \multicolumn{5}{|c|}{ Y-12 Plant in-stream locations } \\
\hline 304 & Bear Creek, Plant Exit (west) & 1/week & 7-day composite & 1.8 \\
\hline Station 17 & East Fork Poplar Creek, Plant Exit (east) & $1 /$ week & 7-day composite & 2.4 \\
\hline Station 8 & East Fork Poplar Creek, Plant Site & $1 /$ week & 7-day composite & 1.7 \\
\hline & North/South Pipes & $1 /$ week & 24-hour composite & 1.4 \\
\hline $\mathrm{km} 11.97$ & Bear Creek & $1 /$ week & Grab & 22 \\
\hline
\end{tabular}

${ }^{a}$ Outfall identifications have been changed by the new NPDES permit effective July $1,1995$.

improvement can be seen in Fig. 4.11, which shows ${ }^{238} \mathrm{U}$ concentrations since 1989.
Additional radiological monitoring at kilometer 12.4 (mile 7.7) on Upper Bear Creek was historically conducted in response to 
ORNL-DWG 94M-8726R4

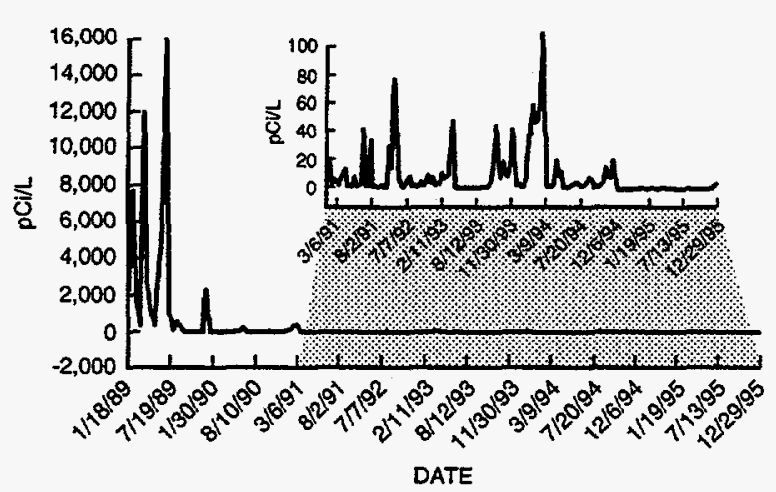

Fig. 4.11. Concentrations of ${ }^{238} \mathrm{U}$ at the Y 12 Plant Outfall 501, January 1989 through December 1995. The allowable DCG for ${ }^{238} \mathrm{U}$ is $600 \mathrm{pCi} / \mathrm{L}$.

Table 4.12. Release of uranium from

the Y-12 Plant to the off-site

environment as a liquid effuent, 1990-95

\begin{tabular}{lll}
\hline Year & \multicolumn{2}{c}{ Quantity released } \\
\cline { 2 - 3 } & $\mathrm{Ci}^{\mathrm{a}}$ & $\mathbf{k g}$ \\
\hline & Station 17 & \\
1990 & 0.135 & 197 \\
1991 & 0.162 & 235 \\
1992 & 0.087 & 130 \\
1993 & 0.081 & 134 \\
1994 & 0.11 & 185 \\
1995 & 0.069 & 143 \\
& $0 u$ Offall 304 & \\
1990 & 0.131 & 204 \\
1991 & 0.082 & 159 \\
1992 & 0.060 & 110 \\
1993 & 0.094 & 167 \\
1994 & 0.13 & 236 \\
1995 & 0.066 & 105 \\
\hline
\end{tabular}

${ }^{a}{ }_{1} \mathrm{Ci}=3.7 \mathrm{E}+10 \mathrm{~Bq}$.

Section IV, Part 4, of a 1983 memorandum of understanding agreed to by DOE, EPA, and TDEC. The monitoring continued as a best management practice until July 1995 . Monitoring at kilometer 11.97, which has been proposed as a replacement site, continued throughout the year. These changes were proposed with ORR Environmental Monitoring Plan for implementation in 1995. Analytical data are reported monthly to TDEC as an attachment

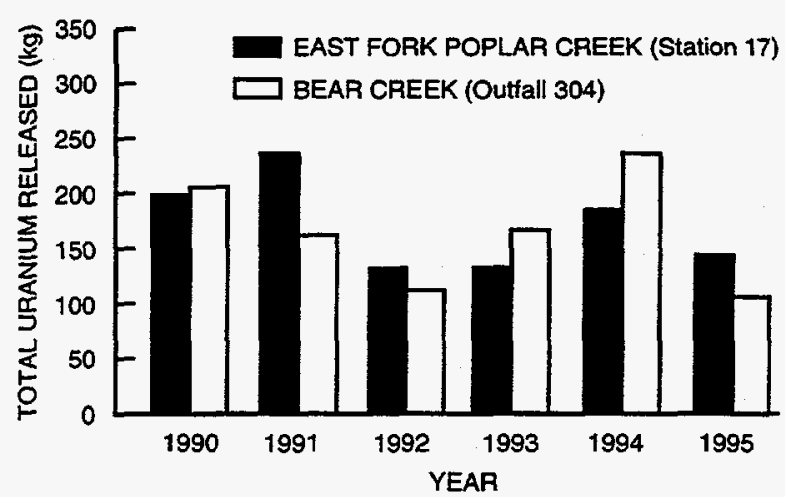

Fig. 4.12. Five-year trend of Y-12 Plant release of uranium to surface water.

to the discharge monitoring report required by NPDES. For each of these in-stream locations, all radiological results for 1995 were below $10 \%$ of the DCGs.

In 1995, the total of uranium and associated curies released from the Y-12 Plant at the easternmost monitoring station, Station 17 on Upper East Fork Poplar Creek (UEFPC), and the westernmost monitoring station, at Bear Creek kilometer (BCK) 4.55 (NPDES Outfall 304), was $105 \mathrm{~kg}$, or $0.135 \mathrm{Ci}(5.0 \mathrm{E}+9 \mathrm{~Bq}$ ) (Table 4.12$)$. Figure 4.12 illustrates a 5-year trend of these releases.

The City of Oak Ridge Industrial and Commercial User Waste Water Discharge Permit allows the Y-12 Plant to discharge wastewater to be treated at the Oak Ridge Wastewater Treatment Facility through the East End Sanitary Sewer Monitoring Station (EESSMS), also identified as SS-6 (Fig. 4.10).

No single radionuclide in the Y-12 Plant contribution to the sanitary sewer exceeded $1 \%$ of the DCG. Summed percentages of DCGs calculated from the Y-12 Plant contribution to the sewer are essentially zero. Results of radiological monitoring were reported to the city of Oak Ridge with the quarterly monitoring report (Table 4.13).

Potential sources of radionuclides discharging to the sanitary sewer had been identified in previous studies at the Y-12 Plant as part of a best management practices initiative to meet the ALARA goals of the Y-12 Plant. These data show that levels of radioactivity are orders of magnitude below regulatory levels established 
Table 4.13. Y-12 Plant Discharge Point SS6, Sanitary Sewer Station 61995 radiological summary

\begin{tabular}{|c|c|c|c|c|c|c|c|c|c|}
\hline \multirow[t]{2}{*}{ Parameter } & \multirow{2}{*}{$\begin{array}{l}\text { Number of } \\
\text { Samples }\end{array}$} & \multicolumn{5}{|c|}{ Concentration $(\mathrm{pCi} / \mathrm{L})$} & \multirow{2}{*}{$\begin{array}{c}\text { Standard } \\
\text { error }\end{array}$} & \multirow{2}{*}{$\begin{array}{c}\text { Percentage } \\
\text { of DCG }\end{array}$} & \multirow{2}{*}{$\begin{array}{l}\text { Total } \\
\text { curies }\end{array}$} \\
\hline & & $\operatorname{Max}$ & $+1-$ & Min & $+1-$ & Median & & & \\
\hline Alpha activity & 54 & 26.0 & 14 & $-11.0^{a}$ & 0.80 & 3.3 & 0.90 & $b$ & $2.50 \mathrm{E}-03$ \\
\hline Beta activity & 54 & 21.0 & 11 & $-7.8^{a}$ & 65 & 7.6 & 0.95 & $b$ & $4.23 \mathrm{E}-03$ \\
\hline Gross gamma & 52 & 230.0 & 13 & $-19.0^{a}$ & 30 & 28.5 & 7.36 & $b$ & $2.44 \mathrm{E}-02$ \\
\hline${ }^{238} \mathrm{Pu}$ & 54 & $0.34^{a}$ & 0.27 & $-0.37^{a}$ & 0.29 & 0.0023 & 0.015 & 0.0058 & $-4.78 \mathrm{E}-07$ \\
\hline${ }^{239} \mathrm{Pu}$ & 54 & 0.31 & 0.26 & $-0.18^{a}$ & 0.18 & 0.0 & 0.011 & 0.0 & $7.85 \mathrm{E}-06$ \\
\hline${ }^{234} U$ & 54 & 55.0 & 10 & 0.83 & 0.32 & 2.8 & 1.1 & 0.56 & $2.91 \mathrm{E}-03$ \\
\hline${ }^{235} \mathrm{U}$ & 54 & 2.9 & 1.0 & $-0.055^{a}$ & 0.11 & 0.10 & 0.059 & 0.017 & $1.26 \mathrm{E}-04$ \\
\hline${ }^{236} \mathrm{U}$ & 54 & 1.3 & 0.62 & $-0.034^{a}$ & 0.068 & 0.053 & 0.025 & 0.011 & $5.38 \mathrm{E}-05$ \\
\hline${ }^{238} \mathrm{U}$ & 54 & 100.0 & 18 & 0.43 & 0.31 & 1.5 & 1.8 & 0.25 & $2.06 \mathrm{E}-03$ \\
\hline
\end{tabular}

${ }^{a}$ Provisional data because the results are less than the method detection limit.

${ }^{b}$ Not applicable.

ORNL-DWG 95M-7719R

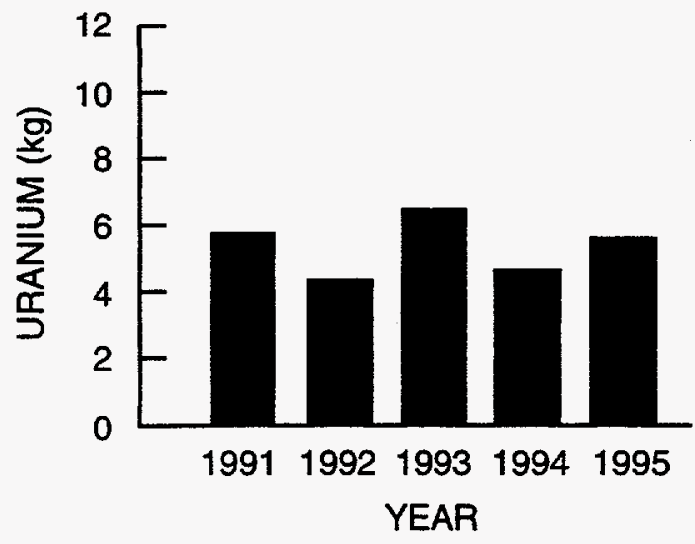

Fig. 4.13. Five-year trend of total uranium discharges from the Y-12 Plant Sanitary Sewer.

in DOE orders and are not thought to pose a safety or health risk. A 1995 report, Update Summary of the 1991 Discharge of Enriched Uranium to the Sanitary Sewer (DEUSS) Report (Energy Systems 1995), was issued in 1995 to further document radionuclide discharges to the sanitary sewer. Figure 4.13 illustrates the 5 -year trend of total uranium discharges from the Y-12 Plant Sanitary Sewer.

\section{ORNL Radiological Summary}

\section{ORNL Surface Waters Receiving Effluents}

Under the Radiological Monitoring Plan for the ORNL NPDES Permit, sampling for radiological analyses is conducted at five NPDES stations and at six ambient stream locations around ORNL. The five NPDES stations are Sewage Treatment Plant (X01), Nonradiological Wastewater Treatment Facility (NRWTF) (X12), Melton Branch 1 (X13), White Oak Creek (WOC) (X14), and White Oak Dam (WOD) (X15). The six ambient stations are 7500 Road Bridge, First Creek, Fifth Creek, Melton Branch 2, Northwest Tributary, and Raccoon Creek (Fig. 4.14). In addition, water samples are collected for radiological analyses from the Clinch River at Melton Hill Dam and from WOC headwaters, two locations above ORNL discharge points that serve as references for other water sampling locations at the ORNL site.

DOE DCGs are used in this document as a means of standardized comparison for effluent points with different isotope signatures. The average concentration is expressed as a percentage of the DCG when a DCG exists and when the average concentration is significantly greater than zero. The calculation of percentage of the DCG for ingestion of water does not imply that effluent points or ambient water sampling stations at ORNL are sources of drinking water. For 1995, only three radionuclides had an average concentration greater than $5 \%$ of the relevant DCG; they were ${ }^{3} \mathrm{H}$, total radioactive strontium, and ${ }^{137} \mathrm{Cs}$. The largest percentage was the ${ }^{3} \mathrm{H}$ concentration at Melton Branch 1 , at $21 \%$ of the DCG (Fig. 4.15). Following guidelines given in DOE Order 5400.5, fractional DCG values for the radionuclides detected at 


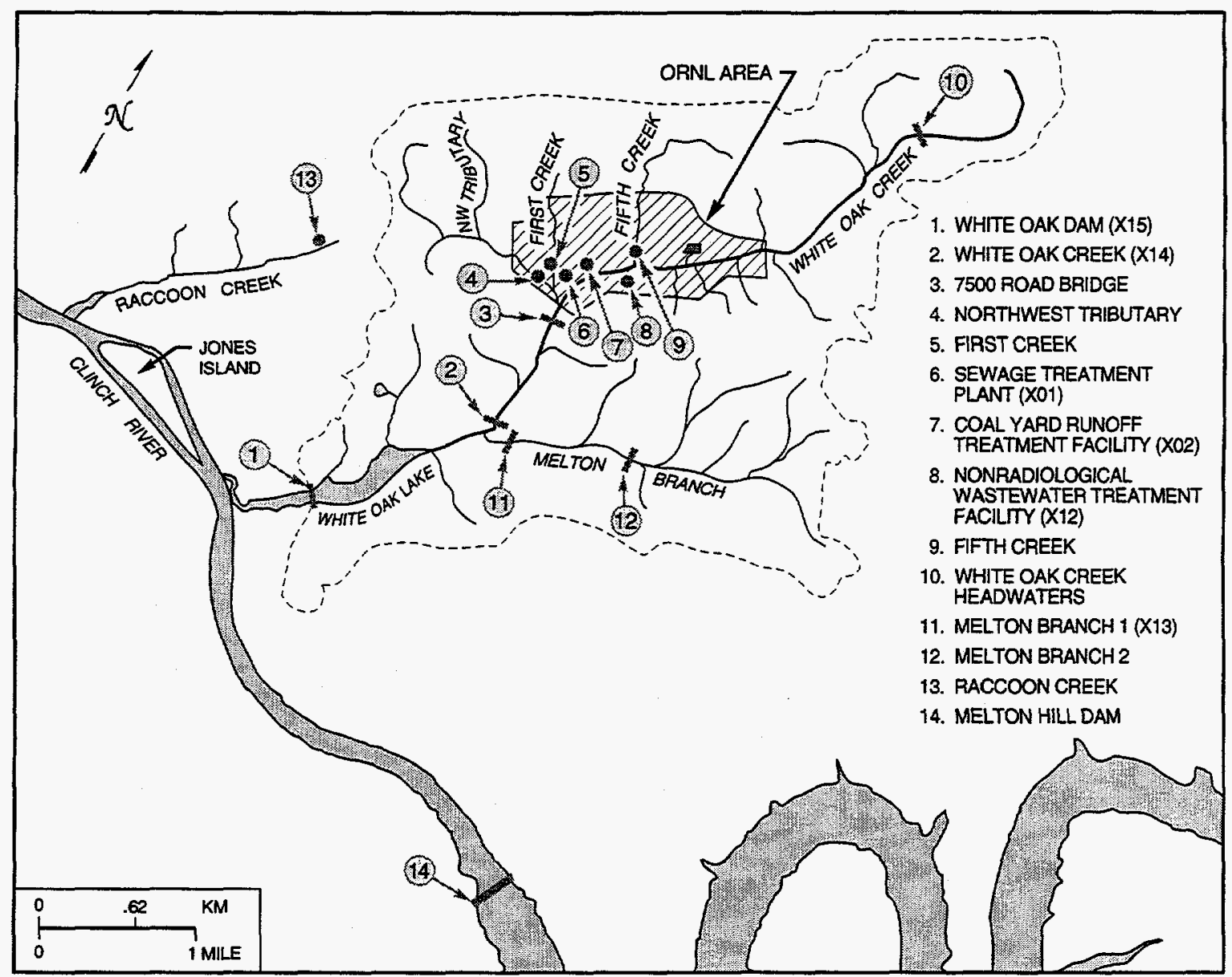

Fig. 4.14. ORNL surface water, NPDES, and reference sampling locations. Bars (|) indicate sampling locations that have weirs.

ORNL-DWG 94M-8673R2

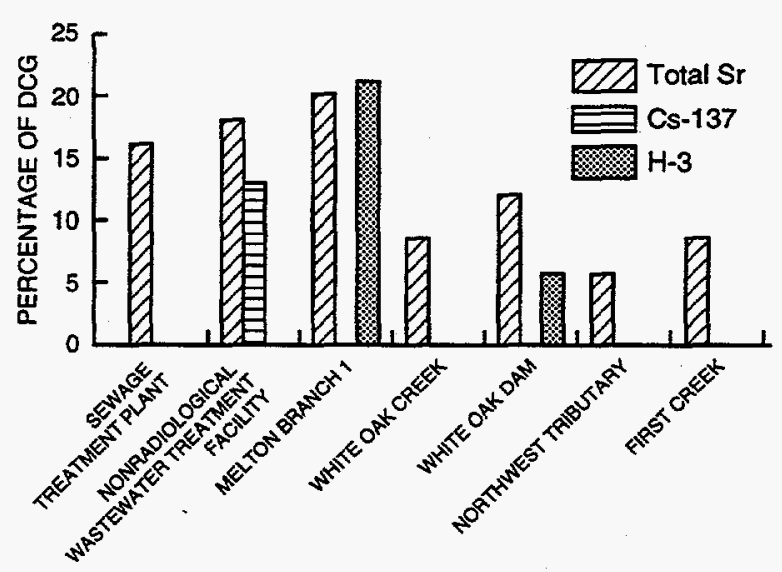

Fig. 4.15. Radionuclides at ORNL sampling sites having average concentrations greater than $5 \%$ of the relevant derived concentration guides in 1995. each monitoring point are summed to determine whether radioactivity is within acceptable levels. In 1995, the sum of DCG percentages at each effluent point and ambient water station was less than $100 \%$, and therefore within acceptable levels.

The discharge from ORNL of radioactive contaminants to the Clinch River is affected by stream flows. Clinch River flows are regulated by a series of TVA dams, one of which is Melton Hill Dam. The flow in Melton Branch is usually less than one-third of that in WOC. In 1995, the monthly ratio of flow in WOC (measured at WOD) to flow in the Clinch River (measured at Melton Hill Dam) ranged from 0.0016 to 0.023 , thus providing significant dilution of any radioactivity released into the Clinch River from WOC. 
ORNL-DWG 94M-8727R2

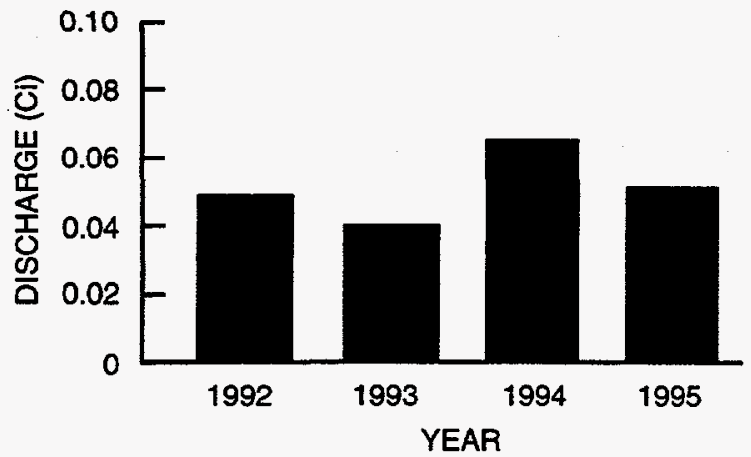

Fig. 4.16. Cobalt-60 discharges at White Oak Dam, 1992-95.

ORNL-DWG 94M-8728R2

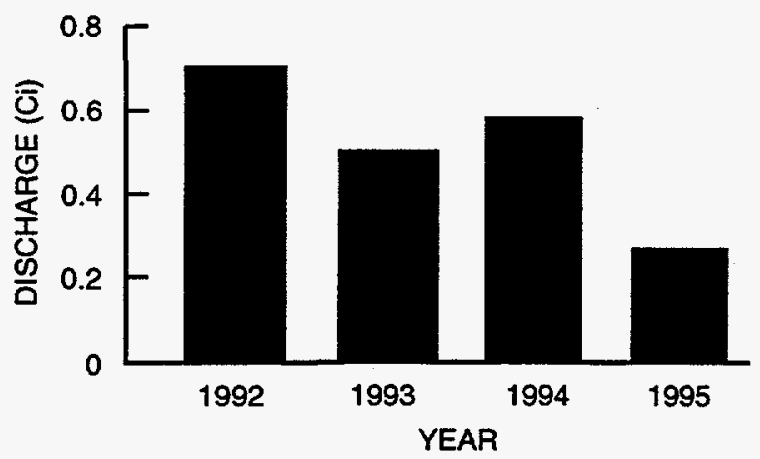

Fig. 4.17. Cesium-137 discharges at White Oak Dam, 1992-95.

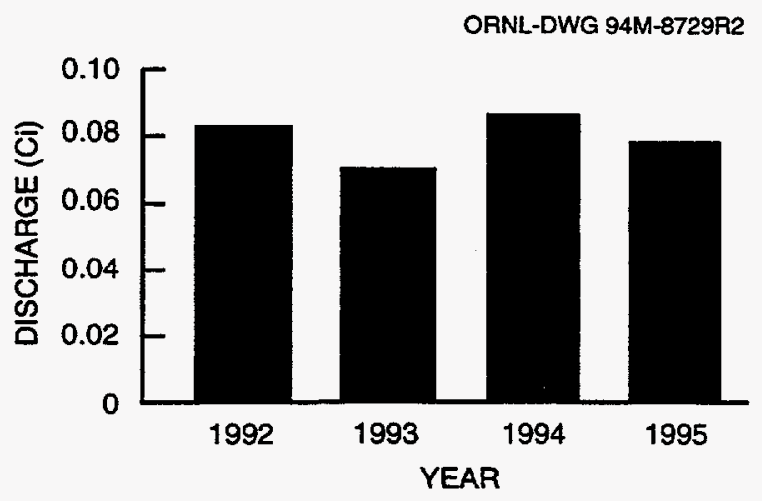

Fig. 4.18. Gross alpha discharges at White Oak Dam, 1992-95.

Amounts of radioactivity released at WOD are calculated from concentration and flow. As shown in Figs. 4.16 through 4.21 , the total discharges, or amounts, of radioactivity released at WOD during the past 4 years have remained in the same range of values but showed a slight decrease in 1995 from 1994.

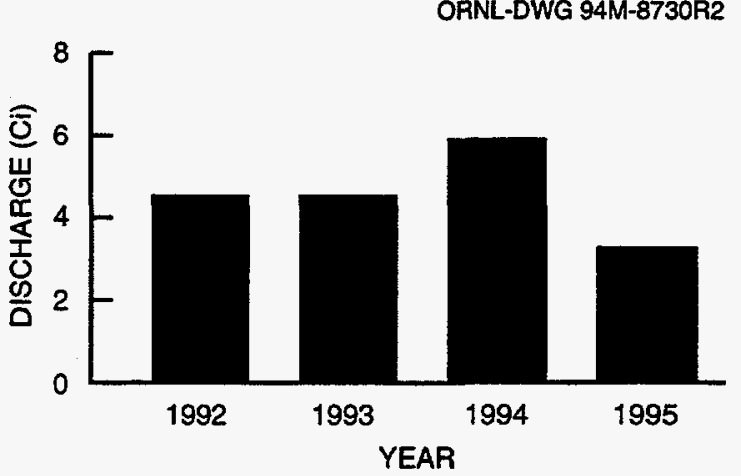

Fig. 4.19. Gross beta discharges at White Oak Dam, 1992-95.

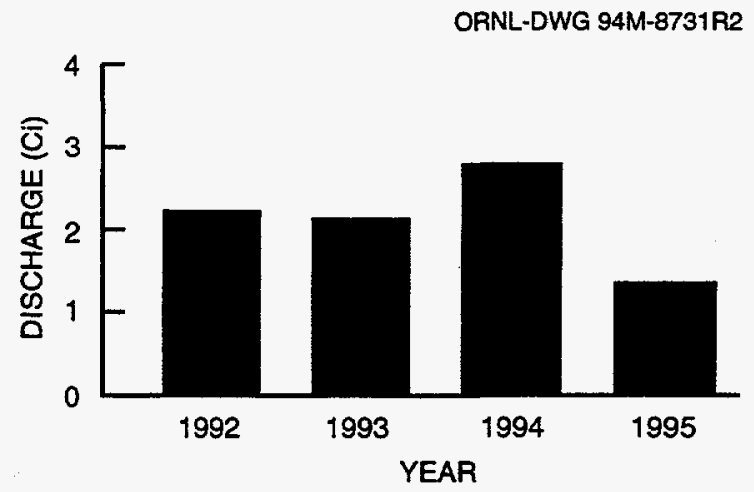

Fig. 4.20. Total radioactive strontium discharges at White Oak Dam, 1992-95.

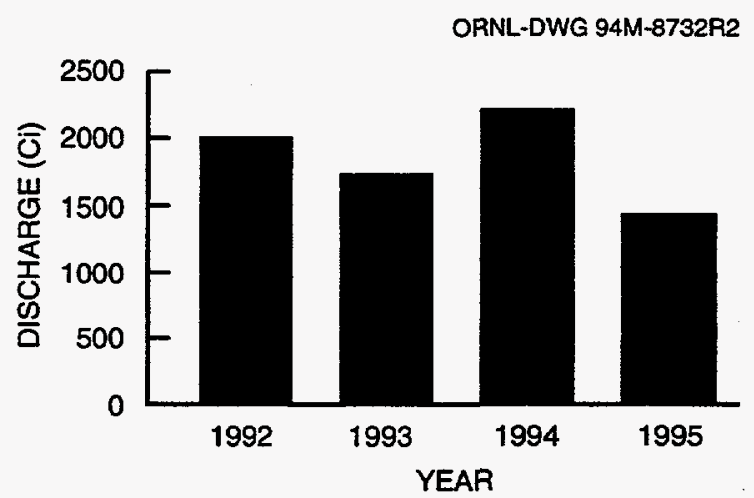

Fig. 4.21. Tritium discharges at White Oak Dam, 1992-95.

\section{Categories of Effluents}

Radiological monitoring is conducted at NPDES Category I and Category II outfalls. Category I outfalls are storm drains. Category II outfalls are roof drains, parking lot drains, storage area drains, spill area drains, once-through cooling water, cooling-tower blowdown, condensate, and drains in the 


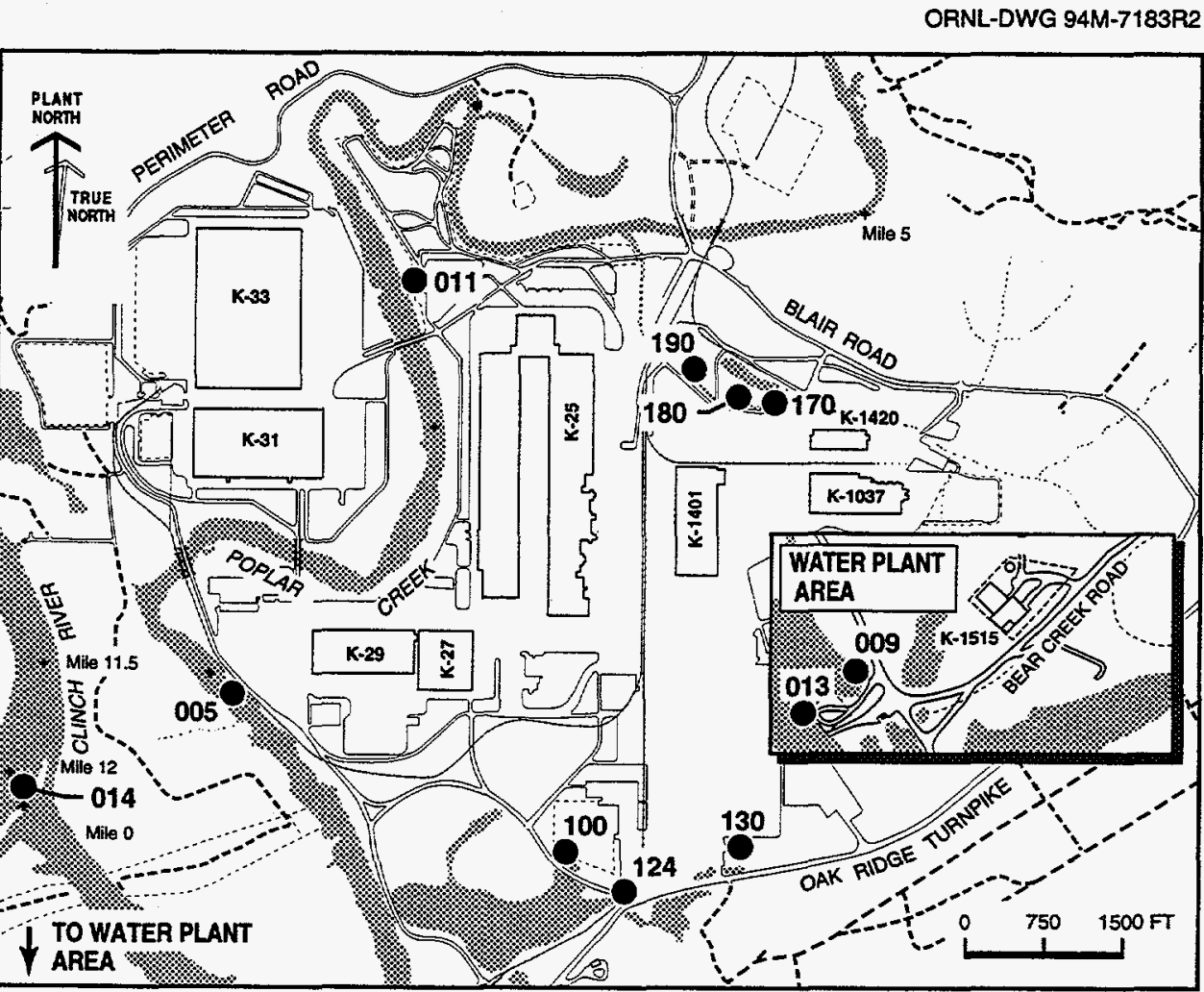

Fig. 4.22. K-25 Site NPDES major outfalls and Category I storm drain outfalls.

disposal demonstration area. Under the NPDES Radiological Monitoring Plan, gross beta is measured at Category I and Category II outfalls. If a gross beta result exceeds a trigger level $(810 \mathrm{pCi} / \mathrm{L})$, then a total radioactive strontium analysis is conducted.

In 1995, only one Category II gross beta result triggered a total radioactive strontium analysis; none of the Category I gross beta results exceeded the strontium trigger level. The maximum gross beta value of $3200 \mathrm{pCi} / \mathrm{L}$ occurred at Category II Outfall 204, which discharges into WOC west of Building 3544. The next highest value was considerably lower, $500 \mathrm{pCi} / \mathrm{L}$, at Category II Outfall 207, which discharges into WOC east of Building 3534.

\section{K-25 Site Radiological Summary}

The K-25 Site conducts radiological monitoring of liquid effluent to determine compliance with applicable dose standards and the ALARA process by maintaining potential exposures to members of the public as low as is reasonably achievable.

\section{Sample Collection and Analytical Procedure}

The K-25 Site monitors three major effluent discharge points for radiological parameters: the K-1203 Sewage Treatment Plant discharge (Outfall 005), the K-1407-J treated effluent from the CNF (Outfall 011), and the K-1515-C filter backwash from the Sanitary Water Treatment Facility (Outfall 009) (Fig. 4.22). Weekly samples are collected from each of these locations. The weekly samples are composited into monthly samples and analyzed for radionuclides. Results of these sampling efforts are compared with the DCGs.

\section{Results}

The sum of the fractions of the DCGs at K-1407-J was calculated at $69 \%$ for CY 1995 ; however, most discharges occurred during the 
Table 4.14. Radionuclides discharged to off-site

surface waters from the K-25 Site, 1995. Effluent

discharge locations are K-1203, K-1407-J, and K-1515-C.

\begin{tabular}{lrll}
\hline Isotope & $\begin{array}{c}\text { Amount } \\
(\mathbf{C i})^{a}\end{array}$ & Isotope & \multicolumn{1}{c}{$\begin{array}{c}\text { Amount } \\
(\mathbf{C i}){ }^{a}\end{array}$} \\
\hline${ }^{137} \mathrm{Cs}$ & $-1.2 \mathrm{E}-03$ & ${ }^{234} \mathrm{Th}$ & $1.1 \mathrm{E}-02$ \\
${ }^{40} \mathrm{~K}$ & $5.9 \mathrm{E}-04$ & ${ }^{234} \mathrm{U}$ & $2.1 \mathrm{E}-02$ \\
${ }^{237} \mathrm{~Np}$ & $4.1 \mathrm{E}-05$ & ${ }^{235} \mathrm{U}$ & $1.7 \mathrm{E}-03$ \\
${ }^{238} \mathrm{Pu}$ & $7.9 \mathrm{E}-04$ & ${ }^{236} \mathrm{U}$ & $4.1 \mathrm{E}-04$ \\
${ }^{239} \mathrm{Pu}$ & $2.4 \mathrm{E}-05$ & ${ }^{238} \mathrm{U}$ & $2.4 \mathrm{E}-02$ \\
${ }^{99} \mathrm{Tc}$ & $3.9 \mathrm{E}-02$ & & \\
\hline
\end{tabular}

${ }^{a} 1 \mathrm{Ci}=3.7 \mathrm{E}+10 \mathrm{~Bq}$

ORNL-DWG 94M-9701R2

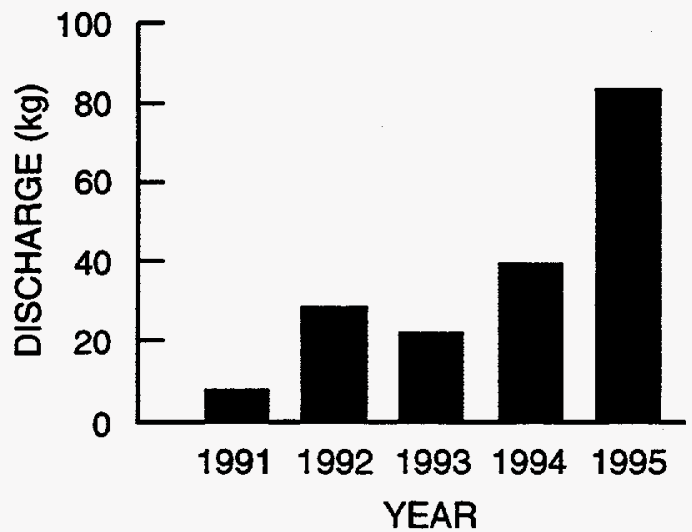

Fig. 4.23. Five-year trend of uranium releases to surface waters from the K-25 Site. Analysis includes discharge locations K-1203 and K-1407-J.

ORNL-DWG 95M-6683R

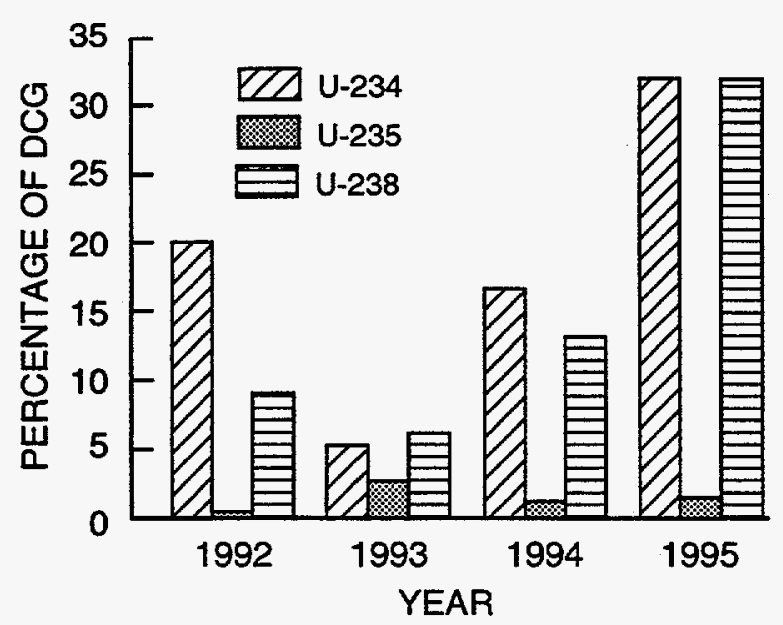

Fig. 4.24. Percentage of DCG for uranium isotopes from $\mathrm{K}-1407-\mathrm{J}$. first half of the year. The increase in 1995 was determined to be caused by changes in TSCA Incinerator feed material. Changes in operations during the second half of 1995 significantly improved the removal efficiency of the CNF and resulted in reduced discharges of radionuclides. The sum of the fractions of the DCGs for effluent locations K-1203 and K-1515-C remained below $3 \%$. Table 4.14 lists radionuclides discharged from the K-25 Site to off-site surface waters in 1995.

Uranium discharges to surface waters over a 5-year period were investigated to observe their trend (Fig. 4.23). The effluent point having the greatest DCG percentage was the $\mathrm{K}-1407-\mathrm{J}$ outfall. Uranium isotopes contributed to this percentage as shown in Fig. 4.24. The increase in uranium discharges is attributed to TSCA Incinerator wastewater, which is sent to the CNF for treatment before discharging at K-1407-J (Outfall 011).

\section{Nonradiological Liquid Discharges}

The Federal Water Pollution Control Act and its amendments, more commonly known as the CWA, were the culmination of almost a century of litigation and political debates about water pollution. The two main goals of the CWA are (1) to attain a level of water quality that provides for the protection and propagation of fish, shellfish, and wildlife and provides for recreation in and on the water and (2) to eliminate the discharge of pollutants into waters of the United States. 
The CWA requires that EPA establish limits on the amounts of specific pollutants that may be discharged to surface waters. The standards, called effluent limitations, are written into NPDES permits issued to all municipal and industrial dischargers. The Y-12 Plant, ORNL, and the K-25 Site are each required to monitor discharges at frequencies specified in their permits to ensure compliance with the NPDES effluent limitations. The TDEC Division of Water Pollution Control has the authority to issue NPDES permits and to monitor compliance with the permits in the state of Tennessee under the Tennessee Water Control Act and according to the rules and regulations of the Tennessee Water quality control (QC) Board. DOE waste treatment facilities have formal wastewater acceptability control and surveillance programs that ensure the protection of the facilities and the proper treatment of wastes. Among other things, these programs define pretreatment requirements and waste acceptance criteria. Discharges are regulated under NPDES permits.

The CWA also created the Federal Pretreatment Program to regulate industrial discharges to sanitary sewer systems, which are also referred to as POTW. Under the Federal Pretreatment Program, industries are required to monitor and regulate their discharges to a POTW. The state of Tennessee has created the Tennessee Pretreatment Program, which requires municipalities to develop their own municipal POTWs for their local industries. Municipal POTWs issue permits to industries, spelling out the responsibilities of the industries for pretreatment and compliance with the sewer-use ordinance. These responsibilities include the monitoring of their waste streams to determine pollutant concentration limits.

Sanitary wastewater from the Y-12 Plant is discharged to the city of Oak Ridge POTW. Both ORNL and the K-25 Site have on-site sewage treatment plants.

\section{Y-12 Plant Surface Water and Liquid Effluents}

The current Y-12 Plant NPDES permit, issued on April 28, 1995 and effective on July 1,
1995, requires sampling, analysis, and reporting at approximately 100 outfalls. The number is subject to change as outfalls are eliminated or consolidated or if permitted discharges are added. Three outfalls to EFPC (Outfalls 32, 122 , and 133) were physically eliminated in 1995 after permit issuance. During the previous 2 years, 46 outfalls were eliminated as part of a program to remove or consolidate outfall pipes on EFPC. Since the mid-1980s more than 250 untreated wastewater point sources that previously discharged to surface waters have been either eliminated from direct discharge or routed to a wastewater treatment facility. Currently, the Y-12 Plant has outfalls and monitoring points in the following water drainage areas: EFPC, Bear Creek, an unnamed tributary to $\mathrm{McCoy}$ Branch, and two unnamed tributaries to the Clinch River. At the end of 1995 there were sixty outfalls discharging various types of waste water (condensate, cooling water, groundwater, water from building sumps, treated process wastewaters, and other wastewaters). Of the 60 outfalls, nine discharge storm water only, three discharge steam condensate only, two discharge groundwater only, and two are potable water blowdowns. Twenty-eight of the permitted outfalls are actually in-stream monitoring locations throughout the Y-12 Plant area. Five internal monitoring points monitor the effluent from wastewater treatment facilities.

The water quality of surface streams in the vicinity of the Y-12 Plant is affected by current and past operations. Discharges from Y-12 Plant processes affect water quality and flow in EFPC before entering the Clinch River. In past years, discharge of coal bottom ash slurry to the McCoy Branch Watershed from the Y-12 Steam Plant occurred. This practice has been stopped, and coal ash is currently collected dry and is being used for recycle or for filler to support landfill operations.

Bear Creek water quality is affected by area source runoff and groundwater discharges. Discharges to surface water allowed under the permit include storm drainage, cooling water, cooling tower blowdown, and treated process wastewaters, including effluents from wastewater treatment facilities. Sumps that 
collect groundwater inflow in building basements are also permitted for discharge to the creek. The monitoring data collected by the sampling and analysis of permitted discharges are compared with the appropriate NPDES limits when a limit exists for each parameter. Some parameters are "monitor only," with no limits specified.

During the first 6 months of 1995 the Y-12 Plant operated under a permit that had been issued in 1985. In 1989 an application for permit renewal was submitted to TDEC. Eamest consideration of the permit renewal request began in 1992 with information meetings conducted between representatives of the TDEC, DOE, and Lockheed Martin. The Y-12 Plant submitted a storm water permit application in 1992, and an update or addendum to the 1989 permit application was filed in early 1993. A new permit was issued on April 28, 1995. Compliance monitoring in accordance with new permit conditions was initiated on the permit effective date (July 1, 1995). The effluent limitations contained in the permit are based on the protection of water quality in the receiving streams. The permit places emphasis on storm water runoff and biological, toxicological, and radiological monitoring. Some of the more significant changes in the new permit are as follows.

- toxicity limitation for the headwaters of EFPC,

- quarterly toxicity testing at the wastewater treatment facilities,

- a compliance schedule to reduce mercury in EFPC,

- a compliance schedule for chlorine limitations at outfalls containing cooling water,

- chlorine limitations of water quality criteria at the headwaters of EFPC,

- a compliance schedule for correction of elevated ammonia concentrations discharged to EFPC from a groundwater spring,

- a requirement to manage the flow of EFPC such that a minimum flow of 7 million gal per day is guaranteed by adding raw water from the Clinch River to the headwaters of the creek,

- sampling of storm water at a minimum of 25 locations per year,

- a storm water pollution plan, and

- in-stream pH limitations on tributaries to Bear Creek and various other tributaries on the south side of Chestnut Ridge.

\section{Sanitary Wastewater}

Sanitary wastewater from the Y-12 Plant is discharged to the city of Oak Ridge POTW under Industrial and Commercial Users Wastewater Permit Number 1-91. Monitoring is conducted under the terms of the permit for a variety of organic and inorganic pollutants. During 1995 the wastewater flow in this system averaged about $825,000 \mathrm{gal} /$ day $(3,121,800 \mathrm{~L} /$ day $)$.

Prior to June 28,1994 , samples from the sanitary sewer were collected from two sites to monitor compliance to the permit: the City Monitoring Station (SS4) and the Union Valley Station (SS5). The Y-12 Plant contribution was calculated by subtracting the loading of the Union Valley Station from the loading of the City Station. The Union Valley Station does not have any Y-12 Plant waste streams associated with it. Two additional in-plant monitoring points (SS1 and SS2) were monitored as a best management practice. In July 1994, the EESSMS (SS-6) (Fig. 4.10) was put into service. Completion of the monitoring station and rerouting of the associated sewer line combined all Y-12 Plant sanitary sewer effluent into one discharge line. The EESSMS is capable of monitoring all Y-12 Plant sanitary sewer effluent. Thus no additional sampling sites are required and back-calculation of contaminant releases based on two monitoring location is no longer necessary.

The Industrial User Permit expired at the end of August 1995. As required by the city, a sanitary sewer permit application and questionnaire form were submitted in July 1995. The questionnaire is used by the city's Department of Public Works staff to set limits for industrial and commercial discharges. Reissuance of the Y-12 Plant permit is in part contingent on review of permits issued to other 
industrial customers and on the issuance of an NPDES permit for the city's wastewater treatment facility.

\section{Results}

In 1995 the Y-12 Plant reduced NPDES excursions by $45 \%$ from 1994 (from 11 in 1994 to 6 in 1995). Only two of the excursions were caused by exceedences of wastewater discharge limits. In 1995 none of the Y-12 Plant NPDES excursions were attributable to administrative errors such as missing analytical sample holding times, loss of a sample, or improper sample preservation. All Y-12 Plant NPDES permit excursions recorded in 1995 are summarized in Appendix F, Table F.1. Tables 4.15 and 4.16 record the NPDES compliance monitoring requirements and the 1995 compliance record.

The PCB Monitoring Plan for the Y-12 Plant specifies sampling locations and frequencies of sampling for PCBs. All results for the year were less than the analytical detection limit, which is $0.0005 \mathrm{mg} / \mathrm{L}$ (Table 4.17).

Monitoring of nonradiological parameters at kilometer 12.4 (mile 7.7) on Upper Bear Creek continued until July 1995, as it did for radiological parameters, to monitor the influence of seepage from the $\mathrm{S}-3$ ponds site. Because of decreased flow at this site since closure of the S-3 ponds, a new site at kilometer 11.97 has also been monitored as a replacement site. Analytical data from both sites have been compared, and changes in the monitoring routine were implemented in July 1995 . Analytical data are reported monthly to TDEC in an attachment to the discharge monitoring report required by NPDES. These sites were monitored once per week for nonradiological parameters. Surface water in the upper reaches of Bear Creek contains elevated trace metals and nitrate concentrations.

Table 4.18 summarizes Y-12 Plant contributions to the sanitary sewer system for 1995.

\section{Progress in Implementing Corrective Actions and Significant Improvements}

\section{East Fork Poplar Creek Dechlorination}

Two dechlorination systems that began operating in December 1992 continued to provide dechlorination for $75 \%$ of EFPC flow (20\% of EFPC flow is estimated to be groundwater). In-stream levels of total residual chlorine were typically about $0.01 \mathrm{mg} / \mathrm{L}$ during 1995 as compared with outfall discharge levels before 1993 of about 0.3 to $1.0 \mathrm{mg} / \mathrm{L}$. Fish populations and density have increased significantly. Additional dechlorination has been achieved by installation of five tablet dechlorinators during 1995 (which now total 38) at chlorine-discharge sources. Outfall 125, the next largest nondechlorinated outfall, began treatment in 1995, following installation of a dechlorination system in late 1994.

Ecological recovery of EFPC is continuing, with some significant recent trends. Pollution-intolerant fish species are being found below Lake Reality, and there has been substantial reduction in toxicity above Lake Reality. However, both fish and benthic macroinvertebrate communities in UEFPC are dominated by pollution-tolerant species, especially above Lake Reality. Additional recovery may occur in response to reductions in mercury levels in EFPC. Complete recovery may not occur because water temperatures are elevated, inadvertent discharges/spills may occur, and availability of habitat is limited above Lake Reality.

\section{Flow Management (or Raw Water) Project}

Discharges to EFPC have decreased in volume from about $10 \mathrm{million}$ gal/day ( 38 million $\mathrm{L}$ /day) in the early 1980 s to about 3.5 million gal/day (13.2 million L/day) currently, primarily because of reductions in plant operations.

These reductions have increased concern about maintaining water quality and stable flow in the upper reaches of EFPC. Accordingly, the new NPDES permit requires addition of Clinch River water to the headwaters of EFPC (North/South Pipe-Outfall 200 area) by March 1997 so that a 
Table 4.15. NPDES compliance monitoring requirements and record for the Y-12 Plant, January through June, 1995

\begin{tabular}{|c|c|c|c|c|c|c|c|}
\hline \multirow{2}{*}{$\begin{array}{l}\text { Discharge } \\
\text { point }\end{array}$} & \multirow{2}{*}{$\begin{array}{c}\text { Effluent } \\
\text { parameter }\end{array}$} & \multicolumn{4}{|c|}{ Effuent limits } & \multirow{2}{*}{$\begin{array}{c}\text { Percentage } \\
\text { of } \\
\text { compliance }\end{array}$} & \multirow{2}{*}{$\begin{array}{l}\text { No. of } \\
\text { samples }\end{array}$} \\
\hline & & $\begin{array}{l}\text { Daily } \\
\text { av } \\
(\mathrm{kg} / \mathrm{d})\end{array}$ & $\begin{array}{c}\text { Daily } \\
\text { max } \\
(\mathrm{kg} / \mathrm{d})\end{array}$ & $\begin{array}{c}\text { Daily } \\
\text { av } \\
\text { (mg/L) }\end{array}$ & $\begin{array}{c}\text { Daily } \\
\text { max } \\
(\mathrm{mg} / \mathrm{L})\end{array}$ & & \\
\hline \multirow[t]{5}{*}{301 (Kerr Hollow Quarry) } & Lithium & & & & 5.0 & 100 & 12 \\
\hline & $\mathrm{pH}$, standard units & & & $a$ & 8.5 & 100 & 12 \\
\hline & Total suspended solids & & & 30.0 & 50.0 & 100 & 12 \\
\hline & Temperature, ${ }^{\circ} \mathrm{C}$ & & & & 30.5 & 100 & 12 \\
\hline & Zirconium & & & & 3.0 & 100 & 12 \\
\hline \multirow[t]{5}{*}{302 (Rogers Quarry) } & Oil and grease & & & 10.0 & 15.0 & 100 & 26 \\
\hline & $\mathrm{pH}$, standard units & & & $a$ & 8.5 & 100 & 26 \\
\hline & Settleable solids, $\mathrm{mL} / \mathrm{L}$ & & & & 0.5 & 100 & 26 \\
\hline & Total suspended solids & & & 30.0 & $50.0^{b}$ & 100 & 26 \\
\hline & Temperature, ${ }^{\circ} \mathrm{C}$ & & & & 30.5 & 100 & 26 \\
\hline \multirow[t]{2}{*}{304 (Bear Creek) } & Oil and grease & & & 10.0 & 15.0 & 100 & 26 \\
\hline & $\mathrm{pH}$, standard units & & & $a$ & 8.5 & 100 & 26 \\
\hline \multirow[t]{4}{*}{307 (West Borrow Area) $^{c}$} & Temperature, ${ }^{\circ} \mathrm{C}$ & & & & & 100 & 2 \\
\hline & $\mathrm{pH}$, standard units & & & & & 100 & 2 \\
\hline & Oil and grease & & & & & 100 & 2 \\
\hline & Total suspended solids & & & & & 100 & 2 \\
\hline \multirow[t]{4}{*}{308 (East Borrow Area) $^{c}$} & Temperature, ${ }^{\circ} \mathrm{C}$ & & & & & 100 & 2 \\
\hline & $\mathrm{pH}$, standard units & & & & & 100 & 2 \\
\hline & Oil and grease & & & & & 100 & 2 \\
\hline & Total suspended solids & & & & & 100 & 2 \\
\hline 501 [Central Pollution & Cadmium, total & 0.07 & 0.19 & 0.26 & 0.69 & 100 & 16 \\
\hline \multirow[t]{12}{*}{ Control Facility (CPCF-I)] } & Chromium, total & 0.5 & 0.75 & 1.71 & 2.77 & 100 & 16 \\
\hline & Copper, total & 0.6 & 0.9 & 2.07 & 3.38 & 100 & 16 \\
\hline & Cyanide, total & 0.2 & 0.33 & 0.65 & 1.20 & 100 & 16 \\
\hline & Lead, total & 0.12 & 0.19 & 0.43 & 0.69 & 100 & 16 \\
\hline & Nickel, total & 0.65 & 1.1 & 2.38 & 3.98 & 100 & 16 \\
\hline & Oil and grease & 7.1 & 14.2 & 26.0 & 52.0 & 100 & 16 \\
\hline & $\mathrm{pH}$, standard units & & & $a$ & 9.0 & 100 & 16 \\
\hline & Silver, total & 0.07 & 0.12 & 0.24 & 0.43 & 100 & 16 \\
\hline & Temperature, ${ }^{\circ} \mathrm{C}$ & & & & 30.5 & 100 & 16 \\
\hline & Total suspended solids & 8.5 & 16.4 & 31.0 & 60.0 & 100 & 16 \\
\hline & Total toxic organics & & 0.6 & & 2.13 & 100 & 16 \\
\hline & Zinc, total & 0.4 & 0.7 & 1.48 & 2.61 & 100 & 16 \\
\hline 502 [West End Treatment & Cadmium, total & 0.07 & 0.019 & 0.26 & 0.69 & $d$ & 0 \\
\hline \multirow[t]{4}{*}{ Facility (WETF)] } & Chromium, total & 0.5 & 0.75 & 1.71 & 2.77 & $d$ & 0 \\
\hline & Copper, total & 0.6 & 0.92 & 2.07 & 3.38 & $d$ & 0 \\
\hline & Cyanide, total & 0.2 & 0.33 & 0.65 & 1.20 & $d$ & 0 \\
\hline & Lead, total & 0.12 & 0.19 & 0.43 & 0.69 & $d$ & 0 \\
\hline
\end{tabular}


Annual Site Environmental Report

Table 4.15 (continued)

\begin{tabular}{|c|c|c|c|c|c|c|c|}
\hline \multirow{2}{*}{$\begin{array}{l}\text { Discharge } \\
\text { point }\end{array}$} & \multirow{2}{*}{$\begin{array}{c}\text { Effuent } \\
\text { parameter }\end{array}$} & \multicolumn{4}{|c|}{ Effluent limits } & \multirow{2}{*}{$\begin{array}{c}\text { Percentage } \\
\text { of } \\
\text { compliance }\end{array}$} & \multirow{2}{*}{$\begin{array}{l}\text { No. of } \\
\text { samples }\end{array}$} \\
\hline & & $\begin{array}{l}\text { Daily } \\
\text { av } \\
(\mathbf{k g} / \mathbf{d})\end{array}$ & $\begin{array}{c}\text { Daily } \\
\max \\
(\mathrm{kg} / \mathrm{d})\end{array}$ & $\begin{array}{c}\text { Daily } \\
\text { av } \\
\text { (mg/L) }\end{array}$ & $\begin{array}{c}\text { Daily } \\
\text { max } \\
(\mathbf{m g} / \mathbf{L})\end{array}$ & & \\
\hline & $\begin{array}{l}\text { Nickel, total } \\
\text { Oil and grease } \\
\text { pH, standard units } \\
\text { Silver, total } \\
\text { Temperature, }{ }^{\circ} \mathrm{C} \\
\text { Total suspended solids } \\
\text { Total toxic organics } \\
\text { Zinc, total }\end{array}$ & $\begin{array}{l}0.65 \\
7.1 \\
0.07 \\
8.5 \\
0.4\end{array}$ & $\begin{array}{c}1.10 \\
14.2 \\
0.12 \\
16.4 \\
0.6 \\
0.7\end{array}$ & $\begin{array}{c}2.38 \\
26.0 \\
a \\
0.24 \\
31.0 \\
1.48\end{array}$ & $\begin{array}{c}3.98 \\
52.0 \\
9.0 \\
0.43 \\
30.5 \\
60.0 \\
2.13 \\
2.61\end{array}$ & $\begin{array}{l}d \\
d \\
d \\
d \\
d \\
d \\
d \\
d\end{array}$ & $\begin{array}{l}0 \\
0 \\
0 \\
0 \\
0 \\
0 \\
0 \\
0\end{array}$ \\
\hline $\begin{array}{l}503 \text { (Steam Plant Wastewater } \\
\text { Treatment Facility }\end{array}$ & $\begin{array}{l}\text { Chromium, total } \\
\text { Copper, total } \\
\text { Iron, total } \\
\text { Zinc, total } \\
\text { Oil and grease } \\
\text { Total suspended solids } \\
\text { Temperature, }{ }^{\circ} \mathrm{C} \\
\text { pH, standard units }\end{array}$ & $\begin{array}{c}0.38 \\
1.89 \\
1.89 \\
1.89 \\
28.4 \\
57.0\end{array}$ & $\begin{array}{c}0.38 \\
1.89 \\
1.89 \\
1.89 \\
37.9 \\
189.0\end{array}$ & $\begin{array}{r}0.20 \\
1.0 \\
1.0 \\
1.0 \\
15.0 \\
30.0 \\
\\
\quad a\end{array}$ & $\begin{array}{r}0.20 \\
1.0 \\
1.0 \\
1.0 \\
20.0 \\
100.0 \\
30.5 \\
9.0\end{array}$ & $\begin{array}{l}d \\
d \\
d \\
d \\
d \\
d \\
d \\
d\end{array}$ & $\begin{array}{l}0 \\
0 \\
0 \\
0 \\
0 \\
0 \\
0 \\
0\end{array}$ \\
\hline $\begin{array}{l}\text { Category I outfalls } \\
\text { (precipitation runoff and } \\
\text { small amounts of } \\
\text { groundwater) }\end{array}$ & pH, standard units & & & $a$ & 8.5 & 100 & 56 \\
\hline $\begin{array}{l}\text { Category II outfalls } \\
\text { (cooling waters, condensate, } \\
\text { precipitation runoff, and } \\
\text { building, roof, and } \\
\text { foundation drains) }\end{array}$ & $\begin{array}{l}\mathrm{pH}, \text { standard units } \\
\text { Temperature, }{ }^{\circ} \mathrm{C} e\end{array}$ & & & $a$ & 8.5 & 100 & $\begin{array}{r}39 \\
100\end{array}$ \\
\hline $\begin{array}{l}\text { Category III outfalls } \\
\text { (process wastewaters) }\end{array}$ & $\mathrm{pH}$, standard units & & & $a$ & 8.5 & 100 & 30 \\
\hline $\begin{array}{l}\text { Category IV outfalls } \\
\text { (untreated process } \\
\text { wastewaters) }\end{array}$ & $\mathrm{pH}$, standard units & & & $a$ & 8.5 & 100 & 35 \\
\hline 504 (Plating Rinsewater & Cadmium, total & 0.07 & 0.019 & 0.26 & 0.69 & 100 & 4 \\
\hline Treatment Facility) & $\begin{array}{l}\text { Chromium, total } \\
\text { Copper, total } \\
\text { Cyanide, total } \\
\text { Lead, total } \\
\text { Nickel, total } \\
\text { Oil and grease } \\
\text { pH, standard units }\end{array}$ & $\begin{array}{l}0.50 \\
0.60 \\
0.2 \\
0.12 \\
0.65 \\
7.1\end{array}$ & $\begin{array}{c}0.75 \\
0.92 \\
0.33 \\
0.19 \\
1.10 \\
14.2\end{array}$ & $\begin{array}{c}1.71 \\
2.07 \\
0.65 \\
0.43 \\
2.38 \\
26.0 \\
a\end{array}$ & $\begin{array}{c}2.77 \\
3.38 \\
1.20 \\
0.69 \\
3.98 \\
52.0 \\
9.0\end{array}$ & $\begin{array}{l}100 \\
100 \\
100 \\
100 \\
100 \\
100 \\
100\end{array}$ & $\begin{array}{l}4 \\
4 \\
4 \\
4 \\
4 \\
4 \\
4\end{array}$ \\
\hline
\end{tabular}


Table 4.15 (continued)

\begin{tabular}{|c|c|c|c|c|c|c|c|}
\hline \multirow{2}{*}{$\begin{array}{l}\text { Discharge } \\
\text { point }\end{array}$} & \multirow{2}{*}{$\begin{array}{c}\text { Effluent } \\
\text { parameter }\end{array}$} & \multicolumn{4}{|c|}{ Effuent limits } & \multirow{2}{*}{$\begin{array}{l}\text { Percentage } \\
\text { of } \\
\text { compliance }\end{array}$} & \multirow{2}{*}{$\begin{array}{l}\text { No. of } \\
\text { samples }\end{array}$} \\
\hline & & $\begin{array}{l}\text { Daily } \\
\text { av } \\
(\mathrm{kg} / \mathrm{d})\end{array}$ & $\begin{array}{c}\text { Daily } \\
\max \\
(\mathbf{k g} / \mathbf{d})\end{array}$ & $\begin{array}{c}\text { Daily } \\
\text { av } \\
\text { (mg/L) }\end{array}$ & $\begin{array}{c}\text { Daily } \\
\text { max } \\
(\mathbf{m g} / \mathbf{L})\end{array}$ & & \\
\hline & $\begin{array}{l}\text { Silver, total } \\
\text { Temperature, }{ }^{\circ} \mathrm{C} \\
\text { Total suspended solids } \\
\text { Total toxic organics } \\
\text { Zinc, total }\end{array}$ & $\begin{array}{l}0.07 \\
8.5 \\
0.4\end{array}$ & $\begin{array}{r}0.12 \\
16.4 \\
0.6 \\
0.7\end{array}$ & $\begin{array}{l}0.24 \\
31.0 \\
1.48\end{array}$ & $\begin{array}{l}0.43 \\
30.5 \\
60.0 \\
2.13 \\
2.61\end{array}$ & $\begin{array}{l}100 \\
100 \\
100 \\
100 \\
100\end{array}$ & $\begin{array}{l}4 \\
4 \\
4 \\
4 \\
4\end{array}$ \\
\hline $\begin{array}{l}501 / 504 \text { (combined discharge } \\
\text { from Central Pollution } \\
\text { Control Facility and Plating } \\
\text { Rinsewater Treatment } \\
\text { Facility) }\end{array}$ & $\begin{array}{l}\text { Cadmium, total } \\
\text { Chromium, total } \\
\text { Copper, total } \\
\text { Cyanide, total } \\
\text { Lead, total } \\
\text { Nickel, total } \\
\text { Oil and grease } \\
\text { pH, standard units } \\
\text { Silver, total } \\
\text { Temperature, }{ }^{\circ} \mathrm{C} \\
\text { Total suspended solids } \\
\text { Total toxic organics } \\
\text { Zinc, total }\end{array}$ & $\begin{array}{l}0.07 \\
0.50 \\
0.60 \\
0.2 \\
0.12 \\
0.65 \\
7.1 \\
0.07 \\
8.5 \\
0.4\end{array}$ & $\begin{array}{l}0.019 \\
0.75 \\
0.92 \\
0.33 \\
0.19 \\
1.10 \\
14.2 \\
\\
0.12 \\
\\
16.4 \\
0.6 \\
0.7\end{array}$ & $\begin{array}{c}0.26 \\
1.71 \\
2.07 \\
0.65 \\
0.43 \\
2.38 \\
26.0 \\
a \\
0.24 \\
31.0 \\
1.48\end{array}$ & $\begin{array}{c}0.69 \\
2.77 \\
3.38 \\
1.20 \\
0.69 \\
3.98 \\
52.0 \\
9.0 \\
0.43 \\
30.5 \\
60.0 \\
2.13 \\
2.61\end{array}$ & $\begin{array}{l}d \\
d \\
d \\
d \\
d \\
d \\
d \\
d \\
d \\
d \\
d \\
d \\
d\end{array}$ & \\
\hline $\begin{array}{l}623 \text { (Steam Plant fly } \\
\text { ash sluice water) }\end{array}$ & $\mathrm{pH}$, standard units & & & $a$ & 8.5 & $d$ & \\
\hline $\begin{array}{l}506 \text { (9204-3 sump } \\
\text { pump oil) }\end{array}$ & $\begin{array}{l}\text { Temperature, }{ }^{\circ} \mathrm{C} \\
\text { Oil and grease } \\
\text { pH, standard units }\end{array}$ & & & $\begin{array}{r}10.0 \\
a\end{array}$ & $\begin{array}{r}30.5 \\
15.0 \\
8.5\end{array}$ & $\begin{array}{l}d \\
d \\
d\end{array}$ & \\
\hline $\begin{array}{l}508 \text { (Experimental Mobile } \\
\text { Wastewater Treatment } \\
\text { Facility) }\end{array}$ & $\begin{array}{l}\text { Mercury, total } \\
\text { pH, standard units } \\
\text { Total suspended solids }\end{array}$ & & & $\begin{array}{c}0.002 \\
a \\
30.0\end{array}$ & $\begin{array}{c}0.004 \\
9.0 \\
45.0\end{array}$ & $\begin{array}{l}d \\
d \\
d\end{array}$ & $a$ \\
\hline $\begin{array}{l}510 \text { (Waste Coolant } \\
\text { Processing Facility) }\end{array}$ & $\begin{array}{l}\text { Biochemical oxygen demand } \\
\text { Oil and grease } \\
\text { pH, standard units } \\
\text { Temperature, }{ }^{\circ} \mathrm{C} \\
\text { Total suspended solids }\end{array}$ & 1.33 & 2.65 & $\begin{array}{r}15.0 \\
a \\
30.0\end{array}$ & $\begin{array}{r}20.0 \\
9.0 \\
30.5 \\
50.0\end{array}$ & $\begin{array}{l}d \\
d \\
d \\
d \\
d\end{array}$ & \\
\hline $\begin{array}{l}512 \text { (Groundwater } \\
\text { Treatment Facility) }\end{array}$ & $\begin{array}{l}\text { Oil and grease } \\
\text { Iron, total } \\
\text { pH, standard units } \\
\text { PCBs }\end{array}$ & & & $\begin{array}{l}a \\
a \\
a\end{array}$ & $\begin{array}{l}15 \\
1.0 \\
9.0\end{array}$ & $\begin{array}{l}100 \\
100 \\
100 \\
100\end{array}$ & $\begin{array}{c}296 \\
296 \\
\text { continuous } \\
296\end{array}$ \\
\hline
\end{tabular}


Table 4.15 (continued)

\begin{tabular}{|c|c|c|c|c|c|c|c|}
\hline \multirow{2}{*}{$\begin{array}{l}\text { Discharge } \\
\text { point }\end{array}$} & \multirow{2}{*}{$\begin{array}{c}\text { Effluent } \\
\text { parameter }\end{array}$} & \multicolumn{4}{|c|}{ Efffuent limits } & \multirow{2}{*}{$\begin{array}{l}\text { Percentage } \\
\text { of } \\
\text { compliance }\end{array}$} & \multirow{2}{*}{$\begin{array}{l}\text { No. of } \\
\text { samples }\end{array}$} \\
\hline & & $\begin{array}{l}\text { Daily } \\
\text { av } \\
(\mathbf{k g} / \mathrm{d})\end{array}$ & $\begin{array}{c}\text { Daily } \\
\text { max } \\
(\mathrm{kg} / \mathrm{d})\end{array}$ & $\begin{array}{c}\text { Daily } \\
\text { av } \\
(\mathrm{mg} / \mathrm{L})\end{array}$ & $\begin{array}{c}\text { Daily } \\
\text { max } \\
(\mathrm{mg} / \mathrm{L})\end{array}$ & & \\
\hline $\begin{array}{l}\text { Miscellaneous discharges } \\
\text { (cooling tower blowdown) }\end{array}$ & $\begin{array}{l}\text { Free available chlorine } \\
\mathrm{pH} \text {, standard units } \\
\text { Temperature, }{ }^{\circ} \mathrm{C}\end{array}$ & & & $\begin{array}{r}0.2 \\
35\end{array}$ & $\begin{array}{l}0.5 \\
8.5 \\
38\end{array}$ & $\begin{array}{l}100 \\
100 \\
100\end{array}$ & $\begin{array}{l}21 \\
21 \\
21\end{array}$ \\
\hline $\begin{array}{l}\text { Miscellaneous discharges } \\
\text { (demineralizers) }\end{array}$ & $\begin{array}{l}\mathrm{pH}, \text { standard units } \\
\text { Total suspended solids }\end{array}$ & & & $30^{a}$ & $\begin{array}{l}8.5 \\
50\end{array}$ & $\begin{array}{l}d \\
d\end{array}$ & \\
\hline
\end{tabular}

\footnotetext{
${ }^{a}$ Not applicable.

${ }^{b}$ Limit not applicable during periods of increased surface runoff resulting from precipitation.

${ }^{c}$ Application submitted to add this outfall to the permit. No limits have been set.

${ }^{d}$ No discharge.

${ }^{e}$ Temperature shall be controlled such that the stream temperature standards delineated in the General Water Quality Criteria for the Definition and Control of Pollution in the Waters of Tennessee, as amended, are not violated as a result of this discharge.
} 
Table 4.16. NPDES compliance monitoring requirements and record for the Y-12 Plant, July through December 1995

\begin{tabular}{|c|c|c|c|c|c|c|c|}
\hline \multirow{2}{*}{$\begin{array}{l}\text { Discharge } \\
\text { point }\end{array}$} & \multirow{2}{*}{$\begin{array}{c}\text { Effiuent } \\
\text { parameter }\end{array}$} & \multicolumn{4}{|c|}{ Effuent limits } & \multirow{2}{*}{$\begin{array}{c}\text { Percentage } \\
\text { of } \\
\text { compliance }\end{array}$} & \multirow{2}{*}{$\begin{array}{l}\text { No. of } \\
\text { samples }\end{array}$} \\
\hline & & $\begin{array}{c}\text { Daily av } \\
\text { (lb/d) }\end{array}$ & $\begin{array}{c}\text { Daily max } \\
\text { (lb/d) }\end{array}$ & $\begin{array}{l}\text { Daily av } \\
\text { (mg/L) }\end{array}$ & $\begin{array}{c}\text { Daily max } \\
(\mathbf{m g} / \mathbf{L})\end{array}$ & & \\
\hline Outfall 066 & $\mathrm{pH}$, standard units & & & $a$ & 9.0 & 100 & 2 \\
\hline Outfall 068 & $\mathrm{pH}$, standard units & & & $a$ & 9.0 & 100 & 6 \\
\hline Outfall 117 & $\mathrm{pH}$, standard units & & & $a$ & 9.0 & 100 & 3 \\
\hline Outfall 073 & $\begin{array}{l}\mathrm{pH}, \text { standard units } \\
\text { Total residual chlorine }\end{array}$ & & & $a$ & $\begin{array}{l}9.0 \\
0.5\end{array}$ & $\begin{array}{l}100 \\
100\end{array}$ & $\begin{array}{l}6 \\
6\end{array}$ \\
\hline Outfall 077 & $\begin{array}{l}\mathrm{pH}, \text { standard units } \\
\text { Total residual chlorine }\end{array}$ & & & $a$ & $\begin{array}{l}9.0 \\
0.5\end{array}$ & $\begin{array}{l}100 \\
100\end{array}$ & $\begin{array}{l}6 \\
6\end{array}$ \\
\hline Outfall 122 & $\begin{array}{l}\mathrm{pH}, \text { standard units } \\
\text { Total residual chlorine }\end{array}$ & & & $a$ & $\begin{array}{l}9.0 \\
0.5\end{array}$ & $\begin{array}{l}b \\
b\end{array}$ & $\begin{array}{l}0 \\
0\end{array}$ \\
\hline Outfall 133 & $\begin{array}{l}\mathrm{pH}, \text { standard units } \\
\text { Total residual chlorine }\end{array}$ & & & $a$ & $\begin{array}{l}9.0 \\
0.5\end{array}$ & $\begin{array}{l}b \\
b\end{array}$ & $\begin{array}{l}0 \\
0\end{array}$ \\
\hline Outfall 125 & $\begin{array}{l}\mathrm{pH}, \text { standard units } \\
\text { Total residual chlorine }\end{array}$ & & & $a$ & $\begin{array}{l}9.0 \\
0.5\end{array}$ & $\begin{array}{l}100 \\
100\end{array}$ & $\begin{array}{l}6 \\
6\end{array}$ \\
\hline $\begin{array}{l}\text { Category I outfalls } \\
\text { (Storm water, steam } \\
\text { condensate, cooling } \\
\text { tower blowdown, and } \\
\text { groundwater) }\end{array}$ & $\mathrm{pH}$, standard units & & & $a$ & 9.0 & 100 & 27 \\
\hline $\begin{array}{l}\text { Category I outfalls } \\
\text { (Outfalls S15 } \\
\text { and S16) }\end{array}$ & $\mathrm{pH}$, standard units & & & $a$ & 10.0 & 100 & 2 \\
\hline $\begin{array}{l}\text { Category II outfalls } \\
\text { (cooling water, steam } \\
\text { condensate, storm } \\
\text { water, and } \\
\text { groundwater) }\end{array}$ & $\begin{array}{l}\mathrm{pH}, \text { standard units } \\
\text { Total residual chlorine }\end{array}$ & & & $a$ & $\begin{array}{l}9.0 \\
0.5\end{array}$ & $\begin{array}{r}100 \\
98\end{array}$ & $\begin{array}{l}46 \\
44\end{array}$ \\
\hline $\begin{array}{l}\text { Category II outfalls } \\
(\$ 21, S 22, S 25 \\
\text { S26, S27, S28, } \\
\text { and S29) }\end{array}$ & pH, standard units & & & $a$ & 10.0 & 100 & 12 \\
\hline $\begin{array}{l}\text { Outfall S19 } \\
\text { (Rogers Quarry) }\end{array}$ & $\mathrm{pH}$, standard units & & & $a$ & 9.0 & 100 & 6 \\
\hline
\end{tabular}


Table 4.16 (continued)

\begin{tabular}{|c|c|c|c|c|c|c|c|}
\hline \multirow{2}{*}{$\begin{array}{l}\text { Discharge } \\
\text { point }\end{array}$} & \multirow{2}{*}{$\begin{array}{l}\text { Effuent } \\
\text { parameter }\end{array}$} & \multicolumn{4}{|c|}{ Effluent limits } & \multirow{2}{*}{$\begin{array}{l}\text { Percentage } \\
\text { of } \\
\text { compliance }\end{array}$} & \multirow{2}{*}{$\begin{array}{l}\text { No. of } \\
\text { samples }\end{array}$} \\
\hline & & $\begin{array}{c}\text { Daily av } \\
\text { (lb/d) }\end{array}$ & $\begin{array}{c}\text { Daily max } \\
\text { (lb/d) }\end{array}$ & $\begin{array}{c}\begin{array}{c}\text { Daily av } \\
(\mathrm{mg} / \mathrm{L})\end{array} \\
\end{array}$ & $\begin{array}{c}\text { Daily max } \\
\text { (mg/L) }\end{array}$ & & \\
\hline $\begin{array}{l}\text { Category III outfalls } \\
\text { (storm water, cooling } \\
\text { water, cooling tower } \\
\text { blowdown, steam } \\
\text { condensate, and } \\
\text { groundwater) }\end{array}$ & $\begin{array}{l}\mathrm{pH}, \text { standard units } \\
\text { Total residual chlorine }\end{array}$ & & & $a$ & $\begin{array}{l}9.0 \\
0.5\end{array}$ & $\begin{array}{l}100 \\
100\end{array}$ & $\begin{array}{l}80 \\
58\end{array}$ \\
\hline $\begin{array}{l}\text { Outfall } 201 \text { (below } \\
\text { the North/South } \\
\text { pipes) } \\
\text { Outfall } 200 \\
\text { (North/South Pipes) }\end{array}$ & $\begin{array}{l}\text { Total residual chlorine } \\
\text { Temperature, }{ }^{\circ} \mathrm{C} \\
\text { pH, standard units } \\
\text { Oil and grease }\end{array}$ & & & $\begin{array}{l}0.011 \\
10^{a}\end{array}$ & $\begin{array}{l}0.019 \\
30.5 \\
8.5 \\
15\end{array}$ & $\begin{array}{c}97 \\
100 \\
100 \\
100\end{array}$ & $\begin{array}{l}92 \\
78 \\
79 \\
78\end{array}$ \\
\hline Outfall 021 & $\begin{array}{l}\text { Total residual chlorine } \\
\text { Temperature, }{ }^{\circ} \mathrm{C} \\
\text { pH, standard units }\end{array}$ & & & $\begin{array}{l}0.080 \\
a\end{array}$ & $\begin{array}{l}0.188 \\
30.5 \\
9.0\end{array}$ & $\begin{array}{l}100 \\
100 \\
100\end{array}$ & $\begin{array}{l}78 \\
85 \\
82\end{array}$ \\
\hline Outfall 017 & $\begin{array}{l}\text { pH, standard units } \\
\text { Ammonia as } \mathrm{N}\end{array}$ & & & $\begin{array}{c}a \\
32.4\end{array}$ & $\begin{array}{r}9.0 \\
64.8\end{array}$ & $\begin{array}{l}100 \\
100\end{array}$ & $\begin{array}{l}26 \\
26\end{array}$ \\
\hline Outfall 055 & $\begin{array}{l}\text { pH, standard units } \\
\text { Mercury } \\
\text { Total residual chlorine }\end{array}$ & & & $a$ & $\begin{array}{l}9.0 \\
0.004 \\
0.5\end{array}$ & $\begin{array}{l}100 \\
100 \\
100\end{array}$ & $\begin{array}{l}53 \\
53 \\
52\end{array}$ \\
\hline Outfall 55A & $\begin{array}{l}\text { pH, standard units } \\
\text { Mercury }\end{array}$ & & & $a$ & $\begin{array}{l}9.0 \\
0.004\end{array}$ & $\begin{array}{l}100 \\
100\end{array}$ & $\begin{array}{l}52 \\
52\end{array}$ \\
\hline Outfall 550 & $\begin{array}{l}\text { pH, standard units } \\
\text { Mercury }\end{array}$ & & & $\begin{array}{c}a \\
0.002\end{array}$ & $\begin{array}{l}9.0 \\
0.004\end{array}$ & $\begin{array}{l}b \\
b\end{array}$ & $\begin{array}{l}0 \\
0\end{array}$ \\
\hline Outfall 551 & $\begin{array}{l}\text { pH, standard units } \\
\text { Mercury }\end{array}$ & & & & $\begin{array}{l}9.0 \\
0.004\end{array}$ & $\begin{array}{l}b \\
b\end{array}$ & $\begin{array}{l}0 \\
0\end{array}$ \\
\hline Outfall 051 & $\mathrm{pH}$, standard units & & & $a$ & 9.0 & 100 & 52 \\
\hline $\begin{array}{l}\text { Outfall } 501 \text { (Central } \\
\text { Pollution Control } \\
\text { Facility) }\end{array}$ & $\begin{array}{l}\text { pH, standard units } \\
\text { Total suspended solids } \\
\text { Total toxic organics } \\
\text { Oil and grease } \\
\text { Cadmium } \\
\text { Chromium } \\
\text { Copper } \\
\text { Lead } \\
\text { Nickel } \\
\text { Silver } \\
\text { Zinc } \\
\text { Cyanide } \\
\text { PCB }\end{array}$ & $\begin{array}{l}0.16 \\
1.0 \\
1.2 \\
0.26 \\
1.4 \\
0.14 \\
0.9 \\
0.4\end{array}$ & $\begin{array}{l}0.4 \\
1.7 \\
2.0 \\
0.4 \\
2.4 \\
0.26 \\
1.6 \\
0.72\end{array}$ & $\begin{array}{l}a \\
31.0 \\
\\
10 \\
0.075 \\
0.5 \\
0.5 \\
0.10 \\
2.38 \\
0.05 \\
1.48 \\
0.65\end{array}$ & $\begin{array}{l}9.0 \\
40.0 \\
2.13 \\
15 \\
0.15 \\
1.0 \\
1.0 \\
0.20 \\
3.98 \\
0.05 \\
2.0 \\
1.20 \\
0.001\end{array}$ & $\begin{array}{l}100 \\
100 \\
100 \\
100 \\
100 \\
100 \\
100 \\
100 \\
100 \\
100 \\
100 \\
100 \\
100\end{array}$ & $\begin{array}{l}8 \\
8 \\
1 \\
8 \\
8 \\
8 \\
8 \\
8 \\
8 \\
8 \\
8 \\
8 \\
1\end{array}$ \\
\hline
\end{tabular}


Table 4.16 (continued)

\begin{tabular}{|c|c|c|c|c|c|c|c|}
\hline \multirow{2}{*}{$\begin{array}{c}\text { Discharge } \\
\text { point }\end{array}$} & \multirow{2}{*}{$\begin{array}{c}\text { Effluent } \\
\text { parameter }\end{array}$} & \multicolumn{4}{|c|}{ Effluent limits } & \multirow{2}{*}{$\begin{array}{c}\text { Percentage } \\
\text { of } \\
\text { compliance }\end{array}$} & \multirow{2}{*}{$\begin{array}{c}\text { No. of } \\
\text { samples }\end{array}$} \\
\hline & & $\begin{array}{c}\text { Daily av } \\
\text { (lb/d) }\end{array}$ & $\begin{array}{c}\text { Daily max } \\
\text { (lb/d) }\end{array}$ & $\begin{array}{c}\text { Daily av } \\
\text { (mg/L) }\end{array}$ & $\begin{array}{c}\text { Daily max } \\
(\mathrm{mg} / \mathrm{L})\end{array}$ & & \\
\hline $\begin{array}{l}\text { Outfall } 502 \text { (West } \\
\text { End Treatment } \\
\text { Facility) }\end{array}$ & $\begin{array}{l}\mathrm{pH}, \text { standard units } \\
\text { Total suspended solids } \\
\text { Total toxic organics } \\
\text { Nitrate/nitrite } \\
\text { Oil and grease } \\
\text { Cadmium } \\
\text { Chromium } \\
\text { Copper } \\
\text { Lead } \\
\text { Nickel } \\
\text { Silver } \\
\text { Zinc } \\
\text { Cyanide } \\
\text { PCB }\end{array}$ & $\begin{array}{l}0.16 \\
1.0 \\
1.2 \\
0.26 \\
1.4 \\
0.14 \\
0.9 \\
0.4\end{array}$ & $\begin{array}{l}0.4 \\
1.7 \\
2.0 \\
0.4 \\
2.4 \\
0.26 \\
1.6 \\
0.72\end{array}$ & $\begin{array}{c}a \\
31.0 \\
100 \\
10 \\
0.075 \\
0.5 \\
0.5 \\
0.10 \\
2.38 \\
0.05 \\
1.48 \\
0.65\end{array}$ & $\begin{array}{l}9.0 \\
40.0 \\
2.13 \\
150 \\
15 \\
0.15 \\
1.0 \\
1.0 \\
0.20 \\
3.98 \\
0.05 \\
2.0 \\
1.2 \\
0.001\end{array}$ & $\begin{array}{l}100 \\
100 \\
100 \\
100 \\
100 \\
100 \\
100 \\
100 \\
100 \\
100 \\
100 \\
100 \\
100 \\
100\end{array}$ & $\begin{array}{r}39 \\
39 \\
6 \\
39 \\
39 \\
39 \\
39 \\
39 \\
39 \\
39 \\
39 \\
39 \\
39 \\
6\end{array}$ \\
\hline $\begin{array}{l}\text { Outfall } 503 \text { (Steam } \\
\text { Plant Wastewater } \\
\text { Treatment Facility) }\end{array}$ & $\begin{array}{l}\mathrm{pH}, \text { standard units } \\
\text { Total suspended solids } \\
\text { Oil and grease } \\
\text { Iron } \\
\text { Cadmium } \\
\text { Chromium } \\
\text { Copper } \\
\text { Lead } \\
\text { Zinc }\end{array}$ & $\begin{array}{l}125 \\
62.6 \\
4.17 \\
\\
0.83 \\
4.17 \\
\\
4.17\end{array}$ & $\begin{array}{c}417 \\
83.4 \\
4.17 \\
\\
0.83 \\
4.17 \\
\\
4.17\end{array}$ & $\begin{array}{l}\quad a \\
30.0 \\
10 \\
1.0 \\
0.075 \\
0.20 \\
0.20 \\
0.10 \\
1.0\end{array}$ & $\begin{array}{l}9.0 \\
40.0 \\
15 \\
1.0 \\
0.15 \\
0.20 \\
0.40 \\
0.20 \\
1.0\end{array}$ & $\begin{array}{l}b \\
b \\
b \\
b \\
b \\
b \\
b \\
b \\
b\end{array}$ & $\begin{array}{l}0 \\
0 \\
0 \\
0 \\
0 \\
0 \\
0 \\
0 \\
0\end{array}$ \\
\hline $\begin{array}{l}\text { Outfall } 512 \\
\text { (Groundwater } \\
\text { Treatment Facility) }\end{array}$ & $\begin{array}{l}\mathrm{pH} \\
\text { Iron } \\
\mathrm{PCB}\end{array}$ & . & & $a$ & $\begin{array}{l}9.0 \\
1.0 \\
0.001\end{array}$ & $\begin{array}{l}100 \\
100 \\
100\end{array}$ & $\begin{array}{r}77 \\
77 \\
6\end{array}$ \\
\hline Outfall 520 & $\mathrm{pH}$, standard units & & & & 9.0 & $b$ & 0 \\
\hline
\end{tabular}


Table 4.17. Surface water analytical results of polychlorinated biphenyls monitoring for the Y-12 Plant, 1995

\begin{tabular}{llcc}
\hline Site No. & \multicolumn{1}{c}{ Location } & Date sampled & $\begin{array}{c}\text { PCB concentration } \\
\text { (mg/L) }\end{array}$ \\
\hline PCB-1 & Outfall 301, Kerr Hollow Quarry & $1 / 19$ & $<0.0005$ \\
& & $6 / 14$ & $<0.0005$ \\
PCB-2 & Outfall 302, Rogers Quarry & $1 / 19$ & $<0.0005$ \\
& & $6 / 14$ & $<0.0005$ \\
PCB-3 & Outfall 303, New Hope Pond & $a$ & $<0.0005$ \\
PCB-5 & New Hope Pond Inlet & $b$ & $<0.0005$ \\
PCB-6 & Upstream of Outfall 135 & $1 / 19$ & $<0.0005$ \\
& & $6 / 14$ & $<0.0005$ \\
PCB-7 & Outfall 304, Bear Creek & $1 / 19$ & $<0.0005$ \\
& & $6 / 14$ & $<0.0005$ \\
\hline
\end{tabular}

\footnotetext{
${ }^{a}$ This outlet was closed in April 1989.

${ }^{b}$ This inlet was closed in November 1988.
}

Table 4.18. Y-12 Plant Discharge Point SS6, Sanitary Sewer Station SS-6 nonradiological summary, 1995

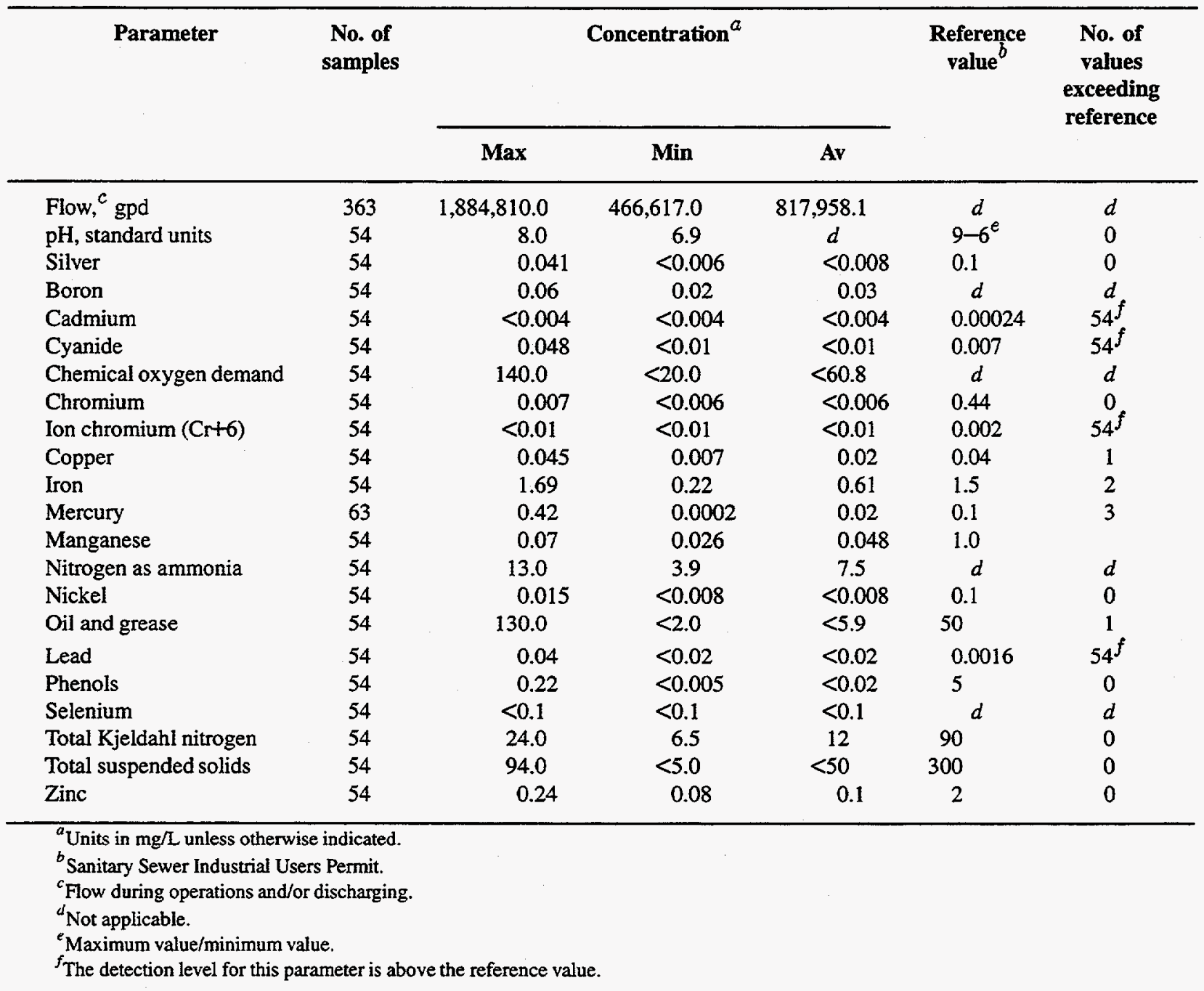


minimum flow of 7 million gal/day (26.5 million $\mathrm{L}$ /day) is maintained at the point where EFPC leaves the reservation. Design of this project was completed in early 1995. Construction is planned to be completed in 1996.

\section{Ammonia Reduction at Outfall 17}

A urea pile was maintained above Outfall 17 for about 10 years; the urea was used for deicing roads and sidewalks. Elevated levels of ammonia nitrate in EFPC were traced to Outfall 17 as a result of a fish kill in December 1992. The urea pile was removed at that time; however, the soil in the area of the pile remains contaminated. The sudden toxic effect on fish was attributed to the start-up of dechlorination efforts on EFPC in the preceding month, which reduced available chlorine that apparently was reacting with and neutralizing the ammonia.

A feasibility study completed in late 1994 defines possible corrective actions. The new NPDES permit contains compliance requirements for Outfall 17, which are being achieved (since early 1993) as a result of natural flushing of contaminants from the site.

\section{Non-Point-Source Studies}

Storm water runoff is required to be periodically sampled and analyzed for a large number of contaminants by the Y-12 Plant Stormwater Pollution Prevention Plan. The plan was issued in September 1995 in accordance with provisions of the NPDES permit. The plan presents (1) programmatic and physical best management practice controls implemented at the Y-12 Plant, (2) surveillance programs, and (3) a monitoring plan for characterizing storm water discharges. Storm water runoff data from previous years were analyzed and the Feasibility Study of Best Management Practices for Non-Point Source Pollution Control at the Oak Ridge Y-12 Plant (CDM 1993) was issued in 1993. Additional studies were initiated on the basis of this report. Sampling of parking lots, the metal scrap yard, and selected building roofs was completed in 1994. The data will help determine whether the areas are specific sources of contaminants observed in storm water flow in
EFPC. These types of investigations will continue as necessary to ensure compliance with the NPDES permit and other regulatory requirements.

\section{Drain Modifications and Reroutes}

Extensive drain surveys conducted in years previous to 1993 identified incorrectly connected building drains to either the sanitary or storm sewers. Most of these drains were administratively closed at that time. Permanent and physical changes to provide correct drain routings were designed and initiated in 1993 for 32 "major" buildings. One building was completed in 1993, and 25 buildings were completed in 1994. Several changes were made to the initial plans because of the ongoing downsizing of the plant. The remaining buildings will be completed as funding appropriations permit.

An additional design effort, which began in 1993, identified drains (primarily floor drains) that needed to be closed to ensure that accidental or unauthorized discharges are not made to either sanitary or storm sewers. The original scope included 21 buildings but has been reduced to 18 because managers were proactive in closing off drains that were under their control and for which sufficient funding was available. This design was completed in 1994. Work in 6 buildings was completed in 1994 and in the remaining 12 in 1995.

Several additional projects have been initiated to eliminate drains incorrectly discharging to EFPC or the sanitary sewer. Two main buildings in the Biology complex (9208 and 9207) were corrected in 1993 and 1994 , respectively, by the rerouting of drains from EFPC to the sanitary sewer. A steam condensate discharge of about $40,000 \mathrm{gal} /$ day $(150,000 \mathrm{~L} /$ day) to the sanitary sewer from Building 9769 was rerouted to the steam plant in early 1995.

In addition, a project was begun in late 1994 to survey all the remaining and previously unsurveyed building drains at the Y-12 Plant. The survey was completed in early 1995. Incorrectly routed drains have been identified for closure or correction, and many drains were corrected or eliminated. Further corrective 
actions will be taken as funding appropriations permit.

\section{Reduction of Mercury in Plant Effluent (RMPE): Phase II}

The legacy of contamination resulting from use and storage of mercury at the Y-12 Plant has prompted a series of remedial measures. The RMPE II program is structured to serve as a bridge between downstream remediation of EFPC and upstream remedial actions at the Y-12 Plant. These efforts are directed toward meeting the NPDES permit requirements of $5 \mathrm{~g} /$ day from the Y-12 Plant by December 31, 1998. Six projects (four building source elimination efforts and two treatment units) have been identified under the RMPE II program to reduce mercury contamination to UEFPC.

Significant progress was made in 1994 and 1995 toward reduction of mercury in discharges to EFPC. Construction and start-up of the Interim Mercury Treatment Unit (IHgTU) for Building 9201-2 was completed in September 1994. A study was initiated in 1995 to evaluate upgrading the $\mathrm{IHgTU}$ to a permanent system. The upgrade will be complete in early 1996 . The IHgTU, which continues to operate, treated more than 1 million gal ( 3.78 million $\mathrm{L})$ of water in 1994 and 4.3 million gal (16.27 million L) in 1995. In addition, rerouting pipes for buildings $9201-2$ and $9201-5$ was completed to eliminate sources of mercury. Design work was completed in 1994 for reroutes in buildings $9201-4$ and 9204-4; construction is expected to be completed in early 1996.

To provide permanent mercury treatment capability, the Central Mercury Treatment System (CMTS) was designed in 1995; construction will be completed in 1996. The facility will be located in the existing Central Pollution Control Facility in Building 9623. Mercury-contaminated groundwater originating from sumps in buildings $9201-4,9201-5$, and 9204-4 will be collected and transported to CMTS for treatment. The system will be sized based on treatability studies such that water released to EFPC is within the NPDES limits ( 2 parts per billion, monthly average). The discharge of the CMTS will be through a new NPDES outfall.

\section{Fish Kill Summary}

During 1995 the Y-12 Plant reported two incidents to TDEC involving fish kills within the Y-12 Plant boundaries. One incident was attributed to activities within the plant; the other incident was attributed to natural causes.

Between January 6 and January 8, 1995, approximately 1800 dead fish were retrieved from EFPC. Water quality data thoroughly documents rapid and wide fluctuations in temperature and conductivity following ice and thunderstorms on January 6,1995 . These water-quality changes were a direct result of the unusual weather conditions and the associated application of road de-icer compounds. Toxicity tests and calculations of maximum concentrations of salts suggest that the impact from the road de-icers was far less significant than the effect of the rapid drop in temperature.

On August 3, 1995, an estimated 5 gal (19 L) of wastewater containing an unsaturated polyester resin ( $43 \%$ styrene) was released to the storm sewer system during an in situ pipe-relining operation. A small amount of resin failed to catalyze and harden during the curing process and was released to EFPC at Outfall 109. The discharge resulted in the death of approximately 5500 minnow-sized fish in the upper reaches of EFPC within the Y-12 Plant boundaries. The project plan has been revised to include the use of physical barriers to prevent the release of wastewater associated with this activity.

\section{ORNL Nonradiological Summary}

\section{Effluents}

ORNL NPDES permit TN0002941 became effective on April 1, 1986, and expired in March 1991; the conditions of the expired permit remain in effect until a new permit is negotiated. The permit renewal application was submitted in September 1990. It is anticipated that ORNL's permit will be renewed in 1996. Data collected for the NPDES permit are submitted to the 


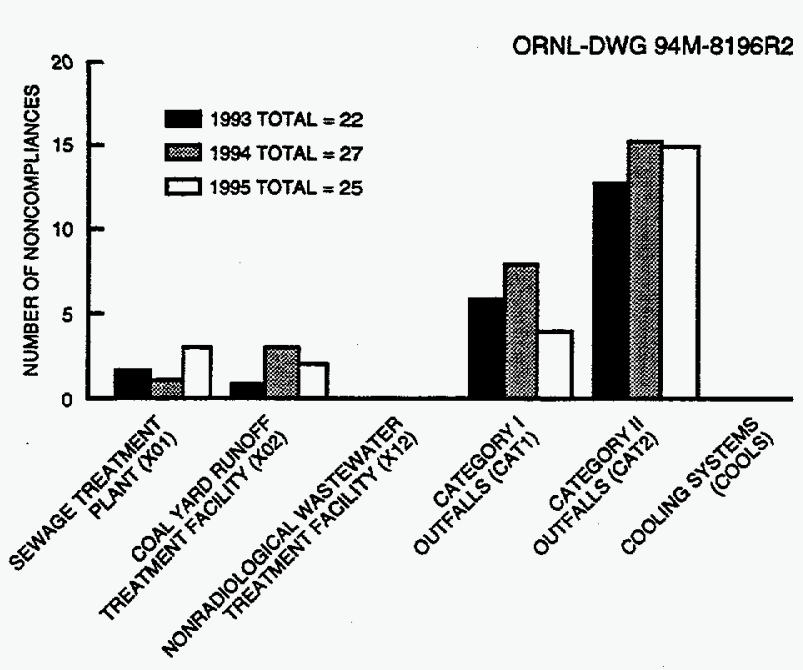

Fig. 4.25. ORNL NPDES limit compliance status comparison and locations of noncompliances, 1993-95.

state of Tennessee in the monthly Discharge Monitoring Report.

ORNL's current NPDES permit requires that point-source outfalls be sampled before they are discharged into receiving waters or before they mix with any other wastewater stream (see Fig. 4.14). Numeric and aesthetic effluent limits have been placed on the following locations:

- X01-Sewage Treatment Plant (STP);

- X02-Coal Yard Runoff Treatment Facility (CYRTF);

- X12-NRWTF;

- X13-Melton Branch;

- X14-WOC;

- X15-WOD;

- CAT1-Category I outfalls (storm drains);

- CAT2-Category II outfalls (roof drains, parking lot drains, storage area drains, spill area drains, once-through cooling water, cooling-tower blowdown, condensate, and disposal demonstration area);

- CAT3 - Category III outfalls (drains that at one time included process and/or lab constituents); and

- COOLS-Cooling Systems (cooling water, cooling tower blowdown, and cleaning wastes originating at space cooling facilities).
Permit limits and compliance are shown by location in Table 4.19. Compliance with the NPDES permit for the last 3 years is summarized by major effluent locations in Fig. 4.25. The figure provides a list of the effluent locations and the number of noncompliances at each location. The majority of permit limit excursions in 1995 occurred at the Category II outfalls. All Category II limit excursions in 1995 were associated with total suspended solids, typically residual dust or dirt particles, conveyed in storm water runoff.

In 1995, at X01, no certain cause was established for February and October fecal coliform excursions. Effluent chlorine and suspended solids concentrations were normal at the times of the excursions. ORNL staff investigated whether rainfall could have contributed to the excursions, via rain dropping from a collection-point grate into the sample bottle. In addition, the possibility of STP facility maintenance contributing to the excursions was being investigated. Procedural modifications have been made with regard to these possible causes. The June 1995 chlorine excursion at X01 was attributed to malfunction of an automatic feed valve in the sewage treatment plant's effluent chlorination system. The component was promptly replaced and no subsequent excursions have occurred. At X02, no certain cause was established for oil-and-grease and suspended solids excursions that occurred in June and October, respectively. An ORNL project, Upgrade Coal Yard Runoff Treatment Facility, will be concluded in 1996 and will provide additional removal capability for solids, oils, and greases. At X12, all parameters were $100 \%$ in compliance. ORNL had no fish kills in 1995.

At the Category I and II outfalls, exceedences of limits on total suspended solids were attributed to flushing of parking lots or streets by storm water runoff. Category I and II outfalls are not contaminated by any known activity, nor do they discharge through any oil-water separator, other treatment facility, or equipment. During rain events, waters from the parking lots and surrounding areas drain into these outfalls, carrying suspended solids and other residue. This situation may result 
Table 4.19. 1995 NPDES compliance at ORNL

\begin{tabular}{|c|c|c|c|c|c|c|c|c|c|}
\hline \multirow[t]{2}{*}{ Discharge point } & \multirow[t]{2}{*}{ Effluent parameters } & \multicolumn{5}{|c|}{ Permit limits } & \multicolumn{3}{|c|}{ Permit compliance } \\
\hline & & $\begin{array}{c}\text { Monthly } \\
\text { av } \\
(\mathbf{k g} / \mathbf{d})\end{array}$ & $\begin{array}{c}\text { Daily } \\
\text { max } \\
(\mathbf{k g} / \mathbf{d})\end{array}$ & $\begin{array}{c}\text { Monthly } \\
\text { av } \\
\text { (mg/L) }\end{array}$ & $\begin{array}{c}\text { Daily } \\
\max \\
(\mathrm{mg} / \mathrm{L})\end{array}$ & $\begin{array}{c}\text { Daily } \\
\text { min } \\
(\mathbf{m g} / \mathbf{L})\end{array}$ & $\begin{array}{c}\text { Number } \\
\text { of } \\
\text { noncompliances }\end{array}$ & $\begin{array}{c}\text { Number } \\
\text { of } \\
\text { samples }\end{array}$ & $\begin{array}{c}\text { Percentage } \\
\text { of } \\
\text { compliance }^{a}\end{array}$ \\
\hline $\mathrm{X} 01$ & Ammonia, as $\mathrm{N}$ (summer) & 3.5 & 5.2 & 4.0 & 6.0 & & 0 & 93 & 100 \\
\hline Sewage Treatment & Ammonia, as $\mathrm{N}$ (winter) & 7.8 & 11.8 & 9.0 & 13.5 & & 0 & 63 & 100 \\
\hline \multirow[t]{9}{*}{ Plant) } & $\begin{array}{l}\text { Biochemical oxygen demand } \\
\text { (summer) }\end{array}$ & 8.7 & 13.1 & 10 & 15 & & 0 & 93 & 100 \\
\hline & $\begin{array}{l}\text { Biochemical oxygen demand } \\
\text { (winter) }\end{array}$ & 17.4 & 26.2 & 20 & 30 & & 0 & 63 & 100 \\
\hline & Chlorine, total residual & & & & 0.5 & & 1 & 158 & 99 \\
\hline & Dissolved oxygen & & & & & 6.0 & 0 & 249 & 100 \\
\hline & Downstream pH (SU) & & & & 9.0 & 6.0 & 0 & 52 & 100 \\
\hline & Fecal coliform $(\mathrm{col} / 100 \mathrm{~mL})^{b}$ & & & 1000 & 5000 & & 2 & 156 & 99 \\
\hline & Oil and grease & 8.7 & 13.1 & 10 & 15 & & 0 & 156 & 100 \\
\hline & $\mathrm{pH}(\mathrm{SU})$ & & & & 9.0 & 6.0 & 0 & 52 & 100 \\
\hline & Total suspended solids & 26.2 & 39.2 & 30 & 45 & & 0 & 156 & 100 \\
\hline $\mathrm{X} 02$ & Chromium, total & & & 0.2 & 0.2 & & 0 & 52 & 100 \\
\hline (Coal Yard Runoff & Copper, total & & & 1.0 & 1.0 & & 0 & 52 & 100 \\
\hline \multirow[t]{8}{*}{ Treatment Facility) } & Downstream pH (SU) & & & & 9.0 & 6.0 & 0 & 109 & 100 \\
\hline & Iron, total & & & 1.0 & 1.0 & & 0 & 52 & 100 \\
\hline & $\mathrm{pH}(\mathrm{SU})$ & & & & 9.0 & 6.0 & 0 & 109 & 100 \\
\hline & Oil and grease & & & 15 & 20 & & 1 & 52 & 98 \\
\hline & Selenium, total & & & 0.22 & 0.95 & & 0 & 52 & 100 \\
\hline & Temperature $\left({ }^{\circ} \mathrm{C}\right)$ & & & & 30.5 & & 0 & 109 & 100 \\
\hline & Total suspended solids & & & & 50 & & 1 & 52 & 98 \\
\hline & Zinc & & & 1.0 & 1.0 & & 0 & 52 & 100 \\
\hline $\mathrm{X} 12$ & Cadmium, total & 0.79 & 2.09 & 0.26 & 0.69 & & 0 & 52 & 100 \\
\hline (Nonradiological & Chromium, total & 5.18 & 8.39 & 1.71 & 2.77 & & 0 & 52 & 100 \\
\hline Wastewater Treatment & Copper, total & 6.27 & 10.24 & 2.07 & 3.38 & & 0 & 52 & 100 \\
\hline \multirow[t]{8}{*}{ Facility) } & Cyanide, total & 1.97 & 3.64 & 0.65 & 1.20 & & 0 & 52 & 100 \\
\hline & Downstream pH (SU) & & & & 9.0 & 6.0 & 0 & 249 & 100 \\
\hline & Lead, total & 1.30 & 2.09 & 0.43 & 0.69 & & 0 & 52 & 100 \\
\hline & Nickel, total & 7.21 & 12.06 & 2.38 & 3.98 & & 0 & 52 & 100 \\
\hline & Oil and grease & 30.3 & 45.4 & 10 & 15 & & 0 & 52 & 100 \\
\hline & $\mathrm{pH}(\mathrm{SU})$ & & & & 9.0 & 6.0 & 0 & $c$ & 100 \\
\hline & Silver, total & 0.73 & 1.30 & 0.24 & 0.43 & & 0 & 52 & 100 \\
\hline & Temperature $\left({ }^{\circ} \mathrm{C}\right)$ & & & & 30.5 & & 0 & 249 & 100 \\
\hline
\end{tabular}


Table 4.19 (continued)

\begin{tabular}{|c|c|c|c|c|c|c|c|c|c|}
\hline \multirow[t]{2}{*}{ Discharge point } & \multirow[t]{2}{*}{ Effuent parameters } & \multicolumn{5}{|c|}{ Permit limits } & \multicolumn{3}{|c|}{ Permit compliance } \\
\hline & & $\begin{array}{c}\text { Monthly } \\
\text { av } \\
\text { (kg/d) }\end{array}$ & $\begin{array}{c}\text { Daily } \\
\max \\
(\mathrm{kg} / \mathrm{d})\end{array}$ & $\begin{array}{c}\text { Monthly } \\
\text { av } \\
\text { (mg/L) }\end{array}$ & $\begin{array}{c}\text { Daily } \\
\max \\
(\mathbf{m g} / \mathbf{L})\end{array}$ & $\begin{array}{c}\text { Daily } \\
\text { min } \\
(\mathrm{mg} / \mathrm{L})\end{array}$ & $\begin{array}{c}\begin{array}{c}\text { Number } \\
\text { of } \\
\text { noncompliances }\end{array} \\
\end{array}$ & $\begin{array}{c}\text { Number } \\
\text { of } \\
\text { samples }\end{array}$ & $\begin{array}{c}\text { Percentage } \\
\text { of } \\
\text { compliance }^{a} \\
\end{array}$ \\
\hline & Total suspended solids & 93.9 & 182 & 31 & 60 & & 0 & 52 & 100 \\
\hline & Total toxic organics & & 6.45 & & 2.13 & & 0 & 52 & 100 \\
\hline & Zinc, total & 4.48 & 7.91 & 1.48 & 2.61 & & 0 & 52 & 100 \\
\hline \multirow[t]{5}{*}{ Category I outfall $^{d}$} & Downstream pH (SU) & & & & 9.0 & 6.0 & 0 & 22 & 100 \\
\hline & Oil and grease & . & & 10 & 15 & & 0 & 22 & 100 \\
\hline & $\mathrm{pH}(\mathrm{SU})$ & & & & 9.0 & 6.0 & 0 & 22 & 100 \\
\hline & Temperature $\left({ }^{\circ} \mathrm{C}\right)$ & & & & 30.5 & & 0 & 22 & 100 \\
\hline & Total suspended solids & & & 30 & 50 & & 4 & 22 & 82 \\
\hline \multirow[t]{5}{*}{ Category II outfalls } & Downstream pH (SU) & & & & 9.0 & 6.0 & 0 & 143 & 100 \\
\hline & Downstream temperature $\left({ }^{\circ} \mathrm{C}\right)^{e}$ & & & & 30.5 & & 0 & 40 & 100 \\
\hline & Oil and grease & & & 10 & 15 & & 0 & 143 & 100 \\
\hline & $\mathrm{pH}(\mathrm{SU})$ & & & & 9.0 & 6.0 & 0 & 143 & 100 \\
\hline & Total suspended solids & & & 30 & 50 & & 15 & 143 & 90 \\
\hline \multirow[t]{7}{*}{ Cooling Systems } & Chlorine, total residual & & & & 0.2 & & 0 & 33 & 100 \\
\hline & Chromium, total & & & & 1.0 & & 0 & 33 & 100 \\
\hline & Copper, total & & & 0.5 & 1.0 & & 0 & 33 & 100 \\
\hline & Downstream pH (SU) & & & & 9.0 & 6.0 & 0 & 33 & 100 \\
\hline & $\mathrm{pH}(\mathrm{SU})$ & & & & 9.0 & 6.0 & 0 & 33 & 100 \\
\hline & Temperature $\left({ }^{\circ} \mathrm{C}\right)$ & & & 35 & 38 & & 0 & 33 & 100 \\
\hline & Zinc, total & & & 0.5 & 1.0 & & 0 & 33 & 100 \\
\hline
\end{tabular}

Percentage compliance $=100-[($ number of noncompliances/number of samples $) * 100]$.

Colonies per $100 \mathrm{~mL}$.

${ }^{c} \mathrm{pH}$ monitoring is continuous.

${ }^{d}$ Category I outfalls are monitored annually by the NPDES Permit year of April 1-March 31.

'Downstream temperature is monitored to check that the stream temperature standards given in the Tennessee Water Quality Standards are not violated as a result of this discharge. 


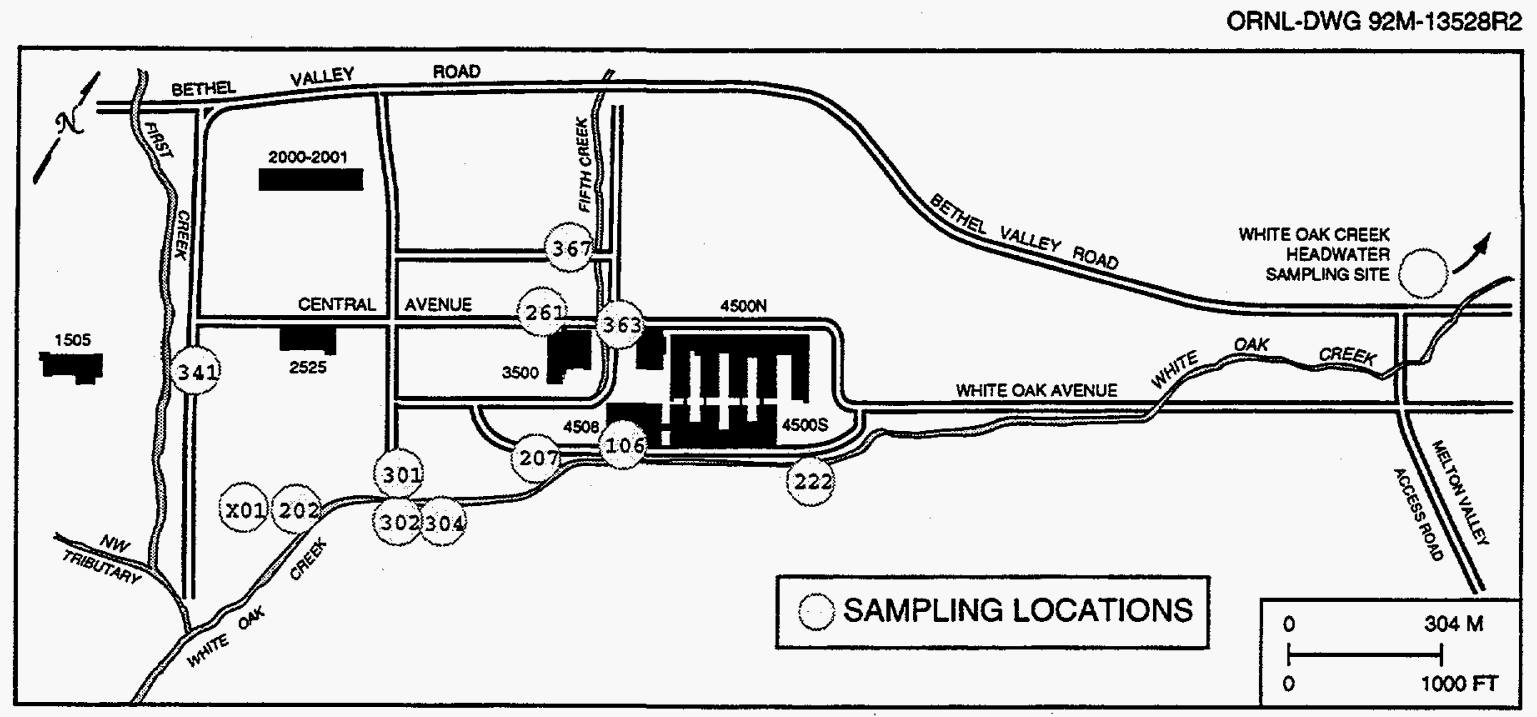

Fig. 4.26. ORNL sampling locations for mercury in water.

in total-suspended-solid exceedences. Best management practices (including frequent street sweeping) are in place to help avoid these exceedences. In addition, a plan is currently being carried out to improve sampling points at selected outfalls. At the cooling systems, all parameters were $100 \%$ in compliance.

\section{Mercury in the Aquatic Environment}

The mercury monitoring program at ORNL is conducted to comply with the CWA and Part III of the ORNL NPDES permit. Samples of surface water and stream sediment in Bethel and Melton valleys are collected semiannually and analyzed for mercury content. The primary purpose of this effort is to identify, locate, and minimize all mercury contamination from ORNL discharges to the aquatic environment.

Prior to the stringent regulations now in effect, some contaminants reached various streams primarily as the result of accidental spills or leakages. Most mercury spills occurred from 1954 through 1963, during a period when ORNL was involved with OREX and METALLEX separations processes. Most of this activity occurred in or around buildings 4501,4505 , and 3592 in the main plant area. These processes are no longer in operation at ORNL. During the time of operation, an unknown number of mercury spills occurred. The spills were cleaned up; however, some quantities of mercury escaped and reached the surrounding environment. Sampling locations have been selected in areas surrounding known mercury spills. Additional sampling locations have been selected downstream from the outfalls and drains to determine the extent to which any mercury is being transported in surface water and sediment.

Surface water locations are shown in Fig. 4.26. In 1995 a total of 78 samples were taken from 13 locations. Samples were collected by the manual grab method and placed in 500-mL polyethylene bottles with polyethylene caps. In the laboratory, the samples were analyzed for total mercury content by manual cold vapor atomic absorption. Mercury was detected at 9 of the 13 sampling locations. The highest value reported was $0.44 \mu \mathrm{g} / \mathrm{L}$ near Outfall 207 in WOC, nearly identical to the 1994 high value of 0.43 at the same location. Average concentrations ranged from 0.050 to 0.25 . The Tennessee Water Quality Criteria for the protection of fish and aquatic life sets a maximum concentration of $2.4 \mu \mathrm{g} / \mathrm{L}$ for mercury in water. The highest concentration, near Outfall 207, was $18 \%$ of the reference value.

Sediment sampling locations are shown in Fig. 4.27. In 1995, a total of 54 sediment samples were taken from nine stream locations. Samples were collected by the manual grab method and placed in glass containers. In the laboratory, the samples were analyzed for total 
ORNL-DWG 92M-13531R2

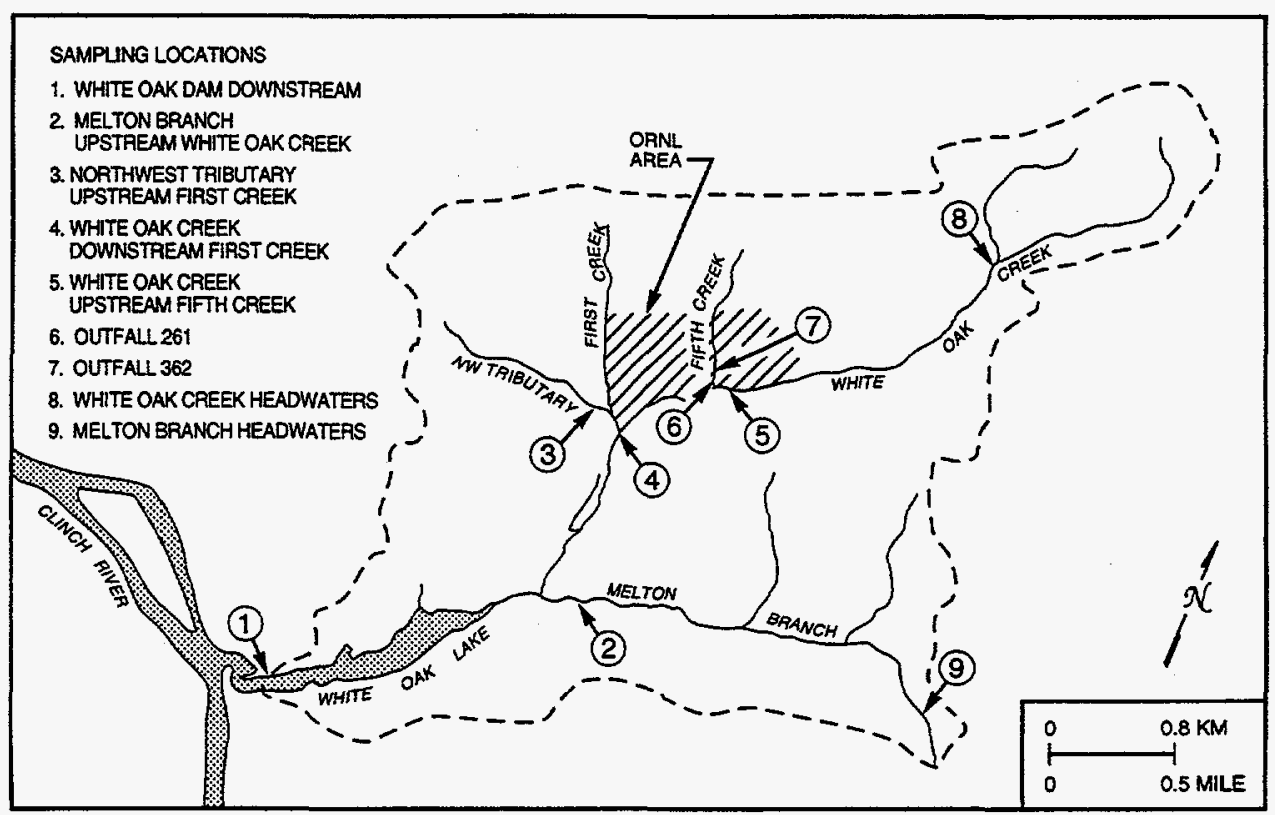

Fig. 4.27. ORNL sampling locations for mercury in sediment.

mercury content by manual cold vapor atomic absorption. The highest value reported was $880 \mu \mathrm{g} / \mathrm{g}$ near Outfall 261 on Fifth Creek. Average values at the other sites ranged from 0.019 to $16 \mu \mathrm{g} / \mathrm{g}$. In general, results from samples collected in 1995 were similar to those for 1994.

\section{PCBs in the Aquatic Environment}

The PCB monitoring program at ORNL is conducted to comply with the CWA and Part III of the ORNL NPDES permit. Samples of stream sediment are collected semiannually and analyzed for PCB Aroclor content. The program to collect water samples for PCB analysis was dropped in 1992, because PCB levels in the water samples had been below analytical detection limits for several years.

In 1995, duplicate samples of sediment were collected at ten locations in streams at and around ORNL (Figs. 4.28 and 4.29). Samples from each location were analyzed by the analytical laboratory for Aroclors 1016, 1221, $1232,1242,1248,1254$, and 1260 . Only one location had results above detection limits. Four additional locations had laboratory-estimated values below the detection limit. The single maximum concentration above detection limit,
$330 \mu \mathrm{g} / \mathrm{kg}$ for Aroclor-1254, was reported at the confluence of Fifth Creek and WOC. Detected Aroclor levels are similar or slightly lower than those detected in 1994. Results for most samples collected in 1995 were either below laboratory detection limits or were estimated by the laboratory.

\section{K-25 Site Surface Water Effluents}

The current K-25 Site NPDES permit went into effect on October 1, 1992, and was issued a major revision effective June $1,1995$. The revision included the removal of inactive outfalls, the addition of effluent limits for new treatment technologies at CNF, the addition of new storm drains, and clarification of various requirements. In accordance with the NPDES permit, the K-25 Site is authorized to discharge process wastewater, cooling water, storm water, steam condensate, and groundwater to the Clinch River, Poplar Creek, and Mitchell Branch. The permit currently includes five facility outfalls and 137 storm drain outfalls. Compliance with the permit for the last 5 years is summarized by the major effluent locations in Fig. 4.30. Table 4.20 details the permit requirements and compliance records for all of the outfalls that discharged during 1995 . The table provides a list of the 
Table 4.20. NPDES compliance at the K-25 Site, 1995

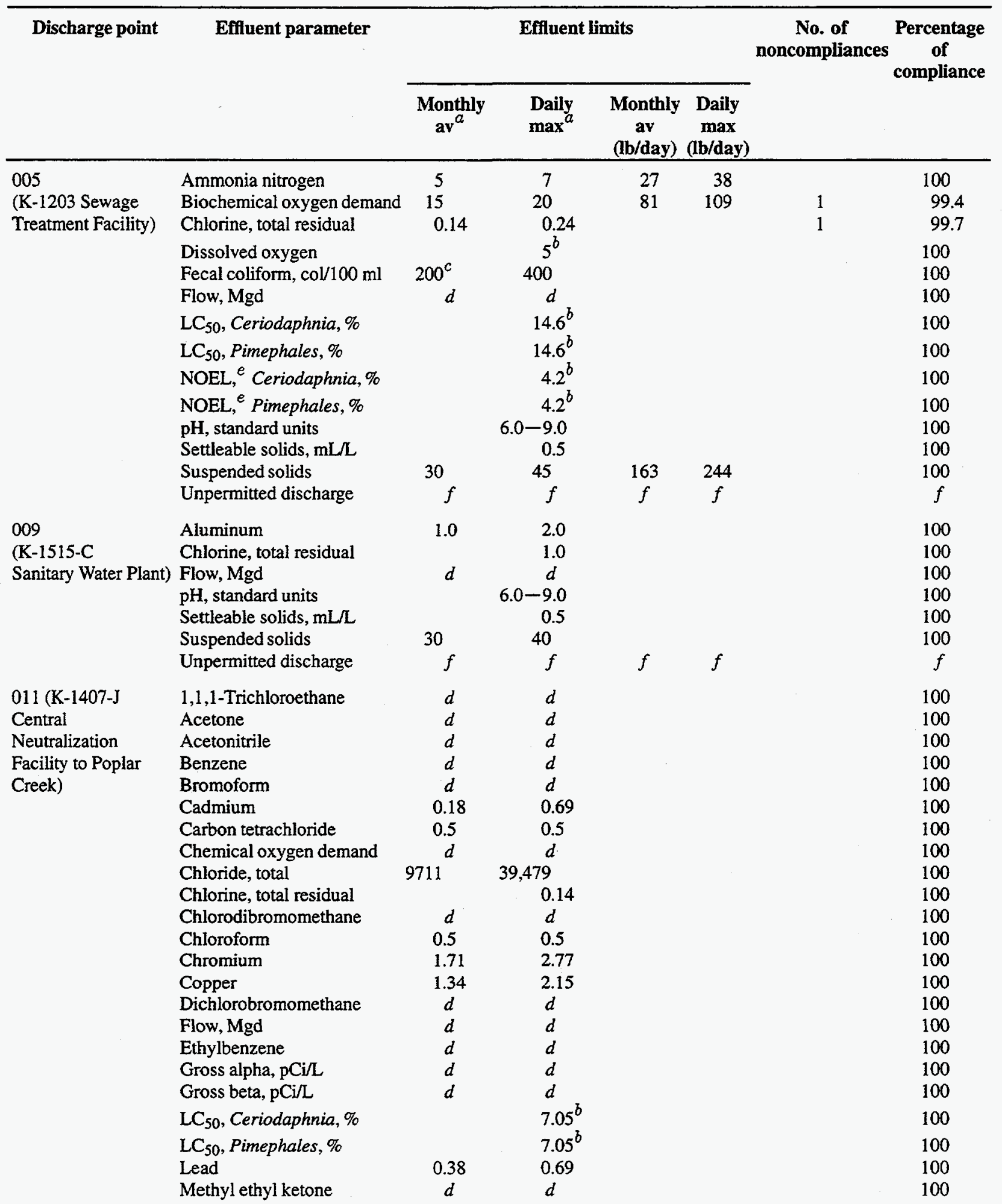


Table 4.20 (continued)

\begin{tabular}{|c|c|c|c|c|c|c|c|}
\hline \multirow[t]{2}{*}{ Discharge point } & \multirow[t]{2}{*}{ Effluent parameter } & \multicolumn{4}{|c|}{ Effluent limits } & \multirow{2}{*}{$\begin{array}{c}\text { No. of } \\
\text { noncompliances }\end{array}$} & \multirow{2}{*}{$\begin{array}{l}\text { Percentage } \\
\text { of } \\
\text { compliance }\end{array}$} \\
\hline & & $\begin{array}{l}\text { Monthly } \\
\operatorname{av}^{a}\end{array}$ & $\begin{array}{l}\text { Daily } \\
\max ^{a}\end{array}$ & $\begin{array}{c}\text { Monthly } \\
\text { av } \\
\text { (lb/day) }\end{array}$ & $\begin{array}{c}\text { Daily } \\
\text { max } \\
\text { (lb/day) }\end{array}$ & & \\
\hline & $\begin{array}{l}\text { Methylene chloride } \\
\text { Naphthalene } \\
\text { Nickel } \\
\text { NOEL, Ceriod } \\
\text { NOEL, }{ }^{e} \text { Pimeph } \\
\text { Oil and grease } \\
\text { PCB } \\
\text { pH, standard units } \\
\text { Silver } \\
\text { Suspended solids } \\
\text { Temperature, }{ }^{\circ} \mathrm{C} \\
\text { Tetrachloroethylene } \\
\text { Toluene } \\
\text { Total toxic organics } \\
\text { Trichloroethylene } \\
\text { Unpermitted discharge } \\
\text { Uranium, total } \\
\text { Vinyl chloride } \\
\text { Zinc }\end{array}$ & $\begin{array}{l}0.00014 \\
0.24 \\
g \\
d \\
\\
0.5 \\
f \\
d \\
0.2 \\
1.48\end{array}$ & $\begin{array}{c}d \\
d \\
3.98 \\
2.11^{b} \\
2.11^{b} \\
30 \\
0.00014 \\
6.0-9.0 \\
0.43 \\
40 \\
g \\
0.7 \\
d \\
2.13 \\
0.5 \\
f \\
d \\
0.2 \\
2.61\end{array}$ & $f$ & $f$ & & $\begin{array}{l}100 \\
100 \\
100 \\
100 \\
100 \\
100 \\
100 \\
100 \\
100 \\
100 \\
100 \\
100 \\
100 \\
100 \\
100 \\
f \\
100 \\
100 \\
100\end{array}$ \\
\hline $\begin{array}{l}013 \text { (K-1513 Sanitary } \\
\text { Water Intake and } \\
\text { Backwash filter) }\end{array}$ & $\begin{array}{l}\text { Visual inspection of } \\
\text { receiving stream }\end{array}$ & & & & & & \\
\hline $\begin{array}{l}014 \text { (K-1407-J } \\
\text { Central } \\
\text { Neutralization } \\
\text { Facility to } \\
\text { Clinch River) }\end{array}$ & $\begin{array}{l}\text { 1,1,1-Trichloroethane } \\
\text { Acetone } \\
\text { Acetonitrile } \\
\text { Benzene } \\
\text { Bromoform } \\
\text { Cadmium } \\
\text { Carbon tetrachloride } \\
\text { Chemical oxygen demand } \\
\text { Chloride, total } \\
\text { Chlorine, total residual } \\
\text { Chlorodibromomethane } \\
\text { Chloroform } \\
\text { Chromium } \\
\text { Copper } \\
\text { Dichlorobromomethane } \\
\text { Flow, Mgd } \\
\text { Ethylbenzene } \\
\text { Gross alpha, pCi/L } \\
\text { Gross beta, pCi/L } \\
\text { Lead } \\
\text { Methyl ethyl ketone } \\
\text { Methylene chloride } \\
\text { Naphthalene } \\
\text { Nickel }\end{array}$ & $\begin{array}{c}d \\
d \\
d \\
d \\
d \\
0.18 \\
0.5 \\
d \\
35,000 \\
\\
d \\
0.5 \\
1.71 \\
1.34 \\
d \\
d \\
d \\
d \\
d \\
0.38 \\
d \\
d \\
d \\
2.38\end{array}$ & $\begin{array}{c}d \\
d \\
d \\
0.005 \\
d \\
0.69 \\
0.5 \\
d \\
70,000 \\
1.0 \\
d \\
0.5 \\
2.77 \\
2.15 \\
d \\
d \\
0.01 \\
d \\
d \\
0.69 \\
d \\
d \\
d \\
3.98\end{array}$ & & & & $\begin{array}{l}100 \\
100 \\
100 \\
100 \\
100 \\
100 \\
100 \\
100 \\
100 \\
100 \\
100 \\
100 \\
100 \\
100 \\
100 \\
100 \\
100 \\
100 \\
100 \\
100 \\
100 \\
100 \\
100 \\
100\end{array}$ \\
\hline
\end{tabular}


Annual Site Environmental Report

Table 4.20 (continued)

\begin{tabular}{|c|c|c|c|c|c|c|c|}
\hline \multirow[t]{2}{*}{ Discharge point } & \multirow[t]{2}{*}{ Effuent parameter } & \multicolumn{4}{|c|}{ Effluent limits } & \multirow{2}{*}{$\begin{array}{c}\text { No. of } \\
\text { noncompliances }\end{array}$} & \multirow{2}{*}{$\begin{array}{c}\text { Percentage } \\
\text { of } \\
\text { compliance }\end{array}$} \\
\hline & & $\begin{array}{l}\text { Monthly } \\
\operatorname{av}^{a}\end{array}$ & $\begin{array}{l}\text { Daily } \\
\max ^{a}\end{array}$ & $\begin{array}{c}\text { Monthly } \\
\text { av } \\
(\mathrm{kg} / \mathrm{d})\end{array}$ & $\begin{array}{c}\text { Daily } \\
\text { max } \\
(\mathrm{kg} / \mathrm{d}) \\
\end{array}$ & & \\
\hline & $\begin{array}{l}\text { Oil and grease } \\
\text { PCB } \\
\text { Petroleum hydrocarbons } \\
\text { pH, standard units } \\
\text { Silver } \\
\text { Suspended solids } \\
\text { Tetrachloroethylene } \\
\text { Toluene } \\
\text { Total toxic organics } \\
\text { Trichloroethylene } \\
\text { Unpermitted discharge } \\
\text { Uranium, total } \\
\text { Vinyl chloride } \\
\text { Zinc }\end{array}$ & $\begin{array}{c}d \\
0.5 \\
f \\
d \\
0.2 \\
1.48\end{array}$ & $\begin{array}{l}30 \\
0.00045 \\
d \\
-9.0 \\
0.43 \\
40 \\
0.7 \\
d \\
2.13 \\
0.5 \\
f \\
d \\
0.2 \\
2.61\end{array}$ & $\begin{array}{r}0.1 \\
0.01 \\
f\end{array}$ & $f$ & & $\begin{array}{l}100 \\
100 \\
100 \\
100 \\
100 \\
100 \\
100 \\
100 \\
100 \\
100 \\
f \\
100 \\
100 \\
100\end{array}$ \\
\hline $\begin{array}{l}\text { Category I } \\
\text { storm drains }\end{array}$ & $\begin{array}{l}\text { Flow, Mgd } \\
\text { pH, standard units } \\
\text { Unpermitted discharge }\end{array}$ & $\begin{array}{l}d \\
f\end{array}$ & $\begin{array}{c}d \\
-9.0 \\
f\end{array}$ & $f$ & $f$ & & $\begin{array}{c}100 \\
100 \\
f\end{array}$ \\
\hline $\begin{array}{l}\text { Category II } \\
\text { storm drains }\end{array}$ & $\begin{array}{l}\text { Flow, Mgd } \\
\text { pH, standard units } \\
\text { Suspended solids } \\
\text { Unpermitted discharge }\end{array}$ & $\begin{array}{l}d \\
d \\
f\end{array}$ & $\begin{array}{l}d \\
-9.0 \\
d \\
f\end{array}$ & $f$ & $f$ & & $\begin{array}{c}100 \\
100 \\
100 \\
f\end{array}$ \\
\hline $\begin{array}{l}\text { Category III } \\
\text { storm drains }\end{array}$ & $\begin{array}{l}\text { Flow, Mgd } \\
\text { Oil and grease } \\
\text { pH, standard units } \\
\text { Suspended solids } \\
\text { Unpermitted discharge }\end{array}$ & $\begin{array}{l}d \\
d \\
d \\
f\end{array}$ & $\begin{array}{c}d \\
d \\
-9.0 \\
d \\
f\end{array}$ & $f$ & $f$ & 2 & $\begin{array}{l}100 \\
100 \\
100 \\
100 \\
f\end{array}$ \\
\hline $\begin{array}{l}\text { Category IV } \\
\text { storm drains } \\
\text { (to Poplar } \\
\text { Creek) }\end{array}$ & $\begin{array}{l}\text { Chlorine, total residual } \\
\text { Flow, Mgd } \\
\text { Oil and grease } \\
\text { pH, standard units } \\
\text { Suspended solids } \\
\text { Unpermitted discharge }\end{array}$ & $\begin{array}{l}d \\
d \\
d \\
f\end{array}$ & $\begin{array}{c}0.14 \\
d \\
d \\
-9.0 \\
d \\
f\end{array}$ & $f$ & & 1 & $\begin{array}{l}99.4 \\
100 \\
100 \\
100 \\
100 \\
f\end{array}$ \\
\hline $\begin{array}{l}\text { Category IV } \\
\text { storm drains } \\
\text { (to Mitchell } \\
\text { Branch) }\end{array}$ & $\begin{array}{l}\text { Chlorine, total residual } \\
\text { Flow, Mgd } \\
\text { Oil and grease } \\
\text { pH, standard units } \\
\text { Suspended solids } \\
\text { Unpermitted discharge }\end{array}$ & $\begin{array}{l}d \\
d \\
d \\
f\end{array}$ & $\begin{array}{c}0.019 \\
d \\
d \\
-9.0 \\
d \\
f\end{array}$ & $f$ & $f$ & & $\begin{array}{c}100 \\
100 \\
100 \\
100 \\
100 \\
f\end{array}$ \\
\hline
\end{tabular}

\footnotetext{
${ }^{a}$ Units are $\mathrm{mg} / \mathrm{L}$ unless otherwise stated.

${ }^{b}$ Daily minimum.

${ }^{c}$ Geometric mean.

${ }^{d}$ Nonlimited parameter.

${ }^{e}$ No-observed-effect limit.

$f_{\text {Not applicable. }}$

${ }^{8}$ Effiuent must not cause the temperature of the receiving stream to exceed $30.5^{\circ} \mathrm{C}$.
} 


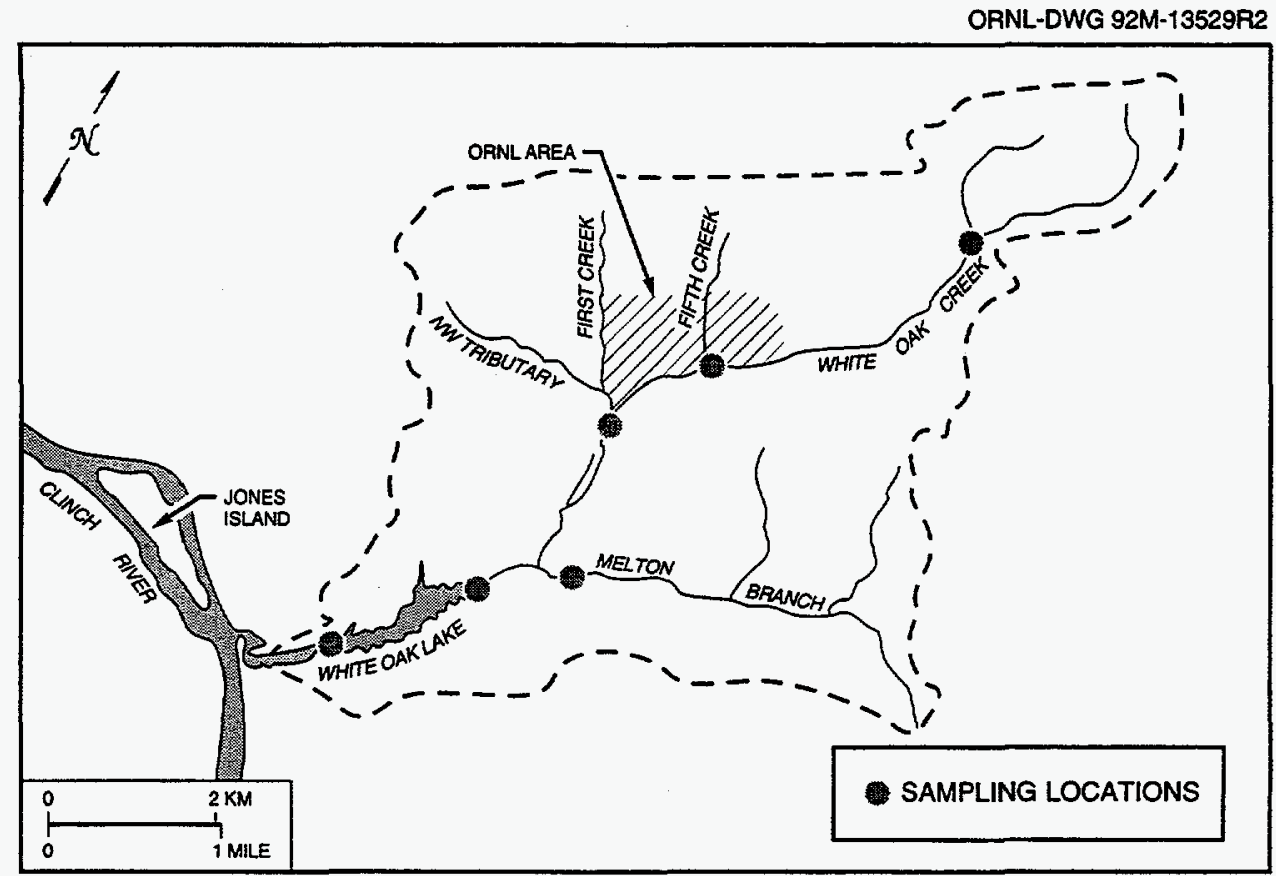

Fig. 4.28. ORNL sampling locations for polychlorinated biphenyls.

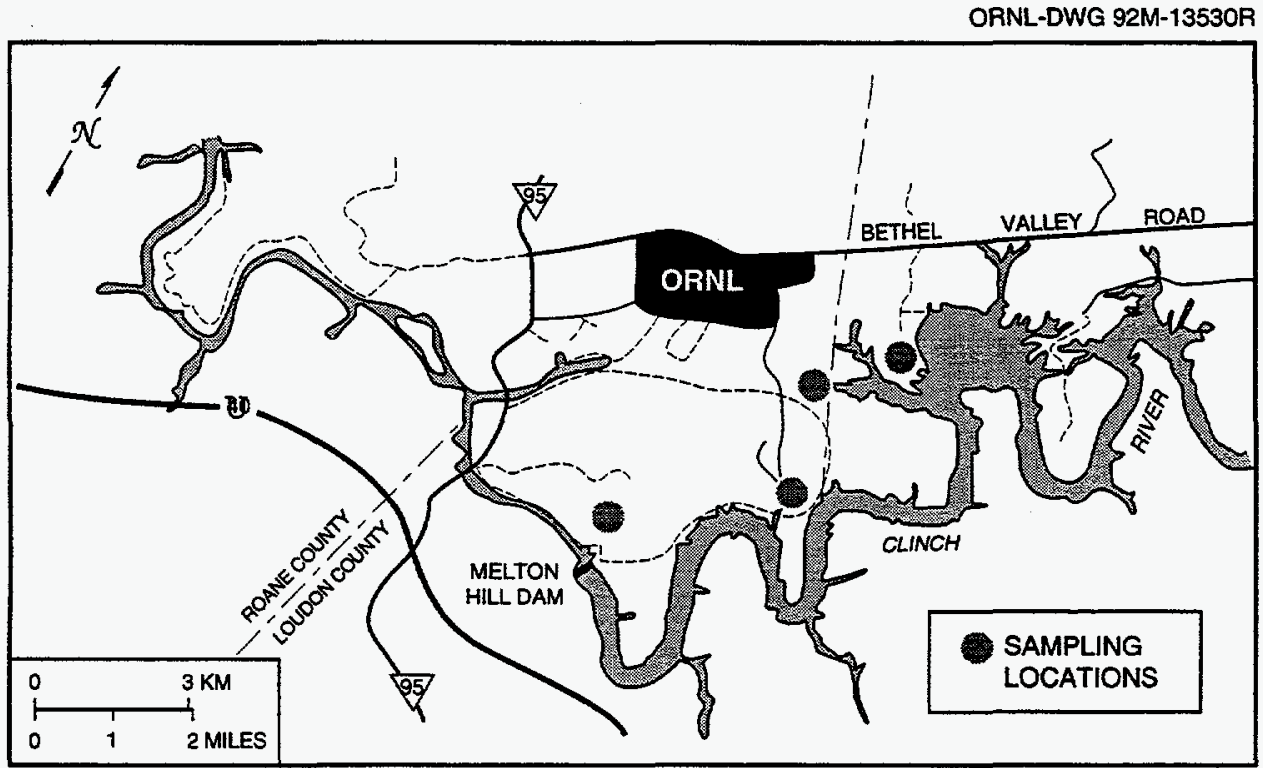

Fig. 4.29. Sampling locations for polychlorinated biphenyls in the greater ORNL area.

discharge points, effluent analytes, permit limits, number of noncompliances, and the percentage of compliance for 1995. Samples from these outfalls are collected and analyzed as specified in the NPDES permit.

The following are the five permitted major outfalls at the K-25 Site (Fig. 4.22):
- 005 (K-1203 Sewage Treatment Plant),

- 009 (K-1515 Sanitary Water Treatment Facility),

- 011 (K-1407-J CNF discharge to Poplar Creek),

- 013 (K-1513 Sanitary Water Intake Backwash Filter), and 


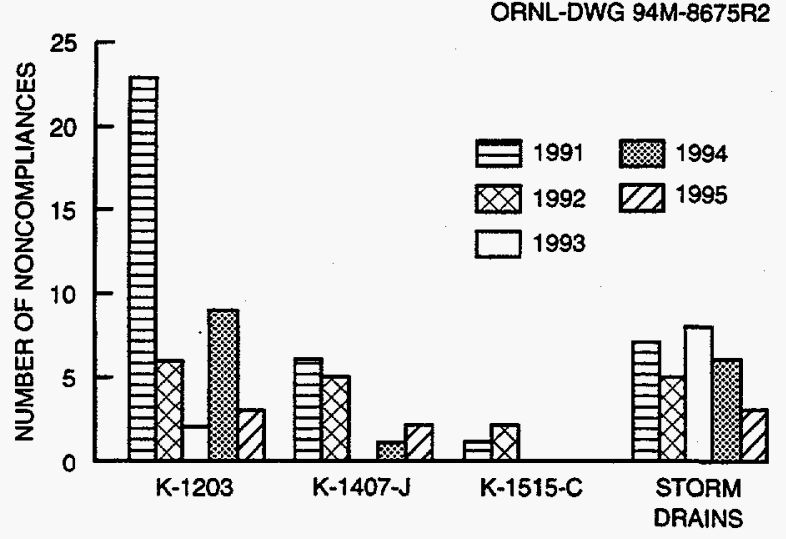

Fig. 4.30. K-25 Site NPDES compliance history by source of noncompliance.

\section{- $014(\mathrm{~K}-1407-\mathrm{J}$ CNF discharge to the Clinch} River).

In accordance with the compliance schedule in Part I, Section E, of the NPDES permit, the discharges through Outfalls 010 and 012 ceased permanently on December 30, 1993. These outfalls were removed from the permit in 1995. Although no monitoring is required at Outfall 013 , routine inspections are conducted to ensure that no unsightly debris or scum is discharged through this point as the result of backwash operations at the K-1513 sanitary intake filter. Outfall 014 is a permitted outfall for the discharge of effluent from the CNF to the Clinch River. Part I, Section E, of the permit required that $\mathrm{CNF}$ discharges through Outfall 011 cease and CNF discharges through Outfall 014 be fully operational no later than April 30, 1996. Discharges through Outfall 014 began in November 1995. During operational startup and testing, discharges from CNF were routed concurrently through both Outfalls 011 and 014 . The project is on schedule to meet the compliance deadline.

Part I, Section E, of the permit also requires that K-1515 sanitary water plant (Outfall 009) discharges be rerouted to the Clinch River by September 30,1995. Discharges from the new K-1515-F treatment lagoon to the Clinch River began on June 12, 1995, and all phases of operational and postoperational testing were completed by September 18, 1995. By September 30, 1995, the Outfall 009 compliance schedule was completed and notification of completion was submitted to TDEC.

\section{Results}

Outfall 005 is the discharge point for the K-25 Site sewage treatment plant, which is an extended aeration treatment plant having a rated capacity of 2.3 million $\mathrm{L} / \mathrm{d}$ [0.6 million gallons per day (Mgd)] and a current use of about 1.4 million L/d (0.36 Mgd). Treated effluent from the main plant is discharged into Poplar Creek through this outfall. This facility had two NPDES permit noncompliances during 1995.

The K-1203 Sewage Treatment Plant (Outfall 005) experienced a total residual chlorine (TRC) noncompliance in February 1995 during an upset condition caused by excessive rainfall and infiltration into the sewage collection system. During the upset condition the chlorine disinfection system and the ultraviolet (UV) light disinfection system were operated concurrently in accordance with operating procedures for upset events to provide maximum disinfection. TRC concentrations prior to an on subsequent days following the upset were well below the permit limit. Because this noncompliance was during an excessive rainfall event, the receiving water for Outfall 005 (Poplar Creek) was at a high flow rate, thus minimizing any potential for the TRC concentration in the effluent to have a negative impact to the environment. Observations of the receiving water confirmed that there were no adverse environmental impacts.

The sewage plant was placed in service in 1976, and many factors, including age, have contributed to degradation of the sewage collection system network. The degradation has allowed infiltration of storm water and groundwater into the system, which has contributed to influent volumes exceeding the plant design capacity. A sanitary sewer upgrade project to minimize infiltration was initiated in 1990. Phase I of this project, which has been completed, included raising the on-site manholes. Phase 2 of the project, which started in November 1994, includes relining the sanitary sewer system pipes. Relining activities continued through 1995 and point-source repairs for seriously damaged sections were initiated. 
The K-1203 Sewage Treatment Plant (Outfall 005) experienced a BOD noncompliance with the NPDES Permit in February 1995. A thorough investigation into this event was conducted, including consultation with the Operator Training Center in Murfreesboro, Tennessee. The investigation revealed that there had not been a BOD shock to the treatment system because the microorganisms would not have recovered without operational reseeding. Furthermore, there would have been evidence of the plant going septic as a result of the microorganisms dying, and no such evidence existed. All other NPDES parameters measured at the time of the incident were well within permit limits and indicated proper operation of the system.

Outfall 009 is the discharge point for the $\mathrm{K}-1515$ sanitary water plant, which provides sanitary water to the K-25 Site to be used for drinking, fire protection, and other purposes. It also provides water to two industries in the Bear Creek Road Industrial Park through an arrangement with the city of Oak Ridge. Raw water is taken from the Clinch River and treated at K-1515. In accordance with the NPDES permit, the K-1515-F settling lagoon was constructed and began discharging to the Clinch River in June 1995. Successful completion of the operational and postoperational testing phase was completed before the September 1995 compliance schedule date. The $\mathrm{K}-1515$ sanitary. water plant exhibited $100 \%$ compliance with the K-25 NPDES permit during 1995.

The K-25 Site CNF, Outfalls 011 and 014, has provisions for the treatment of nonhazardous and hazardous wastes. Nonhazardous flow entering the CNF consists of steam plant effluents and various small-quantity or infrequent streams from waste disposal requests. Hazardous streams include effluents from the TSCA Incinerator, the steam plant hydrogen softener waste stream, and various small-quantity or infrequent streams from waste disposal requests. The NPDES permit requires termination of CNF discharges to Poplar Creek through Outfall 011 by April 30, 1996. Installation of a new pipeline from CNF to Outfall 014 in the Clinch River was completed in October 1995, and TDEC approval to begin operation was received. All postoperational testing of the pipeline and termination of Outfall 011 discharges to Poplar Creek were completed by January 1996 and the compliance schedule for this outfall was met four months ahead of schedule. CNF exhibited $100 \%$ compliance with the K-25 NPDES permit during 1995.

The K-25 NPDES Permit includes 137 storm drain outfalls that are grouped into four categories based on their potential for pollutants to be present in their discharge. Category I storm drains have intermittent flow and drain storm water runoff from areas remotely associated with plant activities and subsurface runoff; Category II storm drains have intermittent flow and drain stormwater runoff from building roof drains and paved areas associated with plant activities; Category III storm drains have intermittent flow and drain storm water runoff from areas associated with concentrated storage areas, roof drains, coolant systems, and parking lots; and Category IV storm drains have continuous flow and drain cooling water discharges and runoff from industrial areas. Monitoring at storm drain outfalls is conducted semiannually, quarterly, monthly, or weekly for Categories I through IV, respectively, with those storm drains that have the highest potential for pollution being sampled most frequently.

The remaining three $\mathrm{K}-25$ site NPDES noncompliances for 1995 occurred at storm drain outfalls. These noncompliances occurred at Outfall 120, Outfall 480/490, and Outfall 100.

In February 1995 a sewage bypass pump failed during a relining operation as part of the sanitary sewer upgrade project at the low point of system, causing sewage to back up and overflow from a manhole. As a result, approximately $100 \mathrm{gal}(378 \mathrm{~L})$ of raw sewage spilled onto a parking area and flowed into a nearby storm drain catch basin leading to Outfall 120. The bypass pump was immediately brought back on line and the sewage remaining in the parking area was washed back into the sanitary sewer system.

A visible sheen was observed emanating from Outfall 480/490 on May 1, 1995. Oil-absorbent booms and pads were utilized to contain and remove the sheen and a walkdown 
of the complete storm drain system was initiated to find the source of the sheen. Areas of specific concern were not identified in the investigation.

In December 1995 freezing conditions caused a sanitary water line break, resulting in a discharge of chlorinated water through Outfall 100, which is a Category IV storm drain. The discharge caused the TRC limit at Outfall 100 to be exceeded. As the water line was being repaired a temporary dechlorination system was installed in the storm drain network to ensure that chlorine levels at the outfall were maintained within NPDES permit limits. The temporary dechlorination system was removed from the storm drain network after repairs on the sanitary water line were completed.

A Storm Water Pollution Prevention Program (SWPPP) is another requirement of the NPDES permit. The K-25 SWPPP was initiated in October 1993 and addresses the following components:

- the storm water monitoring program;

- a site assessment;

- best management practices;

- development of a site map;

- inspections, evaluation, and record keeping; and

- definition of organizational responsibilities.

The sampling program is conducted to evaluate and characterize storm water runoff. Storm drains were monitored for various contaminants, depending on the types of areas drained by the system. PCBs, chemical oxygen demand, and radioactivity are sampled in all areas of the site. Through the evaluation of storm water effluent, further sampling or investigation was defined, and pollutant sources and areas for corrective actions were identified.

The FY 1995 sampling and analysis plan was developed with the information from the 1987 and 1994 sampling results, knowledge of various processes and functions conducted at the K-25 Site, material storage and handling practices, and waste disposal practices in the drainage areas for each outfall. Storm drains that drained similar areas were grouped to minimize the number of storm drains to be sampled.
Thirty storm drains were placed into six groups located at the powerhouse area. One storm drain from each group and all other outfalls were sampled according to the plan. Dry- and wet-weather samples are planned to be collected in FY 1996 at continuous-flow storm drains in conjunction with water and sediment sampling to be conducted within the piping systems.

An assessment of the K-25 Site was conducted to determine which areas, activities, or materials may be contributing pollutants to the storm drain system. When a potential source was identified, management practices were reviewed to determine if there was a risk of pollutants entering storm water. If there was a risk, either corrective actions were identified or best management practices were applied. Best management practice plans were developed for the TSCA Incinerator, the CNF, the K-1501 Steam Plant, and the K-1414 Garage. These facilities were considered to be at risk because of the nature of the activities and because they are operating facilities. In 1995, best management practice plans were developed for the K-1417 Drum Storage Yard and for construction activities because contaminants may reach storm water. There are also three ongoing activities that are considered to be site-wide best management practices because they provide the site with information on contamination, transport of storm water, and effects of contamination. These three best management practices are the storm drain survey, radiological survey, and BMAP.

An SWPPP site map was developed as a visual aid to bring all of the site data together. Knowing the location of all identified potential pollutant sources in relation to the storm drain system (and sensitive environmental areas) gives the user an idea of potential pollutants that can be expected to be found at a particular outfall. By using the map, pollutants can be traced from an outfall to a source or from a potential source to its respective outfall.

Two semiannual inspections were performed in 1995. The first site inspection, performed in January 1995, comprised an assessment of compliance at various facilities with existing CWA best management practices, a site-wide dry-weather inspection, and a site-wide inspection 
during a storm event. The second inspection was performed in August 1995. Inspection criteria included evaluation of erosion-control methods employed during construction projects at the site, and the extent to which control guidelines were followed.

\section{TOXICITY CONTROL AND MONITORING PROGRAM}

\section{Y-12 Plant Toxicity Control and Monitoring Program}

In accordance with the 1985 NPDES Permit (Part III-C, page III-3), a Toxicity Control and Monitoring Program (TCMP) that evaluates plant discharges for toxicity is required. Results of toxicity tests from three wastewater treatment facilities (Central Pollution Control Facility, West End Treatment Facility (WETF), and Groundwater Treatment Facility), an in-stream monitoring location (Outfall 201), and four locations in the storm sewer system are given in Table 4.21. For each site, the table shows the date the test was initiated, the no-observed-effect concentration (NOEC) and/or the 48- or 96-hour $\mathrm{LC}_{50}$ for Ceriodaphnia dubia and fathead minnows (Pimephales promelas), and the calculated in-stream waste concentration (IWC). The TCMP was conducted from January 1 to June 30,1995, until the effective date of the 1995 NPDES Permit.

Effluent from the Groundwater Treatment Facility was tested in April and June using Ceriodaphnia and fathead minnows. In April, the effluent's NOEC was $0.5 \%$ for Ceriodaphnia and $10 \%$ for fathead minnows. The calculated IWC was $2.09 \%$. In June, the effluent's 48 -hour LC $_{50}$ was $100 \%$ for both Ceriodaphnia and fathead minnows. The calculated IWC was $0.73 \%$.

Effluent from the Central Pollution Control Facility was tested in May and June using Ceriodaphnia and fathead minnows. In May, the treated effluent from the Central Pollution Control Facility had an NOEC of $100 \%$ for both Ceriodaphnia and fathead minnows. In June, the treated effluent from the Central Pollution Control Facility had a 48-hour $\mathrm{LC}_{50}$ of $>100 \%$ for both Ceriodaphnia and fathead minnows. The calculated IWCs of Central
Pollution Control Facility effluent in EFPC were $0.23 \%$ in May and $0.40 \%$ in June. Because the IWCs were less than the NOEC and the $\mathrm{LC}_{50}$, it is unlikely that treated effluent from that facility adversely affected the aquatic biota in EFPC.

Water from the in-stream monitoring point, Outfall 201, was tested seven times during the period using Ceriodaphnia and fathead minnows. Four tests were conducted in May and the NOECs were $100 \%, 80 \%,<80 \%$, and $80 \%$ for Ceriodaphnia; the NOECs were each $100 \%$ for fathead minnows. The 96 -hour $\mathrm{LC}_{50} \mathrm{~s}$ for Ceriodaphnia and fathead minnows were all $>100 \%$. (The 96-hour $\mathrm{LC}_{50} \mathrm{~s}$ were developed during the chronic tests.) Three tests were conducted in June and the NOECs were $80 \%$, $100 \%$, and $100 \%$ for Ceriodaphnia, and were $100 \%, 80 \%$, and $100 \%$ for fathead minnows. The June $\mathrm{LC}_{50}$ s for both Ceriodaphnia and fathead minnows were all $>100 \%$.

Storm sewer monitoring began in June at four locations in the storm system via the Surface Water Hydrological Information Support System (SWHISS), which include Buildings 9422-11, 9422-12, 9422-15, and 9422-16. The water from the storm sewer at Building 9422-11 had a 48 -hour $\mathrm{LC}_{50}$ of $38.5 \%$ for Ceriodaphnia and $>100 \%$ for fathead minnows. The water from the Building 9422-12 storm sewer had 48-hour $\mathrm{LC}_{50} \mathrm{~S}$ of $37.3 \%$ and $74.8 \%$ for Ceriodaphnia and fathead minnows, respectively. Water from the storm sewer at Building 9422-15 had a 48-hour $\mathrm{LC}_{50}$ of $77.2 \%$ for Ceriodaphnia and $>100 \%$ for fathead minnows. The water from the Building 9422-16 storm sewer had a 48-hour $\mathrm{LC}_{50}$ of $>100 \%$ for both Ceriodaphnia and fathead minnows. During the toxicity tests, total residual chlorine was measured in storm sewer water samples from Buildings 9422-12 and 9422-15; therefore, chlorine may have contributed to the mortality of the Ceriodaphnia and fathead minnows in these tests. Later tests include toxicity testing of dechlorinated storm sewer water to evaluate the effects of chlorine on the test results. 
Annual Site Environmental Report

Table 4.21. Y-12 TCMP summary information for $1995^{a}$

\begin{tabular}{|c|c|c|c|c|c|c|}
\hline Site/Building & Test date & Species & $\begin{array}{l}\text { NOEC }^{b} \\
(\%)\end{array}$ & $\underset{(\%)}{48-h ~ L C_{50}{ }^{c}}$ & $\underset{(\%)}{96-\mathrm{h} \mathrm{LC}}{ }_{50}^{d}$ & $\begin{array}{c}\operatorname{IWC}^{e} \\
(\%)\end{array}$ \\
\hline \multirow{4}{*}{$\begin{array}{l}\text { Groundwater Treatment Facility } \\
\text { (Outfall 512) } \\
\text { Outfall 201 }\end{array}$} & $4 / 5$ & Ceriodaphnia & 0.5 & & & 2.09 \\
\hline & & Fathead minnow & 10 & & & 2.09 \\
\hline & $5 / 3$ & Ceriodaphnia & 100 & & $>100$ & $f$ \\
\hline & & Fathead minnow & 100 & & $>100$ & $f$ \\
\hline \multirow[t]{2}{*}{ Outfall 201} & $5 / 10$ & Ceriodaphnia & 80 & & $>100$ & $f$ \\
\hline & & Fathead minnow & 100 & & $>100$ & $f$ \\
\hline \multirow[t]{2}{*}{ Outfall 201} & $5 / 17$ & Ceriodaphnia & $<80$ & & $>100$ & $f$ \\
\hline & & Fathead minnow & 100 & & $>100$ & $f$ \\
\hline \multirow[t]{2}{*}{ Outfall 201} & $5 / 31$ & Ceriodaphnia & 80 & & $>100$ & $f$ \\
\hline & & Fathead minnow & 100 & & $>100$ & $f$ \\
\hline \multirow{4}{*}{$\begin{array}{l}\text { Central Pollution Control Facility } \\
\text { (Outfall 501) } \\
\text { Outfall 201 }\end{array}$} & $5 / 31$ & Ceriodaphnia & 100 & & & 0.23 \\
\hline & & Fathead minnow & 100 & & & 0.23 \\
\hline & $6 / 7$ & Ceriodaphnia & 80 & & $>100$ & $f$ \\
\hline & & Fathead minnow & 100 & & $>100$ & $f$ \\
\hline \multirow[t]{2}{*}{ Outfall 201} & $6 / 14$ & Ceriodaphnia & 100 & & $>100$ & $f$ \\
\hline & & Fathead minnow & 80 & & $>100$ & $f$ \\
\hline Groundwater Treatment Facility & $6 / 15$ & $\begin{array}{l}\text { Ceriodaphnia } \\
\text { Fathead minnow }\end{array}$ & & $\begin{array}{l}>100 \\
>100\end{array}$ & & $\begin{array}{l}0.73 \\
0.73\end{array}$ \\
\hline \multirow[t]{2}{*}{ 9422-11 Storm Sewer } & $6 / 15$ & $\begin{array}{l}\text { Fathead minnow } \\
\text { Ceriodaphnia }\end{array}$ & & 38.5 & & $\begin{array}{l}0.12 \\
g\end{array}$ \\
\hline & & Fathead minnow & & $>100$ & & $g$ \\
\hline \multirow[t]{2}{*}{ 9422-15 Storm Sewer } & $6 / 15$ & Ceriodaphnia & & 77.2 & & $g$ \\
\hline & & Fathead minnow & & $>100$ & & $g$ \\
\hline \multirow[t]{2}{*}{ 9422-12 Storm Sewer } & $6 / 17$ & Ceriodaphnia & & 37.3 & & $g$ \\
\hline & & Fathead minnow & & 74.8 & & $g$ \\
\hline \multirow[t]{2}{*}{ 9422-16 Storm Sewer } & $6 / 17$ & Ceriodaphnia & & $>100$ & & $g$ \\
\hline & & Fathead minnow & & $>100$ & & $g$ \\
\hline \multirow{4}{*}{$\begin{array}{l}\text { Central Pollution Control Facility } \\
\text { (Outfall 501) } \\
\text { Outfall 201 }\end{array}$} & $6 / 19$ & Ceriodaphnia & & $>100$ & . & 0.40 \\
\hline & & Fathead minnow & & $>100$ & & 0.40 \\
\hline & $6 / 21$ & Ceriodaphnia & 100 & & $>100$ & $f$ \\
\hline & & Fathead minnow & 100 & & $>100$ & $g$ \\
\hline
\end{tabular}

\footnotetext{
${ }^{a}$ These 7-day chronic tests and 48-hour acute tests using fathead minnows and Ceriodaphnia were completed in 1995 as part of the TCMP conducted for the Y-12 Plant by ORNL. Summarized are the effluents and their corresponding no-observed-effect concentrations, 48- or 96-hour $\mathrm{LC}_{50}$ s, and in-stream waste concentrations (IWCs). Note: Discharge from the treatment facilities are intermittent because of batch operations.

${ }^{b}$ No-observed-effect concentrations.

cThe concentration of effluent that is lethal to $50 \%$ of the test organisms in 48 hours.

${ }^{d}$ The concentration of effluent that is lethal to $50 \%$ of the test organisms in 96 hours. The 96 -hour $\mathrm{LC}_{50} \mathrm{~s}$ were developed during the chronic tests.

${ }^{e}$ The IWC based on actual flows at East Fork Poplar Creek, station 8.

${ }^{f}$ This is an in-stream point; therefore, an IWC is not applicable.

${ }^{8}$ This point is in the storm sewer system; therefore, an IWC is not applicable.
}

\section{Y-12 Plant Biomonitoring Program}

After the July 1 effective date of the 1995 NPDES Permit, the following toxicity tests were completed between July 1 and December 31, 1995, to fulfill the biomonitoring requirements of the permit (Part III-C, page 39). Table 4.22 is a summary of wastewater treatment system and storm sewer effluents, the corresponding 48-hour $\mathrm{LC}_{50}$, and the calculated IWC. Table 4.23 is a summary of the NOECs and 96-hour $\mathrm{LC}_{50}$ s for the in-stream monitoring location, Outfall 201.

Effluent from the Central Pollution Control Facility was tested in July using Ceriodaphnia and fathead minnows, and in December using only Ceriodaphnia. The effluent's 48 -hour $\mathrm{LC}_{50}$ was $>100 \%$ for all tests. The calculated IWCs $(0.41 \%$ and $0.36 \%)$ were below the $\mathrm{LC}_{50} \mathrm{~s}$; therefore, it is unlikely that treated effluent from the Central Pollution Control Facility adversely affected the aquatic biota in EFPC. 
Table 4.22. Y-12 Plant Biomonitoring Program summary information for wastewater treatment systems and storm sewer effluents for $1995^{a}$

\begin{tabular}{|c|c|c|c|c|}
\hline Site/Building & Test date & Species & 48-h LC Lo $^{b}(\%)$ & $\operatorname{IWC}^{c}(\%)$ \\
\hline \multirow{2}{*}{$\begin{array}{l}\text { Central Pollution Control Facility } \\
\text { (Outfall 501) }\end{array}$} & $7 / 13$ & Ceriodaphnia & $>100$ & 0.41 \\
\hline & & Fathead minnow & $>100$ & 0.41 \\
\hline \multirow{2}{*}{$\begin{array}{l}\text { Groundwater Treatment Facility } \\
\text { (Outfall 512) }\end{array}$} & $7 / 13$ & Ceriodaphnia & 87.6 & 0.43 \\
\hline & & Fathead minnow & 40.7 & 0.43 \\
\hline \multirow[t]{2}{*}{$9422-11$ Storm Sewer } & $7 / 13$ & Ceriodaphnia & $>100$ & $d$ \\
\hline & & Fathead minnow & $>100$ & $d$ \\
\hline \multirow[t]{2}{*}{ 9422-12 Storm Sewer } & $7 / 13$ & Ceriodaphnia & 35.2 & $d$ \\
\hline & & Fathead minnow & 85.4 & $d$ \\
\hline \multirow{2}{*}{$\begin{array}{l}\text { 9422-11 Storm Sewer } \\
\text { (dechlorinated) }\end{array}$} & $7 / 13$ & Ceriodaphnia & $>100$ & $d$ \\
\hline & & Fathead minnow & $>100$ & $d$ \\
\hline \multirow[t]{2}{*}{ 9422-15 Storm Sewer } & $7 / 18$ & Ceriodaphnia & 66.6 & $d$ \\
\hline & & Fathead minnow & $>100$ & $d$ \\
\hline \multirow{2}{*}{$\begin{array}{l}\text { 9422-15 Storm Sewer } \\
\text { (dechlorinated) }\end{array}$} & $7 / 18$ & Ceriodaphnia & 71.8 & $d$ \\
\hline & & Fathead minnow & $>100$ & $d$ \\
\hline \multirow[t]{2}{*}{ 9422-16 Storm Sewer } & $7 / 18$ & Ceriodaphnia & 87.1 & $d$ \\
\hline & & Fathead minnow & $>100$ & $d$ \\
\hline \multirow{2}{*}{$\begin{array}{l}\text { 9422-16 Storm Sewer } \\
\text { (dechlorinated) }\end{array}$} & $7 / 18$ & Ceriodaphnia & $>100$ & $d$ \\
\hline & & Fathead minnow & $>100$ & $d$ \\
\hline \multirow{2}{*}{$\begin{array}{l}\text { West End Treatment Facility } \\
\text { (Outfall 502) }\end{array}$} & $7 / 20$ & Ceriodaphnia & 42.4 & 2.02 \\
\hline & & Fathead minnow & 82.9 & 2.02 \\
\hline $\begin{array}{l}\text { Groundwater Treatment Facility } \\
\text { (Outfall 512) }\end{array}$ & $10 / 12$ & Ceriodaphnia & $>100$ & 0.31 \\
\hline $9422-11$ Storm Sewer & $10 / 12$ & Ceriodaphnia & 39.5 & $d$ \\
\hline 9422-12 Storm Sewer & $10 / 12$ & Ceriodaphnia & 55.4 & $d$ \\
\hline $\begin{array}{l}\text { 9422-12 Storm Sewer } \\
\text { (dechlorinated) }\end{array}$ & $10 / 12$ & Ceriodaphnia & $>100$ & $d$ \\
\hline 9422-15 Storm Sewer & $10 / 18$ & Ceriodaphnia & $>100$ & $d$ \\
\hline 9422-16 Storm Sewer & $10 / 19$ & Ceriodaphnia & $>100$ & $d$ \\
\hline $\begin{array}{l}\text { West End Treatment Facility } \\
\text { (Outfall 502) }\end{array}$ & $10 / 25$ & Ceriodaphnia & 24.2 & 0.78 \\
\hline $\begin{array}{l}\text { Central Pollution Control Facility } \\
\text { (Outfall 501) }\end{array}$ & $12 / 9$ & Ceriodaphnia & $>100$ & 0.36 \\
\hline
\end{tabular}

${ }^{a}$ These 48-hour acute tests using fathead minnows and Ceriodaphnia were completed in 1995 as part of the Biomonitoring Program conducted for the Y-12 Plant by ORNL. Summarized are the effluents and their corresponding 48-hour $\mathrm{LC}_{50} \mathrm{~s}$ and in-stream waste concentrations (IWCs). Note: Discharge from the treatment facilities are intermittent because of batch operations.

${ }^{b}$ The concentration of effluent that is lethal to $50 \%$ of the test organisms in 48 hours.

${ }^{c}$ The in-stream waste concentration based on actual flows at East Fork Poplar Creek, station 8.

${ }^{d}$ This point is in the storm sewer system; therefore, an IWC is not applicable.

Effluent from the Groundwater Treatment Facility was tested in July using Ceriodaphnia and fathead minnows, and in October using only Ceriodaphnia. In July, the treated effluent from the Groundwater Treatment Facility had a 48 -hour $\mathrm{LC}_{50}$ of $87.6 \%$ for Ceriodaphnia and $40.7 \%$ for fathead minnows. In October, Groundwater Treatment Facility effluent had a 48-hour $\mathrm{LC}_{50}$ of $>100 \%$ using onlyCeriodaphnia. The calculated IWCs of Groundwater Treatment Facility effluent was $0.43 \%$ in July and $0.31 \%$ in October. Because the IWCs were less than the $\mathrm{LC}_{50} \mathrm{~s}$, it is unlikely that treated effluent from that facility adversely affected the aquatic biota in EFPC.

Effluent from the WETF was tested in July using Ceriodaphnia and fathead minnows, and in October using only Ceriodaphnia.

The July 48 -hour $\mathrm{LC}_{50}$ s were $42.4 \%$ for Ceriodaphnia and $82.9 \%$ for fathead minnows. The October 48-hour $\mathrm{LC}_{50}$ was $24.2 \%$ using only Ceriodaphnia. The calculated IWCs $(2.02 \%$ and $0.78 \%$ ) were below the $\mathrm{LC}_{50} \mathrm{~s}$; therefore, it is unlikely that treated effluent from the facility adversely affected the aquatic biota in EFPC. 
Annual Site Environmental Report

Table 4.23. Y-12 Plant Biomonitoring Program summary information for Outfall 201 for $1995^{a}$

\begin{tabular}{ccccc}
\hline Site & Test date & \multicolumn{1}{c}{ Species } & $\begin{array}{c}\text { NOEC } \\
(\%)\end{array}$ & 96-h LC $_{50}{ }^{c}(\%)$ \\
\hline Outfall 201 & $7 / 12$ & $\begin{array}{l}\text { Ceriodaphnia } \\
\text { Fathead minnow }\end{array}$ & 100 & $>100$ \\
& & 100 & $>100$ \\
Outfall 201 & $10 / 12$ & Ceriadaphnia & 100 & $>100$ \\
& & Fathead minnow & 100 & $>100$
\end{tabular}

\footnotetext{
${ }^{a}$ These 7-day chronic tests using fathead minnows and Ceriodaphnia were completed in 1995 as part of the Biomonitoring Program for the Y-12 Plant by ORNL. Summarized are the no-observed-effect concentrations and the 96-hour $\mathrm{LC}_{50} \mathrm{~S}$ for the in-stream monitoring location, Outfall 201.

${ }^{b}$ No-observed-effect concentrations.

${ }^{c}$ The concentration of effluent that is lethal to $50 \%$ of the test organisms in 96 hours. The 96 -hour $\mathrm{LC}_{50}$ s were developed during the chronic tests.
}

Toxicity testing of storm sewers is conducted at Buildings $9422-11,9422-12,9422-15$, and 9422-16, which monitor locations in the storm system as part of the SWHISS. Water from the storm sewer at Building 9422-11 was tested in July using Ceriodaphnia and fathead minnows, and in October using Ceriodaphnia only. In July, water from the storm sewer at Building 9422-11 had a 48-hour LC $_{50}$ of $>100 \%$ for both Ceriodaphnia and fathead minnows. A portion of this water was treated by dechlorination before testing. The 48-hour $\mathrm{LC}_{50}$ of the dechlorinated water was $>100 \%$ for both Ceriodaphnia and fathead minnows. In October, the 48 -hour $\mathrm{LC}_{50}$ was $39.5 \%$ using Ceriodaphnia only.

Storm sewer water from Building 9422-12 was tested in July using Ceriodaphnia and fathead minnows and in October using only Ceriodaphnia. In July, the 48-hour LC $_{50}$ was $35.2 \%$ for Ceriodaphnia and $85.4 \%$ for fathead minnows. In October, the 48-hour $\mathrm{LC}_{50}$ was $55.4 \%$ for Ceriodaphnia. The 48-hour $\mathrm{LC}_{50}$ of dechlorinated water was $>100 \%$ using only Ceriodaphnia.

Storm sewer water at Building 9422-15 was tested in July using Ceriodaphnia and fathead minnows, and in October using only Ceriodaphnia. The July 48 -hour $\mathrm{LC}_{50}$ was $66.6 \%$ for Ceriodaphnia and $>100 \%$ for fathead minnows. The 48-hour $\mathrm{LC}_{50} \mathrm{~s}$ of dechlorinated storm sewer water were $71.8 \%$ and $>100 \%$ for Ceriodaphnia and fathead minnows, respectively. In October, the storm sewer at Building 9422-15 had a 48 -hour $\mathrm{LC}_{50}$ of $>100 \%$ using only Ceriodaphnia.

The storm sewer at Building 9422-16 was tested in July using Ceriodaphnia and fathead minnows, and in October using Ceriodaphnia only. The July 48 -hour $\mathrm{LC}_{50}$ was $87.1 \%$ for Ceriodaphnia and $>100 \%$ for fathead minnows. The 48-hour $\mathrm{LC}_{50}$ s for the dechlorinated water were $>100 \%$ for both Ceriodaphnia and fathead minnows. In October, the 48-hour $\mathrm{LC}_{50}$ was $>100 \%$ using Ceriodaphnia only.

Water from the in-stream monitoring point, Outfall 201, was tested twice during the period using Ceriodaphnia and fathead minnows. In July, the NOEC was $100 \%$ for both Ceriodaphnia and fathead minnows; the 96-hour $\mathrm{LC}_{50}$ was $>100 \%$ for both Ceriodaphnia and fathead minnows. In October, the NOEC was $100 \%$ for both Ceriodaphnia and fathead minnows; the 96-hour $\mathrm{LC}_{50}$ was $>100 \%$ for both Ceriodaphnia and fathead minnows.

\section{ORNL Toxicity Control and Monitoring Program}

Under the TCMP, wastewaters from the STP, the CYRTF, and the NRWTF were evaluated for toxicity. In addition, two ambient in-stream sites were evaluated; one site is located on Melton Branch (NPDES permit point X13) and the other on WOC (permit point X14). The results of the toxicity tests of wastewaters from the three treatment facilities and the two ambient stream sites are given in Table 4.24. This table provides, for each wastewater and 
Table 4.24. 1995 toxicity test results of ORNL wastewaters and ambient water

\begin{tabular}{|c|c|c|c|c|c|}
\hline Outfall & Test date & Treatment $^{a}$ & $\begin{array}{l}\text { Fathead minnow } \\
\text { NOEC }^{b}(\%)\end{array}$ & $\begin{array}{l}\text { Ceriodaphnia } \\
\text { NOEC }^{b}\end{array}$ & $\begin{array}{r}\operatorname{IWC}^{C} \\
(\%)\end{array}$ \\
\hline $\begin{array}{l}\text { Coal Yard Runoff } \\
\text { Treatment Facility } \\
(\mathrm{X02})\end{array}$ & $\begin{array}{l}\text { May } \\
\text { Nov } \\
1\end{array}$ & $\begin{array}{l}\mathrm{N} \\
\mathrm{N}\end{array}$ & $\begin{array}{l}100 \\
100\end{array}$ & $\begin{array}{l}50 \\
12\end{array}$ & $\begin{array}{l}0.5 \\
8.0\end{array}$ \\
\hline $\begin{array}{l}\text { Sewage Treatment Plant } \\
\text { (X01) }\end{array}$ & $\begin{array}{l}\text { Apr } \\
\text { Apr } \\
\text { July } \\
\text { Sep } \\
\text { Nov }\end{array}$ & $\begin{array}{l}\mathrm{N} \\
\mathrm{N} \\
\mathrm{N} \\
\mathrm{N} \\
\mathrm{N}\end{array}$ & $\begin{array}{l}d \\
d \\
d \\
d \\
d\end{array}$ & $\begin{array}{r}12 \\
6 \\
50 \\
25 \\
12\end{array}$ & $\begin{array}{l}37.2 \\
22.8 \\
24.5 \\
19.2 \\
15.7\end{array}$ \\
\hline $\begin{array}{l}\text { Nonradiological Wastewater } \\
\text { Treatment Plant (X12) }\end{array}$ & $\begin{array}{l}\text { Apr } \\
\text { Oct }\end{array}$ & $\begin{array}{l}\mathrm{N} \\
\mathrm{N}\end{array}$ & $\begin{array}{l}d \\
d\end{array}$ & $\begin{array}{l}100 \\
100\end{array}$ & $\begin{array}{l}f \\
f\end{array}$ \\
\hline Melton Branch (X13) & $\begin{array}{l}\text { Feb } \\
\text { Feb } \\
\text { Apr } \\
\text { May }^{e} \\
\text { May } \\
\text { June } \\
\text { Aug } \\
\text { Oct } \\
\text { Nov } \\
\text { Dec } \\
\text { Dec }^{e}\end{array}$ & $\begin{array}{l}N \\
U V \\
N \\
N \\
U V \\
N \\
U V \\
N \\
U V \\
N \\
U V \\
N \\
U V \\
N \\
U V \\
N \\
U V \\
N \\
U V \\
N \\
U V\end{array}$ & $\begin{array}{c}100 \\
100 \\
d \\
80 \\
100 \\
g \\
g \\
<80 \\
100 \\
100 \\
100 \\
100 \\
100 \\
<80 \\
100 \\
<80 \\
100 \\
<80 \\
100 \\
100 \\
100\end{array}$ & $\begin{array}{c}80 \\
d \\
100 \\
g \\
d \\
100 \\
d \\
d \\
d \\
100 \\
d \\
100 \\
d \\
100 \\
d \\
d \\
d \\
80 \\
d \\
100 \\
d\end{array}$ & \\
\hline $\begin{array}{l}\text { White Oak Creek } \\
\text { (X14) }\end{array}$ & $\begin{array}{l}\text { Feb } \\
\text { Apr } \\
\text { May } \\
\text { May } \\
\text { June } \\
\text { Aug }\end{array}$ & $\begin{array}{l}\mathrm{N} \\
\mathrm{UV} \\
\mathrm{N} \\
\mathrm{UV} \\
\mathrm{N} \\
\mathrm{UV} \\
\mathrm{N} \\
\mathrm{UV} \\
\mathrm{N} \\
\mathrm{UV} \\
\mathrm{N} \\
\mathrm{UV}\end{array}$ & $\begin{array}{c}100 \\
100 \\
80 \\
100 \\
g \\
g \\
80 \\
100 \\
100 \\
100 \\
100 \\
100\end{array}$ & $\begin{array}{c}100 \\
d \\
g \\
d \\
100 \\
d \\
d \\
d \\
100 \\
d \\
<80 \\
d\end{array}$ & \\
\hline
\end{tabular}


Annual Site Environmental Report

Table 4.24 (continued)

\begin{tabular}{llcccc}
\hline Outfall & Test date & Treatment $^{a}$ & $\begin{array}{c}\text { Fathead minnow }^{\text {NOEC }}(\%) \\
\text { NOriodaphnia }^{b}\end{array}$ & $\begin{array}{c}\text { IWC }^{c} \\
\text { NOEC }^{b}\end{array}$ \\
\hline & Sep & N & $d$ & 100 \\
& Oct & N & 100 & 100 \\
& Dec & N & 100 & $d$ \\
& UV & 100 & 80 \\
& Dec & N & 100 & $d$ \\
& & $d$ & 100 \\
\hline
\end{tabular}

\footnotetext{
${ }^{a} \mathrm{~N}=$ no sample pretreatment; $\mathrm{UV}=$ ultraviolet light pretreatment.

${ }^{b}$ No-observed-effect concentration.

"In-stream waste concentration (based on critical low flow of White Oak Creek).

${ }^{d}$ Not tested.

${ }^{e}$ Confirmatory test.

${ }^{f}$ Not calculated.

${ }^{8}$ Invalid test.
} 
Table 4.25. 1995 average water quality parameters measured during toxicity tests of ORNL wastewaters and ambient waters. Values are for full-strength wastewater for each test $(N=7)$ or averages of full-strength ambient water for each test $(N=7)$.

\begin{tabular}{|c|c|c|c|c|c|}
\hline Outfall & Test date & $\begin{array}{c}\text { pH } \\
\text { (standard units) }\end{array}$ & $\begin{array}{c}\text { Conductivity } \\
(\mu \mathrm{S} / \mathrm{cm})\end{array}$ & $\begin{array}{c}\text { Alkalinity } \\
\left.(\mathrm{mg} / \mathrm{L} \mathrm{CaCO})_{3}\right)\end{array}$ & $\begin{array}{c}\text { Hardness } \\
\left.(\mathrm{mg} / \mathrm{L} \mathrm{CaCO})_{3}\right)\end{array}$ \\
\hline $\begin{array}{l}\text { Coal Yard Runoff } \\
\text { Treatment Facility } \\
\text { (X02) }\end{array}$ & $\begin{array}{l}\text { May } \\
\text { Nov }\end{array}$ & $\begin{array}{l}8.00 \\
7.29\end{array}$ & $\begin{array}{l}3240 \\
3580\end{array}$ & $\begin{array}{l}23 \\
22\end{array}$ & $\begin{array}{l}1460 \\
1510\end{array}$ \\
\hline Sewage Treatment Plant & $\mathrm{Apr}^{a}$ & 7.91 & 385 & 108 & 151 \\
\hline$(\mathrm{X} 01)$ & $\begin{array}{l}\text { Apr } \\
\text { July } \\
\text { Sep } \\
\text { Nov }\end{array}$ & $\begin{array}{l}7.89 \\
7.91 \\
7.72 \\
7.82\end{array}$ & $\begin{array}{l}408 \\
331 \\
363 \\
450\end{array}$ & $\begin{array}{r}104 \\
81 \\
76 \\
76\end{array}$ & $\begin{array}{l}147 \\
140 \\
143 \\
168\end{array}$ \\
\hline $\begin{array}{l}\text { Nonradiological Wastewater } \\
\text { Treatment Facility }(X 12)\end{array}$ & $\begin{array}{l}\text { Apr } \\
\text { Oct }\end{array}$ & $\begin{array}{l}8.04 \\
7.85\end{array}$ & $\begin{array}{l}431 \\
626\end{array}$ & $\begin{array}{l}83 \\
58\end{array}$ & $\begin{array}{r}77 \\
108\end{array}$ \\
\hline Melton Branch (X13) & $\begin{array}{l}\mathrm{Feb}^{c} \\
\mathrm{Feb}^{d} \\
\mathrm{Apr} \\
\mathrm{May}^{e}\end{array}$ & $\begin{array}{l}7.95 \\
7.07 \\
8.05 \\
8.03\end{array}$ & $\begin{array}{l}392 \\
215 \\
423 \\
579\end{array}$ & $\begin{array}{r}90 \\
71 \\
116 \\
106\end{array}$ & $\begin{array}{l}184 \\
109 \\
213 \\
297\end{array}$ \\
\hline 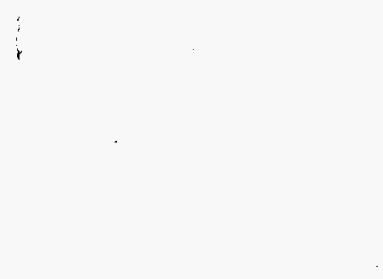 & $\begin{array}{l}\text { May } \\
\text { June } \\
\text { Aug } \\
\text { Oct } \\
\text { Nov } \\
\text { Dec } \\
\operatorname{Dec}^{h}\end{array}$ & $\begin{array}{l}8.03 \\
8.04 \\
8.04 \\
7.83 \\
7.84 \\
7.94 \\
7.80\end{array}$ & $\begin{array}{l}501 \\
430 \\
536 \\
680 \\
423 \\
342 \\
618\end{array}$ & $\begin{array}{r}121 \\
101 \\
114 \\
92 \\
138 \\
109 \\
101\end{array}$ & $\begin{array}{l}260 \\
211 \\
270 \\
335 \\
217 \\
186 \\
291\end{array}$ \\
\hline White Oak Creek (X14) & $\begin{array}{l}\text { Feb } \\
\text { Apr } \\
\text { May }^{e} \\
\text { May } \\
\text { June } \\
\text { Aug } \\
\text { Sep } \\
\text { Oct } \\
\text { Dec }^{g} \\
\text { Dec }^{h}\end{array}$ & $\begin{array}{l}8.05 \\
8.16 \\
8.17 \\
8.11 \\
8.16 \\
8.08 \\
7.93 \\
8.00 \\
8.00 \\
7.97\end{array}$ & $\begin{array}{l}370 \\
308 \\
322 \\
337 \\
354 \\
367 \\
326 \\
391 \\
368 \\
401\end{array}$ & $\begin{array}{r}106 \\
107 \\
107 \\
106 \\
105 \\
97 \\
101 \\
105 \\
116 \\
117\end{array}$ & $\begin{array}{l}154 \\
139 \\
146 \\
145 \\
147 \\
161 \\
152 \\
165 \\
181 \\
167\end{array}$ \\
\hline
\end{tabular}

${ }^{a}$ Data for test conducted April 7-14, 1994.

${ }^{b}$ Data for test conducted April 21-28, 1994.

${ }^{c}$ Data for test conducted February 3-10, 1994.

${ }^{d}$ Data for test conducted February 10-16, 1994.

${ }^{e}$ Data for test conducted May 12-19, 1994.

${ }^{f}$ Data for test conducted May 20-27, 1994.

${ }^{8}$ Data for test conducted December 8-15, 1994.

${ }^{h}$ Data for test conducted December 29-January 5, 1995.

ambient water, the month the test was conducted, sample treatment (if any), the wastewater's NOEC for fathead minnows and Ceriodaphnia, and the IWC, if appropriate. The NOEC is the concentration that did not reduce survival or growth of fathead minnows or survival or reproduction of Ceriodaphnia. Average water quality measurements obtained during each toxicity test are shown in Table 4.25.

During 1994, the CYRTF and the NRWTF were tested twice each, and the Sewage Treatment Plant was tested five times. The 
CYRTF wastewater's NOECs were $100 \%$ for fathead minnows and $50 \%$ and $12 \%$ for Ceriodaphnia. The corresponding wastewater's IWCs were $0.5 \%$ and $8.0 \%$. Because the IWC was consistently lower than the NOEC, it is unlikely that wastewater from the CYRTF adversely affected the aquatic biota of WOC during 1995.

Full-strength wastewater from the NRWTF was not toxic to Ceriodaphnia during the April and October tests; therefore, no IWC was calculated on the NRWTF for 1995. Fathead minnow testing for this facility was discontinued as allowed in the NPDES permit guidelines. The STP wastewater's NOEC for Ceriodaphnia ranged from $6 \%$ to $50 \%$ during 1994 . The NOEC for the STP was $6 \%$ in April, $12 \%$ on two occasions (April and November), $50 \%$ in July, and 25\% in September. Per guidelines in the NPDES permit, no fathead minnow tests were conducted for the STP. Because the IWC exceeded the NOEC for both tests conducted in April, a Toxicity Control Plan for the STP was developed and implemented in July, and toxicity testing for this facility was increased to every other month.

During 1994 the Melton Branch (X13) site was tested 11 times, and the WOC (X14) site was tested 10 times. Water from $\mathrm{X} 13$ reduced fathead minnow survival on five occasions (April, May, October, November, and December) and Ceriodaphnia reproduction on two occasions (February and December). Confirmatory tests conducted in May and November again resulted in reduced fathead minnow survival. Follow-up confirmatory tests conducted in June and December showed the water to be nontoxic; thus the toxicity appeared to be transient. Confirmatory tests using Ceriodaphnia were conducted in February and December. Both confirmatory tests resulted in NOECs of $100 \%$. Water from X14 reduced fathead minnow survival on two occasions (April and May) and Ceriodaphnia reproduction on two occasions (August and December). A confirmatory test of fathead minnows, conducted in May, again resulted in reduced fathead minnow survival. A secondary confirmatory test conducted in June showed the water to be nontoxic; thus the toxicity appeared to be transient. Confirmatory tests using Ceriodaphnia were conducted in September and December. Both confirmatory tests resulted in NOECs of $100 \%$. To determine whether fathead minnow mortality in the ambient water samples might be caused by a fungal or bacterial pathogen, water from X13 and X14 was exposed to UV light for a 20 -min period. Tests of water from sites X13 and X14 showed improved fathead minnow survival or growth in water treated with UV light (NOECs were $100 \%)$.

\section{K-25 Site Toxicity Control and Monitoring Program}

The NPDES permit requires that toxicity testing be performed at Outfall 005 and Outfall 011. Accordingly, toxicity testing was conducted at Outfall 005 and Outfall 011 bimonthly until October 1993. Outfall 011 passed every toxicity test during the first year of the permit, and in accordance with the NPDES permit it was placed on a biannual testing schedule for 1994. It passed all toxicity tests that were conducted in 1995 . Outfall 005 passed all tests and was also placed on a biannual sampling schedule in July 1995.

The results of the toxicity tests of wastewaters from K-1407-J and K-1203 conducted during 1995 are given in Table 4.26. This table provides the month the test was conducted, the wastewater's no-observed-effect level (NOEL), and 96-hour lethal concentration for $50 \%$ of the test organisms $\left(\mathrm{LC}_{50}\right)$ for fathead minnows and Ceriodaphnia for each wastewater. Average water quality measures obtained during each toxicity test are shown in Table 4.27.

Effluent from K-1407-J (Outfall 011) was tested twice with fathead minnows and Ceriodaphnia. The effluent's NOELs were $75 \%$ on both occasions for fathead minnows and $25 \%$ and $75 \%$ for Ceriodaphnia. The $\mathrm{LC}_{50} \mathrm{~s}$ were $>75 \%$ for fathead minnows on both occasions, $>25 \%$ in the May tests, and $75 \%$ in the November test for Ceriodaphnia. The toxicity tests conducted for this outfall were within the limits specified by the NPDES permit. 
Table 4.26. 1995 K-25 Site NPDES Permit Number TN 0002950 toxicity tests results

\begin{tabular}{|c|c|c|c|c|c|}
\hline K-25 Site Outfall & Test date & Species & $\operatorname{NOEL}^{a}(\%)$ & $\mathbf{L C}_{50}^{b}(\%)$ & $\operatorname{IWC}^{c}(\%)$ \\
\hline \multirow[t]{4}{*}{ K-1407-J (Outfall 011) } & May & Fathead minnow & 75 & $>75$ & 0.72 \\
\hline & & Ceriodaphnia & 25 & $>25$ & 0.72 \\
\hline & November & Fathead minnow & 75 & $>75$ & 0.00018 \\
\hline & & Ceriodaphnia & 75 & $>75$ & 0.00018 \\
\hline \multirow[t]{8}{*}{ K-1203 (Outfall 005) } & January & Fathead minnow & 100 & $>100$ & 2.91 \\
\hline & & Ceriodaphnia & 100 & $>100$ & 2.91 \\
\hline & March & Fathead minnow & 100 & $>100$ & 1.99 \\
\hline & & Ceriodaphnia & 100 & $>100$ & 1.99 \\
\hline & May & Fathead minnow & 100 & $>100$ & 2 \\
\hline & & Ceriodaphnia & 100 & $>100$ & 2 \\
\hline & July & Fathead minnow & 100 & $>100$ & 1.6 \\
\hline & & Ceriodaphnia & 100 & $>100$ & 1.6 \\
\hline
\end{tabular}

\footnotetext{
${ }^{a}$ No-observable-effect level.

${ }^{b} 96$-hour lethal concentration for $50 \%$ of the test organisms.

${ }^{c}$ Instream waste concentration (based on critical low flow of Poplar Creek).
}

Table 4.27. $1995 \mathrm{~K} \cdot 25$ Site average water quality parameters measured during toxicity tests of the K-25 Site wastewaters. Values are averages of full-strength wastewater for each test $(N=7)$.

\begin{tabular}{llcccc}
\hline $\begin{array}{l}\text { K-25 Site } \\
\text { Outfall }\end{array}$ & Test date & $\begin{array}{c}\text { pH } \\
\text { (standard units) }\end{array}$ & $\begin{array}{c}\text { Conductivity } \\
(\mu \mathrm{S} / \mathbf{c m})\end{array}$ & $\begin{array}{c}\text { Alkalinity } \\
\left(\mathbf{m g} / \mathbf{C a C O}_{3}\right)\end{array}$ & $\begin{array}{c}\text { Hardness } \\
\left(\mathbf{m g} / \mathbf{L} \mathbf{C a C O}_{3}\right)\end{array}$ \\
\hline K-1407-J (011) & May & 8.21 & 2374 & 81 & 299 \\
& November & 7.95 & 1240 & 78 & 456 \\
K-1203 (005) & January & 8.06 & 303 & 109 & 130 \\
& March & 8.02 & 299 & 108 & 125 \\
& May & 8.09 & 290 & 85 & 124 \\
& July & 7.97 & 276 & 80 & 124 \\
\hline
\end{tabular}

Effluent from K-1203 was tested four times with fathead minnows and with Ceriodaphnia. In all four tests, full-strength samples did not reduce survival, growth, or reproduction. Thus the NOELs were $100 \%$ and the $L C_{50}$ s were $>100 \%$.

\section{BIOLOGICAL MONITORING AND ABATEMENT PROGRAM}

\section{Monitoring Contaminant Concentrations}

The BMAPs mandated by NPDES permits at the Y-12 Plant, ORNL, and the K-25 Site each contain tasks concerned with monitoring the accumulation of contaminants in the biota of receiving waters. The primary objectives of the contaminant-accumulation studies are (1) to identify substances that accumulate to undesirable levels in biota as a result of discharges from DOE facilities, (2) to determine the significance of those discharges relative to other sources in determining contaminant concentrations in biota in receiving waters, and (3) to provide a baseline measure of biotic contamination to use in evaluating the effectiveness of any future remedial measures. The nonradiological contaminants of most concern in biota have been found to be mercury and PCBs. Elevated concentrations (relative to local reference sites) of 


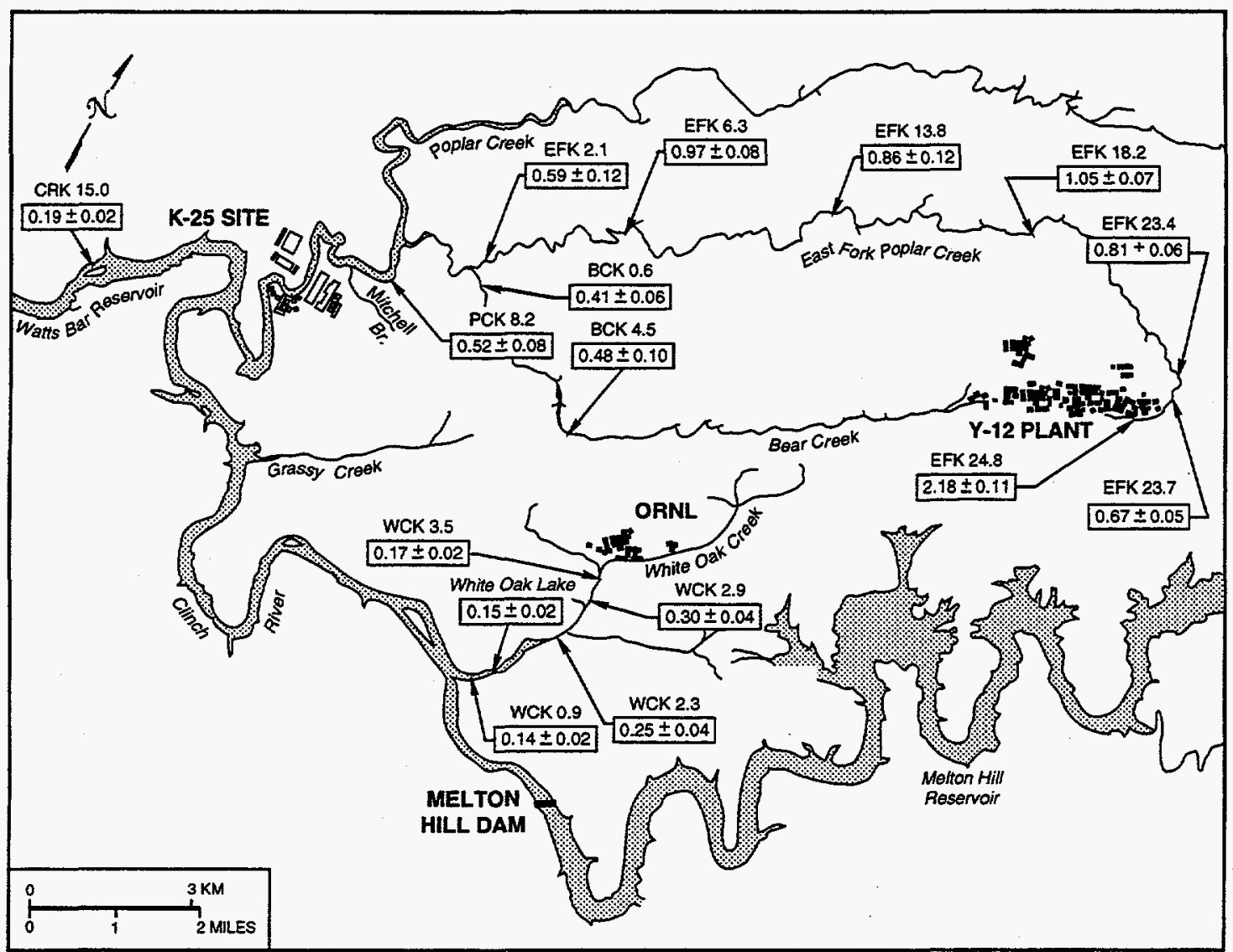

Fig. 4.31. Average concentrations ( \pm standard error) of mercury (in micrograms per gram) in sunfish collected from November 1994 to March 1995 at sites on the ORR. Fish are redbreast sunfish (Lepomis auritus) at East Fork Poplar Creek kilometer (EFK) sites and White Oak Creek kilometer (WCK) 2.9; rock bass (Ambloplites rupestris) at BCK sites; and bluegill ( $L$. macrochirus) at the remaining sites.

mercury and PCBs in biota are associated with discharges at all three facilities (Figs. 4.31 and 4.32).

From November 1994 to March 1995, the highest mercury concentrations in sunfish on the ORR continued to be in fish from EFPC (Fig. 4.31). Mean mercury concentrations in sunfish from the middle sections of East Fork (from EFK 6.3 to EFK 23.4) were similar, with lower mercury concentrations in fish from areas downstream [EFK 2.1, Poplar Creek kilometer (PCK) 6.9, Clinch River kilometer (CRK) 15.0]. The twofold to threefold higher concentrations in sunfish above Lake Reality suggests that Y-12 Plant discharges continue to be an important source of mercury in fish in the upper reaches of EFPC. In addition to EFPC, elevated concentrations of mercury were clearly evident in fish from Poplar Creek, Bear Creek, and WOC. Overall, mean mercury concentrations in fish in 1994/1995 on the ORR were similar to those observed in 1993-94.

A pattern of decreasing concentration with distance downstream is apparent for PCBs in redbreast sunfish in EFPC (Fig. 4.32). Redbreast sunfish from sites upstream of EFK 23.4 (EFK 23.7, EFK 24.8) contained PCB concentrations in December 1994 substantially higher than those observed in fish from other EFPC sites. The high concentrations in fish at sites in UEFPC indicate the importance of the industrialized portion of the Y-12 Plant as a source in relation to contaminated sediment and soil downstream of Lake Reality. Mean PCB concentrations in sunfish were also elevated in WOC and Bear Creek during the same time 


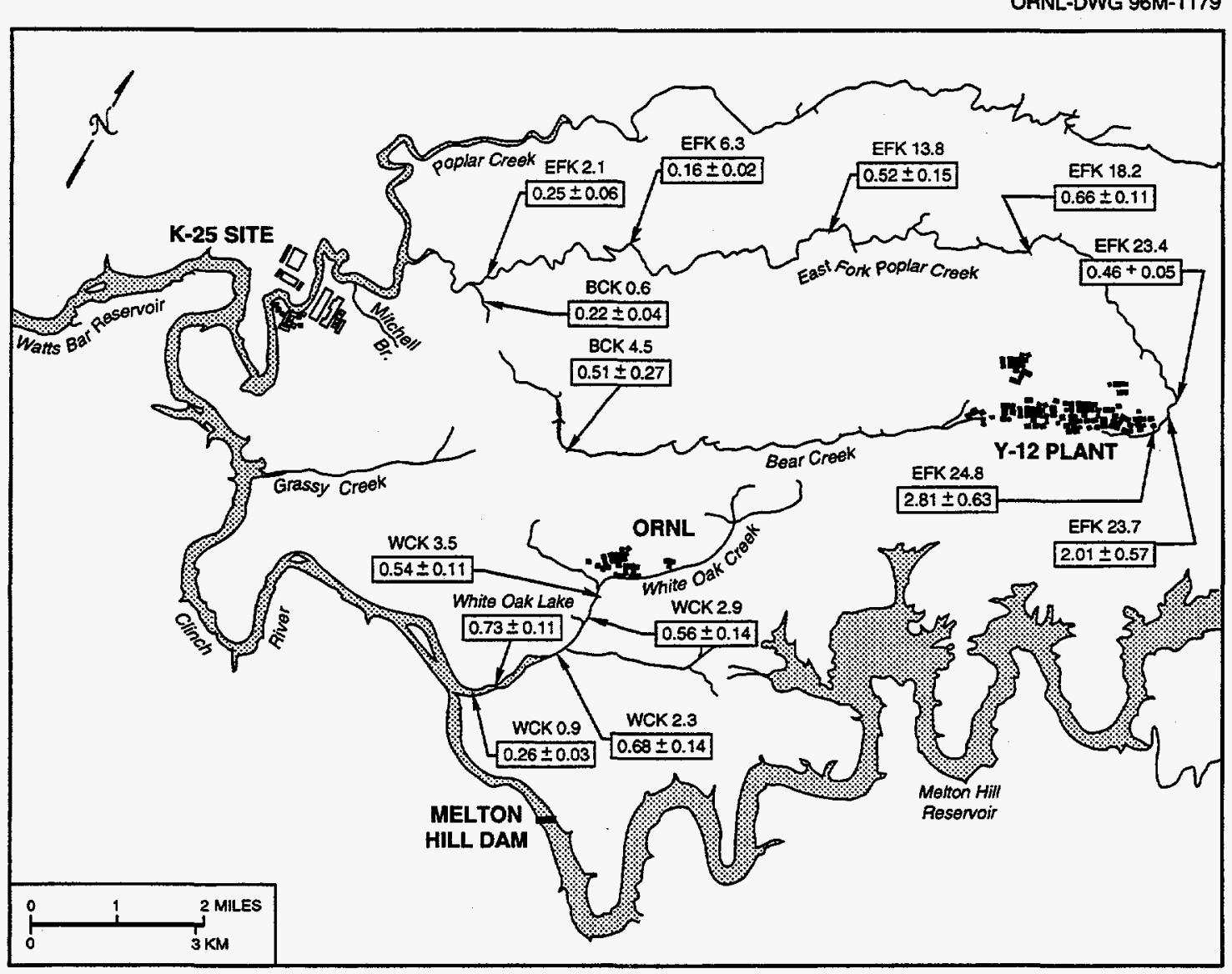

Fig. 4.32. Average concentrations ( \pm standard error) of PCBs (in micrograms per gram) in sunfish collected from November 1994 to March 1995 at sites on the ORR. Fish are redbreast sunfish (Lepomis auritus) at EFK sites and WCK 2.9; rock bass (Ambloplites rupestris) at BCK sites; and bluegill (L. macrochirus) at the remaining sites.

period. In general, mean $\mathrm{PCB}$ concentrations in sunfish collected in 1993-95 from EFPC and WOC are substantially higher than those observed in fish collected in previous years.

Toxicity tests on effluent from the two major liquid waste treatment plants at the K-25 Site (the K-1203 sewage treatment plant and the K-1407-J CNF) show that discharges from the plants are usually well within the permit limits, and often have no effect on survival, growth or reproduction even at full strength. The single exception occurred in the March 1994 testing of the sewage treatment plant effluent, when the fathead minnow survival was below the permit limit of a minimum No Observed Effect Limit of $4.2 \%$. A confirmatory test conducted later the same month produced results well within the permit limits. Toxicity tests on the CNF effluent have all produced results within the permit limits for the past two years. The tests at this outfall are scheduled to be discontinued, as a new outfall has been constructed directly on the Clinch River. Toxicity testing will not be required under the terms of the NPDES permit at this new outfall as the Clinch River as a much larger flow than Poplar Creek. Because of the consistently good test results, the testing frequency of effluent from the K-1203 sewage treatment plant was reduced to twice per year in July 1995.

While the NPDES permit does not have toxicity testing limits on stormwater discharges, testing is conducted to ensure that these discharges are not inimical to aquatic life. Discharges from two storm drains, SD-170 and SD-190, frequently demonstrate some impact to the test organisms. Some of the reduction in 
survival of fathead minnows in samples from various $K-25$ Site locations may be due to a naturally occurring pathogen. Water samples disinfected with UV light often show increased survival compared to untreated samples.

Toxicity tests on water from in-stream locations occasionally exhibit reduction in survival or reproduction of Ceriodaphnia, and reductions in fathead minnow survival also occur occasionally. As is the case for the storm drains, this reduction may largely be explained by the occurrence of a natural pathogen, such as a fungus or virus, as disinfection of the water samples often increase survival.

Bioaccumulation studies have been carried out by collecting fish or caged clams from the subject waters, and analyzing the soft tissue for contaminants of concern. Fish collected from Mitchell Branch and the K-901-A and K-1007-B ponds in 1994 showed elevated levels of PCBs when compared with fish from reference locations. Whole body analysis of prey fish (chiefly shad) likely to be preyed upon by terrestrial piscivores show that many contain levels of PCBs above the concentration shown to be detrimental to some predators, such as mink. Some fish collected from Poplar Creek also contained concentrations of mercury above the levels detrimental to mink. Caged clams placed in the pond and stream also showed detectable levels of PCBs. The results so far seem to indicate that one or more storm drains entering the pond carry PCBs, and that much of the PCBs deposited in the pond so far have remained in the pond, rather than migrating into Poplar Creek. A similar situation appears to exist in Mitchell Branch, but the levels of PCBs involved seem to be significantly lower. However, sunfish collected from various localities along Poplar Creek do not show much variation, indicating that the contribution of PCBs to Poplar Creek from the $\mathrm{K}-25$ Site is small. Waterfowl collected near the Site have not shown detectable levels of PCBs.

Raccoons feed upon fish and other aquatic organisms, so some have been trapped and analyzed. Lead, mercury, and cadmium have been found in the raccoons trapped near the $\mathrm{K}-25$ Site. The mercury concentrations were higher in those raccoons collected along EFPC.
This correlates with the elevated mercury levels found in the prey fish. Although no relative contribution can be quantified, all indications are that the $\mathrm{K}-25$ Site is a relatively small contributor of mercury to Poplar Creek. At this time, sources for the lead and cadmium cannot be determined.

Water taken from Mitchell Branch kilometer (MIK) 0.12 was tested on Medaka fish embryos, and proved toxic to them. Other fish health studies conducted on fish from Mitchell Branch show that these fish are stressed relative to the fish collected from the reference sites. This stress is evidenced by elevated levels of liver detoxification enzymes, gill and liver dysfunctions and changes, and by an abnormal population distribution of size and age class. In particular, there were very few individuals from the 1992 brood. However, fish born in 1992 were also scarce at the reference sites. It is possible that this scarcity may therefore reflect some widespread natural disturbance of breeding patterns that occurred in 1992. This, and the trends of the other indicators and the fact that the fish community as a whole seems to be rebounding, suggest that the stress is due to a variety of causes, and that some or all of them may be episodic in nature.

The community studies conducted in Mitchell Branch show that the stream has been impacted. Studies of the benthic macroinvertebrate fauna show that both species diversity and richness are below that of the reference sites. Although there has been considerable variation in the sample results through time, it does appear that Mitchell Branch is recovering. As the studies have progressed, there has also been a gradual increase in the number of fish species present in the creek, as well as in numbers of individuals.

In the summer of 1995, the K-25 Site program was modified. Several tasks were reduced in scope or frequency, and some subtasks were eliminated altogether. Toxicity testing was eliminated from Poplar Creek and the Clinch River, and the frequency was reduced at storm drain 180 , which has not historically exhibited toxicity in the effluent. Fathead minnow toxicity tests on storm drain effluent was also discontinued, as Ceriodaphnia tests have proven 
to be more sensitive. If a problem is found at any of the storm drains, fathead minnow tests will be reinstated. Fish bioaccumulation studies in Mitchell Branch and the $\mathrm{K}-1007$ Ponds were discontinued, as it has already been demonstrated that some contaminants are accumulating in fish from these waters. Similarly, whole body analysis of prey fish has been discontinued, as data sufficient for the present uses has already been collected. The assessment of fish health and the in-stream monitoring of Mitchell Branch have been discontinued for the present. In-stream monitoring will resume on a two year cycle, and the assessment of fish health may be re-instated after further remediation activities on the K-25 Site are completed. All of these modifications were made with the approval of the TDEC.

\section{Toxicity of Lithium Discharges to Oak Ridge Stream Is Mitigated by Sodium}

Routine compliance tests conducted for a groundwater treatment facility (GWTF) at the Oak Ridge Y-12 Plant showed that the facility's effuent was acutely toxic to Ceriodaphnia dubia (a microcrustacean) and fathead minnow (Pimephales promelas) larvae. Chemical analyses of GWTF effiuent identified lithium as a potential toxicant-a noticeable increase in toxicity corresponded to an increase in lithium. Because little information has been published on lithium toxicity to aquatic organisms, the Toxicology Laboratory in the Environmental Sciences Division at ORNL initiated an investigation to assess the toxicity of lithium and the possible mitigating effects of sodium. Tests conducted with fathead minnows, C. dubia, a snail (Elimia clavaeformis), and buttercrunch lettuce (Lactuca sativa) demonstrated that lithium was acutely toxic at concentrations as low as $1 \mathrm{mg} / \mathrm{L}$ and was the component of the GWTF effiuent responsible for decreasing the survival of $C . d u b i a$ and fathead minnows in laboratory tests. Tests with $\mathrm{LiCl}$ in combination with $\mathrm{Na}_{2} \mathrm{SO}_{4}$ demonstrated that the presence of sodium reduced the toxicity of lithium to $C$. dubia. Survival and reproduction of $C$. dubia exposed to $1-4 \mathrm{mg}$ of lithium $/ \mathrm{L}$ were not adversely affected when the molar ratio of $\mathrm{Na}: \mathrm{Li}$ was $\geq 2$. These findings are significant to the ORR because the sodium content of the receiving stream EFPC will likely render lithium discharged from the GWTF nontoxic. The findings are also applicable beyond the reservation because lithium is widely used in industry (e.g., lithium-aluminum alloys) and can accumulate in soils.

\section{Reduction of Aqueous Mercury Inputs to East Fork Poplar Creek Is Slow To Produce a Corresponding Decrease in Mercury Bioaccumulation in Fish}

Since 1980 , the RMPEs program at the Y-12 Plant has reduced average mercury concentrations and loading in upper EFPC by $-50 \%$ and $80 \%$, respectively. However, the expected corresponding decrease in mercury bioaccumulation in fish in EFPC has not occurred. Since 1985, mercury concentrations in redbreast sunfish have been monitored twice yearly at five sites in EFPC downstream from the Y-12 Plant as part of the BMAP and as required by the plant's NPDES permit. Although a striking decrease in mercury bioaccumulation in redbreast sunfish was observed from 1988 to 1991, following closure and replacement of New Hope Pond in upper EFPC, that decrease did not continue over the ensuing 3 years, and mean mercury concentrations in sunfish at the Y-12 Plant boundary have remained essentially unchanged for the entire post-New Hope Pond period. At sites located 5 and $10 \mathrm{~km}$ downstream from the boundary, mean mercury concentrations in sunfish have not exhibited an increasing or decreasing trend over the past 10 years. The expected response has probably been delayed and offset in part by biological responses to water quality improvements in upper EFPC. Reaches of EFPC upstream from the plant's boundary that once contained few fish now have fish population densities 3 to 5 times greater than reference sites. Biological activity in this reach of EFPC produces methylmercury, which is accumulated in fish and stream invertebrates. Because methylmercury in fish is efficiently 
recycled by food-chain transfer and the total mass of methylmercury present in the EFPC fish population is a significant fraction of the amount of methylmercury exported by annual base stream flow, this new reservoir of methylmercury in expanded fish populations in upper EFPC acts as a continuing source of methylmercury to aquatic life at downstream sites. Although this reservoir may delay the response in fish to elimination of mercury sources, reductions in aqueous mercury inputs should eventually translate into decreased mercury contamination in aquatic life.

\section{Sources of Contamination to Stream Biota Are Identified and Evaluated}

Past monitoring of stream biota on the DOE ORR identified high concentrations of mercury and PCBs in fish collected near the three DOE facilities. Resident fish suitable for use in bioaccumulation monitoring studies, however, were often not present in the shallow headwater areas nearest the facility discharges. A major objective of more recent monitoring was to identify and evaluate specific sources of bioavailable contamination in some of these headwater areas. Researchers placed uncontaminated Asiatic clams (Corbicula fluminea) in cages for 4-week exposure periods in an upstream reach of Mitchell Branch, a stream near the K-25 Site. A total of five cages of clams were placed upstream and downstream of each of four locations - three major storm drains (SD170, SD180, and SD190) and a sediment deposition area of the stream-to ascertain the relative $\mathrm{PCB}$ contributions, if any, from these sources. Whereas mean $\mathrm{PCB}$ concentrations in clams were similar at the three most upstream cage sites, they were nearly double the concentrations at the site downstream of SD190. The mean PCB concentration in clams placed at the lowermost site (i.e., in the sediment deposition area) was approximately one-third higher than the concentration in clams placed downstream of SD190, suggesting that the sediment deposition area was also a source of PCBs to downstream waters. To evaluate mercury bioavailability in Mitchell Branch and in Bear Creek, a stream near the Y-12 Plant, researchers caged blacknose dace (Rhinichthys atratulus), a common stream minnow, in these streams for 12-week exposure periods. Although mercury concentrations in the caged dace were found to be relatively low, the concentrations were high enough to indicate that the two streams contain sources of biologically available mercury atypical of background conditions in East Tennessee. Overall, use of these caged sentinels, in conjunction with monitoring of resident sunfish, was successful in identifying and evaluating some of the small (but potentially significant) point sources of contamination to aquatic life.

\section{Fish Communities in Mitchell Branch Are Recovering Following Remedial Actions}

Ecological monitoring of Mitchell Branch, which originates near the northeast boundary of the K-25 Site, was initiated in September 1986. To identify impacts and to document recovery resulting from remedial actions, surveys of fish communities were conducted at two monitoring sites: MIK 0.71, which is located downstream of SD-170, and MIK 0.45, which is located downstream of all major effluents. Assessments of fish communities included species richness (number of species) and fish density (number per unit area). The fish communities at the two sites consisted of only three species in 1986 and 1987; fish were absent at these sites from 1988 through 1990 . However, several remedial actions were taken during the period 1987-94 to improve the water quality in Mitchell Branch. Following these remedial actions, the fish communities began to recover. Total fish species at the two monitoring sites increased gradually from two in 1991 to ten in 1994. Although five of the ten species were represented by only a few individuals, which do not represent stable populations, their presence may be indicative of improving water quality conditions within Mitchell Branch. Individual fish densities for the more common species have fluctuated throughout the 1986-94 sampling period. Populations of central stoneroller (Campostoma 
anomalum), blacknose dace (Rhinichthys atratulus), creek chub (Semotilus atromaculatus), banded sculpin (Cottus carolinae), and redbreast sunfish (Lepomis auritus) appear to be well established but may continue to change as the fish communities change. Stabilization of species richness and densities is expected to occur in the later stages of recovery.

\section{Cessation of Fly Ash Discharges to McCoy Branch Leads to Recovery of the Benthic Macroinvertebrate Community}

From 1955 through 1988, the steam plant of DOE's Oak Ridge Y-12 Plant sluiced all fly ash and bottom ash generated during operations into the headwaters of McCoy Branch. In late 1988, coal usage and discharges had declined by $-40 \%$. Beginning in late 1989 , all discharges of ash were sluiced directly to a quarry that transected the stream, $-1 \mathrm{~km}$ from the ash's original point of entry. A biological monitoring program was implemented in 1989 to help evaluate the ecological condition of the stream and the response of the biota to these changes in ash discharges. As a component of this program, the benthic macroinvertebrate community was surveyed from April 1989 through October 1993 at two sites in McCoy Branch (one just upstream and one downstream of the quarry) and at one site in a nearby, relatively unimpacted reference stream. Community structure was evaluated with the following indices: total richness; richness of Ephemeroptera, Plecoptera, and Trichoptera (EPT); and abundances of EPT taxa. During the first year of the survey, these indices were substantially lower in McCoy Branch-particularly upstream of the quarry-than at the reference site, implying that ash discharges were adversely affecting the macroinvertebrate community. However, after January 1990, marked increases were observed in total richness, EPT richness, and relative abundances of EPT taxa in McCoy Branch; these increases persisted through 1993. Although indices of benthic community structure for McCoy Branch continue to show evidence of slight ecological impact, they generally fall within or near the ranges of indices typical of local reference streams. Documenting these changes demonstrates the importance of using long-term benthic macroinvertebrate studies to evaluate the effectiveness of abatement activities and remedial actions. 


\section{Environmental Surveillance}

M. A. Bogle, M. L. Coffey, K. G. Hanzelka, J. F. Hughes, H. B. McElhoe, I. D. Shelton, and

M. M. Stevens

\section{Abstract}

Annual environmental surveillance is a major activity on the ORR. Environmental surveillance consists of the collection and analysis of samples of air, water, soil, foodstuffs, biota, and other media from the reservation and its surroundings. External radiation is also measured. Samples are analyzed for chemical content and for the presence of radioisotopes. Data collected from environmental surveillance activities are used to demonstrate compliance with applicable standards, to assess exposures to members of the public, and to assess effects (if any) on the local population, and the environment.

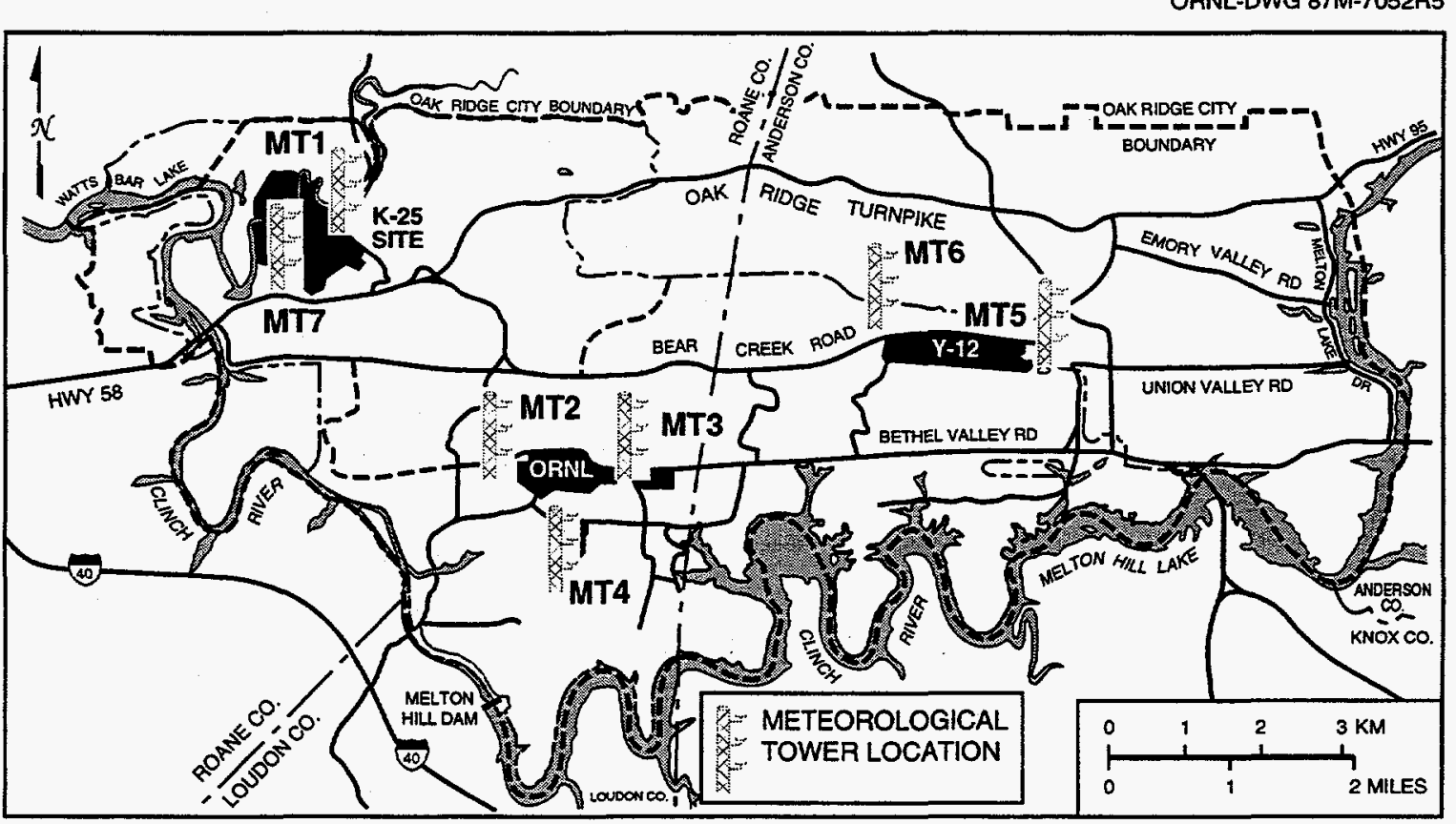

Fig. 5.1. The ORR meteorological monitoring network.

\section{METEOROLOGICAL MONITORING}

Seven meteorological towers provide data on meteorological conditions and on the transport and diffusion qualities of the atmosphere on the ORR. Data collected at the towers are used in routine dispersion modeling to predict impacts from facility operations and as input to emergency response atmospheric models used in the event of accidental releases from a facility. Data from the towers are also used to support various research and engineering projects.

\section{Description}

The seven meteorological towers, depicted in Fig. 5.1, consist of one $330-\mathrm{ft}(100-\mathrm{m})$ tower (MT5) and one 200-ft (60-m) tower (MT6) at the Y-12 Plant, one 330-ft tower (MT2) and two 100-ft towers (MT3 and MT4) at ORNL, and one 
200-ft tower (MT1) and one 100-ft (MT7) tower at the K-25 Site.

Data are collected at different levels to determine the vertical structure of the atmosphere and the possible effects of vertical variations on releases from facilities. At all towers, data are collected at $32.8 \mathrm{ft}$ and at the top of the tower. At the 330- $\mathrm{ft}$ towers, data are collected at an intermediate $100-\mathrm{ft}$ level as well. At each measuring level on each tower, temperature, wind speed, and wind direction are measured. Humidity and data needed to determine atmospheric stability (a measure of the dispersive capability of the atmosphere) are also measured at each tower. Barometric pressure is measured at one tower at each facility. Precipitation is measured at MT1 and MT7 at the $\mathrm{K}-25$ Site and at MT2 at ORNL; solar radiation is measured at MT2.

Data from the towers at each site are collected by a dedicated control computer at that site. The towers are polled, and the data are filed on disk. Fifteen-minute and hourly values are stored at each site for a running 24-hour period, but only hourly data are routinely stored beyond 24 hours. The meteorological monitoring data from all towers are summarized quarterly at the Y-12 Plant and monthly at ORNL and the K-25 Site. Quarterly calibration of the instruments is conducted for each site by an outside contractor.

Fifteen-minute and hourly data are used directly at each site computer for emergency-response purposes such as input to dispersion models. Annual dose estimates are calculated from archived data (either hourly values or summary tables of atmospheric conditions). Data quality is checked continuously against predetermined data constraints, and out-of-range parameters are marked invalid and are not input to the dispersion models.

\section{Results}

Prevailing winds are generally up-valley from the southwest and west southwest or down-valley from the nor heast and east-northeast. This pattern is the result of the channeling effect of the ridges flanking the site.
Winds in the valleys tend to follow the ridges, with limited cross-ridge flow. These conditions are dominant over the entire reservation, with the exception of the K-25 Site, which is located in a relatively open area that has a more varied flow. Weaker valley flows are noted in this area, particularly in locations near the Clinch River.

On the reservation, low-speed winds predominate at the surface level. This characteristic is noted at all tower locations, as is the increase in wind speed at the height at which measurements are made. This activity is typical of tower locations and is important when selecting appropriate data for input to dispersion studies.

The atmosphere over the reservation is dominated by stable conditions on most nights and in early morning hours. These conditions, coupled with the low wind speeds and channeling effects of the valleys, result in poor dilution of material emitted from the facilities. These features are captured in the data input to the dispersion models and are reflected in the modeling studies conducted for each facility.

Precipitation data from tower MT2 are used in stream-flow modeling and in certain research efforts. The data indicate the variability of regional precipitation: the high winter rainfall amounts resulting from frontal storms and the uneven, but occasionally intense, summer rainfall associated with thunderstorms.

The average data capture efficiency (a measure of acceptable data) across all locations and at the 16 tower levels was $98.3 \%$ in 1995 . The maximum capture efficiency was $99.9 \%$ at Y-12 MTW at $60 \mathrm{~m}$, and the minimum capture efficiency was $97 \%$ at ORNL MT3 at $10 \mathrm{~m}$.

\section{EXTERNAL GAMMA RADIATION MONITORING}

External gamma radiation measurements are made to determine whether routine radioactive effluents from the ORR are increasing external radiation levels significantly above normal background levels.

\section{5-2 Environmental Surveillance}




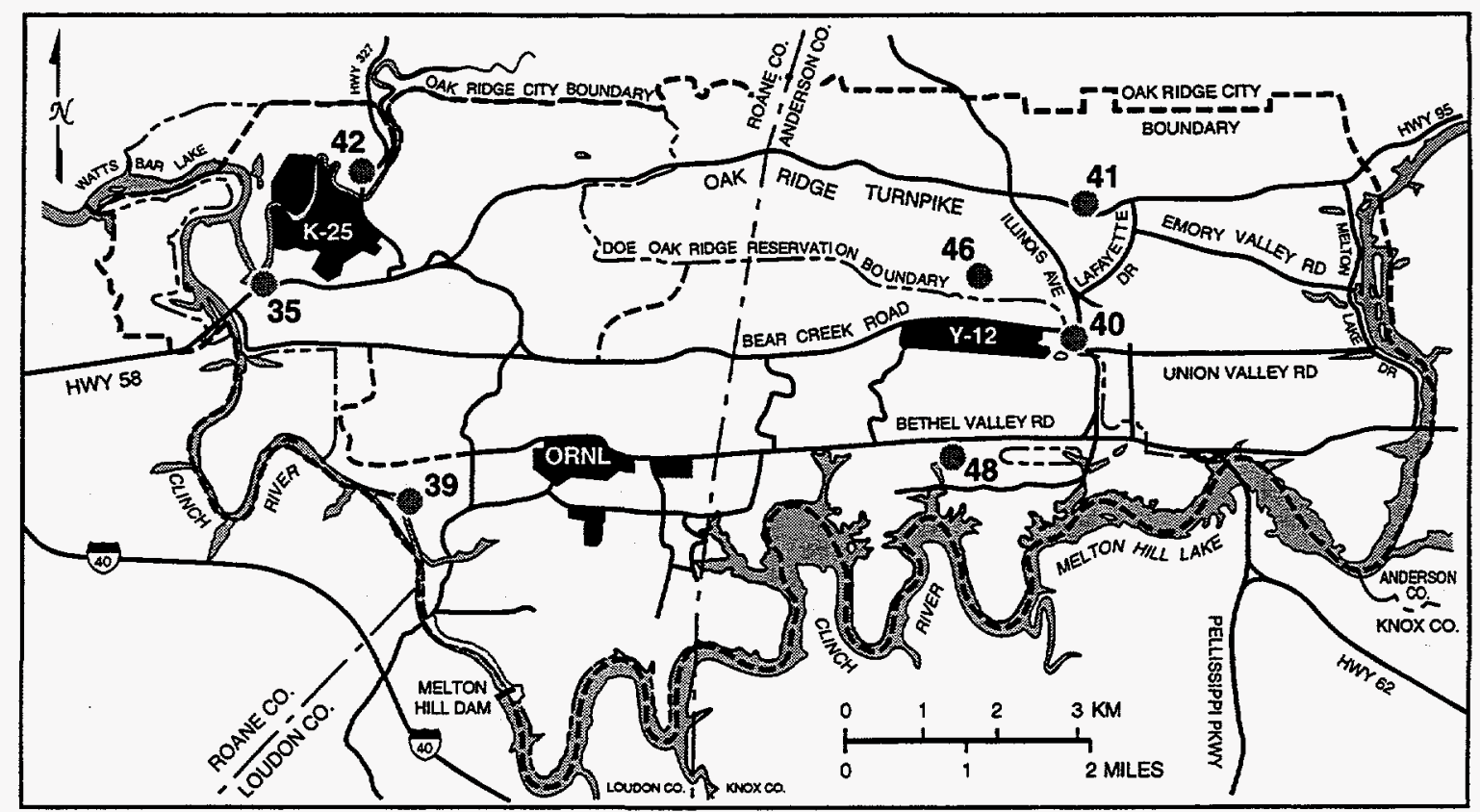

Fig. 5.2. External gamma radiation monitoring locations on the ORR.

Table 5.1. External gamma averages, 1995

\begin{tabular}{cccccc}
\hline Location & $\begin{array}{c}\text { Number of } \\
\text { samples }\end{array}$ & \multicolumn{3}{c}{ Measurement $(\mu \mathrm{R} / \mathrm{hour})$} & $\begin{array}{c}\text { Standard error } \\
\text { of mean }\end{array}$ \\
\cline { 3 - 5 } & & Min & Max & Mean $^{a}$ & \\
\hline 39 & 51 & 0.4 & 9.9 & 7.5 & 0.41 \\
40 & 47 & 7.3 & 14.5 & 8.0 & 0.16 \\
41 & 50 & 1.7 & 21.9 & 9.0 & 0.52 \\
42 & 50 & 4.1 & 8.8 & 6.9 & 0.10 \\
46 & 48 & 2.8 & 16.3 & 8.5 & 0.27 \\
48 & 50 & 6.8 & 7.7 & 7.0 & 0.03 \\
51 & 50 & 6.2 & 10.2 & 7.7 & 0.10 \\
\hline
\end{tabular}

${ }^{a}$ To convert microroentgens per hour to milliroentgens per year, multiply by 8.766 .

\section{Sample Collection and Analytical Procedures}

External gamma measurements are recorded weekly at six ambient air stations (Fig. 5.2). In addition, measurements were collected at the American Museum of Science and Energy (Station 41).

\section{Results}

Table 5.1 presents the following data for individual stations: number of measurements, maximum value, minimum value, average value, and standard error of the mean. The median value for the ORR in 1995 was $7.6 \mu R /$ hour, while the median value for cities in the United States during 1989 was $9.3 \mu \mathrm{R} /$ hour (EPA 1990). Any contribution to the external gamma signature by the DOE facilities is not distinguishable at the ORR perimeter air monitoring station (PAM) locations.

\section{AMBIENT AIR MONITORING}

In addition to stack monitoring conducted at the DOE Oak Ridge installations, ambient air 
ORNL-DWG 92M-5318R2

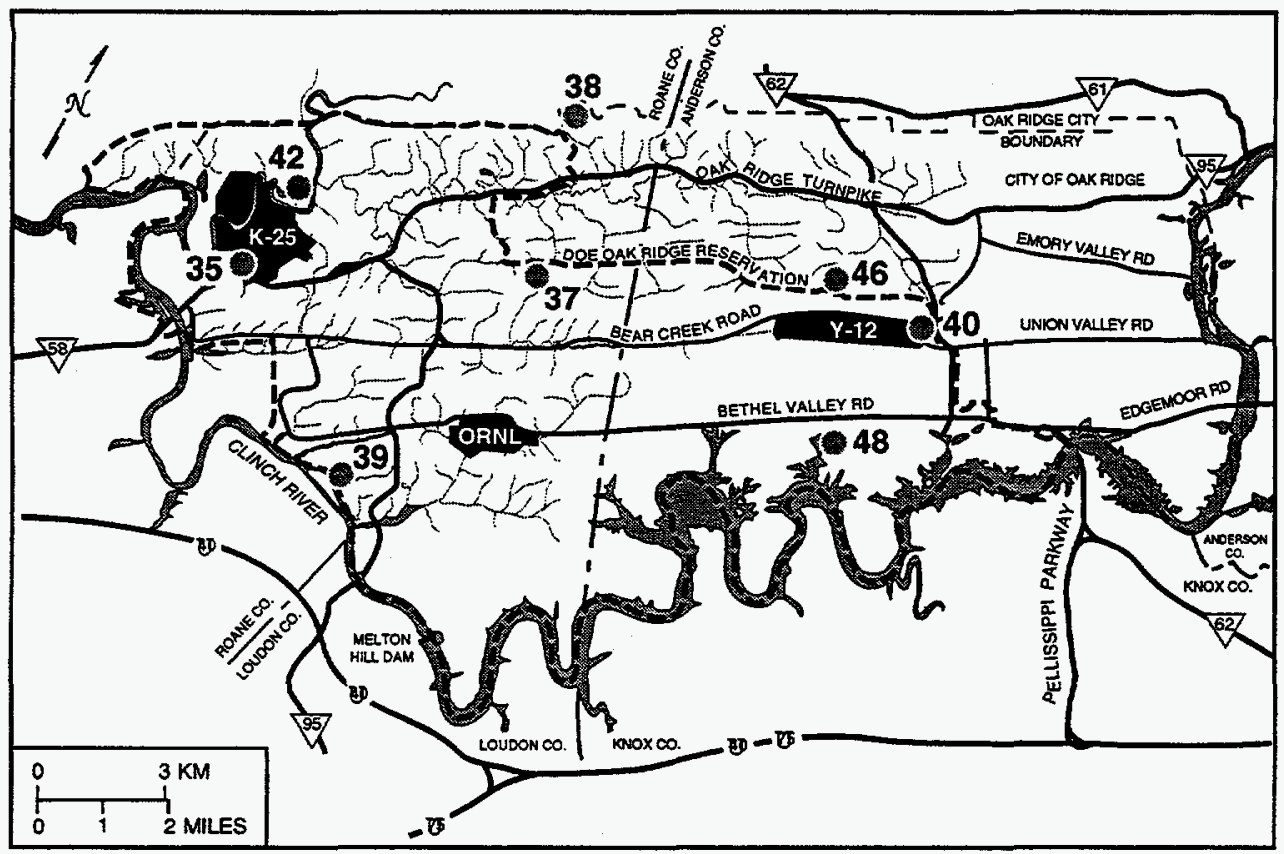

Fig. 5.3. Location of ORR perimeter air monitoring stations. Not shown are remote air monitoring station 51 (at Norris Dam, 26 miles northeast of ORNL) and station 52 (at Fort Loudoun Dam, 10 miles southeast of ORNL). The ORR stations also serve as soil sampling locations.

monitoring is performed to measure radiological and other selected parameters directly in the ambient air adjacent to the facilities. Ambient air monitoring provides direct measurement of airborne concentrations of radionuclides and other hazardous pollutants in the environment surrounding the facilities, allows facility personnel to determine the relative level of contaminants at the monitoring locations during an emergency, verifies that the contributions of fugitive and diffuse sources are insignificant, and serves as a check on dose-modeling calculations.

The following sections discuss the ambient air monitoring networks for the ORR, the Y-12 Plant, ORNL, and the K-25 Site.

\section{ORR Ambient Air Monitoring}

The objectives of the ORR ambient air monitoring program are (1) to perform surveillance of airborne radionuclides at the reservation perimeter and (2) to collect reference data from remote locations. The ORR PAM network associated with objective 1 includes stations $35,37,38,39,40,42,46$, and 48 (Fig. 5.3); the remote air monitoring (RAM) network (objective 2) consists of stations 51 (Norris Dam) and 52 (Fort Loudoun Dam). Sampling was conducted at each ORR station to quantify levels of alpha-, beta-, and gamma-emitting radionuclides, tritium, beryllium, and total radioactive strontium during 1995.

Atmospheric dispersion modeling was used to select appropriate sampler locations. The locations selected are those most likely to be affected by routine releases from the Oak Ridge facilities. Therefore, it is predicted that no residence or business in the vicinity of the ORR would be affected by undetected releases of radioactive materials. To provide an estimate of background radionuclide concentrations, two additional stations are located at sites not affected by releases from the ORR.

The sampling system consists of two separate instruments. The particulates are captured using a high-volume air sampler on glass fiber filters. The filters are collected weekly, composited every 4 weeks, then submitted to the laboratory for isotopic analysis. The second system is designed to collect tritiated 
water vapor. The sampler consists of a prefilter followed by an adsorbent trap consisting of indicating silica gel. The samples are collected weekly, composited monthly, then submitted to the laboratory for tritium analysis.

The ORR ambient air network (Fig. 5.3) provides appropriate monitoring for all facilities within the reservation, which eliminates the necessity for site-specific programs ambient air programs. As part of the ORR network, an ambient air monitoring station located in the Scarboro Community of Oak Ridge (Station 46) measures off-site impacts of Y-12 Plant operation, and is located near the theoretical area of maximum public pollutant concentrations as calculated by air-quality modeling. Station 40 of the ORR network monitors the east end of the Y-12 Plant, and Station 37 monitors the overlap of Y-12 Plant, ORNL, and K-25 Site emissions.

\section{Results}

The ORR PAM stations assess the impact to air quality of operations on the entire reservation. The RAM stations provide information on reference concentrations of radionuclides and gross parameters for the region. A comparison of DCG percentages for the ORR PAM station sampling data with those from the RAM stations shows that ORR operations do not significantly affect local air quality (Tables 5.2 and 5.3).

Table 5.4 represents the average concentration of three isotopes of uranium at each station for sampling years 1992, 1993, 1994, and 1995.

\section{Y-12 Plant Ambient Air Monitoring}

In 1994, Y-12 Plant personnel issued Evaluation of the Ambient Air Monitoring Program at the Oak Ridge Y-12 Plant (Energy Systems 1994a) and worked with the DOE and TDEC in reviewing the ambient air program for applicability and usefulness of the data. There are no federal regulations, state regulations, or DOE orders that require this monitoring. All ambient air monitoring systems at the Y-12 Plant are operated as a best management practice. With the reduction of plant operations and improved emission and administrative controls, levels of measured pollutants have decreased significantly during the past several years. In addition, processes that result in the emission of enriched and depleted uranium are equipped with stack samplers that have been reviewed and approved by the EPA to meet requirements of the NESHAP regulations. ORR air sampling stations, operated by ORNL in accordance with DOE orders, are located around the reservation. Their locations ensure that areas of potentially high exposure to the public are monitored continuously for parameters of concern.

With agreement from TDEC personnel, the ambient air sampling program at the Y-12 Plant has been significantly reduced, effective at the end of 1994. All fluoride, total suspended particulates (TSP), and particulate matter less than 10 microns in diameter (PM10) sampling has been discontinued, and all but 3 of the 12 uranium samplers have been shut down. The mercury sampling program will continue to monitor ambient air level concentrations as a result of remediation and decommissioning and decontamination activities.

The following types of ambient air monitoring systems were operated by the Y-12 Plant in 1995:

- three low-volume uranium particulate monitoring stations and

- four mercury monitoring stations.

The locations of these monitoring stations are shown in Fig. 5.4.

\section{Uranium}

Samples for routine measurement of uranium particulate were collected by pulling ambient air through a square $14-\mathrm{cm}$ (5.5-in.) filter, which was analyzed by the Y-12 Plant Analytical Services Organization for total uranium and for the percentage of ${ }^{235} \mathrm{U}$. Prior to 1993 , the samples were analyzed for gross alpha and beta and for activity levels of specific uranium isotopes; however, in 1993, the analysis program for radionuclides was revised as described in 
Table 5.2. ORR environmental surveillance multimedia by station ${ }^{a, b}$

\begin{tabular}{|c|c|c|c|c|c|c|c|c|c|c|c|}
\hline Media & ${ }^{7} \mathrm{Be}$ & ${ }^{60} \mathrm{Co}$ & ${ }^{137} \mathrm{Cs}$ & ${ }^{40} \mathbf{K}$ & ${ }^{3} \mathbf{H}$ & ${ }^{234} \mathbf{U}$ & ${ }^{235} \mathbf{U}$ & ${ }^{238} \mathbf{U}$ & Total U & Gross alpha & Gross beta \\
\hline \multicolumn{12}{|c|}{ Station 35} \\
\hline Air filter & $1.6 E-13$ & $4.3 \mathrm{E}-17$ & $7.6 \mathrm{E}-17$ & $3.8 \mathrm{E}-15$ & $c$ & $1.5 E-17$ & $4.4 E-19$ & $1.8 \mathrm{E}-17$ & $d$ & $2.6 \mathrm{E}-15$ & $6.7 E-15$ \\
\hline Tomatoes & $d$ & $d$ & $d$ & $d$ & $d$ & $d$ & $d$ & $d$ & $d$ & $d$ & $d$ \\
\hline Lettuce & $1.0 \mathrm{E}+00$ & $c$ & $c$ & $1.2 \mathrm{E}+0 \mathrm{I}$ & $d$ & $d$ & $d$ & $d$ & $c$ & $1.1 \mathrm{E}-01$ & $3.5 E+00$ \\
\hline Turnips & $c$ & $c$ & $c$ & $c$ & $d$ & $d$ & $d$ & $d$ & $7.6 \mathrm{E}-03$ & $c$ & $c$ \\
\hline Soil & $d$ & $c$ & $6.8 \mathrm{E}-02$ & $5.8 \mathrm{E}+00$ & $d$ & $1.5 \mathrm{E}-01$ & $c$ & $c$ & $d$ & $1.6 \mathrm{E}+00$ & $5.3 E+00$ \\
\hline \multicolumn{12}{|c|}{ Station 37} \\
\hline Air filter & $1.7 \mathrm{E}-13$ & $3.7 E-17$ & $3.7 \mathrm{E}-17$ & $4.7 \mathrm{E}-15$ & $c$ & $1.3 \mathrm{E}-17$ & $1.4 \mathrm{E}-18$ & $1.3 \mathrm{E}-17$ & $d$ & $2.4 E-15$ & $6.3 \mathrm{E}-15$ \\
\hline Tomatoes & $c$ & $c$ & $5.4 \mathrm{E}-04$ & $2.7 \mathrm{E}+0.0$ & $d$ & $d$ & $d$ & $d$ & 8.1E-04 & $4.6 \mathrm{E}-02$ & $1.4 \mathrm{E}+00$ \\
\hline Lettuce & $7.0 \mathrm{E}-01$ & $c$ & $c$ & $1.4 \mathrm{E}+01$ & $d$ & $d$ & $d$ & $d$ & $c$ & $1.8 \mathrm{E}-01$ & $3.2 \mathrm{E}+00$ \\
\hline Turnips & $c$ & $c$ & $c$ & $3.2 \mathrm{E}+00$ & $d$ & $d$ & $d$ & $d$ & $c$ & $c$ & $2.7 \mathrm{E}+\infty$ \\
\hline Soil & $d$ & $c$ & $c$ & $7.6 \mathrm{E}+00$ & $d$ & $c$ & $1.4 \mathrm{E}-02$ & $4.7 \mathrm{E}-01$ & $d$ & $c$ & $3.1 \mathrm{E}+00$ \\
\hline \multicolumn{12}{|c|}{ Station 38} \\
\hline Air filter & $1.6 \mathrm{E}-13$ & $4.0 \mathrm{E}-17$ & $2.8 \mathrm{E}-17$ & $4.8 \mathrm{E}-15$ & $c$ & $1.1 \mathrm{E}-17$ & $2.7 \mathrm{E}-19$ & $1.1 \mathrm{E}-17$ & $d$ & $2.1 \mathrm{E}-15$ & $5.5 \mathrm{E}-15$ \\
\hline Tomatoes & $c$ & $4.6 \mathrm{E}-03$ & $2.4 \mathrm{E}-03$ & $2.7 E+00$ & $d$ & $d$ & $d$ & $d$ & $2.2 \mathrm{E}-03$ & $c$ & $9.5 \mathrm{E}-01$ \\
\hline Lettuce & $1.0 \mathrm{E}+00$ & $c$ & $4.3 E-02$ & $1.4 \mathrm{E}+01$ & $d$ & $d$ & $d$ & $d$ & $c$ & $1.1 \mathrm{E}-01$ & $3.2 \mathrm{E}+00$ \\
\hline Turnips & $c$ & $c$ & $c$ & $3.5 \mathrm{E}+00$ & $d$ & $d$ & $d$ & $d$ & $c$ & $c$ & $2.7 \mathrm{E}+\infty 0$ \\
\hline Soil & $d$ & $4.7 E-02$ & $4.3 E-02$ & $5.3 E+00$ & $d$ & $2.0 \mathrm{E}-0 \mathrm{I}$ & $9.9 \mathrm{E}-03$ & $1.8 \mathrm{E}-01$ & $d$ & $2.1 E+00$ & $8.0 \mathrm{E}+00$ \\
\hline \multicolumn{12}{|c|}{ Station 39} \\
\hline Air filter & $1.4 \mathrm{E}-13$ & $4.2 \mathrm{E}-17$ & $4.3 \mathrm{E}-17$ & $5.5 \mathrm{E}-15$ & $8.6 E-12$ & $1.1 \mathrm{E}-17$ & $1.1 \mathrm{E}-18$ & $9.1 \mathrm{E}-18$ & $d$ & $2.1 \mathrm{E}-15$ & $5.0 \mathrm{E}-15$ \\
\hline Tomatoes & $c$ & $c$ & $8.7 \mathrm{E}-03$ & $1.7 \mathrm{E}+00$ & d & $d$ & $d$ & $d$ & $3.0 \mathrm{E}-03$ & $c$ & $1.1 \mathrm{E}+00$ \\
\hline Lettuce & $9.2 \mathrm{E}-01$ & $c$ & $c$ & $1.3 E+01$ & $d$ & $d$ & $d$ & $d$ & $4.9 E-02$ & 4.1E-01 & $3.8 \mathrm{E}+00$ \\
\hline Turnips & $c$ & $c$ & $c$ & $3.2 \mathrm{E}+00$ & $d$ & $d$ & $d$ & $d$ & $c$ & $2.4 \mathrm{E}-02$ & $2.1 \mathrm{E}+00$ \\
\hline Soil & $d$ & $c$ & $c$ & $c$ & $d$ & $c$ & $c$ & $c$ & $d$ & $c$ & $c$ \\
\hline \multicolumn{12}{|c|}{ Station 40} \\
\hline Air filter & $1.4 \mathrm{E}-13$ & $5.2 \mathrm{E}-17$ & $2.4 \mathrm{E}-17$ & $4.1 E-15$ & $c$ & $5.1 \mathrm{E}-17$ & $3.4 \mathrm{E}-18$ & $1.6 \mathrm{E}-17$ & $d$ & $2.4 \mathrm{E}-15$ & $5.9 E-15$ \\
\hline Tomatoes & c & $c$ & $c$ & $3.2 \mathrm{E}+00$ & $d$ & $d$ & $d$ & $d$ & $7.6 \mathrm{E}-04$ & $2.7 \mathrm{E}-03$ & $1.5 E+00$ \\
\hline Lettuce & $3.8 \mathrm{E}-01$ & $c$ & $c$ & $4.6 \mathrm{E}+00$ & $d$ & $d$ & $d$ & $d$ & $1.8 \mathrm{E}-02$ & $2.2 \mathrm{E}-01$ & $3.2 \mathrm{E}+00$ \\
\hline Turnips ${ }^{e}$ & $c$ & $c$ & $c$ & $c$ & $d$ & $d$ & $d$ & $d$ & $c$ & $c$ & $2.1 E+\infty 0$ \\
\hline Soil & $d$ & $c$ & $c$ & $c$ & $d$ & $2.5 \mathrm{E}-01$ & $c$ & $2.5 E-01$ & $d$ & $1.9 \mathrm{E}+00$ & $2.4 \mathrm{E}+00$ \\
\hline \multicolumn{12}{|c|}{ Station 42} \\
\hline Air filter & $1.5 \mathrm{E}-13$ & $6.0 \mathrm{E}-17$ & $5.3 E-17$ & $3.0 \mathrm{E}-15$ & $5.6 \mathrm{E}-12$ & $1.1 \mathrm{E}-17$ & $1.3 \mathrm{E}-18$ & $1.1 \mathrm{E}-17$ & $d$ & $2.0 \mathrm{E}-15$ & $5.3 E-15$ \\
\hline Tomatoes & $c$ & $c$ & $c$ & $3.0 \mathrm{E}+00$ & $d$ & $d$ & $d$ & $d$ & $7.6 \mathrm{E}-04$ & $2.7 E-03$ & $1.5 E+00$ \\
\hline Lettuce & $1.2 \mathrm{E}+00$ & $c$ & $c$ & $1.2 \mathrm{E}+01$ & $d$ & $d$ & $d$ & $d$ & $c$ & $1.7 \mathrm{E}-01$ & $3.0 E+00$ \\
\hline Turnips & $c$ & c & $c$ & $3.2 \mathrm{E}+00$ & $d$ & $d$ & $d$ & $d$ & $c$ & $c$ & $2.2 E+00$ \\
\hline Soil & $d$ & $c$ & $c$ & $c$ & $d$ & $c$ & $c$ & $3.1 \mathrm{E}-01$ & $d$ & $c$ & $2.7 E+\infty$ \\
\hline \multicolumn{12}{|c|}{ Station 46} \\
\hline Air filter & $1.6 \mathrm{E}-13$ & $2.4 \mathrm{E}-17$ & $2.0 \mathrm{E}-17$ & $3.2 \mathrm{E}-15$ & 4.1E-12 & $2.6 E-17$ & $1.7 \mathrm{E}-18$ & $1.1 \mathrm{E}-17$ & $d$ & $2.1 \mathrm{E}-15$ & $5.9 \mathrm{E}-15$ \\
\hline Tomatoes & $c$ & $c$ & $7.8 \mathrm{E}-03$ & $2.0 \mathrm{E}+00$ & $d$ & $d$ & $d$ & $d$ & $1.4 \mathrm{E}-03$ & $2.7 \mathrm{E}-03$ & $1.6 \mathrm{E}+00$ \\
\hline Lettuce & $8.9 E-01$ & $c$ & $c$ & $1.4 E+01$ & $d$ & $d$ & $d$ & $d$ & $c$ & $1.1 \mathrm{E}-01$ & $2.4 \mathrm{E}+00$ \\
\hline Turnips & $c$ & $c$ & $c$ & $2.7 \mathrm{E}+00$ & $d$ & $d$ & $d$ & $d$ & $c$ & $1.9 \mathrm{E}-01$ & $1.9 E+00$ \\
\hline Soil & $d$ & $c$ & $c$ & $c$ & $d$ & $c$ & $c$ & $3.9 \mathrm{E}-01$ & $d$ & $2.1 \mathrm{E}+00$ & $c$ \\
\hline \multicolumn{12}{|c|}{ Station 48} \\
\hline Air filter & $1.5 \mathrm{E}-13$ & $7.4 \mathrm{E}-17$ & $2.7 \mathrm{E}-17$ & $4.2 \mathrm{E}-15$ & $6.9 \mathrm{E}-12$ & $1.3 \mathrm{E}-17$ & $1.0 \mathrm{E}-18$ & $9.5 E-18$ & $d$ & $2.4 \mathrm{E}-15$ & $6.2 E-15$ \\
\hline Tomatoes & $c$ & $c$ & $c$ & $3.0 \mathrm{E}+00$ & $d$ & $d$ & $d$ & $d$ & $8.1 E-04$ & $c$ & $1.5 E+00$ \\
\hline Lettuce & $1.1 \mathrm{E}+00$ & $c$ & $c$ & $1.3 E+01$ & $d$ & $d$ & $d$ & $d$ & $3.5 E-02$ & $2.2 \mathrm{E}-01$ & $3.2 \mathrm{E}+00$ \\
\hline Turnips & $c$ & $c$ & $c$ & $3.0 \mathrm{E}+00$ & $d$ & $d$ & $d$ & $d$ & $c$ & 2.2E-02 & $2.1 E+00$ \\
\hline Soil & $d$ & $c$ & $c$ & $2.3 E+00$ & $d$ & $c$ & $c$ & $2.7 \mathrm{E}-01$ & $d$ & $c$ & $3.5 E+00$ \\
\hline
\end{tabular}


Annual Site Environmental Report

\begin{tabular}{|c|c|c|c|c|c|c|c|c|c|c|c|}
\hline Media & ${ }^{7} \mathbf{B e}$ & ${ }^{60} \mathrm{Co}$ & ${ }^{137} \mathrm{Cs}$ & $40_{K}$ & ${ }^{3} \mathbf{H}$ & ${ }^{234} U$ & ${ }^{235} \mathrm{U}$ & ${ }^{238} \mathbf{U}$ & Total U & Gross alpha & Gross beta \\
\hline \multicolumn{12}{|c|}{ Station 51} \\
\hline Air filter & $1.6 \mathrm{E}-13$ & $2.1 E-17$ & $2.5 E-17$ & $4.9 \mathrm{E}-15$ & $3.3 \mathrm{E}-12$ & $7.2 E-18$ & $2.7 \mathrm{E}-19$ & $5.9 E-18$ & $d$ & $2.2 \mathrm{E}-15$ & $6.2 \mathrm{E}-15$ \\
\hline Tomatoes & $c$ & $6.0 \mathrm{E}-03$ & $4.6 \mathrm{E}-03$ & $2.7 \mathrm{E}+00$ & $d$ & $d$ & $d$ & $d$ & $8.1 E-04$ & $c$ & $2.1 E+00$ \\
\hline Turnips & $c$ & $c$ & $c$ & $3.2 \mathrm{E}+00$ & $d$ & $d$ & $d$ & $d$ & $c$ & $c$ & $2.7 E+00$ \\
\hline Soil & $d$ & $c$ & $c$ & $9.6 \mathrm{E}+00$ & $d$ & $c$ & $c$ & $c$ & $d$ & $c$ & $c$ \\
\hline \multicolumn{12}{|c|}{ Station 52} \\
\hline Air filter & $1.7 \mathrm{E}-13$ & $6.8 E-17$ & $3.4 \mathrm{E}-17$ & $2.7 \mathrm{E}-15$ & $2.6 \mathrm{E}-12$ & $1.2 \mathrm{E}-17$ & $2.2 \mathrm{E}-18$ & $8.9 E-18$ & $d$ & $2.2 \mathrm{E}-15$ & $6.4 \mathrm{E}-15$ \\
\hline
\end{tabular}

All values represent the mean number for each medium and isotope.

${ }^{b}$ Values for air filters are given in microcuries per milliliter. Values for all other media are given in picocuries per gram.

cNot detected.

${ }^{d}$ Not applicable.

${ }^{e}$ Flag. 
Table 53. ORR environmental surveillance multimedia by media ${ }^{a, b}$

\begin{tabular}{|c|c|c|c|c|c|c|c|c|c|c|c|}
\hline Station & ${ }^{7} \mathrm{Be}$ & ${ }^{60} \mathrm{Co}$ & ${ }^{137} \mathrm{Cs}$ & ${ }^{40} \mathrm{~K}$ & ${ }^{3} \mathbf{H}$ & ${ }^{234} \mathrm{U}$ & ${ }^{235} \mathrm{U}$ & ${ }^{238} \mathrm{U}$ & Total U & Gross alpha & Gross beta \\
\hline \multicolumn{12}{|c|}{ Air filters $(\mu \mathrm{C} / \mathrm{mL})$} \\
\hline 35 & $1.6 \mathrm{E}-13$ & $4.3 \mathrm{E}-17$ & $7.6 \mathrm{E}-17$ & $3.8 \mathrm{E}-15$ & $c$ & $1.5 \mathrm{E}-17$ & $4.4 \mathrm{E}-19$ & $1.8 \mathrm{E}-17$ & $d$ & $2.6 \mathrm{E}-15$ & $6.7 \mathrm{E}-15$ \\
\hline 37 & $1.7 \mathrm{E}-13$ & $3.7 \mathrm{E}-17$ & $3.7 \mathrm{E}-17$ & $4.7 \mathrm{E}-15$ & $c$ & $1.3 \mathrm{E}-17$ & $1.4 E-18$ & $1.3 \mathrm{E}-17$ & $d$ & $2.4 \mathrm{E}-15$ & $6.3 E-15$ \\
\hline 38 & $1.6 \mathrm{E}-13$ & $4.0 \mathrm{E}-17$ & $2.8 \mathrm{E}-17$ & $4.8 \mathrm{E}-15$ & $c$ & $1.1 \mathrm{E}-17$ & $2.7 E-19$ & $1.1 E-17$ & $d$ & $2.1 \mathrm{E}-15$ & $5.5 E-15$ \\
\hline 39 & $1.4 \mathrm{E}-13$ & $4.2 \mathrm{E}-17$ & $4.3 E-17$ & $5.5 \mathrm{E}-15$ & $8.6 E-12$ & $1.1 \mathrm{E}-17$ & $1.1 \mathrm{E}-18$ & $9.1 E-18$ & $d$ & $2.1 E-15$ & $5.0 \mathrm{E}-15$ \\
\hline 40 & $1.4 \mathrm{E}-13$ & $5.2 E-17$ & $2.4 \mathrm{E}-17$ & $4.1 \mathrm{E}-15$ & $c$ & $5.1 \mathrm{E}-17$ & $3.4 \mathrm{E}-18$ & $1.6 \mathrm{E}-17$ & $d$ & $2.4 \mathrm{E}-15$ & $5.9 \mathrm{E}-15$ \\
\hline 42 & $1.5 \mathrm{E}-13$ & $6.0 \mathrm{E}-17$ & $5.3 \mathrm{E}-17$ & $3.0 \mathrm{E}-15$ & $5.6 \mathrm{E}-12$ & $1.1 \mathrm{E}-17$ & $1.3 \mathrm{E}-18$ & $1.1 E-17$ & $d$ & $2.0 \mathrm{E}-15$ & $5.3 \mathrm{E}-15$ \\
\hline 46 & $1.6 \mathrm{E}-13$ & $2.4 \mathrm{E}-17$ & $2.0 \mathrm{E}-17$ & $3.2 E-15$ & $4.1 E-12$ & $2.6 \mathrm{E}-17$ & 1.7E-18 & $1.1 \mathrm{E}-17$ & $d$ & $2.1 E-15$ & $5.9 \mathrm{E}-15$ \\
\hline 48 & $1.5 \mathrm{E}-13$ & $7.4 \mathrm{E}-17$ & $2.7 \mathrm{E}-17$ & $4.2 \mathrm{E}-15$ & $6.9 \mathrm{E}-12$ & $1.3 \mathrm{E}-17$ & $1.0 \mathrm{E}-18$ & $9.5 \mathrm{E}-18$ & $d$ & $2.4 E-15$ & $6.2 E-15$ \\
\hline 51 & $1.6 \mathrm{E}-13$ & $2.1 \mathrm{E}-17$ & $2.5 \mathrm{E}-17$ & $4.9 E-15$ & $3.3 \mathrm{E}-12$ & $7.2 \mathrm{E}-18$ & $2.7 E-19$ & $5.9 \mathrm{E}-18$ & $d$ & $2.2 \mathrm{E}-15$ & $6.2 \mathrm{E}-15$ \\
\hline 52 & $1.7 E-13$ & $6.8 \mathrm{E}-17$ & $3.4 \mathrm{E}-17$ & $2.7 \mathrm{E}-15$ & $2.6 \mathrm{E}-12$ & $1.2 E-17$ & $2.2 E-18$ & $8.9 E-18$ & $d$ & $2.2 \mathrm{E}-15$ & $6.4 \mathrm{E}-15$ \\
\hline \multicolumn{12}{|c|}{ Tomatoes $\{p C i / g)$} \\
\hline 35 & $d$ & $d$ & $d$ & $d$ & $d$ & $d$ & $d$ & $d$ & $d$ & $d$ & $d$ \\
\hline 37 & $c$ & $c$ & $5.4 \mathrm{E}-04$ & $2.7 \mathrm{E}+00$ & $d$ & $d$ & $d$ & $d$ & $8.1 E-04$ & $4.6 \mathrm{E}-02$ & $1.4 \mathrm{E}+00$ \\
\hline 38 & $c$ & $4.6 \mathrm{E}-03$ & $2.4 \mathrm{E}-03$ & $2.7 \mathrm{E}+00$ & $d$ & $d$ & $d$ & $d$ & $2.2 \mathrm{E}-03$ & $c$ & $9.5 \mathrm{E}-01$ \\
\hline 39 & $c$ & $c$ & $8.7 \mathrm{E}-03$ & $1.7 \mathrm{E}+00$ & $d$ & $d$ & $d$ & $d$ & $3.0 \mathrm{E}-03$ & $c$ & $1.1 \mathrm{E}+00$ \\
\hline 40 & $c$ & $c$ & $c$ & $3.2 \mathrm{E}+0.0$ & $d$ & $d$ & $d$ & $d$ & $7.6 \mathrm{E}-04$ & $2.7 \mathrm{E}-03$ & $1.5 \mathrm{E}+00$ \\
\hline 42 & $c$ & $c$ & $c$ & $3.0 \mathrm{E}+00$ & $d$ & $d$ & $d$ & $d$ & $7.6 \mathrm{E}-04$ & $2.7 E-03$ & $1.5 \mathrm{E}+00$ \\
\hline 46 & $c$ & $c$ & $7.8 \mathrm{E}-03$ & $2.0 \mathrm{E}+00$ & $d$ & $d$ & $d$ & $d$ & $1.4 \mathrm{E}-03$ & $2.7 \mathrm{E}-03$ & $1.6 \mathrm{E}+00$ \\
\hline 48 & $c$ & $c$ & $c$ & $3.0 \mathrm{E}+00$ & $d$ & $d$ & $d$ & $d$ & $8.1 E-04$ & $c$ & $1.8 \mathrm{E}+00$ \\
\hline 51 & $c$ & $6.0 \mathrm{E}-03$ & $4.6 \mathrm{E}-03$ & $2.7 \mathrm{E}+00$ & $d$ & $d$ & $d$ & $d$ & $8.1 E-04$ & $c$ & $2.1 E+00$ \\
\hline \multicolumn{12}{|c|}{ Lettuce $(p \mathrm{Ci} / g)$} \\
\hline 35 & $1.0 \mathrm{E}+00$ & c & c & $1.2 \mathrm{E}+01$ & $d$ & $d$ & $d$ & $d$ & $c$ & $1.1 \mathrm{E}-01$ & $3.5 E+\infty 0$ \\
\hline 37 & $7.0 \mathrm{E}-01$ & $c$ & $c$ & $1.4 \mathrm{E}+01$ & $d$ & $d$ & $d$ & $d$ & $c$ & $1.8 \mathrm{E}-01$ & $3.2 \mathrm{E}+00$ \\
\hline 38 & $1.0 E+00$ & $c$ & $4.3 \mathrm{E}-02$ & $1.4 \mathrm{E}+01$ & $d$ & $d$ & $d$ & $d$ & $c$ & $1.1 \mathrm{E}-01$ & $3.2 \mathrm{E}+00$ \\
\hline 39 & $9.2 \mathrm{E}-01$ & $c$ & $c$ & $1.3 E+01$ & $d$ & $d$ & $d$ & $d$ & $4.9 \mathrm{E}-02$ & $4.1 E-01$ & $3.8 \mathrm{E}+00$ \\
\hline 40 & $3.8 E-01$ & $c$ & $c$ & $4.6 \mathrm{E}+00$ & $d$ & $d$ & $d$ & $d$ & $1.8 \mathrm{E}-02$ & $2.2 \mathrm{E}-01$ & $3.2 \mathrm{E}+00$ \\
\hline 42 & $1.2 E+\infty$ & $c$ & $c$ & $1.2 \mathrm{E}+01$ & $d$ & $d$ & $d$ & $d$ & $c$ & $1.7 \mathrm{E}-01$ & $3.0 E+00$ \\
\hline 46 & $8.9 E-01$ & $c$ & $c$ & $1.4 \mathrm{E}+01$ & $d$ & $d$ & $d$ & $d$ & $c$ & $1.1 \mathrm{E}-01$ & $2.4 \mathrm{E}+00$ \\
\hline 48 & $1.1 \mathrm{E}+00$ & $c$ & $c$ & $1.3 E+01$ & $d$ & $d$ & $d$ & $d$ & $3.5 \mathrm{E}-02$ & $2.2 \mathrm{E}-01$ & $3.2 E+00$ \\
\hline 51 & $c$ & $c$ & $c$ & $1.4 E+01$ & $d$ & $d$ & $d$ & $d$ & $1.6 \mathrm{E}-02$ & $c$ & $3.0 \mathrm{E}+00$ \\
\hline \multicolumn{12}{|c|}{ Tumips ( $p C i / g$ ) } \\
\hline 35 & $c$ & $c$ & $c$ & $c$ & $d$ & $d$ & $d$ & $d$ & $7.6 \mathrm{E}-03$ & $c$ & $c$ \\
\hline 37 & $c$ & $c$ & $c$ & $3.2 \mathrm{E}+\infty 0$ & $d$ & $d$ & $d$ & $d$ & $c$ & $c$ & $2.7 E+00$ \\
\hline 38 & $c$ & c & $c$ & $3.5 E+\infty 0$ & $d$ & $d$ & $d$ & $d$ & $c$ & c & 2.7E+00 \\
\hline 39 & $c$ & $c$ & $c$ & $3.2 E+00$ & $d$ & $d$ & $d$ & $d$ & $c$ & $2.4 E-02$ & $2.1 E+00$ \\
\hline $40^{e}$ & $c$ & $c$ & $c$ & $c$ & $d$ & $d$ & $d$ & $d$ & $c$ & $c$ & $2.1 E+00$ \\
\hline 42 & $c$ & $c$ & $c$ & $3.2 E+00$ & $d$ & $d$ & $d$ & $d$ & $c$ & $c$ & $2.2 E+00$ \\
\hline 46 & $c$ & $c$ & $c$ & $2.7 \mathrm{E}+00$ & $d$ & $d$ & $d$ & $d$ & $c$ & $1.9 \mathrm{E}-01$ & $1.9 E+00$ \\
\hline 48 & $c$ & $c$ & $c$ & $3.0 \mathrm{E}+00$ & $d$ & $d$ & $d$ & $d$ & $c$ & $2.2 \mathrm{E}-02$ & $2.1 \mathrm{E}+00$ \\
\hline 51 & $c$ & $c$ & $\mathfrak{c}$ & $3.2 \mathrm{E}+00$ & $d$ & $d$ & $d$ & $d$ & $c$ & $c$ & $2.7 E+00$ \\
\hline \multicolumn{12}{|c|}{ Soil $(p C \mathrm{z} / g)$} \\
\hline 35 & $d$ & $c$ & $6.8 \mathrm{E}-02$ & $5.8 \mathrm{E}+00$ & $d$ & $1.5 \mathrm{E}-01$ & $c$ & $c$ & $d$ & $1.6 \mathrm{E}+00$ & $5.3 E+00$ \\
\hline 37 & $d$ & $c$ & $c$ & $7.6 \mathrm{E}+00$ & $d$ & $c$ & $1.4 \mathrm{E}-02$ & $4.7 E-01$ & $d$ & $c$ & $3.1 \mathrm{E}+00$ \\
\hline 38 & $d$ & $c$ & $c$ & $5.3 \mathrm{E}+00$ & $d$ & $2.0 \mathrm{E}-01$ & $c$ & $c$ & $d$ & $2.1 E+00$ & $8.0 E+00$ \\
\hline 39 & $d$ & $c$ & $c$ & $c$ & $d$ & $c$ & $c$ & $c$ & $d$ & $c$ & $c$ \\
\hline 40 & $d$ & $c$ & $c$ & $6.8 E+00$ & $d$ & $2.5 \mathrm{E}-01$ & $c$ & $2.5 \mathrm{E}-01$ & $d$ & $1.9 E+\infty 0$ & $2.4 E+00$ \\
\hline 42 & $d$ & $c$ & $c$ & $8.2 \mathrm{E}+00$ & $d$ & $3.2 \mathrm{E}-01$ & $2.6 \mathrm{E}-03$ & $3.1 \mathrm{E}-01$ & $d$ & $c$ & $2.7 \mathrm{E}+00$ \\
\hline 46 & $d$ & $c$ & $c$ & $c$ & $d$ & $c$ & $c$ & $c$ & $d$ & $2.1 E+00$ & $c$ \\
\hline 48 & $d$ & $c$ & $c$ & $2.3 E+00$ & $d$ & $2.6 \mathrm{E}-01$ & $6.5 E-03$ & $2.7 \mathrm{E}-01$ & $d$ & $2.1 E+00$ & $3.5 \mathrm{E}+00$ \\
\hline 51 & $d$ & $c$ & $c$ & $c$ & $d$ & $c$ & $c$ & $c$ & $d$ & $3.5 \mathrm{E}+00$ & $1.5 E+00$ \\
\hline
\end{tabular}

the Environmental Monitoring Plan for the Oak Ridge Reservation (EMP) to obtain total uranium particulate and the percentage of ${ }^{235} \mathrm{U}$. In this manner, uranium concentrations in ambient air could be better correlated to stack emission data, which is also measured as total uranium. 
Table 5.4. Uranium concentrations in ambient air on the ORR

\begin{tabular}{|c|c|c|c|c|}
\hline \multirow[t]{2}{*}{ Isotope } & \multicolumn{4}{|c|}{$\begin{array}{c}\text { Concentration } \\
\left(10^{-15} \mu \mathrm{Ci} / \mathrm{mL}\right)\end{array}$} \\
\hline & 1992 & 1993 & 1994 & 1995 \\
\hline & & Station 35 & & \\
\hline${ }^{234} \mathrm{U}$ & $3.6 \mathrm{E}-02$ & $4.2 \mathrm{E}-02$ & $3.5 E-02$ & $1.5 \mathrm{E}-02$ \\
\hline${ }^{235} \mathrm{U}$ & $0.0 \mathrm{E}+00$ & $1.1 \mathrm{E}-02$ & $3.0 \mathrm{E}-03$ & $4.4 \mathrm{E}-04$ \\
\hline \multirow[t]{2}{*}{${ }^{238} \mathrm{U}$} & $9.4 \mathrm{E}-03$ & $2.2 \mathrm{E}-02$ & $2.4 \mathrm{E}-02$ & $1.8 \mathrm{E}-02$ \\
\hline & & Station 37 & & \\
\hline${ }^{234} U$ & $5.0 E-03$ & $5.4 \mathrm{E}-02$ & $3.5 \mathrm{E}-02$ & $1.3 \mathrm{E}-02$ \\
\hline${ }^{235} \mathrm{U}$ & $8.6 \mathrm{E}-03$ & $9.0 \mathrm{E}-03$ & $3.0 \mathrm{E}-03$ & $1.4 \mathrm{E}-03$ \\
\hline \multirow[t]{2}{*}{${ }^{238} \mathrm{U}$} & $2.1 \mathrm{E}-02$ & $1.8 \mathrm{E}-02$ & $1.9 \mathrm{E}-02$ & $1.3 \mathrm{E}-02$ \\
\hline & & Station 38 & & \\
\hline${ }^{234} U$ & $2.3 E-02$ & $3.7 \mathrm{E}-02$ & $2.9 \mathrm{E}-02$ & $1.1 \mathrm{E}-02$ \\
\hline${ }^{235} \mathrm{U}$ & $0.0 \mathrm{E}+00$ & $7.0 \mathrm{E}-03$ & $4.0 \mathrm{E}-03$ & $2.7 \mathrm{E}-04$ \\
\hline \multirow[t]{2}{*}{${ }^{238} \mathrm{U}$} & $9.8 \mathrm{E}-03$ & $1.7 \mathrm{E}-02$ & $1.6 \mathrm{E}-02$ & $1.1 \mathrm{E}-07$ \\
\hline & & Station 39 & & \\
\hline${ }^{234} \mathrm{U}$ & $3.1 \mathrm{E}-02$ & $4.1 \mathrm{E}-02$ & $2.7 \mathrm{E}-02$ & $1.1 \mathrm{E}-02$ \\
\hline${ }^{235} \mathrm{U}$ & $4.7 \mathrm{E}-03$ & $1.0 \mathrm{E}-02$ & $5.0 \mathrm{E}-03$ & $1.1 \mathrm{E}-03$ \\
\hline \multirow[t]{2}{*}{${ }^{238} \mathrm{U}$} & $1.9 \mathrm{E}-02$ & $1.6 \mathrm{E}-02$ & $9.0 E-03$ & $9.1 \mathrm{E}-03$ \\
\hline & & Station 40 & & \\
\hline${ }^{234} \mathrm{U}$ & $1.2 \mathrm{E}-01$ & $1.1 \mathrm{E}-01$ & $8.9 E-02$ & $5.1 \mathrm{E}-02$ \\
\hline${ }^{235} \mathrm{U}$ & $8.7 \mathrm{E}-03$ & $1.0 \mathrm{E}-03$ & $9.0 \mathrm{E}-03$ & $3.4 \mathrm{E}-03$ \\
\hline \multirow[t]{2}{*}{${ }^{238} \mathrm{U}$} & $1.8 \mathrm{E}-02$ & $2.1 \mathrm{E}-02$ & $1.6 \mathrm{E}-02$ & $1.6 \mathrm{E}-02$ \\
\hline & & Station 42 & & \\
\hline${ }^{234} \mathrm{U}$ & $5.0 \mathrm{E}-02$ & $2.5 \mathrm{E}-02$ & $1.9 \mathrm{E}-02$ & $1.1 \mathrm{E}-02$ \\
\hline${ }^{235} \mathrm{U}$ & $0.0 \mathrm{E}+00$ & $3.0 \mathrm{E}-03$ & $2.0 \mathrm{E}-03$ & $1.3 E-03$ \\
\hline \multirow[t]{2}{*}{${ }^{238} \mathrm{U}$} & $1.5 \mathrm{E}-03$ & $2.2 \mathrm{E}-02$ & $1.5 \mathrm{E}-02$ & $1.1 \mathrm{E}-02$ \\
\hline & & Station 46 & & \\
\hline${ }^{234} \mathrm{U}$ & $2.1 \mathrm{E}-01$ & $1.0 \mathrm{E}-01$ & $4.4 \mathrm{E}-02$ & $2.6 \mathrm{E}-02$ \\
\hline${ }^{235} \mathrm{U}$ & $5.2 \mathrm{E}-02$ & $1.2 \mathrm{E}-02$ & $6.0 \mathrm{E}-03$ & $1.7 \mathrm{E}-03$ \\
\hline \multirow[t]{2}{*}{${ }^{238} \mathrm{U}$} & $3.2 \mathrm{E}-02$ & $1.8 \mathrm{E}-02$ & $1.5 \mathrm{E}-02$ & $1.1 \mathrm{E}-02$ \\
\hline & & Station 48 & & \\
\hline${ }^{234} U$ & $3.2 \mathrm{E}-02$ & $5.2 \mathrm{E}-02$ & $2.3 \mathrm{E}-02$ & $1.3 \mathrm{E}-02$ \\
\hline${ }^{235} \mathrm{U}$ & $5.9 \mathrm{E}-03$ & $1.0 \mathrm{E}-02$ & $1.0 \mathrm{E}-03$ & $1.0 \mathrm{E}-03$ \\
\hline \multirow[t]{2}{*}{${ }^{238} \mathrm{U}$} & $1.2 \mathrm{E}-02$ & $2.1 \mathrm{E}-02$ & $1.1 \mathrm{E}-02$ & $9.5 \mathrm{E}-03$ \\
\hline & & Station 51 & & \\
\hline${ }^{234} U$ & $3.4 \mathrm{E}-02$ & $4.3 \mathrm{E}-02$ & $1.0 \mathrm{E}-02$ & $7.2 \mathrm{E}-03$ \\
\hline${ }^{235} \mathrm{U}^{-}$ & $2.9 \mathrm{E}-03$ & $9.0 \mathrm{E}-03$ & $2.0 \mathrm{E}-03$ & $2.7 \mathrm{E}-03$ \\
\hline \multirow[t]{2}{*}{${ }^{238} \mathrm{U}$} & $1.1 \mathrm{E}-02$ & $1.4 \mathrm{E}-02$ & $6.0 \mathrm{E}-03$ & $5.9 \mathrm{E}-03$ \\
\hline & & Station 52 & & \\
\hline${ }^{234} \mathrm{U}$ & $2.7 \mathrm{E}-02$ & $3.3 \mathrm{E}-02$ & $1.6 \mathrm{E}-02$ & $1.2 \mathrm{E}-02$ \\
\hline${ }^{235} \mathrm{U}$ & $5.0 \mathrm{E}-03$ & $7.0 \mathrm{E}-03$ & $2.0 \mathrm{E}-02$ & $2.2 \mathrm{E}-03$ \\
\hline${ }^{238} \mathrm{U}$ & $7.4 \mathrm{E}-03$ & $1.6 \mathrm{E}-02$ & $6.0 \mathrm{E}-03$ & $8.9 \mathrm{E}-03$ \\
\hline
\end{tabular}

For 1995, the average 7-day concentration of uranium at the 3 monitored locations ranged from a low of $0.00001 \mu \mathrm{g} / \mathrm{m}^{3}$ at Station 8 to a high of $0.00707 \mu \mathrm{g} / \mathrm{m}^{3}$ at Station 8 (Table 5.5). 


\section{ORNL-DWG 86M-9184R4}

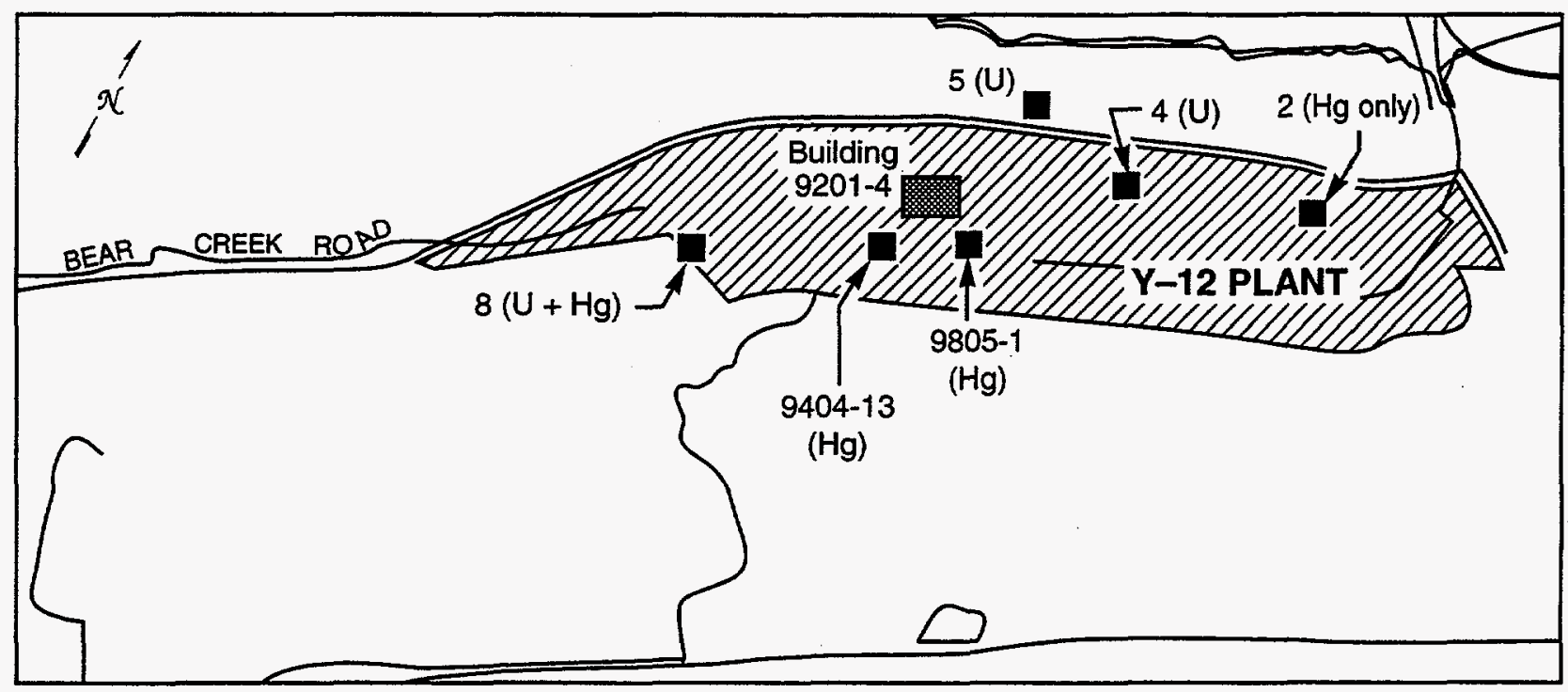

Fig. 5.4 Locations of ambient air monitoring stations at the Y-12 Plant.

Table 5.5. Uranium in ambient air at the Y-12 Plant, 1995

\begin{tabular}{ccccc}
\hline $\begin{array}{c}\text { Station } \\
\text { No. }\end{array}$ & $\begin{array}{c}\text { No. of } \\
\text { samples }\end{array}$ & \multicolumn{3}{c}{$\begin{array}{c}\text { 7-day concentration } \\
\left(\mu \mathrm{g}_{\mathrm{m}} \mathbf{3}^{3}\right)\end{array}$} \\
\cline { 3 - 5 } & & Max & Min & Av \\
\hline 4 & 52 & 0.00047 & 0.00003 & 0.00008 \\
5 & 52 & 0.00060 & 0.00002 & 0.00009 \\
8 & 52 & 0.00707 & 0.00001 & 0.00020 \\
\hline
\end{tabular}

\section{Mercury}

1995 was the tenth year of an on-site monitoring program established at the Y-12 Plant to measure mercury vapor concentrations in ambient air. When originally established, the goals of the program were to establish a historical database of mercury concentration in ambient air at the Y-12 Plant, identify spatial and temporal trends in mercury vapor concentrations at the Y-12 Plant, and demonstrate protection of the environment and human health from releases of mercury from the Y-12 Plant to the atmosphere. With the purchase and installation in late 1995 of near-continuous mercury vapor monitors that provide readouts at 10 -minute intervals, a goal of better understanding the nature and location of fugitive mercury vapor sources at Y-12 was added. Outdoor airborne mercury at the Y-12 Plant results primarily from mercury vaporization from contaminated soils, the burning of coal at the Y-12 Steam Plant, and fugitive emissions from Building 9201-4, a former lithium isotope separation facility contaminated with mercury.

Four outdoor ambient mercury monitoring stations (stations on the east and west ends of the plant and two stations near Building 9201-4) were established on-site in 1986 and are still being monitored. An additional site was added at New Hope Pond in August 1987 and monitored while the pond was being closed and capped (1987-89). In February 1988, a control or reference site was established at Rain Gage No. 2 on Chestnut Ridge in the Walker Branch Watershed. This reference site was discontinued after collecting data for approximately 20 months to establish background concentrations and a seasonal pattern. Data for the New Hope Pond and Rain Gage No. 2 sites have been presented in earlier ORR environmental reports. In late 1995, an additional site was established at SWHISS House 9422-13 south and west of the old site near Building 9404-13.

Because no established or EPA-approved methods for measuring mercury vapor in ambient air existed when the program was initiated, staff of the ORNL Environmental Sciences Division developed a method to meet the needs of the monitoring program for the Y-12 Plant. At each

\section{5-10 Environmental Surveillance}


Annual Site Environmental Report

Table 5.6. 1995 results of the Y-12 Plant ambient air mercury monitoring program

\begin{tabular}{|c|c|c|c|c|c|}
\hline \multirow[t]{2}{*}{ Ambient air monitoring site } & \multirow[t]{2}{*}{ Number } & \multicolumn{4}{|c|}{ Mercury vapor concentration $\left(\mu \mathrm{g} / \mathrm{m}^{3}\right)$} \\
\hline & & $\operatorname{Max}$ & $\operatorname{Min}$ & $\mathbf{A v}$ & $\begin{array}{c}1986-88 \\
\text { average }^{a}\end{array}$ \\
\hline Station No. 2 (east end of Y-12 Plant) & 49 & 0.009 & $<0.002$ & 0.005 & 0.010 \\
\hline Station No. 8 (west end of Y-12 Plant) & 49 & 0.018 & $<0.002$ & .0 .007 & 0.033 \\
\hline Bldg. 9404-13 (SW of Bldg. 9201-4) & 49 & 0.389 & 0.016 & 0.075 & 0.145 \\
\hline Bldg. 9805-1 (SE of Bldg. 9201-4) & 49 & 0.181 & 0.013 & 0.066 & 0.099 \\
\hline Reference site, Rain Gage No. $2\left(1988^{b}\right)$ & 47 & 0.016 & 0.002 & 0.006 & $c$ \\
\hline$\left(1989^{d}\right)$ & 47 & 0.015 & $<0.001$ & 0.005 & $c$ \\
\hline
\end{tabular}

\footnotetext{
${ }^{a}$ NESHAP 30-day average standard equals $1 \mu \mathrm{g} / \mathrm{m}^{3}$. ACGIH 8-hour day, 40 -hour work week standard equals $50 \mu \mathrm{g} / \mathrm{m}^{3}$.

${ }^{b}$ Data for February 9 through December 31, 1988.

'Not applicable.

${ }^{d}$ Data for January 1 through October 31, 1989.
}

of the monitoring sites, airborne mercury vapor is adsorbed onto iodated charcoal by pulling air through a Teflon filter, a flow-limiting orifice, and a glass sampling tube packed with the iodated charcoal. The charcoal sampling tubes are routinely changed every 7 days. Average air concentration of mercury vapor for each sampling period is calculated by dividing the total quantity of mercury collected on the charcoal by the total volume of air pulled through the tube.

Table 5.6 presents mercury monitoring data for 1995, data from the 1986 through 1988 period, and data from the reference or control site. Figure 5.5 shows the trends in mercury concentrations for the four active ambient air mercury monitoring sites since the inception of the program in 1986.

With few exceptions, annual average mercury vapor concentrations have been lower in recent years than concentrations measured during the early years of the monitoring program (1986 through 1988). This trend continues through 1995 (see Table 5.6). All four of the monitoring sites recorded significantly lower annual averages (Student's $t$-test at the $1 \%$ level) for mercury-vapor concentration than the 1986 through 1988 average. With the exception of the site at Building 9404-13, 1995 averages for all sites are lower, though not significantly, than those recorded for 1994. The general decrease in ambient mercury recorded at the Y-12 sites since 1989 is thought to be related to the reduction in coal burned at the Y-12 Steam Plant beginning in 1989 and to the completion prior to 1989 of several major engineering projects (e.g., New Hope Pond closure, the Perimeter Intrusion Detection Assessment System (PIDAS), RMPE, and Utility Systems Restoration) that may have caused a temporary increase in mercury air concentrations due to disturbances to contaminated soil and sediment. The seasonal pattern of higher mercury vapor concentrations during the warmer months of the year continued through 1995 (see Fig. 5.5).

In 1995, though, ambient mercury concentrations at the two monitoring sites near Bldg. 9201-4 were elevated above natural background. Results indicate that the concentrations of mercury vapor are well below the NESHAP guideline of $1 \mu \mathrm{g} / \mathrm{m}^{3}$ (30-d average) and the American Conference of Governmental Industrial Hygienists (ACGIH) threshold limit value of $50 \mu \mathrm{g} / \mathrm{m}^{3}$ (time weighted average for 8-hour workday and 40-hour work week). The maximum weekly concentration measured in $1995\left(0.389 \mu \mathrm{g} / \mathrm{m}^{3}\right.$ at Building 9404-13) is less than $1 \%$ of the ACGIH limit for a 40-hour work week. Average concentrations at the monitoring sites located at the east and west end of the Y-12 Plant are as low as levels measured at our reference site on Chestnut Ridge.

In late 1995, Tekran ${ }^{\mathrm{TM}}$ Model 2537A mercury vapor analyzers were installed 


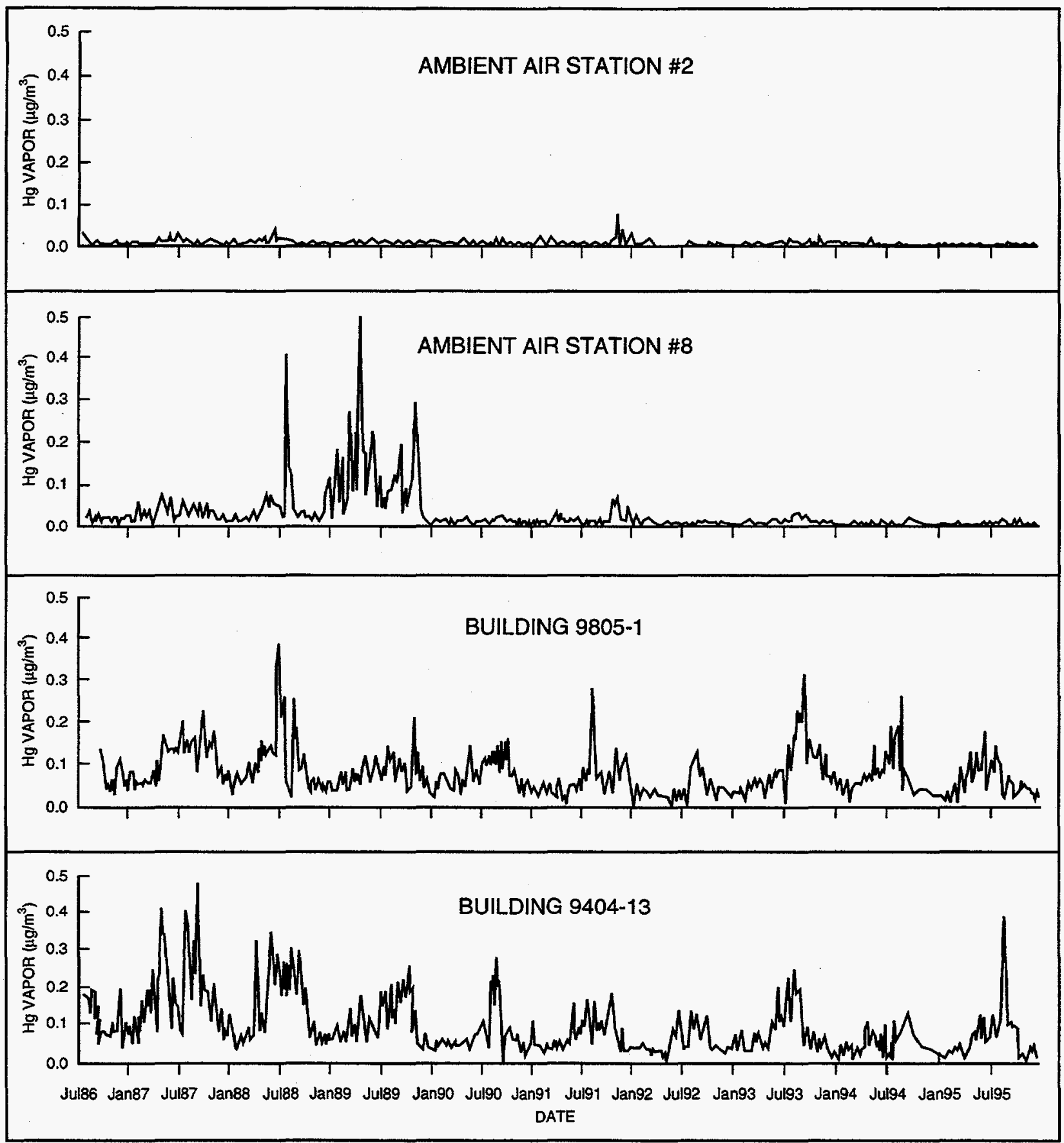

Fig. 5.5. Time trends in mercury vapor concentrations for the four active airborne mercury monitoring sites at the Y-12 Plant (1986 through 1995).

at Ambient Station No. 8 and SWHISS

House 9422-13 located southwest of the Building 9404-13 site. These new monitors are self-calibrating, include mass flow controllers, and can provide almost continuous analysis of mercury vapor in air at sub-ng/ $\mathrm{cm}^{3}$ levels at time intervals as short as 10 minutes. Plans are for two additional Tekran analyzers to be installed at Ambient Station No. 2 and a not yet determined location near the present monitoring site at Building 9805-1. The new monitors are presently being run simultaneously

\section{5-12 Environmental Surveillance}




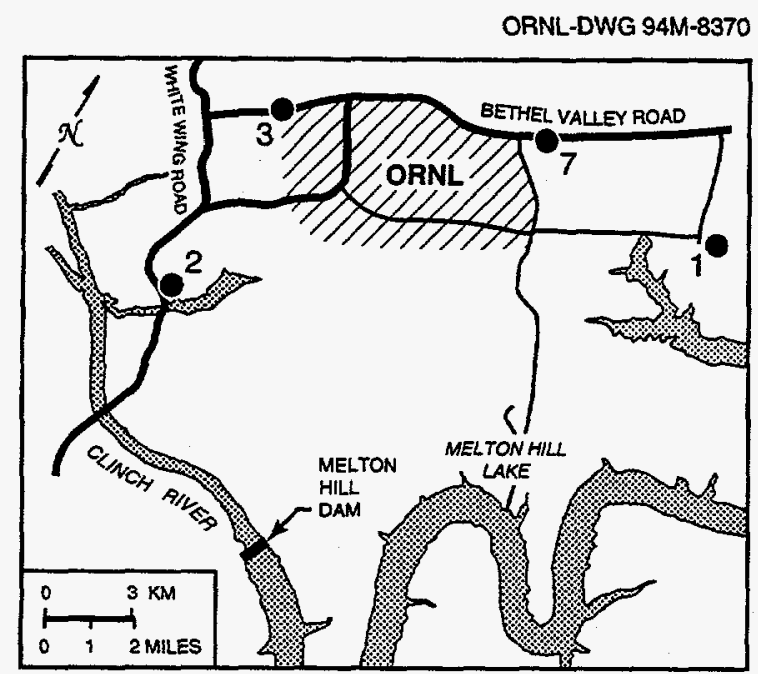

Fig. 5.6. Locations of ambient air monitoring stations at ORNL.

Table 5.7. Radionuclide concentrations measured at ORNL perimeter air monitoring stations, $1995(\mu \mathrm{Ci} / \mathrm{mL})^{a}$

\begin{tabular}{|c|c|c|c|c|}
\hline \multirow[t]{2}{*}{ Parameter } & \multicolumn{4}{|c|}{ Station } \\
\hline & 1 & 2 & 3 & 7 \\
\hline & $b$ & $b$ & $b$ & $b$ \\
\hline & $2.3 E-14$ & $2.5 \mathrm{E}-14$ & $5.1 \mathrm{E}-14$ & $5.3 \mathrm{E}-14$ \\
\hline $\mathrm{Cm}$ & $5.1 \mathrm{E}-18$ & $5.6 E-18$ & $b$ & $b$ \\
\hline & $b$ & $b$ & $3.7 \mathrm{E}-16$ & $b$ \\
\hline${ }^{137} \mathrm{Cs}$ & $b$ & $b$ & $2.0 \mathrm{E}-16$ & $b$ \\
\hline${ }^{3} \mathrm{H}$ & $3.0 \mathrm{E}-11$ & $4.8 \mathrm{E}-11$ & $1.2 \mathrm{E}-11$ & $5.5 \mathrm{E}-11$ \\
\hline${ }^{131}$ I & $1.5 \mathrm{E}-15$ & $1.3 \mathrm{E}-15$ & $1.4 \mathrm{E}-15$ & 7.1E-16 \\
\hline${ }^{133} \mathbf{I}$ & $4.2 \mathrm{E}-15$ & $3.1 \mathrm{E}-15$ & $1.1 \mathrm{E}-15$ & $2.2 \mathrm{E}-15$ \\
\hline $135_{I}$ & $2.3 E-14$ & $1.4 \mathrm{E}-14$ & $1.0 \mathrm{E}-14$ & $9.8 \mathrm{E}-15$ \\
\hline & $b$ & $b$ & $b$ & $b$ \\
\hline${ }^{18} \mathrm{Pu}$ & $b$ & $b$ & $b$ & $b$ \\
\hline & $b$ & $b$ & $1.5 \mathrm{E}-18$ & $4.7 \mathrm{E}-18$ \\
\hline & $8.2 E-17$ & $b$ & $b$ & $6.9 E-17$ \\
\hline${ }^{228} \mathrm{Th}$ & $7.6 \mathrm{E}-18$ & $4.6 \mathrm{E}-18$ & $3.3 E-18$ & $5.7 \mathrm{E}-18$ \\
\hline${ }^{230} \mathrm{Th}$ & $2.5 \mathrm{E}-17$ & $1.7 \mathrm{E}-17$ & $1.3 E-17$ & $1.1 \mathrm{E}-17$ \\
\hline${ }^{232} \mathrm{Th}$ & $1.2 \mathrm{E}-17$ & $7.0 \mathrm{E}-18$ & $7.8 \mathrm{E}-18$ & $6.0 E-18$ \\
\hline${ }^{234} \mathrm{U}$ & $4.0 \mathrm{E}-17$ & $3.0 \mathrm{E}-17$ & $4.2 \mathrm{E}-17$ & $3.5 E-17$ \\
\hline${ }^{235} \mathrm{U}$ & $2.2 \mathrm{E}-18$ & $b$ & $b$ & $3.3 E-18$ \\
\hline${ }^{238} \mathrm{U}$ & $4.0 \mathrm{E}-17$ & $3.1 E-17$ & $2.7 E-17$ & $3.2 \mathrm{E}-17$ \\
\hline
\end{tabular}

\footnotetext{
${ }^{a} 1 \mu \mathrm{Ci}=3.7 \mathrm{E}+4 \mathrm{~Bq}$.

${ }^{b}$ Not detected.
}

with the existing monitoring system (i.e., the iodated charcoal traps) to verify comparability of the measurements. As the reliability and comparability of data of the Tekrans is established, the use of the iodated charcoal traps will be phased out. The monitors provide data on demand and, because of their high sensitivity, are averaged over much shorter time intervals than the charcoal tube data (i.e., minutes instead of days). When combined with synoptic meteorologic data (wind speed and direction), the data generated by this new monitoring system can be used to better understand the nature and location of fugitive mercury vapor sources at the Y-12 Plant. Preliminary analysis of the data collected at the two existing Tekran sites shows a strong correlation between wind direction and mercury-vapor concentration with significantly higher mercury-vapor concentrations measured at both sites when the prevailing wind direction is from the east and north.

\section{ORNL Ambient Air Monitoring}

The objectives of the ORNL ambient air monitoring program are (1) to sample at stations that are most likely to show impacts of airborne emissions from the operation of ORNL and (2) to provide for emergency response capability. The specific stations associated with these objectives are 1,2,3, and 7 (Fig. 5.6). Sampling is conducted at each ORNL station to quantify levels of adsorbable gas (e.g., iodine); beryllium; and gross alpha-, beta-, and gamma-emitting radionuclides (Table 5.7).

The sampling system consists of a low-volume air sampler for particulate collection using a 47-mm glass fiber filter. The filters are collected biweekly, composited annually, then submitted to the laboratory for isotopic analysis. Following the filter is a charcoal cartridge used to collect adsorbable gases (e.g., iodine). In 1995, tritium monitoring was initiated at ORNL Stations 1 and 2 and continued at Stations 3 and 7. A silica gel column is used for the collection of tritium as tritiated water. The samples are collected biweekly. The silica gel is composited monthly, then submitted to the laboratory for tritium analysis. The charcoal cartridges are analyzed biweekly using gamma spectroscopy for adsorbable gas quantification.

\section{Results}

The ORNL PAM stations are designed to collectively assess the specific impact of 


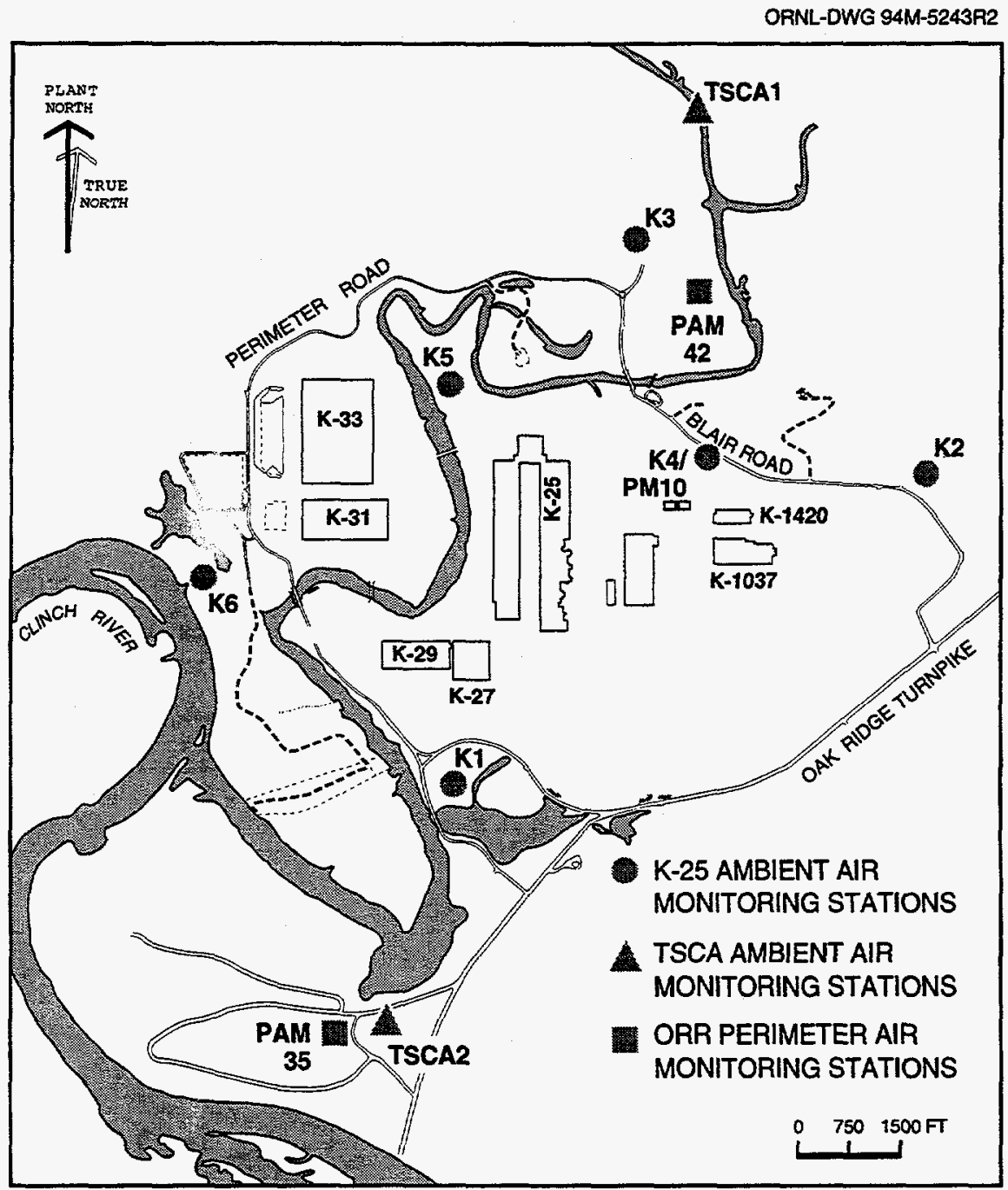

Fig. 5.7. Locations of ambient air monitoring stations at the

K-25 Site. Note: Station K7 is located west of the site.

ORNL operations on local air quality. Sampling data from the ORNL PAM stations (Table 5.7) is compared with air sampling data from the reference stations at Norris Dam (51) and Fort Loudon (52) (Table 5.2). Comparison of the data in the two tables shows that ORNL has not had a significant impact on local air quality.

\section{K-25 Site Ambient Air Monitoring}

The K-25 Site ambient air monitoring program is designed to monitor selected pollutants for the ongoing monitoring of plant operations impact on the immediate environment. Specific locations were selected to determine pollutant concentrations in the prevailing upwind and downwind directions and radiological measurements in the direction of both the nearest and most exposed member of the public. The locations of these monitoring stations are shown in Fig. 5.7. The K-25 Site ambient air monitoring program complies with all requirements of $\mathrm{DOE}$ orders. The $C A A$ regulations are referenced by $D O E$ orders as guidance with respect to ambient air concentrations of certain air contaminants. These regulations specify 24 -hour, quarterly, and annual standards for defined pollutants.

The ambient air program sampling schedule and monitoring capabilities for airborne. particulate matter, uranium, and metals are listed in Table 5.8. All parameters are chosen 
Table 5.8. Summary of ambient air pollutants measured at the K-25 Site, 1995

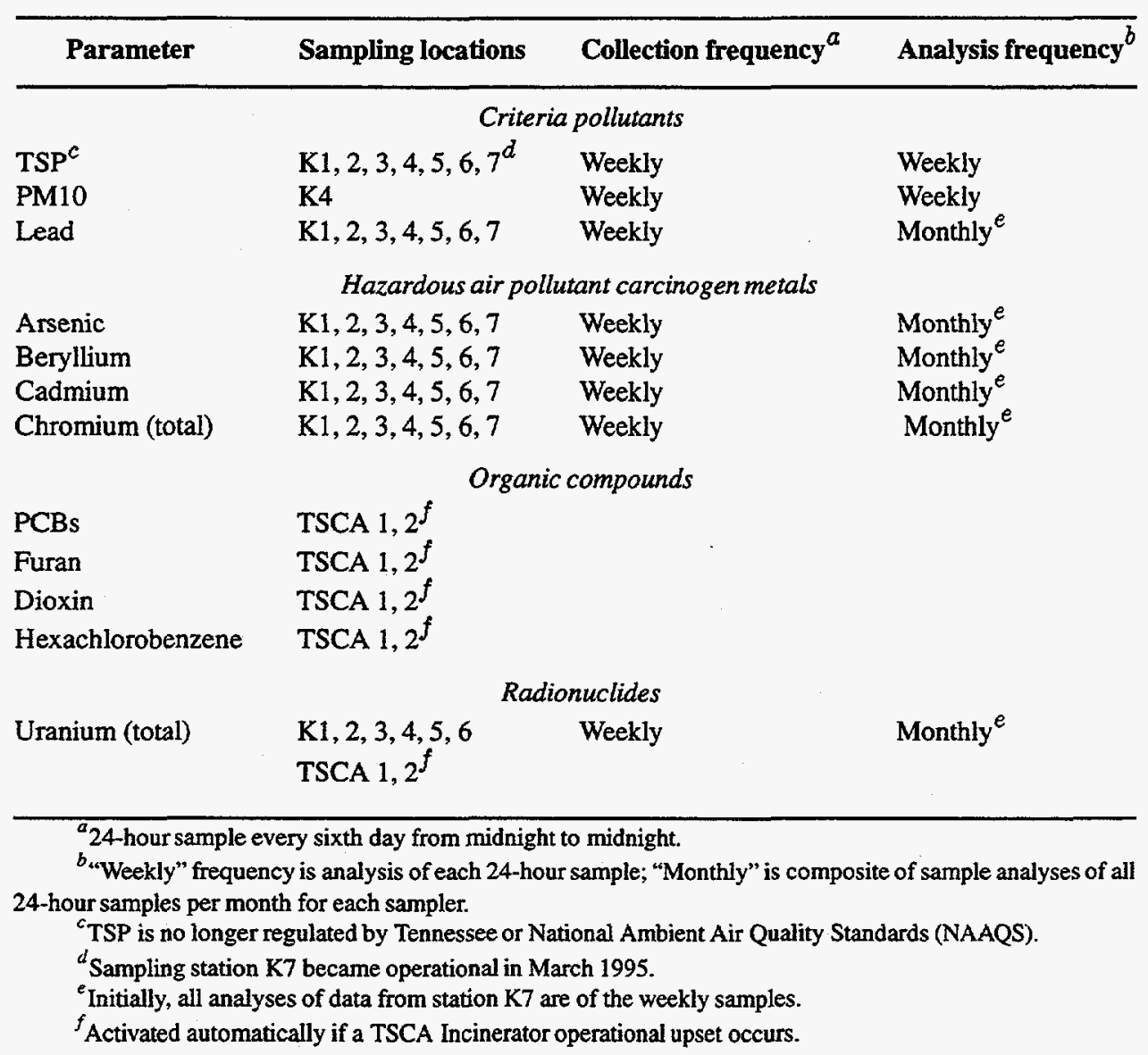

with consideration of existing and proposed regulations and the level and type of operations in and around the K-25 Site. Changes in emissions, wind profile, site activities, or any other parameter that may alter the potential impact of K-25 Site activities on the environment or community may warrant periodic changes of pollutants measured, number of stations, or relocation of existing stations.

During this reporting period, the network was reevaluated with respect to K-25 Site operations. Because of the scheduled facility demolition outside of the current perimeter monitoring network, a temporary station (K7) was activated in March 1995. Following the conclusion of major portions of the demolition activities, a systematic monitoring network change was initiated in December 1995 with the shut down of HV sampling at Stations K4, K5, and K7. Station K4 was identified as redundant to the prevailing downwind monitoring of the $\mathrm{K}-25$ Site. Station $\mathrm{K} 7$ was designated as a major demolition project monitoring network. Stations for the K-700 Powerhouse complex and Station K5 were similarly designated for the Cooling Tower demolition project. These stations and their operations were no longer needed because demolition of the major facilities was nearly complete. These changes were initiated only after review and concurrence by DOE and TDEC.

\section{Results}

No standards were exceeded and there were no significant elevations of pollutant concentrations associated with site operations. Sampling results assessing specific site activities impact on air quality show that the K-25 Site and the project-specific operations did have a measurable but not a significant impact on local air quality. These data also support the state classification of this area, including the 
Table 5.9. Total suspended particulates in ambient air at the K-25 Site, 1995

\begin{tabular}{|c|c|c|c|c|c|c|}
\hline \multirow[t]{2}{*}{ Station } & \multirow[t]{2}{*}{$\begin{array}{l}\text { Number of } \\
\text { samples }\end{array}$} & \multicolumn{3}{|c|}{$\begin{array}{l}\text { Annual summary of TSP concentrations } \\
\qquad\left(\mu \mathrm{g} / \mathrm{m}^{3}\right)\end{array}$} & \multicolumn{2}{|c|}{$\begin{array}{l}\text { Max percentage of } \\
\text { primary standard }^{a}\end{array}$} \\
\hline & & 24-hour max & 24-hour min & Annual av & Annual & 24-hour \\
\hline K1 & 54 & 83.7 & 6.1 & 27.6 & 36.9 & 32.2 \\
\hline K2 & 53 & 97.7 & 7.7 & 24.3 & 32.3 & 37.6 \\
\hline K3 & 51 & 79.8 & 5.8 & 26.4 & 35.2 & 30.7 \\
\hline K4 & 47 & 91.6 & 8.2 & 30.3 & 40.4 & 35.3 \\
\hline K5 & 49 & 79.6 & 9.7 & 32.4 & 43.2 & 30.6 \\
\hline K6 & 50 & 71.9 & 7.8 & 25.2 & 33.5 & 27.7 \\
\hline $\mathbf{K} 7^{b}$ & 37 & 99.4 & 13.1 & 47.7 & 63.6 & 38.2 \\
\hline
\end{tabular}

\footnotetext{
${ }^{a}$ TSP is no longer regulated; however, previous Tennessee and national primary standards were $260 \mu \mathrm{g} / \mathrm{m}^{3}$ per 24 hours and $75 \mu \mathrm{g} / \mathrm{m}^{3}$ per year geometric mean. Secondary standards were $150 \mu \mathrm{g} / \mathrm{m}^{3}$ per 24 hours and $60 \mu \mathrm{g} / \mathrm{m}^{3}$ per year.

${ }^{b}$ Temporary sampling station K7 became operational in March 1995.
}

$\mathrm{K}-25$ Site, as in attainment for PM10. Table 5.8 lists selected parameters measured during 1995.

\section{Criteria Pollutant Levels}

Measurements of 24-hour TSP concentrations were performed for all high-volume samplers. A summary of all TSP measurement results are in Table 5.9. For 1995, the 24-hour TSP concentration for all measurement sites ranged from a low of 6.1 to $99.4 \mu \mathrm{g} / \mathrm{m}^{3}$. Station $\mathrm{K} 7$ demonstrated the highest 24-hour result. Typically, all the sites yield comparable TSP concentration levels during concurrent monitoring unless events such as construction or demolition occur, which can produce a localized impact. TSP is no longer regulated by the state or federal government. The highest measured value for all stations was $38.2 \%$ of the previous 24 -hour primary standard and $66.3 \%$ of the secondary standard; both values occurred at Station K7. No monitoring station measured TSP levels of environmental concern.

TSP 24-hour results for Stations K1 and K7 have been analyzed for impact of the K-700 complex demolition project on the local air quality. TSP concentrations ranged from a low of 6.1 to $99.4 \mu \mathrm{g} / \mathrm{m}^{3}$. Station $\mathrm{K} 7$ demonstrated the highest 24-hour result. TSP results for Stations K5 and K6 have been identified to measure any impact of the K-861/K-892 cooling tower structures demolition project on the local air quality. TSP concentrations ranged from a low of 7.8 to $79.6 \mu \mathrm{g} / \mathrm{m}^{3}$. Station $\mathrm{K} 6$ demonstrated the highest 24 -hour result. Results did not indicate a measurable TSP contribution that could be attributed directly to either demolition project. No TSP concentration levels of environmental concern were measured.

Annual TSP geometric averages of 24-hour measurements are presented in Table 5.9. TSP is no longer regulated; however, data are compared with previous Tennessee and national primary and secondary standards. The annual TSP results range from a low of 24.3 to $47.7 \mu \mathrm{g} / \mathrm{m}^{3}$. The highest average TSP value was only $63.6 \%$ and $79.5 \%$ of the previous annual primary and secondary standards, respectively. Historical data shows that these levels are typical for this period of the year. Annual results from stations identified to measure the impact of demolition activities did not indicate a measurable TSP contribution that could be directly attributed to either project. No TSP concentration levels of environmental concern were measured (see Fig. 5.8 for 5-year TSP trend).

Daily PM10 analyses were performed on all 24-hour samples. A summary of all PM10 measurements is presented in Table 5.10. For 1995, the 24-hour PM10 concentrations ranged from 6.4 to $51.9 \mu \mathrm{g} / \mathrm{m}^{3}$. The highest measured value was $34.6 \%$ of the Tennessee 24-hour primary and secondary standards (i.e., $150 \mu \mathrm{g} / \mathrm{m}^{3}$ ). These levels are not an environmental concern. 
Annual Site Environmental Report

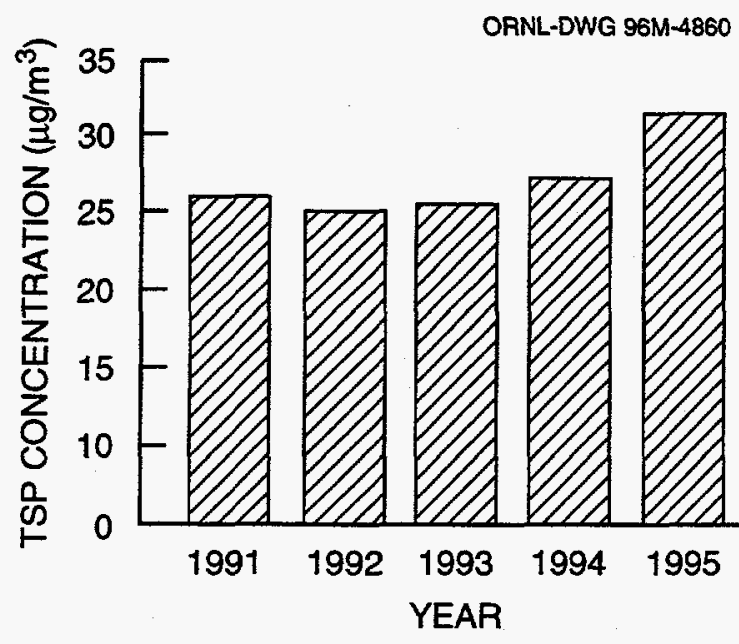

Fig. 5.8. Five-year total suspended particulate results at the K-25 Site. (Note: TSP is no longer regulated. Previously, the state and federal primary air quality standard was $75 \mu \mathrm{g} / \mathrm{m}^{3}$; the secondary standard was $60 \mu \mathrm{g} / \mathrm{m}^{3}$.)

Annual PM10 arithmetic averages of 24-hour measurements are presented in Table 5.10. The averaged PM10 annual result was $23.3 \mu \mathrm{g} / \mathrm{m}^{3}$. This value was only $46.6 \%$ of the Tennessee and national annual primary and secondary standards for PM10 (i.e., $50 \mu \mathrm{g} / \mathrm{m}^{3}$ ). Historical data shows that this level is typical of measurements during this period of the year; it is of no environmental concern (see Fig. 5.9 for 5-year PM10 trend).

Quarterly lead results were determined from analyses of monthly composites of 24-hour samples for each station. The total masses of lead were determined by the inductively coupled plasma mass spectrometry (ICP-MS) analytical technique. This technique was initiated in 1993, replacing a graphite furnace atomic absorption method (thus simplifying all metals analyses to one method). A summary of lead measurement results are presented in Table 5.11 and compared against the Tennessee and national quarterly standard of $1.5 \mu \mathrm{g} / \mathrm{m}^{3}$. There are no 24-hour ambient or monthly ambient air criteria pollutant standards for lead. The maximum quarterly lead result was $0.0029 \mu \mathrm{g} / \mathrm{m}^{3}$. This value was only $0.19 \%$ of the quarterly standard for lead. Quarterly summaries from Stations K1, $\mathrm{K} 5$, $\mathrm{K} 6$, and $\mathrm{K} 7$ were identified to measure the impact of demolition activities. These results did not indicate a measurable lead contribution that could be directly attributed to either project. No lead concentration levels of environmental concern were measured (see Fig. 5.10 for 5-year lead trend).

\section{Hazardous Air Pollutant Carcinogen Metal Levels}

Measurements of HAP carcinogen metals (arsenic, beryllium, cadmium, and chromium) were performed on a monthly composite of 24-hour samples from each station. The total mass of each selected metal was determined by ICP-MS analytical technique. This technique was initiated in 1993, replacing a flame atomic absorption method. The ICP-MS analytical technique simplified all chemical analyses to one method. There are no Tennessee or national ambient air quality standards for HAP carcinogen metals. However, monthly composite arsenic concentration results for all measurement sites ranged from less than 0.000001 up to $0.006837 \mu \mathrm{g} / \mathrm{m}^{3}$. Monthly composite beryllium concentration results for all measurement sites was $<0.000001 \mu \mathrm{g} / \mathrm{m}^{3}$. Monthly composite cadmium concentration results for all measurement sites ranged from 0.000124 up to $0.000601 \mu \mathrm{g} / \mathrm{m}^{3}$. Composite

Table 5.10. PM10 particulates in ambient air at the K-25 Site, 1995

\begin{tabular}{|c|c|c|c|c|c|c|}
\hline \multirow[t]{2}{*}{ Station } & \multirow[t]{2}{*}{$\begin{array}{c}\text { Number of } \\
\text { samples }\end{array}$} & \multicolumn{3}{|c|}{$\begin{array}{c}\text { Annual summary of PM10 } \\
\text { concentrations } \\
\left(\mu \mathrm{g} / \mathrm{m}^{3}\right) \\
\end{array}$} & \multicolumn{2}{|c|}{$\begin{array}{c}\text { Max percentage } \\
\text { of standard }^{a}\end{array}$} \\
\hline & & $\begin{array}{l}\text { 24-hour } \\
\text { max }\end{array}$ & $\begin{array}{c}\text { 24-hour } \\
\text { min }\end{array}$ & Annual av & Annual & 24-hour \\
\hline PM10 & 55 & 51.9 & 6.4 & 23.3 & 46.6 & 34.6 \\
\hline
\end{tabular}

\footnotetext{
${ }^{a}$ PM10 Tennessee and national primary and secondary standards are $150 \mu \mathrm{g} / \mathrm{m}^{3}$ per 24 hours and $50 \mu \mathrm{g} / \mathrm{m}^{3}$ per year arithmetic average.
} 


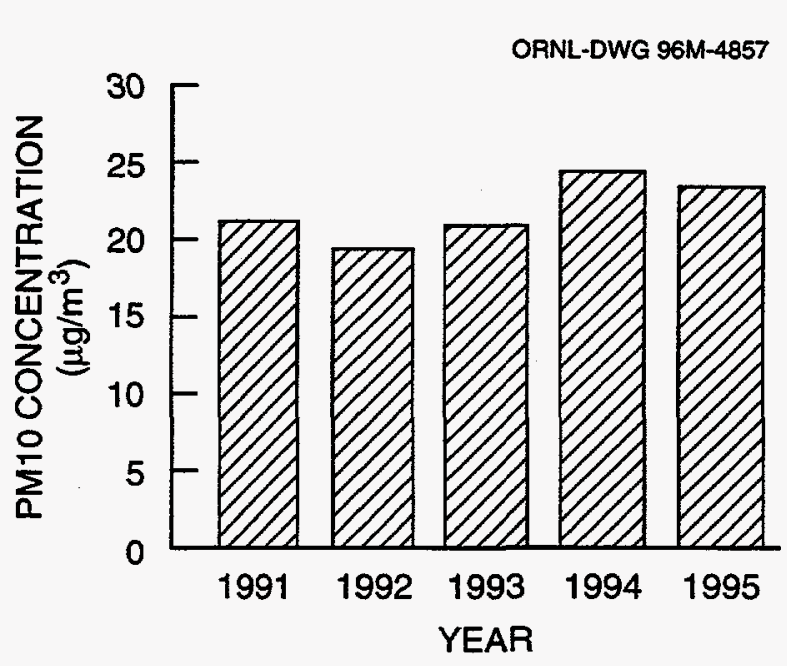

Fig. 5.9. Five-year PM10 results at the K-25 Site. (Note: $50 \mu \mathrm{g} / \mathrm{m}^{3}=$ both the state and national primary and secondary air quality standards for PM10.)

monthly chromium concentration results for all measurement sites ranged from less than 0.000001 up to $0.045086 \mu \mathrm{g} / \mathrm{m}^{3}$. An annual summary of all HAP carcinogen metals measurement results are in Table 5.12.

Stations $\mathrm{K} 1, \mathrm{~K} 3, \mathrm{~K} 5, \mathrm{~K} 6$, and $\mathrm{K} 7$ were identified to measure the impact of demolition activities. Measured levels of arsenic and chromium at stations sensitive to the cooling tower demolition project were above typical levels during this reporting period. These measurements were isolated to Stations $\mathrm{K} 5$ and, to a lesser extent, $\mathrm{K} 3$, which are in the prevailing downwind direction from the cooling tower demolition areas at the $\mathrm{K}-25$ Site. Building materials were known to have been treated or exposed to arsenic and chromium compounds.

\section{Radionuclide Levels}

Of the radionuclides, only uranium was measured as a monthly composite of 24-hour samples from each station. The total uranium mass for each composite sample was determined by ICP-MS analytical technique. The uranium concentration for all measurement sites ranged from a low of $<0.000001$ up to $0.000500 \mu \mathrm{g} / \mathrm{m}^{3}$ at Station K4 (Table 5.13). Stations K2 and $\mathrm{K} 4$ are in the prevailing downwind direction of the K-25 Site. The annual average values for all stations were less than $1 \%$ of the annual standard of $0.15 \mu \mathrm{g} / \mathrm{m}^{3}\left(1.0 \mathrm{E}-1 \mathrm{pCi} / \mathrm{m}^{3}\right)$ for naturally occurring uranium. Annual results from Stations K1, K5, K6, and K7 (identified to measure the impact of demolition activities) did not indicate a measurable uranium contribution that could be directly attributed to either project. No uranium concentration levels of environmental concern were measured (see Fig. 5.11 for 5-year uranium trend).

\section{Organic Compound Levels}

Currently, measurements of organics are performed only during an operational upset of the TSCA Incinerator. Five upsets occurred during waste burning operations in 1995 that activated the TSCA ambient air stations and subsequent

Table 5.11. Lead concentrations in ambient air at the K-25 Site, 1995

\begin{tabular}{|c|c|c|c|c|c|c|c|}
\hline \multirow[t]{2}{*}{ Station } & \multicolumn{4}{|c|}{$\begin{array}{l}\text { Quarterly averages of monthly composites } \\
\qquad\left(\mu \mathrm{g} / \mathrm{m}^{3}\right)\end{array}$} & \multirow{2}{*}{$\begin{array}{l}\text { Max } \\
\text { individual } \\
\text { measures }^{a}\end{array}$} & \multirow{2}{*}{$\begin{array}{c}\text { Min } \\
\text { individual } \\
\text { measures }^{a}\end{array}$} & \multirow{2}{*}{$\begin{array}{l}\text { Percentage } \\
\text { of quarteriy } \\
\text { stancuard }^{\delta}\end{array}$} \\
\hline & 1 & 2 & 3 & 4 & & & \\
\hline $\mathrm{K} 1$ & 0.00273 & 0.00081 & 0.00137 & 0.00137 & 0.00311 & $<0.00001$ & 0.18 \\
\hline $\mathrm{K} 2$ & 0.00198 & 0.00034 & 0.00121 & 0.00222 & 0.00382 & $<0.00001$ & 0.15 \\
\hline $\mathrm{K} 3$ & 0.00142 & 0.00114 & 0.00085 & 0.00176 & 0.00311 & $<0.00001$ & 0.12 \\
\hline K4 & 0.00257 & 0.00091 & 0.00090 & 0.00055 & 0.00433 & $<0.00001$ & 0.17 \\
\hline K5 & 0.00290 & 0.00146 & 0.00156 & 0.00052 & 0.01399 & $<0.00001$ & 0.19 \\
\hline K6 & 0.00220 & $<0.00001$ & $<0.00001$ & $<0.00001$ & 0.00439 & $<0.00001$ & 0.15 \\
\hline $\mathrm{K} 7^{c}$ & $<0.00001$ & $<0.00001$ & $<0.00001$ & $<0.00001$ & $<0.00001$ & $<0.00001$ & $<0.01$ \\
\hline
\end{tabular}

\footnotetext{
${ }^{a}$ Maximum/minimum individual monthly composite results.

${ }^{b}$ Tennessee and national air quality standard for lead is $1.5 \mu \mathrm{g} / \mathrm{m}^{3}$ quarterly arithmetic average.

${ }^{c}$ Temporary sampling station K7 became operational in March 1995.
} 


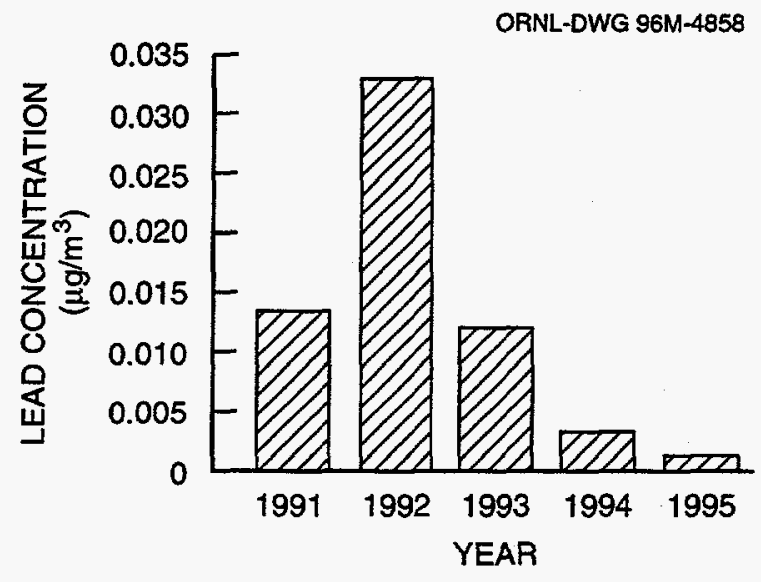

Fig. 5.10. Ambient air monitoring 5-year trend results for lead at the K-25 Site.

measurements of PCBs, furans, dioxin, and hexachlorobenzene during this reporting period. Sampling and analytical results showed that there was no off-site impact as a result of these events beyond that which would result from normal background levels.

\section{Five-Year Trends}

Five-year summaries of K-25 Site ambient air monitoring data are shown in Figs. 5.8-5.11 for TSP, PM10, lead, and uranium only. Other measured pollutant trends are discussed in this section. Localized operations coinciding with TSP variations in 1994 and 1995 included logging operations in the areas of Stations K2, $\mathrm{K} 3$, K4, and $\mathrm{K} 7$; K-1407 pond closure activities in 1995 in the area of $\mathrm{K} 4$; and major demolition activities in 1995 in the areas of $\mathrm{K} 1, \mathrm{~K} 5, \mathrm{~K} 6$, and K7. Variations of PM10 measurements were insignificant and most likely reflect background concentration variations of air quality. Lead measurement variations from 1991 through 1993 were primarily due to changes in analytical techniques. From 1993 to the present, lead

Table 5.12. HAP carcinogen metals in ambient air $^{a}$ at the K-25 Site, 1995

\begin{tabular}{lcrcr}
\hline Parameter & $\begin{array}{c}\text { Number of samples } \\
\text { (all stations) }\end{array}$ & \multicolumn{3}{c}{ Annual summary of monthly composites $\left(\mu \mathrm{g}^{\prime} \mathbf{m}^{3}\right.$ ) } \\
\cline { 3 - 5 } & & Monthly max & Monthly min & Annual av ${ }^{b}$ \\
\hline Arsenic & 396 & 0.006837 & $<0.000001$ & 0.000304 \\
Beryllium & 396 & $<0.000001$ & $<0.000001$ & $<0.000001$ \\
Cadmium & 396 & 0.003200 & 0.000124 & 0.000601 \\
Chromium & 396 & 0.045086 & $<0.000001$ & 0.001491 \\
\end{tabular}

\footnotetext{
${ }^{a}$ There are no Tennessee or national ambient air quality standards. However, EPA has identified arsenic, beryllium, cadmium, and chromium as HAP carcinogen metals.

${ }^{b}$ Average of all station measurements.
}

Table 5.13. Uranium in ambient air at the K-25 Site, 1995

\begin{tabular}{|c|c|c|c|c|}
\hline \multirow[t]{2}{*}{ Station } & \multirow[t]{2}{*}{ Number of samples } & \multicolumn{3}{|c|}{ Annual summary of monthly composites $\left(\mu \mathrm{g} / \mathrm{m}^{3}\right)$} \\
\hline & & Monthly $\max ^{a}$ & Monthly $\min ^{a}$ & Annual av ${ }^{b}$ \\
\hline K1 & 55 & 0.000420 & $<0.000001$ & 0.000075 \\
\hline $\mathbf{K} 2$ & 54 & 0.000291 & $<0.000001$ & 0.000112 \\
\hline $\mathrm{K} 3$ & 53 & 0.000257 & $<0.000001$ & 0.000033 \\
\hline K4 & 51 & 0.000580 & $<0.000001$ & 0.000100 \\
\hline K5 & 47 & 0.000210 & $<0.000001$ & 0.000063 \\
\hline K6 & 50 & 0.000070 & $<0.000001$ & 0.000007 \\
\hline $\mathbf{K} 7^{c}$ & 37 & 0.000278 & $<0.000001$ & 0.000021 \\
\hline
\end{tabular}




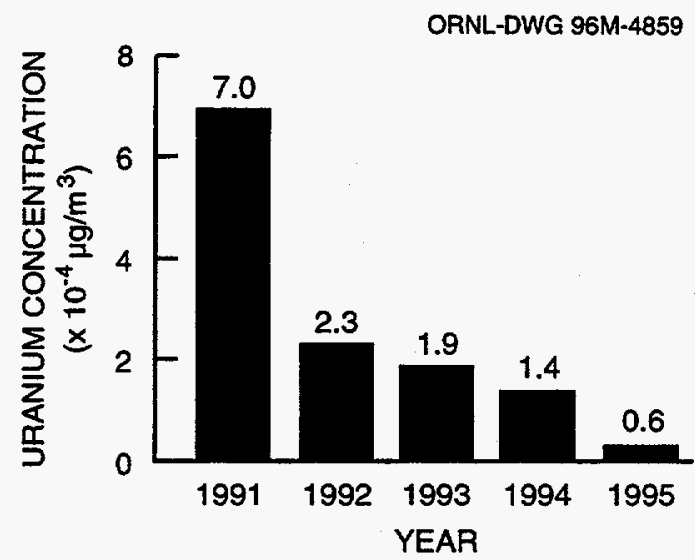

Fig. 5.11. Ambient air monitoring 5-year trend results for uranium at the K-25 Site.

levels have been declining and most likely reflect the reduction of lead and lead compounds in motor vehicle fuels. No variations due to K-25 Site activities could be differentiated from background levels of this pollutant. Arsenic, beryllium, and cadmium measurements were initiated in 1993. Arsenic variations in 1995 were coincidental to demolition activities that affected structural materials treated with arsenic compounds. No measurements of beryllium have been above analytical detection limits. Cadmium concentration variations occurred during 1994 and 1995. This was coincidental to logging and the pond closure operations. Variations of chromium measurements from 1991 through 1994 show no identifiable K-25 Site contribution. Changes in analytical techniques were responsible for most of the variations up to 1994. Chromium variations in 1995 were coincidental to demolition activities that affected structural materials that had long-term exposure to chromium compounds. The 5-year trend for uranium indicates the level of work at the K-25 Site. TSCA Incinerator operations began during 1991, burning low levels of radiologically contaminated wastes. The downward trend. after 1991 reflects the reduction of radiological emissions due to K-25 Site and TSCA Incinerator operations. No monitoring station has measured any pollutant levels of environmental concern.
SURFACE WATER MONITORING ORR Surface Water Monitoring

Under the ORR EMP, samples are collected and analyzed from 22 locations around the ORR to assess the impact of past and current DOE operations on the quality of local surface water. Sample locations are on streams downstream of ORR waste sources, at reference points on streams and reservoirs upstream of waste sources, on reference streams off site, and at public water intakes (Fig. 5.12). Sample locations include the following:

- Bear Creek downstream from Y-12 Plant inputs (BCK 0.6),

- Bear Creek downstream from Y-12 Plant burial grounds (BCK 9.4),

- Clinch River downstream from all DOE inputs (CRK 16),

- Water supply intake for the K-25 Site (CRK 23),

- Clinch River downstream from ORNL (CRK 32),

- Water supply intake for Knox County (CRK 58),

- Melton Hill Reservoir above city of Oak Ridge water intake (CRK 66),

- Melton Hill Reservoir at Oak Ridge Marina (CRK 80),

- Melton Hill Reservoir above all DOE inputs at the Anderson County Filtration Plant (CRK 84),

- EFPC downstream from floodplain (EFK 5.4),

- EFPC downstream from Y-12 Plant (EFK 23.4),

- Hinds Creek (reference site for EFPC) (HC),

- Melton Branch downstream from ORNL (MEK 0.2),

- Melton Branch upstream from ORNL (MEK 2.1),

- Mitchell Branch downstream from K-25 Site (MIK 0.1), 


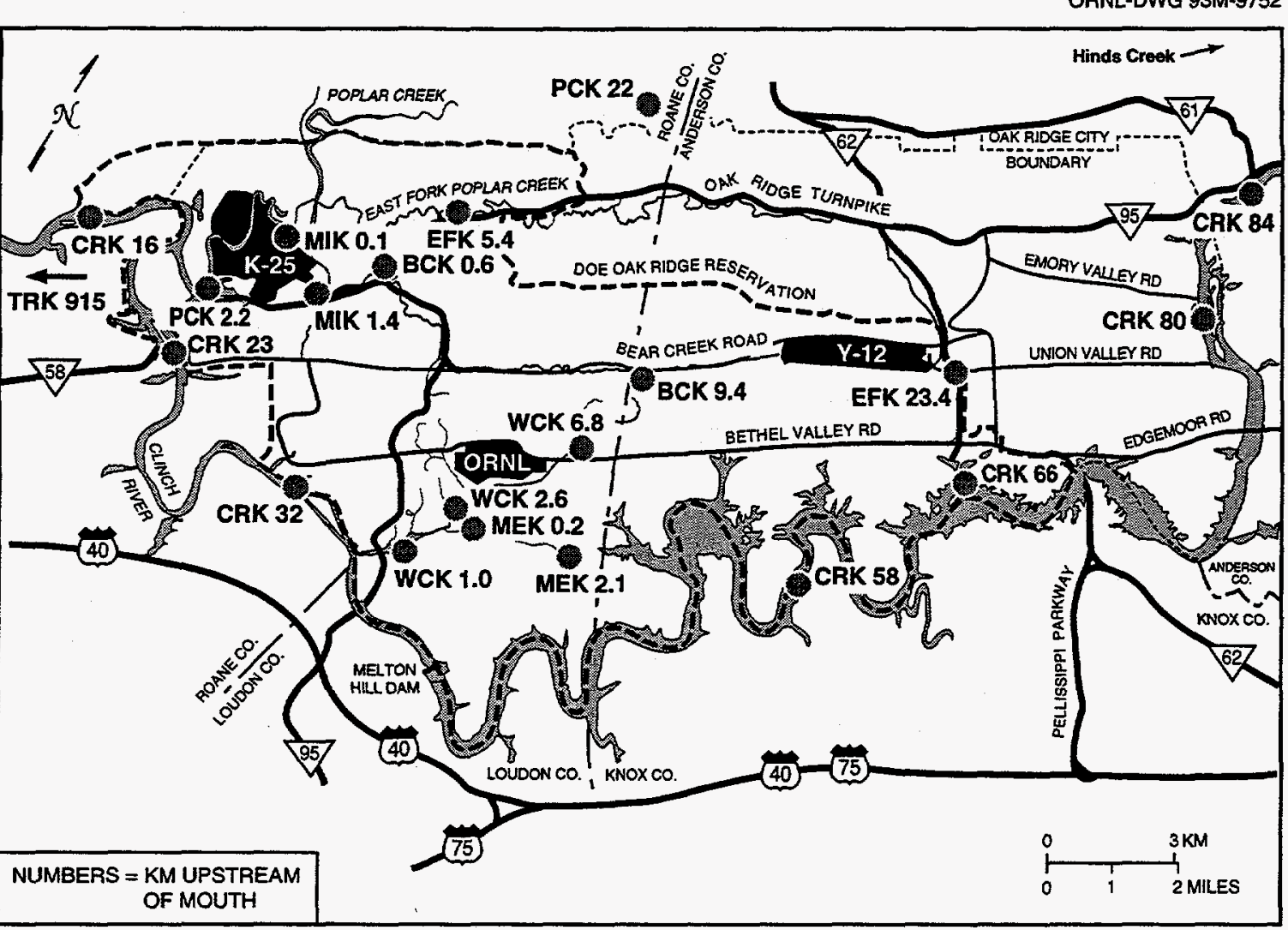

Fig. 5.12. Locations of ORR surface water sampling stations.

- Mitchell Branch upstream from K-25 Site (MIK 1.4),

- Poplar Creek downstream from K-25 Site (PCK 2.2),

- Poplar Creek upstream from K-25 Site and EFPC (PCK 22),

- Water supply intake for city of Kingston (TRK 915),

- White Oak Lake (WOL) at WOD (WCK 1.0),

- WOC downstream from ORNL (WCK 2.6), and

- WOC upstream from ORNL (WCK 6.8).

Water quality measurements serve as guides to the general health of the environment. The sampling and analysis in this program are conducted in addition to requirements mandated in NPDES permits for individual ORR DOE facilities. Although there is some overlap of sampling sites in the NPDES and environmental monitoring plan programs, frequency and analytical parameters vary.

Sampling frequency under the environmental monitoring plan is bimonthly, with half of the sites being sampled one month and the other half in the following month. Grab samples are collected and analyzed for general water quality parameters, total metals, and volatile organics. They are also screened for radioactivity and analyzed for specific radionuclides when appropriate.

In 1994 the collection of semiannual composite samples from WOC at White Oak Dam (WCK 1.0) and the Clinch River downstream from all DOE inputs (CRK 16) was implemented. These samples are analyzed for isotopic uraniums, thoriums, and transuranics.

Most of these locations are classified by Tennessee for certain uses, for example, domestic water supplies or recreational use. Tennessee water quality criteria for domestic water supplies, for freshwater fish and aquatic life, and for recreation (water and organisms), are 
used as references for locations where they are applicable. Out of the 79 parameters analyzed for at each of the 22 locations, chromium at White Oak Dam (WCK 1.0), arsenic and mercury at the Melton Hill Reservoir at the Oak Ridge Marina (CRK 80), and arsenic at the water supply intake for Knox County (CRK 58) are the only parameters that exceeded a reference value in 1995. Of these, chromium at White Oak Dam has been historically detected at elevated levels.

The Tennessee water quality criteria do not include criteria for radionuclides. Radionuclides were detected (statistically significant at a $95 \%$ confidence interval) at all of these surface water locations in 1995. The following observations are made from examining three years of historic data. Bear Creek downstream from the Y-12 Plant Burial Grounds (BCK 9.4) has consistently had the highest levels of gross alpha activity and, associated with the alpha activity, total uranium and uranium isotopes. BCK 9.4 also has elevated levels of gross beta activity. The highest levels of gross beta, total rad strontium, and tritium have been at Melton Branch downstream from ORNL (MEK 0.2), White Oak Creek at White Oak Dam (WCK 1.0) and White Oak Creek downstream from ORNL (WCK 2.6). These data are consistent with the processes or legacy activities nearby or upstream from these locations. The results for the semiannual composites at CRK 16 and WCK 1.0 are consistent with the bimonthly samples collected from these locations.

\section{Y-12 Plant Surface Water Monitoring}

Routine surface water monitoring that is not required by the NPDES permit is performed at the Y-12 Plant site for a variety of reasons, and various radiological and nonradiological parameters are monitored. Monitoring results are compared with state water quality criteria and with DOE order requirements. Data collected for nonradiological parameters are compared with Tennessee water quality criteria if a criterion exists for a given parameter. The most restrictive of either the fresh water fish and aquatic life criterion maximum concentration (CMC) or the "recreation concentration for organisms only" standard $\left(10^{-5}\right.$ risk factor for carcinogens) was used.

The water quality monitoring is done as a best management practice. In some instances the water quality criteria are below the reported analytical detection limits (examples are mercury, selenium, and silver). On some occasions, interferences with the analytical instrumentation, such as high levels of suspended solids after a rainfall, may result in a laboratory reporting a detection limit that is higher than normal and above a water quality criterion. This monitoring serves as a record of water quality criteria and provides an informal comparison. Of all the parameters measured in the surface water as a best management practice, mercury is the only demonstrated contaminant of concern. Continued reductions of mercury in plant effluent and monitoring for mercury discharge at Station 17 is a requirement of the new NPDES permit.

Radiological data are compared with DCGs published in DOE Order 5400.5. The DCG for water is the concentration of a given radionuclide that, if the water were ingested at the rate of $730 \mathrm{~L} /$ year, would result in an EDE of $100 \mathrm{mrem} /$ year to "reference man," as defined by ICRP Publication 23 . Radiological data are reported as percentages of the DCGs for given radionuclides. If the sum of DCG percentages for a location ever exceeds $100 \%$, an analysis of the best available technology to reduce the sum of the percentages of the radionuclide concentrations to their respective DCGs to less than $100 \%$ would be required as specified in DOE Order 5400.5.

Station 17, located near the junction of Bear Creek and Scarboro roads, is used to monitor EFPC downstream of Lake Reality but prior to its leaving the easternmost Y-12 Plant boundary (Fig. 5.13). Discharges from Y-12 Plant processes affect water quality and flow in EFPC before it enters the Clinch River. Samples were obtained for radiological and nonradiological parameters and grab samples for mercury and volatile organics were obtained daily at Station 17. With the exception of holidays, 24-hour composite samples were obtained every day of the week; a 72-hour composite was

\section{5-22 Environmental Surveillance}




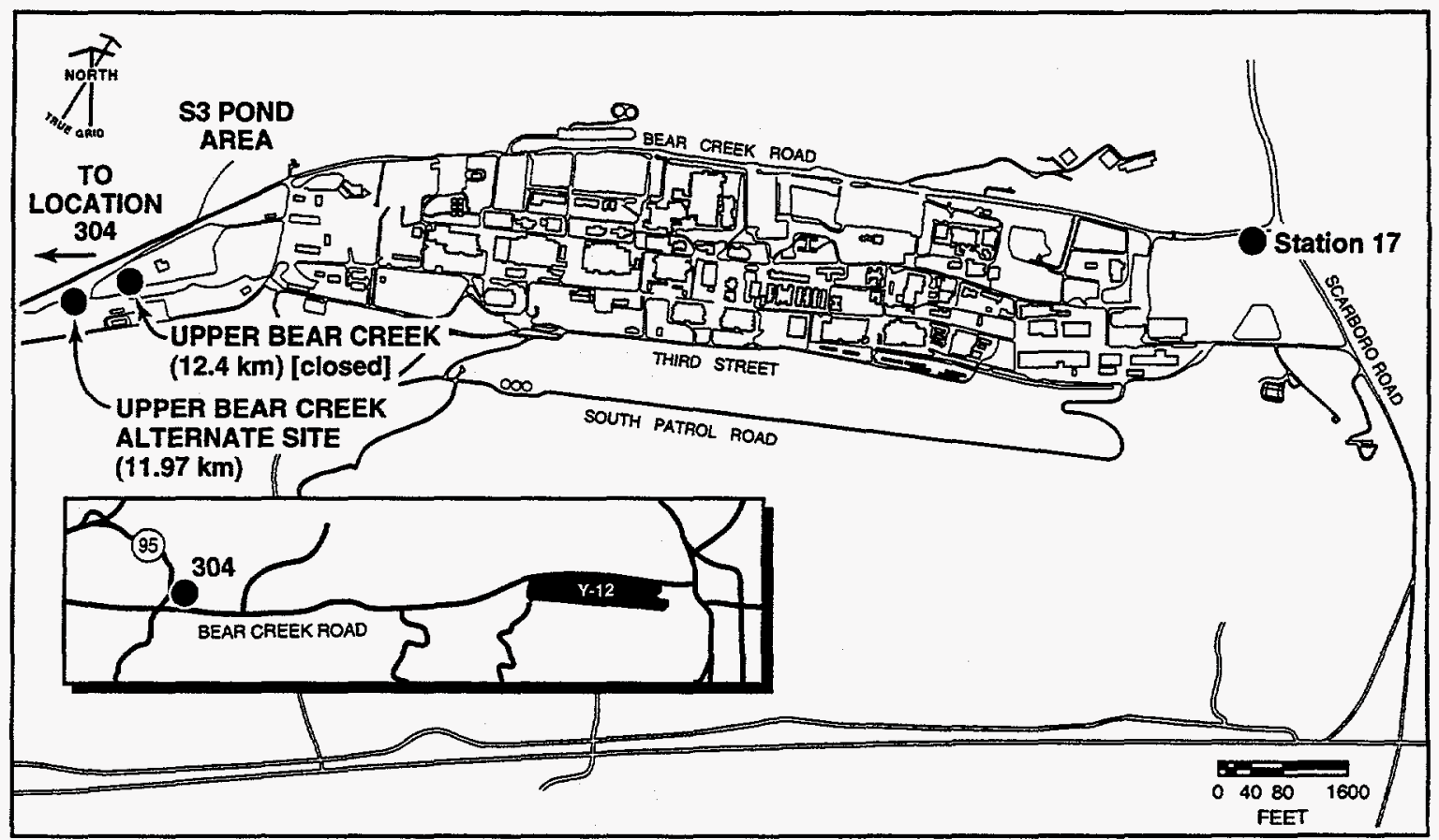

Fig. 5.13. Locations of Y-12 Plant surface water sampling stations.

collected on weekends for a variety of chemical parameters.

More than 200 samples were collected in 1995 at Station 17 for analysis of nonradiological parameters, resulting in more than 15,000 measurements. Comparisons with Tennessee water quality criteria, for parameters where there was an exceedence, are shown in Table 5.14. All 246 measurements for silver, arsenic, selenium, cadmium, and zinc were above those criteria because the detection limits of the analytical method are above the water quality criteria (see Table 5.14). Of the remaining measurements, some measurements for copper and mercury exceeded the criteria. On eleven occasions the measured value for copper exceeded the water quality criteria.

Mercury data are used for long- and short-term trending of mercury concentrations in plant effiuents. The legacy of contamination resulting from the use and storage of mercury at the Y-12 Plant has been previously acknowledged and has prompted a series of remedial measures. In the late 1950 s, the average annual concentration of mercury in EFPC peaked at about $2.3 \mathrm{mg} / \mathrm{L}(2,300 \mu \mathrm{g} / \mathrm{L})$. Recent annual average concentrations ranged from 0.0014 to $0.0016 \mathrm{mg} / \mathrm{L}$ ( 1.4 to $1.6 \mu \mathrm{g} / \mathrm{L})$. Because of mercury abatement activities, mercury loading to EFPC from the Y-12 Plant has decreased significantly. Average daily values were about $60 \mathrm{~g} /$ day in the early $1980 \mathrm{~s}$, whereas recent values are nearly $15 \mathrm{~g} /$ day, representing a $75 \%$ decrease in mercury releases during the past decade.

All radiological measurements at Station 17 were well below the DCGs. The summed percentage of DCGs for measured radionuclides at Station 17 was $2.5 \%$. The largest single contributor to this total was ${ }^{238} \mathrm{U}$. The median value for ${ }^{238} \mathrm{U}$ at this location for 1995 was $6.6 \mathrm{pCi} / \mathrm{L}$, which represents $1.1 \%$ of the DCG. In 1995, the total uranium and associated curies released from the Y-12 Plant, as measured at Station 17 on UEFPC, was $143 \mathrm{~kg}$, or $0.069 \mathrm{Ci}$ $\left(2.6 \times 10^{9} \mathrm{~Bq}\right)$.

Sampling locations S19 (formerly Outfall 302 at Rogers Quarry) and 304 on BCK 4.55 are considered in-stream sampling points for McCoy Branch and Bear Creek. In past years, coal bottom ash slurry was discharged to the McCoy Branch Watershed from the 
Table 5.14. Surface water sampling measurements exceeding Tennessee water quality criteria at the Y-12 Plant, 1995

\begin{tabular}{|c|c|c|c|c|c|c|c|}
\hline \multirow[t]{2}{*}{ Parameter } & \multirow[t]{2}{*}{ Location } & \multirow{2}{*}{$\begin{array}{c}\text { Number of } \\
\text { samples }\end{array}$} & \multicolumn{3}{|c|}{ Concentration (mg/L) } & \multirow{2}{*}{$\begin{array}{l}\text { Water quality } \\
\text { criteria } \\
\text { (mg/L) }\end{array}$} & \multirow{2}{*}{$\begin{array}{c}\text { Number of } \\
\text { measurements } \\
\text { exceeding criteria }\end{array}$} \\
\hline & & & $\begin{array}{c}\text { Detection } \\
\text { limit }\end{array}$ & $\operatorname{Max}$ & $\mathbf{A v}$ & & \\
\hline Silver & Station 17 & 246 & 0.006 & $<0.02$ & $<0.006$ & 0.004 & 246 \\
\hline Arsenic & Station 17 & 246 & 0.04 & $<0.04$ & $<0.04$ & 0.0014 & 246 \\
\hline Cadmium & Station 17 & 246 & 0.004 & $<0.004$ & $<0.004$ & 0.0039 & 246 \\
\hline Copper & Station 17 & 246 & 0.006 & 0.031 & $<0.008$ & 0.018 & 11 \\
\hline Mercury & Station 17 & 493 & 0.0002 & 0.0100 & 0.0010 & 0.00015 & 492 \\
\hline Selenium & Station 17 & 246 & 0.1 & $<0.1$ & $<0.1$ & 0.02 & 246 \\
\hline Zinc & Station 17 & 246 & 0.01 & 0.33 & 0.07 & 0.0063 & 246 \\
\hline Silver & Station 304 & 6 & 0.006 & $<0.006$ & $<0.006$ & 0.004 & 6 \\
\hline Arsenic & Station 304 & 6 & 0.04 & $<0.04$ & $<0.04$ & 0.0014 & 6 \\
\hline Cadmium & Station 304 & 6 & 0.004 & $<0.004$ & $<0.004$ & 0.0039 & 6 \\
\hline Mercury & Station 304 & 6 & 0.0002 & $<0.0002$ & $<0.0002$ & 0.00015 & 6 \\
\hline Selenium & Station 304 & 6 & 0.1 & $<0.1$ & $<0.1$ & 0.02 & 6 \\
\hline Zinc & Station 304 & 6 & 0.01 & $<0.01$ & $<0.01$ & 0.0063 & 6 \\
\hline Silver & Outfall 302 (\$19) & 6 & 0.006 & $<0.006$ & $<0.006$ & 0.004 & 6 \\
\hline Arsenic & Outfall 302 (S19) & 32 & 0.04 & $<0.04$ & $<0.04$ & 0.0014 & 32 \\
\hline Cadmium & Outfall 302 (S19) & 32 & 0.004 & $<0.004$ & $<0.004$ & 0.0039 & 32 \\
\hline Selenium & Outfall 302 (S19) & 32 & 0.1 & $<0.1$ & $<0.1$ & 0.02 & 32 \\
\hline Zinc & Outfall 302 (S19) & 32 & 0.01 & $<0.01$ & $<0.01$ & 0.0063 & 32 \\
\hline
\end{tabular}

Y-12 Steam Plant. Bear Creek water quality is affected by area source runoff and groundwater discharges from waste disposal sites. Of measurements collected and comparisons made to state water quality criteria for surface water surveillance, selenium, silver, arsenic, cadmium, and zinc exceeded the criteria at Rogers Quarry. This was because the analytical-method detection limits for these parameters exceed the water quality criterion $(0.00015 \mathrm{mg} / \mathrm{L})$. At Outfall 304 , silver, arsenic, cadmium, mercury, selenium, and zinc exceeded water quality criteria because the analytical method detection limits exceed the water quality criterion.

Additional surface water sampling is conducted at Outfall 304 by the Y-12 Plant Groundwater Protection Program (GWPP) to monitor trends throughout the Bear Creek Hydrogeologic Regime (see Sect. 7).

In addition to surveillance monitoring via conventional surface water sampling, the Y-12 Plant has established a series of monitoring stations on the storm sewer collection system and EFPC. These stations are officially known as the SWHISS. The SWHISS network is designed to monitor and record various surface water parameters to aid in spill tracking and water quality determination. Ten stations are currently operational (Fig. 5.14).

Telemetry delivers real-time monitoring data to the Utilities Monitoring Station 9 and the SWHISS house central computer in Building 9704-1. Real-time monitoring parameters vary for each site but typically include $\mathrm{pH}$, temperature, conductivity, dissolved oxygen, and flow. Two locations on EFPC also measure chlorine.

\section{ORNL Reference Surface Water Monitoring}

The net impact of ORNL activities on surface waters is evaluated by comparing data from samples collected at reference locations with information from samples collected downstream of the facility. Monthly surface water samples are collected at two sampling locations to determine contamination levels before the influence of WOC, the primary discharge point into Watts Bar Lake from the ORNL plant site. One sampling location is Melton Hill Dam above ORNL's main discharge 


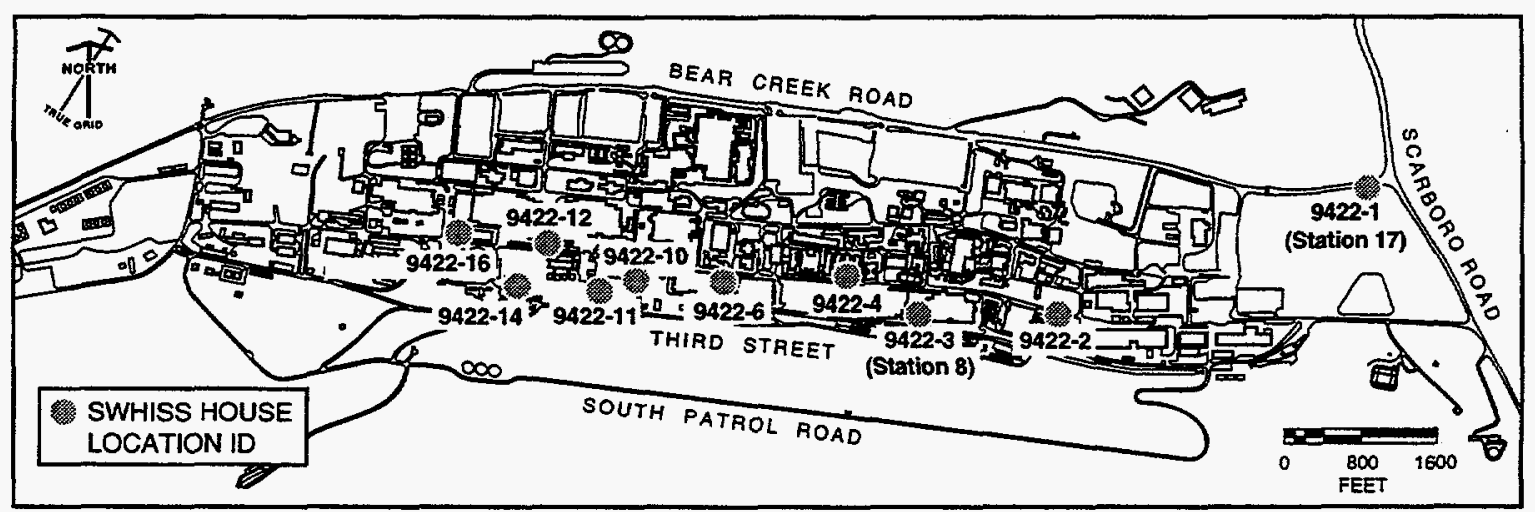

Fig. 5.14. Operating Surface Water Hydrological Information Support System monitoring locations.

point into the Clinch River. The other sampling location is WOC headwaters above any ORNL discharge points to WOC (Fig. 4.14).

Analyses were performed to detect radioactivity and conventional, inorganic, and organic pollutants in the water. Conventional pollutants are indicated by conductivity, temperature, turbidity, $\mathrm{pH}$, total dissolved solids, total suspended solids, and oil and grease. Inorganic parameters are indicated by analyses for metals and anions. The presence of organic pollutants is indicated by results from total organic carbon analysis. If the total organic carbon result is greater than $2.5 \mathrm{mg} / \mathrm{L}$, analyses for volatile and semivolatile organic compounds will be conducted.

There were no high levels of organic compounds detected by the total organic carbon analysis at either location, as indicated by the maximum value of $2.1 \mathrm{mg} / \mathrm{L}$ at Melton Hill Dam and by the maximum value of $2.2 \mathrm{mg} / \mathrm{L}$ at WOC headwaters.

In an effort to provide a basis for evaluation of analytical results and for assessment of surface water quality, Tennessee General Water Quality Criteria (TWQC) have been used as reference values. TWQC for Domestic Water Supply have been used at Melton Hill Dam; TWQC for Fish and Aquatic Life have been used at WOC headwaters.

There is reasonably good agreement between parameters measured at WOC headwaters and those at Melton Hill Dam. The average concentration is expressed as a percentage of the reference value when the parameter is a contaminant, the parameter was detected, and a reference value exists. Three parameters met this criteria; the largest was zinc at WOC headwaters at $12 \%$ of the reference value.

Radiological data are compared with DOE DCGs. The average concentration for a radionuclide is expressed as a percentage of its DCG when a DCG exists and when the average concentration is significantly greater than zero. At the reference locations, only one average for 1995 met the criteria; the average concentration of ${ }^{137} \mathrm{Cs}$ at WOC headwaters was less than $1 \%$ of its DCG.

\section{ORNL Radiological Liquid Effluent Monitoring Program Under the EMP}

In 1994 monitoring for gamma activity and tritium was added at the ORNL NPDES Category I and Category II outfalls. Category I outfalls are storm drains; Category II outfalls are storage area drains, once-through cooling water, cooling-tower blowdown, and condensate drains. With the exception of total radioactive $\mathrm{Sr}$ at the Category II outfalls, radionuclides detected at the remaining outfalls in 1995 were $<1 \%$ of the DCG for the respective radionuclide. 


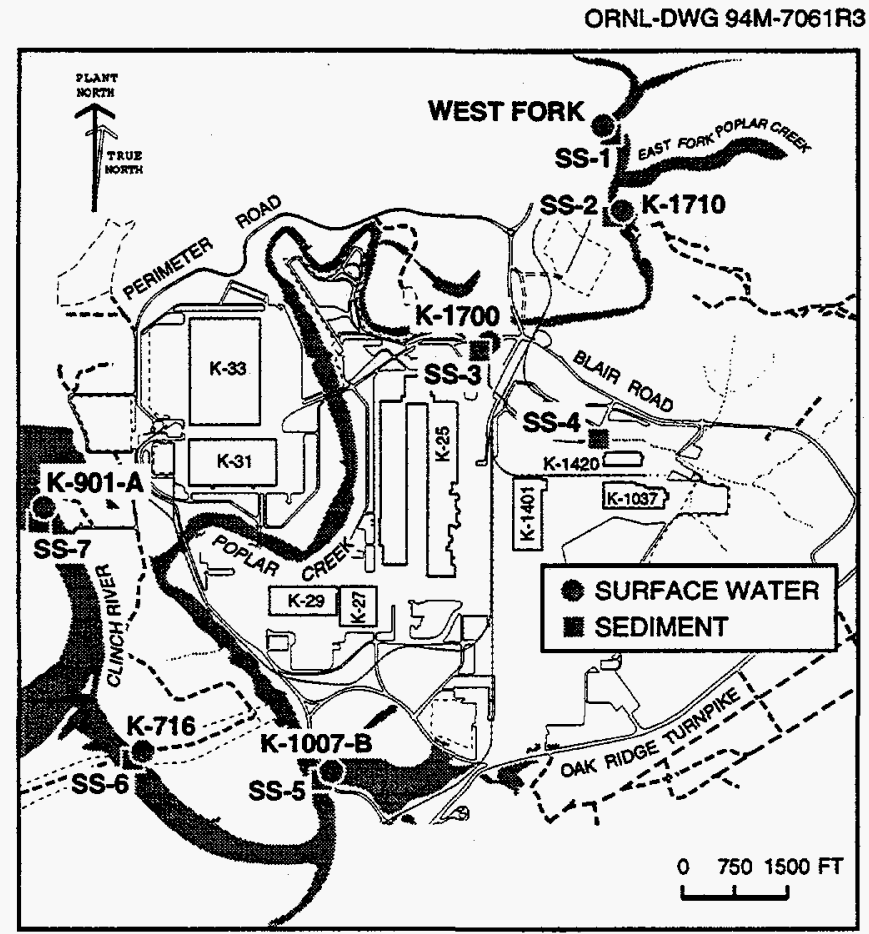

Fig. 5.15. Monitoring locations for surface

water at the K-25 Site.

\section{K-25 Site Surface Water Monitoring}

In addition to the ORR surface water surveillance program, surface water surveillance is conducted at six locations at the K-25 Site (Fig. 5.15) as a best management practice. The West Fork Poplar Creek and K-1710 sampling locations provide information representative of surface water conditions upstream of the $\mathrm{K}-25$ Site. Station K-716 is located downstream of most K-25 Site operations and provides information on the cumulative effects of the operations of the K-25 Site as well as those upstream. The remaining sampling locations are at points where drainage in the major surface water basins converges before discharging to Poplar Creek (K-1007-B and K-1700) or to the Clinch River (K-901-A).

Samples are analyzed monthly for radionuclides. Quarterly samples from the six locations are collected and analyzed for general water quality parameters, selected metals, and organic compounds. In addition, samples from K-901-A and K-1007-B are analyzed monthly for PCBs. Samples from the remaining locations are analyzed quarterly for PCBs. Radionuclide results are compared with the DCGs. Nonradiological results are compared with Tennessee water quality standards for fish and aquatic life, where such standards are published.

In most instances, results of the analyses for nonradiological parameters are well below the applicable standards. Lead, nickel, and mercury were occasionally detected but always in very low concentrations. For iron and manganese, water quality standards (WQSs) are sometimes exceeded, but the WQSs are below the level present in ambient waters. Both elements are abundant in the soil of East Tennessee, and water samples collected upstream of K-25 Site operations often show results above the standards. In addition, natural conditions cause periodic exceedences of WQSs for dissolved oxygen and pH. During 1995, Aroclor 1254 was detected at K-1007-B and K-1700 on several occasions. However, in all cases the reported values were below the lowest calibration point for the analytical method. No other PCBs were detected at these or any other $\mathrm{K}-25$ surface water monitoring locations. 


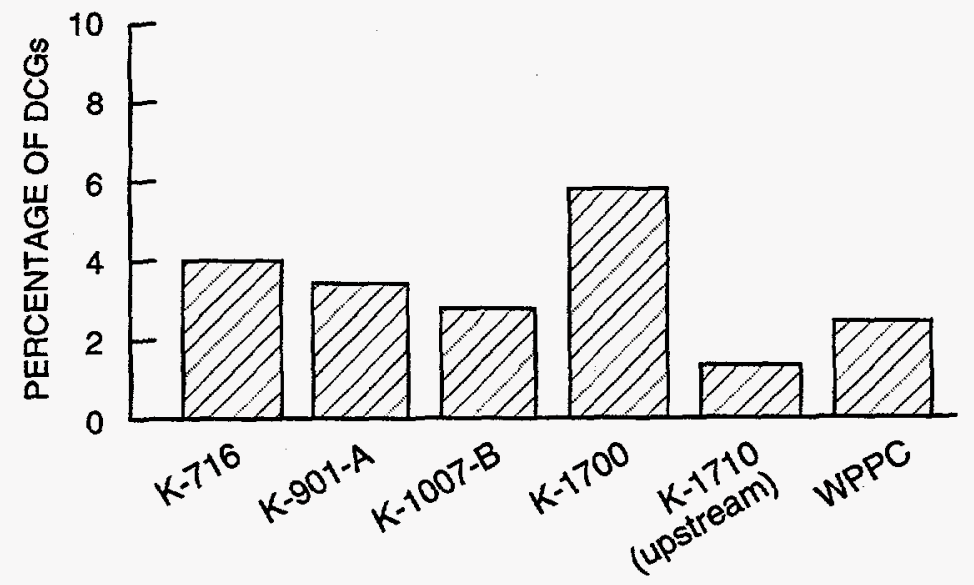

Fig. 5.16. Percentage of DCGs for K-25 Site surface water monitoring locations.

Dissolved oxygen measurements regularly fall below the minimum water quality standard during the summer months because of increased temperature (and therefore lower solubility of the gas) and increased biological activity. Similarly, increased photosynthesis during the summer months causes an increase in the $\mathrm{pH}$ of area waterways, sometimes exceeding the maximum water quality standard. Water bodies in the vicinity of the K-25 Site are regularly inspected for signs of stress on aquatic organisms during these periods. No evidence that these conditions have a negative impact on the aquatic communities was discovered during 1995. For most of the analyses, results are below detection limits for the instrument and method. Moreover, analytical results for samples collected upstream of the K-25 Site are chemically similar in most respects to those collected below the K-25 Site.

The sum of the fractions of the DCGs for all six sampling locations remained below the annual limit, as required by DOE Order 5400.5 (Fig. 5.16). The highest sum of the fractions, $2.2 \%$ of the allowable sum of the fractions of the DCGs, was reported for sampling location K-1700. These results are still well below the conservative limits established by the order. The 1995 radiological data do not indicate any significant radiological effects from K-25 Site operations on perimeter surface waters.

\section{Off-Site Spring and Residential Well Monitoring}

In 1989, ORNL implemented a long-term program to monitor off-site residential drinking water quality. The objective of the program is to document quantitative measurements of selected pollutants in culinary water drawn from groundwater surrounding the ORR in order to help assure residents that their drinking water sources have not been adversely affected by DOE-ORO plant operations.

Currently, 3 springs and 16 wells are included in the program. These locations were selected because of their proximity to the ORR and because they are located on a representative distribution of sources from the different geologic formations of the area. They are sampled semiannually and the results are provided in individual reports to the owners. Seventeen locations were sampled in February 1995 and again in August 1995.

Parameters monitored include volatile organics, metals, anions, and the radioactive parameters: gross alpha activity, gross beta activity, total radioactive strontium, technetium-99, tritium, and radionuclides observed in a gamma scan.

In past years, sampling has not indicated any contaminant movement to these sites, and results from sampling in 1995 continue to support this finding. The federal DWS for fluoride and the TWQC for domestic water supplies for lead was 


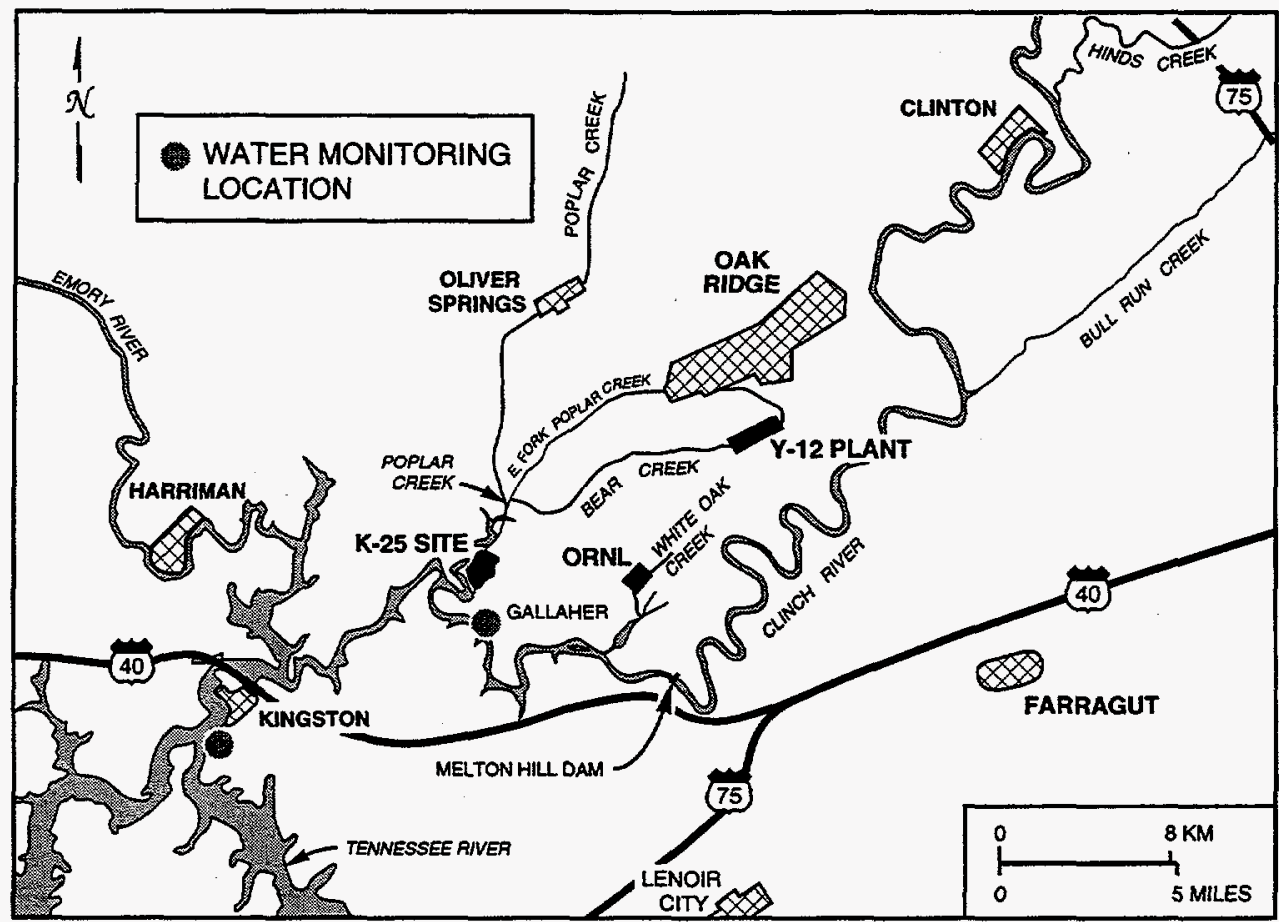

Fig. 5.17. Sampling locations for off-site treated water.

exceeded during both sampling events at one well, and the standard for nitrate was exceeded at another well during the February event.

At the first well, the fluoride concentration was consistent with the historical data for the well. The well exceeding fluoride limits is located deep in the Conasauga formation; the high fluoride concentration most likely results from natural chemical reactions that can occur in deep wells that penetrate the Conasauga geologic group. The lead concentration was higher than previous results.

In the second well, the nitrate concentration was consistent with the historical data for the well. Nitrate in groundwater is commonly associated with nearby farming operations and is a likely cause in this instance.

\section{Off-Site Treated Water Monitoring}

The ORNL program for assessing impacts to the Clinch and Tennessee rivers uses empirical data from samples taken at the Kingston and Gallaher potable water treatment plants (Fig. 5.17). In 1995, composite samples of treated water samples were collected monthly and analyzed quarterly for total uranium and specific radionuclides.

Federal and state DWSs (40 CFR Parts 141 and 143 and TWQC for Domestic Water Supply) were used as reference values. If a DWS for a radionuclide has not been established, then $4 \%$ of the DOE DCG for that radionuclide is used as the reference value. The average radionuclide concentration is expressed as a percentage of the reference value when a reference exists and when the average is significantly greater than zero. In 1995, there were no average radionuclide concentrations greater than $15 \%$ of reference values at the Kingston Water Treatment Plant and none greater than $16 \%$ of reference values at the Gallaher Water Treatment Plant. The laboratory method used for total uranium does not permit a test of significance for the maximum and minimum, but the average concentrations of uranium at both Gallaher and Kingston were $<0.6 \%$ of the gross alpha standard $(15 \mathrm{pCi} / \mathrm{L})$. The total uranium measurement is converted to an activity by assuming natural abundance of uranium isotopes ${ }^{234} \mathrm{U},{ }^{235} \mathrm{U}$, and ${ }^{238} \mathrm{U}$. 


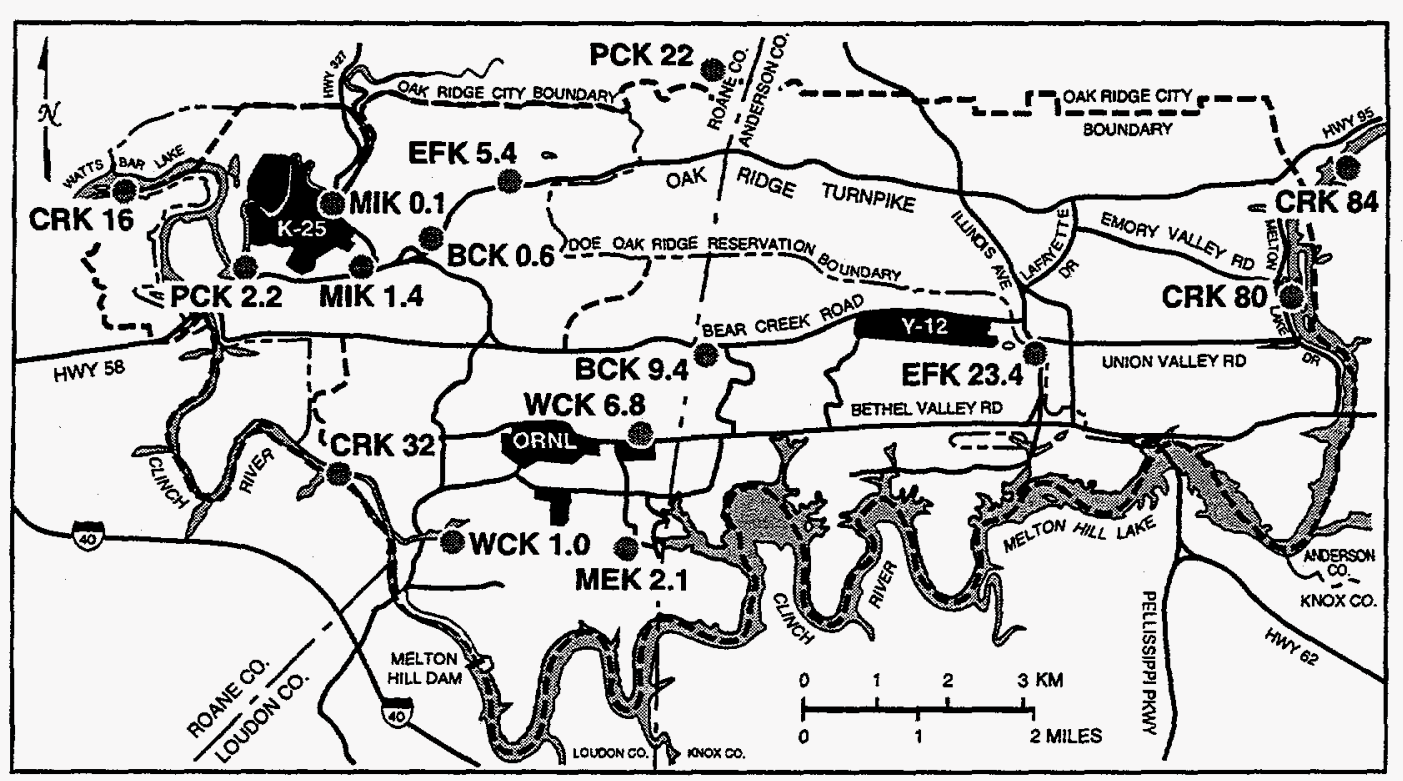

Fig. 5.18. ORR environmental monitoring plan sediment sampling locations.

\section{SOIL}

Soil is an integrating medium that can contain pollutants originally released to the air and can thus provide a measure of pollutant deposition from the atmosphere. Soil sampling and analysis is used to evaluate long-term accumulation trends.

Soil plots consisting of a known mixture of soil were erected at nine of the ambient air stations in the fall of 1992 (eight perimeter stations and the remote station at Norris Dam; see Fig. 5.3). These soil plots eliminate the differences in the mechanics of transport in the different types of soil found naturally on the ORR. The soil plot program is described in detail in the environmental monitoring plan for the ORR.

Vertical composite samples were collected at the nine stations once during 1995. Samples were analyzed for gross alpha and beta activity, gamma emitters, total radiological strontium, and uranium. Soil sampling results are presented in Tables 5.2 and 5.3.

\section{SEDIMENT}

\section{ORR Sediment}

Stream and lake sediments act as a record of some aspects of water quality by concentrating and storing certain contaminants. Annually, under the ORR Environmental Monitoring Plan, sediment samples are collected at 16 sites near surface water and biological monitoring locations in and around the reservation (Fig. 5.18). The sampling sites are as follows:

- Bear Creek downstream from all DOE inputs (BCK 0.6),

- Bear Creek downstream from Y-12 Plant burial grounds (BCK 9.4),

- Clinch River downstream from all DOE inputs (CRK 16),

- Clinch River downstream from ORNL (CRK 32),

- Melton Hill Reservoir at Oak Ridge Marina (CRK 80),

- Melton Hill Reservoir above all DOE inputs at the Anderson County Filtration Plant (CRK 84),

- EFPC downstream from floodplain (EFK 5.4), 
- EFPC downstream from the Y-12 Plant (EFK 23.4),

- Hinds Creek (reference site for EFPC) (HC),

- Melton Branch upstream from ORNL (MEK 2.1),

- Mitchell Branch downstream from K-25 Site (MIK 0.1),

- Mitchell Branch upstream from K-25 Site (MIK 1.4),

- Poplar Creek downstream from K-25 Site (PCK 2.2),

- Poplar Creek upstream from K-25 Site and EFPC (PCK 22),

- White Oak Lake at White Oak Dam (WCK 1.0), and

- White Oak Creek upstream from ORNL (WCK 6.8).

Sediments are effective at concentrating and storing contaminants that have a high affinity for organic and inorganic surfaces, but they also contain naturally occurring organic and inorganic chemicals. In analytical measurements, the naturally occurring chemicals in sediment lead to higher backgrounds and less sensitivity than those found in water samples. Sediments are best analyzed for substances that are concentrated and retained in sediment, resulting in sensitive, time-integrated measurements of contamination. The program was initiated in 1993, and the locations are sampled annually. Samples were analyzed for total metals, chlorinated pesticides, PCBs, semivolatile organic compounds, and selected radionuclides.

By examining the 3 years' worth of data available from this program, a few observations may be made. There is no evidence of PCBs at the Clinch River locations (CRK 16, 32, 80, and 84), Hinds Creek, the Mitchell Branch location (MEK 2.1), and Poplar Creek upstream from the K-25 Site and EFPC (PCK 22). PCBs, in particular Aroclor-1254 and Aroclor-1260, have consistently been detected downstream from the Y-12 Plant at EFK 23.4. Lower levels of PCBs have been detected at EFK 5.4, and estimated levels have been detected at the remaining sediment sampling locations.
Metals have been detected at all of the locations. Those that are especially higher at a particular location are mercury at EFK 23.4 and EFK 5.4, arsenic at MIK 0.1, barium at MEK 2.1, lead at MIK 0.1 and WCK 6.8, and total uranium at MIK 0.1.

The locations where radionuclides have been detected at consistently higher concentrations are WCK $1.0\left({ }^{60} \mathrm{Co}\right.$ and ${ }^{137} \mathrm{Cs}$ ) and MIK 0.1 (gross alpha and beta, ${ }^{99} \mathrm{Tc}$, and alpha-emitting isotopes of plutonium, neptunium, and uranium).

In most cases, these observations reflect the processes occurring nearby or upstream of the particular sampling location, which is what one would expect.

\section{FOOD}

Collection and analysis of vegetation samples serves three purposes: to evaluate potential radiation doses received by people consuming food crops; to predict possible concentrations in meat, eggs, and milk from animals consuming grains; and to monitor trends in environmental contamination and possible long-term accumulation of radionuclides.

\section{Hay}

Hay is cut on the ORR and sold to area farmers for fodder. Six areas from which hay is cut have been identified as potential depositional areas for airborme materials from ORR sources (Fig. 5.19). Areas 1, 2, and 3 are within the predicted air plume for an ORNL source and could also be affected by the K-25 Site. Baled hay was collected from each of these three sites and composited for analysis. Areas 2, 4, 5, and 6 are within the predicted air plume for the K-25 Site, an ORNL, and a Y-12 Plant source. Baled hay was collected from each of these sites and composited for laboratory analysis. Area 6 best represents the combined plumes from all three sites; baled hay was collected from this site. Area 7, not shown on Fig. 5.19, represents a reference site near the Norris Dam ambient air station. 


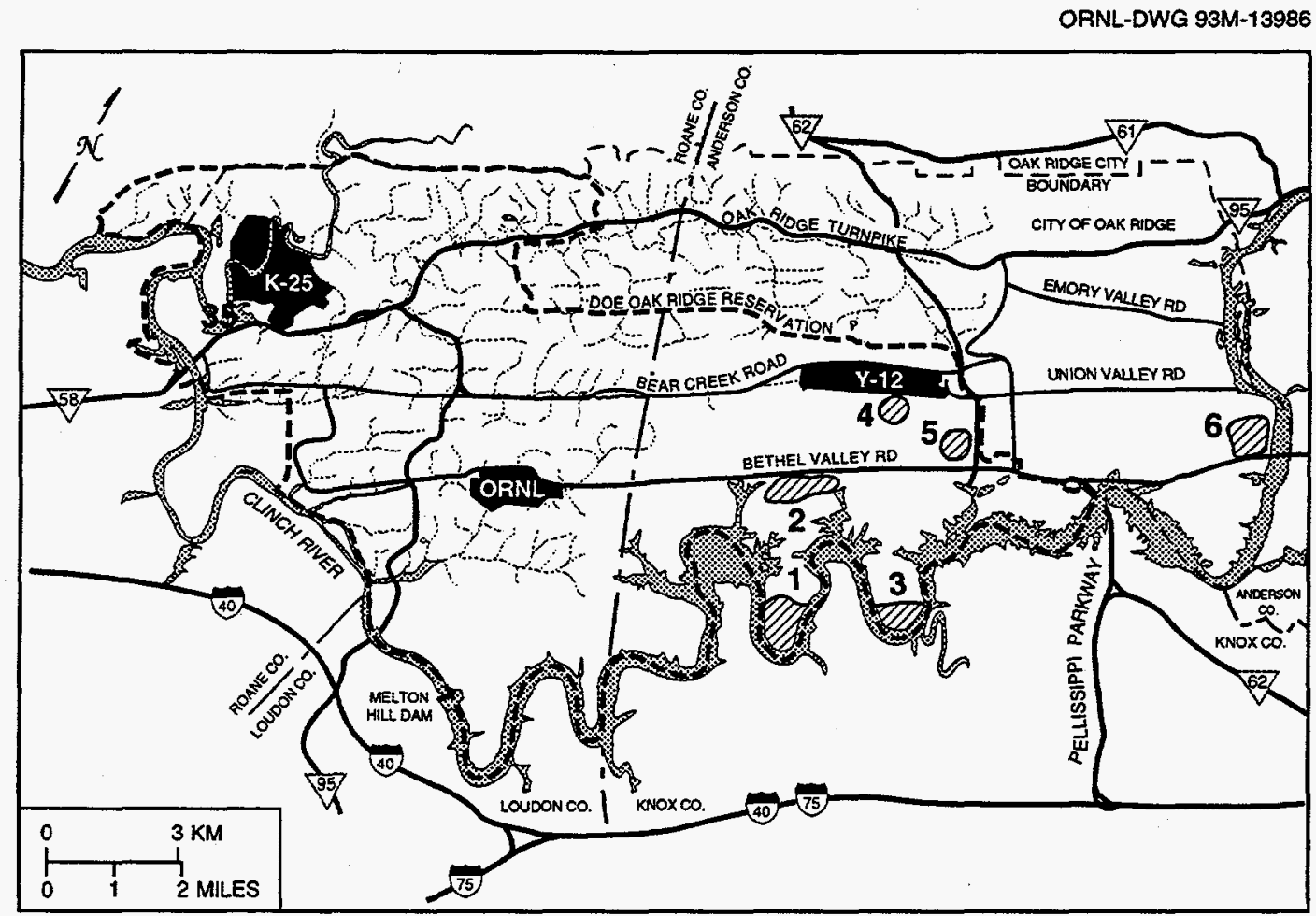

Fig. 5.19. Hay sampling locations on the ORR.

\section{Results}

Hay samples were collected during June 1995, and samples were analyzed for gross alpha and beta, gamma emitters, iodine, and fluorides. There were no statistically significant radiological results in any of the 1995 hay samples.

\section{Vegetables}

Tomatoes, lettuce, and turnips were grown in nine soil plots established at the ORR ambient air stations as shown in Fig. 5.3. All crops were harvested except tomatoes at Station 35, where a crop failure occurred. The failure was attributed to natural causes.

\section{Results}

Samples were analyzed for gross alpha and beta, gamma emitters, and total uranium. Table 5.2 summarizes the results of the sampling effort. The analytical results indicate that radionuclide concentrations in tomatoes, lettuce, and turnips do not vary significantly when comparing samples collected at reference
Station 51 with those obtained from the ORR plots or purchased from representative gardens near ORR plots.

\section{Milk}

Ingestion is one of the pathways of exposure to radioactivity for humans. Radionuclides can be transferred from the environment to people via food chains such as the grass-cow-milk pathway. Milk is a potentially significant source to humans of some radionuclides deposited from airborne emissions because of the relatively large surface area that a cow can graze daily, the rapid transfer of milk from producer to consumer, and the importance of milk in the diet.

The 1995 milk sampling program consisted of monthly grab samples collected from five locations in the vicinity of the ORR (Fig. 5.20). In 1995, the Solway site was dropped, and a new site was selected in Karns to ensure sample availability. Milk samples are analyzed at ORNL for radioactive iodine $\left({ }^{131} \mathrm{I}\right)$ by gamma spectrometry and for total radioactive strontium $\left({ }^{89} \mathrm{Sr}+{ }^{90} \mathrm{Sr}\right)$ by chemical separation 


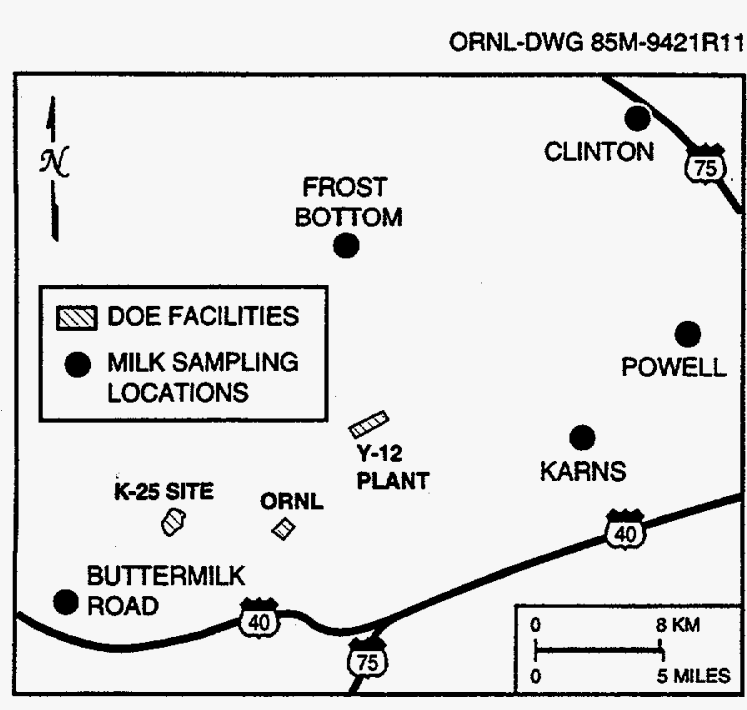

Fig. 5.20. Milk sampling locations in the vicinity of the ORR.

and low-background beta counting. Liquid scintillation is used to analyze for tritium $\left({ }^{3} \mathrm{H}\right)$.

\section{Results}

Radioactivity measurements are reported as the net activity (the difference between the gross activity and instrument background). A 95\% confidence level is used to determine statistical significance. Concentrations of total radioactive strontium detected in milk were consistent with averaged concentrations for the region (Table 5.15). There were no detected concentrations of ${ }^{131} \mathrm{I}$ or ${ }^{3} \mathrm{H}$. Average values for radioactive strontium were converted to EDEs and are presented in Section 6 of this report.
Results are consistent with data from previous years.

\section{Honey}

Before 1995, honey from privately owned hives in the vicinity of the ORR was analyzed for radionuclides to determine whether a potential exposure pathway existed. In 1995, beehives were established on the reservation at strategic locations at the Y-12 Plant, ORNL, and the $\mathrm{K}-25$ Site. Honey samples from the hives were analyzed in 1995. The results of the radiological analysis of honey collected from sites on the ORR are summarized in Table 5.16.

\section{Fish}

Members of the public potentially could be exposed to contaminants originating from DOE-ORO activities through consumption of fish caught in area waters. This exposure pathway is monitored under the ORR environmental monitoring plan by collecting fish from 14 locations annually and analyzing edible fish flesh. Sampling locations are located downstream of DOE activities, at on-site creek locations, and at one off-site reference location. Sampling sites are divided into six larger river locations and eight smaller creek locations. Because of the limited number and size of fish available for sampling on the creek locations, different fish-processing and analytical procedures

Table 5.15. Concentrations of total radioactive strontium $\left({ }^{89} \mathrm{Sr}+{ }^{90} \mathrm{Sr}\right)$ in raw milk, $1995(\mathrm{pCi} / \mathrm{L})^{a}$

\begin{tabular}{|c|c|c|c|c|c|}
\hline \multirow[t]{2}{*}{ Station } & \multirow{2}{*}{$\begin{array}{l}\text { No. Detected/ } \\
\text { No. of samples }\end{array}$} & \multicolumn{3}{|c|}{ Detected concentration } & \multirow{2}{*}{$\begin{array}{l}\text { Standard } \\
\text { error of mean }\end{array}$} \\
\hline & & Max & Min & $\mathbf{A v}$ & \\
\hline Buttermilk Road & $9 / 12$ & 2.2 & 0.14 & $1.0^{b}$ & 0.17 \\
\hline Powell & $12 / 12$ & 2.7 & 0.89 & $1.7^{b}$ & 0.18 \\
\hline Clinton & $11 / 11$ & 2.5 & 0.95 & $1.5^{b}$ & 0.13 \\
\hline Frost Bottom & $12 / 12$ & 3.0 & 0.78 & $2.3^{b}$ & 0.17 \\
\hline Karns & $10 / 10$ & 2.7 & 1.1 & 1.9 & 0.17 \\
\hline Network summary & $53 / 53$ & 3.0 & 0.14 & $1.7^{b}$ & 0.09 \\
\hline
\end{tabular}


Table 5.16. Significant radiological results for honey sampled from hives on the ORR, $1995^{a}$

\begin{tabular}{llcc}
\hline Parameter & Station & $\begin{array}{c}\text { Uncertainty }^{b} \\
(\mathbf{p C i} / \mathbf{k g})^{c}\end{array}$ & Value $(\mathbf{p C i} / \mathbf{k g})^{c}$ \\
\hline${ }^{40} \mathrm{~K}$ & K-25 Site & 49 & 62 \\
${ }^{40} \mathrm{~K}$ & X-10 Site & 35 & 65 \\
Gross alpha & Y-12 Plant & 11 & 9.2 \\
Gross beta & Y-12 Plant & 27 & 46 \\
${ }^{40} \mathrm{~K}$ & Y-12 Plant & 41 & 62
\end{tabular}

\footnotetext{
${ }^{a}$ All samples were taken on November 13, 1995.

${ }^{b}$ Uncertainty is arrived at by calculating two standard deviations.

${ }^{c} 1 \mathrm{pCi}=3.7 \mathrm{E}-02 \mathrm{~Bq}$.
}

are used. Only results from sampling at river locations are presented in this report.

The river locations include five sites on the Clinch River and one location on Poplar Creek (Fig. 5.21):

- Melton Hill Reservoir above all DOE inputs at Anderson County Filtration Plant (CRK 84),

- Melton Hill Reservoir at Oak Ridge Marina (CRK 80),

- Melton Hill Reservoir above the city of Oak Ridge water intake (CRK 66),
- Clinch River downstream from ORNL (CRK 32),

- Clinch River downstream from all DOE inputs (CRK 16), and

- Poplar Creek downstream from the K-25 Site (PCK 2.2).

Sunfish (Lepomis macrochirus, L. auritus, and Ambloplites rupestris) are collected from each of the six river locations, filleted, and frozen. When enough fish have been collected (typically 150 to 200 per location), the samples are thawed and fillets from six of the largest are analyzed for selected metals, pesticides, and PCBs. The rest (separated into three composite samples) are ashed and analyzed for ${ }^{60} \mathrm{Co},{ }^{137} \mathrm{Cs}$, and total radioactive strontium. To provide data from a second species, annual catfish sampling was initiated in 1993. Six to ten catfish are collected at the CRK 16 and CRK 32 locations, and a composite sample is analyzed for selected metals, pesticides, and PCBs. A composite sample is also ashed and analyzed for ${ }^{60} \mathrm{Co}$, ${ }^{137} \mathrm{Cs}$, and total radioactive strontium.

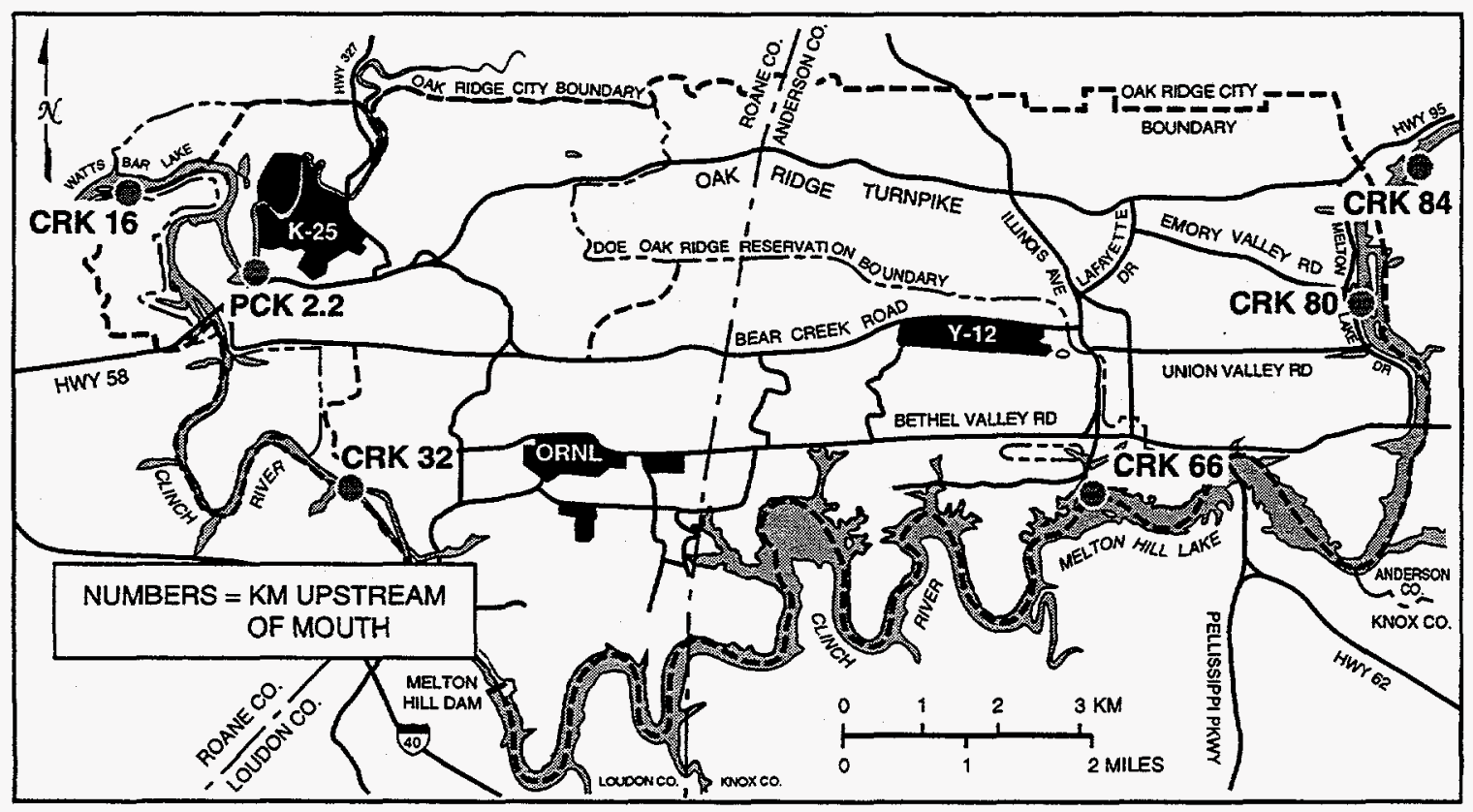

Fig. 5.21. Fish sampling locations along the Clinch River. 


\section{Results}

In 1995, most parameters analyzed for in sunfish and catfish were undetected.

For PCBs, reported values for sunfish and catfish were below the U.S. Food and Drug Administration (FDA) tolerance of $2 \mathrm{ppm}$; for mercury, all reported values were below the FDA action level of $1 \mathrm{ppm}$ This has been true for all years of the program. Information regarding potential health impacts associated with the sunfish and catfish data is provided in Section 6. When PCBs have been detected, they have been primarily Aroclor-1254 and Aroclor-1260, at estimated low levels.

\section{White-Tailed Deer}

The eleventh annual deer hunts managed by DOE and the TWRA were held on the ORR during the final quarter of 1995. ORNL staff, TWRA, and student members of the Wildlife Society (University of Tennessee Chapter) performed most of the necessary operations at the checking station.

All three hunts this year were gun hunts with two archery-only hunt areas designated. The two archery-only areas were on the northeast side of ORNL and in an area next to the Clinch River and Bear Creek. These areas allowed archery hunting during all three gun-hunt periods. On the last hunt (December 9-10), hunters were allowed to harvest two deer. The two-deer limit for a gun hunt was a first for the ORR. The two-deer limit had been reserved for archery-only hunts.

From the total harvest of 489 animals, 295 (60.3\%) were bucks and 194 (39.7\%) were does. The heaviest buck had nine antler points and weighed $176 \mathrm{lb}$. The greatest number of antler points (13) was found on a buck weighing $147 \mathrm{lb}$; however, that deer was confiscated. The heaviest doe weighed $121 \mathrm{lb}$.

\section{Results}

Of the 489 deer harvested, 8 were confiscated because they exceeded established release limits $\left(5 \mathrm{pCi} / \mathrm{g}\right.$ for ${ }^{137} \mathrm{Cs}$ and $20 \mathrm{pCi} / \mathrm{g}$ for ${ }^{90} \mathrm{Sr}$ ). Concentrations of ${ }^{90} \mathrm{Sr}$ in bone exceeded the confiscation limit in all eight of the deer confiscated. Concentrations of ${ }^{137} \mathrm{Cs}$ (based on field data) in the deer released to the public did not exceed $1.3 \mathrm{pCi} / \mathrm{g}(-4.8 \mathrm{E}-02 \mathrm{~Bq} / \mathrm{g})$. The deer confiscated during the 1995 hunt represent $1.6 \%$ of the total deer harvested. Since the hunts began in $1985,5,885$ deer have been harvested; a total of $147(2.5 \%)$ were retained because of radiological contamination.

\section{Resident Canada Geese}

One objective of the ORR waterfowl program is to determine concentrations of gamma-emitting radionuclides accumulated by waterfowl associated with waste disposal areas. Radioactive elements found in waste material are the primary types of contaminants associated with the ORR. The annual roundup of Canada geese took place between June 28 and 30, 1995. During the roundup, whole-body gamma scans were conducted on 86 geese: 10 geese from ORNL, 20 from the K-25 Site, 20 from Melton Hill Dam, 21 from Oak Ridge Marina, and 15 from the Y-12 Plant were analyzed. Three geese from each location were sacrificed, and samples were analyzed; the remaining geese were released following the gamma scan.

The sampling areas are selected because of high geese congregation. The geese are highly mobile animals that range freely to sites on and off the reservation. For that reason, the results in this report should be taken as an indication of the possible overall impact that the reservation has on the geese rather than as an evaluation of the collection sites.

\section{Results}

Of the 86 geese counted in 1995, 56 had concentrations of ${ }^{137} \mathrm{Cs}$ that were considered to be statistically greater than zero. Of these, the highest concentration, $0.21 \mathrm{pCi} / \mathrm{g}(8.0 \mathrm{E}-03 \mathrm{~Bq} / \mathrm{g})$, was found in a goose collected at the K-25 Site. The average ${ }^{137} \mathrm{Cs}$ concentration in the 56 geese was estimated to be $0.08 \mathrm{pCi} / \mathrm{g}(-3 \mathrm{E}-03 \mathrm{~Bq} / \mathrm{g})$.

\section{Turkey Monitoring}

Wild turkeys on the ORR are not presently considered a potential pathway for radiation 
exposure to humans because there are no permitted turkey hunts on the reservation or in the surrounding areas. However, proposals for hunts on the ORR and in both Knox and Roane counties are under consideration. During the first quarter of 1995, TWRA trapped 12 wild turkeys on the reservation for relocation to an off-site wildlife-management area.

\section{Results}

Prior to release, a whole-body count was performed on the birds to gather preliminary data. Cesium- 137 was detected in only one bird at $0.09 \mathrm{pCi} / \mathrm{g}$. 


\title{
6. Dose
}

S. J. Cotter, F. R. O Donnell, and P. A. Scofield

\begin{abstract}
The interaction of radiation emitted by radionuclides with human tissue accounts for most of the doses from radionuclides in the environment. Radionuclides can be taken into the body through ingestion, inhalation, and skin absorption. Humans can also be exposed directly to radiation sources outside the body, which can include radionuclides. Radiation dose can be estimated based on type of radiation, route and length of exposure, and organs exposed. This section presents estimates of radiation doses due to small quantities of radionuclides released to air and water as a result of operations at the ORR facilities during 1995 and describes the methods used to make these estimates.
\end{abstract}

\section{RADIATION DOSE}

Small quantities of radionuclides were released to the environment from operations at the ORR facilities during 1995. Those releases are quantified and characterized in Sects. 4, 5, and 7 . This section presents estimates of the potential radiation doses to the public from the releases and describes the methods used to make the estimates.

\section{Terminology}

Most doses associated with radionuclide releases to the environment are caused by interactions between radiation emitted by the radionuclides and human tissue. These interactions involve the transfer of energy from the radiation to tissue, a process that may damage the tissue. The radiation may come from radionuclides located outside the body (in or on environmental media or objects) or from radionuclides deposited inside the body (by inhalation, ingestion, and, in a few cases, absorption through the skin).

Exposures to radiation from nuclides located outside the body are called external exposures; exposures to radiation from nuclides deposited inside the body are called internal exposures. This distinction is important because external exposures occur only when a person is near or in a radionuclide-containing medium; internal exposures continue as long as the radionuclides remain inside the person. Also, external exposures may result in uniform irradiation of the entire body and all its components; internal exposures usually result in nonuniform irradiation of the body. (When taken into the body, most radionuclides deposit preferentially in specific organs or tissues and thus do not irradiate the body uniformly.)

A number of the specialized terms and units used to characterize exposures to ionizing radiation are defined in Appendix A. One of these is used repeatedly in this section and is defined as the EDE, a risk-based dose equivalent that can be used to estimate health-effects risks to exposed persons. It is a weighted sum of dose equivalents to specified organs, expressed in rem or sieverts $(1 \mathrm{rem}=0.01 \mathrm{~Sv})$.

\section{Methods of Evaluation}

\section{Airborne Radionuclides}

Characterization of the radiological consequences of radionuclides released to the atmosphere from ORR operations during 1995 was accomplished by calculating, for each plant and for the entire ORR, EDEs to maximally exposed off-site individuals and to the entire population residing within $80 \mathrm{~km}$ ( 50 miles) of the center of the ORR. The dose calculations were made using the CAP-88 package of computer codes (Beres 1990), 
which was developed under EPA sponsorship to demonstrate compliance with Rad-NESHAP 40 CFR 61, Subpart $H$. This package contains the most recent, approved version of the AIRDOS-EPA and DARTAB computer codes and the ALLRAD88 radionuclide data file. The AIRDOS-EPA computer code implements a steady-state Gaussian plume atmospheric dispersion model to calculate concentrations of radionuclides in the air and on the ground. It also uses Regulatory Guide 1.109 (NRC 1977) food chain models to calculate radionuclide concentrations in foodstuffs (vegetables, meat, and milk) and subsequent intakes by humans.

The concentrations and human intakes are used by EPA's latest version of the DARTAB computer code to calculate EDEs from radionuclides released to the atmosphere. The dose calculations use the dose conversion factors (DCFs) contained in the ALLRAD88 data file (Beres 1990).

Three types of radionuclide releases were reported in the ORR Rad-NESHAP report for 1995: monitored, sampled, and calculated. Monitored releases are quantified using data from continuous sampling systems. Monitored sources during 1995 included the combined monitored stacks at the Y-12 Plant; stacks associated with buildings $2026,2523,3020,3039,7830,7877$, and Stack 7911 at ORNL; and the K-25 Site TSCA Incinerator (K-1435) stack.

Sampled releases are calculated from measured radionuclide contents of various media (e.g., grab samples of room air concentrations and sections of filters) and measured flow rates through the sampled media. Sampled sources during 1995 include room exhausts at the Y-12 Plant; stacks associated with buildings $2000,3018,3074,3544,7025$, and 7512 at ORNL; and discharge points associated with the $\mathrm{K}-1015$ laundry, $\mathrm{K}-31 / \mathrm{K}-33$, and $\mathrm{K}-1037$ at the K-25 Site.

Calculated releases are determined from source inventories (e.g., hot cell, hood, and storage area) using EPA-approved emission factors. Therefore, these calculated releases are conservative and largely hypothetical. Their purpose is to determine whether source monitoring or sampling is required. All doses (including those derived from these hypothetical releases) must be reported in the Annual Site Environmental Report and in the Rad-NESHAP report; however, it is important to realize that radiation doses associated with calculated releases, which may be hypothetical, are added to the doses associated with monitored and sampled releases.

Monitored and sampled radionuclide releases were modeled for 1 combined release point at the Y-12 Plant, for 13 release points at ORNL, and for 3 release points at the K-25 Site. Table 6.1 lists the source parameter values used in the calculations.

Meteorological data used in the calculations were in the form of joint frequency distributions of wind direction, wind speed class, and atmospheric stability category. These data were derived from data collected during 1995 at the 60-m height on MT6 for the Y-12 Plant; at the 100-m height on meteorological tower 2 (MT2) for stacks $2000,2026,2523,3018,3020,3039$, 3074,3544 , and 7025 and at the $30-\mathrm{m}$ height on MT4 for stacks $7512,7830,7877$, and 7911 at ORNL; and at the 60-m height on MT1 for the K-25 Site. Rainfall on the ORR during 1995 was $120 \mathrm{~cm}$ (47 in.), the average air temperature was $14^{\circ} \mathrm{C}\left(56^{\circ} \mathrm{F}\right)$, and the average mixing layer height was $1000 \mathrm{~m}$ (3280 ft).

The dose calculations are based on the assumption that each person remained at home (actually, outside the house), unprotected, during the entire year and obtained food according to the rural pattern defined in the NESHAP background documents (EPA 1989). This pattern specifies that $70 \%$ of the vegetables and produce, $44.2 \%$ of the meat, and $39.9 \%$ of the milk consumed by each person are produced in the local area (e.g., a home garden). The remaining portion of each food is assumed to be produced within $80 \mathrm{~km}$ ( 50 miles) of the ORR. For collective EDE estimates, production of beef, milk, and crops within $80 \mathrm{~km}$ of the ORR was calculated using the state-specific production rates provided with CAP-88.

\section{Results}

Calculated EDEs from radionuclides emitted to the atmosphere from the ORR are 
Annual Site Environmental Report

Table 6.1. Monitored and sampled release point parameters and receptor locations used in the dose calculations

\begin{tabular}{|c|c|c|c|c|c|c|c|}
\hline \multirow[t]{2}{*}{$\begin{array}{l}\text { Source } \\
\text { name }\end{array}$} & \multirow[t]{2}{*}{ Type } & \multirow[t]{2}{*}{$\begin{array}{l}\text { Release } \\
\text { height } \\
\text { (m) }\end{array}$} & \multirow[t]{2}{*}{$\begin{array}{l}\text { Inner } \\
\text { diameter } \\
\text { (m) }\end{array}$} & \multirow[t]{2}{*}{$\begin{array}{l}\text { Gas exit } \\
\text { relocity } \\
(\mathrm{m} / \mathrm{s})\end{array}$} & \multirow[t]{2}{*}{$\begin{array}{c}\text { Gas exit } \\
\text { temperature } \\
\left.{ }^{\circ} \mathrm{C}\right)\end{array}$} & \multicolumn{2}{|c|}{$\begin{array}{l}\text { Distance (m) and } \\
\text { direction to maximally } \\
\text { exposed individual }\end{array}$} \\
\hline & & & & & & Plant & ORR \\
\hline \multicolumn{8}{|c|}{ Y-12 Plant } \\
\hline All & Point & 20 & 0 & 0 & Ambient & $1080 \mathrm{NNE}$ & $1080 \mathrm{NNE}$ \\
\hline \multicolumn{8}{|c|}{ ORNL } \\
\hline 2026 & Point & 22.9 & 1.05 & 11.0 & Ambient & $4060 \mathrm{SSW}$ & $9300 \mathrm{NE}$ \\
\hline 3020 & Point & 61.0 & 1.96 & 5.5 & Ambient & 4060 SSW & $9300 \mathrm{NE}$ \\
\hline 3039 & Point & 76.2 & 5.68 & 2.7 & Ambient & 4060 SSW & $9300 \mathrm{NE}$ \\
\hline 7025 & Point & 4.0 & 0.3 & 12.9 & Ambient & $5710 \mathrm{SW}$ & $7550 \mathrm{NNE}$ \\
\hline 7512 & Point & 30.5 & 0.91 & 7.7 & Ambient & $3720 \mathrm{SW}$ & $9640 \mathrm{NNE}$ \\
\hline 7911 & Point & 76.2 & 3.43 & 3.0 & Ambient & $3720 \mathrm{SW}$ & $9640 \mathrm{NNE}$ \\
\hline 7830 & Point & 4.6 & 0.21 & 12.9 & Ambient & $2350 \mathrm{SW}$ & $10990 \mathrm{NNE}$ \\
\hline 7877 & Point & 13.9 & 0.51 & 9.3 & Ambient & $2350 \mathrm{SW}$ & $10990 \mathrm{NNE}$ \\
\hline 2000 & Point & 15.2 & 0.66 & 8.3 & Ambient & 4060 SSW & $9300 \mathrm{NE}$ \\
\hline 3018 & Point & 61.0 & 4.11 & 0.2 & Ambient & $4060 \mathrm{SSW}$ & $9300 \mathrm{NE}$ \\
\hline 3074 & Point & 4.0 & 0.26 & 10.2 & Ambient & 4060 SSW & $9300 \mathrm{NE}$ \\
\hline 3544 & Point & 9.5 & 0.27 & 28.3 & Ambient & 4060 SSW & $9300 \mathrm{NE}$ \\
\hline 2523 & Point & 7.0 & 0.3 & 4.8 & 57.2 & 4060 SSW & $9300 \mathrm{NE}$ \\
\hline \multicolumn{8}{|c|}{$K-25$ Site } \\
\hline K-1435 & Point & 30.5 & 1.37 & 5.6 & 79.2 & 5180 WSW & $13000 \mathrm{ENE}$ \\
\hline $\mathrm{K}-1015$ & Point & 3.7 & 0 & 0 & Ambient & 4340 WSW & $14000 \mathrm{ENE}$ \\
\hline $\mathrm{K}-31 / \mathrm{K}-33$ & Point & 25.9 & 0 & 0 & Ambient & 3330 WSW & $14800 \mathrm{ENE}$ \\
\hline $\mathrm{K}-1037$ & Point & 10.5 & 1.1 & 6.3 & Ambient & 4820 WSW & $13250 \mathrm{ENE}$ \\
\hline
\end{tabular}

Table 6.2. Calculated radiation doses to maximally exposed off-site individuals from airborne releases during 1995

\begin{tabular}{|c|c|c|}
\hline \multirow[t]{2}{*}{ Plant } & \multicolumn{2}{|c|}{$\begin{array}{l}\text { Total effective dose equivalents } \\
\text { [mrem (mSv)] }\end{array}$} \\
\hline & Plant max & ORR max \\
\hline ORNL & $2.0 \mathrm{E}-01(1.0 \mathrm{E}-03)^{a}$ & $1.8 \mathrm{E}-02(3.0 \mathrm{E}-04)$ \\
\hline $\begin{array}{l}\text { K-25 Site } \\
\text { Y-12 Plant } \\
\text { Entire ORR }\end{array}$ & $\begin{array}{c}5.2 \mathrm{E}-02(5.2 \mathrm{E}-04)^{b} \\
4.6 \mathrm{E}-01(4.6 \mathrm{E}-03)^{c} \\
d\end{array}$ & $\begin{array}{l}1.3 \mathrm{E}-02(1.3 \mathrm{E}-04) \\
4.6 \mathrm{E}-01(4.6 \mathrm{E}-03) \\
5.0 \mathrm{E}-01(5.0 \mathrm{E}-03)^{e}\end{array}$ \\
\hline \multicolumn{3}{|c|}{$\begin{array}{l}{ }^{a} \text { The maximally exposed individual is located } 4060 \mathrm{~m} \text { ( } 2.5 \text { miles) SSW } \\
\text { of the } 3039 \text { stack and } 3720 \mathrm{~m} \text { ( } 2.3 \text { miles) SW of the } 7911 \mathrm{stack} \text {. } \\
{ }^{b} \text { The maximally exposed individual is located } 5180 \mathrm{~m} \text { ( } 3.2 \text { miles) WSW } \\
\text { of the K- } 1435 \text { stack. } \\
\text { of The maximally exposed individual is located } 1080 \mathrm{~m} \text { ( } 0.7 \text { miles) NNE } \\
\text { of the Y-12 Plant release point. } \\
{ }^{d} \text { Not applicable. } \\
\text { eThe maximally exposed individual for the entire ORR is the Y-12 Plant } \\
\text { maximally exposed individual. }\end{array}$} \\
\hline
\end{tabular}

listed in Tables 6.2 (maximum individual) and 6.3 (collective). The EDE received by the hypothetical, maximally exposed individual for the ORR was calculated to be about $0.5 \mathrm{mrem}$ ( $0.005 \mathrm{mSv})$, which is below the NESHAP standard of $10 \mathrm{mrem}(0.10 \mathrm{mSv})$ and well 
Table 6.3. Calculated collective EDEs

from airborne releases during 1995

\begin{tabular}{lcc}
\hline \multicolumn{1}{c}{ Plant } & \multicolumn{2}{c}{ Effective dose equivalents } \\
\cline { 2 - 3 } & Person-rem & Person-Sv \\
\hline ORNL & 3 & 0.03 \\
K-25 Site & 3 & 0.03 \\
Y-12 Plant & 6 & 0.06 \\
ORR & 11 & 0.11 \\
& \\
\hline \multicolumn{2}{c}{${ }^{a}$ The collective effective dose equivalents to the 879,546 persons residing } \\
within $80 \mathrm{~km}$ (50 miles) of the ORR.
\end{tabular}

below the 300 mrem ( $3 \mathrm{mSv}$ ) that the average individual receives from natural sources of radiation. About $0.1 \mathrm{mrem}(0.01 \mathrm{mSv})$ of the $0.5 \mathrm{mrem}$ is from calculated emissions. The maximally exposed individual is located about $9300 \mathrm{~m}$ (5.8 miles) northeast of the 3039 stack at ORNL, about $13,000 \mathrm{~m}$ (8.1 miles) east-northeast of the K-1435 (TSCA Incinerator) stack at the K-25 Site, and about $1080 \mathrm{~m}$ (0.7 miles) north-northeast of the Y-12 Plant release point. The calculated collective EDE to the entire population within $80 \mathrm{~km}$ ( 50 miles) of the ORR (about 879,546 persons) was about 11 person-rem ( 0.11 person-Sv), which is $0.004 \%$ of the 264,000 person-rem that this population could have received from natural sources of radiation. About 2 of the 11 person-rem are from calculated emissions.

The EDE received by the hypothetical, maximally exposed individual for the Y-12 Plant was calculated to be $0.46 \mathrm{mrem}(0.0046 \mathrm{mSv})$. This individual is located about $1080 \mathrm{~m}$ (0.7 miles) north-northeast of the Y-12 Plant release point. Essentially, all ( $-96 \%)$ of this dose is from ingestion and inhalation of uranium, primarily ${ }^{234} \mathrm{U},{ }^{235} \mathrm{U}$, and ${ }^{238} \mathrm{U}$ and about $1 \%$ of the dose is due to ${ }^{239} \mathrm{Pu}$. The contribution of Y-12 Plant emissions to the 50-year committed collective EDE to the population residing within $80 \mathrm{~km}$ of the ORR was calculated to be about 6 person-rem ( 0.06 person-Sv), which is approximately $51 \%$ of the collective EDE for the ORR.

The EDE received by the hypothetical, maximally exposed individual for ORNL was calculated to be $0.2 \mathrm{mrem}(0.002 \mathrm{mSv})$.
This individual is located $4060 \mathrm{~m}$ (2.5 miles) south-southwest of the 3039 stack and $3720 \mathrm{~m}$ ( 2.3 miles) southwest of the 7911 stack. About $54 \%$ of this dose is from ingestion and inhalation of ${ }^{212} \mathrm{~Pb}$, about $21 \%$ is from immersion in noble gases (primarily ${ }^{41} \mathrm{Ar}$ ), and about $14 \%$ is from ingestion and inhalation of ${ }^{138} \mathrm{Cs}$. Other nuclides contributing $-1 \%$ or more to the dose are ${ }^{3} \mathrm{H}$ $(2.4 \%)$ and thorium nuclides $(-1 \%)$. Calculated source terms account for about $20 \%$ of the dose. The contribution of ORNL emissions to the collective EDE to the population residing within $80 \mathrm{~km}$ of the ORR was calculated to be about 3 person-rem ( 0.03 person-Sv), which is approximately $25 \%$ of the collective EDE for the ORR.

The EDE received by the hypothetical, maximally exposed individual for the K-25 Site was calculated to be $0.05 \mathrm{mrem}(0.0005 \mathrm{mSv})$. This individual is located about $5180 \mathrm{~m}$ (3.2 miles) west-southwest of the TSCA Incinerator (K-1435) stack. About $93 \%$ of this dose is from ingestion and inhalation of uranium, about $5.6 \%$ is from ${ }^{40} \mathrm{~K}$, and about $1 \%$ is from ${ }^{99} \mathrm{Tc}$. The contribution of K-25 Site emissions to the collective EDE to the population residing within $80 \mathrm{~km}$ of the ORR was calculated to be about 3 person-rem ( 0.03 person-Sv), which is approximately $24 \%$ of the collective EDE for the reservation.

The reasonableness of the calculated radiation doses can be inferred by examining the radiation doses that could be received from measured air concentrations of radionuclides at the ORR PAMs and RAMs (Fig. 5.3). Hypothetical individuals assumed to reside 
at the PAMs could have received EDEs between 0.089 and 4.7 mrem/year $(0.00089$ and $0.047 \mathrm{mSv} /$ year); these EDEs include contributions from naturally occurring (background) radionuclides, from radionuclides released from the ORR, and radionuclides released from any other sources. The highest calculated potential dose rate, $4.7 \mathrm{mrem} /$ year at PAM 35, is due to tritium of unknown origin. An indication of doses from sources other than those on the ORR can be obtained from the EDEs calculated at the two RAMs, which averaged $0.062 \mathrm{mrem} /$ year $(0.00062 \mathrm{mSv} /$ year $)$. Between 30 and $90 \%$ of the calculated EDEs at the PAMs are attributable to tritium, some of which was produced naturally.

Of particular interest is a comparison of doses calculated using measured air concentrations at PAMs located near the maximally exposed individuals for each plant and doses calculated to those individuals using CAP-88 and measured emissions. PAM 46 is located near the maximally exposed individual for the Y-12 Plant and the entire ORR. The EDE calculated at PAM 46 was $0.09 \mathrm{mrem} /$ year $(0.0009 \mathrm{mSv} / \mathrm{year})$, which is $20 \%$ of the $0.46 \mathrm{mrem} /$ year $(0.046 \mathrm{mSv} / \mathrm{year})$ to the maximally exposed individual modeled by the CAP-88 code. PAM 39 is located near the maximally exposed individual for ORNL. The EDE calculated at PAM 39 was $0.11 \mathrm{mrem} /$ year ( $0.0011 \mathrm{mSv} /$ year), which is about half the $0.20 \mathrm{mrem} /$ year $(0.0020 \mathrm{mSv} /$ year $)$ based on CAP-88 code modeling. PAM 35 is located near the maximally exposed individual for the K-25 Site. The EDE calculated at PAM 35 was $4.7 \mathrm{mrem} /$ year $(0.047 \mathrm{mSv} / \mathrm{year})$, which is much higher than the $0.052 \mathrm{mrem} /$ year $(0.00052 \mathrm{mSv} /$ year) modeled value to the maximally exposed individual.

\section{Waterborne Radionuclides}

Radionuclides discharged to surface waters from the ORR enter the Tennessee River system by way of the Clinch River and various feeder streams. Discharges from the Y-12 Plant enter the Clinch River by way of Bear Creek and EFPC, both of which enter Poplar Creek before it enters the Clinch River. Discharges from ORNL enter the Clinch River by way of WOC and WOL. Discharges from the K-25 Site enter the Clinch River by way of Poplar Creek. This section discusses the potential radiological impacts of these discharges to persons who drink water, eat fish, swim, boat, and use the shoreline at various locations along the Clinch and Tennessee rivers.

Measured, annual-average concentrations of radionuclides in water samples taken at the K-25 Site (Gallaher) water plant and at the Kingston municipal water plant were used to calculate potential maximum individual EDEs from drinking water. A worker who drank $365 \mathrm{~L}$ (half of the worker's total water consumption) of K-25 Site water during 1995 could have received an EDE of about $0.10 \mathrm{mrem}(0.0010 \mathrm{mSv})$; a person who drank $730 \mathrm{~L}$ of Kingston water could have received about 0.15 mrem $(0.0015 \mathrm{mSv})$.

There are other unsampled water treatment plants along the Clinch-Tennessee River system. Three plants are located above Melton Hill Dam, and others are located on tributaries of Watts Bar and Chicamauga Lakes. The three upstream plants are located near sampling points CRK 84, CRK 66, and CRK 58. Persons drinking $730 \mathrm{~L}$ of sampled water per year could receive EDEs of $0.16,0.28$, and 0.31 mrem $(0.0016,0.0028$, and $0.0031 \mathrm{mSv}$ ), respectively. (These dose estimates may be high because they are based on water samples taken before processing in the plants.) Persons drinking water from the Watts Bar and Chicamauga plants should receive EDEs lower than the 0.15 mrem calculated for the Kingston water treatment plant.

A program initiated during 1993 involves collecting samples of water and fish at selected locations along the Clinch River, Poplar Creek, and near the intake of the Kingston city water plant on the Tennessee River (Fig. 5.21). The results of this sampling program were used to illustrate potential radiation doses from radionuclides found in waters above and below inputs from the ORR.

Measured concentrations of radionuclides in water at the selected locations were input to the LADTAP XI computer code to calculate potential EDEs to maximally exposed individuals 
Table 6.4. Potential maximum individual EDEs from use of off-site waters (mrem) ${ }^{a, b}$

\begin{tabular}{|c|c|c|c|c|c|}
\hline Location & Eating fish & $\begin{array}{l}\text { Swimming } \\
\text { or wading }\end{array}$ & Boating & $\begin{array}{c}\text { Using } \\
\text { shoreline }\end{array}$ & Total \\
\hline Clinch River above all DOE input (CRK 84) & $\begin{array}{l}1.7 \mathrm{E}-1 \\
3.5 \mathrm{E}-2\end{array}$ & $1.2 \mathrm{E}-4$ & $3.9 \mathrm{E}-5$ & 6.5.E-2 & $2.4 \mathrm{E}-1$ \\
\hline Clinch River at Oak Ridge Marina (CRK 80) & $\begin{array}{l}9.3 \mathrm{E}-1 \\
2.4 \mathrm{E}-2\end{array}$ & $2.3 E-4$ & $9.4 \mathrm{E}-5$ & $2.1 \mathrm{E}-1$ & $1.1 \mathrm{E}+0$ \\
\hline Clinch River above Oak Ridge city water intake (CRK 66) & $\begin{array}{l}4.2 E-1 \\
2.5 E-3\end{array}$ & $1.3 \mathrm{E}-4$ & $5.9 \mathrm{E}-5$ & $9.8 \mathrm{E}-2$ & $5.2 \mathrm{E}-1$ \\
\hline Clinch River at Knox County water intake (CRK 58) & $3.8 \mathrm{E}-1$ & $5.2 \mathrm{E}-5$ & $1.7 \mathrm{E}-5$ & $2.9 \mathrm{E}-2$ & $4.1 \mathrm{E}-1$ \\
\hline Clinch River below ORNL (CRK 32) & $\begin{array}{l}4.8 E-1 \\
1.3 E-1\end{array}$ & $7.6 \mathrm{E}-5$ & $3.4 \mathrm{E}-5$ & $5.6 \mathrm{E}-2$ & $5.4 \mathrm{E}-1$ \\
\hline Clinch River at K-25 Site water intake (CRK 23) & $3.8 \mathrm{E}-1$ & $4.2 \mathrm{E}-5$ & $1.8 \mathrm{E}-5$ & $3.0 \mathrm{E}-2$ & $4.1 \mathrm{E}-1$ \\
\hline Clinch River below all DOE inputs (CRK 16) & $\begin{array}{l}5.1 E-1 \\
8.0 E-2\end{array}$ & $1.2 \mathrm{E}-4$ & $5.9 \mathrm{E}-5$ & $9.8 \mathrm{E}-2$ & $6.1 \mathrm{E}-1$ \\
\hline Tennessee River at Kingston Water Plant intake (TRK 915) & $2.4 \mathrm{E}-1$ & $5.5 \mathrm{E}-6$ & $8.2 \mathrm{E}-8$ & $9.4 \mathrm{E}-4$ & $2.4 \mathrm{E}-1$ \\
\hline Poplar Creek above union with East Fork Poplar Creek (PCK 22) & $2.8 \mathrm{E}-1$ & $1.7 \mathrm{E}-7$ & $8.6 \mathrm{E}-8$ & $1.1 \mathrm{E}-3$ & $2.8 \mathrm{E}-1$ \\
\hline Poplar Creek below the K-25 Site (PCK 2.2) & $\begin{array}{l}7.6 \mathrm{E}-1 \\
6.9 \mathrm{E}-2\end{array}$ & & $4.6 \mathrm{E}-5$ & & $7.6 \mathrm{E}-1$ \\
\hline
\end{tabular}

\footnotetext{
${ }^{a}$ To convert mrem to $\mathrm{mSv}$, divide the given values by 100 .

${ }^{b}$ All values are based on measured concentrations of radionuclides in water except the second set of values for eating fish, which are based on measured concentrations of radionuclides in fish.
}

who are assumed to eat $21 \mathrm{~kg}$ of fish/year, to swim or wade for 27 hours/year, to boat for 63 hours/year, and to use the shoreline for 67 hours/year at the sampled location. Also, fish sampling data were used to calculate maximum individual EDEs from eating $21 \mathrm{~kg}$ of fish. Table 6.4 is a summary of the potential EDEs. Eating fish and shoreline usage are the only significant contributors to potential EDEs. Doses attributable to swimming or wading and boating are negligibly small.

EDEs from eating fish also are estimated using measured concentrations of radionuclides in fish. Because of differences in the radionuclides reported as present, doses calculated using concentrations in water exceeded those calculated using concentrations in fish tissue. The results are presented in Table 6.4.

Calculated EDEs ranged from 0.2 to $1.1 \mathrm{mrem}(0.002$ to $0.011 \mathrm{mSv})$ per year. High and low dose estimates are found both above and below DOE inputs. Doses that result from eating fish range from 0.002 to 0.93 mrem $(0.00002$ to $0.0093 \mathrm{mSv}$ ) per year, and doses resulting from shoreline exposures ranged from negligible to $0.2 \mathrm{mrem}(0.002 \mathrm{mSv})$ per year. The highest EDEs were calculated at a location (CRK 80) upstream from almost all $\mathrm{DOE}$ inputs.

When all pathways are considered, the maximum EDE resulting from waterborne radionuclide discharges could have been about 1.2 mrem ( $0.012 \mathrm{mSv})$ : $1.1 \mathrm{mrem}$ $(0.011 \mathrm{mSv})$ from use of off-site waters plus $0.1 \mathrm{mrem}(0.001 \mathrm{mSv})$ from drinking $\mathrm{K}-25$ or Kingston water. The collective EDE to the 50-mile population was estimated to be about 9 person-rem ( 0.09 person-Sv). These are small percentages of individual and collective doses attributable to natural background radiation, $0.4 \%$ and $0.003 \%$, respectively. 
Table 6.5. Average EDEs from ingesting vegetables grown at ORR ambient air monitoring stations, 1995

\begin{tabular}{llc}
\hline Vegetable & \multicolumn{2}{c}{ EDE } \\
& \multicolumn{2}{c}{ [mrem (mSv)] } \\
\cline { 2 - 3 } & $\begin{array}{c}\text { All reported } \\
\text { radionuclides }\end{array}$ & Excluding ${ }^{40} \mathbf{K}$ \\
\hline Tomatoes & $1.4 \mathrm{E}+00(1.4 \mathrm{E}-02)$ & $1.6 \mathrm{E}-02(1.6 \mathrm{E}-04)$ \\
Lettuce & $2.0 \mathrm{E}+00(2.0 \mathrm{E}-02)$ & $2.3 \mathrm{E}-02(2.3 \mathrm{E}-04)$ \\
Turnips & $1.9 \mathrm{E}+00(1.9 \mathrm{E}-02)$ & $8.0 \mathrm{E}-03(8.0 \mathrm{E}-05)$ \\
Total & $5.3 \mathrm{E}+00(5.3 \mathrm{E}-02)$ & $4.7 \mathrm{E}-02(4.7 \mathrm{E}-04)$ \\
\end{tabular}

\section{Radionuclides in Other Environmental Media}

The CAP- 88 computer codes calculate radiation doses from ingestion of meat, milk, and vegetables that contain radionuclides released to the atmosphere. The doses are included in the dose calculations for airborne radionuclides.

\section{Milk}

One environmental pathway for ingestion, drinking milk, also was evaluated using concentrations of strontium, tritium, and ${ }^{131} I$ measured in milk collected from nearby farms. If, during the year, an individual drank $310 \mathrm{~L}$ of milk containing the highest detectable quantity of strontium, the individual could have received an EDE of about $0.1 \mathrm{mrem}(0.001 \mathrm{mSv})$ or less. The average EDE associated with drinking milk in EPA Region 4 is about 0.09 mrem (0.0009 mSv) (EPA 1993a). Neither tritium nor ${ }^{131}$ I were detected in milk samples during 1995.

\section{Honey}

Three bee colonies are located on the ORR. The honey produced in these hives was sampled, and the sampling results are used to give an indication of potential EDEs to persons who eat honey produced by bees that may have collected pollen on the ORR. If an adult consumed $1 \mathrm{~kg}$ $(2.2 \mathrm{lb})$ of the sampled honey during the year, the resulting EDE could be no higher than 0.09 mrem $(0.0009 \mathrm{mSv})$. The average adult likely consumes less than $1 \mathrm{~kg}$ of honey per year. The total production of honey in Anderson, Loudon, and Roane counties during 1992 (the latest available data) was approximately $1500 \mathrm{~kg}(3200 \mathrm{lb})$. In the extremely unlikely event that all the honey produced in the three counties contained the sampled concentrations of radionuclides, the resulting collective dose could be 0.3 person-rem.

\section{Crops}

Another environmental pathway for ingestion that was evaluated separately is eating vegetables. In 1995, three types of vegetables were sampled: tomatoes, lettuce, and turnips. These vegetable types were chosen as representative of fruit-bearing, leafy, and root vegetables. Tomatoes and turnips were sampled from eight plots, and lettuce was sampled from nine plots, located at the ORR PAMs. Hay grown on the ORR also was sampled, as was hay from one reference location.

To calculate potential EDEs from eating the sampled vegetables, it was assumed that a person ate $32 \mathrm{~kg}(70.56 \mathrm{lb})$ of homegrown tomatoes, $10 \mathrm{~kg}(22.05 \mathrm{lb})$ of leafy vegetables, and $37 \mathrm{~kg}(81.58 \mathrm{lb})$ of root vegetables during the year. These consumption rates, which differ from those used in 1994, were obtained from Exposure Factors Handbook-Draft (EPA 1995). It provides a thorough summation of U.S. vegetation consumption rates (EPA 1996). Based on these assumptions, the average individual's EDE from eating all three vegetable types could be about $5.3 \mathrm{mrem}(0.053 \mathrm{mSv})$, about $1.4 \mathrm{mrem}$ $(0.014 \mathrm{mSv})$ from fruit-bearing vegetables, about $2.0 \mathrm{mrem}(0.02 \mathrm{mSv})$ from leafy vegetables, and about $1.9 \mathrm{mrem}(0.019 \mathrm{mSv})$ from root vegetables (Table 6.5). If the contribution (about $99 \%$ ) of ${ }^{40} \mathrm{~K}$, which is strictly a naturally occurring radionuclide, to this dose is excluded, the maximum individual EDE could have been about 0.047 mrem ( $4.7 \mathrm{E}-4 \mathrm{mSv})$. This 0.047 mrem was from the other radionuclides detected in the vegetables. Detected isotopes include ${ }^{238} \mathrm{U},{ }^{137} \mathrm{Cs}$, and ${ }^{60} \mathrm{Co}$. Although these radionuclides are measured in emissions from the ORR, uranium isotopes occur naturally in soil and fertilizers that are spread on gardens. Therefore, most of the radioactivity found in the vegetables and the associated radiation doses are not attributable to ORR operations. The 
estimated EDEs for ingesting vegetables grown at the ORR monitoring sites are summarized in Table 6.5.

Hay samples were collected from one background location and from six ORR locations. The six ORR samples were combined into three samples. Statistically significant concentrations were found for ${ }^{7} \mathrm{Be}$ and ${ }^{40} \mathrm{~K}$, both of which are naturally occurring radionuclides. Essentially all of the dose to humans (about 99\%) from eating beef and drinking milk from cattle that eat hay was from the naturally occurring ${ }^{40} \mathrm{~K}$. Including the contribution from ${ }^{40} \mathrm{~K}$, the EDE from drinking milk and eating beef was estimated to be about $20 \mathrm{mrem}(0.2 \mathrm{mSv})$; excluding ${ }^{40} \mathrm{~K}$, the EDE was estimated to be about $1.4 \mathrm{E}-03$ mrem $(1.4 \mathrm{E}-05 \mathrm{mSv})$.

\section{White-Tailed Deer}

Several deer hunts were held on the ORR during 1995. A total of 489 deer were killed, of which 8 were confiscated because their radionuclide content potentially exceeded the release limit ( $20 \mathrm{pCi} / \mathrm{g}{ }^{90} \mathrm{Sr}$ in bone). The remaining 481 deer had an average field-dressed weight of about $39 \mathrm{~kg}$ ( $86 \mathrm{lb}$ ). Assuming 55\% of the dressed weight is edible, the average deer would yield about $21.5 \mathrm{~kg}$ (47.3 lb) of meat. Therefore, based on the average weight, the total harvest of edible meat was about $10,320 \mathrm{~kg}$ $(22,750 \mathrm{lb})$.

All deer were surveyed at the TWRA inspection station to determine the ${ }^{137} \mathrm{Cs}$ content in tissue and total strontium in bone. Based on field measurements, the average ${ }^{137} \mathrm{Cs}$ concentration in the 481 released deer was $0.18 \mathrm{pCi} / \mathrm{g}(0.0067 \mathrm{~Bq} / \mathrm{g})$. The EDE for an individual consuming one deer with the average concentration of ${ }^{137} \mathrm{Cs}$ was estimated to be $0.2 \mathrm{mrem}(0.002 \mathrm{mSv})$. The collective EDE from eating all the harvested deer meat with an average ${ }^{137} \mathrm{Cs}$ concentration of $0.18 \mathrm{pCi} / \mathrm{g}$ could have been about 0.09 person-rem (9E-4 person-Sv).

EDEs were estimated for hunters with the highest potential intake (in terms of concentration and field dress weight) who harvested two deer. Using actual field-derived ${ }^{137} \mathrm{Cs}$ concentrations and field-dressed weights, and assuming that one individual consumed all the deer meat, the highest EDE was about $1 \mathrm{mrem}(0.037 \mathrm{mSv})$.

In 1994, random muscle, liver, bone, and/or thyroid samples were collected from 36 nonconfiscated deer. In 1995, samples were collected from 25 nonconfiscated deer. The 1994 average ${ }^{90} \mathrm{Sr}$ concentration in nonconfiscated deer muscle was $0.96 \mathrm{pCi} / \mathrm{g}(0.036 \mathrm{~Bq} / \mathrm{g})$. Assuming that the 1994 tissue analyses are representative of $1995{ }^{90} \mathrm{Sr}$ concentrations in deer, and the ${ }^{137} \mathrm{Cs}$ concentration is $0.18 \mathrm{pCi} / \mathrm{g}(0.0067 \mathrm{~Bq} / \mathrm{g})$, the average EDE from consuming a deer [edible tissue weight of $21.5 \mathrm{~kg}(47.3 \mathrm{lb})$ ] is estimated to be about 3 mrem $(0.03 \mathrm{mSv})$.

Four deer were collected from Chuck Swan State Park in 1994; these are considered to represent background tissue samples. In the limited number of background deer tissue (muscle and liver) samples, the average ${ }^{137} \mathrm{Cs}$ concentration was $-0.2 \mathrm{pCi} / \mathrm{g}(7.4 \mathrm{E}-03 \mathrm{~Bq} / \mathrm{g})$ and the average ${ }^{90} \mathrm{Sr}$ concentration was $\sim 0.96 \mathrm{pCi} / \mathrm{g}$ $(0.036 \mathrm{~Bq} / \mathrm{g})$. Essentially, similar average ${ }^{137} \mathrm{Cs}$ concentrations were found in deer harvested on the ORR in 1995 , and similar average ${ }^{90} \mathrm{Sr}$ concentrations were found in deer harvested on the ORR in 1994.

\section{Canada Geese}

During the annual roundup of Canada geese, whole-body gamma scans were conducted on 86 geese at the deer-checking station. The geese were collected from the Y-12 Plant (15 geese), ORNL (10 geese), the K-25 Site (20 geese), Melton Hill Dam (20 geese), and the Oak Ridge Marina (21 geese). The average field ${ }^{137} \mathrm{Cs}$ concentration was $0.084 \mathrm{pCi} / \mathrm{g}(0.003 \mathrm{~Bq} / \mathrm{g})$. The maximum field ${ }^{137} \mathrm{Cs}$ concentration, surveyed in a goose collected from the K-25 Site, was $0.21 \mathrm{pCi} / \mathrm{g}(0.008 \mathrm{~Bq} / \mathrm{g})$.

The average weight of the Canada geese scanned during the roundup was about $3.8 \mathrm{~kg}(8.4 \mathrm{lb})$, half of which is assumed to be edible. A person eating a Canada goose with the average field ${ }^{137} \mathrm{Cs}$ concentration could have received an EDE of about 0.008 mrem $(0.00008 \mathrm{mSv})$. A person eating a Canada goose with the maximum ${ }^{137} \mathrm{Cs}$ concentration and the maximum weight of a goose surveyed [5.2 $\mathrm{kg}(11 \mathrm{lb})]$, could receive an EDE of 
about 0.03 mrem $(0.0003 \mathrm{mSv})$. If a person consumed 8 geese [this number is based on 2.15 geese, the average number of geese harvested per hunter in the East Tennessee Zone during the September hunt, (Warr 1996)], each with an average ${ }^{137} \mathrm{Cs}$ concentration [0.084 $\mathrm{pCi} / \mathrm{g} 0.003 \mathrm{~Bq} / \mathrm{g}$ )], the estimated EDE would be $0.06 \mathrm{mrem}(0.0006 \mathrm{mSv})$. This is a conservative assumption, since most hunters harvest on average 1 to 2 geese per hunting season (Warr 1996; USFWS 1995.)

Of the geese harvested in the four surrounding counties Anderson, Knox, Loudon, and Roane), it is estimated that about 160 of these geese could have spent time on the ORR. Therefore, the collective EDE from eating 160 geese harvested in 1995 could have been about $1.9 \mathrm{E}-04$ person-rem (1.9E-06 person-Sv), assuming all were contaminated at the average concentration.

Eleven geese were sacrificed and tissue, bone, and thyroid samples were collected and analyzed. In addition, six background geese also were sacrificed and samples were collected and analyzed. The average tissue ${ }^{137} \mathrm{Cs}$ concentration derived from laboratory analyses was $0.013 \mathrm{pCi} / \mathrm{g}(4.8 \mathrm{E}-4 \mathrm{~Bq} / \mathrm{g})$, which was lower than the average ${ }^{137} \mathrm{Cs}$ concentration estimated at the deer counting station. The average ${ }^{90} \mathrm{Sr}$ concentration in tissue was $6.8 \mathrm{pCi} / \mathrm{g}$ $(0.25 \mathrm{~Bq} / \mathrm{g})$. Taking into account these analytical results, if an individual consumed one goose with these average concentrations of ${ }^{137} \mathrm{Cs}$ and ${ }^{90} \mathrm{Sr}$, the EDE is estimated to be $2 \mathrm{mrem}(0.02 \mathrm{mSv})$. Taking into account the maximum concentration of ${ }^{137} \mathrm{Cs}$ and ${ }^{90} \mathrm{Sr}$ detected in the goose samples, $0.54 \mathrm{pCi} / \mathrm{g}(0.02 \mathrm{~Bq} / \mathrm{g})$ and $11 \mathrm{pCi} / \mathrm{g}(0.41 \mathrm{~Bq} / \mathrm{g})$, respectively, and the maximum goose weight of $5.2 \mathrm{~kg}(11 \mathrm{lb})$, the EDE is estimated to be $4.5 \mathrm{mrem}(0.045 \mathrm{mSv})$.

\section{Eastern Wild Turkey}

Twelve live eastern wild turkeys were collected on the ORR during February 1995. These turkeys were whole-body counted at the deer counting station and released in an off-site wildlife management area. Cesium-137 was detected in 1 of the 12 turkeys that were counted. The estimated ${ }^{137} \mathrm{Cs}$ concentration was $0.09 \mathrm{pCi} / \mathrm{g}$
$(0.0033 \mathrm{~Bq} / \mathrm{g})$. The average weight of a male wild turkey is about $24 \mathrm{lb}(10.9 \mathrm{~kg})$ and the female wild turkey weighs about $12 \mathrm{lb}(5.4 \mathrm{~kg})$. If a turkey [average weight $18 \mathrm{lb}(8.16 \mathrm{~kg})$ ] was consumed by one individual and the edible portion was $4.08 \mathrm{~kg}$ ( $9 \mathrm{lb})(50 \%$ of the total weight of the turkey), the estimated EDE would be about 0.02 mrem ( $2 \mathrm{E}-4 \mathrm{mSv}$ ). Two turkeys are the bag limit in a wildlife management area per season. If one individual consumed two birds collected from a wildlife management area at the aforementioned ${ }^{137} \mathrm{Cs}$ concentration, the estimated EDE would be about 0.04 mrem (4E-4 mSv).

\section{Direct Radiation}

External exposure rates from background sources in the state of Tennessee average about $6.4 \mu \mathrm{R} /$ hour and range from 2.9 to $11 \mu \mathrm{R} /$ hour. These exposure rates translate into annual EDE rates that average $42 \mathrm{mrem} /$ year $(0.42 \mathrm{mSv} / \mathrm{year})$ and range between 19 and $72 \mathrm{mrem} / \mathrm{year}$, or 0.19 and $0.72 \mathrm{mSv} /$ year (Myrick et al. 1981). External radiation exposure rates are measured at a number of locations on and off the ORR. The average exposure rate at PAMs around the ORR during 1995 was about $7.8 \mu R$ hour. This equals a dose rate of about $51 \mathrm{mrem} / \mathrm{year}$ (0.51 mSv/year). Except for two locations, all measured exposure rates beyond the ORR boundaries are near background levels. The two exceptions are a stretch of bank along the Clinch River and a section of Poplar Creek that flows through the K-25 Site.

During 1987, external exposure rate measurements were taken along a $1.7-\mathrm{km}$ (1.1-mile) length of Clinch River bank. Measured exposure rates along this stretch of bank averaged $13 \mu \mathrm{R} / \mathrm{hour}$ and ranged between 3.5 and $18 \mu \mathrm{R} /$ hour. These measured exposure rates are attributable to radiation emanating from a nearby field that contains the remnants of a ${ }^{137} \mathrm{Cs}$ seeding experiment. The experimental plots were remediated during 1994, but measurements to confirm that the exposure rate along the Clinch River has decreased were not performed. Therefore, we assume the exposure rate along the Clinch River caused by the cesium plots was the same as reported last year, about $8 \mu \mathrm{R} /$ hour (0.006 $\mathrm{mrem} /$ hour) above background. 
A potential maximally exposed individual is a hypothetical fisherman who was assumed to spend 5 hours/week ( 250 hours/year) near the point of average exposure. This hypothetical, maximally exposed individual could have received an EDE of about 1 mrem $(0.01 \mathrm{mSv})$ during 1995. This dose estimate is high because most of the ${ }^{137} \mathrm{Cs}$ was removed from the experimental fields in 1994.

The radiation field along Poplar Creek emanates from storage areas within the K-25 Site. The section of the creek affected by this area runs through the plant and is used at times by fishermen. Exposure rate measurements, corrected for background, taken along the creek during 1995 ranged between 3.9 and $8.3 \mu \mathrm{R} /$ hour, which is equivalent to an EDE rate from 0.003 to $0.006 \mathrm{mrem} /$ hour (between 0.00003 and $0.00006 \mathrm{mSv} / \mathrm{hour}$ ). The average exposure rate was about $5.1 \mu \mathrm{R} /$ hour, which corresponds to an EDE rate of $0.004 \mathrm{mrem} /$ hour. A 4-hour fishing trip could have resulted in reception of an EDE between 0.01 to 0.02 mrem ( 0.0001 to $0.0002 \mathrm{mSv}$ ). If the hypothetical Clinch River fisherman is used, the 250-hour/year exposure time could have resulted in reception of an EDE of about $1 \mathrm{mrem}(0.01 \mathrm{mSv})$. It is extremely unlikely that anyone would fish this stretch of Poplar Creek for 250 hours/year.

\section{Doses to Aquatic Biota}

DOE Order 5400.5, Chapter II, sets an interim absorbed dose rate limit of $1 \mathrm{rad} /$ day ( $0.01 \mathrm{~Gy} /$ day) to native aquatic organisms. To demonstrate compliance with this limit, absorbed dose rates to fish, crustacea (e.g., crayfish), and muskrats were calculated using the computer code CRITR2 (Baker and Soldat 1993). Fish and crustacea are considered to be primary aquatic organisms, those that reside in the aquatic ecosystem. Muskrats are considered to be secondary organisms, those that subsist on aquatic plants. Maximum and average concentrations of radionuclides measured in surface waters on and around the ORR are used to estimate dose rates from internal and external exposures. Internal dose rates are calculated using organism- and nuclide-specific bioaccumulation factors and absorbed energy fractions. External dose rates are calculated for submersion in water and irradiation from bottom sediments. Exposure to sediments is particularly meaningful for crawling or fixed organisms (such as crayfish and mollusks). Direct radiation doses from sediment are estimated from water concentrations using factors such as a geometry roughness factor, sediment deposition transfer factor, and nuclide-specific ground-surface irradiation dose factors.

Table 6.6 lists average and maximum total dose rates to aquatic organisms from waterways at the Y-12 Plant, ORNL, and the K-25 Site. The doses for ORNL are based on water concentrations associated with nine different sampling locations: Melton Branch (Outfalls X-13 and 2), WOC (Outfall X-14), WOD (Outfall X-15), First Creek, Fifth Creek, Raccoon Creek, Northwest Tributary, and at the 7500 Bridge. The results from these calculations indicate that absorbed dose rates to aquatic biota are much less than $1 \mathrm{rad} /$ day $(0.01 \mathrm{~Gy} /$ day $)$.

At ORNL the highest dose rates, which were associated with maximum concentrations of radionuclides in water, occurred at WOC (X14): $0.0022 \mathrm{rad} /$ day (2.2E-5 Gy/day) to fish, and at Melton Branch (X-13): $0.013 \mathrm{rad} /$ day (1.3E-4 Gy/day) to crustacea, and $0.004 \mathrm{rad} /$ day (4E-5 Gy/day) to muskrats. Even with maximum radionuclide concentrations at these locations, the absorbed doses were significantly less than the limit of $1 \mathrm{rad} /$ day $(0.01 \mathrm{~Gy} /$ day $)$.

At the Y-12 Plant, aquatic organism doses were estimated from radionuclide water concentrations obtained at EFPC (Station 17), Bear Creek (Outfall 304), and Rogers Quarry (Outfall 302). At East Fork Poplar Creek the maximum dose rates to fish, crustacea, and muskrats were ascertained: $5.5 \mathrm{E}-4 \mathrm{rad} /$ day $(5.5 \mathrm{E}-6 \mathrm{~Gy} /$ day) and $0.0058 \mathrm{rad} /$ day $(5.8 \mathrm{E}-5 \mathrm{~Gy} /$ day), and $0.069 \mathrm{rad} /$ day $(6.9 \mathrm{E}-4 \mathrm{~Gy} /$ day), respectively. In 1995, the sampling periods were split into two 6-month increments $(1 / 1$ to $6 / 30$ and $7 / 1$ to 12/31) at Bear Creek (Outfall 304) and Rogers Quarry (Outfall 302).

Similar analyses were conducted at the $\mathrm{K}-25$ Site. The waterways evaluated were

\section{6-10 Dose}


Annual Site Environmental Report

Table 6.6. 1995 total dose rate for aquatic organisms ( $\mathrm{rad} /$ day) ${ }^{a, b}$

\begin{tabular}{|c|c|c|c|c|c|c|}
\hline \multirow{2}{*}{$\begin{array}{l}\text { Measurement } \\
\text { location }\end{array}$} & \multicolumn{2}{|c|}{ Fish } & \multicolumn{2}{|c|}{ Crustacea } & \multicolumn{2}{|c|}{ Muskrat } \\
\hline & Average & Maximum & Average & Maximum & Average & Maximum \\
\hline \multicolumn{7}{|c|}{$O R N L$} \\
\hline Melton Branch (X13) & $1.1 \mathrm{E}-3$ & $1.9 E-3$ & $2.8 \mathrm{E}-3$ & $1.3 \mathrm{E}-2$ & $2.8 \mathrm{E}-3$ & $4.0 E-3$ \\
\hline White Oak Creek (X14) & $7.6 \mathrm{E}-4$ & $2.2 E-3$ & $4.2 \mathrm{E}-3$ & $7.5 \mathrm{E}-3$ & $1.2 \mathrm{E}-3$ & $2.4 \mathrm{E}-3$ \\
\hline White Oak Dam (X15) & $2.0 \mathrm{E}-5$ & $1.6 \mathrm{E}-3$ & $4.1 \mathrm{E}-5$ & $9.7 \mathrm{E}-3$ & $1.2 \mathrm{E}-5$ & $2.7 E-3$ \\
\hline 7500 Road Bridge & $4.6 \mathrm{E}-4$ & $1.2 \mathrm{E}-3$ & $2.5 E-3$ & $4.6 \mathrm{E}-3$ & $7.3 \mathrm{E}-4$ & $1.5 \mathrm{E}-3$ \\
\hline First Creek & $4.3 \mathrm{E}-4$ & $1.4 \mathrm{E}-3$ & $4.2 \mathrm{E}-3$ & $1.2 \mathrm{E}-2$ & $1.1 \mathrm{E}-3$ & $3.0 \mathrm{E}-3$ \\
\hline Fifth Creek & $1.1 \mathrm{E}-4$ & $1.9 \mathrm{E}-4$ & $1.1 \mathrm{E}-3$ & $1.9 \mathrm{E}-3$ & $2.8 \mathrm{E}-4$ & $4.9 E-4$ \\
\hline Melton Branch $2^{\epsilon}$ & $1.2 \mathrm{E}-4$ & $3.3 \mathrm{E}-4$ & $2.6 \mathrm{E}-4$ & $7.3 \mathrm{E}-4$ & $4.2 \mathrm{E}-5$ & $1.2 \mathrm{E}-4$ \\
\hline Northwest Tributary ${ }^{d}$ & $2.8 \mathrm{E}-4$ & $4.3 E-4$ & $2.7 E-3$ & $4.2 \mathrm{E}-3$ & $7.2 \mathrm{E}-4$ & $1.1 \mathrm{E}-3$ \\
\hline Raccoon Creek & $1.2 \mathrm{E}-4$ & $6.6 \mathrm{E}-4$ & $1.2 \mathrm{E}-3$ & $3.8 E-3$ & $3.1 \mathrm{E}-4$ & $9.2 \mathrm{E}-4$ \\
\hline \multicolumn{7}{|c|}{ Y-12 Plant } \\
\hline East Fork Poplar Creek (Station 17) & $1.2 \mathrm{E}-4$ & $5.5 \mathrm{E}-4$ & $7.4 \mathrm{E}-4$ & $5.8 \mathrm{E}-3$ & $1.5 \mathrm{E}-4$ & $6.9 \mathrm{E}-2$ \\
\hline Bear Creek ${ }^{e}$ (Outfall 304) & $1.9 \mathrm{E}-4$ & $3.9 \mathrm{E}-4$ & $9.7 \mathrm{E}-4$ & $3.8 \mathrm{E}-3$ & $4.4 E-2$ & $3.2 \mathrm{E}-2$ \\
\hline & $1.8 \mathrm{E}-4$ & $2.7 E-4$ & $8.1 E-4$ & $1.7 \mathrm{E}-3$ & $1.8 \mathrm{E}-4$ & $1.9 \mathrm{E}-2$ \\
\hline Rogers Quarry ${ }^{f}$ (Outfall 302) & $2.3 E-5$ & $4.9 \mathrm{E}-5$ & $1.1 \mathrm{E}-4$ & $3.2 \mathrm{E}-4$ & $4.7 E-5$ & $3.7 \mathrm{E}-4$ \\
\hline & $8.0 \mathrm{E}-5$ & $9.0 \mathrm{E}-5$ & $3.1 \mathrm{E}-4$ & $6.8 \mathrm{E}-4$ & $2.8 \mathrm{E}-4$ & $8.2 E-3$ \\
\hline \multicolumn{7}{|c|}{$K-25$ Site } \\
\hline Mitchell Branch (K-1700) & $3.5 \mathrm{E}-5$ & 4.1E-4 & $3.4 \mathrm{E}-3$ & $3.8 \mathrm{E}-3$ & $1.2 \mathrm{E}-4$ & $2.5 \mathrm{E}-4$ \\
\hline Poplar Creek (K-1007B) & $3.9 \mathrm{E}-4$ & $5.1 \mathrm{E}-4$ & $3.9 \mathrm{E}-3$ & $5.1 E-3$ & $2.1 \mathrm{E}-5$ & $9.5 \mathrm{E}-5$ \\
\hline Poplar Creek (Sewage Treatment Plant, K-1203) & $3.2 E-4$ & $3.9 E-4$ & $3.1 E-3$ & $3.5 \mathrm{E}-3$ & $7.2 \mathrm{E}-5$ & $2.6 \mathrm{E}-4$ \\
\hline Clinch River (K-901-A) & $3.8 \mathrm{E}-4$ & $4.3 \mathrm{E}-4$ & $3.8 \mathrm{E}-3$ & $4.4 \mathrm{E}-3$ & $3.0 \mathrm{E}-5$ & $9.9 \mathrm{E}-5$ \\
\hline
\end{tabular}

\footnotetext{
${ }^{a}$ Total dose rate includes the contribution of internally deposited radionuclides, sediment exposure (derived from water concentrations), and water immersion.

${ }^{b}$ To convert from radiday to Gy/day divide by 100 .

${ }^{c}$ No samples were taken during October and November due to sampling station construction.

${ }^{d}$ No samples were taken during June, July, and August due to sampling station construction.

'Two sampling periods are exhibited for Bear Creek outfall 304; one is from 1/1/95 to 6/30/95 and the other is from 7/1/95 to 12/31/95.

${ }^{f}$ Outfall 302 and $\mathrm{S} 19$ are at the same discharge point. Sampling data from Outfall 302 is from 1/1/95 to 6/30/95. Sampling data for $\$ 19$ is from $7 / 1 / 95$ to $12 / 31 / 95$.
}

Mitchell Branch (K-1700), Poplar Creek at the sewage treatment plant $(\mathrm{K}-1203)$, outfall K-1007B, and outfall K-901A. At Poplar Creek (K-1007B) the maximum dose rates to fish and crustacea were calculated: $5.1 \mathrm{E}-4 \mathrm{rad} /$ day (5.1E-6 Gy/day) and 5.1E-3 rad/day (5.1E $-5 \mathrm{rad} /$ day), respectively. The maximum dose rates to a muskrat were estimated at Mitchell Branch (K-1700) and at Poplar Creek: $2.5 \mathrm{E}-4 \mathrm{rad} /$ day $(2.5 \mathrm{E}-6 \mathrm{~Gy} / \mathrm{day})$ and $2.6 \mathrm{E}-4 \mathrm{rad} /$ day $(2.6 \mathrm{E}-6 \mathrm{~Gy} /$ day), respectively. Absorbed doses estimated from maximum radionuclide water concentrations determined on the ORR resulted in doses significantly less than the $1 \mathrm{rad} /$ day ( $0.01 \mathrm{~Gy} /$ day) limit prescribed in DOE Order 5400.5.

\section{Current-Year Summary}

A summary of the maximum EDEs to individuals by several pathways of exposure is given in Table 6.7. It is unlikely (if not impossible) that any real person could have been irradiated by all of these sources and pathways for a period of 1 year; however, if the resident who received the highest EDE [0.5 mrem $(0.005 \mathrm{mSv})]$ from gaseous effluents, also drank water from the Kingston plant $[0.15$ mrem $(0.0015 \mathrm{mSv})]$, ate fish from CRK 80 [0.93 mrem (0.0093 mSv), and fished the Clinch River near the cesium field or Poplar Creek inside the $\mathrm{K}-25$ Site $11 \mathrm{mrem}(0.01 \mathrm{mSv})$, he or she could have received a total EDE of about $2.6 \mathrm{mrem}$ $(0.026 \mathrm{mSv})$, or about $0.9 \%$ of the annual dose 
Table 6.7. Summary of estimated effective dose equivalents to an adult during 1995 at locations of maximum exposure near the ORR

\begin{tabular}{|c|c|c|}
\hline Pathway & Location & Effective dose equivalent (mrem) ${ }^{a}$ \\
\hline $\begin{array}{l}\text { Gaseous effluents } \\
\text { Inhalation plus direct } \\
\text { radiation from air, } \\
\text { ground, and food chains }\end{array}$ & $\begin{array}{l}\text { Maximally exposed resident to } \\
\text { Y-12 Plant } \\
\text { ORNL } \\
\text { K-25 Site } \\
\text { ORR }\end{array}$ & $\begin{array}{c}0.46 \\
0.2 \\
0.052 \\
0.5\end{array}$ \\
\hline $\begin{array}{l}\text { Liquid effluents } \\
\text { Drinking water } \\
\text { Eating fish } \\
\text { Other activities }\end{array}$ & $\begin{array}{l}\text { Kingston Water Plant } \\
\text { Melton Hill Lake, CRK } 80 \\
\text { Melton Hill Lake, CRK } 80\end{array}$ & $\begin{array}{l}0.15 \\
0.93 \\
0.21\end{array}$ \\
\hline $\begin{array}{l}\text { Eating deer } \\
\text { Eating geese }\end{array}$ & & $\begin{array}{c}3 \\
0.06\end{array}$ \\
\hline Direct radiation & $\begin{array}{l}\text { Clinch River shoreline } \\
\text { Poplar Creek (K-25 Site) }\end{array}$ & $1^{b}$ \\
\hline
\end{tabular}

Table 6.8. Trends in total effective dose equivalent for selected pathways

\begin{tabular}{lllllll}
\hline \multicolumn{1}{c}{ Pathway } & \multicolumn{5}{c}{$\begin{array}{c}\text { Effective dose equivalent } \\
\text { (mrem) }\end{array}$} \\
\cline { 2 - 7 } & $\mathbf{1 9 9 0}$ & $\mathbf{1 9 9 1}$ & $\mathbf{1 9 9 2}$ & $\mathbf{1 9 9 3}$ & $\mathbf{1 9 9 4}$ & 1995 \\
\hline All air & 2 & 2 & 1.3 & 1.4 & 1.7 & 0.5 \\
Fish consumption & 0.3 & 0.3 & 0.4 & 0.2 & 1.6 & 0.9 \\
Drinking water (Kingston) & 0.04 & 0.1 & 0.05 & 0.07 & 0.04 & 0.15 \\
Direct radiation (Clinch River) & $1^{b}$ & $1^{b}$ & $1^{b}$ & $1^{b}$ & $1^{c}$ & $1^{c}$ \\
Direct radiation (Poplar Creek) & & & $11^{b}$ & 1 & 1 & 1
\end{tabular}

\footnotetext{
${ }^{a}$ To convert mrem to $\mathrm{mSv}$, divide by 100 .

${ }^{b}$ These values have been corrected by removing the contribution of natural background radiation and by using International Commission on Radiological Protection recommendations for converting external exposure to effective dose equivalent.

${ }^{c}$ This is an overestimate of the potential dose because the source of the direct radiation was remediated during 1993 and 1994.
}

[300 mrem ( $3 \mathrm{mSv})$ ] from background radiation. If a person ate a deer harvested on the ORR, that person could have received a committed EDE of about 3 mrem ( $0.03 \mathrm{mSv})$.

DOE Order 5400.5 limits to no more than $100 \mathrm{mrem}(1 \mathrm{mSv})$ the EDE that an individual may receive from all exposure pathways from all radionuclides released from the ORR during 1 year. As described in the preceding paragraph, the 1995 maximum EDE could have been about $6 \mathrm{mrem}(0.06 \mathrm{mSv})$, or about $6 \%$ of the limit given in DOE Order 5400.5. For further information, see Table A.2, which provides a summary of dose levels associated with a wide range of activities.

\section{Five-Year Trends}

Dose equivalents associated with selected exposure pathways for the years from 1990 to 1995 are given in Table 6.8. The variations in values over this 5-year period likely are not 
statistically significant. The dose estimates for direct irradiation along the Clinch River have been corrected for background.

\section{Potential Contributions from Off-Site Sources}

Four off-site facilities were identified as potential contributors to radiation exposure of the public around the ORR. These facilities include a waste processing facility located on Bear Creek Road, a depleted uranium processing facility located on Illinois Avenue, a decontamination facility located on Flint Road in Oak Ridge, and a waste processing facility located on Gallaher Road in Kingston.

Airborne emissions from these facilities (based on information supplied by the facilities) should not cause any individual to receive an EDE greater than 1.7 mrem $(0.017 \mathrm{mSv})$. When combined with impacts caused by emissions from the ORR, no individual should receive an EDE in excess of EPA or DOE limits. No information was obtained about waterborne releases, if any, from these facilities.

\section{Findings}

The maximally exposed off-site individual could have received a 50 -year committed EDE of about $0.5 \mathrm{mrem}(0.005 \mathrm{mSv})$ from airborne effluents from the ORR. This dose is within the limit specified in the CAA for DOE facilities. The estimated collective committed EDE to the about 880,000 persons living within $80 \mathrm{~km}$ ( 50 miles) of the ORR was about 11 person-rem (0.11 person-Sv) for 1995 airborne emissions. This represents about $0.004 \%$ of the 264,000 person-rem $(2,640$ person-Sv) that the surrounding population would receive from all sources of natural radiation.

\section{CHEMICAL DOSE}

\section{Terminology}

The following terms are pertinent to the understanding of chemical exposure. See
Appendix B for further explanation of terms and methodology.

- slope factor (SF). A plausible upper-bound estimate of the probability of a response per unit intake of a chemical over a lifetime. The SF is used to estimate an upper-bound probability of an individual developing cancer as a result of lifetime exposure to a particular level of a potential carcinogen. Units are expressed as $\mathrm{mg} \mathrm{kg}^{-1} \mathrm{day}^{-1}$.

- maximum contaminant level (MCL). EPA National Interim Primary and National Primary Drinking Water regulations that apply to all community or public water systems.

- reference dose (RfD). An estimate of the daily exposure to the human population, including sensitive individuals, that is likely to be without an appreciable risk of deleterious effects during a lifetime.

- secondary maximum contaminant level (SMCL). EPA National Secondary Drinking Water regulations that apply to public water systems. The EPA SMCLs are unenforceable criteria that apply to aesthetic water quality; however, Tennessee SMCLs, which are the same as the federal SMCLs, are enforceable.

RfDs, which are used to evaluate potential health effects from noncarcinogens, are derived from doses of chemicals that result in no adverse effect or the lowest dose that showed an adverse effect on humans or laboratory animals (See Appendix B). The EPA maintains the Integrated Risk Information System (IRIS) data base, which contains verified RfDs and SFs and up-to-date health risk and EPA regulatory information for numerous chemicals.

For chemicals for which RfDs are not available, national primary (MCL) and secondary drinking water regulation (SMCL) concentrations, expressed in milligrams per liter, are converted to $\mathrm{RfD}$ values by multiplying by $2 \mathrm{~L}$ (the average daily adult water intake) and dividing by $70 \mathrm{~kg}$ (the reference adult body weight). The result is a dose expressed in $\mathrm{mg} \mathrm{kg}^{-1}$ day $^{-1}$. Table 6.9 lists the RfDs SFs used in this analysis. 
Table 6.9. Chemical reference doses and slope factors used in drinking water and fish intake analysis

\begin{tabular}{|c|c|c|}
\hline Chemical & $\begin{array}{l}\text { Reference dose or } \\
\text { slope factor }\end{array}$ & Reference $^{a}$ \\
\hline Acetone & $1.00 \mathrm{E}-01$ & RfD \\
\hline Aluminum & $6.00 \mathrm{E}-03$ & SMCL \\
\hline Arsenic & $3.00 \mathrm{E}-04$ & $\mathrm{RfD}$ \\
\hline Barium & $7.00 \mathrm{E}-02$ & RfD \\
\hline 2-Butanone & $6.00 \mathrm{E}-01$ & RfD \\
\hline Carbide disulfide & $1.00 \mathrm{E}-01$ & RfD \\
\hline Chloride & $7.14 \mathrm{E}+00$ & SMCL \\
\hline Chromium (VI) & $5.00 \mathrm{E}-03$ & RfD \\
\hline Copper & $4.00 \mathrm{E}-02$ & MCL \\
\hline $4,4^{\prime}-\mathrm{DDE}$ & $3.40 \mathrm{E}-01$ & SF \\
\hline Dieldrin & $1.60 \mathrm{E}+01$ & SF \\
\hline Fluoride & $6.00 \mathrm{E}-02$ & RfD \\
\hline Iron & $9.00 \mathrm{E}-03$ & SMCL \\
\hline Lead & $4.00 \mathrm{E}-04$ & $\mathrm{MCL}$ \\
\hline Manganese & $4.60 \mathrm{E}-02$ & RfD \\
\hline Mercury & $5.70 \mathrm{E}-05$ & $\mathrm{MCL}$ \\
\hline Nickel (soluble salts) & $2.00 \mathrm{E}-02$ & RfD \\
\hline Nitrate & $1.60 \mathrm{E}+00$ & RfD \\
\hline PCBs & $7.70 \mathrm{E}+00$ & SF \\
\hline Selenium & $5.00 \mathrm{E}-03$ & $\mathrm{RfD}$ \\
\hline Silver & $5.00 \mathrm{E}-03$ & $\mathrm{RfD}$ \\
\hline Sulfate & $1.43 \mathrm{E}+01$ & $\mathrm{MCL}$ \\
\hline Thallium & $8.00 \mathrm{E}-05$ & $\mathrm{RfD}$ \\
\hline Uranium (soluble salts) & $3.00 \mathrm{E}-03$ & RfD \\
\hline Vanadium & $7.00 \mathrm{E}-03$ & RfD \\
\hline Zinc & $3.00 \mathrm{E}-01$ & RfD \\
\hline
\end{tabular}

\footnotetext{
${ }^{a} \mathrm{RfD}$ : reference dose $\left(\mathrm{mg} \mathrm{kg}^{-1} \mathrm{day}^{-1}\right.$ ); SF: slope factor (risk per $\mathrm{mg} \mathrm{kg}^{-1} \mathrm{day}^{-1}$ ). The maximum contaminant level (MCL) and secondary maximum contaminant level (SMCL) are in units of $\mathrm{mg} / \mathrm{L}$. To convert the concentration to a $\mathrm{RfD}$ ( $\mathrm{mg} \mathrm{kg}^{-1}$ day $^{-1}$ ), multiply by the consumption rate $(2 \mathrm{~L} /$ day $)$ and divide by the mass of a reference man, $70 \mathrm{~kg}$
}

SFs are used to evaluate carcinogenic impacts. The SF converts the estimated daily intake averaged over a lifetime exposure to the incremental risk of an individual developing cancer. Because it is unknown whether a threshold (a dose below which no adverse effect occurs) exists for carcinogens, units for carcinogens are set in terms of risk. For potential carcinogens at the ORR, a risk of developing cancer over a human lifetime of 1 in 100,000 $\left(10^{-5}\right)$ was used to establish acceptable levels of exposure. That is, the EPA estimates that a certain concentration of a chemical, if ingested, could cause a risk of one additional cancer case for every 100,000 exposed persons.

\section{Methods of Evaluation}

\section{Airborne Chemicals}

Air permits issued by TDEC allow release of permitted quantities of chemicals. Sampling or monitoring is required only at the ORNL Steam Plant. No air monitoring data amenable to human exposure analysis were available. (See Sect. 4, "Airborne Discharges.")

\section{Waterborne Chemicals}

Current risk assessment methodologies use the term HQ to evaluate noncarcinogenic health effects. Intakes, calculated in $\mathrm{mg} \mathrm{kg}^{-1}$ day $^{-1}$ in the HQ methodology, are expressed in terms of dose. For carcinogens, the estimated dose (I) from ingestion of water or fish is divided by the chronic daily intake (CDI), which corresponds to a $10^{-5}$ lifetime risk of developing cancer. See Appendix B for a more detailed discussion.

\section{Drinking Water}

HQs and I/CDI ratios for chemicals concentrations found in surface water are summarized in Table 6.10. The tilde $(-)$ indicates that estimated values and/or detection limits were used in estimating the average concentration of a chemical. This symbol is listed beside the estimated HQ or intake (estimated dose)/calculated daily intake (I/CDI) ratios to indicate the type of data used.

To evaluate the drinking water pathway, HQs and I/CDIs were estimated at current drinking water supply locations (CRK 23 and 58) both below and above the ORR. The Gallaher Water Station (CRK 23) is located near the water intake for the K-25 Site and is below the ORNL effluent discharge point. The Knox county water supply intake (CRK 58) is located above the ORR discharge points. In addition, the drinking water pathway was evaluated at the Anderson County Filtration Plant (CRK 84) which is above all DOE inputs, and at CRK 16, which is a location downstream of all DOE inputs.

With the exception of aluminum, arsenic, and iron, the HQ values were less than 1 . Elevated aluminum and iron HQs were estimated 
Table 6.10. 1995 chemical hazard quotients and $\mathrm{VCDI}$ for drinking water ${ }^{a}$

\begin{tabular}{|c|c|c|c|c|c|}
\hline \multirow[t]{2}{*}{ Chemical } & \multicolumn{5}{|c|}{ Hazard quotient and I/CDI ratios } \\
\hline & CRK $84^{b}$ & CRK $58^{c}$ & $\begin{array}{c}\text { CRK 23 }^{d} \\
\text { HQ }\end{array}$ & $\begin{array}{c}\text { CRK } 23^{d} \\
\text { I/CDI }\end{array}$ & CRK $16^{e}$ \\
\hline \multicolumn{6}{|c|}{ Metals } \\
\hline $\begin{array}{l}\text { Aluminum } \\
\text { Arsenic }\end{array}$ & $2.2 \mathrm{E}+00$ & $\begin{array}{r}9.6 \mathrm{E}-01 \\
-4.7 \mathrm{E}+00\end{array}$ & $7.3 \mathrm{E}-01$ & & $1.6 \mathrm{E}+00$ \\
\hline Barium & $1.4 \mathrm{E}-02$ & $1.2 \mathrm{E}-02$ & $1.3 \mathrm{E}-02$ & & $1.4 \mathrm{E}-02$ \\
\hline Chromium & & $-3.2 E-02$ & & & $-2.5 E-02$ \\
\hline Copper & $-4.9 \mathrm{E}-03$ & & & & \\
\hline Iron & $1.7 \mathrm{E}+00$ & $7.9 \mathrm{E}-01$ & $6.4 \mathrm{E}-01$ & & $1.4 \mathrm{E}+00$ \\
\hline Manganese & $6.0 \mathrm{E}-02$ & $2.5 \mathrm{E}-02$ & $2.4 \mathrm{E}-02$ & & $3.9 \mathrm{E}-02$ \\
\hline Mercury & $-3.5 \mathrm{E}-02$ & $-2.8 \mathrm{E}-02$ & & & $-2.5 \mathrm{E}-01$ \\
\hline Selenium & $-2.8 \mathrm{E}-01$ & & & & \\
\hline Uranium & $1.4 \mathrm{E}-03$ & $-1.5 \mathrm{E}-03$ & $-2.9 \mathrm{E}-03$ & & $\sim 1.9 \mathrm{E}-03$ \\
\hline Vanadium & $-9.4 \mathrm{E}-03$ & $-1.0 \mathrm{E}-02$ & $-8.2 \mathrm{E}-03$ & & $-9.0 \mathrm{E}-03$ \\
\hline Zinc & $-1.6 \mathrm{E}-03$ & $-5.0 \mathrm{E}-04$ & $-5.3 \mathrm{E}-04$ & & $-8.9 E-04$ \\
\hline \multicolumn{6}{|c|}{ Anions } \\
\hline Chloride & $1.9 \mathrm{E}-02$ & $1.6 \mathrm{E}-02$ & $1.6 \mathrm{E}-02$ & & $1.5 \mathrm{E}-02$ \\
\hline Fluoride & $-5.5 \mathrm{E}-02$ & $-4.6 \mathrm{E}-02$ & $-4.6 E-02$ & & \\
\hline Nitrate & $3.8 \mathrm{E}-02$ & $2.9 \mathrm{E}-02$ & $6.7 \mathrm{E}-02$ & & $3.4 \mathrm{E}-02$ \\
\hline Sulfate & $3.8 \mathrm{E}-02$ & $4.0 \mathrm{E}-02$ & $4.0 \mathrm{E}-02$ & & $3.8 \mathrm{E}-02$ \\
\hline \multicolumn{6}{|c|}{ Volatile organics } \\
\hline 2-Butanone & $-2.0 \mathrm{E}-04$ & $\sim 2.7 \mathrm{E}-04$ & $-2.3 \mathrm{E}-0.4$ & \multirow{4}{*}{$-3.6 \mathrm{E}-01$} & $\sim 2.2 \mathrm{E}-04$ \\
\hline Acetone & $-2.2 E-03$ & $-2.3 \mathrm{E}-03$ & $-2.4 \mathrm{E}-03$ & & \\
\hline Benzene & & & & & \\
\hline Carbon disulfide & $-1.2 \mathrm{E}-03$ & & $-1.3 \mathrm{E}-03$ & & \\
\hline
\end{tabular}

both upstream and downstream of the ORR. At CRK 58, upstream of ORR discharge points, an HQ greater than 1 was estimated for arsenic.

\section{Fish Consumption}

Chemicals in water can be accumulated by aquatic organisms that may be eaten by humans. Bluegill (sunfish) and catfish (at two locations) collected from the Clinch River and Poplar Creek were analyzed for a number of metals, pesticides, and PCBs. Table 6.11 summarizes the $H Q$ and $I / C D I$ ratios derived on average chemical concentrations in fish samples found both upstream and downstream locations from the ORR. Arsenic, lead, and mercury concentrations in fish tissue resulted in HQs greater than 1.
HQs greater than 1 for arsenic and mercury were found in sunfish upstream and downstream of the ORR, catfish downstream of the ORR, and in sunfish found in Poplar Creek (PCK 2.2). An HQ greater than 1 for lead also was calculated for sunfish collected from CRK 16; however, estimated values and/or the detection limit were used in estimating the average concentration.

For carcinogens, I/CDI ratios greater than 1 indicate a risk greater than $10^{-5}$. Chemicals for which I/CDIs were greater than 1 were PCBs (Aroclor 1248, 1254, and 1260), 4,4'-DDE, and dieldrin. I/CDIs greater than 1 for these PCBs and pesticides were found in both sunfish and catfish collected up and downstream of the ORR. In many cases, the tissue concentrations of PCBs, $4,4^{\prime}-\mathrm{DDE}$, and dieldrin were estimated at or 
Table 6.11. 1995 chemical hazard quotients (HQs) for metals and estimated dose/chronic daily intake (I/CDIs) for carcinogens in fish ${ }^{a}$

\begin{tabular}{|c|c|c|c|c|c|c|c|c|}
\hline \multirow[t]{2}{*}{ Parameters } & \multicolumn{6}{|c|}{ Sunfish } & \multirow{2}{*}{$\frac{\text { Catfish }}{\text { CRK } 32^{e}}$} & \multirow[b]{2}{*}{ CRK $16^{f}$} \\
\hline & CRK $84^{b}$ & CRK $80^{c}$ & CRK $66^{d}$ & $\operatorname{CRK} 32^{e}$ & CRK $16^{f}$ & $\operatorname{PCK} 2.2^{g}$ & & \\
\hline \multicolumn{9}{|c|}{$H Q$ s for metals } \\
\hline Arsenic & & $-2.4 \mathrm{E}+00$ & & $-2.8 \mathrm{E}+00$ & $-2.5 \mathrm{E}+00$ & $-2.4 \mathrm{E}+00$ & $2.8 \mathrm{E}+00$ & \\
\hline Chromium & $2.8 \mathrm{E}-02$ & $2.6 \mathrm{E}-02$ & $3.1 \mathrm{E}-02$ & $2.8 \mathrm{E}-02$ & $3.6 \mathrm{E}-02$ & $2.5 \mathrm{E}-02$ & $3.1 \mathrm{E}-02$ & $1.1 \mathrm{E}-02$ \\
\hline Copper & $8.1 \mathrm{E}-03$ & $6.1 E-03$ & $4.8 \mathrm{E}-03$ & $1.0 \mathrm{E}-02$ & $8.7 \mathrm{E}-03$ & $8.7 \mathrm{E}-03$ & $8.7 \mathrm{E}-03$ & $1.5 \mathrm{E}-02$ \\
\hline Lead & & & & & -1.7 & & & \\
\hline Mercury & $1.4 \mathrm{E}+00$ & $1.7 \mathrm{E}+00$ & $1.4 \mathrm{E}+00$ & $3.4 \mathrm{E}+00$ & $3.6 \mathrm{E}+00$ & $5.9 \mathrm{E}+00$ & $3.6 \mathrm{E}+00$ & $1.8 \mathrm{E}+00$ \\
\hline Nickel & & $-7.7 \mathrm{E}-03$ & & & & & & \\
\hline Selenium & & $-1.5 \mathrm{E}-01$ & & $-1.9 \mathrm{E}-01$ & $-1.5 \mathrm{E}-01$ & $-1.5 \mathrm{E}-01$ & & $2.1 \mathrm{E}-01$ \\
\hline Silver & & & & & $-1.6 \mathrm{E}-02$ & $-1.6 \mathrm{E}-02$ & & \\
\hline Thallium & & & & $1.0 \mathrm{E}-01$ & $8.5 \mathrm{E}-02$ & $1.9 \mathrm{E}-01$ & $4.0 \mathrm{E}-02$ & $4.0 E-02$ \\
\hline Uranium & & & & & & $-4.7 \mathrm{E}-04$ & & \\
\hline Zinc & $6.0 \mathrm{E}-02$ & $6.4 \mathrm{E}-02$ & $6.9 \mathrm{E}-02$ & $4.7 \mathrm{E}-02$ & $6.0 \mathrm{E}-02$ & $5.2 \mathrm{E}-02$ & $2.9 \mathrm{E}-02$ & $3.0 \mathrm{E}-02$ \\
\hline \multicolumn{9}{|c|}{ I/CDIs for carcinogens (pesticides and PCBs) } \\
\hline $4,4^{\prime}-\mathrm{DDE}$ & & & & & $-1.5 \mathrm{E}+00$ & $-4.8 \mathrm{E}-01$ & & \\
\hline Dieldrin & & & & $-1.1 \mathrm{E}+02$ & $-1.2 \mathrm{E}+02$ & & & \\
\hline Aroclor- 1248 & & & & $-2.4 \mathrm{E}+01$ & & & & \\
\hline Aroclor-1254 & & $-2.2 \mathrm{E}+02$ & $-2.3 \mathrm{E}+02$ & $-2.5 \mathrm{E}+02$ & $-2.2 \mathrm{E}+01$ & $-2.4 \mathrm{E}+02$ & & \\
\hline Aroclor- 1260 & $-4.6 \mathrm{E}+02$ & $-4.6 \mathrm{E}+02$ & & & $-2.7 \mathrm{E}+01$ & $-1.2 \mathrm{E}+02$ & $-3.9 \mathrm{E}+02$ & $5.0 \mathrm{E}+02$ \\
\hline
\end{tabular}

below the analytical detection limit. Because of analytical detection limitations, the actual fish tissue concentrations are unknown (an exception is the average Aroclor- 1260 concentration in the catfish tissue samples collected at CRK 16). 


\section{Groundwater}

W. K. Jago, R. S. Loffman, and C. A. Motley

\section{Abstract}

Most residents in the Oak Ridge area do not rely on groundwater for potable supplies, although suitable water is available. Local groundwater provides some domestic, municipal, farm, irrigation, and industrial uses, however, and must be viewed as both a potential pathway for exposure to hazardous wastes and as a means for contaminant transport. Statutes codified into regulations by the EPA specifically target the protection of groundwater from contamination by hazardous wastes. The regulations guide groundwater monitoring at the DOE plants in Oak Ridge. Monitoring programs established on the ORR assess groundwater contamination and transport on and off the reservation and are intended to comply with established regulatory requirements.

\section{INTRODUCTION}

The groundwater monitoring programs at the ORR gather information to determine the effects of DOE operations on groundwater quality in compliance with all applicable requirements.

The location and movement of groundwater must be determined to identify the extent of contamination in groundwater and to predict the possible fate of contaminants. To make this determination, an understanding is required of how groundwater moves in general and how that movement will be influenced by the geological setting.

\section{Geological Setting}

The ORR is located in the Tennessee portion of the Valley and Ridge Province, which is part of the southern Appalachian fold and thrust belt. As a result of thrust faulting and varying erosion rates, a series of parallel valleys and ridges have formed that trend southwest-northeast.

Two geologic units on the ORR, designated as the Knox Group and the Maynardville Limestone of the Conasauga Group, both consisting of dolostone and limestone, constitute the Knox Aquifer. A combination of fractures and solution conduits in this aquifer control flow over substantial areas, and relatively large quantities of water may move relatively long distances. Active groundwater flow can occur at substantial depths in the Knox Aquifer [ 300 to $400 \mathrm{ft}(91.5$ to $122 \mathrm{~m})]$. The Knox Aquifer is the primary source of groundwater to many streams (base-flow), and most large springs on the ORR discharge from the Knox Aquifer. Yields of some wells penetrating larger solution conduits are reported to exceed $1000 \mathrm{gal} / \mathrm{min}(3784 \mathrm{~L} / \mathrm{min})$.

The remaining geologic units on the ORR (the Rome Formation, the Conasauga Group below the Maynardville Limestone, and the Chickamauga Group) constitute the ORR Aquitards, which consist mainly of siltstone, shale, sandstone, and thinly bedded limestone of low to very low permeability. Nearly all groundwater flow in the aquitards occurs through fractures. The typical yield of a well in the aquitards is less than $1 \mathrm{gal} / \mathrm{min}(3.8 \mathrm{~L} / \mathrm{min})$, and the base flows of streams draining areas underlain by the aquitards are poorly sustained because of such flow rates.

\section{Hydrogeological Setting Groundwater Hydrology}

When rain falls, a portion of the rainwater accumulates as groundwater by soaking into the ground, infiltrating soil and rock. The accumulation of groundwater in pore spaces of sediments and bedrock creates sources of usable water, which flows in response to external forces. Groundwater eventually reappears at the surface in springs, swamps, stream and river 


\section{Glossary}

aquiclude - a saturated geologic unit that does not transmit significant quantities of water. Although the transmissive capabilities of the aquiclude on the ORR are poorly known, the term is used in this report to denote the zone below active circulation. aquifer - a saturated permeable geologic unit that transmits significant quantities of groundwater. The common definition is that an aquifer yields usable quantities of water to wells, but that definition is relaxed in this report (see aquitard).

aquitard - less permeable geologic units. In this report the term is used in contrast to aquifer, which contains more permeable flow networks.

base flow - the sustained, or "fair weather" flow of a stream.

flux - a state of flow change or fluctuation.

regolith - all subsoils (nonlithified, less cohesive materials) above bedrock, either formed in place or transported.

saprolite - weathered bedrock that has not been transported and that retains some of the original structure.

stormflow zone - approximately corresponds to the root zone of vegetation and is observed to be thickest in fertile, well-developed, and densely vegetated soils.

thrust fault - a low-angle fault that results in surface compression.

unsaturated zone - limited above by the land surface and below by the water table. saturated zone - area beneath the water table bearing as much water as it can hold.

beds, or pumped wells. Thus, groundwater is a reservoir for which the primary input is recharge from infiltrating rainwater and whose output is discharge to springs, swamps, rivers, streams, and wells.

Water infiltrates by percolating downward through the pore spaces between sediment grains and also through fractures in bedrock. The smaller the pore spaces or fractures, the slower the flow of water through the subsurface.
The physical property that describes the ease with which water may move through the pore spaces and fractures in a given material is called permeability, and it is largely determined by the volume and size of these features and how well they are connected.

As water infiltrates the earth, it travels down through the unsaturated zone, where the pore spaces and fractures are partly filled with water and partly filled with air. Water moving down through the unsaturated zone will eventually reach the saturated zone, where the pore spaces and fractures are completely filled with water. The boundary between the unsaturated and the saturated zones is known as the water table, which generally follows, in subtle form, the contour of the surface topography. Springs, swamps, and beds of streams and rivers are the outcrops of the water table, where groundwater is discharged to the surface.

Because the earth's permeability varies greatly, groundwater flowing through subsurface strata does not travel at a constant rate or without impediment. Strata that transmit water easily (such as those composed primarily of sand) are called aquifers, and strata that restrict water movement (such as clay layers) are called aquitards. An aquifer with an aquitard lying above and beneath it is termed a confined aquifer. Groundwater moves through aquifers toward natural exits, or discharge points, to reappear at the surface.

The direction of groundwater flow through an aquifer system is determined by the permeability of the strata containing the aquifer and by the hydraulic gradient, which is a measure of the difference in hydraulic head over a specified distance. Differences in hydraulic head comprise the driving force for groundwater movement through the saturated zone. The hydraulic head at any given point in an aquifer is a function of the energy associated with the water's elevation above sea level and the pressures exerted on it by surrounding water. Because hydraulic head is not solely a function of elevation, downgradient is not necessarily synonymous with downhill. The downgradient direction will have a horizontal and vertical component, just as a household drain moves wastewater both horizontally and vertically, 


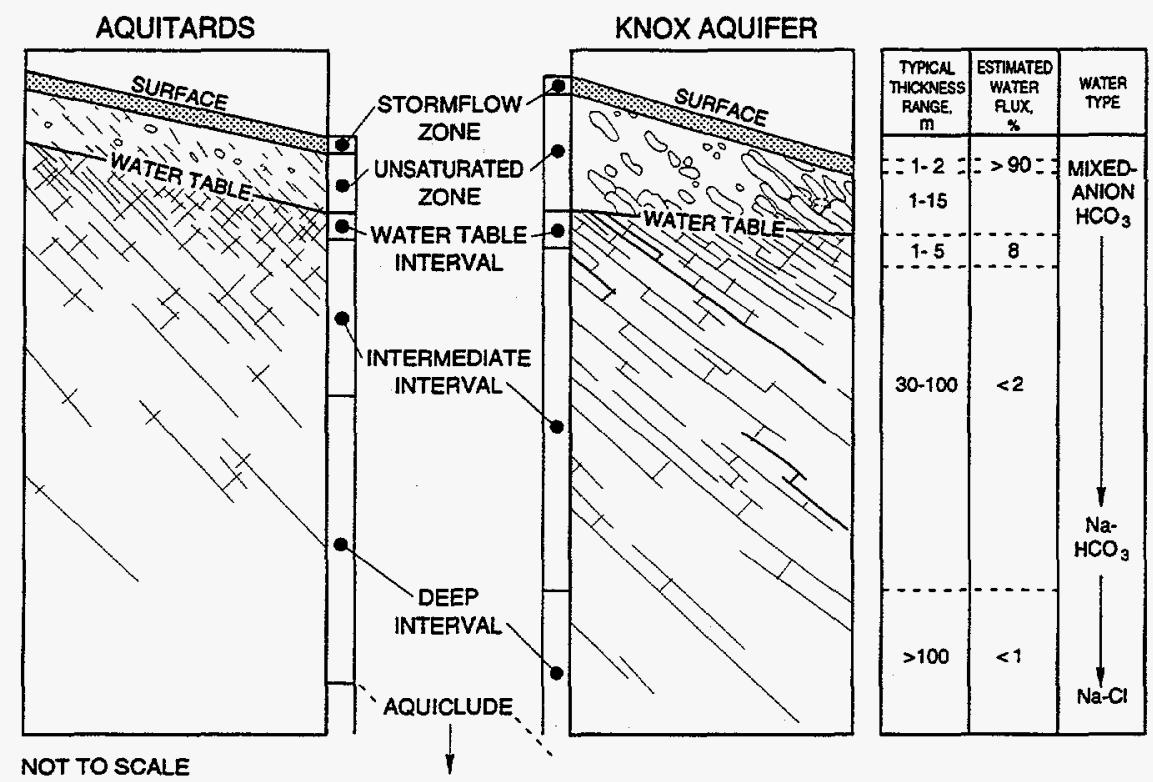

Fig. 7.1. Vertical relationships of flow zones of the ORR: estimated thicknesses, water flux, and water types.

seeking the lowest point of exit. Aquitards deflect groundwater movement just as drain pipe walls control the direction of wastewater movement. In an aquifer constrained by aquitards such as horizontal clay layers, the downgradient direction tends to be more horizontal than vertical.

Groundwater on the ORR occurs both in the unsaturated zone as transient, shallow subsurface stormflow and within the saturated zone. An unsaturated zone of variable thickness separates the stormflow zone and water table. Adjacent to surface water features or in valley floors, the water table is found at shallow depths and the unsaturated zone is thin. Along the ridge tops or near other high topographic areas, the unsaturated zone is thick, and the water table often lies at considerable depth [15 to $50 \mathrm{~m}$ (50 to $175 \mathrm{ft}$ )]. In low-lying areas where the water table occurs near the surface, the stormflow zone and saturated zone are indistinguishable.

Several distinct flow intervals occur within the water table aquifer: the uppermost water table interval; the intermediate interval; the deep interval; and the aquiclude, which is defined by a transition to saline water (Fig. 7.1). The divisions within the saturated zone grade into one another vertically and are not separated by distinct boundaries but reflect an overall decrease in the rate of groundwater flow with depth. Within the ORR aquitards, the greatest groundwater flow rates occur in the stormflow zone and the smallest within the deep zone. Water does not flow in the aquiclude. In the Knox Aquifer, the greatest groundwater flow is in the water table and intermediate intervals [depths to approximately $300 \mathrm{ft}(91.5 \mathrm{~m})]$.

As denoted earlier, two broad hydrologic units are identified on the ORR: the Knox Aquifer and the ORR Aquitards, which consist of less permeable geologic units. Figure 7.2 is a generalized map showing surface distribution of the Knox Aquifer and the ORR Aquitards. Many waste areas on the ORR are located in areas underlain by the ORR Aquitards.

\section{Unsaturated Zone Hydrology}

In undisturbed, naturally vegetated areas on the ORR, about $90 \%$ of the infiltrating precipitation does not reach the water table but travels through the 1- to 2-m-deep stormflow zone, which approximately corresponds to the root zone. Because of the permeability contrast between the stormflow zone and the underlying unsaturated zone, the stormflow zone partially 


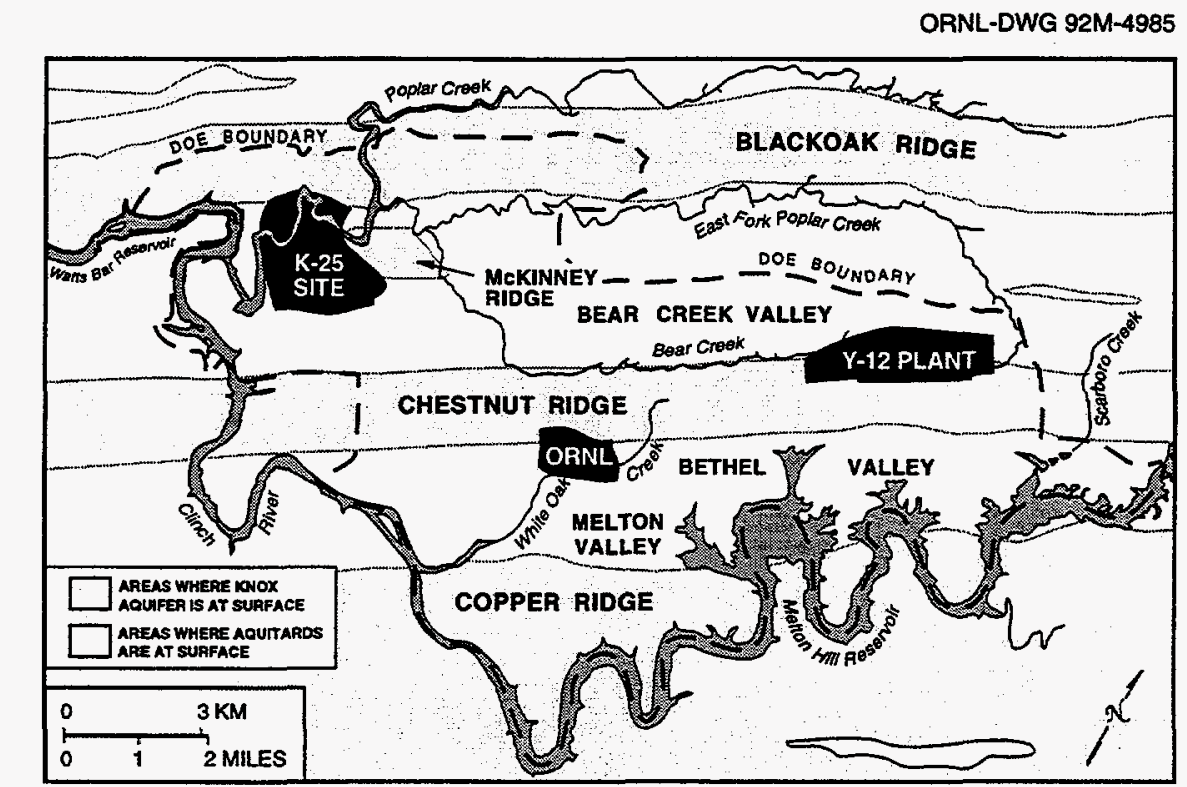

Fig. 7.2. The Knox Aquifer and the aquitards on the Oak Ridge Reservation.

ORNL-DWG 92M-4986

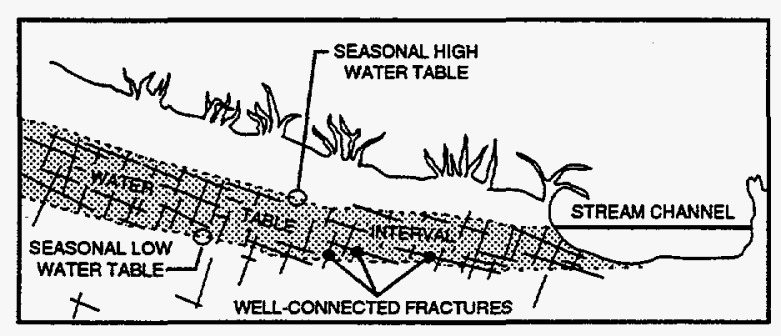

Fig. 7.3. Water table interval.

or completely saturates during rainfall events, and then water flows laterally, following very short flow paths to adjacent streams. When the stormflow zone becomes completely saturated, flow of water over the land occurs. Between rainfall events, as the stormflow zone drains, flow rates decrease dramatically and water movement becomes nearly vertical toward the underlying water table.

The rate at which groundwater is transmitted through the stormflow zone is attributed to large pores (root channels, worm bores, and relict fractures). Stormflow is primarily a transport mechanism in undisturbed or vegetated areas, where it intersects shallow waste sources. Most buried wastes are below the stormflow zone; however, in some trenches a commonly observed condition known as "bathtubbing" can occur, in which the excavation fills with water and may overflow into the stormflow zone. All stormflow ultimately discharges to streams on the ORR.

\section{Saturated Zone Hydrology}

As shown in Fig. 7.1, the saturated zone on the ORR can be divided into four vertically distinct flow zones; an uppermost water table interval, an intermediate zone, a deep zone, and an aquiclude. Available evidence indicates that most water in the saturated zone in the aquitards is transmitted through a 1-to 6-m-thick (3- to $20-\mathrm{ft}$ ) layer of closely spaced, well-connected fractures near the water table (the water table interval) as shown in Fig. 7.3.

As in the stormflow zone, the bulk of groundwater in the saturated zone resides within the pore spaces of the rock matrix. The rock matrix typically forms blocks that are bounded by fractures. Contaminants in the fractures typically occur in higher concentrations than in the matrix; thus, the contaminants tend to move (diffuse) into the matrix. This process, termed diffusive exchange, between water in matrix pores and water in adjacent fractures reduces the overall contaminant migration rates relative to groundwater flow velocities. For example, the leading edge of a geochemically nonreactive contaminant mass such as tritium

\section{7-4 Groundwater}


may migrate along fractures at a typical rate of $3 \mathrm{ft} /$ day $(1 \mathrm{~m} /$ day); however, the center of mass of a contaminant plume typically migrates at a rate less than $0.2 \mathrm{ft} /$ day $(0.66 \mathrm{~m} /$ day $)$.

In the aquitards, chemical characteristics of groundwater change from mixed-cation- $\mathrm{HCO}_{3}$ water type at shallow depth to a $\mathrm{Na}-\mathrm{HCO}_{3}$ water type at deeper levels. This transition, not marked by a distinct change in rock properties, serves as a useful marker and can be used to distinguish the more active water table and intermediate groundwater intervals from the sluggish flow of the deep interval. There is evidence of similar change with depth in the chemical characteristics of water in the Knox Aquifer. Although the mechanism responsible for this change in water types is not quantified, it most likely is related to the amount of time the water is in contact with a specific type of rock.

Most groundwater flow in the saturated zone occurs within the water table interval. Most flow is through weathered, permeable fractures and matrix rock and within solution conduits in the Knox Aquifer. The range of seasonal fluctuations in depth to the water table and in rates of groundwater flow varies significantly across the reservation. In areas underlain by the Knox Aquifer, seasonal fluctuations in water levels average $5.3 \mathrm{~m}(17 \mathrm{ft})$, and mean discharge from the active groundwater zone is typically $85 \mathrm{gal} / \mathrm{min}$ ( $322 \mathrm{~L} / \mathrm{min})$ per square mile. In the aquitards of BCV, Melton Valley, East Fork Valley, and Bethel Valley, seasonal fluctuations in water levels average $5 \mathrm{ft}(1.5 \mathrm{~m})$ and typical mean discharge is $26 \mathrm{gal} / \mathrm{min}$ ( $98 \mathrm{~L} / \mathrm{min}$ ) per square mile.

In the intermediate interval, groundwater flow paths are a product of fracture density and orientation. In this interval, groundwater movement occurs primarily in permeable fractures that are poorly connected. In the Knox Aquifer a few cavity systems and fractures control groundwater movement in this zone, but in the aquitards the bulk of flow is through fractures along which permeability may be increased by weathering.

The deep interval of the saturated zone is delineated by a change to a $\mathrm{Na}-\mathrm{HCO}_{3}$ water type. Hydrologically active fractures in the deep interval are significantly fewer in number and shorter in length than in the other intervals, and the spacing is greater. Wells finished in the deep interval of the ORR aquitards typically yield less than $0.3 \mathrm{gal} / \mathrm{min}(1.1 \mathrm{~L} / \mathrm{min})$ and thus are barely adequate for water supply.

In the aquitards, saline water characterized by total dissolved solids ranging up to $2.75 \times 10^{5} \mathrm{mg} / \mathrm{L}$ and chlorides generally in excess of $5 \times 10^{4} \mathrm{mg} / \mathrm{L}$ (ranging up to $1.63 \times 10^{5} \mathrm{mg} / \mathrm{L}$ ) lies beneath the deep interval of the groundwater zone, delineating an aquiclude. Chemically, this water resembles brines typical of major sedimentary basins; but its origin is not known. The chemistry suggests extremely long residence times (i.e., very low flow rates) and little or no mixing with shallow groundwater.

The aquiclude has been encountered at depths of 125 and $244 \mathrm{~m}$ (400 and $800 \mathrm{ft}$ ) in Melton and Bethel valleys, respectively (near ORNL), and it is believed to approach $305 \mathrm{~m}(1000 \mathrm{ft}$ ) in portions of BCV (near the Y-12 Plant) underlain by aquitard formations. Depth to the aquiclude in areas of the Knox Aquifer is not known but is believed to be greater than $366 \mathrm{~m}$ (1200 ft); depth to the aquiclude has not been established in the vicinity of the K-25 Site.

\section{Groundwater Flow}

Many factors influence groundwater flow on the ORR. Topography, surface cover, geologic structure, and rock type exhibit especially strong influence on the hydrogeology. Variations in these features result in variations of the total amount of groundwater moving through the system (flux). (Average flux rates for the aquitards and the Knox Aquifer formations are shown in Fig. 7.1.) As an example, the overall decrease in open fracture density with depth results in a decreased groundwater flux with depth.

Topographic relief on the ORR is such that most active subsurface groundwater flow occurs at shallow depths. U.S. Geological Survey modeling (Tucci 1992) suggests that $95 \%$ of all groundwater flow occurs in the upper 15 to 
$30 \mathrm{~m}(50$ to $100 \mathrm{ft})$ of the saturated zone in the aquitards. As a result, flow paths in the active-flow zones (particularly in the aquitards) are relatively short, and nearly all groundwater discharges to local surface water drainages on the ORR. Conversely, in the Knox Aquifer, it is believed that solution conduit flow paths may be considerably longer, perhaps as much as $1.6 \mathrm{~km}$ ( 2 miles) long in the along-strike direction. No evidence at this time substantiates the existence of any deep, regional flow off the ORR or between basins within the ORR in either the Knox Aquifer or the aquitards. Data collected in CY 1994 and 1995, however, has demonstrated that groundwater flow and contaminant transport occur off of the ORR in the intermediate interval of the Knox Aquifer, near the east end of the Y-12 Plant.

Migration rates of contaminants transported in groundwater are strongly influenced by natural chemical and physical processes in the subsurface (including diffusion and adsorption). Peak concentrations of solutes, including contaminants such as tritium moving from a waste area, for instance, can be delayed for several to many decades in the aquitards, even along flow paths as short as a few hundred feet. The processes that naturally retard contaminant migration and store contaminants in the subsurface are less effective in the Knox Aquifer than in the aquitards because of rapid flow along solution features allowing minimal time for diffusion to occur.

\section{Groundwater Monitoring Considerations}

Because of the complexity of the hydrogeologic framework on the ORR, groundwater flow and, therefore, contaminant transport are difficult to predict on a local scale. Consequently, individual plume delineation is not always feasible on the ORR. Stormflow and most groundwater discharge to the surface water drainages on the ORR. For that reason, monitoring springs, seeps, and surface water quality is one of the best ways to assess the extent to which groundwater from a large portion of the ORR transports contaminants; however, contaminant transport may occur at depth as well. The center of mass of the VOC plume in the Maynardville Limestone east of the Y-12 Plant lies at a depth of $300 \mathrm{ft}(91.5 \mathrm{~m})$. Transport of the highest VOC concentrations occurs in this interval because VOCs are more dense than water, and there is little dilution.

\section{Off-Site Spring and Residential Well Monitoring}

Groundwater monitoring of residential wells and springs in the vicinity of the ORR is summarized in Sect. 5.

\section{Groundwater Monitoring Program on the ORR}

The groundwater surveillance monitoring programs implemented at the DOE facilities have been designed to obtain full compliance with regulatory requirements and to meet objectives. Site-specific regulatory monitoring programs are supported technically by site characterization and regional studies of the geohydrologic and chemical aspects of the flow system. QC procedures for every aspect of data collection and analysis have been established, and data bases are used to organize and report analytical results.

Thus, the groundwater surveillance monitoring program for the ORR, while disposal site- and facility-specific, contains a number of common components that are interrelated and coordinated to allow both time- and cost-effective project management.

\section{GROUNDWATER MONITORING AT THE Y-12 PLANT}

\section{Background and Regulatory Setting}

Most of the groundwater monitoring at the Y-12 Plant is conducted within the scope of a single, comprehensive groundwater monitoring program, which included the following elements in 1995:

\section{7-6 Groundwater}


- monitoring to comply with requirements of RCRA interim status assessment and detection monitoring,

- compliance with RCRA postclosure monitoring requirements,

- monitoring to support CERCLA RI/FS efforts and records of decision,

- compliance with TDEC solid waste management (SWM) regulations,

- monitoring to support DOE Order 5400.1 requirements (exit pathway and surveillance monitoring),

- compliance with regulatory monitoring requirements for petroleum USTs, and

- monitoring to support best management practices.

Through incorporation of these multiple considerations, the comprehensive monitoring program at the Y-12 Plant addresses multiple regulatory considerations and technical objectives. It eliminates redundancy between different regulatory programs and ensures consistent data collection and evaluation.

More than 200 sites have been identified at the Y-12 Plant that represent known or potential sources of contamination to the environment as a result of past waste management practices. These sites are being addressed either by the ER Program under exclusively CERCLA programs or a combination of CERCLA and RCRA regulations. The ER Program and Y-12 Plant management share responsibilities for sites regulated under dual CERCLA and RCRA drivers.

A number of the inactive waste management sites were grouped in 1992 into OUs under CERCLA as part of an FFA negotiated between EPA, TDEC, and DOE. Two types of OUs were identified: (1) source OUs consisting of sites or groups of sites that were known sources of contamination to the environment and (2) integrator OUs consisting of media, such as groundwater, soils, and surface water, that had been impacted by the source OUs. RI/FS activities were initiated for these OUs; however, as these activities progressed, it became evident that administrative separation of source and integrator OUs was not a technically feasible approach to ER because contamination from numerous source OUs had mingled and integrator OUs had been impacted significantly by multiple source OUs. As a result, distinction of the nature and extent of contamination, risk, and evaluation of remedial actions for individual source OUs was not practicable. An agreement was reached among regulatory agencies and DOE in 1994 to proceed with an integrated RU/FS strategy. In the integrated strategy, former source OUs and integrator OUs are addressed concurrently in a characterization area (CA) defined by physical limits, such as watershed boundaries and/or groundwater flow regimes (Fig. 7.4). Specific sites or locations of high risk or concern within the CA are targeted for focused, rapid remedial actions, while a general remedial strategy and/or administrative controls for the CA progresses. Individual focused actions are designated as OUs and documented under separate RODs.

Two CAs incorporating 27 known source units have been established for the Y-12 Plant, the UEFPC CA and the Bear Creek Valley (BCV) CA.

In addition, four individual source OUs remain on Chestnut Ridge, where available data indicate that contamination from each unit is distinct and separable. The remaining sites have been grouped into Y-12 Plant study areas that constitute lower-priority units that will be investigated under CERCLA as preliminary assessment/site investigations (PA/SIs). New OUs or additions to existing CAs will be made if the degree of contamination determined by the PA/SI warrants further study under an RI/FS.

Postclosure maintenance, monitoring, and reporting requirements of RCRA also apply to seven inactive CERCLA-regulated units that meet the definition of RCRA hazardous waste TSD facilitates. These units include the S-3 Site, portions of the Bear Creek Burial Grounds, Oil Landfarm, New Hope Pond, Chestnut Ridge Security Pits, Chestnut Ridge Sediment Disposal Basin, and Kerr Hollow Quarry. Postclosure requirements will be outlined in RCRA postclosure permits currently being issued by TDEC. These requirements will be integrated with CERCLA programs. Corrective 
$\tilde{\omega}$

ORNL-DWG 94M-7177R

옹

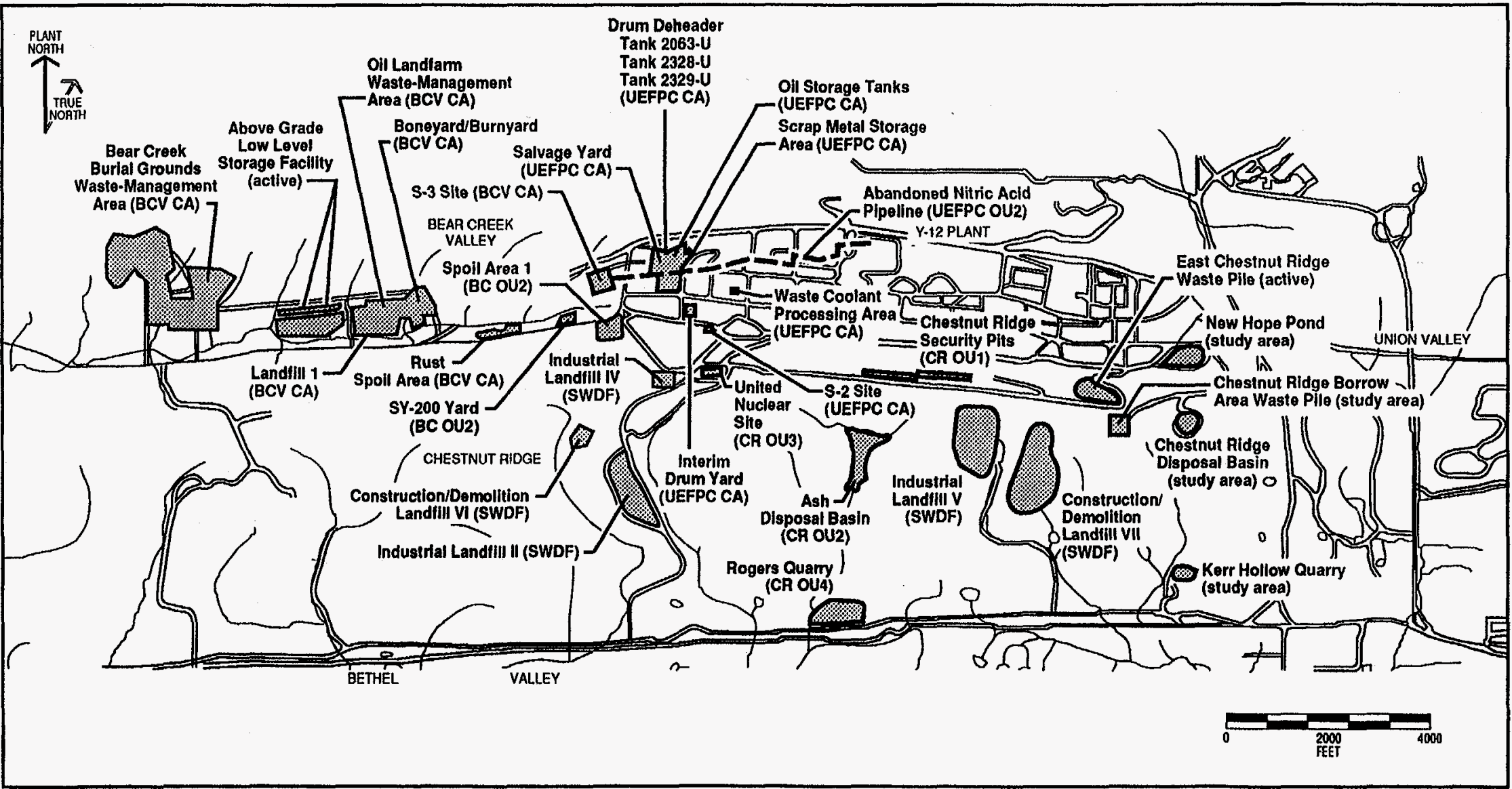

Fig. 7.4 . Y-12 Plant inactive regulated units, study areas, and active facilities for which groundwater monitoring was conducted in CY 1995. 


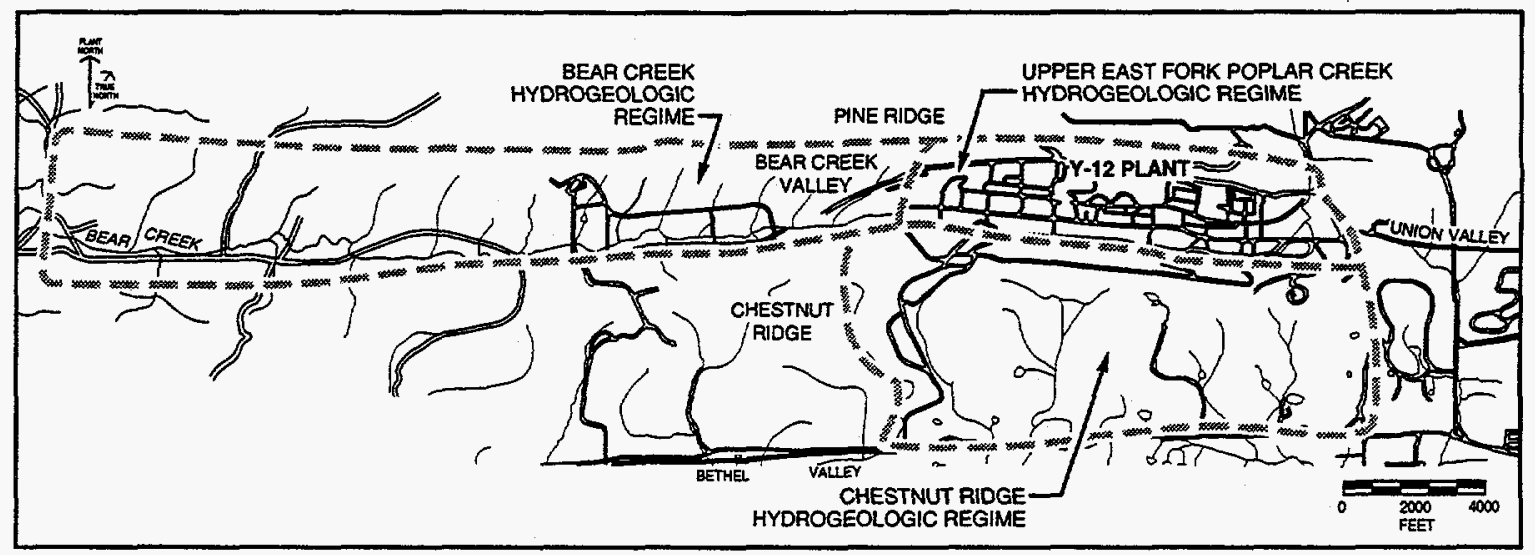

Fig. 7.5. Hydrogeologic regimes at the Y-12 Plant.

actions addressing contaminant releases will be deferred to the CERCLA RI/FS process.

Additional primary regulatory drivers for groundwater monitoring at the Y-12 Plant are the TDEC regulations governing nonhazardous solid waste disposal facilities (SWDFs) and TDEC regulations governing petroleum USTs. Two facilities (Centralized Sanitary Landfill II and Industrial Landfill IV) have been subject to groundwater monitoring under the SWDF regulations since the late 1980s. Construction of three additional landfill facilities was completed between 1993 and 1994 (Industrial Landfill V, Construction/Demolition Landfill VI, and Construction/Demolition Landfill VII). Baseline groundwater monitoring has been completed for all SWDFs, and all of the sites are now under a semiannual detection monitoring program. Groundwater monitoring to support the petroleum UST program at the Y-12 Plant has progressed past the assessment phase into the corrective action phase, which requires only limited monitoring.

Specific regulatory requirements do not address all groundwater monitoring concerns at the Y-12 Plant. Selected areas where contamination is most likely to migrate to potential exposure points off of the ORR are monitored as part of DOE Order 5400.1 exit-pathway monitoring. Also, monitoring is performed as part of DOE 5400.1 surveillance monitoring in general areas not specifically regulated and not representing specific exit pathways off of the reservation, such as a large part of the industrialized portion of the Y-12 Plant. Surveillance monitoring is conducted to monitor contaminant plume boundaries and to trend contaminant concentrations specifically to augment regulatory and exit-pathway monitoring programs. Best management practice monitoring is conducted at a number of selected sites or locations either at the request of internal organizations, the TDEC/DOE Oversight Division, or in lieu of regulatory required monitoring at active facilities.

\section{Hydrogeologic Setting and Summary of Groundwater Quality}

In the comprehensive monitoring program, the Y-12 Plant is divided into three hydrogeologic regimes delineated by surface water drainage patterns, topography, and groundwater flow characteristics. The regimes are further defined by the waste sites they contain. These regimes include the Bear Creek Hydrogeologic Regime (Bear Creek regime), the Upper East Fork Poplar Hydrogeologic Regime (East Fork regime), and the Chestnut Ridge Hydrogeologic Regime (Chestnut Ridge regime) (Fig. 7.5). Most of the Bear Creek and East Fork regimes are underlain by the ORR aquitards. The extreme southern portion of these two regimes is underlain by the Maynardville Limestone, which is part of the Knox Aquifer. The entire Chestnut Ridge regime is underlain by the Knox Aquifer.

In general, groundwater flow in the water table interval follows topography. Shallow 
groundwater flow in the Bear Creek and East Fork regimes is divergent from a topographic and groundwater table divide located near the western end of the Y-12 Plant. Shallow groundwater flow directions east and west of the divide are predominantly easterly and westerly, respectively. This divide defines the boundary between the Bear Creek and Chestnut Ridge regimes. In addition, flow converges toward the primary surface streams from Pine Ridge to the north and Chestnut Ridge to the south of the Y-12 Plant. In the Chestnut Ridge regime, a groundwater table divide exists that approximately coincides with the crest of the ridge. Shallow groundwater flow, therefore, tends to be toward either flank of the ridge, with discharge primarily to surface streams and springs located in Bethel Valley to the south and $B C V$ to the north.

In $\mathrm{BCV}$, groundwater in the intermediate and deep intervals moves predominantly through fractures in the ORR aquitards, converging toward and moving through fractures and solution conduits in the Maynardville Limestone. Karst development in the Maynardville Limestone has a significant impact on groundwater flow paths in the water table and intermediate intervals. In general, groundwater flow parallels geologic strike. Groundwater flow rates in $\mathrm{BCV}$ vary widely; they are very slow within the deep interval of the ORR aquitards but can be quite rapid within solution conduits in the Maynardville Limestone. The rate of groundwater flow perpendicular to geologic strike from the ORR aquitards to the Maynardville Limestone has not been well established. Several investigations are currently under way or planned to attempt to identify how quickly groundwater beneath waste sites over the ORR aquitards moves to the Maynardville Limestone. Recent data obtained as part of hydrologic studies in the Bear Creek regime suggest that strike-parallel transport of some contaminants can occur within the ORR aquitards for significant distances. Continuous elevated levels of nitrate within the ORR aquitards are now known to extend west from the S-3 Site for a distance of about $3000 \mathrm{ft}$, approximately twice the previous estimates. VOCs at source units in the ORR aquitards, however, tend to remain close to source areas because they tend to adsorb to the bedrock matrix, diffuse into pore spaces within the matrix, and degrade prior to migrating to exit pathways, where rapid transport for long distances can occur.

Groundwater flow in the Chestnut Ridge regime is almost exclusively through fractures and solution conduits in the Knox Group. Discharge points for intermediate and deep flow are not well known. Groundwater is currently presumed to flow primarily toward BCV to the north and Bethel Valley to the south. Groundwater from intermediate and deep zones may discharge at certain spring locations along the flanks of Chestnut Ridge. Along the crest of the ridge, water table elevations decrease from west to east, implying an overall easterly trend in groundwater flow.

Historical monitoring efforts have shown that groundwater quality at the Y-12 Plant has been affected by four types of contaminants: nitrate, VOCs, metals, and radionuclides. Of these, nitrate and VOCs are the most widespread, although data obtained since 1988 suggest that the extent of some radionuclides may also be significant, particularly in the Bear Creek regime. Trace metals, the least extensive groundwater contaminants, generally occur in a small area of low-pH groundwater at the west end of the Y-12 Plant, in the vicinity of the S-3 Site. Data obtained as a result of previous monitoring efforts show that contaminant plumes from multiple source units have mixed with one another and that contaminants (other than nitrate) are no longer easily associated with a single source.

\section{Well Installation and Plugging and Abandonment Activities}

The monitoring objectives for the wells at the Y-12 Plant are divided into four categories: Category I wells, to obtain additional data to delineate the extent of groundwater contamination; Category II wells, to monitor potential exit pathways for groundwater contamination; Category III wells, as new or replacement wells for compliance monitoring; 


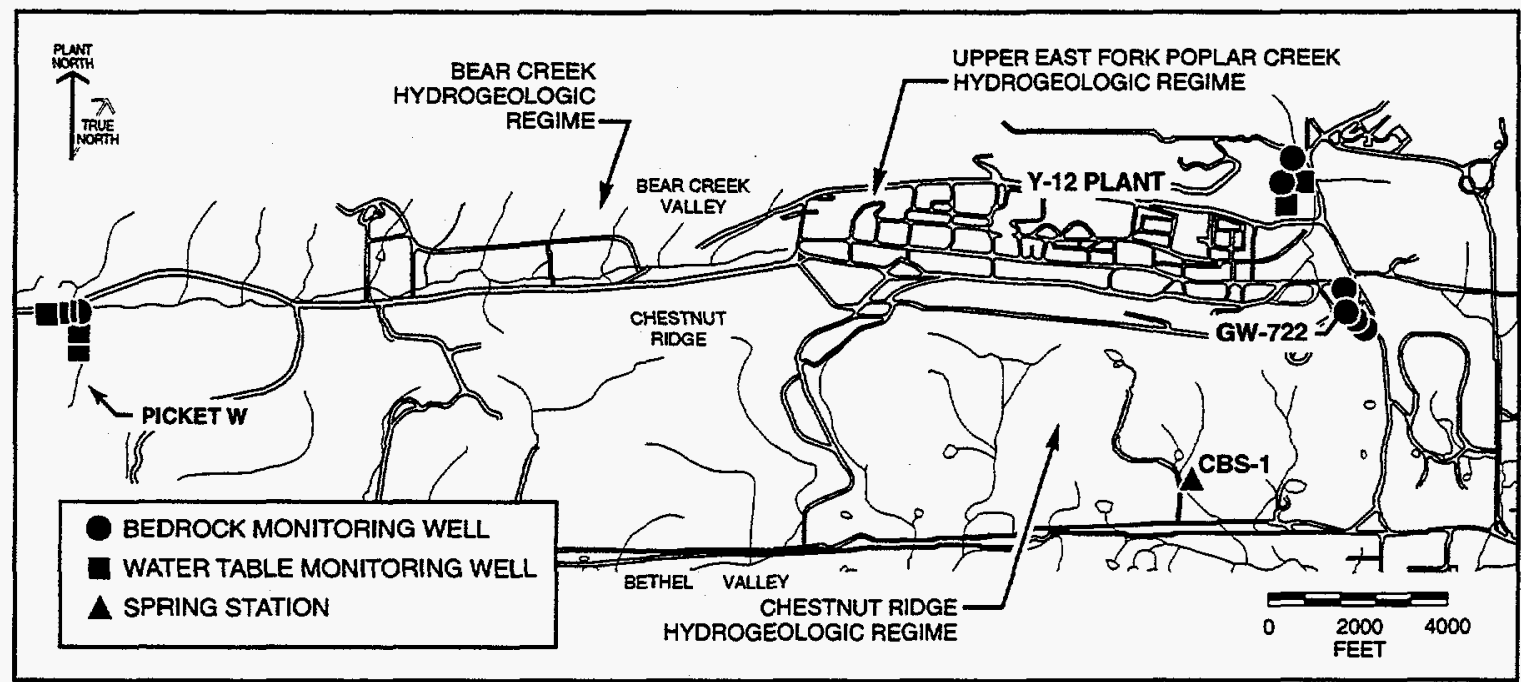

Fig. 7.6. Locations of ORR perimeter surveillance wells and multiport monitoring wells specified in the Environmental Monitoring Plan. Well GW-722 is a multiport monitoring well that is also designated as a perimeter surveillance well.

and Category IV wells, under the direction of the Y-12 Plant ER Program, to obtain specific data required for CERCLA remedial investigations (RIs). In 1995, two new Category I groundwater monitoring wells were installed in the Bear Creek regime to monitor contamination migration within the ORR Aquitards.

The Y-12 Plant GWPP conducts well plugging and abandonment activities as part of an overall program to maintain the Y-12 Plant monitoring well network. Wells that are damaged beyond rehabilitation, interfere with planned construction activities, or for which no useful data can be obtained, are selected for plugging and abandonment. In 1995, 55 wells were plugged and abandoned. A majority of these wells were located in the extreme western portion of the Bear Creek regime. The wells were plugged and abandoned because of poor condition, historical lack of security or identity, or no identifiable future use.

\section{Monitoring Programs}

Groundwater monitoring in 1995 addressed multiple requirements from regulatory drivers, DOE orders, Y-12 Plant ER programs, and best management practices. Table 7.1 contains a summary of monitoring activities conducted by the Y-12 Plant GWPP, as well as the programmatic requirements that apply to each site.

Figure 7.6 shows the locations of ORR perimeter monitoring stations as specified in the EMP.

Detailed data reporting for monitoring activities conducted by the Y-12 Plant GWPP is contained within the 1995 annual groundwater quality reports for each hydrogeologic regime (Energy Systems 1996a, 1996b, and 1996c). Details of small-scale monitoring efforts performed by organizations other than the Y-12 Plant GWPP specifically for CERCLA OUs are published in RI reports.

\section{Y-12 Plant Groundwater Quality}

\section{Upper East Fork Poplar Creek Hydrogeologic Regime}

The East Fork regime encompasses the Y-12 Plant complex, extending west from Scarboro Road. It is separated from the Bear Creek regime by a topographic and hydrologic boundary located near the west end of the plant. The 1995 monitoring locations, waste management sites, and petroleum fuel USTs in the East Fork regime that are addressed in this document are shown in Fig. 7.7. Regulatory 
Table 7.1. Summary of the comprehensive groundwater monitoring program at the Y-12 Plant, $1995^{a}$

\begin{tabular}{|c|c|c|}
\hline $\begin{array}{l}\text { Hydrogeologic regime/waste } \\
\text { disposal site }\end{array}$ & Requirements ${ }^{b}$ & $\begin{array}{l}\text { Number of } \\
\text { wells }\end{array}$ \\
\hline \multicolumn{3}{|c|}{ Bear Creek Hydrogeologic Regime } \\
\hline Bear Creek Springs & EXP & 9 \\
\hline Bear Creek surface water & EXP & 6 \\
\hline Maynardville Limestone & EXP/RCRA-CM & 23 \\
\hline Oil Landfarm & RCRA-AM/SMP & 15 \\
\hline Rust Spoil Area & RCRA-AM & 2 \\
\hline S-3 Site & RCRA-CM/SMP & 10 \\
\hline Spoil Area I & RCRA-AM & 2 \\
\hline Y-12 Burial Grounds & RCRA-AM/SMP/RCRA-CM & 27 \\
\hline BCV CA Nitrate Assessment & RI/FS & 4 \\
\hline BCV CA Radiological Assessment & RI/FS & 32 \\
\hline Above-Grade Low-Level Storage Facility & BMP & 3 \\
\hline TSD Garage Facility & UST & 1 \\
\hline \multicolumn{3}{|c|}{ East Fork Poplar Creek Hydrogeologic Regime } \\
\hline Surface water & EXP & 1 \\
\hline Maynardville Limestone & EXP & 9 \\
\hline Scarboro Road north of Y-12 & EXP & 4 \\
\hline Y-12 Plant: & SMP/BMP & 73 \\
\hline -Active Facilities & & \\
\hline$-S-2$ Site & & \\
\hline -Rust Garage & & \\
\hline -Waste Coolant Area & & \\
\hline -Salvage Yard & & \\
\hline -Fire Training Facility & & \\
\hline -Beta-4 Security Pits & & \\
\hline -Grid Network & & \\
\hline New Hope Pond & RCRA-AM & 9 \\
\hline Union Valley & EXP/RIFS & 7 \\
\hline \multicolumn{3}{|c|}{ Chestmut Ridge Hydrogeologic Regime } \\
\hline Springs & EXP/BMP & 2 \\
\hline Ash Disposal Basin & BMP & 4 \\
\hline Chestnut Ridge Security Pits & RCRA-AM & 10 \\
\hline East Chestnut Ridge Waste Pile & BMP & 4 \\
\hline Kerr Hollow Quarry & RCRA-DM & 7 \\
\hline Landfill II & SWDF & 3 \\
\hline Chestnut Ridge Borrow Area Waste Pile & BMP & 6 \\
\hline Landfill IV & SWDF & 5 \\
\hline Landfill V & SWDF & 5 \\
\hline Landfill VI & SWDF & 7 \\
\hline Landfill VII & SWDF & 4 \\
\hline
\end{tabular}


Table 7.1 (continued)

\begin{tabular}{llc}
\hline $\begin{array}{c}\text { Hydrogeologic regime/waste } \\
\text { disposal site }\end{array}$ & \multicolumn{1}{c}{ Requirements $^{b}$} & $\begin{array}{c}\text { Number of } \\
\text { wells }\end{array}$ \\
\hline Rogers Quarry & BMP & 4 \\
Sediment Disposal Basin & RCRA-DM & 8 \\
United Nuclear Site & ROD & 6
\end{tabular}

${ }^{a}$ Baseline analytical parameters include ICP metals scan; $\mathrm{Cd}, \mathrm{Cr}, \mathrm{Pb}$ by atomic absorption spectroscopy; $\mathrm{Hg}$; U (total); VOCs; major anions; gross alpha; gross beta; $\mathrm{pH}$; conductance; TSS; TDS; turbidity; standard field parameters, including dissolved oxygen, water level, $\mathrm{pH}$, temperature, conductance, and redox potential. RCRA corrective action monitoring in the Bear Creek regime includes ${ }^{241} \mathrm{Am},{ }^{129}{ }_{1},{ }^{237} \mathrm{~Np},{ }^{238} \mathrm{Pu}$, total radium, total strontium, ${ }^{99} \mathrm{Tc},{ }^{3} \mathrm{H},{ }^{234} \mathrm{U},{ }^{235} \mathrm{U}$, and ${ }^{238} \mathrm{U}$. SWDF monitoring required by TDEC Rule 1200-1-7-.04 includes chemical oxygen demand, cyanide, TOC, TOX, ammonia (as N), gamma activity, and additional VOC list required by TDEC Rule 1200-1-7-.04. Analyte lists for some sites were tailored to meet specific programmatic, technical, or regulatory requirements.

${ }^{b} \mathrm{BMP}=$ best management practices monitoring; EXP = exit-pathway or perimeter monitoring under DOE Order 5400.1; RCRA-AM = RCRA Assessment Monitoring at interim status units; RCRA-DM = RCRA Detection Monitoring; RCRA-CM = RCRA post-closure corrective action monitoring; SMP = DOE Order 5400.1 surveillance monitoring; UST = petroleum underground storage tank locations; SWDF = monitoring for solid waste disposal facilities under TDEC Rule 1200-1-7-.04; ROD = CERCLA record of decision post-closure monitoring; RL/FS = CERCLA remedial investigation monitoring. 


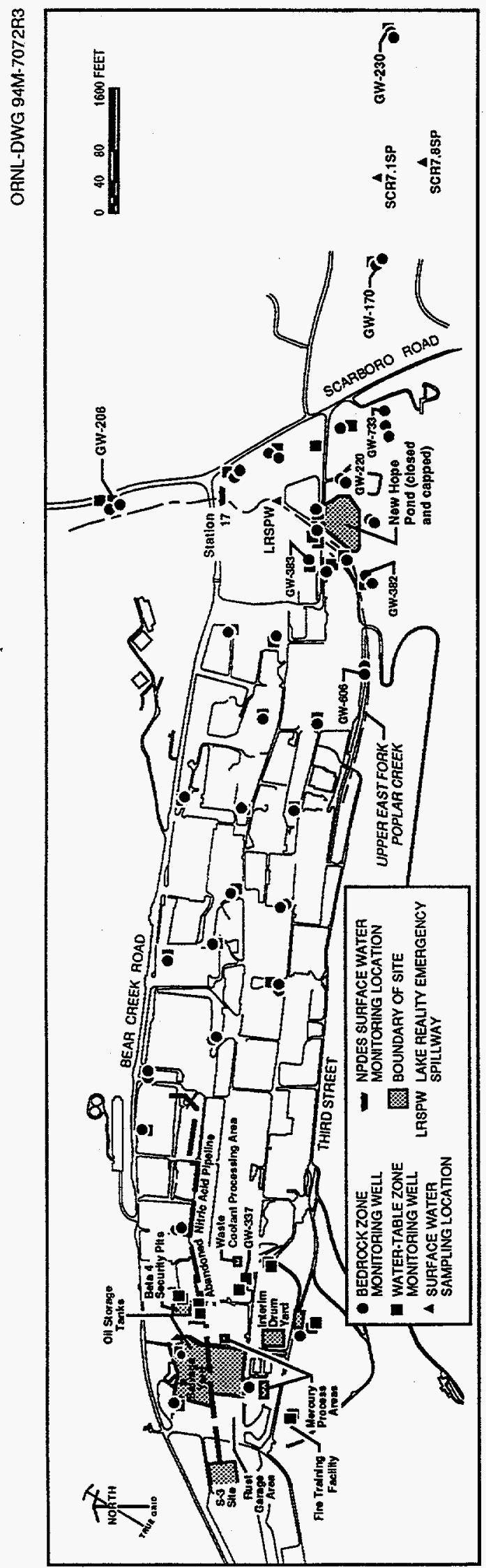

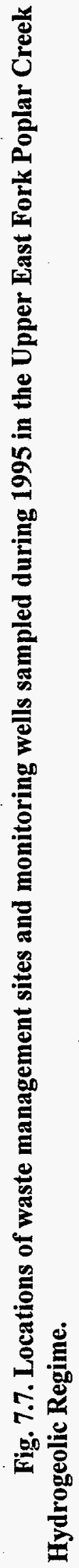


Table 7.2. Regulatory status and operational history of waste management units and underground storage tanks included in the 1995 Comprehensive Groundwater Monitoring Program; Upper East Fork Poplar Creek Hydrogeologic Regime

\begin{tabular}{|c|c|c|}
\hline Site & $\begin{array}{l}\text { Historicalcurrent } \\
\text { regulatory } \\
\text { classification }^{a}\end{array}$ & Historical data \\
\hline New Hope Pond & TSD/Study Area & $\begin{array}{l}\text { Built in } 1963 . \text { Regulated flow of water in UEFPC before exiting the Y-12 Plant } \\
\text { grounds. Sediments include PCBs, mercury, and uranium but not hazardous } \\
\text { according to toxicity characteristic leaching procedure. Closed under RCRA in } \\
1990 \text {. }\end{array}$ \\
\hline $\begin{array}{l}\text { Abandoned Nitric Acid } \\
\text { Pipeline }\end{array}$ & SWMU/UEFPC OU2 & $\begin{array}{l}\text { Used from } 1951 \text { to } 1983 \text {. Transported liquid nitric acid wastes and dissolved } \\
\text { uranium from Y-12 Plant process areas to the S-3 Site. Leaks were the release } \\
\text { mechanisms to groundwater. A CERCLA ROD has been issued. }\end{array}$ \\
\hline $\begin{array}{l}\text { Salvage Yard Scrap Metal } \\
\text { Storage Area }\end{array}$ & SWMU/UEFPC CA & $\begin{array}{l}\text { Used from } 1950 \text { to present for scrap metal storage. Some metals contaminated } \\
\text { with low levels of depleted or enriched uranium. Runoff and infiltration are the } \\
\text { principal release mechanisms to groundwater. }\end{array}$ \\
\hline $\begin{array}{l}\text { Salvage Yard Oil/Solvent } \\
\text { Drum Storage Area }\end{array}$ & SWMU/UEFPC CA & $\begin{array}{l}\text { Primary wastes included waste oils, solvents, uranium, and beryllium. Both } \\
\text { closed under RCRA. Leaks and spills represent the primary contamination mech- } \\
\text { anisms for groundwater. }\end{array}$ \\
\hline $\begin{array}{l}\text { Salvage Yard Oil Storage } \\
\text { Tanks }\end{array}$ & SWMU/UEFPC CA & $\begin{array}{l}\text { Used from } 1978 \text { to } 1986 \text {. Two tanks used to store PCB-contaminated oils, both } \\
\text { within a diked area. }\end{array}$ \\
\hline $\begin{array}{l}\text { Salvage Yard Drum De- } \\
\text { header Facility }\end{array}$ & SWMUЛUEFC CA & $\begin{array}{l}\text { Used from } 1959 \text { to } 1989 \text {. Sump tanks } 2063-\mathrm{U}, 2328-\mathrm{U} \text {, and } 2329-\mathrm{U} \text { received } \\
\text { residual drum contents. Sump leakage is a likely release mechanism to ground- } \\
\text { water. }\end{array}$ \\
\hline S-2 Site & SWMU/UEFPC CA & $\begin{array}{l}\text { Used from } 1945 \text { to } 1951 \text {. An unlined reservoir received liquid wastes. Infiltration } \\
\text { is the primary release mechanism to groundwater. }\end{array}$ \\
\hline $\begin{array}{l}\text { Waste Coolant Processing } \\
\text { Area }\end{array}$ & SWMU/UEFPC CA & $\begin{array}{l}\text { Former biodegradation facility used to treat waste coolants from various machin- } \\
\text { ing processes. Closed under RCRA in } 1988 .\end{array}$ \\
\hline Building 81-10 Area & NA/UEFPC CA & $\begin{array}{l}\text { Staging facility. Potential historical releases to groundwater from leaks and spills } \\
\text { of liquid wastes or mercury. }\end{array}$ \\
\hline Coal Pile Trench & SWMU/UEFPC CA & $\begin{array}{l}\text { Located beneath the current steam plant coal pile. Disposals included solid } \\
\text { materials (primarily alloys). Trench leachate is a potential release mechanism to } \\
\text { groundwater. }\end{array}$ \\
\hline Interim Drum Yard & SWMU/Study Area & $\begin{array}{l}\text { Diked outdoor storage area once used to store drums of liquid and solid wastes. } \\
\text { Partially closed under RCRA in } 1988 .\end{array}$ \\
\hline Beta-4 Security Pits & SWMU/Study Area & $\begin{array}{l}\text { Used from } 1968 \text { to } 1972 \text { for disposal of classified materials, scrap metals, and } \\
\text { liquid wastes. Site is closed and capped. Primary release mechanism to ground- } \\
\text { water is infiltration. }\end{array}$ \\
\hline Rust Garage Area & UST/Study Area & $\begin{array}{l}\text { Former vehicle and equipment maintenance area, including four former } \\
\text { petroleum USTs. Petroleum product releases to groundwater are documented. }\end{array}$ \\
\hline Garage Underground Tanks & SWMU/Study Area & $\begin{array}{l}\text { Fuel USTs used from } 1944 \text { to } 1978 \text {. Converted to waste oil storage in 1978; } \\
\text { removed in } 1989 \text {. Petroleum and waste oil leaks represent probable releases to } \\
\text { groundwater. The unit was clean-closed under RCRA in } 1995 \text {. }\end{array}$ \\
\hline
\end{tabular}

\footnotetext{
${ }^{a}$ Regulatory status before the 1992 Federal Facility Agreement: TSD-RCRA-regulated, land-based treatment, storage, or disposal unit; SWMU-RCRAregulated solid waste management unit; and UST-petroleum underground storage tank. Current regulatory status: study area-Y-12 Plant study area; UEFPC OU2-Upper East Fork Poplar Creek Operable Unit 2; UEFPC CA-Upper East Fork Poplar Creek Characterization Area.
}

status of waste management sites in the East Fork Regime is summarized on Fig. 7.4. Brief descriptions of the waste management sites are presented in Table 7.2. Detailed operational histories of these sites have been published in previous ORR annual site environmental reports.

The East Fork Regime contains the UEFPC CA, which consists of source units, surface water, and groundwater components of the hydrogeologic system within the East Fork regime and Union Valley to the east of the Y-12 Plant. Numerous sources of contamination to both surface water and groundwater exist within the plant area. Chemical constituents from the S-3 Site dominate groundwater contamination in the western portion of the UEFPC CA. In addition to potential surface water and groundwater contamination sources identified 
as OUs, most of the potentially contaminated units making up the Y-12 study areas are within the East Fork regime. Potential surface-water contamination associated with the storm sewer system and East Fork mercury use areas is of primary interest and will also be addressed in the UEFPC CA RI/FS.

\section{Discussion of Monitoring Results}

The objectives of the 1995 groundwater monitoring program in the East Fork regime were (1) to further define contaminant plume boundaries and (2) to evaluate potential contaminant exit pathways by using the existing monitoring well network in the Maynardville Limestone. Locations of monitoring stations are shown in Fig. 7.7.

\section{Plume Delineation}

The primary groundwater contaminants in the East Fork regime are nitrate, VOCs, trace metals, and radionuclides. Sources of nitrate, trace metals, and radionuclides are the S-2 Site, the Abandoned Nitric Acid Pipeline, and the S-3 Site. Although it is located west of the hydrologic divide that separates the East Fork regime from the Bear Creek regime, the S-3 Site has contributed to groundwater contamination in the western part of the regime. A mound in the water table created by disposal of large volumes of liquid wastes during operation of the S-3 Site (formerly the S-3 Ponds) allowed contaminants to move into areas east of the current hydrologic divide. Sources of VOCs in the East Fork regime include the S-3 Site, several sites located within the Y-12 Salvage Yard, the Waste Coolant Processing Area, petroleum USTs, and process/production buildings in the plant.

\section{Nitrate}

Nitrate concentrations exceeded the $10 \mathrm{mg} / \mathrm{L}$ maximum contamination level during 1994 in a large part of the western portion of the East Fork regime (Fig. 7.8). (A complete list of DWSs is presented in Appendix D.) Groundwater containing nitrate concentrations as high as $10,000 \mathrm{mg} / \mathrm{L}$ occurs in the unconsolidated zone and at shallow bedrock depths just east of the
S-3 Site. In 1994, the highest observed annual average nitrate value was in well GW-251, about $2000 \mathrm{ft}(610 \mathrm{~m})$ southeast of the S-3 Site (Fig. 7.8).

The extent of the nitrate plume is essentially defined in the unconsolidated zone and the shallow bedrock zone. In both zones, the nitrate plume extends about $2500 \mathrm{ft}(762.5 \mathrm{~m})$ eastward from the S-3 Site to just downgradient of the S-2 Site. Nitrate has traveled farthest in groundwater in the Maynardville Limestone.

\section{Trace Metals}

Concentrations of barium, cadmium, chromium, and lead exceeded maximum contamination levels during 1994 in samples collected from monitoring wells at the S-2 Site, the Y-12 Salvage Yard, the Waste Coolant Processing Area, the 9754 and 9754-2 Fuel facilities, Rust Garage, two exit-pathway wells, and New Hope Pond. Elevated concentrations of these metals were most commonly reported for groundwater samples collected from wells monitoring the unconsolidated zone. Groundwater at shallow bedrock depths contained elevated metals concentrations near the Y-12 Salvage Yard, the S-2 Site, and at New Hope Pond. A definable plume of elevated metals contaminants is not present; metals above maximum contaminant levels tend to occur adjacent to the source units. A rigorous statistical evaluation was conducted as part of the RCRA postclosure permit application for the East Fork regime to determine whether New Hope Pond was a source of metals contamination. The analysis showed that New Hope Pond was not a statistically discernable source of metals, gross alpha activity, or gross beta activity.

\section{Volatile Organic Compounds}

Because of the many source areas, VOCs are the most widespread groundwater contaminants in the East Fork regime. Dissolved VOCs in the regime generally consist of two types of compounds: chlorinated solvents and petroleum hydrocarbons. The highest concentrations of dissolved chlorinated solvents (about $12 \mathrm{mg} / \mathrm{L}$ ) are found at the Waste Coolant Processing Area 


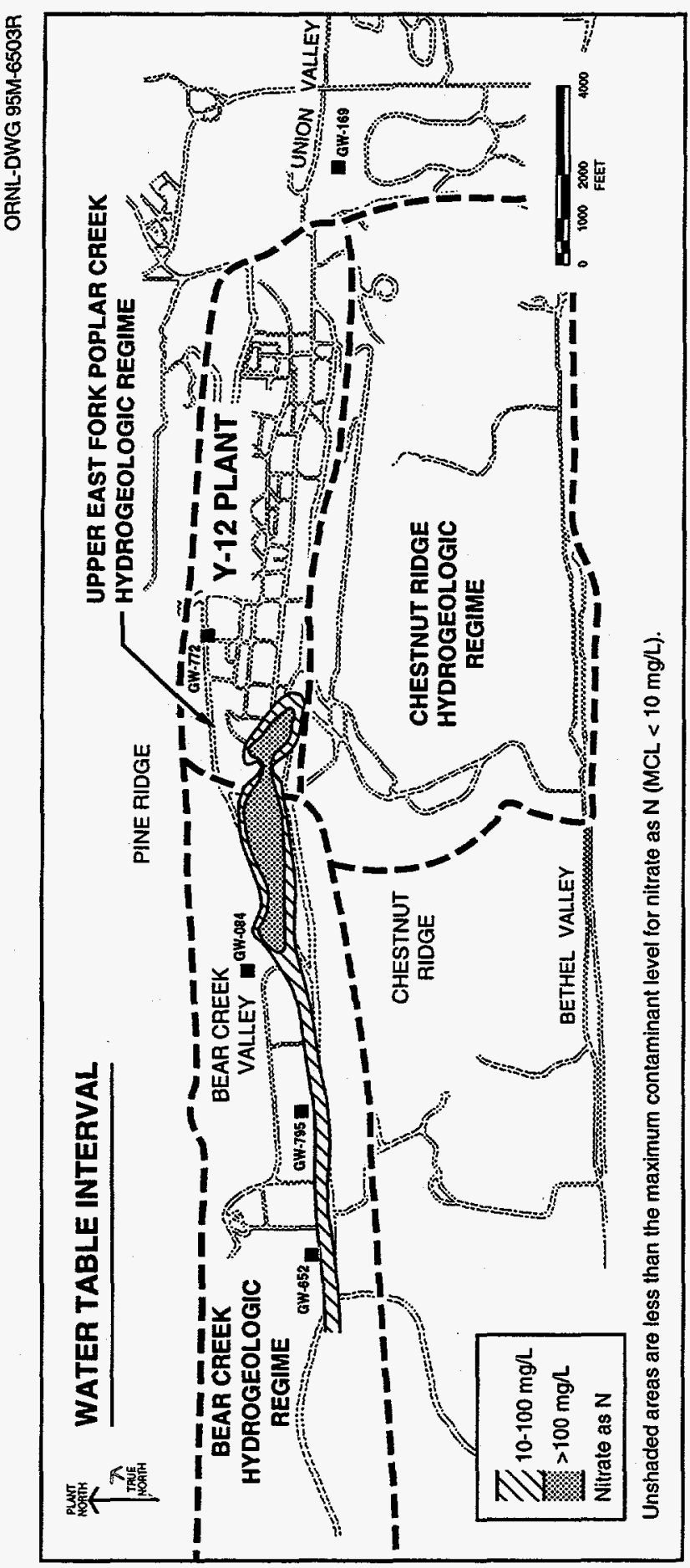

and Y-12 Salvage Yard. The highest dissolved concentrations of petroleum hydrocarbons (about $60 \mathrm{mg} / \mathrm{L}$ ) occur in groundwater near the Rust Garage Area.

Concentrations of VOCs in most of the East Fork regime have remained relatively

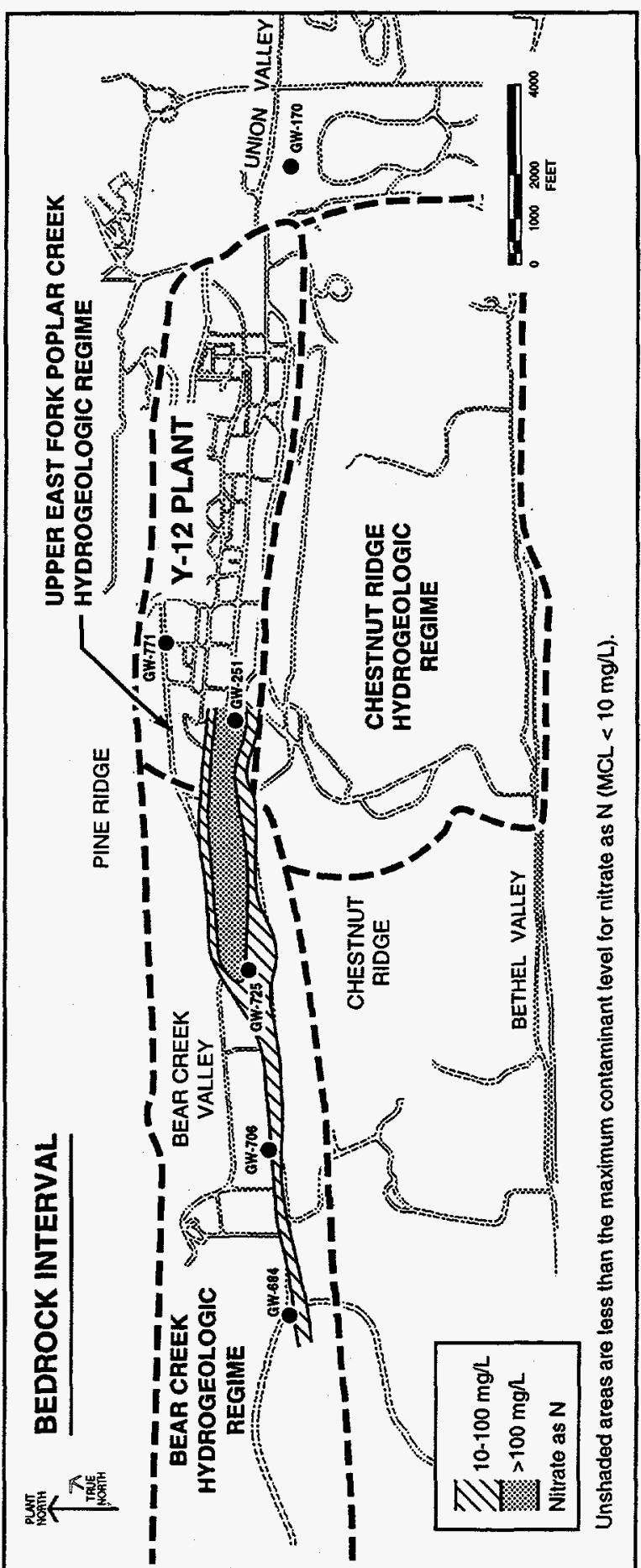

constant since 1988 (Fig. 7.9). Some monitoring locations (e.g., GW-220 and GW-733) on the eastern end of the regime, east of New Hope Pond, have shown increasing VOC concentrations, indicative of an easterly movement of part of the plume (Fig. 7.10). 

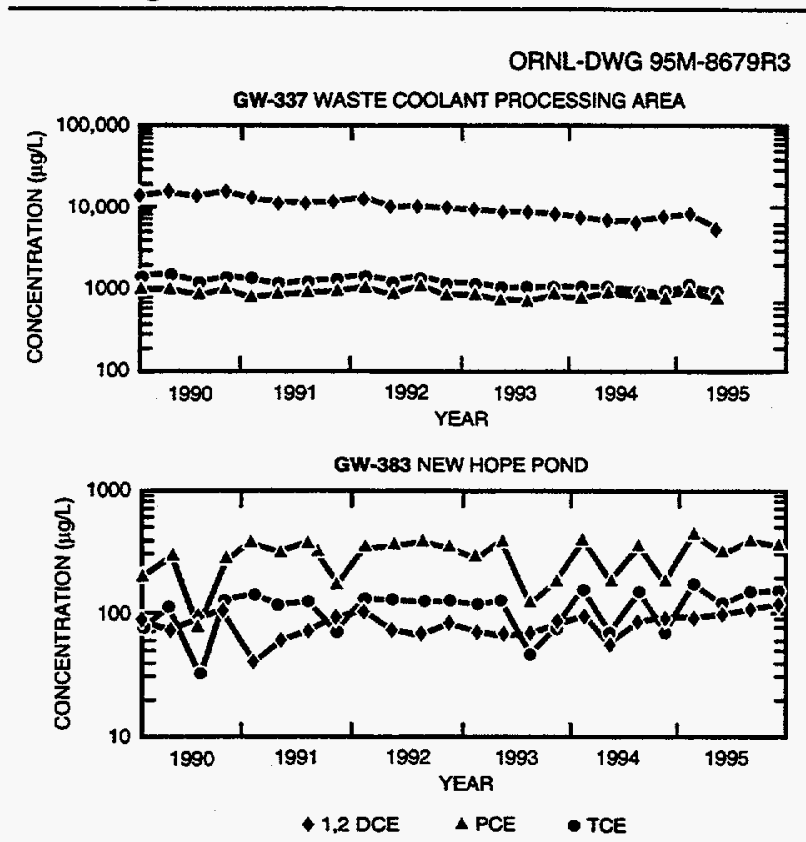

Fig. 7.9. Quarterly volatile organic compound concentrations in groundwater in selected wells in the East Fork regime.
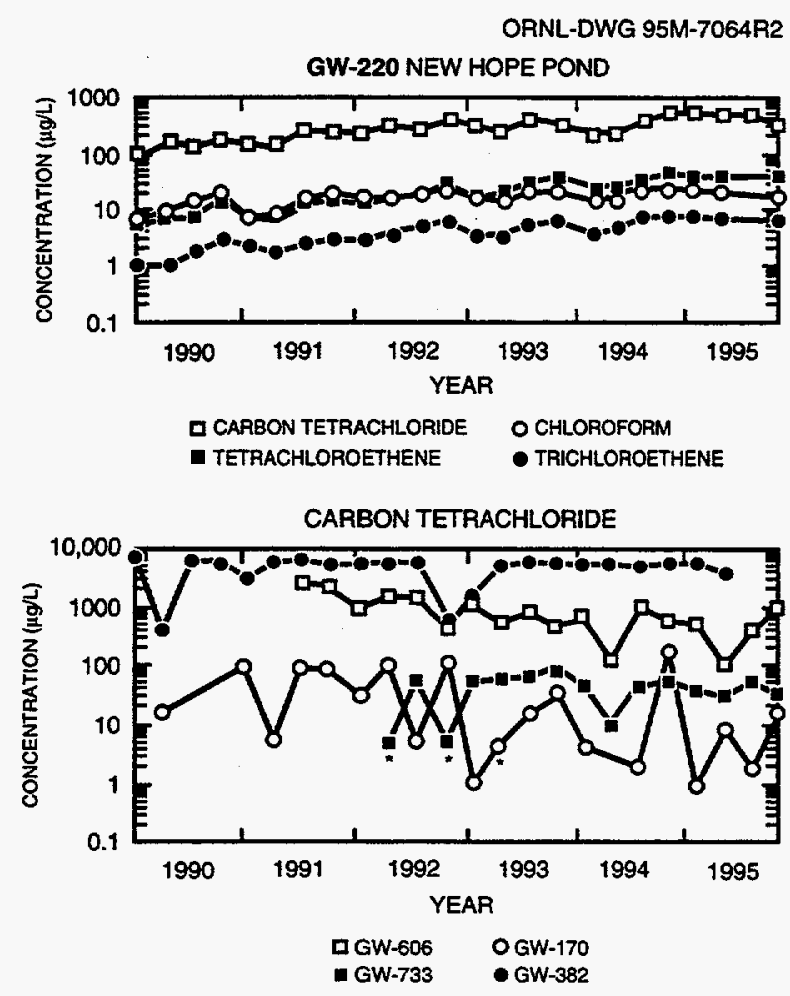

- REPORTING LIMIT IS $5 \mu \mathrm{g} / \mathrm{L}$

Fig. 7.10. Quarterly volatile organic compound concentrations in selected wells near New Hope Pond and exit-pathway wells.
Data show that VOCs are the most extensive laterally in the shallow groundwater; however, data indicate that once contaminants migrate into the Maynardville Limestone, they tend to concentrate at depths between 100 and $500 \mathrm{ft}$. The highest VOC concentrations appear to be between 200 and $500 \mathrm{ft}$, as exemplified by vertical carbon tetrachloride distribution at the east end of the Y-12 Plant (Fig. 7.11).

The 1995 monitoring results generally confirm findings from the previous 4 years of monitoring. A continuous dissolved VOC plume in groundwater in the bedrock zone extends eastward from the S-3 Site over the entire length of the regime (Fig. 7.12). Additionally, the 1995 data confirm previous results identifying the Waste Coolant Processing Facility area as a VOCs source area. Pockets of VOCs also are present in groundwater at the Building 9754 and 9754-2 fuel facilities and upgradient of New Hope Pond. Data from the East Fork regime surveillance monitoring network show that a major source area also lies within process areas in the central portion of the plant.

Chloroethene compounds (perchloroethene, trichloroethene, dichloroethene, and vinyl chloride) tend to dominate the VOC plume composition in the western and central portions of the Y-12 Plant. However, perchloroethene and isomers of dichloroethene are almost ubiquitous throughout the extent of the VOC plume, indicating many source areas. Chloromethane compounds (carbon tetrachloride, chloroform, and methylene chloride) are the predominant VOCs in the eastern and southeastern portions of the plant.

\section{Radionuclides}

As in the Bear Creek regime, the primary alpha-emitting radionuclides found in the East Fork regime are isotopes of uranium, radium, neptunium, and americium. The primary beta-emitting radionuclide is technetium.

Groundwater with gross alpha activity greater than $15 \mathrm{pCi} / \mathrm{L}$ occurs in scattered areas throughout the East Fork regime (Fig. 7.13). Historical data collected about 5 years ago show that gross alpha activity exceeding the MCL for drinking water (annual average activity level of $15 \mathrm{pCi} / \mathrm{L}$ ) is most extensive in groundwater in 

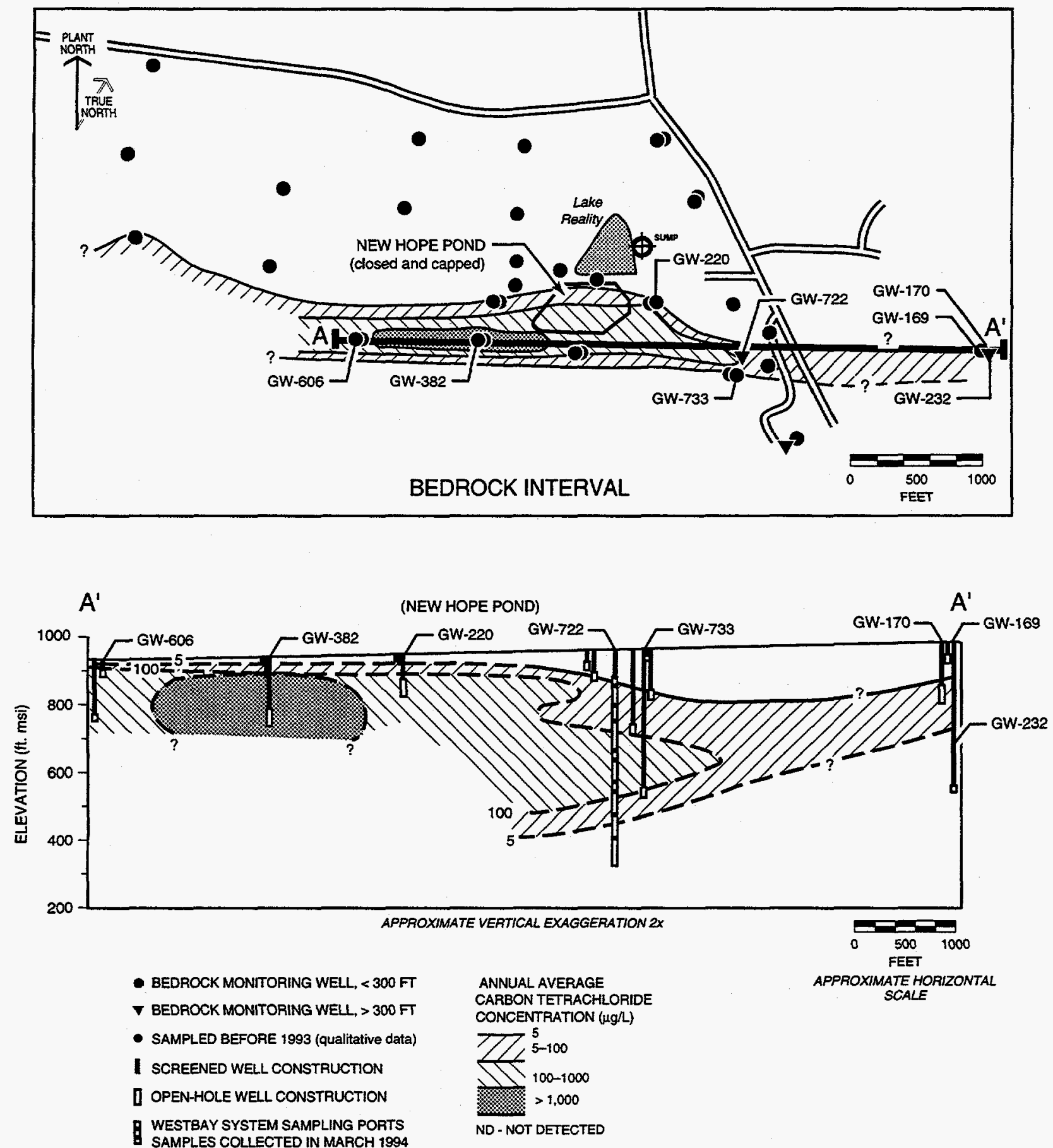

Fig. 7.11. VOC concentrations in Maynardville Limestone, at depths between 200 and $500 \mathrm{ft}$.

the unconsolidated zone in the western portion of the Y-12 Plant. Surveillance data collected from several wells in the western portion of the Y-12 Plant during 1995 show that gross alpha (and gross beta) activity levels remained elevated well above the MCL (wells GW-108, GW-109, GW-274, GW-275, and GW-782). Previous monitoring results have also suggested an area of elevated gross alpha activity west of New Hope Pond. Monitoring results during 


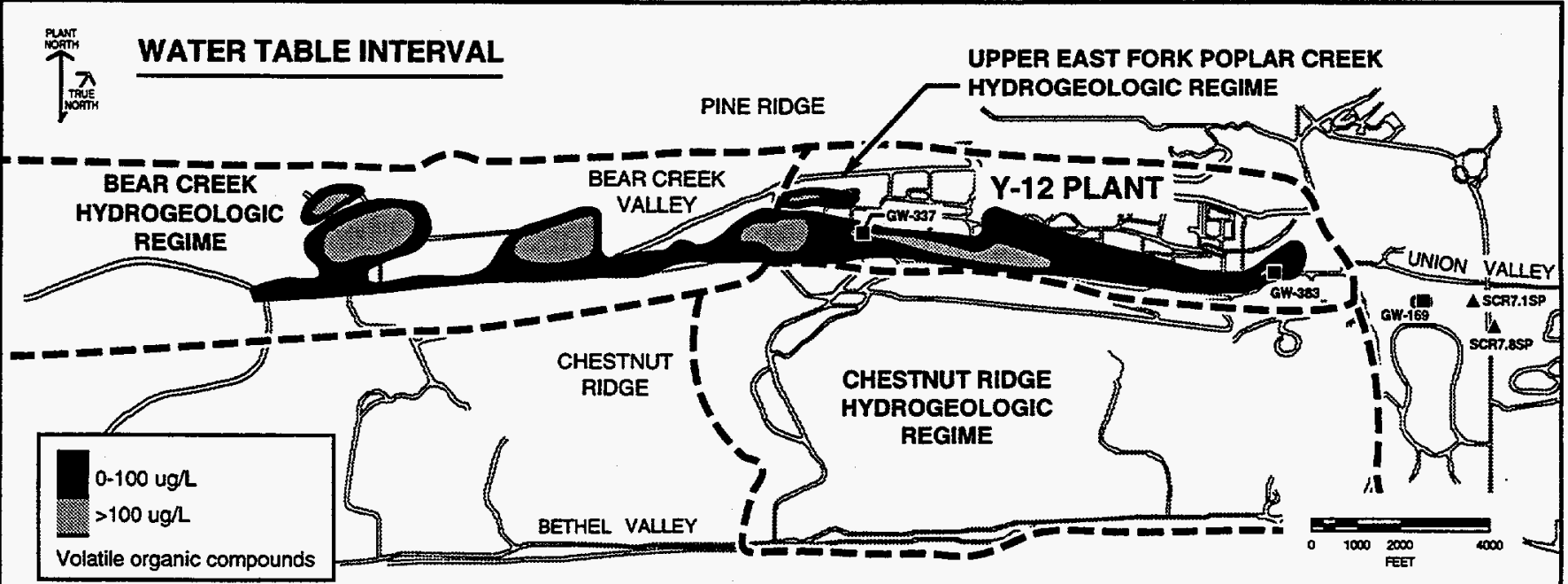

Unshaded areas indicate no detected volatile organic compounds.

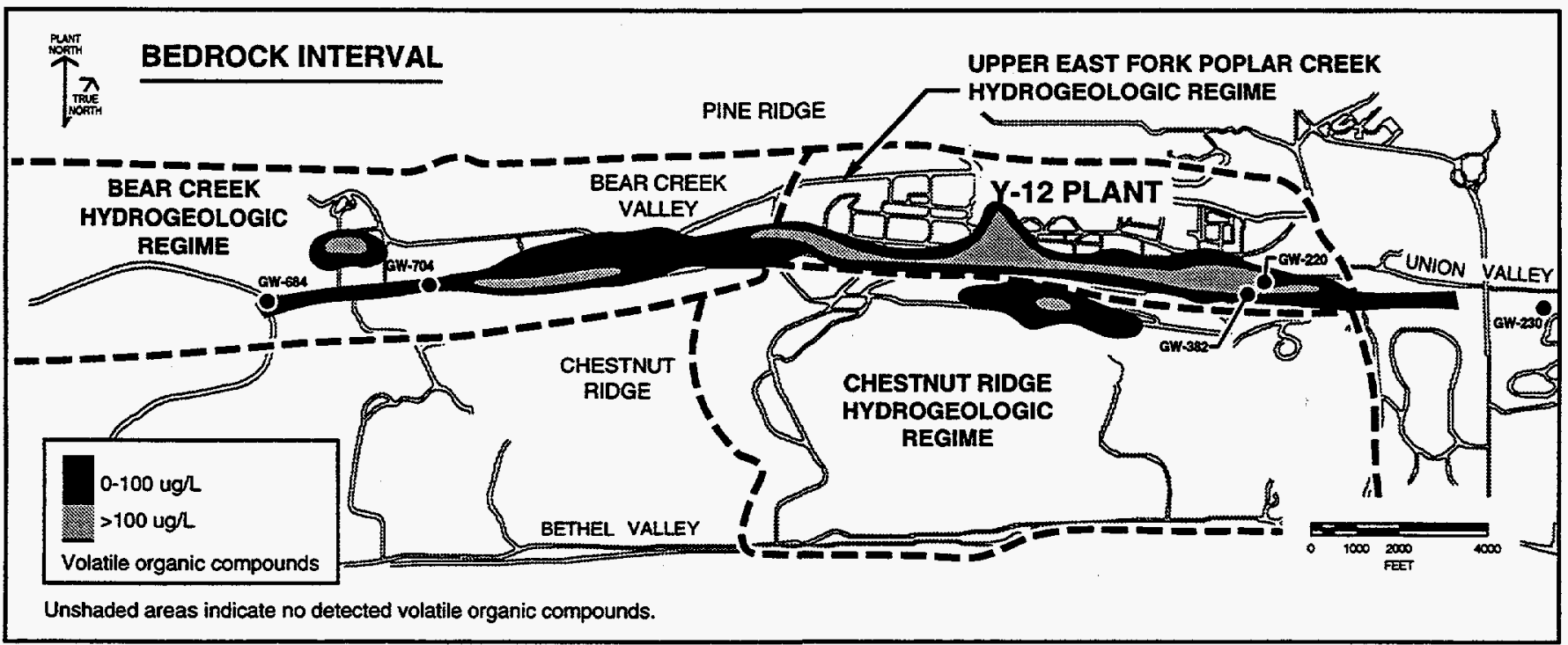

Fig. 7.12. Summed volatile organic compounds in groundwater at the Y-12 Plant.

1995 confirmed that gross alpha activity remains elevated above MCLs in the southeastern portions of the Y-12 Plant (wells GW-154, GW-222, and GW-605). Sporadic gross alpha activity was also observed in several shallow wells scattered across the East Fork regime, notably in exit pathway well GW-169 in Union Valley (Fig. 7.13). Erratic data distribution, coupled with high turbidity and total suspended solids content in samples from most of the wells, indicates that these sporadic values are false positives.
Elevated gross beta activity in groundwater in the East Fork regime shows a pattern similar to that observed for gross alpha activity (Fig. 7.14). In general, gross beta activity consistently exceeds the annual average $\mathrm{MCL}$ of $50 \mathrm{pCi} / \mathrm{L}$ in groundwater in the western portion of the regime, with the primary source being the S-3 Site. Monitoring data collected in 1995 showed annual average gross beta activity greater than the MCL near the Salvage Yard and Rust Garage (wells GW-108, GW-109, GW-274, and GW-275). Also, consistent with historical 

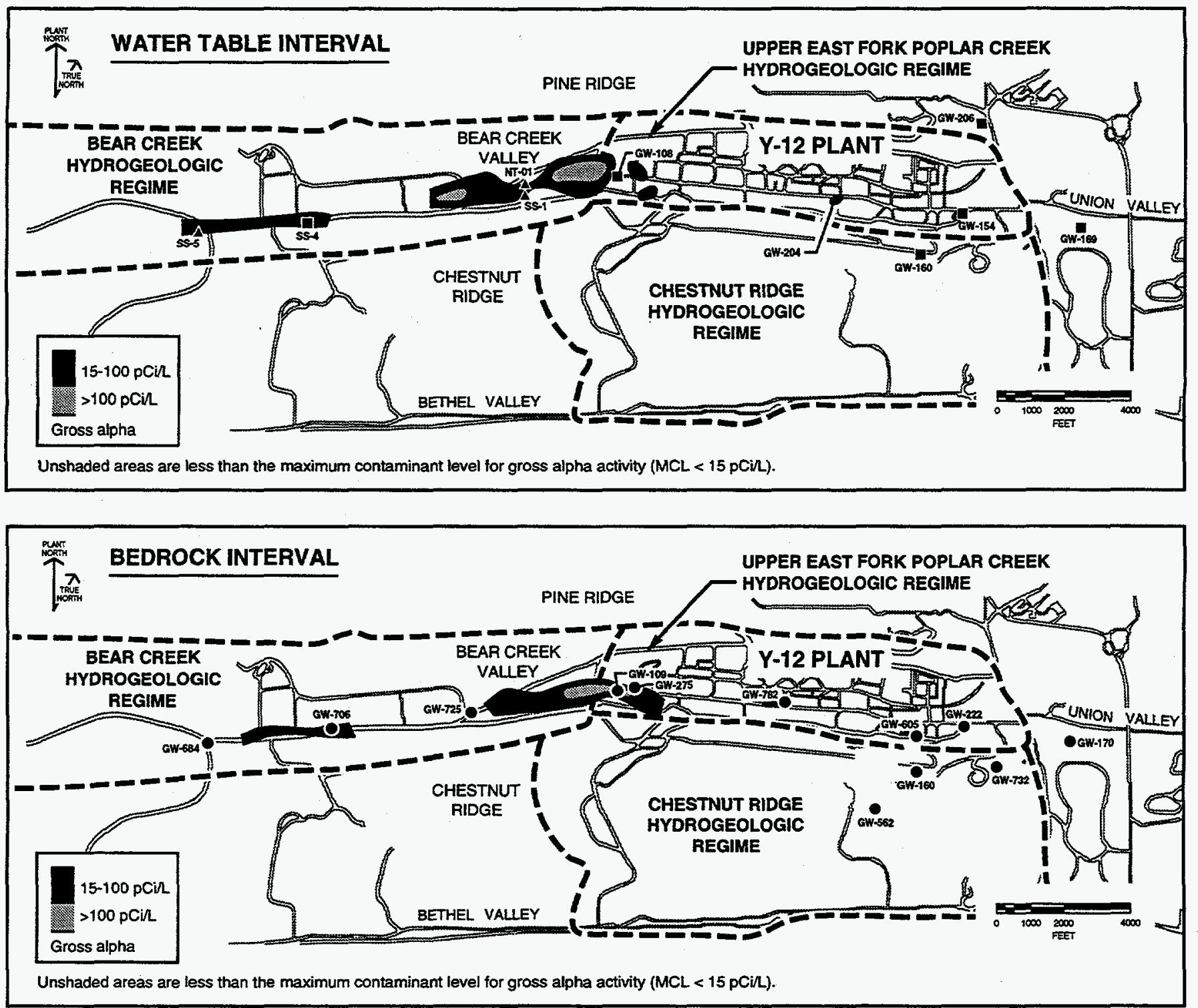

Fig. 7.13. Gross alpha activity in groundwater at the Y-12 Plant.

patterns, elevated gross beta was observed in an area immediately west of New Hope Pond within the Maynardville Limestone. Elevated sporadic gross beta activity observed in 1994 in off-site exit-pathway wells GW-169 and GW-170, located in Union Valley, was not observed during 1995.

\section{Exit-Pathway and Perimeter Monitoring}

Exit-pathway groundwater monitoring activities in the East Fork regime in 1995 involved ongoing monitoring and trending of data from exit-pathway wells installed in 1992.
The 1992 ORR environmental report contained a detailed discussion of the new exit-pathway monitoring network. Surface water quality in UEFPC is regularly monitored in accordance with NPDES permits, and the results are summarized in Sect. 4.

Chemical water quality data from exit-pathway wells monitored in 1993 provided the first strong indication that VOCs are being transported off the ORR through the Maynardville Limestone at depths of approximately 100 to $300 \mathrm{ft}$ ( 30.5 


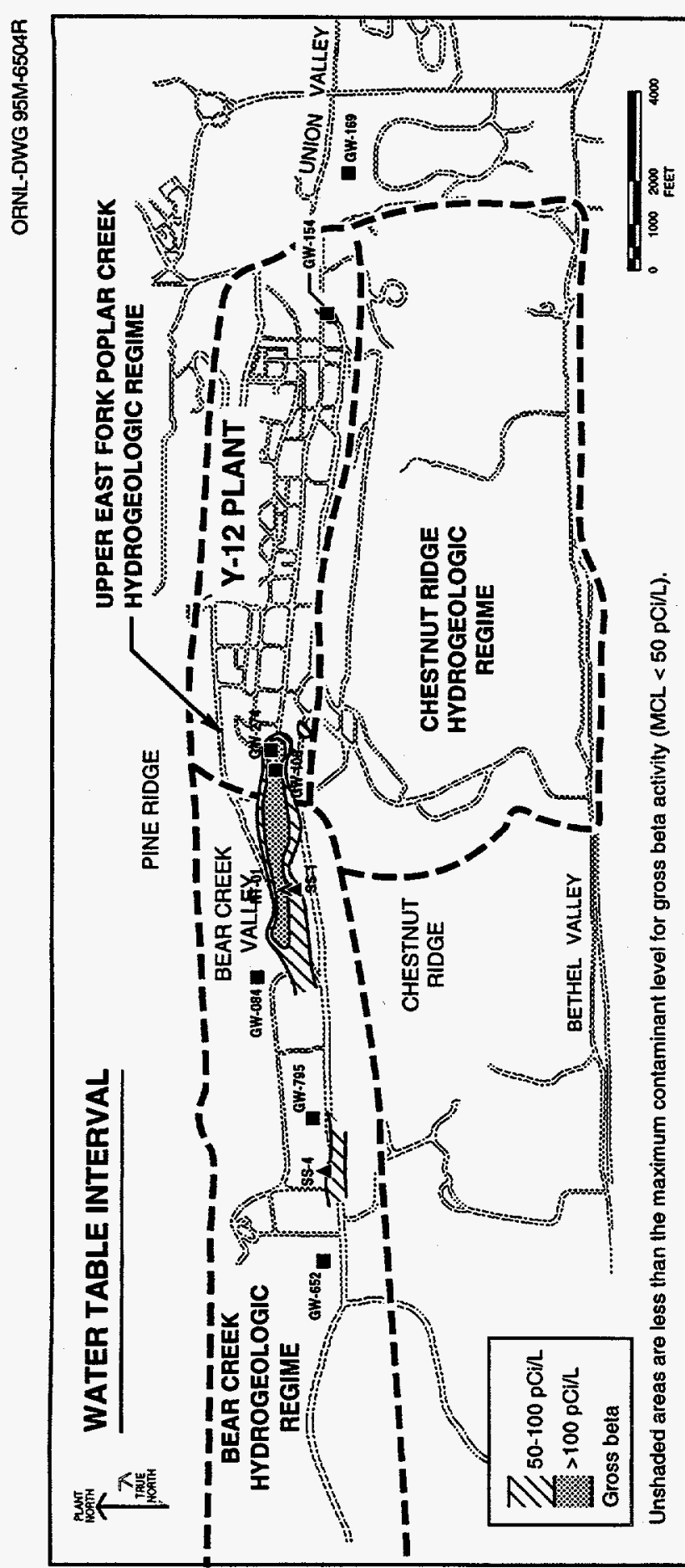

to $91.5 \mathrm{~m}$ ). Sporadic occurrences of common chlorinated solvents, carbon tetrachloride and tetrachloroethene, above DWSs were confirmed at a depth of $160 \mathrm{ft}(49 \mathrm{~m})$ in both on-site and off-site wells (wells GW-170 and GW-733, Figs. 7.11 and 7.12). Well GW-170 is located

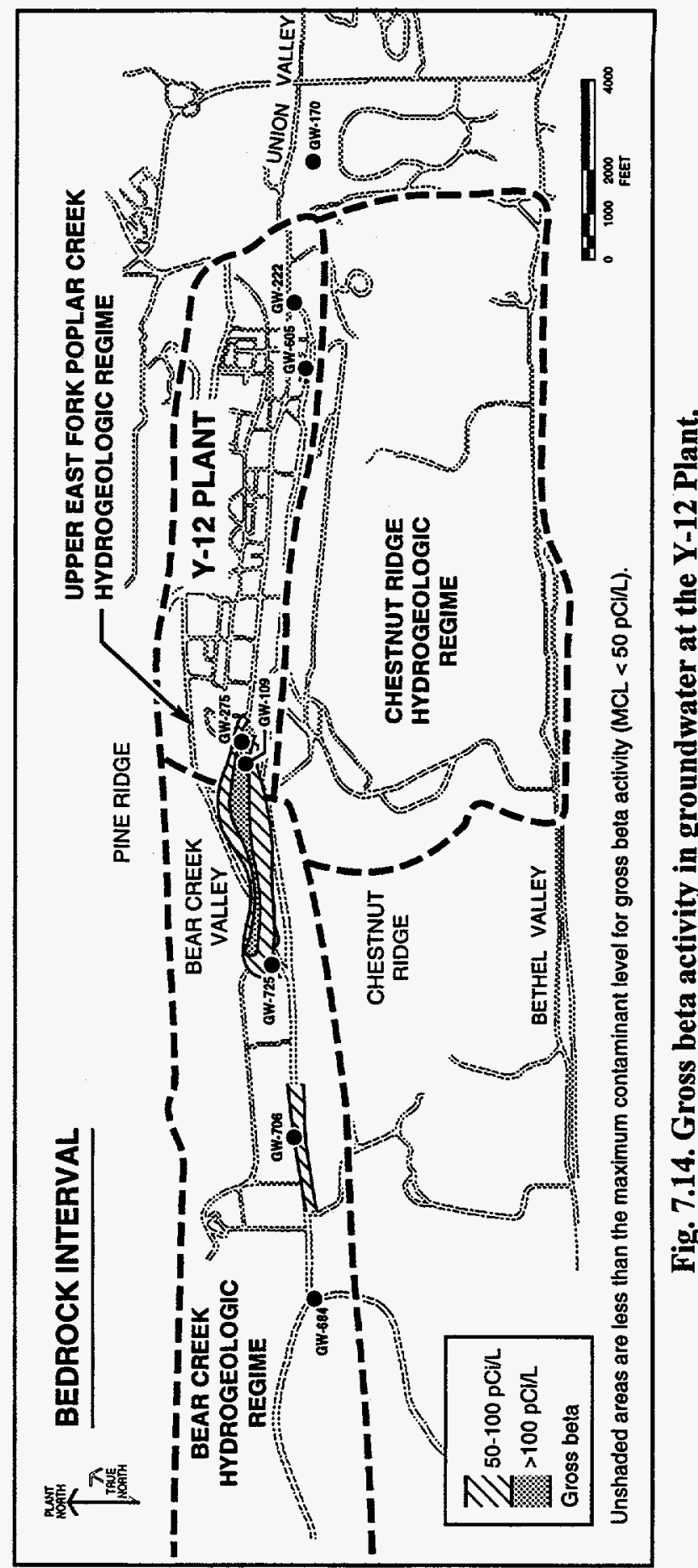

approximately $1500 \mathrm{ft}(458 \mathrm{~m})$ east of the eastern ORR boundary. This off-site well also contained chloroform and trichloroethene, although below the MCLs for these two compounds. Two additional wells at the same location as Well GW-170 have also been sampled quarterly 
since 1990. Well GW-169 is approximately $40 \mathrm{ft}(12.2 \mathrm{~m})$ deep. Only trace levels of VOCs continue to be observed in this well; one sample for trichloroethene was slightly above the MCL in 1991. Carbon tetrachloride and chloroform have not been present above detection levels in this shallow well. Well GW-232 is approximately $400 \mathrm{ft}(122 \mathrm{~m})$ deep. No VOCs have been detected in this well. Carbon tetrachloride has also been detected at low levels in spring station SCR 7.1SP, located east of Well GW-170. Several VOCs were also observed at low levels in a spring located along South Illinois Avenue (SCR 7.8SP). Low levels of 1,2-dichloroethene have also been detected at Well GW-230, located east of South Illinois Avenue, which may or may not be connected to Y-12 Plant operations.

The concentration trend for carbon tetrachloride, the primary contaminant of concern, in both wells GW-170 and GW-733 is illustrated in Fig. 7.10. An areal distribution of VOCs is shown in Fig. 7.12. The data to date indicate that VOC transport is occurring at depth within the Maynardville Limestone and is restricted to that formation. A vertical profile of VOC contamination was obtained from a multiport monitoring well (GW-722), near the eastern boundary of the ORR (Fig. 7.6). The data show that the highest VOC concentrations occurred at depths between 200 and $500 \mathrm{ft}$ (61 and $152.5 \mathrm{~m}$ ) below ground surface (Fig. 7.11). VOC concentrations are highest at these depths because most dilution and mixing with rainwater occurs in the shallow portions of the Maynardville Limestone. VOCs have not been observed in exit-pathway wells drilled to a variety of depths in the ORR aquitards north of Well GW-733. Conversely, VOCs have not been observed at concentrations exceeding MCLs in several wells located south of Well GW-733 in the Knox Aquifer.

VOC data were obtained for the first time in 1994 from two sampling points near Lake Reality: a dewatering sump (LRS, Fig. 7.7) located just east of the site and groundwater seeps north of the site within the emergency overflow spillway (LRSPW, Fig. 7.7). These samples contained VOCs (in particular carbon tetrachloride), indicating that groundwater may be moving preferentially through permeable fill zones beneath a concrete-lined diversion channel for UEFPC. The sump was originally installed in 1990 to prevent the bottom liner for Lake Reality from floating as a result of upward hydrostatic pressure. The sump was intermittently active during 1992 and 1993, and was deactivated in mid-1994 because of concerns that it was inducing shallow groundwater flow to the north. The sump had to be reactivated in CY 1995. Monitoring of the groundwater seepage in the overflow spillway continued in 1995 to determine whether any trends in VOC levels resulted from deactivation of the sump. Results indicate that VOC levels did increase during periods of sump operation. In addition, VOC levels in well GW-220 (Fig. 7.12) located south of the sump have increased over time and the sump is documented as having a significant [approximate radius of $1000 \mathrm{ft}(305 \mathrm{~m})$ ] zone of influence on groundwater table levels. Therefore, sump operation has been kept to minimal levels with monitoring of discharge when operation is required.

\section{Union Valley Focus Study}

Upon confirmation by the exit-pathway and perimeter monitoring programs that VOCs were migrating off of the ORR, the Y-12 Plant ER Program was assigned as the lead organization for future actions using CERCLA criteria. Immediate notifications were made to appropriate local, state, and EPA agencies through the DOE occurrence reporting process. A public meeting was held in March 1994 to present the data obtained to date, address any concerns by stakeholders, and describe both short-term and long-term actions that would be taken to investigate the problem, determine if any risk to public health and the environment existed, and develop interim corrective measures, if required.

An interim study, described in the 1994 ASER, was completed in the fall of 1994. Monitoring of wells and selected springs and surface water stations continued during 1995. Based on the results of the interim study, immediate actions to remediate or intercept groundwater were deemed unwarranted. An 
interim proposed plan defining administrative controls and public notification has been drafted and submitted to regulatory agencies for review and comment. Additional investigations and any long-term remedial actions in this area will be addressed in conjunction with DOE, TDEC, EPA, and the public as the RI/FS for the UEFPC CA progresses.

\section{Bear Creek Hydrogeologic Regime}

Located west of the Y-12 Plant in BCV, the Bear Creek regime is bounded to the north by Pine Ridge and to the south by Chestnut Ridge. The regime encompasses the portion of $\mathrm{BCV}$ extending from the west end of the Y-12 Plant to Highway 95 . Figures 7.15 and 7.16 show the Bear Creek regime, locations of stations sampled in 1995, and the locations of its waste management sites. The BCV CA lies within the regime and includes all source units, groundwater, surface water, and soils/sediments, with the exception of the SY-200 Yard and Spoil Area I, which are separate actions (Fig. 7.4; Table 7.3).

A major milestone in the environmental remediation process occurred for the Bear Creek regime in 1995. With completion of the CERCLA RI for the BCV CA and completion of RCRA postclosure permits as discussed below, characterization of the nature and extent of contamination in the regime is essentially complete. TDEC and EPA have concurred that sufficient data exist in general to proceed with the next step in the process: risk assessment, evaluation, and selection of remedial alternatives and/or administrative controls.

All baseline RI field activities under the scope of the BCV CA were completed in August 1995. The RI-generated results and conclusions have been integrated into a draft RI report, which is in the process of being finalized. As the next step in the CERCLA process, remedial actions under the scope of a feasibility study will be initiated where sufficient data exist to conduct risk assessments and evaluate alternatives. Where data gaps exist preventing full evaluation of remedial alternatives, focused studies with limited scopes and short durations will be completed to obtain the specific, required data.

Under RCRA, all interim-status assessment monitoring was discontinued by September 1995 upon issuance of the final modifications to the postclosure permit for the Bear Creek regime. The focus of monitoring efforts changed to postclosure corrective action monitoring, exit pathway monitoring, and surveillance of contaminant plume boundaries. These objectives were met by formulating a composite monitoring of 65 wells, 9 springs, and 6 surface water locations specified by the RCRA postclosure permit, the ORR EMP, and primary exit-pathway and surveillance-monitoring points. This composite of locations represents a stable, long-term corrective action/surveillance monitoring network for the regime. The network will be sampled at a baseline semiannual frequency. Any monitoring requirements dictated by CERCLA RODs issued for the BCV CA will be integrated into the long-term corrective action/surveillance-monitoring network for the regime.

\section{Discussion of Monitoring Results}

Groundwater-monitoring efforts in the Bear Creek regime during 1995 were (1) to maintain surveillance of contaminant plumes (both extent and concentration of contaminants); (2) to conduct trending at potential contaminant exit pathways in the Maynardville Limestone using existing monitoring locations; and (3) to conduct corrective action monitoring at point-of-compliance sites, exit pathways, and background wells in accordance with the Bear Creek regime RCRA postclosure permit.

\section{Plume Delineation}

The primary groundwater contaminants in the Bear Creek regime are nitrate, trace metals, VOCs, and radionuclides. The S-3 Site is the primary source of nitrate, radionuclides, and trace metals. Sources of VOCs include the S-3 Site, the Rust Spoil Area, Oil Landfarm waste management area, and the Bear Creek Burial Grounds waste management area; the latter two sites are the principal sources. 


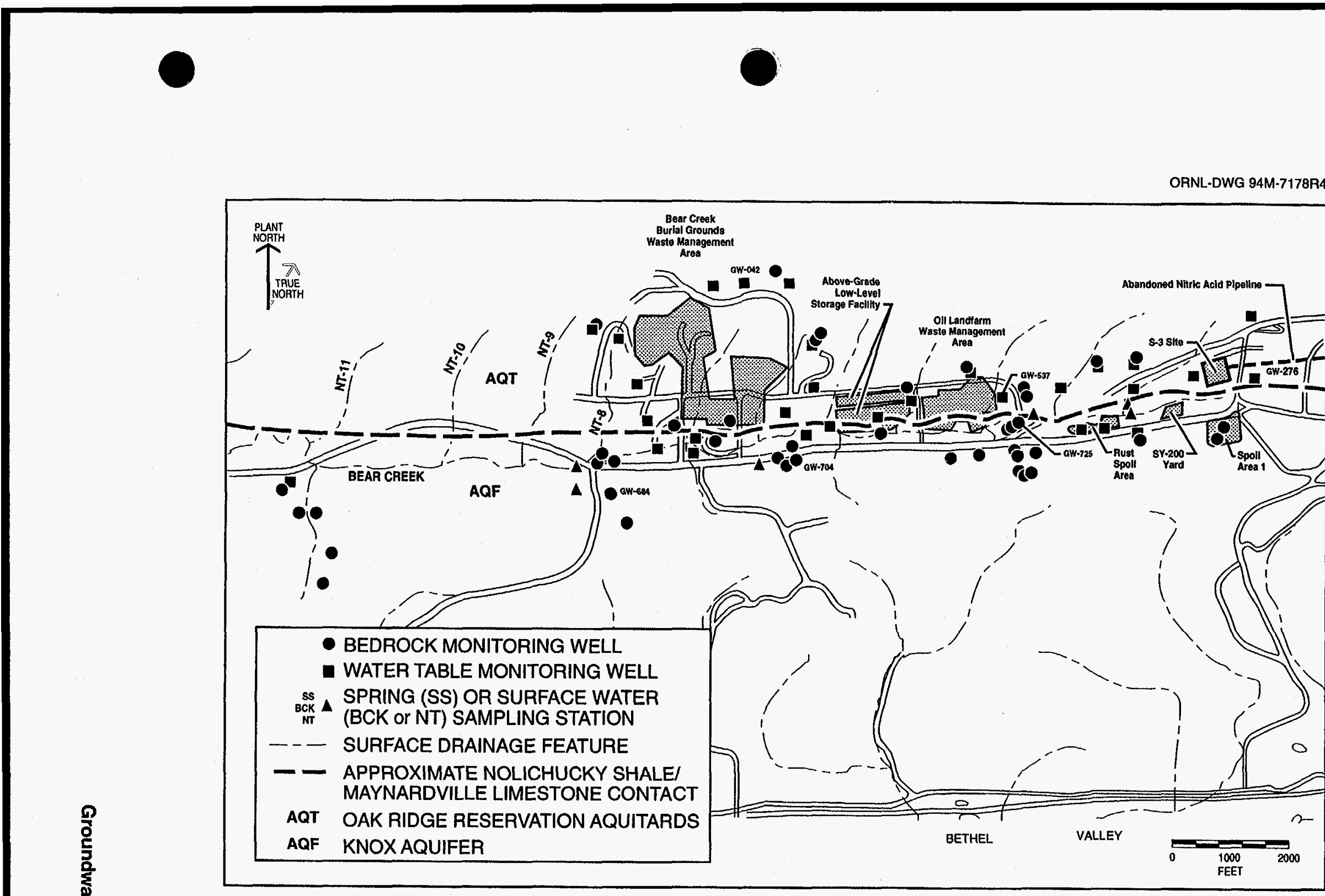

Fig. 7.15. Locations of waste management sites and monitoring wells sampled during 1995 in the Bear Creek Hydrogeolic Regime.

今̦ 


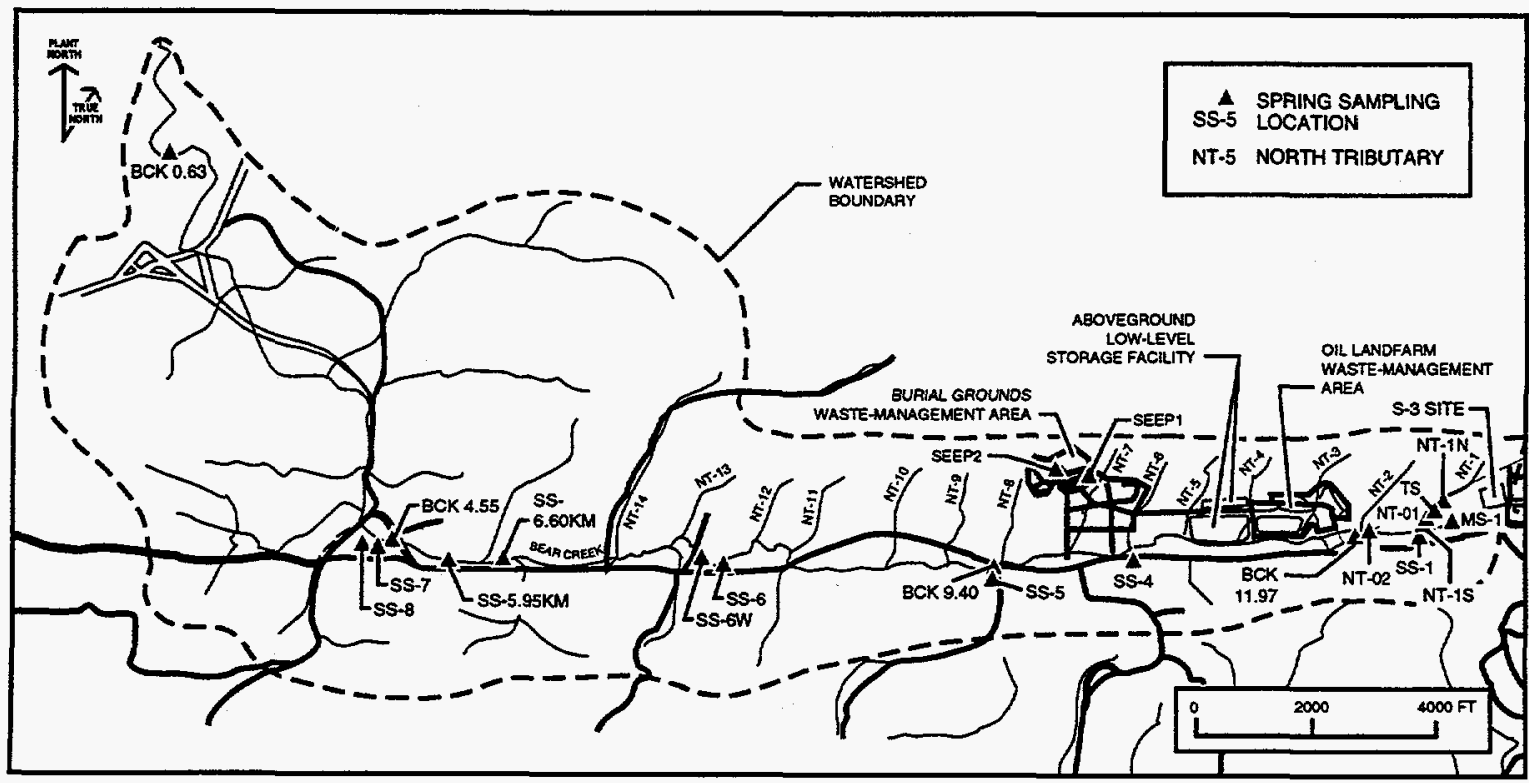

Fig. 7.16. Surface water and spring stations sampled during 1995 in the Bear Creek Hydrogeologic Regime.

Dense nonaqueous phase liquids (DNAPLs)

exist at a depth of $270 \mathrm{ft}$ below the Bear Creek Burial Grounds. The DNAPLs consist primarily of tetrachloroethene, trichloroethene, 1,1-dichloroethene, 1,2-dichloroethene, and high concentrations of PCBs.

Contaminant plume boundaries are essentially defined in the bedrock formations that directly underlie many waste disposal areas in the Bear Creek regime, particularly the Nolichucky Shale. The elongated shape of the contaminant plumes in the Bear Creek regime is the result of preferential transport of the contaminants parallel to strike in both the Knox Aquifer and the ORR aquitards. A review of historical data suggests that, in general, contaminant concentrations in the Bear Creek regime, within the ORR aquitards, have remained relatively constant since 1986 . Certain contaminants at specific sites, however, have shown non-steady-state concentration patterns, as detailed in the 1992 ORR environmental report (Energy Systems 1993b). The same trends have been observed in exit-pathway wells located in the Bear Creek regime (Fig. 7.17), with slight increases or decreases observed for selected contaminants.

\section{Nitrate}

Unlike most of the other groundwater contaminants, nitrate moves easily with the groundwater. The limits of the nitrate plume probably define the maximum extent of subsurface contamination in the Bear Creek regime.

Data obtained during 1995 indicate that nitrate concentrations exceed the $10 \mathrm{mg} / \mathrm{L}$ $M C L$ in an area that extends west from the S-3 Site for several thousand feet down BCV (Fig. 7.8). Nitrate concentrations greater than $100 \mathrm{mg} / \mathrm{L}$ extend about $3000 \mathrm{ft}(915 \mathrm{~m})$ west of the S-3 Site. During 1995, the highest nitrate concentrations continued to be seen adjacent to the S-3 Site in groundwater in the unconsolidated zone and at shallow depths [less than $100 \mathrm{ft}$ $(30.5 \mathrm{~m}$ ) below the ground surface] in the Nolichucky Shale.

The horizontal extent of the nitrate plume is essentially defined in groundwater in the upper part of the aquifer [less than $200 \mathrm{ft}(61 \mathrm{~m})$ below the ground surface]. Data obtained from exit-pathway monitoring wells installed during 1991 and 1992 suggest that the nitrate plume in groundwater within bedrock in the Maynardville Limestone extends about $12,000 \mathrm{ft}(3,660 \mathrm{~m})$ 
Table 7.3. Regulatory status and operational history of waste management units included in the 1995 Comprehensive Groundwater Monitoring Program; Bear Creek Hydrogeologic Regime

\begin{tabular}{|c|c|c|}
\hline Site & $\begin{array}{l}\text { Historical/current } \\
\text { regulatory } \\
\text { classification }^{a}\end{array}$ & Historical data \\
\hline S-3 Site & TSD/TSD-BCV CA & $\begin{array}{l}\text { Four unlined surface impoundments constructed in 1951. Received liquid } \\
\text { nitric acid/uranium-bearing wastes via the Nitric Acid Pipeline until } 1984 \text {. } \\
\text { Closed and capped under RCRA in 1988. Infiltration was the primary release } \\
\text { mechanism to groundwater. }\end{array}$ \\
\hline Oil Landfarm & TSD/TSD-BCV CA & $\begin{array}{l}\text { Operated from } 1973 \text { to } 1982 \text {. Received waste oils and coolants tainted with } \\
\text { metals and PCBs. Closed and capped under RCRA in } 1989 \text {. Infiltration was } \\
\text { the primary release mechanism to groundwater. }\end{array}$ \\
\hline Boneyard & SWMU/BCV CA & $\begin{array}{l}\text { Unlined shallow trenches used to dispose of construction debris and to bum } \\
\text { magnesium chips and wood. }\end{array}$ \\
\hline Burnyard & SWMU/BCV CA & $\begin{array}{l}\text { Used from } 1943 \text { to } 1968 \text {. Wastes, metal shavings, solvents, oils, and labora- } \\
\text { tory chemicals were burned in two unlined trenches. }\end{array}$ \\
\hline $\begin{array}{l}\text { Hazardous Chemical } \\
\text { Disposal Area }\end{array}$ & SWMU/BCV CA & $\begin{array}{l}\text { Built over the bumyard. Handled compressed gas cylinders and reactive } \\
\text { chemicals. Residues placed in a small, unlined pit. }\end{array}$ \\
\hline Sanitary Landfill I & SWMU/BCV CA & $\begin{array}{l}\text { Used from } 1968 \text { to } 1982 \text {. TDEC-permitted, nonhazardous industrial landfill. } \\
\text { May be a source of certain contaminants to groundwater. Closed and capped } \\
\text { under TDEC requirements in } 1983 \text {. }\end{array}$ \\
\hline $\begin{array}{l}\text { Bear Creek Burial } \\
\text { Grounds: A, C, and } \\
\text { Walk-in Pits }\end{array}$ & TSD/TSD-BCV CA & $\begin{array}{l}\text { A and } C \text { received waste oils, coolants, beryllium and uranium, various metallic } \\
\text { wastes, and asbestos into unlined trenches and standpipes. Walk-in Pits } \\
\text { received chemical wastes, shock-sensitive reagents, and uranium saw fines. } \\
\text { Activities ceased in 1981. Final closure certified for A (1989), C (1993), } \\
\text { and the Walk-in Pits (1995). Infiltration is the primary release mechanism to } \\
\text { groundwater. }\end{array}$ \\
\hline $\begin{array}{l}\text { Bear Creek Burial } \\
\text { Grounds: B, D, E, } \\
\text { J, and Oil Retention } \\
\text { Ponds } 1 \text { and } 2\end{array}$ & SWMUs/BCV CA & $\begin{array}{l}\text { Burial Grounds B, D, E, and J, unlined trenches, received depleted uranium } \\
\text { metal and oxides and minor amounts of debris and inorganic salts. Ponds } 1 \\
\text { and } 2 \text {, built in } 1971 \text { and 1972, respectively, captured waste oils seeping into } \\
\text { two Bear Creek tributaries. The ponds were closed and capped under RCRA } \\
\text { in } 1989 \text {. Certification of closure and capping of Burial Grounds B and part } \\
\text { of C was granted } 2 / 95 \text {. }\end{array}$ \\
\hline Rust Spoil Area & SWMU/BCV CA & $\begin{array}{l}\text { Used from } 1975 \text { to } 1983 \text { for disposal of construction debris, but may have } \\
\text { included materials bearing solvents, asbestos, mercury, and uranium. Closed } \\
\text { under RCRA in 1984. Site is a source of VOCs to shallow groundwater } \\
\text { according to CERCLA RI. }\end{array}$ \\
\hline Spoil Area I & SWMU/BC OU 2 & $\begin{array}{l}\text { Used from } 1980 \text { to about } 1987 \text { for disposal of construction debris and other } \\
\text { stable, nonrad wastes. Permitted under TDEC solid waste management } \\
\text { regulations in 1986; closure began shortly thereafter. Soil contamination is } \\
\text { of primary concem. }\end{array}$ \\
\hline SY-200 Yard & SWMU/BC OU 2 & $\begin{array}{l}\text { Used from } 1950 \text { s to } 1986 \text { for equipment and materials storage. No docu- } \\
\text { mented waste disposal at the site occurred. Leaks, spills, and soil contami- } \\
\text { nation are concerns. }\end{array}$ \\
\hline $\begin{array}{l}\text { Above-Grade LLW } \\
\text { Storage Facility }\end{array}$ & Active & $\begin{array}{l}\text { Constructed in 1993. Consists of six above-grade storage pads used to } \\
\text { store inert, low-level radioactive debris and solid wastes packaged in steel } \\
\text { containers. }\end{array}$ \\
\hline
\end{tabular}

${ }^{a}$ Regulatory status before the 1992 Federal Facilities Agreement: TSD-RCRA regulated, land-based treatment, storage, or disposal unit; SWMU-RCRA-regulated solid waste management unit; NA-not regulated. Current regulatory status: BCV CA-Bear Creek Valley Characterization Area; BC OU 02-Bear Creek Operable Unit 02; active-active waste storage facility.

west along $\mathrm{BCV}$, which is consistent with CY 1993 and CY 1994 data.

Vertical plume boundaries are not so well defined. Typically, nitrate concentrations exceed the MCL in groundwater in the upper $300 \mathrm{ft}$ $(91.5 \mathrm{~m})$ of the Maynardville Limestone. Below this depth nitrate concentrations exceed $10 \mathrm{mg} / \mathrm{L}$ in an area immediately down-dip (south) of 
ORNL-DWG 95M-7063R2
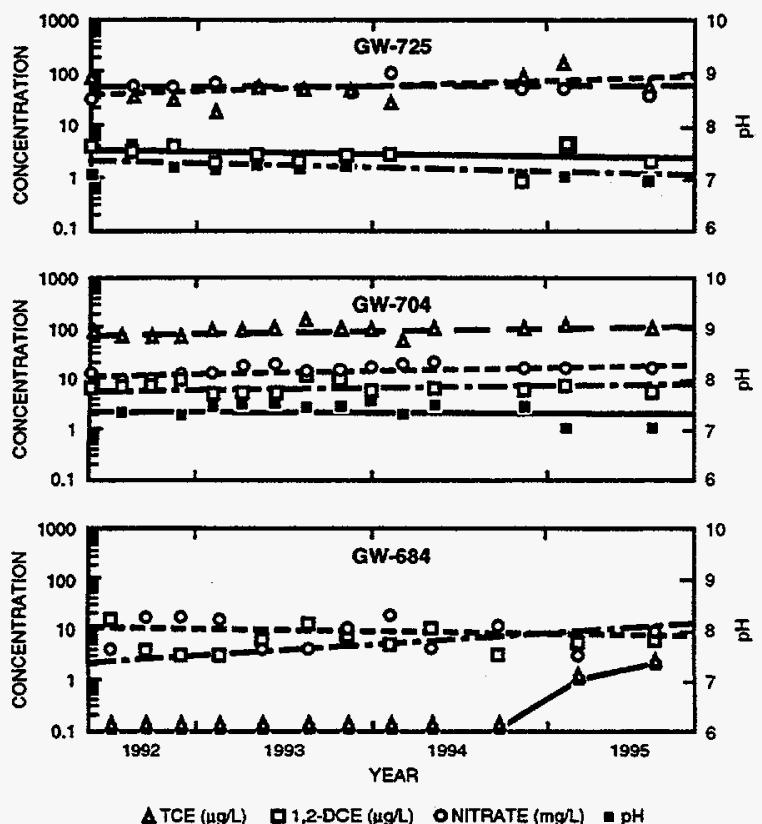

Fig. 7.17. Concentrations of selected contaminants in exit-pathway monitoring wells GW-725, GW-704, and GW-684 in the Bear Creek Hydrogeologic Regime.

the S-3 Site. Data obtained since 1986 suggest that the nitrate plume extends more than $600 \mathrm{ft}$ $(183 \mathrm{~m})$ below the ground surface within the ORR aquitards at the S-3 Site.

\section{Trace Metals}

Barium, cadmium, chromium, lead, and mercury have been identified from previous monitoring as the principal trace metal contaminants in groundwater in the Bear Creek regime. Historically, the concentrations of these metals exceeded maximum contamination levels or natural (background) levels primarily in low-pH groundwater at shallow depths near the S-3 Site. Disposal of acidic liquid wastes at this site reduced the $\mathrm{pH}$ of the groundwater, which allows the metals to remain in solution. Elsewhere in the Bear Creek regime, where relatively high $\mathrm{pH}$ conditions prevail, only sporadic occurrences of elevated trace metal concentrations are evident.

Based on the 1995 data, barium was consistently reported ( $>50 \%$ of samples) for samples from Well GW-537 and wells at the S-3 Site. Cadmium was consistently detected above its maximum contaminant level samples from well GW-042 (a background well in the Bear Creek Burial Grounds) and well GW-276 at the S-3 Site waste management area (Fig. 7.15).

Other trace metal contaminants in the Bear Creek regime are beryllium, boron, cobalt, copper, nickel, strontium, and uranium. Concentrations of these metals have commonly exceeded background levels in groundwater near the S-3 Site, Bear Creek Burial Grounds, and Oil Landfarm waste management areas. Selected stream and spring locations and exit-pathway study wells also have exhibited total uranium and strontium concentrations above background values.

\section{Volatile Organic Compounds}

Like nitrate, VOCs are widespread in groundwater in the Bear Creek regime (Fig. 7.12). The primary compounds are tetrachloroethene, trichloroethene, 1,2-dichloroethene, 1,1,1-trichloroethane, and 1,1 -dichloroethane. In most areas, the VOCs are dissolved in the groundwater, but nonaqueous phase accumulations of tetrachloroethene and trichloroethene occur in bedrock more than $250 \mathrm{ft}$ below the Bear Creek Burial Grounds waste management area.

Groundwater in the unconsolidated zone that contains detectable levels of VOCs occurs primarily within about $1000 \mathrm{ft}(305 \mathrm{~m})$ of the source areas. The highest VOC concentrations (greater than $10,000 \mathrm{mg} / \mathrm{L}$ ) in the unconsolidated zone occur at the Bear Creek Burial Grounds waste management area.

The extent of the dissolved VOC plumes is slightly greater in the underlying bedrock. Although the plumes generally do not extend more than $1000 \mathrm{ft}$ from the source areas in groundwater in the low-permeability formations that underlie many waste sites, significant transport of the VOCs has occurred in the Maynardville Limestone.

Data obtained from exit-pathway monitoring locations show that in the vicinity of the water table, an apparently continuous dissolved VOC plume extends for about $12,000 \mathrm{ft}(3,660 \mathrm{~m})$ westward from the S-3 Site to just west of the Bear Creek Burial Grounds waste management 
area. The highest levels of VOCs in the Bear Creek regime occur in bedrock, just south of the Bear Creek Burial Grounds Waste Management Area. Historical levels have been as high as $7000 \mathrm{mg} / \mathrm{L}$ in groundwater near the source area. Typical VOC levels in the exit pathway (Maynardville Limestone) range from about $160 \mu \mathrm{g} / \mathrm{L}$ in the eastern part of the regime (well GW-725, Fig. 7.12) to less than detectable levels in the western part of the regime.

\section{Radionuclides}

Uranium, neptunium, americium, and naturally occurring isotopes of radium have been identified as the primary alpha-particle emitting radionuclides in the Bear Creek regime. Technetium is the primary beta-particle emitting radionuclide in the regime, but tritium and isotopes of strontium also may be present in groundwater near the S-3 Site.

Evaluations of the extent of these radionuclides in groundwater in the Bear Creek regime during 1995 were based primarily on measurements of gross alpha activity and gross beta activity. If the annual average gross alpha activity in groundwater samples from a well exceeded $15 \mathrm{pCi} / \mathrm{L}$ (the MCL for gross alpha activity), then one or more of the alpha-emitting radionuclides were assumed to be present in the groundwater monitored by the well. A similar rationale was used for annual average gross beta activity that exceeded $50 \mathrm{pCi} / \mathrm{L}$.

As shown in Fig. 7.13, groundwater with elevated levels of gross alpha activity occurs in the water table interval in the vicinity of the S-3 Site, the Bear Creek Burial Grounds, and the Oil Landfarm waste management areas. In the bedrock interval, gross alpha activity exceeds $15 \mathrm{pCi} / \mathrm{L}$ in groundwater in the Nolichucky Shale near the S-3 Site, the southern sides of the Bear Creek Burial Grounds, and east of the Oil Landfarm waste management areas. Data obtained from exit-pathway monitoring stations show that gross alpha activity in groundwater in the Maynardville Limestone exceeds the maximum contamination level for $10,000 \mathrm{ft}$ $(3,050 \mathrm{~m})$ west of the S-3 Site. Elevated gross alpha activities were observed in four exit-pathway spring and stream monitoring locations (NT-01, SS-1, SS-4, and SS-5;

Fig. 7.13).

The distribution of gross beta radioactivity in groundwater in the unconsolidated zone is similar to that of gross alpha radioactivity (Fig. 7.14). During 1995 gross beta activity exceeded $50 \mathrm{pCi} / \mathrm{L}$ within the water table interval in the Maynardville Limestone from south of the S-3 Site to the Oil Landfarm waste management area. Within the intermediate bedrock interval in the Maynardville Limestone, the elevated gross beta activity extends as far west as does gross alpha activity, just to the west of the Bear Creek Burial Grounds waste management area. Elevated gross beta activity was observed in two springs and one stream monitoring station (NT-01, SS-1, and SS-4; Fig. 7.14) that also exhibited elevated gross alpha activity.

\section{Exit-Pathway and Perimeter Monitoring}

Exit-pathway monitoring began in 1990 to provide data on the quality of groundwater and surface water exiting the Bear Creek regime. The Maynardville Limestone is the primary exit pathway for groundwater. Bear Creek, which flows across the Maynardville Limestone in much of the Bear Creek regime, is the principal exit pathway for surface water. Various studies have shown that surface water in Bear Creek and groundwater in the Maynardville Limestone are hydraulically connected. The westem exit-pathway well transect (Picket W) serves as the ORR perimeter wells for the Bear Creek Regime (Fig. 7.6).

Exit-pathway study activities in 1995 consisted of continued monitoring at four well transects (pickets). The 1992 ORR environmental report and (Shevenell et al. 1992) contain detailed information about the construction of these pickets and the rationale for their construction. Other related investigations initiated as part of exit-pathway studies have included evaluation of the geologic characteristics of the Maynardville Limestone, geochemical characterization of groundwater types in BCV, analysis of controlling variables for development of preferred groundwater flow paths, and cross-borehole testing. Studies are ongoing of the transport of contaminants adsorbed to 
colloidal particles and of contaminant transport in relation to rainfall events within the Maynardville Limestone.

Groundwater quality data obtained during 1995 from the exit-pathway monitoring wells confirmed previous data that contaminated groundwater does not seem to occur much beyond the western side of the Bear Creek Burial Grounds waste management area.

Surface water and spring samples collected during CY 1995 (Fig. 7.16) indicate that spring discharges and water in upper reaches of Bear Creek contain many of the compounds found in the groundwater; however, the concentrations in the creek and spring discharges decrease rapidly with distance downstream of the waste disposal sites. This assessment is consistent with data from previous years. CY 1995 data indicate an improvement in water quality in the lower reaches of Bear Creek over past years.

For example, in CY 1995, nitrate concentrations in Bear Creek exceeded $100 \mathrm{mg} / \mathrm{L}$ during 1995 from NT-01 west of the S-3 Site to BCK 11.97 (Fig. 7.16). Nitrate levels at BCK 9.40 averaged about $4.9 \mathrm{mg} / \mathrm{L}$. Nitrate concentrations at BCK 4.55 (NPDES Outfall 304), at the junction of Bear Creek Road and Highway 95 , averaged $1.35 \mathrm{mg} / \mathrm{L}$, down from $2.7 \mathrm{mg} / \mathrm{L}$ in CY 1994 . The average nitrate concentration in surface water samples collected from the farthest downstream point (BCK 0.63), which is located just upstream of the confluence of Bear Creek and EFPC, was $1.25 \mathrm{mg} / \mathrm{L}$, down from $2.5 \mathrm{mg} / \mathrm{L}$ in CY 1994 (background is about $0.2 \mathrm{mg} / \mathrm{L}$ ). Average nitrate concentrations in spring discharges decreased from an average of $25.5 \mathrm{mg} / \mathrm{L}$ at SS-1 to $4.3 \mathrm{mg} / \mathrm{L}$ at SS-5.

Low concentrations of VOCs $(<10 \mu \mathrm{g} / \mathrm{L})$ were detected in surface-water samples and spring discharge samples collected from the upper and middle reaches of Bear Creek (at NT-1 and BCK 9.40). Compounds detected in samples from the creek were trichloroethene, 1,2-dichloroethene, and tetrachloroethene. Spring discharges at SS-1 and SS-4 also contained trace amounts of VOCs. Each of these compounds is a primary component of the VOC plumes in groundwater in the regime.
Based on the 1995 data, uranium is again the most common trace metal contaminant in Bear Creek. Concentrations of uranium exceeded background levels throughout reaches of the creek upstream of BCK 9.40. Moreover, uranium concentrations in the creek slightly exceeded background levels at the farthest downstream sampling point (BCK 0.63). Uranium concentrations in spring effluents exceed background levels as far west as the SS-5 location.

Annual average gross alpha activity in 1994 mirrored the results of previous years. Gross alpha was above $15 \mathrm{pCi} / \mathrm{L}$ only at $\mathrm{BCK} 11.97$ and BCK 9.40 along Bear Creek. Spring discharges west as far as SS-5 had annual average gross alpha above $15 \mathrm{pCi} / \mathrm{L}$. Gross beta activity exceeded $50 \mathrm{pCi} / \mathrm{L}$ at $\mathrm{BCK} 11.97$ and NT-01. Annual average gross beta exceeded $50 \mathrm{pCi} / \mathrm{L}$ at SS-1 and SS-4.

\section{Chestnut Ridge Hydrogeologic Regime}

The Chestnut Ridge regime is south of the Y-12 Plant and is flanked to the north by BCV and to the south by Bethel Valley Road (Fig. 7.5). The regime encompasses the portion of Chestnut Ridge extending from Scarboro Road east of the Y-12 Plant to an unnamed drainage basin on the ridge located just west of Centralized Sanitary Landfill II. Figure 7.18 shows the approximate boundaries of the regime and locations of waste management units and monitoring wells sampled in 1995.

Four categories of sites are located within the Chestnut Ridge regime: (1) RCRA interim-status units, (2) RCRA 3004(u) SWMUs and solid waste disposal units, (3) TDEC-permitted solid waste disposal facilities, and (4) CERCLA OUs. The Chestnut Ridge Security Pits is the only documented source of groundwater contamination in the regime. No integrating CA has been established for the regime because contamination from the Security Pits is distinct and is not mingled with plumes from other sources. Groundwater media will be addressed as part of the RI/FS for each source. Table 7.4 summarizes the regulatory status and operational history of 
ORNL-DWG 93M-9607R4
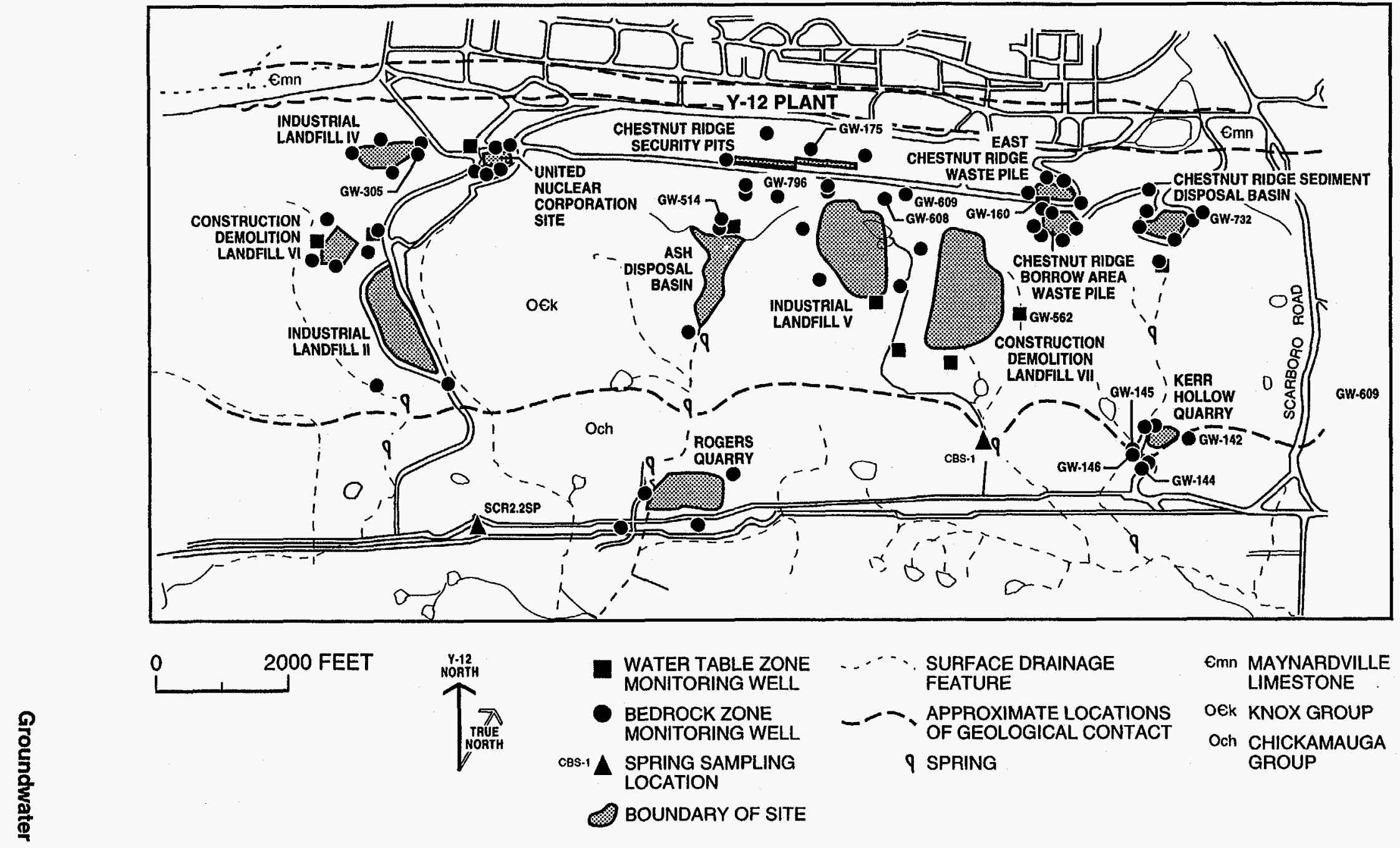

Fig. 7.18. Locations of waste management sites and monitoring wells sampled during 1995 in the Chestnut Ridge Hydrogeologic Regime. 
Table 7.4. Regulatory status and operational history of waste management units included in the 1995 Comprehensive Groundwater Monitoring Program; Chestnut Ridge Hydrogeologic Regime

\begin{tabular}{|c|c|c|}
\hline Site & $\begin{array}{l}\text { Historical/current } \\
\text { regulatory } \\
\text { classification }^{a}\end{array}$ & Historical data \\
\hline $\begin{array}{l}\text { Chestnut Ridge Sediment } \\
\text { Disposal Basin }\end{array}$ & TSD/TSD-Study Area & $\begin{array}{l}\text { Operated from } 1973 \text { to } 1989 \text {. Received soil and sediment from New } \\
\text { Hope Pond and mercury-contaminated soils from the Y-12 Plant. } \\
\text { Site was closed under RCRA in 1989. Not a documented source of } \\
\text { groundwater contamination. }\end{array}$ \\
\hline Kerr Hollow Quarry & TSD/TSD-Study Area & $\begin{array}{l}\text { Operated from } 1940 \text { s to } 1988 \text {. Used for the disposal of reactive ma- } \\
\text { terials, compressed gas cylinders, and various debris. RCRA closure } \\
\text { (waste removal) was conducted between } 1990 \text { and } 1993 \text {. Certifica- } \\
\text { tion of closure with some wastes remaining in place was approved by } \\
\text { TDEC } 2 / 95 \text {. }\end{array}$ \\
\hline $\begin{array}{l}\text { Chestnut Ridge Security } \\
\text { Pits }\end{array}$ & TSD/TSD-CR OU 1 & $\begin{array}{l}\text { Operated from } 1973 \text { to } 1988 \text {. Series of trenches for disposal of } \\
\text { classified materials, liquid wastes, thorium, uranium, heavy metals } \\
\text { and various debris. Closed under RCRA in 1989. Infiltration is the } \\
\text { primary release mechanism to groundwater. }\end{array}$ \\
\hline $\begin{array}{l}\text { East Chestnut Ridge } \\
\text { Waste Pile }\end{array}$ & TSD/TSD & $\begin{array}{l}\text { An active, lined, RCRA-permitted hazardous waste storage facility } \\
\text { for contaminated soils from the Y- } 12 \text { Plant. }\end{array}$ \\
\hline Ash Disposal Basin & SWMU/CR OU 2 & $\begin{array}{l}\text { Used until 1967. Site received Y-12 Steam Plant coal ash slumies. } \\
\text { Leaching of metals to groundwater are of concern. }\end{array}$ \\
\hline $\begin{array}{l}\text { United Nuclear } \\
\text { Corporation Site }\end{array}$ & SWMU/CR OU 3 & $\begin{array}{l}\text { Received about } 29,000 \text { drums of cement-fixed sludges and soils demo- } \\
\text { lition materials, and low-level radioactive contaminated soils. Closed } \\
\text { in 1992, CERCLA ROD has been issued. }\end{array}$ \\
\hline Rogers Quarry & SWMU/CR OU 4 & $\begin{array}{l}\text { Used from } 1960 \text { s until } 1993 \text { for disposal of steam-plant coal ash and } \\
\text { process debris. Metals contaminants are of primary concern. }\end{array}$ \\
\hline $\begin{array}{l}\text { Chestnut Ridge Borrow } \\
\text { Area Waste Pile }\end{array}$ & Not regulated/Study Area & $\begin{array}{l}\text { Contains soils from off-site locations in Oak Ridge bearing low levels } \\
\text { of mercury and other metals. }\end{array}$ \\
\hline $\begin{array}{l}\text { Centralized Sanitary } \\
\text { Landfill II }\end{array}$ & $\begin{array}{l}\text { TDEC-permitted Class II } \\
\text { industrial SWDF }\end{array}$ & $\begin{array}{l}\text { Central sanitary landfill for the ORR. Detection monitoring under } \\
\text { TDEC-SWM regulations has been ongoing since } 1986 \text {. }\end{array}$ \\
\hline Industrial Landfill IV & $\begin{array}{l}\text { TDEC-permitted Class II } \\
\text { industrial SWDF }\end{array}$ & $\begin{array}{l}\text { Permitted to receive only, nonhazardous industrial solid wastes. De- } \\
\text { tection monitoring under TDEC-SWM regulations has been ongoing } \\
\text { since } 1988 \text {. }\end{array}$ \\
\hline Industrial Landfill V & $\begin{array}{l}\text { TDEC-permitted Class II } \\
\text { industrial SWDF }\end{array}$ & $\begin{array}{l}\text { New facility completed } 4 / 94 \text {. Baseline groundwater monitoring began } \\
5 / 93 \text { and was completed } 1 / 95 \text {. Currently under TDEC-SWM detection } \\
\text { monitoring. }\end{array}$ \\
\hline $\begin{array}{l}\text { Construction/Demolition } \\
\text { Landfill VI }\end{array}$ & $\begin{array}{l}\text { TDEC-permitted Class IV } \\
\text { construction/demolition } \\
\text { SWDF }\end{array}$ & $\begin{array}{l}\text { New facility completed } 12 / 93 \text {. Baseline groundwater quality monitor- } \\
\text { ing began } 5 / 93 \text { and was completed } 12 / 93 \text {. Waste disposal began } 4 / 94 \text {. } \\
\text { Currently under permit-required detection monitoring per TDEC. }\end{array}$ \\
\hline $\begin{array}{l}\text { Construction/Demolition } \\
\text { Landfill VI }\end{array}$ & $\begin{array}{l}\text { TDEC-permitted Class IV } \\
\text { construction/demolition } \\
\text { SWDF }\end{array}$ & $\begin{array}{l}\text { New facility, construction completed in } 12 / 94 \text {. TDEC granted ap- } \\
\text { proval to operate } 1 / 95 \text {. Baseline groundwater quality monitoring } \\
\text { began in } 5 / 93 \text { and was completed in } 1 / 95 \text {. Currently under permit- } \\
\text { required detection monitoring per TDEC. }\end{array}$ \\
\hline
\end{tabular}

\footnotetext{
${ }^{a}$ Regulatory classification before the 1992 Federal Facilities Agreement: TSD-RCRA regulated, land-based treatment, storage, or disposal facility; SWMU-RCRA-regulated solid waste managementunit. Current regulatory status: study area-Y-12 Plant study area; CR OU $1-$ Chestnut Ridge Operable Unit 1; CR OU 2-Chestnut Ridge Operable Unit 2; CR OU 3-Chestnut Ridge Operable Unit 3; CR OU 4-Chestnut Ridge Operable Unit 4; SWDF-solid waste disposal facility (active landfill).
}

was's management units in the regime. Detailed discissions of these sites have been included in previous annual site environmental reports.

\section{Discussion of Monitoring Results}

Groundwater quality data obtained in the Chestnut Ridge regime during 1995 support conclusions drawn from previous monitoring results. A more comprehensive suite of analytical 
tests is applied to most sites in the Chestnut Ridge regime because of various permitting requirements; however, volatile organics and trace metals are the only categories in which findings currently consistently exceed background levels. Gross alpha and beta activities have sporadically exceeded screening levels in the past in samples taken from wells at the Chestnut Ridge Sediment Disposal Basin, United Nuclear Site, Industrial Landfill III, and Kerr Hollow Quarry. No discernable pattern or consistency to the data has been determined.

In late 1994, a detailed review of groundwater results from Kerr Hollow Quarry was conducted in response to the identification of total strontium and total uranium levels in three wells at the site that were consistently elevated above background concentrations (GW-142, GW-145, and GW-146; Fig. 7.18). The data review indicated that no elevated gross alpha or gross beta was associated with the elevated metals values. Isotopic uranium and strontium analyses also were conducted, with the results showing no elevated activity. Hence, the elevated metals concentrations may reflect natural geochemical variations in groundwater at the site or possibly the impacts of waste disposal operations. In addition to the metals evaluation, VOC occurrences were examined. The evaluation demonstrated that low levels of tetrachloroethene and carbon tetrachloride were sporadically observed in wells GW-142 and GW-144. The occurrences of these compounds were first detected in 1990. The frequency of occurrence increased during 1991 and 1992 and then began to decrease in 1993. The only detectable VOC in 1994 was carbon tetrachloride in one sample from well GW-144 in the second calendar quarter. The occurrences of these VOCs appears to correlate with underwater debris removal and shredding corrective actions at the quarry, which were conducted between August 1990 and October 1993. However, VOCs continued to be observed during CY 1995; therefore, a trend is not well established.

\section{Plume Delineation}

The horizontal extent of the VOC plume at the Chestnut Ridge Security Pits is reasonably well defined in the water table and shallow bedrock zones (Fig. 7.12). Groundwater quality data obtained during 1995 continues to indicate that the lateral extent of the VOC plume at the site is increasing slightly, as evidenced by detectable signature VOCs (1,1,1-trichloroethane) in Wells GW-608, GW-609, GW-514, GW-305, GW-796, and GW-175.

There are two distinct VOCs in groundwater at the security pits. In the western portion of the site, the VOC plume is characterized by high concentrations of 1,1,1-trichloroethane. Tetrachloroethene is a principal component of the VOC plume in the eastern portion of the site. The distinct difference in the composition of the plume is probably related to differences in the types of wastes disposed of in the eastern and western trench areas.

\section{Nitrate}

Nitrate concentrations were well below the DWS of $10 \mathrm{mg} / \mathrm{L}$ in all wells.

\section{Trace Metals}

Chromium concentrations in unfiltered samples sporadically exceeded DWSs in four wells. Cadmium levels exceeded DWSs in single samples collected from two wells. Lead levels exceed DWSs in single samples collected from three wells.

\section{Volatile Organic Compounds}

Efforts to delineate the extent of VOCs in groundwater at the security pits (previously discussed) have been in progress since 1987. A review of historical data suggests that VOC concentrations in groundwater at the site have generally decreased since 1988 (Table 7.5). Low levels of VOCs were observed at a few additional scattered locations in 1995. Of particular note, trace levels of carbon tetrachloride were observed in two samples from Kerr Hollow Quarry (Well GW-144) and perchloroethene was observed in one sample. 
Table 7.5. Annual average summed volatile organic compound (VOC) concentrations in groundwater at the Chestnut Ridge Security Pits

\begin{tabular}{|c|c|c|c|c|c|c|c|c|}
\hline \multirow{2}{*}{$\begin{array}{c}\text { Well } \\
\text { number }\end{array}$} & \multicolumn{7}{|c|}{ Summed average VOC concentration ${ }^{a}(\mu \mathrm{g} / \mathrm{L})$} & \multirow{2}{*}{$\begin{array}{c}\text { Percentage } \\
\text { decrease }\end{array}$} \\
\hline & 1989 & 1990 & 1991 & 1992 & 1993 & 1994 & 1995 & \\
\hline GW-173 & 17.0 & 13.5 & 11.8 & 11.7 & NS & NS & NS & 31 \\
\hline GW-174 & 47.8 & 48.5 & 43.7 & 34.0 & NS & NS & NS & 29 \\
\hline GW-175 & 31.8 & 38.5 & 31.0 & 29.5 & 17.0 & 25.3 & 21.5 & 32 \\
\hline GW-176 & 285.3 & 233.5 & 170.5 & 139.7 & NS & NS & NS & 51 \\
\hline GW-177 & 66.7 & 18.8 & 26.3 & 25.5 & 33.0 & 28.3 & 24.3 & 64 \\
\hline GW-178 & 43.4 & 40.0 & 34.0 & 29.0 & NS & NS & NS & 32 \\
\hline GW-179 & 838.0 & 455.0 & 328.3 & 262.3 & NS & NS & NS & 69 \\
\hline GW-180 & 145.8 & 99.5 & 74.2 & 52.3 & NS & NS & NS & 64 \\
\hline GW-322 & 696.0 & 730.3 & 633.0 & 538.3 & NS & NS & NS & 23 \\
\hline GW-607 & NS & 16.9 & ND & ND & ND & NS & NS & 100 \\
\hline GW-608 & NS & 14.8 & 15.5 & $(4.5)^{b}$ & $(4.0)^{b}$ & $(4.3)^{b}$ & $(0.8)^{b}$ & 95 \\
\hline GW-609 & NS & 78.0 & 67.5 & 35.5 & 28.4 & 54.5 & 28.5 & 63 \\
\hline GW-610 & NS & $(1.0)^{b}$ & $(0.5)^{b}$ & ND & ND & $(0.3)$ & ND & 100 \\
\hline GW-611 & NS & 16.0 & 9.0 & 13.5 & 10.5 & 12.4 & 5.5 & 66 \\
\hline GW-612 & NS & 505.8 & 451.3 & 358.3 & NS & NS & NS & 29 \\
\hline GW-742 & NS & NS & NS & ND & ND & ND & ND & \\
\hline GW-743 & NS & NS & NS & ND & ND & ND & $(2.0)^{b}$ & \\
\hline
\end{tabular}

${ }^{a}$ NS: not sampled. ND: not detected.

${ }^{b}$ Qualitative results; summed average determined exclusively from estimated concentrations reported below the analytical detection limit.

\section{Radionuclides}

Annual average gross alpha exceeded $15 \mathrm{pCi} / \mathrm{L}$ in three wells (GW-160, GW-562, and GW-732; Fig. 7.13). Gross beta activities were below the DWS of $50 \mathrm{pCi} / \mathrm{L}$ at all locations.

\section{Exit-Pathway and Perimeter Monitoring}

Exit-pathway monitoring in the Chestnut Ridge regime has followed a different approach from that used for the other two regimes. Contaminant and groundwater flow paths in the karst bedrock underlying the regime are not best identified through conventional monitoring techniques. The comprehensive groundwater monitoring plan, therefore, presented a rationale for using dye-tracer studies to identify exit pathways. Based on the results of dye-tracer studies, springs and surface streams that represent discharge points for groundwater can be identified for water quality monitoring.

A dye-tracer study was initiated and completed in 1992 (SAIC 1993), primarily to confirm results of an initial study conducted in 1990 (Geraghty and Miller, Inc. 1990). The
1992 study used the same dye injection well near the Chestnut Ridge Security Pits and many of the same monitoring points as did the 1990 study. The primary differences included an expanded monitoring network and the use of two fluorescent dyes to verify dye detection.

Results of the second tracer-dye study showed no conclusive occurrences of dyes at the monitoring points and did not corroborate data for detection points in the first study. The 1992 study also showed that the injection well was inappropriate because dye-uptake rates by the formation were inadequate. It is likely that the dye-uptake rates are inadequate because the source well is not screened in a flow conduit interconnected to the rest of the system. A formal comparison report has been completed that examines results of both studies to provide recommendations for improvements for future dye-tracer studies in this regime. Future dye-tracer studies are possible. The TDEC DOE Oversight Division has conducted a small-scale tracer study east of the Sediment Disposal Basin, although the results have not yet been published. 
Monitoring of one large spring located south of Industrial Landfill $V$ and Construction/Demolition Landfill VII was conducted in 1994 as a best management practice. One other spring location (SCR 2.2SP; Fig. 7.18) was sampled in 1995, also as a best management practice in conjunction with the TDEC DOE Oversight Division.

\section{Special Studies}

Two special studies involving groundwater at the Y-12 Plant were conducted in CY 1995. These investigations included: (1) a continuation of an evaluation of contaminant transport via colloidal particles in groundwater; and (2) study of the controlling influence of man-made (anthropogenic) fill and major utilities on groundwater movement within the Y-12 Plant.

An investigation into contaminant transport via colloidal particles was initiated in 1993 . The study focuses on major ions and metals because these constituent types are the most likely to adsorb onto colloids being transported within the active flow system. The study includes about 30 wells located within the ORR aquitards, Maynardville Limestone, and Knox Group within the Bear Creek and Chestnut Ridge regimes. A wide range of geologic units and depths was selected to examine how colloidal transport of contaminants is related to these variables. Very slow pumping rates are used to sample groundwater. Various sizes of filters are used to filter the samples to obtain aliquots for analysis. The various aliquots are analyzed to determine what size range of colloidal particles adsorb and transport contaminants. All of the subject wells have been sampled to date, and results are being finalized. In addition, the study was amended in 1994 to include sampling of selected wells in conjunction with storm events. The data obtained will provide insight regarding how constituents may be mobilized in the shallow karst system as a result of high-precipitation events. All field efforts are anticipated to be complete by June 1996, with a final due in October 1996.

A short-term study was begun and completed in 1995 to delineate the extent and thickness of anthropogenic fill material emplaced throughout the Y-12 Plant during various periods of construction. These fill zones are thought to play a major role in the movement of contaminants and groundwater flow patterns in the water table interval beneath the Y-12 Plant. Large volumes of topographic data, engineering data, soil-boring logs, and monitoring-well installation logs have been generated throughout the operational history of the Y-12 Plant. These data were compiled, screened for completeness and accuracy, and reduced into tabular formats denoting thickness, extent, and general composition of anthropogenic fill material. These reduced data were used to generate a fill isopach (thickness) map that also delineates the known extent of anthropogenic fill for the entire Y-12 Plant (Sutton and Field 1995). As a follow-on study to begin in 1996 , major underground utilities will be examined to investigate their potential impacts on contaminant distribution and shallow groundwater flow patterns in the Y-12 Plant area. These data are important for identification of potential exit pathways for contaminants, for determining whether existing and planned monitoring activities are adequate, and for helping to identify potential remediation points for source areas.

\section{GROUNDWATER MONITORING AT THE OAK RIDGE NATIONAL LABORATORY}

\section{Background}

The groundwater monitoring program at ORNL consists of a network of wells of two basic types and functions: (1) water quality monitoring wells built to RCRA specifications and used for site characterization and compliance purposes and (2) piezometer wells used to characterize groundwater flow conditions. The ER Program provides comprehensive cleanup of sites where past and current research, development, and waste management activities may have resulted in residual contamination of the environment. Individual monitoring and assessment is assumed to be impractical for each of these sites because their boundaries are indistinct and because there are hydrologic interconnections between many of them. 


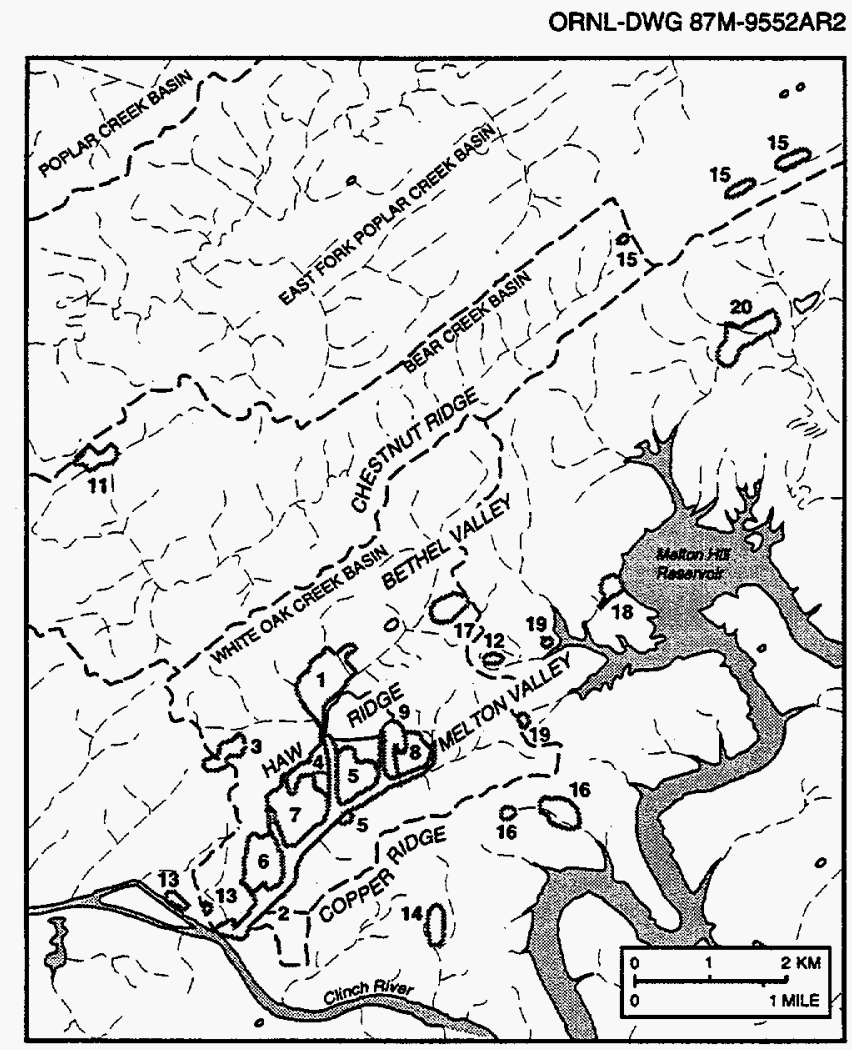

Fig. 7.19. Locations of ORNL waste

area groupings (WAGs). (WAG 10 sites are underground, beneath WAG 5.)

Consequently, the concept of WAGs was developed to facilitate evaluation of potential sources of releases to the environment. A WAG is a grouping of multiple sites that are geographically contiguous and/or that occur within hydrologically (geohydrologic) defined areas. WAGs allow establishment of suitably comprehensive groundwater and surface water monitoring and remediation programs in a far shorter time than that required to deal with every facility, site, or SWMU individually. Some WAGs share boundaries, but each WAG represents a collection of distinct small drainage areas, within which similar contaminants may have been introduced. Monitoring data from each WAG are used to direct further groundwater studies aimed at addressing individual sites or units within a WAG as well as contaminant plumes that extend beyond the perimeter of a WAG.

At ORNL, 20 WAGs were identified by the RCRA Facility Assessment (RFA) conducted in
1987. Thirteen of these have been identified as potential sources of groundwater contamination. Additionally, there are a few areas where potential remedial action sites are located outside the major WAGs. These individual sites have been considered separately (instead of expanding the area of the WAG). Water quality monitoring wells have been established around the perimeters of the WAGs determined to have a potential for release of contaminants. Figure 7.19 shows the location of each of the 20 WAGs.

For discussion purposes the WAGs are grouped by the valley in which they are located; i.e., Bethel Valley WAG s include 1, 3, and 17; Melton Valley WAGs include 2, 4, 5, 6, 7, 8, and 9; and WAG 11 (the White Wing Scrapyard).

The ORNL exit pathway program is discussed in this section. The ORNL program monitors groundwater at four general locations that are thought to be likely exit pathways for groundwater affected by activities at ORNL (Fig. 7.20). 


\section{ORNL-DWG 93M-10468}

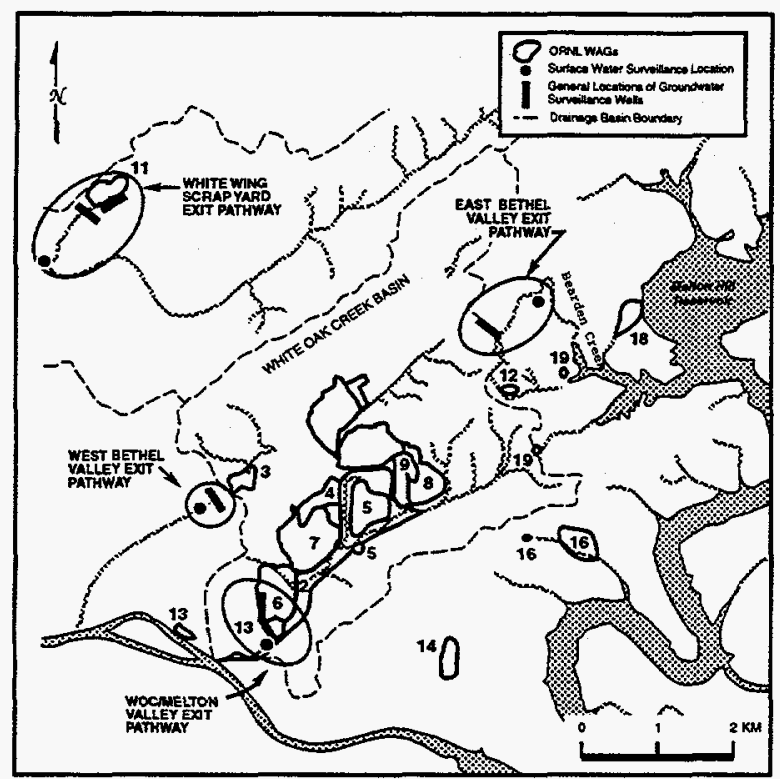

Fig. 7.20. Groundwater exit pathways on the Oak Ridge Reservation that are likely to be affected by ORNL operations.

\section{Bethel Valley}

\section{WAG 1}

WAG 1, the ORNL main plant area, contains about one-half of the remedial action sites identified to date by the ER Program. WAG 1 lies within the Bethel Valley portion of the WOC drainage basin. The boundaries of the basin extend to the southeast and northeast along Chestnut Ridge and Haw Ridge. The WAG boundary extends to the water gap in Haw Ridge. The total area of the basin in Bethel Valley is about 2040 acres. Bedrock beneath the main plant area is limestone, siltstone, and calcareous shale facies of the Ordovician Chickamauga Group.

Most of the WAG 1 sites were used to collect and to store LLW in tanks, ponds, and waste treatment facilities, but some also include landfills and contaminated sites resulting from spills and leaks occurring over the last 50 years. Because of the nature of cleanup and repair, it is not possible to determine which spill or leak sites still represent potential sources of release. Most of the SWMUs are related to ORNL's waste management operations. Recent ER activities within WAG 1 include several CERCLA actions associated with sources of contamination; e.g., Surface Impoundments OU, a treatability study associated with the Gunite and Associated Tank OU, and two removal actions [Corehole 8 and the decontamination and decommissioning (D\&D) of the Waste Evaporator Facility (Building 3506)].

\section{WAG 3}

WAG 3 is located in Bethel Valley about $1 \mathrm{~km}(0.6$ mile $)$ west of the main plant area. WAG 3 is composed of three SWMUs: SWSA 3, the Closed Scrap Metal Area (1562), and the Contractors Landfill (1554).

SWSA 3 and the Closed Scrap Metal Area are inactive landfills known to contain radioactive solid wastes and surplus materials generated at ORNL from 1946 to 1979. Burial of solid waste ceased at this site in 1951; however, the site continued to be used as an above-ground scrap metal storage area until 1979. Sometime during the period from 1946 to 1949 , radioactive solid wastes removed from SWSA 2 were buried at this site. In 1979, most of the scrap metal stored above ground at SWSA 3 was either transferred to other storage areas or buried on site in a triangular-shaped disposal area immediately south of SWSA 3.

Records of the composition of radioactive solid waste buried in SWSA 3 were destroyed in a fire in 1961. Sketches and drawings of the site indicate that alpha and beta-gamma wastes were segregated and buried in separate areas or trenches. Chemical wastes were probably also buried in SWSA 3 because there are no records of disposal elsewhere. Although the information is sketchy, the larger scrap metal equipment (such as tanks and drums) stored on the surface at this site was also probably contaminated. Because only a portion of this material is now buried in the Closed Scrap Metal Area, it is not possible to estimate the amount of contamination that exists in this SWMU.

The Contractors' Landfill was opened in 1975 and is now closed. It was used to dispose of various uncontaminated construction materials. No contaminated waste or asbestos was allowed to be buried at the site. ORNL disposal procedures require that only non-RCRA, 
nonradioactive solid wastes were to be buried in the Contractors' Landfill.

\section{WAG 17}

WAG 17 is located about $1.6 \mathrm{~km}$ ( 1 mile) directly east of the ORNL main plant area. This area has served as the major craft and machine shop area for ORNL since the late 1940s. The area includes the receiving and shipping departments, machine shops, carpenter shops, paint shops, lead-burning facilities, garage facilities, welding facilities, and material storage areas that are needed to support ORNL's routine and experimental operations. It is composed of 17 SWMUs. A former septic tank now used as a sewage collection/pumping station for the area, and seven tanks used for waste oil collection and storage and for storage of photographic reproduction wastes.

\section{Melton Valley}

\section{WAG 2}

WAG 2 is composed of White Oak Creek discharge points and includes the associated floodplain and subsurface environment. It represents the major drainage system for ORNL and the surrounding facilities.

In addition to natural drainage, WOC has received treated and untreated effluents and reactor cooling water from ORNL activities since 1943. Controlled releases include those from the NRWTF, the sewage treatment plant, and a variety of process waste holdup ponds throughout the ORNL main plant area (WAG 1). It also receives groundwater discharge and surface drainage from WAGs $1,4,5,6,7,8$, and 9 .

There is little doubt that WAG 2 represents a source of continuing contaminant release (radionuclides and/or chemical contaminants) to the Clinch River. Although it is known that WAG 2 receives groundwater contamination from other WAGs, the extent to which WAG 2 may be contributing to groundwater contamination has yet to be determined. Recent ER activities include continued monitoring and support of the WAG 5 seeps removal action.

\section{WAG 4}

WAG 4 is located in Melton Valley about $0.8 \mathrm{~km}(0.5 \mathrm{mile})$ southwest of the main ORNL plant site. It comprises the SWSA 4 waste disposal area, liquid low-level (radioactive) waste (LLLW) transfer lines, and the experimental Pilot Pit Area (Area 7811).

SWSA 4 was opened for routine burial of solid radioactive wastes in 1951. From 1955 to 1963, Oak Ridge was designated by the Atomic Energy Commission as the Southern Regional Burial Ground; as such, SWSA 4 received a wide variety of poorly characterized solid wastes (including radioactive waste) from about 50 sources. These wastes consisted of paper, clothing, equipment, filters, animal carcasses, and related laboratory wastes. About $50 \%$ of the waste was received from sources outside of Oak Ridge facilities. Wastes were placed in trenches, shallow auger holes, and in piles on the ground for covering at a later date.

From 1954 to 1975 , LLLW was transported from storage tanks at the main ORNL complex to waste pits and trenches in Melton Valley (WAG 7), and later to the hydrofracture disposal sites, through underground transfer lines. The Pilot Pit Area (Area 7811) was constructed for use in pilot-scale radioactive waste disposal studies from 1955 to 1959; three large concrete cylinders containing experimental equipment remain embedded in the ground. A removal action was initiated at WAG 4 during 1995 to grout, in place, sources of ${ }^{90} \mathrm{Sr}$ contamination emanating from selected trenches located within the WAG. A control building and asphalt pad have been used for storage through the years.

\section{WAG 5}

WAG 5 contains 33 SWMUs, 13 of which are tanks that were used to store LLLW prior to disposal by the hydrofracture process. WAG 5 also includes the surface facilities constructed in support of both the old and new hydrofracture facilities. The largest land areas in WAG 5 are devoted to SWSA 5 South and SWSA 5 North, the TRU Waste Storage Area. The remaining sites are support facilities for ORNL's hydrofracture operations, two LLW pipeline 
leak/spill sites, and an impoundment in SWSA 5 used to dewater sludge from the original Process Waste Treatment Facility. Currently, LLW tanks at the New Hydrofracture Facility are being used to store evaporator concentrates pending a decision regarding ultimate disposal of these wastes.

SWSA 5 South was used to dispose of solid LLW generated at ORNL from 1959 to 1973. From 1959 to 1963 the burial ground served as the Southeastern Regional Burial Ground for the Atomic Energy Commission. At the time SWSA 5 burial operations were initiated, about 10 acres of the site was set aside for the retrievable storage of TRU wastes.

The WAG 5 boundary includes the Old and New Hydrofracture Facilities. Because Melton Branch flows between the old and new hydrofracture facilities, the new hydrofracture facility has a separate boundary.

The WAG 5 RI field activities were completed and the RI report was written in 1995. A CERCLA removal action was initiated in 1994 to remove ${ }^{90} \mathrm{Sr}$ from Seeps C and D located along the southern boundary of WAG 5 .

\section{WAG 6}

WAG 6 consists of four SWMUs: (1) SWSA 6, (2) Building 7878, (3) the explosives detonation trench, and (4) Building 7842. SWSA 6 is located in Melton Valley, northwest of WOL and southeast of Lagoon Road and Haw Ridge. The site is about $2 \mathrm{~km}$ (1.2 miles) south of the main ORNL complex. Waste burials at the 68-acre site were initiated in 1973 when SWSA 5 was closed. Various radioactive and chemical wastes were buried in trenches and auger holes. SWSA 6 is the only currently operating disposal area for LLW at ORNL. The emergency waste basin was constructed in 1961 to provide storage of liquid wastes that could not be released from ORNL to WOC. The basin is located northwest of SWSA 6 and has a capacity of 15 million gal, but has never been used. Radiological sampling of the small drainage from the basin has shown the presence of some radioactivity. The source of this contamination is not known.
WAG 6 was among the first to be investigated at ORNL by the ER Program. WAG 6 is an interim-status RCRA unit because of past disposal of RCRA-regulated hazardous waste. Environmental monitoring is carried out under CERCLA and RCRA. A proposed CERCLA remedial action, which involved capping WAG 6, was abandoned after a public meeting in which members of the community objected to the high cost of capping.

In 1995 ORNL submitted a revision to the 1988 RCRA Closure Plan which proposed an integration of RCRA closure and CERCLA remedial action requirements. As of this writing, ORNL has not received a response from the TDEC.

\section{WAG 7}

WAG 7 is located in Melton Valley about $1.6 \mathrm{~km}$ (1 mile) south of the ORNL main plant area. The major sites in WAG 7 are the seven pits and trenches used from 1951 to 1966 for disposal of LLLW. WAG 7 also includes a decontamination facility, three leak sites, a storage area containing shielded transfer tanks and other equipment, and seven fuel wells used to dispose of acid solutions primarily containing enriched uranium from Homogeneous Reactor Experiment fuel. WAG 7 is being used to demonstrate the efficacy of In-Situ Vitrification (ISV) technology to immobilize radioactive waste streams buried in the WAG.

\section{WAGs 8 and 9}

WAG 8 is located in Melton Valley, south of the main plant area, and is composed of 36 SWMUs that are associated with the reactor facilities in Melton Valley. The SWMUs consist of active LLLW collection and storage tanks, leak/spill sites, a contractors' soils area, radioactive waste ponds and impoundments, and chemical and sewage waste treatment facilities. WAG 8 includes the Molten Salt Reactor Experiment (MSRE) facility, the High Flux Isotope Reactor, and the Radiochemical Engineering Development Center. A removal action was conducted at the MSRE during 1995. 
Radioactive wastes from these facilities are collected in on-site LLLW tanks and periodically pumped to the main plant area (WAG 1) for storage and treatment. The waste includes demineralizer backwash, regeneration effluents, decontamination fluids, experimental coolant, and drainage from the compartmental areas of filter pits.

WAG 9 is located in Melton Valley about $1 \mathrm{~km}(0.6$ miles) southeast of the ORNL main plant area and adjacent to WAG 8 . WAG 9 is composed of eight SWMUs: including the Homogeneous Reactor Experiment pond, which was used from 1958 to 1961 to hold contaminated condensate and shield water from the reactor, and LLLW collection and storage tanks, which were used from 1957 to 1986.

Because of the small number of groundwater monitoring wells in WAG 8 and WAG 9, they are sampled together. The analytical results for the two WAGs are also reported together.

\section{WAG 10}

WAG 10 consists of the Old Hydrofracture Facility (OHF) grout sheets, New Hydrofracture Facility, and New Hydrofracture grout sheets. The surface facilities are associated with WAGs 5,7 , and 8 .

Hydrofracture Experiment Site 1 is located within the boundary of WAG 7 (south of Lagoon Road) and was the site of the first experimental injection of grout (October 1959) as a testing program for observing the fracture pattern created in the shale and for identifying potential operating problems. Injected waste was water tagged with ${ }^{137} \mathrm{Cs}$ and ${ }^{141} \mathrm{Ce}$. Grout consisted of diatomaceous earth and cement.

Hydrofracture Experiment Site 2 is located about $0.8 \mathrm{~km}(0.5 \mathrm{mile})$ south of the 7500 (experimental reactor) area (WAG 8). The second hydrofracture experiment was designed to duplicate, in scale, an actual disposal operation; however, radioactive tracers were used instead of actual waste. Cement, bentonite, and water tagged with ${ }^{137} \mathrm{Cs}$ were used in formulating the grout.

The OHF is located about $1.6 \mathrm{~km}$ (1.0 mile) southwest of the main ORNL complex near the southwest comer of WAG 5 . The facility, commissioned in 1963, disposed of liquid radioactive waste in impermeable shale formations by hydrofracture methods, at depths of 800 to $1000 \mathrm{ft}$. Wastes used in the disposal operations included concentrated LLLW from the Gunite tanks in WAG $2,{ }^{90} \mathrm{Sr},{ }^{137} \mathrm{Cs},{ }^{244} \mathrm{Cm}$, TRU, and other, unidentified radionuclides.

The New Hydrofracture Facility is located $900 \mathrm{ft}$ southwest of the OHF on the south side of Melton Branch. The facility was constructed to replace the OHF. Wastes used in the injections were concentrated LLLW and sludge removed from the Gunite tanks, ${ }^{90} \mathrm{Sr},{ }^{137} \mathrm{Cs},{ }^{244} \mathrm{Cm}$, TRU, and other nuclides. Plans to plug and abandon several deep injection wells at WAG 10 were made in 1995.

\section{White Wing Scrap Yard (WAG 11)}

The White Wing Scrap Yard (WAG 11), a largely wooded area of about 30 acres, is located in the McNew Hollow area on the western edge of East Fork Ridge. It is $1.4 \mathrm{~km}$ ( 0.9 miles) east of the junction of White Wing Road and the Oak Ridge Turnpike. Geologically, the White Oak thrust fault bisects WAG 11. Lower-Cambrian-age strata of the Rome Formation occur southwest of the fault and overlie the younger Ordovician-age Chickamauga Limestone northeast of the fault. There is only one SWMU in WAG 11.

The White Wing Scrap Yard was used for aboveground storage of contaminated material from ORNL, the K-25 Site, and the Y-12 Plant. The material stored at the site by ORNL consisted largely of contaminated steel tanks; trucks; earth-moving equipment; assorted large pieces of steel, stainless steel, and aluminum; and reactor cell vessels removed during cleanup of Building 3019. An interim record of decision was agreed to by the TDEC, EPA, and DOE requiring surface debris to be removed from the site. This work was completed in 1994.

The area began receiving material (primarily metal, glass, concrete, and trash with alpha, beta, and gamma contamination) in the early 1950 s. Information regarding possible hazardous waste contamination has not been found. The 
precise dates of material storage are uncertain, as is the time when the area was closed to further storage. In 1966, efforts were begun to clean up the area by disposing of contaminated materials in ORNL's SWSA 5 and by the sale of uncontaminated material to an outside contractor for scrap. Cleanup continued at least into 1970 , and removal of contaminated soil began in the same year. Some scrap metal, concrete, and other trash are still located in the area. Numerous radioactive areas, steel drums, and PCB-contaminated soil were identified during surface radiological investigations conducted during 1989 and 1990 at WAG 11. The amount of material or contaminated soil remaining in the area is not known.

\section{Groundwater Quality Well Installation, Development, and Sampling Activities}

Groundwater quality monitoring wells for the WAGs are designated as hydraulically upgradient or downgradient (perimeter), depending on their location relative to the general direction of groundwater flow. Upgradient wells are located to provide groundwater samples that are not expected to be affected by possible leakage from the site. Downgradient wells are positioned along the perimeter of the site to detect possible groundwater contaminant migration from the site. There are no groundwater quality monitoring wells installed for the WAG 10 grout sheets.

A summary of the groundwater surveillance program is presented in Table 7.6. RCRA assessment data for WAG 6 were submitted to TDEC in March 1995. As part of the WAG 6 RCRA/CERCLA integrated monitoring approach, RCRA assessment groundwater monitoring continued during 1995 under the auspices of the Environmental Monitoring Plan (EMP) for WAG 6 at ORNL, a CERCLA driver monitoring plan, agreed to in principle by DOE, EPA, and TDEC in June 1994. Baseline groundwater monitoring under the EMP was initiated in October 1994 and ended in September 1995. All 24 RCRA groundwater monitoring wells were sampled with the following recency: eight quarterly and 16 semiannually. Routine groundwater monitoring conducted under the EMP was initiated in October 1995. A subset of 12 RCRA groundwater monitoring wells will be sampled on a semi-annual basis under the routine monitoring scenario. The 12 downgradient wells involved in routine monitoring are 835,837 , $841,842,843,844,4315,4316$, and 4317 . The remaining wells are located upgradient of the hazardous waste disposal area. These wells include 846,857 , and 858 . Under baseline and routine monitoring selected VOCs and radionuclides will be sampled for. The remaining WAGs are currently monitored to comply with DOE orders 5400.1 and 5400.5, which do not specify sampling schedules. ORNL samples groundwater quality wells at the remaining WAGs on a rotational basis.

The plant perimeter surveillance program, as stipulated in the EMP, was initiated in 1993. A summary of the program is presented in Table 7.7.

\section{ORNL Groundwater Quality}

The following section describes the 1995 groundwater monitoring results for the ORNL WAG perimeter monitoring network and the ORNL plant perimeter surveillance (about 200 sampling events). In a few cases, no samples could be collected because the wells were dry.

Eighteen of the 20 wells identified by the EMP represent ORNL's exit pathway and are also part of the WAG perimeter monitoring program (WAG s 2, 3, 6, 11, and 17). As such, 1995 result data from sampling conducted under the WAG perimeter program are used for the monitoring plan program. The other two wells (of the 20) were not sampled in 1995 because a decision is pending regarding installation of dedicated pumps in them. The four surface water locations (Bear Creek, Raccoon Creek, Bearden Creek, and WOC at WOD) were sampled in September 1995. The results of the plant perimeter monitoring program are discussed as part of the OU discussions.

Groundwater quality is regulated under RCRA by referring to the SDWA standards. The standards are applied when a site undergoes RCRA permitting. None of the ORNL WAGs 
Table 7.6. Summary of the groundwater surveillance program at ORNL, 1995

\begin{tabular}{|c|c|c|c|c|c|}
\hline \multirow[t]{2}{*}{ WAG } & \multirow[t]{2}{*}{ Regulatory status } & \multicolumn{2}{|c|}{ Wells } & \multirow[t]{2}{*}{ Parameters monitored $^{a}$} & \multirow{2}{*}{$\begin{array}{l}\text { Frequency and last date } \\
\text { sampled }\end{array}$} \\
\hline & & \multicolumn{2}{|c|}{ Upgradient Downgradient } & & \\
\hline \multicolumn{6}{|c|}{ Bethel Valley } \\
\hline 1 & $\begin{array}{l}\text { CERCLA and DOE } \\
\text { Orders } 5400.1 \text { and } \\
5400.5\end{array}$ & 3 & 24 & Standard & $\begin{array}{l}\text { Rotation } \\
\text { March } 1995\end{array}$ \\
\hline 3 & $\begin{array}{l}\text { DOE Orders } 5400.1 \text { and } \\
5400.5\end{array}$ & 3 & 12 & Standard & $\begin{array}{l}\text { Rotation } \\
\text { May } 1995\end{array}$ \\
\hline 17 & $\begin{array}{l}\text { DOE Orders } 5400.1 \text { and } \\
5400.5\end{array}$ & 4 & 4 & Standard & $\begin{array}{l}\text { Rotation } \\
\text { April } 1995\end{array}$ \\
\hline \multicolumn{6}{|c|}{ Melton Valley } \\
\hline 2 & $\begin{array}{l}\text { CERCLA and DOE } \\
\text { Orders } 5400.1 \text { and } \\
5400.5\end{array}$ & 12 & 8 & Standard & $\begin{array}{l}\text { Rotation } \\
\text { February } 1995\end{array}$ \\
\hline 4 & $\begin{array}{l}\text { CERCLA and DOE } \\
\text { Orders } 5400.1 \text { and } \\
5400.5\end{array}$ & 4 & 11 & Standard & $\begin{array}{l}\text { Rotation } \\
\text { January } 1995\end{array}$ \\
\hline 5 & $\begin{array}{l}\text { CERCLA and DOE } \\
\text { Orders } 5400.1 \text { and } \\
5400.5\end{array}$ & 2 & 20 & Standard & $\begin{array}{l}\text { Rotation } \\
\text { June } 1995\end{array}$ \\
\hline 6 & $\begin{array}{l}\text { RCRA/CERCLA and } \\
\text { DOE Orders } 5400.1 \text { and } \\
5400.5\end{array}$ & 7 & 17 & $\begin{array}{l}\text { Volatile organics, gross } \\
\text { alpha, gross beta, }{ }^{3} \mathrm{H},{ }^{137} \mathrm{Cs} \text {, } \\
{ }^{60} \mathrm{Co} \text {, total rad } \mathrm{Sr} \text { standard } \\
\text { field measurements }\end{array}$ & $\begin{array}{l}\text { Baseline monitoring: } \\
\text { January 1995-September } \\
\text { 1995, } 8 \text { wells quarterly, } \\
\text { 16 wells semiannually; } \\
\text { Routine monitoring: } \\
\text { October-December } 1995,12 \\
\text { wells semiannually }\end{array}$ \\
\hline 7 & $\begin{array}{l}\text { CERCLA and DOE } \\
\text { Orders } 5400.1 \text { and } \\
5400.5\end{array}$ & 2 & 14 & Standard & $\begin{array}{l}\text { Rotation } \\
\text { August } 1995\end{array}$ \\
\hline 8 and 9 & $\begin{array}{l}\text { DOE Orders } 5400.1 \text { and } \\
5400.5\end{array}$ & 2 & 9 & Standard ${ }^{b}$ & $\begin{array}{l}\text { Rotation } \\
\text { November } 1995\end{array}$ \\
\hline \multicolumn{6}{|c|}{ White Wing Scrap Yard } \\
\hline 11 & $\begin{array}{l}\text { DOE Orders } 5400.1 \text { and } \\
5400.5\end{array}$ & 6 & 5 & Standard & $\begin{array}{l}\text { Rotation } \\
\text { September } 1995\end{array}$ \\
\hline
\end{tabular}

a Standard: volatile and semivolatile organics, total organic carbon, total organic halides, metals, anions, total phenolics, total suspended solids, alkalinity, gross alpha and beta, ${ }^{3} \mathrm{H},{ }^{137} \mathrm{Cs},{ }^{60} \mathrm{Co}$, and total radioactive strontium. Standard field measurements: $\mathrm{pH}$, conductivity, turbidity, oxidation/reduction potential, temperature, and dissolved oxygen.

${ }^{b}$ Suite modified to discontinue semivolatile sample collection and analysis.

are under RCRA permits at this time; therefore, no permit standards exist with which to compare sampling results. In an effort to provide a basis for evaluation of analytical results and for assessment of groundwater quality at ORNL WAGs, federal DWSs and Tennessee water quality criteria for domestic water supplies are used as reference values in the following discussions. When no federal or state standard has been established for a radionuclide, then
$4 \%$ of the DOE DCG has been used. Although DWSs are used, it is unrealistic to assume that members of the public are going to drink groundwater from ORNL WAGs. There are no groundwater wells furnishing drinking water to personnel at ORNL. 
Table 7.7. Summary of the plant perimeter surveillance program at ORNL, $1995^{a}$

\begin{tabular}{lccl}
\hline \multicolumn{1}{c}{ Exit pathway } & WAG & Number of wells & \multicolumn{1}{c}{ Surface water locations } \\
\hline White Oak Creek/Melton Valley & 6 and $2^{b}$ & 10 & White Oak Creek at White Oak Dam \\
West Bethel Valley & 3 & 3 & Raccoon Creek \\
East Bethel Valley & 17 & 4 & Bearden Creek \\
White Wing Scrapyard & 11 & 3 & Bear Creek \\
& \\
& ${ }^{6}$ All locations are monitored for volatile organics, tritium, total radioactive strontium, gross alpha and beta, \\
& \\
Co, and ${ }^{137}$ Cs. \\
bour wells are part of the ORNL WAG 6 perimeter network, and four wells are part of the ORNL. WAG \\
2 perimeter network. Two other wells were not sampled in 1995, pending a decision regarding installation of \\
dedicated pumps in them (wells 1236 and 1239).
\end{tabular}

\section{Bethel Valley}

\section{WAG 1}

In 1995, as in the past, radionuclides have been detected in a number of WAG 1 wells, with gross beta activity and total radioactive strontium above DWSs at a few (three) wells. The highest levels of radioactivity have historically been observed in the same five wells: one in the northwest WAG area and four in the southwest and western WAG area. During 1995, four wells were unable to be sampled due to construction activities, including two of the wells which historically have had high levels of radioactivity.

The gross beta activity at the wells of concern is attributable mainly to total radioactive strontium and its daughters. Gross alpha activity at WAG 1 ranged from below detection to $4.3 \mathrm{pCi} / \mathrm{L}$; beta activity ranged from below detection to $270 \mathrm{pCi} / \mathrm{L}$ (the DWS is $50 \mathrm{pCi} / \mathrm{L}$ ); and total radioactive strontium ranged from below detection to $140 \mathrm{pCi} / \mathrm{L}$ (the DWS is $8 \mathrm{pCi} / \mathrm{L})$. All of these much lower than values which have been observed in the past; however, two of the wells which have traditionally had high levels of radioactivity were not sampled this year.

VOCs were detected in some of the wells; however, most of these were also detected in the laboratory blanks. One well had vinyl chloride detected above DWSs and this well has had similar vinyl chloride concentrations in the past.

Fluoride at one well was detected above DWSs; this is the third time fluoride has exceeded the DWS. No well values for metals exceeded DWSs.

\section{WAG 3}

Analytical results for 1995 at WAG 3 are similar to those obtained in the previous 4 years. WAG 3 is located on a north-facing slope, with its upgradient wells to the south. The long axis of the site runs east to west; consequently, most of the downgradient wells are along the northern border.

Strontium has been detected historically in wells along the entire northern perimeter of the site. Values exceeding the primary DWS for total radioactive strontium and gross beta activity have consistently been observed at four wells in every sampling event. The gross beta signatures are mainly attributable to total radioactive strontium. The data for the wells along the eastern and northeastern boundaries show evidence of radioactive contamination, including ${ }^{3} \mathrm{H}$ and gross alpha activity. The data for the northwest boundary show the presence of ${ }^{3} \mathrm{H}$.

Gross alpha activity at WAG 3 ranged from not being detected to $12 \mathrm{pCi} / \mathrm{L}$ (the DWS is $15 \mathrm{pCi} / \mathrm{L}$ ); beta activity ranged from not being detected to $1500 \mathrm{pCi} / \mathrm{L}$ (the DWS is $50 \mathrm{pCi} / \mathrm{L}$ ); and total radioactive strontium ranged from not being detected to $970 \mathrm{pCi} / \mathrm{L}$ (the DWS is $8 \mathrm{pCi} / \mathrm{L}$ ). Tritium ranged from not being detected to $19,000 \mathrm{pCi} / \mathrm{L}$ (the DWS is $20,000 \mathrm{pCi} / \mathrm{L}$ ).

In a few of the downgradient wells, VOCs were detected. Trichloroethene has consistently been detected above DWSs in every sampling event at one well located in the northeast part of the WAG. 


\section{WAG 17}

WAG 17 is located on a northwest-facing slope, with its upgradient wells on the eastern border and downgradient wells on the western border. Although none of the wells had radiological levels above any DWSs, the data for wells along the eastern and western boundaries show evidence of radioactivity, including gross beta activity and ${ }^{3} \mathrm{H}$. In the past, gross alpha activity has exceeded the DWS at two wells; however, this has not occurred in 1994 or 1995 . The highest gross alpha activity was $13 \mathrm{pCi} / \mathrm{L}$; gross beta was $6.8 \mathrm{pCi} / \mathrm{L}$; total radioactive strontium was $5.4 \mathrm{pCi} / \mathrm{L}$; and ${ }^{3} \mathrm{H}$ was $8600 \mathrm{pCi} / \mathrm{L}$.

The data for the wells along the southeastern and southwestern boundaries show evidence of VOCs. The contamination has consistently been located primarily in one well. The pollutants include trichloroethene, 1,2-dichloroethene, vinyl chloride, tetrachloroethene, 1,1-dichloroethene, and benzene.

\section{Exit Pathway}

Historically, no wells in the East and West Bethel Valley exit pathways have had VOC or radiological constituents detected above any DWSs. At the East Bethel Valley surface-water location, neither VOCs nor radiological constituents were detected above any DWS. In the West Bethel Valley exit pathway, gross beta activity and total radioactive strontium were detected above DWSs at the Raccoon Creek surface water location, 145 and $67 \mathrm{pCi} / \mathrm{L}$, respectively. One of the three wells in the West Bethel Valley exit pathway has always been dry when sampled; a second well was also dry at the time of the 1995 sampling.

\section{Melton Valley}

\section{WAG 2}

At WAG 2, most of the downgradient wells are to the west and downstream. The upgradient wells are to the east and upstream. WAG 2 is influenced by other WAGs, and this seems to be reflected in the analytical results. Major contributors of ${ }^{3} \mathrm{H}$ and total radioactive strontium to WAG 2 (in order of contribution) are WAGs 5 , $8,9,4,1,6$, and 7 .

For example, four of the WAG 2 wells that exhibited high levels of ${ }^{3} \mathrm{H}$ are located south of and downgradient of WAGs 5,6, and 8. All of the WAG 2 wells show evidence of radioactivity, including gross alpha and gross beta activity and ${ }^{3} \mathrm{H}$. Gross beta activity above primary DWSs was detected at one well on the west side of WAG 7 and at one well south of WAG 6 . The elevated levels of ${ }^{3} \mathrm{H}$ and total radioactive strontium in the perimeter wells at WOD are believed to be the result of surface-water underflow at the dam, not groundwater contamination. Gross alpha activity at WAG 2 ranged from not being detected to $12 \mathrm{pCi} / \mathrm{L}$ (the DWS is $15 \mathrm{pCi} / \mathrm{L}$ ); beta activity ranged from not being detected to $780 \mathrm{pCi} / \mathrm{L}$ (the DWS is $50 \mathrm{pCi} / \mathrm{L}$ ); and total radioactive strontium ranged from not being detected to $320 \mathrm{pCi} / \mathrm{L}$ (the $\mathrm{DWS}$ is $8 \mathrm{pCi} / \mathrm{L}$ ). Tritium ranged from not being detected to $350,000 \mathrm{pCi} / \mathrm{L}$ (the DWS is $20,000 \mathrm{pCi} / \mathrm{L}$ ).

Chromium and nickel were detected above DWS at a well south of WAG 6. The nickel result was only slightly above DWS and has not been above a standard since 1992. Chromium has been above DWS the past 3 sampling events, and this year it is two and one half times the historical maximum.

\section{WAG 4}

In 1995, as in the past, radionuclides (including gross beta activity, total radioactive strontium, and ${ }^{3} \mathrm{H}$ ) have been detected in a number of WAG 4 wells. The highest levels of radioactivity continue to be observed in the same six wells along the eastern boundary. Gross alpha activity at WAG 4 ranged from not being detected to $6.8 \mathrm{pCi} / \mathrm{L}$ (the $\mathrm{DWS}$ is $15 \mathrm{pCi} / \mathrm{L}$ ); beta activity ranged from not being detected to $1500 \mathrm{pCi} / \mathrm{L}$ (the DWS is $50 \mathrm{pCi} / \mathrm{L}$ ); and total radioactive strontium ranged from not being detected to $590 \mathrm{pCi} / \mathrm{L}$ (the DWS is $8 \mathrm{pCi} / \mathrm{L}$ ). Tritium ranged from not being detected to $7.8 \times 10^{6} \mathrm{pCi} / \mathrm{L}$ (the $\mathrm{DWS}$ is $20,000 \mathrm{pCi} / \mathrm{L}$ ).

VOCs continue to be detected in wells on the eastern boundary. Two wells have

\section{7-44 Groundwater}


consistently had VOC concentrations above DWSs.

\section{WAG 5}

The results for 1995 sampling are similar to results from previous sampling events. WAG 5 contributes a significant percentage of the ${ }^{3} \mathrm{H}$ and total radioactive strontium that exits the ORNL site at WOD via Melton Branch. Tritium contamination is particularly prevalent in one well on the southern and western boundaries, with values as high as $3.2 \times 10^{8} \mathrm{pCi} / \mathrm{L}$.

Total radioactive strontium appears to be the major beta emitter found in WAG 5 groundwater. It is found mainly in one well on the southern perimeter. Alpha activity above DWSs has historically been consistently observed in one well on the northwestern boundary of the WAG. This well was pumped dry in 1994 and in 1995 it was sampled and gross alpha was slightly less than DWS.

Gross alpha activity at WAG 5 ranged from not being detected to $14 \mathrm{pCi} / \mathrm{L}$ (the DWS is $15 \mathrm{pCi} / \mathrm{L}$ ); beta activity ranged from not being detected to $1800 \mathrm{pCi} / \mathrm{L}$ (the DWS is $50 \mathrm{pCi} / \mathrm{L}$ ); and total radioactive strontium ranged from not being detected to $840 \mathrm{pCi} / \mathrm{L}$ (the DWS is $8 \mathrm{pCi} / \mathrm{L})$.

VOCs were detected in the wells along the southern and western boundaries, including vinyl chloride, 1,2-dichloroethene, acetone, carbon disulfide, benzene, and trichloroethene. Several wells have consistently exceeded DWSs for these contaminants.

No upgradient wells exceeded DWSs for radioactivity or volatile organics.

\section{WAG 6}

Results obtained during 1995 were comparable to past results. VOC contamination is apparently isolated in the area around a pair of wells in the northeastern corner of the WAG. During 1995, carbon tetrachloride, and trichloroethene were detected above DWSs at one of these wells in every sampling event.

Elevated levels of ${ }^{3} \mathrm{H}$ are found in wells along the eastern perimeter. Gross alpha activity at WAG 6 ranged from not being detected to
$21 \mathrm{pCi} / L$ (the DWS is $15 \mathrm{pCi} / \mathrm{L}$ ); and total radioactive strontium ranged from not being detected to $54 \mathrm{pCi} / \mathrm{L}$ (the DWS is $8 \mathrm{pCi} / \mathrm{L}$ ). Tritium ranged from not being detected to $3.5 \times 10^{6} \mathrm{pCi} / \mathrm{L}$ (the DWS is $20,000 \mathrm{pCi} / \mathrm{L}$ ).

\section{WAG 7}

In 1995, tritium was detected in more than half of the wells but was highest in wells along the western perimeter next to SWSA 6 .

Gross alpha activity was detected at one well in excess of primary DWSs. Isotopic identification shows this activity to be attributed to ${ }^{241} \mathrm{Am},{ }^{238} \mathrm{Pu},{ }^{239} \mathrm{Pu},{ }^{228} \mathrm{Th},{ }^{230} \mathrm{Th},{ }^{234} \mathrm{U},{ }^{235} \mathrm{U}$, and ${ }^{238} \mathrm{U}$. Gross alpha activity ranged from not being detected to $210 \mathrm{pCi} / \mathrm{L}$.

Gross beta activity was detected at levels in excess of primary DWSs at four wells, and ${ }^{3} \mathrm{H}$ was detected at each of these wells, also above DWSs. Gross beta activity ranged from not being detected to $6200 \mathrm{pCi} / \mathrm{L}$; total radioactive strontium ranged from not being detected to $4.6 \mathrm{pCi} / \mathrm{L}$; and ${ }^{3} \mathrm{H}$ ranged from not being detected to $380,000 \mathrm{pCi} / \mathrm{L}$.

Three wells have consistently had nitrate detected at levels that exceed primary DWSs. One well had fluoride above DWS, consistent with historical values. Minimal VOC contamination has been detected in the WAG 7 wells.

\section{WAGs 8 and 9}

The two upgradient wells are located north of the WAG s, two of the downgradient wells are located northwest of the WAGs, two are located south of WAG 8 , and the remaining five are in WAG 8 west of WAG 9 and in WAG 9. The analytical results for 1995 are comparable to results from the previous years.

All of the perimeter wells show evidence of radioactivity. The data indicate that the gross beta activity is attributable to total radioactive strontium. The two wells on the northwestern perimeter exceeded DWSs: one well with respect to ${ }^{3} \mathrm{H}$ contamination and the other with respect to gross beta activity and total radioactive strontium contamination. Gross alpha activity ranged from not being detected to $4.6 \mathrm{pCi} / \mathrm{L}$ (the DWS is 
$15 \mathrm{pCi} / \mathrm{L})$; beta activity ranged from not being detected to $3800 \mathrm{pCi} / \mathrm{L}$ (the $\mathrm{DWS}$ is $50 \mathrm{pCi} / \mathrm{L}$ ); and total radioactive strontium ranged from not being detected to $1300 \mathrm{pCi} / \mathrm{L}$ (the DWS is $8 \mathrm{pCi} / \mathrm{L})$. Tritium ranged from not being detected to $59,000 \mathrm{pCi} / \mathrm{L}$ (the DWS is $20,000 \mathrm{pCi} / \mathrm{L}$ ).

Total radioactive strontium and gross beta activity levels exceeded the DWSs at the two WAG 9 wells.

VOCs were detected at downgradient wells, all below DWSs. One well has historically shown trichloroethene above DWSs; this year it did not. None of the data for the upgradient wells show evidence of VOCs.

\section{Exit Pathway}

In the Melton Valley exit pathway, WOC at WOD had gross beta activity $(170 \mathrm{pCi} / \mathrm{L})$, total radioactive strontium $(60 \mathrm{pCi} / \mathrm{L})$, and ${ }^{3} \mathrm{H}$ concentrations $(27,000 \mathrm{pCi} / \mathrm{L})$ detected above the DWSs. One of the wells also had gross beta activity, total radioactive strontium, and ${ }^{3} \mathrm{H}$ concentrations detected above DWSs; a second well had ${ }^{3} \mathrm{H}$ concentrations detected above DWSs. This is consistent with historical data in both cases. No VOCs were detected above DWSs in either the wells or the surface-water location.

\section{White Wing Scrapyard (WAG 11)}

WAG 11 has gently rolling terrain, and the upgradient wells are located north, east, and south of the WAG. Gross alpha activity and gross beta activity have been detected at low levels in wells along the entire perimeter of the site, including the upgradient wells. Tritium has been detected in some of the wells. No radiological constituents were detected in 1995 above DWSs. Gross alpha activity ranged from not being detected to $10 \mathrm{pCi} / \mathrm{L}$ (the DWS is $15 \mathrm{pCi} / \mathrm{L})$; beta activity ranged from not being detected to $21 \mathrm{pCi} / \mathrm{L}$ (the DWS is $50 \mathrm{pCi} / \mathrm{L}$ ); and total radioactive strontium ranged from not being detected to $4.1 \mathrm{pCi} / \mathrm{L}$ (the $\mathrm{DWS}$ is $8 \mathrm{pCi} / \mathrm{L}$ ). Tritium ranged from not being detected to $1000 \mathrm{pCi} / \mathrm{L}$ (the DWS is $20,000 \mathrm{pCi} / \mathrm{L}$ ).

Two wells had trichloroethene detected above DWSs, which is consistent with historical data for these two wells. No other VOCs were detected in those wells.

\section{Exit Pathway}

In the White Wing Scrapyard exit pathway, one well had trichloroethene levels above DWSs. None of the wells or the surface water location considered in this exit pathway had radionuclide concentrations above DWSs.

\section{Well Plugging and Abandonment at ORNL}

The purpose of the ORNL well plugging and abandonment program is to remove unneeded wells and boreholes as a possible source of cross-contamination of groundwater from the surface or between geological formations. Because of the complex geology and groundwater pathways at ORNL, it has been necessary to drill many wells and boreholes to establish the information base needed to predict groundwater properties and behavior. However, many of the wells that were established before the 1980s were not constructed satisfactorily to serve current long-term monitoring requirements. Where existing wells do not meet monitoring requirements, they become candidates for plugging and abandonment.

\section{Wells Plugged During 1995}

No wells were plugged and abandoned at ORNL during 1995. A total of 232 wells have been recommended for plugging and abandonment as soon as funds are available.

\section{Methods Used}

Plugging and abandonment is accomplished by splitting the existing well casing and filling the casing and annular voids with grout or bentonite to create a seal between the ground surface and water-bearing formations and between naturally isolated water-bearing formations.

Splitting and abandoning the well casing in place also minimizes the generation of waste that would be created if other methods were used. 
Special tools were developed to split the casings of different sizes and material. A down-hole camera was used during development of the splitting tools to evaluate their effectiveness.

Detailed procedures have been developed and documented regarding the use of specific grout materials in different well environments. These procedures were tested and evaluated during the 1993 plugging and abandonment activities.

\section{GROUNDWATER MONITORING AT THE K-25 SITE}

\section{Background and Hydrogeologic Setting}

Groundwater effluent monitoring at the $\mathrm{K}-25$ Site is focused primarily on investigating and characterizing sites for remediation under CERCLA. As a result of the FFA and certification of closure of the K-1407-B and C ponds, the principal driver at the K-25 Site is CERCLA.

The K-25 Site Groundwater Program is a component in the ORR ER strategy described in the ORR Site Management Plan for the ER Program (DOE 1995). The cleanup strategy described in the site management plan has been developed to accelerate the transition of areas of concern from characterization to remediation by making decisions at the watershed scale based on recommended land use. The watershed is a surface drainage basin that includes an area of concern or group of areas of concern to be investigated and/or remediated. This approach allows for systematic monitoring and evaluation of contaminant sources and migration through the use of integrated surface water and groundwater monitoring.

Only one watershed has been designated at the K-25 Site. In this report, WAG boundaries defined to correspond with perceived hydrogeologic boundaries are used for reporting the results of groundwater monitoring. The WAG designations and associated areas of concern are described in the following section.

Unlike the other ORR facilities, where many source areas are located in relatively undeveloped areas of the reservation, most of the source areas at the K-25 Site are located within the highly industrialized areas of the site. The surface topography has been altered considerably as a result of site construction. Large areas have been excavated or filled to yield the present low-relief landscape. As much as $60 \mathrm{ft}(18.3 \mathrm{~m})$ of materials have been excavated locally, and equal amounts of fill have been placed in adjacent low areas. Where they extend below the water table, the filled areas may represent primary pathways for contaminant migration. A number of sinkholes identified in historical photographs are not visible on the surface today. Many have been filled during construction, and buildings (such as $\mathrm{K}-33$ ) have been erected directly above them.

The storm drain network discharges to Mitchell Branch, the K-1007-P1 pond, the K-901A Holding Pond, or directly to Poplar Creek and the Clinch River. Storm drain video surveys show water flowing both in and out of the storm drain system, suggesting that the storm drains may serve as groundwater sinks or as sources. In addition, at least ten buildings have basements with sumps below the seasonal low water table. Water that accumulates in the sumps is discharged to the sanitary sewer or CNF system, storm drains, or, in rare occasions, to the ground. All of these systems have been active since the construction in the 1940s.

Bedrock underlying the K-25 Site can be broadly categorized as carbonate (Knox and Chickamauga groups) or clastic (Rome formation and possibly the Conasauga group). The carbonates underlie most of the main plant area, including the K-27/29 Peninsula K-1070-A Burial Ground, the K-25 Building, and the K-1004 laboratory area. The eastern portion of the site, including the K-1070-C/D Burial Ground and much of the Mitchell Branch area, is underlain by clastics of the Rome formation and possibly the Conasauga group. The structural geology of the K-25 Site is perhaps the most complicated on the ORR. It includes "map-scale" folds and faults and "outcrop-scale" fractures, folds, and faults. Complex faulting, fracturing, and folding in the clastic bedrock precludes definition of simple 
bedding geometry. Therefore, groundwater flow paths cannot be predicted in this area of the site.

Cavities have been encountered in $39 \%$ of all subsurface penetrations at the K-25 Site. Cavity heights are typically greater in the Knox group carbonates. Recent drilling activities in the vicinity of the K-1070-A Burial Ground have encountered cavernous bedrock with cavities up to $22 \mathrm{ft}(6.7 \mathrm{~m})$ in height; however, based on camera and sonar surveys, the lateral extent of these cavities appears limited. Although large cavities have been reported in some locations in the Chickamauga bedrock, typical cavity heights are generally less than $5 \mathrm{ft}(1.5 \mathrm{~m})$.

Groundwater occurs in both the unconsolidated zone and bedrock, primarily as a single water table aquifer. Perched water may be of local significance. With few exceptions, the water table occurs in the overburden above bedrock across the site, with saturated overburden thickness ranging up to $70 \mathrm{ft}(21.4 \mathrm{~m})$. Because bedrock is exposed along the bottom of the Clinch River and Poplar Creek, the unconsolidated-zone flow paths are truncated at these boundaries. Surveys indicate that groundwater flows radially from higher elevations toward the bounding surface water features; however, the sumps and drains that lie below the seasonal low water table affect the configuration of the water table surface and thus affect the contaminant flow paths.

Groundwater flow in the unconsolidated zones is expected to be in the direction of the mapped hydraulic gradients. In the carbonate bedrock, groundwater flow is expected to be controlled by hydraulic gradients and geologic strike. In the Rome Formation groundwater flow directions cannot be predicted with any certainty. Recent studies have shown that hydraulic gradients are steepest (and consequently, overall flux is greatest) during the wet season and low pool stage periods. Much of the site is paved or otherwise covered, reducing direct recharge by groundwater; however, leaking underground utilities and storm drains are likely to recharge the groundwater substantially.

No perennial springs have been identified along Poplar Creek or the Clinch River. Wet-season springs located along the exposed low pool stage shores of Poplar Creek and the Clinch River do not appear consistently from year to year. It is unlikely that the karst features were active before the impoundment of the Clinch River. It is believed that since that time, however, the dramatic increase in base-level heads has resulted in a "backed-up" karst flow system. Consequently, the presence of karst features at the K-25 Site does not seem to indicate conduit-dominated groundwater flow.

\section{Waste Area Groupings}

The K-25 Site WAGs used for reporting groundwater-monitoring results are described in the following sections and are indicated on Fig. 7.21.

\section{South Main Plant Area}

The south main plant area encompasses the southem area of the K-25 Site and includes the K-1004-J vaults, the K-1004-L UST, the $\mathrm{K}-1004-\mathrm{L}$ recirculating cooling water ( $\mathrm{RCW}$ ) lines, the K-1004 cooling tower basin, the K-1004 laboratory drain, the K-1007-P1 pond, and the K-1007 UST. Potential contaminants include heavy metals, ac is, organic solvents, other organic chemicals, ind radionuclides.

\section{North Main Plant Area}

The north main plant area encompasses the northeastern portion of the K-25 Site and includes the K-1407-A neutralization pit, the former $\mathrm{K}-1407-\mathrm{B}$ and $\mathrm{C}$ ponds, the K-1407-C soil, the K-1700 stream (Mitchell Branch), the $\mathrm{K}-1070$-B old classified burial ground, the $\mathrm{K}-1401$ acid line, the $\mathrm{K}-1401$ degreasers, the $\mathrm{K}-1401$ basement, the K-1413 neutralization pit, the $\mathrm{K}-1420$ building process lines, the $\mathrm{K}-1420$ oil storage area, the K-1420 incinerator, the K-1413 treatment tanks, the $\mathrm{K}-1413$ building and process lines, the K-1070-C/D classified burial ground, the K-1070 concrete pad, the K-1070-D storage dikes, the K-1070 pits, and the K-1414 garage. The potential contaminants include organic solvents, waste oils, heavy metals, PCBs, and radionuclides. 


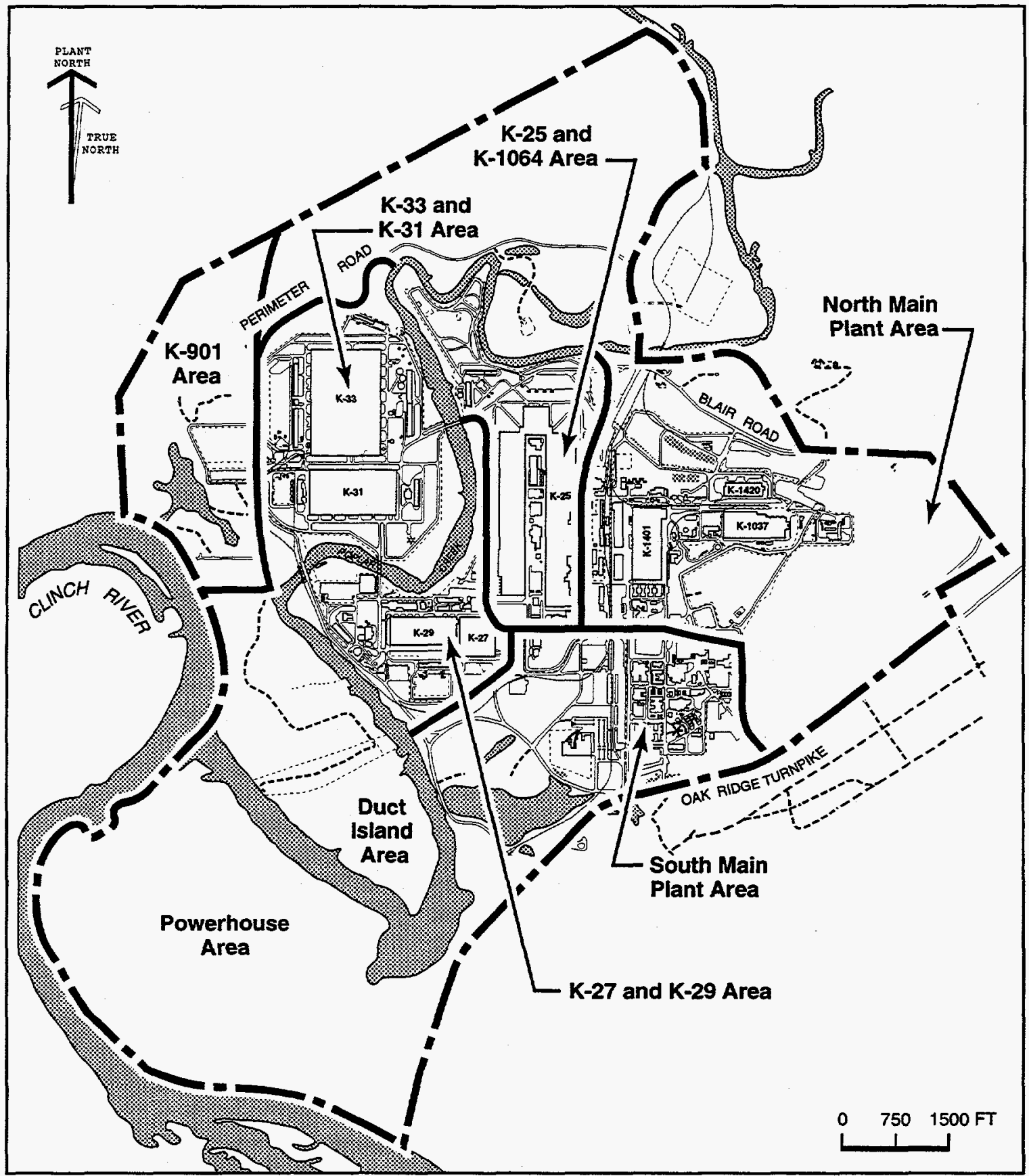

Fig. 7.21. K-25 Site waste area groupings.

\section{K-25 and K-1064 Area}

The K-25 and K-1064 area encompasses the $\mathrm{K}-25$ building and the area north and northwest of the building. AOCs include the K-1066-J cylinder storage yard, K-1024 dilution pit, $\mathrm{K}-1024$ storage areas, $\mathrm{K}-1064$ drum storage and burn area, K-1064 drum deheading facility, and the $\mathrm{K}-802-\mathrm{B}$ and $\mathrm{K}-802-\mathrm{H}$ cooling tower basins. Potential contaminants include waste oils, heavy metals, organic solvents, and radionuclides.

\section{K-33 and K-31 Area}

The K-33 and K-31 area encompasses the area around these two buildings and includes 
the K-892-G, K-892-H, K-892-J, and K-862-E cooling tower basins; the K-31 and K-33 RCW lines; and the K-762 and K-792 switchyards. Potential contaminants are primarily heavy metals, $\mathrm{PCBs}$, and radionuclides.

\section{K-27 and K-29 Area}

The K-27 and K-29 area consists of the $\mathrm{K}-27 / 29$ peninsula in the southwestern portion of the main plant area. AOCs include the $\mathrm{K}-27$ and $\mathrm{K}-29 \mathrm{RCW}$ lines, the $\mathrm{K}-832-\mathrm{H}$ cooling tower basin, the K-732 switchyard, the K-1410 neutralization pit, the K-1131 facility, the K-1232 chemical recovery facility lagoon, and the $\mathrm{K}-1231$ facility. The potential contaminants include organic chemicals, heavy metals, PCBs, and radionuclides.

\section{K-901 Area}

The K-901 area encompasses the northwestern portion of the K-25 Site and includes the K-1070-A burial ground, the $\mathrm{K}-1070$-A landfarm, the K-901-A holding pond, and the $\mathrm{K}-1066-\mathrm{K}$ cylinder storage yard. Potential contaminants are organic chemicals, heavy metals, PCBs, and radionuclides.

\section{Duct Island Area}

The Duct Island area consists of the K-1070-F peninsula on Poplar Creek and contains the $\mathrm{K}-1070-\mathrm{F}$ contractor's burial ground. Potential contaminants are heavy metals, organic chemicals, and uranium.

\section{Powerhouse Area}

The Powerhouse area borders the Clinch River in the southwestern portion of the K-25 Site. AOCs include the K-770 scrap yard, the K-725 beryllium building, and the K-1085 firehouse burn area. The potential contaminants are waste oils, organic chemicals, heavy metals, PCBs, and radionuclides.

\section{Well Installation and Plugging and Abandonment Activities}

At the end of 1995 there were a total of 241 water quality monitoring wells at the K-25 Site. Installation of 17 new monitoring wells was completed in early 1995 . These wells were installed as part of the focused remedial investigation at the $\mathrm{K}-1070-\mathrm{A}$ burial ground in the K-901 area.

No wells were plugged or abandoned during 1995 at the K-25 Site. A detailed evaluation of existing wells to identify candidates for plugging and abandonment will likely be conducted at some time in the future. Wells no longer required for monitoring or wells whose construction or annular seal integrity are in doubt will be designated at that time for plugging and abandonment.

\section{Groundwater Monitoring Program}

In 1995 groundwater samples were collected at the K-25 Site from 200 monitoring wells during February, March, and April, and from 204 wells during September and October. Samples were collected using micropurge and low-flow sampling procedures. Field measurements of temperature, specific conductance, $\mathrm{pH}$, dissolved oxygen, oxidation/reduction potential, and turbidity were collected at each well during sampling. The samples collected between February and April were analyzed for volatile and semivolatile organic chemicals, metals, radioactivity, pesticides, herbicides, PCBs, cyanide, and major ions. Because of the results of the 1994 and spring 1995 sampling events, the list of analytes was drastically reduced for the fall 1995 event as a cost-savings initiative. At most wells, semivolatile organic chemicals, pesticides, herbicides, PCBs, and cyanide were not detected and were eliminated from the analyte list for sampling during the fall of 1995 . These analyses were sought in samples from the few wells where they had been observed in the past. 


\section{Postremediation Monitoring}

Following completion of remedial actions at the former K-1407-B and C ponds in 1995, TDEC/DOE-OD and EPA recommended continued groundwater monitoring at two wells and one surface water location in Mitchell Branch for evaluating the effectiveness of remedial action at the site. The suite of analytes, consisting of constituents expected to be present in the former ponds, includes several metals and radiochemical parameters. Groundwater monitoring at the former $\mathrm{K}-1407-\mathrm{B}$ and $\mathrm{C}$ ponds commenced in the winter of 1996 , to satisfy postremediation requirements.

\section{Exit-Pathway Monitoring}

Exit-pathway groundwater surveillance monitoring is conducted at points where shallow groundwater flows from relatively large areas of the K-25 Site and converges before discharging to surface water locations. The exit-pathway groundwater surveillance network is illustrated in Fig. 7.22. The eight-well network monitors both the unconsolidated zone and bedrock and is supported by surface water monitoring at the weirs next to the monitoring well locations. Groundwater samples were collected from these wells during both of the 1995 sampling events.

\section{Groundwater Monitoring Results}

The following summary of the 1995 groundwater monitoring results focuses on those constituents that were detected at concentrations exceeding DWSs. The results are presented separately for each WAG. The results of the 1995 sampling program are consistent with historical results, which indicate that the primary groundwater contaminants are VOCs; to a lesser extent, radioactivity is found in some areas. Detection of trace metals or semivolatile organic chemicals is rare. The secondary DWSs for aluminum, iron, and manganese were consistently exceeded in wells throughout the K-25 Site because of the natural geochemical nature of the groundwater underlying the site.

\section{South Main Plant Area}

Groundwater samples were collected from 15 monitoring wells located in the south main plant area during 1995 . The primary groundwater contaminants in this portion of the site are VOCs. The predominant VOC detected in groundwater samples was trichloroethene, which exceeded the DWS in 6 of the 15 wells sampled. The maximum concentration of trichloroethene, $120 \mu \mathrm{g} / \mathrm{L}$, was detected during the fall sampling event in a bedrock well near the K-1004 laboratory. Tetrachloroethene exceeded the DWS in two wells in the south main plant area with a maximum concentration of $17 \mu \mathrm{g} / \mathrm{L}$.

Metals in groundwater that exceeded either a primary or secondary DWS include aluminum, chromium, iron, manganese, nickel, and thallium. The DWS for chromium was exceeded at one well during one sampling event. Nickel exceeded the DWS at three wells with a maximum reported concentration of $0.626 \mathrm{mg} / \mathrm{L}$. Thallium exceeded the DWS at two wells during 1995 with a maximum concentration of $0.005 \mathrm{mg} / \mathrm{L}$.

Gross alpha activity was not detected in any of the 15 monitoring wells during 1995. Gross beta activity did not exceed the reference level of $50 \mathrm{pCi} / \mathrm{L}$.

\section{North Main Plant Area}

Groundwater samples from 96 monitoring wells in the north main plant area were collected and analyzed in 1995. The primary contaminants detected were VOCs and radioisotopes. Eleven VOCs exceeded their respective DWSs in wells throughout the north main plant area. The most widespread constituents were trichloroethene and its degradation product (1,2-dichloroethene). Tricholoethene exceeded the DWS in 46 wells; the maximum concentration of $11,000 \mu \mathrm{g} / \mathrm{L}$ was reported for a well in the unconsolidated zone near the K-1070-C/D classified burial ground. The highest concentration of any VOC was also reported for this well at $140,000 \mu \mathrm{g} / \mathrm{L}$ of 1,1,1-trichloroethane. Other VOCs reported at concentrations greater than $1000 \mu \mathrm{g} / \mathrm{L}$ were 1,1-dichloroethene, 1,2-dichloroethene, toluene, and 1,1,2-trichloro-1,2,2-trifluoroethane. 


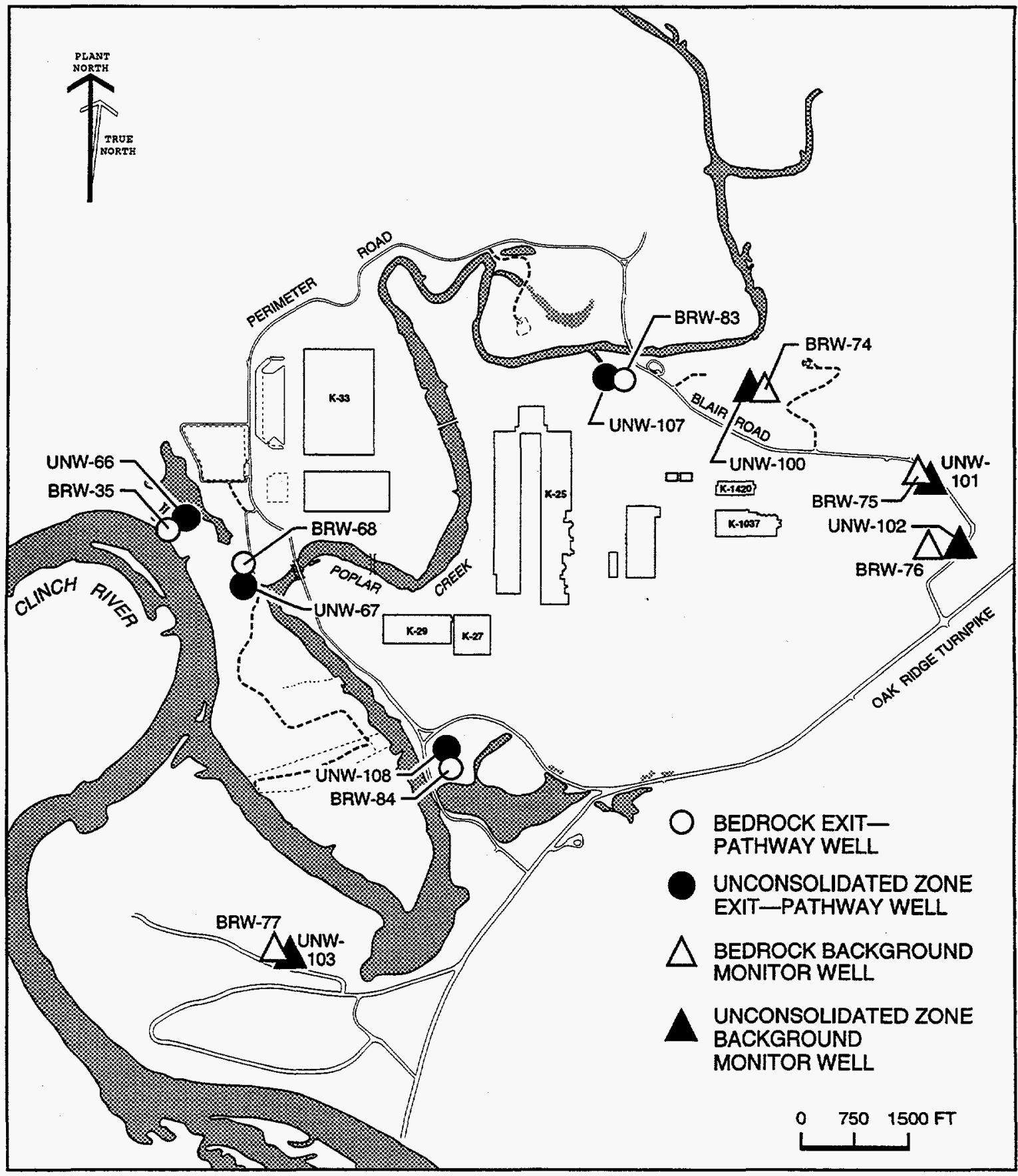

Fig. 7.22. Background and exit-pathway monitoring well locations at the K-25 Site.

The DWS for gross alpha was exceeded in one bedrock well and three unconsolidated-zone wells. Gross alpha activity ranged from 22.2 to $43.2 \mathrm{pCi} / \mathrm{L}$ (limits of error ranged from 5.1 to $8.7 \mathrm{pCi} / \mathrm{L}$ ). Uranium appears to be the primary alpha-emitting isotope present in groundwater in these four wells. Two of the wells are located along Mitchell Branch, one is near the K-1420 Building, and the fourth in the Blair Road Quarry.

Gross beta exceeded the reference value at seven wells within the north main plant area. Activity ranged from 86.1 to $528 \mathrm{pCi} / \mathrm{L}$ (limits of error ranged from 7.3 to $35 \mathrm{pCi} / \mathrm{L}$ ). The wells are 
located in the vicinity of the former K-1407-B and $C$ ponds and the $K-1070-C / D$ classified burial ground.

Metals detected at concentrations above a primary DWS included antimony, arsenic, barium, cadmium, nickel, and thallium. The DWSs for antimony, arsenic, cadmium, and nickel were each exceeded in one well. The DWS for barium was exceeded in two wells. The DWS for thallium was exceeded in six wells; however, this occurred only during the spring sampling event. The DWS for thallium was exceeded at one well during the fall sampling event. The secondary DWSs for aluminum, iron, and manganese were exceeded in numerous wells in this area. In addition, DWSs for chloride, nitrate, and sulfate were exceeded at one well each.

Semivolatile organic chemicals are present in some of the wells in the vicinity of the K-1414 garage. This area is the only location within the K-25 Site where semivolatile organic chemicals that are not common laboratory contaminants have been consistently detected in groundwater samples.

\section{K-25 and K-1064 Area}

Groundwater samples were collected from 11 monitoring wells in the K-25 and K-1064 area during 1995 . The primary groundwater contaminants detected were radioisotopes and VOCs. The predominant VOC detected, trichloroethene, exceeded the DWS in two wells. The concentration of trichloroethene ranged from 7 to $17 \mu \mathrm{g} / \mathrm{L}$. Benzene also exceeded the DWS at one well with a concentration of $6 \mu \mathrm{g} / \mathrm{L}$.

Gross alpha activity at levels exceeding the DWS was reported for four bedrock wells. The gross alpha activities ranged from 15.4 to $32.1 \mathrm{pCi} / \mathrm{L}$ (limits of error ranged from 5.3 to $8.2 \mathrm{pCi} / \mathrm{L}$ ). Based on the limit of error, two of the four wells may not exceed the DWS of $15 \mathrm{pCi} / \mathrm{L}$. Gross beta activity exceeding the reference level of $50 \mathrm{pCi} / \mathrm{L}$ was reported for one bedrock well during one sampling event. Gross beta activity was $60.1 \mathrm{pCi} / \mathrm{L}$ (limit of error of $6.3 \mathrm{pCi} / \mathrm{L}$ ) in well BRW-3 during the spring of 1995.
The primary DWSs for arsenic and lead were exceeded at one well each, but this exceedence occurred during only one of the two sampling events. Aluminum, iron, and manganese exceeded secondary DWSs at four wells. Fluoride and sulfate also exceeded DWSs at one well.

\section{K-33 and K-31 Area}

Groundwater samples were collected from 17 monitoring wells in the $\mathrm{K}-33$ and $\mathrm{K}-31$ area during 1995 . The primary contaminants detected were VOCs and metals. Trichloroethene concentrations exceeding a DWS were detected at two bedrock wells. Reported concentrations ranged from 10 to $43 \mu \mathrm{g} / \mathrm{L}$. Additional VOCs detected in monitoring wells, but not exceeding a DWS, include 1,1,1-trichloroethane, 1,1-dichloroethene, 1,2-dichloroethene, methylene chloride, and toluene.

Reported metals concentrations exceeding DWSs included aluminum, chromium, iron, manganese, nickel, and thallium. The primary DWS for chromium was exceeded at two bedrock wells, for nickel at one bedrock well and three unconsolidated-zone wells, and for thallium at one unconsolidated zone well.

Gross alpha activity and gross beta activity were detected in some monitoring wells; however, none of the reported activities exceeded a DWS.

\section{K-27 and K-29 Area}

Groundwater samples were collected from 18 monitoring wells in the $\mathrm{K}-27$ and $\mathrm{K}-29$ area in 1995 . VOCs were the primary contaminants detected. Reported concentrations for five VOCs exceeded their respective DWSs: 1,1-dichloroethene, 1,2-dichloroethene, carbon tetrachloride, trichloroethene, and vinyl chloride. Concentrations of trichloroethene, the predominant VOC in this area, ranged from $6 \mu \mathrm{g} / \mathrm{L}$ at an unconsolidated zone well to $860 \mu \mathrm{g} / \mathrm{L}$ in a bedrock well. Vinyl chloride exceeded the DWS at two wells. The remaining VOCs exceeding DWSs were detected at one well each. 
Chromium concentrations in excess of the primary DWS were reported for three unconsolidated-zone wells. Chromium concentrations ranged from 0.112 to $0.741 \mathrm{mg} / \mathrm{L}$. The DWS for nickel was exceeded at one unconsolidated-zone well and for thallium at four unconsolidated-zone wells and one bedrock well. Aluminum, iron, and manganese exceeded secondary DWSs at several wells. Fluoride exceeded its DWS at one well.

Gross beta activity was detected at many of the wells in this area; however, neither the gross beta activities nor the gross alpha activities reported for any of the wells exceeded its DWS.

\section{K-901 Area}

Groundwater samples from 30 monitoring wells in the K-901 area were collected and analyzed during 1995 . The primary contaminants are VOCs and radioisotopes.

Nine VOCs were detected at concentrations exceeding their respective DWSs: 1,1,1-trichloroethane, 1,1,2-trichloroethane, 1,1-dichloroethene, benzene, carbon tetrachloride, chloroform, methylene chloride, tetrachloroethene, and trichloroethene. Trichloroethene is the predominant VOC; the DWS was exceeded in 20 monitoring wells. Reported concentrations of trichloroethene ranged from 7 to $3600 \mu \mathrm{g} / \mathrm{L}$ in both unconsolidated-zone wells and bedrock wells. Two VOCs, 1,1,1-trichloroethane and 1,1-dichloroethene, were detected at concentrations in excess of $1000 \mu \mathrm{g} / \mathrm{L}$. Benzene, chloroform, and methylene chloride were detected above their DWSs in one well apiece. Generally, the wells in the K-901 area that exhibited contamination from VOCs are located near the K-1070-A burial ground.

Gross beta activity exceeded the reference value of $50 \mathrm{pCi} / \mathrm{L}$ in nine wells (six bedrock wells and three unconsolidated zone wells). The reported gross beta activities ranged from $59 \mathrm{pCi} / \mathrm{L}$ (limit of error of $5.6 \mathrm{pCi} / \mathrm{L}$ ) to $6,770 \mathrm{pCi} / \mathrm{L}$ (limit of error of $340 \mathrm{pCi} / \mathrm{L}$ ). Gross alpha activity exceeded the DWS at one bedrock well with a reported activity of $19.2 \mathrm{pCi} / \mathrm{L}$ (limit of error of $4.2 \mathrm{pCi} / \mathrm{L}$ ).
Nickel, lead, and thallium were the only metals exceeding a primary DWS in this area. Nickel and thallium exceeded the DWS at one well each. Lead exceeded the DWS at two wells. Aluminum, iron, and manganese exceeded their respective secondary DWSs at several wells.

\section{Duct Island Area}

Groundwater samples were collected from five monitoring wells located in the Duct Island area in 1995. Analytical results continue to indicate that little groundwater contamination is associated with this area.

Aluminum, iron, and manganese are the metals that exceeded a DWS. Low concentrations of several VOCs and semivolatile organic compounds were detected; however, only trichloroethene exceeded a DWS. A concentration of $16 \mu \mathrm{g} / \mathrm{L}$ of trichloroethene was reported for one well during the fall sampling event.

Beta activity was detected in most of the wells. The maximum reported activity of $20.2 \mathrm{pCi} / \mathrm{L}$ is well below the reference value of $50 \mathrm{pCi} / \mathrm{L}$. Gross alpha activity was not detected at any wells.

\section{Powerhouse Area}

Groundwater samples were collected from 17 wells in the powerhouse area during 1995. The primary groundwater contaminants detected were radionuclides. Gross alpha activity exceeded the DWS at one well with results ranging from $50 \mathrm{pCi} / \mathrm{L}$ to $56 \mathrm{pCi} / \mathrm{L}$ during the two sampling events. Gross beta activity exceeded the reference value at two monitoring wells in this area. Gross beta activities ranged from $141 \mathrm{pCi} / \mathrm{L}$ to $233 \mathrm{pCi} / \mathrm{L}$ at these two unconsolidated-zone monitoring wells.

The DWS for nickel was exceeded in one well; the concentration was reported as $0.154 \mathrm{mg} / \mathrm{L}$. The DWS for thallium was exceeded in four wells; concentrations ranged from 0.007 to $0.021 \mathrm{mg} / \mathrm{L}$. Secondary DWSs were exceeded for sulfate, aluminum, iron, and manganese in several wells.

Low concentrations of several VOCs were reported for some wells; however, no VOCs were detected at concentrations above a DWS. 


\section{K-25 Site Springs}

Eight springs in and around the K-25 Site were sampled during the spring of 1995 . Two are located downgradient of known areas of waste management activities at the K-25 Site. Six samples were obtained in the fall of 1995 because two springs were dry at the time of sample collection.

Aluminum, iron, and manganese exceeded DWSs at most of the spring locations. No other metals exceeded a DWS at any of the springs. Two VOCs, tetrachloroethene and trichloroethene, were detected at concentrations exceeding DWSs at one spring within the plant site. This spring is located downgradient of the $\mathrm{K}-1070-\mathrm{C} / \mathrm{D}$ classified burial ground.

\section{K-25 Site Exit-Pathway Monitoring Results}

The K-25 Site exit-pathway monitoring network consists of eight monitoring wells.
Groundwater samples were collected from them in 1995. The only metals detected above DWSs at the exit-pathway wells were aluminum, iron, and manganese. The presence of these metals can be attributed to the natural groundwater chemistry at the site. Several VOCs were detected at exit-pathway wells, but none exceeded a DWS.

Gross alpha activity exceeded the DWS of $15 \mathrm{pCi} / \mathrm{L}$ at one monitoring well location; however, taking into account the limit of error, this result may or may not be above the DWS. The reported activity was $17 \mathrm{pCi} / \mathrm{L}$ (limit of error of $7.1 \mathrm{pCi} / \mathrm{L}$ ). This well is located near the $\mathrm{K}-1007-\mathrm{P} 1$ pond in the southern portion of the $\mathrm{K}-25$ Site. This exceedence was reported for the spring sampling event but was not repeated during the fall sampling event. None of the gross beta activity results for the exit-pathway wells exceeded the reference level of $50 \mathrm{pCi} / \mathrm{L}$. 


\title{
8. Quality Assurance
}

L. W. McMahon, J. L. Miranda, and L. D. Welch

\begin{abstract}
The overall goal of a well-designed and well-implemented sampling and analysis program is to measure accurately what is really there. Environmental decisions are made on the assumption that analytical results are, within known limits of accuracy and precision, representative of site conditions. Many sources of error exist that could affect the analytical results. Factors to consider as sources of error include improper sample collection, handling, preservation, and transport; inadequate personnel training; and poor analytical methods, data reporting, and record keeping. A quality assurance (QA) program is designed to minimize these sources of error and to control all phases of the monitoring process.
\end{abstract}

\section{INTRODUCTION}

The application of a quality assurance/quality control (QA/QC) program for environmental monitoring activities at the ORR is essential to generating data of known and defensible quality. Each aspect of the environmental monitoring program, from sample collection to data management, must address and meet applicable quality standards.

The 1995 QA/QC results for the three sites have been compiled into a summary that represents the performance of the reservation as a whole. In past years, the results were reported separately for each of the three site analytical laboratories. The three laboratories were recently combined into a single entity, the Analytical Services Organization. The 1995 results are based on data from the Analytical Services Organization, the ORNL Environmental Sciences Division, the ORNL Industrial Hygiene Department and the K-25 Site Technical Division.

\section{FIELD SAMPLING QUALITY ASSURANCE}

Field sampling QA encompasses many practices that minimize error and evaluate sampling performance. Some key quality practices include the following:
- use of standard operating procedures (SOPs) for sample collection and analysis;

- use of chain-of-custody and sample-identification procedures;

- instrument standardization, calibration, and verification;

- technician and analyst training;

- sample preservation, handling, and decontamination; and

- use of QC samples such as field and trip blanks, duplicates, and equipment rinses.

Preparation of SOPs is a continually evolving process. In 1988, the Environmental Surveillance Procedures QC Program was issued for use by Energy Systems, with oversight by DOE-ORO and the EPA.

A process is in place for continuous improvement in the field sampling QA program and for incorporation of new procedures to reflect changing technologies and regulatory protocols. An Environmental Surveillance Procedures QC Committee is tasked with updating the field sampling and QC procedures. Membership in the committee includes representatives from each of the five Energy Systems facilities, DOE, ER, Central Waste Management, and the Analytical Services Organization. The committee ensures that requirements from relevant federal and state regulations are incorporated into the procedures and that new procedures are incorporated 
only after appropriate review and approval. In addition, site specific procedures are reviewed internally.

Because of changing technologies and regulatory protocols, training of field personnel is a continuing process. To ensure that qualified personnel are available for the array of sampling tasks within Energy Systems, training programs by EPA as well as private contractors have been used to supplement internal training. Examples of topics addressed include the following:

- planning, preparation, and record keeping for field sampling;

- well construction and groundwater sampling;

- surface water, leachate, and sediment sampling;

- soil sampling;

- stack sampling;

- decontamination procedures; and

- health and safety considerations.

\section{ANALYTICAL QUALITY ASSURANCE}

The Energy Systems analytical laboratories have well-established QA/QC programs, well-trained and highly qualified staff, and excellent equipment and facilities. Current, approved analytical methodologies employing good laboratory and measurement control practices are used routinely to ensure analytical reliability. The analytical laboratories conduct extensive internal QC programs with a high degree of accuracy, participate in several external QC programs, and use statistics to evaluate and to continuously improve performance. Thus, QA and QC are daily responsibilities of all employees.

\section{Internal Quality Control}

Analytical activities are supported by the use of standard materials or reference materials (e.g., materials of known composition that are used in the calibration of instruments, methods standardization, spike additions for recovery tests, and other practices). Certified standards from the
National Institute of Standards and Technology (NIST), EPA, or other DOE laboratories are used for such work. The laboratories operate under specific QA/QC criteria at each installation. Additionally, separate QA/QC documents relating to analysis of environmental samples associated with regulatory requirements are developed.

QA/QC measurement control programs external to the sample analysis groups have single-blind control samples submitted to the analytical laboratories to monitor performance. The results of such periodic measurement programs are statistically evaluated and reported to the laboratories and their customers. Most reports are issued quarterly, and some laboratories compile annual summary reports. These reports assist in evaluating the adequacy of analytical support programs and procedures. If serious deviations are noted by the QC groups, the operating laboratories are promptly notified so that corrective actions can be initiated and problems can be resolved. QC data are stored in an easily retrievable manner so that they can be related to the analytical results they support.

\section{External Quality Control}

In addition to the internal programs, all Energy Systems analytical laboratories are directed by DOE and are expected by EPA to participate in external QA programs. The QA programs generate data that are readily recognizable as objective packets of results. The external QA programs typically consist of the Energy Systems laboratories analyzing a sample of unknown composition provided by various QA organizations. The organizations know the true composition of the sample and provide the Energy Systems laboratories with a data report on their analytical performance. The sources of these programs are laboratories in EPA, DOE, and the commercial sector. Energy Systems participates in ten such programs (Table 8.1). The following sections describe the external QA programs in which Energy Systems participates.

\section{8-2 Quality Assurance}


Table 8.1. QAVQC results for the Oak Ridge Reservation, 1995

\begin{tabular}{|c|c|c|c|}
\hline \multirow[t]{2}{*}{ Program } & \multirow{2}{*}{$\begin{array}{l}\text { Total number } \\
\text { of analytes }\end{array}$} & \multicolumn{2}{|c|}{ Acceptable } \\
\hline & & Total & Percentage \\
\hline EPA Contract Laboratory Program (CLP) ${ }^{a}$ & & & 92.69 \\
\hline $\begin{array}{l}\text { EPA Discharge Monitoring Report Quality Assurance } \\
\text { Study (DMR) }\end{array}$ & 92 & 91 & 98.91 \\
\hline $\begin{array}{l}\text { AIHA Environmental Lead Proficiency Analytical Testing } \\
\text { Program (ELPAT) }\end{array}$ & 68 & 59 & 86.76 \\
\hline DOE Environmental Measurements Laboratory (EML) & 218 & 195 & 89.45 \\
\hline EPA National Exposure Research & 132 & 111 & 84.09 \\
\hline $\begin{array}{l}\text { Laboratory at Las Vegas (NERL-LV) Intercomparison Ra- } \\
\text { dionuclide Control Program }{ }^{c}\end{array}$ & & & \\
\hline $\begin{array}{l}\text { DOE Mixed Analyte Performance Evaluation Program } \\
\text { (MAPEP) }\end{array}$ & 145 & 137 & 97.36 \\
\hline AIHA Proficiency Analytical Testing Program (PAT) ${ }^{d}$ & 312 & 306 & 98.08 \\
\hline Proficiency Environmental Testing Program (PET) & 4831 & 4740 & 98.12 \\
\hline $\begin{array}{l}\text { Water Pollution Performance Evaluation QC Program } \\
(\text { WP })^{c}\end{array}$ & 341 & 332 & 97.36 \\
\hline Water Supply Laboratory Performance QC Program (WS) & 201 & 190 & 94.53 \\
\hline
\end{tabular}

\section{Environmental Protection Agency Contract Laboratory Program (CLP)}

The Contract Laboratory Program (CLP) is an EPA-administered QA element used to evaluate laboratory analytical proficiency in comparison with analyte and the current state of work. The program operates from the Contract Laboratory Analytical Services Support office at Alexandria, Virginia, in cooperation with the EPA regional offices. This program evaluates laboratories for the determination of organic and inorganic contaminants in aqueous and solid hazardous waste materials and enforces stringent QA/QC requirements to ensure comparable data. This program scores on additional criteria other than an "acceptable-unacceptable" evaluation of the measurement result. By the CLP scoring algorithm, performance of $75 \%$ or better indicates acceptable performance. Values below this score indicate that deficiencies exist and that the participant has failed to demonstrate the capability to meet the contract requirements.

\section{Water Supply Laboratory Performance Quality Control Program}

This program is administered by EPA and is used by the state of Tennessee to certify laboratories for drinking water analysis. To maintain a certification, a laboratory must meet a specified set of criteria relating to technical personnel, equipment, work areas, QA/QC operating procedures, and successful analysis of QA samples. In addition, inclusion on the state of Tennessee's UST approved listing may be granted as a result of successful participation in this program. 
Water Pollution Performance Evaluation Quality Control Program

This program is used by DOE to evaluate laboratories engaged in analysis of polluted water samples at existing and former DOE sites. It is administered by EPA in Cincinnati, Ohio (Region V). It is also used by some states as part of their laboratory certification process.

\section{American Industrial Hygiene Association Proficiency Analytical Testing Program}

The American Industrial Hygiene Association (AIHA) administers the Proficiency Analytical Testing (PAT) Program as part of its AIHA accreditation process for laboratories performing analyses of industrial hygiene air samples.

\section{EPA Discharge Monitoring Report Quality Assurance Study}

EPA conducts a national QA program in support of the NPDES permits, and it is mandatory for major permit holders. The EPA supplies the QA samples and furnishes the evaluated results to the permittee, who is required to report the results and any necessary corrective actions to the state or regional coordinator.

\section{EPA Intercomparison Radionuclide Control Program}

The EPA Intercomparison Radionuclide Control Program is administered by NERL-LV. Samples include water, air filters, and milk. The state of Tennessee requires participation for drinking-water certification of radionuclide analysis, and all sites are involved. The NERL-LV program calculates a normalized standard deviation for each laboratory based on all reported results. By their criteria, any reported value above three standard deviations is considered unacceptable.

\section{Environmental Lead Proficiency Analytical Testing (ELPAT) Program}

This program was established by AIHA in 1992 to evaluate analysis of environmental lead samples in different matrices. The matrices evaluated are paint, soil, and dust wipes. The participating laboratory analyzes each matrix at four levels. In addition, a laboratory may request to become accredited for lead analysis in this program. The Environmental Lead Proficiency Analytical Testing Program (ELPAT) is administered by AIHA.

\section{Mixed Analyte Performance Evaluation Program (MAPEP)}

The Mixed Analyte Performance Evaluation Program (MAPEP) is a program set up by the DOE Radiological and Environmental Sciences Laboratory in conjunction with the Laboratory Management Division of the Office of Technology Development to evaluate analysis of mixed-waste samples. The program is evaluated by Argonne National Laboratory.

\section{DOE Environmental Measurements Laboratory (EML) Quality Assessment Program}

Participation in the radionuclide Quality Assessment Program, administered by DOE Environmental Measurements Laboratory (EML) in New York, is required by DOE Order 5400.1. Various matrices, such as soil, water, air filters, and vegetation, are submitted semiannually for analysis of a variety of radioactive isotopes. All matrices, except air filters, are actual materials obtained from the environment at a DOE facility. A statistical report is submitted to the sites by EML for each period.

\section{Proficiency Environmental Testing (PET) Program}

The Proficiency Environmental Testing (PET) program is a service purchased from an outside vendor and is used by all five Energy Systems analytical laboratories and the DOE laboratory at the Fernald, Ohio, facility, to meet the need 
for a QA program for all environmental analyses. The samples are supplied by the commercial company at two concentration levels (high and low). All data from each of the six laboratories are reported to the supplier. The commercial supplier provides a report on the evaluated data to the site QA/QC managers. The report includes a percentage recovery of the referenced value, deviation from the mean of all reported data, specific problems in a site lab, and other statistical information. A corporate report is also provided that compares the data from the Energy Systems laboratories with those of other corporate laboratories.

\section{Quality Assessment Program for Subcontracted Laboratories}

\section{Requirements for $Q C$ of Analytical Data} for the ER Program (Energy Systems 1992b) defines the basic requirements that laboratories must satisfy in providing support to ORR ER projects. Oversight of subcontracted commercial laboratories is performed by Technical Subcontracting Office (TSO) personnel, who conduct on-site laboratory reviews and monitor the performance of all subcontracted laboratories. follows.

The components of the review process are as

- Laboratory Quality Assurance Plan (LQAP)-A review of the LQAP is performed by the TSO prior to an initial audit of the laboratory. Each laboratory is required to have an LQAP in place and to correct any deficiencies noted by the TSO review.

- Performance evaluation samples-Each laboratory is required to successfully participate in an external performance evaluation program for analytes representative of those anticipated in the environmental samples. Participation is reviewed before samples are submitted to the laboratory and as part of the initial audit and periodic audits.

- Initial audit-After the laboratory has satisfactorily responded to LQAP comments and submitted the required performance evaluation data, an audit is conducted to verify that conditions of Requirements for $Q C$ of Analytical Data for the ER Program (Energy Systems 1992b) are being implemented.

- Periodic audits-Audits of laboratories participating in the TSO pricing agreement are conducted every 6 to 12 months to verify continuing compliance with requirements.

- Monthly progress reports--Reports are submitted to the TSO by each laboratory to maintain communication so that changes in certification status, personnel, or facilities may be monitored.

- Project-specific surveillances-Surveillances are conducted as required to monitor specific project data quality.

\section{DATA MANAGEMENT, VERIFICATION, AND VALIDATION}

Verification and validation of environmental data are performed as components of the data collection process, which includes planning, sampling, analysis, and data review. Verification and validation of field and analytical data collected for environmental monitoring and restoration programs are necessary to ensure that data conform with applicable regulatory and contractual requirements. Validation of field and analytical data is a technical review performed to compare data with established quality criteria to ensure that data are adequate for intended use. The extent of project data verification and validation activities is based upon project-specific requirements.

Over the years, the environmental data verification and data validation processes used by ORR environmental programs have evolved to meet continuing regulatory changes and monitoring objectives. Procedures have been written to document the processes. For routine environmental effluent monitoring and surveillance monitoring, data verification activities may include processes of checking whether (1) data have been accurately transcribed and recorded, (2) appropriate procedures have 
been followed, (3) electronic and hard-copy data show one-to-one correspondence, and (4) data are consistent with expected trends. For example, the requirements for self-monitoring of surface-water and wastewater effluents under the terms of an NPDES permit require the permittee to conduct the analyses as defined in 40 CFR 136 and to certify that the data reported in the monthly discharge monitoring report are true and accurate.

Typically, routine data verification actions alone are sufficient to document the truthfulness and accuracy of the discharge monitoring report. For ER projects, routine verification activities are more contractually oriented and include checks for data completeness, consistency, and compliance against a predetermined standard or contract.

Certain projects may perform a more thorough technical validation of the data as mandated by the project's data quality objectives. For example, sampling and analyses conducted as part of a remedial investigation to support the CERCLA process may generate data that are needed to evaluate risk to human health and the environment, to document that no further remediation is necessary, or to support a multimillion-dollar construction activity and treatment alternative. In that case, the data quality objectives of the project may mandate a more thorough technical evaluation of the data against predetermined criteria. For example, EPA has established functional guidelines for validation of organic and inorganic data collected under the protocol of the EPA's CLP. These guidelines are used to offer assistance to the data user in evaluating and interpreting the data generated from monitoring activities that require CLP performance.

The validation process may result in identifying data that do not meet predetermined QC criteria (in flagging quantitative data that must be considered qualitative only) or in the ultimate rejection of data from its intended use. Typical criteria evaluated in the validation of CLP data include the percentage of surrogate recoveries, spike recoveries, method blanks, instrument tuning, instrument calibration, continuing calibration verifications, internal standard response, comparison of duplicate samples, and sample holding times.

Electronic data transfers from portable computers in the field and from laboratory information management systems used by on-site and commercial analytical laboratories to environmental data management systems have greatly enhanced the efficiency of the review process. In addition, the ongoing development of data-review software applications continues to provide necessary tools for data review. For example, as groundwater monitoring data are compiled, computer capabilities accomplish the following tasks:

- calculate charge balance;

- calculate conductivity and compare the data with field and laboratory measurements of conductivity;

- compare alkalinities and $\mathrm{pH}$, field-duplicate measurements, results of filtered and unfiltered samples for elemental analyses, and current data with historical data to note results that are statistical outliers from established patterns;

- generate a summary of holding times for volatile organics; and

- screen volatile-organic results from samples against volatile-organic results from laboratory blanks.

Irregularities in the laboratory results that are discovered through this program are flagged and reviewed with the laboratory. If corrections need to be made, the laboratory provides a revised laboratory report. If a data point is found to be an outlier, it remains flagged in the data base as information for the data user.

Continuing improvements are being made to computerized environmental data management systems maintained by the Y-12 Plant, ORNL, and the K-25 Site to improve the functionality of the systems, to allow access by a wide range of data users, and to integrate the mapping capabilities of a geographic information system (GIS) with the data bases containing results of environmental monitoring activities.

Integration of compliance-monitoring data for the ORR with sampling and analysis 
results from remedial investigations by the ER Division is a function of the Oak Ridge Environmental Information System (OREIS). OREIS is necessary to fulfill requirements prescribed in both the FFA and TOA and to support data management activities for all five facilities managed by Energy Systems. The FFA, a tripartite agreement between DOE, EPA Region IV, and the state of Tennessee, requires DOE to maintain one consolidated data base for environmental data generated at DOE facilities on the ORR. According to the FFA, the consolidated data base is to include data generated pursuant to the FFA as well as data generated under federal and state environmental permits. The
TOA further defines DOE staff obligations to develop a quality assured, consolidated data base of monitoring information that will be shared electronically on a near-real-time basis with the state staff.

OREIS is the primary component of the data management program for the ER Program, providing consolidated, consistent, and well documented environmental data and data products to support planning, decision making, and reporting activities. OREIS provides a direct electronic link of ORR monitoring and remedial investigation results to EPA Region IV and the state of Tennessee DOE Oversight Division. 
Appendix A: Radiation 
-

-

- 


\section{Appendix A: Radiation}

This appendix presents basic facts about radiation. The information is intended to be a basis for understanding the potential doses associated with releases of radionuclides from the Oak Ridge Reservation (ORR), not as a comprehensive discussion of radiation and its effects on the environment and biological systems.

Radiation comes from natural and human-made sources. People are exposed to naturally occurring radiation constantly. For example, cosmic radiation; radon in air; potassium in food and water; and uranium, thorium, and radium in the earth's crust are all sources of radiation. The following discussion describes important aspects of radiation, including atoms and isotopes; types, sources, and pathways of radiation; radiation measurement; and dose information.

\section{ATOMS AND ISOTOPES}

ORNL-DWG 94M-5236

All matter is made up of atoms. An atom is "a unit of matter consisting of a single nucleus surrounded by a number of electrons equal to the number of protons in the nucleus" (ANS 1986). The number of protons in the nucleus determines an element's atomic number or chemical identity. With the exception of hydrogen, the nucleus of each type of atom also contains at least one neutron. Unlike protons, the neutrons may vary in number among atoms of the same element. The number of neutrons and protons determines the atomic weight. Atoms of the same element that have different numbers of neutrons are called isotopes. In other words, isotopes have the same chemical properties but different atomic weights (Fig. A.1).

For example, the element uranium has 92 protons. All isotopes of uranium, therefore, have 92 protons. However, each uranium isotope has a different number of
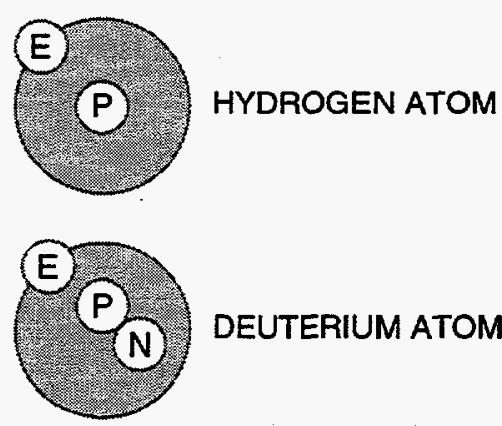

DEUTERIUM ATOM

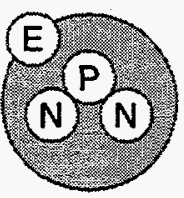

TRITIUM ATOM

\begin{tabular}{lc|c} 
& PROTONS & NEUTRONS \\
\cline { 2 - 3 } HYDROGEN & 1 & 0 \\
DEUTERIUM & 1 & 1 \\
TRITIUM & 1 & 2
\end{tabular}

Fig. A.1. The hydrogen atom and its isotopes. neutrons. Uranium-238 has 92 protons and 146 neutrons; uranium-235 has 92 protons and 143 neutrons; and uranium-234 has 92 protons and 142 neutrons.

Some isotopes are stable, or nonradioactive; some are radioactive. Radioactive isotopes are called radionuclides, or radioisotopes. In an attempt to become stable, radionuclides "throw away," or emit, rays or particles. This emission of rays and particles is known as radioactive decay. Each radioisotope has a "radioactive half-life," which is the average time that it takes for half of a specified number of atoms to decay. Half-lives can be very short (fractions of a second) or very long (thousands of years), depending on the isotope (Table A.1). 
Table A.1. Radionuclide nomenclature

\begin{tabular}{|c|c|c|c|c|c|}
\hline Radionuclide & Symbol & Half-life & Radionuclide & Symbol & Half-life \\
\hline Americium-241 & ${ }^{241} \mathrm{Am}$ & 432.2 years & Plutonium-238 & & 87.75 years \\
\hline Americium-243 & ${ }^{243} \mathrm{Am}$ & $7.38 \mathrm{E}+3$ years & Plutonium-239 & & $2.41 E+4$ years \\
\hline Antimony-125 & ${ }^{125} \mathrm{Sb}$ & 2.77 years & Plutonium-240 & ${ }^{240} \mathrm{Pu}$ & $6.569 \mathrm{E}+3$ years \\
\hline Argon-41 & ${ }^{41} \mathrm{Ar}$ & 1.827 hours & Potassium-40 & & $1.2777 \mathrm{E}+9$ years \\
\hline Beryllium-7 & ${ }^{7} \mathrm{Be}$ & 53.44 days & Promethium-147 & ${ }^{147} \mathrm{Pm}$ & 2.6234 years \\
\hline Californium-252 & ${ }^{252} \mathrm{Cf}$ & 2.639 years & Protactinium-234m & ${ }^{234 m} \mathrm{~Pa}$ & 1.17 minutes \\
\hline Carbon-14 & ${ }^{14} \mathrm{C}$ & $5.730 \mathrm{E}+3$ years & Radium-226 & ${ }^{226} \mathrm{Ra}$ & $1.6 \mathrm{E}+3$ years \\
\hline Cerium-141 & ${ }^{141} \mathrm{Ce}$ & 32.50 days & Radium-228 & ${ }^{228} \mathrm{Ra}$ & 5.75 years \\
\hline Cerium-143 & ${ }^{143} \mathrm{Ce}$ & 1.38 days & Ruthenium-103 & ${ }^{103} \mathrm{Ru}$ & 39.35 days \\
\hline Cerium-144 & ${ }^{144} \mathrm{Ce}$ & 284.3 days & Ruthenium-106 & ${ }^{106} \mathrm{Ru}$ & 368.2 days \\
\hline Cesium-134 & ${ }^{134} \mathrm{Cs}$ & 2.062 years & Strontium-89 & ${ }^{89} \mathrm{Sr}$ & 50.55 days \\
\hline Cesium-137 & ${ }^{137} \mathrm{Cs}$ & 30.17 years & Strontium-90 & ${ }^{90} \mathrm{Sr}$ & 28.6 years \\
\hline Cobalt-58 & ${ }^{58} \mathrm{Co}$ & 70.80 days & Technetium-99 & & $2.13 E+5$ years \\
\hline Cobalt-60 & ${ }^{60} \mathrm{Co}$ & 5.271 years & Thorium-228 & ${ }^{228} \mathrm{Th}$ & 1.9132 years \\
\hline Curium-242 & ${ }^{242} \mathrm{Cm}$ & 163.2 days & Thorium-230 & ${ }^{230} \mathrm{Th}$ & $7.54 \mathrm{E}+4$ years \\
\hline Curium-244 & ${ }^{244} \mathrm{Cm}$ & 18.11 years & Thorium-232 & ${ }^{232} \mathrm{Th}$ & $1.405 \mathrm{E}+10$ years \\
\hline Iodine-129 & ${ }^{129} \mathrm{I}$ & $157 \mathrm{E}+7$ years & Thorium-234 & ${ }^{234} \mathrm{Th}$ & $2.41 E+1$ days \\
\hline Iodine-131 & ${ }^{131} \mathbf{I}$ & 8.04 days & Tritium & ${ }^{3} \mathrm{H}$ & 12.28 years \\
\hline Krypton-85 & ${ }^{85} \mathrm{Kr}$ & 10.72 years & Uranium-234 & ${ }^{234} \mathrm{U}$ & $2.445 \mathrm{E}+5$ years \\
\hline Krypton-88 & ${ }^{88} \mathrm{Kr}$ & 2.84 hours & Uranium-235 & ${ }^{235} \mathrm{U}$ & $7.038 \mathrm{E}+8$ years \\
\hline Manganese-54 & ${ }^{54} \mathrm{Mn}$ & 312.7 days & Uranium-236 & ${ }^{236} \mathrm{U}$ & $2.3415 \mathrm{E}+7$ years \\
\hline Neptunium-237 & ${ }^{237} \mathrm{~Np}$ & $2.14 \mathrm{E}+6$ years & Uranium-238 & ${ }^{238} \mathrm{U}$ & $4.468 \mathrm{E}+9$ years \\
\hline Niobium-95 & ${ }^{95} \mathrm{Nb}$ & 35.06 days & Xenon-133 & ${ }^{133} \mathrm{Xe}$ & $5.245 \mathrm{E}+9$ years \\
\hline Osmium-185 & ${ }^{185}$ Os & 93.6 days & Xenon-135 & ${ }^{135} \mathrm{Xe}$ & 9.11 hours \\
\hline Phosphorus-32 & ${ }^{32} \mathrm{p}$ & 14.29 days & Yttrium-90 & ${ }^{90} \mathrm{Y}$ & 64.1 hours \\
\hline Polonium-210 & ${ }^{210} \mathrm{Po}$ & 138.378 days & Zirconium-95 & ${ }^{95} \mathrm{Zr}$ & 64.02 days \\
\hline
\end{tabular}

Source: Radioactive Decay Tables: A Handbook of Decay Data for Application to Radioactive Dosimetry and Radiological Assessments (DOE 1989).

\section{RADIATION}

Radiation, or radiant energy, is energy in the form of waves or particles moving through space. Visible light, heat, radio waves, and alpha particles are examples of radiation. When people feel warmth from the sunlight, they are actually absorbing the radiant energy emitted by the sun.

Electromagnetic radiation is radiation in the form of electromagnetic waves. Examples include gamma rays, ultraviolet light, and radio waves. Particulate radiation is radiation in the form of particles. Examples include alpha and beta particles. Radiation also is characterized as ionizing or nonionizing because of the way in which it interacts with matter.

\section{lonizing Radiation}

Normally, an atom has an equal number of protons and electrons; however, atoms can lose or gain electrons in a process known as ionization. Some forms of radiation (called ionizing radiation) can ionize atoms by "knocking" electrons off atoms. Examples of ionizing radiation include alpha, beta, and gamma radiation.

Ionizing radiation is capable of changing the chemical state of matter and subsequently causing biological damage. By this mechanism, it is potentially harmful to human health. 


\section{Nonionizing Radiation}

Nonionizing radiation bounces off or passes through matter without displacing electrons. Examples include visible light and radio waves. At this time it is unclear whether or not nonionizing radiation is harmful to human health. In the discussion that follows, the term radiation is used to describe ionizing radiation.

\section{SOURCES OF RADIATION}

Radiation is everywhere. Most occurs naturally; a small percentage is humanmade. Naturally occurring radiation is known as background radiation.

\section{Background Radiation}

Many materials are naturally radioactive. In fact, this naturally occurring radiation is the major source of radiation in the environment. Although people have little control over the amount of background radiation to which they are exposed, this exposure must be put into perspective. Background radiation remains relatively constant over time and is present in the environment today much as it was hundreds of years ago.

Sources of background radiation include uranium in the earth, radon in the air, and potassium in food. Background radiation is categorized as cosmic, terrestrial, or internal, depending on its origin.

\section{Cosmic Radiation}

Energetically charged particles from outer space continuously hit the earth's atmosphere. These particles and the secondary particles and photons they create are called cosmic radiation. Because the atmosphere provides some shielding against cosmic radiation, the intensity of this radiation increases with altitude above sea level. In other words, a person in Denver, Colorado, is exposed to more cosmic radiation than a person in New Orleans, Louisiana.
Principal Radiation Types Emitted by Radionuclides

Alpha

A particle consisting of two protons and two neutrons emitted from the nucleus.

Low penetration: the mean range of a $5-\mathrm{MeV}$ aipha particle in air is about $3.5 \mathrm{~cm}$; in tissue its range is about $44 \mu \mathrm{m}$ (Shapiro).

For environmental dosimetry, particularly important as an internal emitter, especially in the respiratory passages, on bone surfaces, and in red marrow. Its energy is concentrated along short paths and can deliver high localized doses to sensitive surface regions.

\section{Beta}

An electron emitted from the nucleus.

The average range of a $1-\mathrm{MeV}$ beta particle is about $3 \mathrm{~m}$ in air but only about $3 \mathrm{~mm}$ in tissue.

For environmental dosimetry, of primary concern as an internal emitter. Because of their relatively short range in tissue, beta particles principally irradiate the organs in which they originate.

\section{Gamma and $X$ rays}

Electromagnetic radiation, emitted as energy packets called photons, similar to light and radio waves but from a different energy region of the electromagnetic spectrum. $X$ rays originate in the orbital electron field surrounding the nucleus; gamma rays are emitted from the nucleus.

Gamma radiation: to absorb $95 \%$ of the gamma energy from a ${ }^{60} \mathrm{Co}$ source, $6 \mathrm{~cm}$ of lead, $10 \mathrm{~cm}$ of iron, or $33 \mathrm{~cm}$ of concrete would be needed.

For environmental dosimetry, important both for internal and external exposure. Gamma emitters deposited in one organ of the body can significantly irradiate other organs. 


\section{Terrestrial Radiation}

Terrestrial radiation refers to radiation emitted from radioactive materials in the earth's rocks, soils, and minerals. Radon ( $R n)$; radon progeny (the relatively short-lived decay products from the decay of ${ }^{222} \mathrm{Rn}$ ); potassium $\left({ }^{40} \mathrm{~K}\right)$; isotopes of thorium (Th); and isotopes of uranium $(\mathrm{U})$ are the elements responsible for most terrestrial radiation.

\section{Internal Radiation}

Radionuclides in the environment enter the body with the air people breathe and the foods they eat. They also can enter through an open wound. Natural radionuclides that can be inhaled and ingested include isotopes of uranium and its progeny, especially radon $\left({ }^{222} \mathrm{Rn}\right)$ and its progeny, thoron $\left({ }^{220} \mathrm{Rn}\right)$ and its progeny, potassium $\left({ }^{40} \mathrm{~K}\right)$, rubidium $\left({ }^{87} \mathrm{Rb}\right)$, and carbon $\left({ }^{14} \mathrm{C}\right)$. Radionuclides contained in the body are dominated by ${ }^{40} \mathrm{~K}$ and ${ }^{210} \mathrm{Po}$; others include rubidium $\left({ }^{87} \mathrm{Rb}\right)$ and carbon $\left({ }^{14} \mathrm{C}\right)$ (NCRP 1987).

\section{Human-Made Radiation}

In addition to background radiation, there are human-made sources of radiation to which most people are exposed. Examples include consumer products, medical sources, fallout from atmospheric atomic bomb tests, and industrial by-products. No atmospheric testing of atomic weapons has occurred since 1980 (NCRP 1987).

\section{Consumer Products}

Some consumer products are sources of radiation. The radiation in some of these products, such as smoke detectors and airport X-ray baggage inspection systems, is essential to the performance of the device. In other products, such as televisions and tobacco products, the radiation occurs incidentally to the product function.

\section{Medical Sources}

Radiation is an important tool of diagnostic medicine and treatment and is the main source of exposure to the public from human-made radiation. Exposure is deliberate and directly beneficial to the patients exposed. In general, medical exposures from diagnostic or therapeutic $\mathrm{X}$ rays result from beams directed to specific areas of the body. Thus, all body organs generally are not irradiated uniformly. Nuclear medicine examinations and treatments involve the internal administration of radioactive compounds, or radiopharmaceuticals, by injection, inhalation, consumption, or insertion. Even then, radionuclides are not distributed uniformly throughout the body. Radiation and radioactive materials also are used in the preparation of medical instruments, including the sterilization of heat-sensitive products such as plastic heart valves.

\section{Other Sources}

Radioactive fallout, the by-product of nuclear-weapon testing in the atmosphere, is a source of radiation. Other sources of radiation include emissions of radioactive materials from nuclear facilities such as uranium mines, fuel-processing plants, and nuclear power plants; transportation of radioactive materials; and emissions from mineral-extraction facilities. 


\section{PATHWAYS OF RADIONUCLIDES}

People can be exposed to radionuclides in the environment through a number of routes (Fig. A.2). Potential routes for internal and/or external exposure are referred to as pathways. For example, radionuclides in the air could fall on a pasture. The grass then could be eaten by cows, and the radionuclides deposited on the grass would show up in milk. People drinking the milk would be exposed to this radiation. People also could simply inhale airborne radionuclides. Similarly, radionuclides in water could be ingested by fish, and people eating the fish would also ingest the radionuclides in the fish tissue. People swimming in the water would be exposed also.

\section{MEASURING RADIATION}

To determine the possible effects of radiation on the health of the environment and people, the radiation must be measured. More precisely, its potential to cause damage must be ascertained.
ORNL-DWG 94M-5235R2

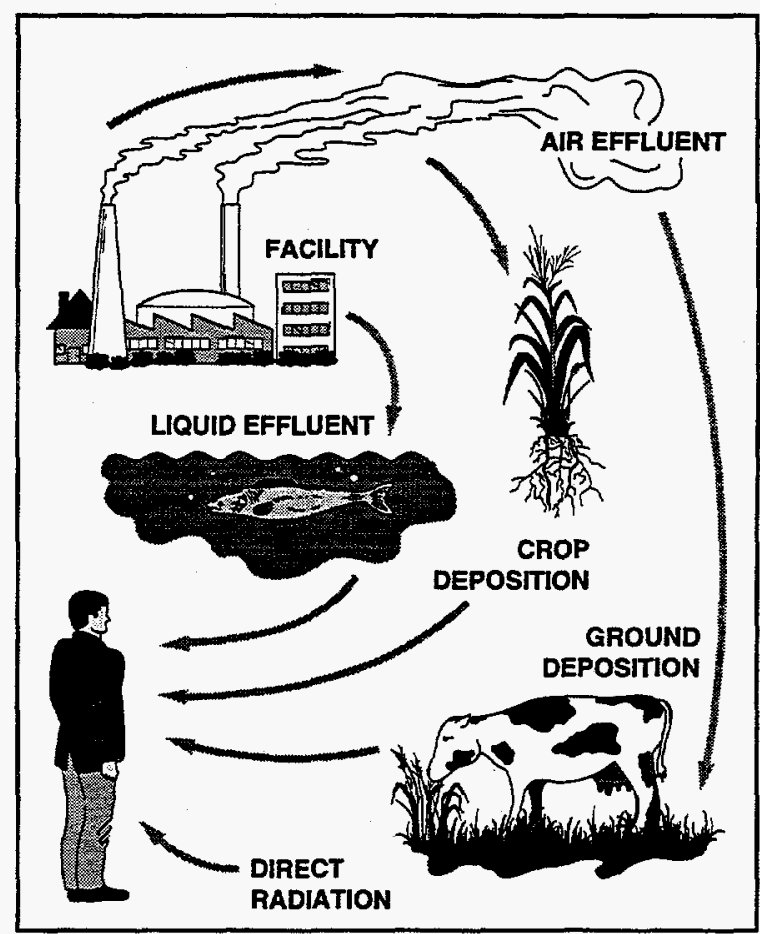

Fig. A.2. Examples of radiation pathways.

\section{Activity}

When we measure the amount of radiation in the environment, what is actually being measured is the rate of radioactive decay, or activity. The rate of decay varies widely among the various radioisotopes. For that reason, one gram of a radioactive substance may contain the same amount of activity as several tons of another material. This activity is expressed in a unit of measure known as a curie ( $\mathrm{Ci}$ ). More specifically, one curie equals $3.7 \times 10^{10}(37,000,000,000)$ atomic disintegrations per second (dps). In the international system of units, $1 \mathrm{dps}$ equals 1 becquerel (Bq).

\section{Absorbed Dose}

The total amount of energy absorbed per unit mass of the exposed material as a result of exposure to radiation is expressed in a unit of measure known as a rad. In this case, it is the effect of the absorbed energy (the biological damage that it causes) that is important, not the actual amount. In the international system of units, 100 rad equals 1 gray (Gy). 


\section{Dose Equivalent}

The measure of potential biological damage to specific body organs or tissues caused by exposure to and subsequent absorption of radiation is expressed in a unit of measure known as a rem. One rem of any type of radiation has the same total damaging effect. Because a rem represents a fairly large dose equivalent, dose equivalents are expressed as fractions of a rem-millirem (mrem), which is $1 / 1000$ of a rem. In the international system of units, 1 sievert (Sv) equals $100 \mathrm{rem} ; 1$ millisievert (mSv) equals $100 \mathrm{mrem}$. Specific types of dose equivalents are defined as follows.

- committed dose equivalent-the total dose equivalent to an organ during the 50 -year period following intake.

- effective dose equivalent (EDE)-the weighted sum of dose equivalents to a specified list of organs. The organs and weighting factors are selected on the basis of risk to the entire body.

"EDE" is the unit used in the Annual Site Environmental Report.

- committed effective dose equivalent-the total effective dose to specified organs in the human body during the 50 -year period following intake.

- collective effective dose equivalent-the sum of effective dose equivalents of all members of a given population.

\section{Dose Determination}

Determining dose is an involved process in which complex mathematical equations based on several factors, including the type of radiation, the rate of exposure, weather conditions, and typical diet, are used. Basically, radioactive decay, or activity, generates radiant energy. People absorb some of the energy to which they are exposed. The effect of this absorbed energy is responsible for an individual's dose. Whether radiation is natural or human-made, it has the same effect on people.

Many terms are used to report dose. The terms take several factors into account, including the amount of radiation absorbed, the organ absorbing the radiation, and the effect of the radiation over a 50 -year period. The term "dose," in this report, means the committed EDE, which is the

\section{Units of Radiation Measure}

To comply with DOE orders, this report will present results using the current system followed by Système International (SI) units in parentheses. For example, the dose from a typical chest $X$ ray is $10 \mathrm{mrem}(0.10 \mathrm{mSv})$.

Current System SI System Conversion

Activity

curie (Ci) becquerel $(\mathrm{Bq}) \quad 1 \mathrm{Ci}=3.7 \times 10^{10} \mathrm{~Bq}$

Absorbed dose

rad (radiation absorbed $\quad \operatorname{gray}(\mathrm{Gy}) \quad 1 \mathrm{rad}=0.01 \mathrm{~Gy}$ dose)

Dose equivalent rem (roentgen equivalent sievert (Sv) $1 \mathrm{rem}=0.01 \mathrm{~Sv}$ man

\section{Converting Dose Equivalent}

Because a rem represents a fairly large dose of radiation, dose is best expressed as a millirem, or 1/1000 of a rem. The same is true of sieverts. Dose is expressed in millisieverts (mSv). Because 1 mrem equals $0.01 \mathrm{mSv}$, converting from millirem to millisieverts is simply a matter of moving the decimal point two places to the left. For example, 267 mrem equals $2.67 \mathrm{mSv}$. 
total effective dose equivalent that will be received during a specified time ( 50 years) from radionuclides taken into the body in the current year, and the EDE attributable to penetrating radiation from sources external to the body.

\section{Dose Conversion Factor}

A dose conversion factor (DCF) is defined as the dose equivalent received from exposure to a unit quantity of a radionuclide by way of a specific exposure pathway. Two types of DCFs exist. One type gives the committed dose equivalent (rem) resulting from intake (by inhalation and ingestion) of a unit activity $(1.0 \mu \mathrm{Ci})$ of a radionuclide. The second gives the dose equivalent rate (millirem per year) per unit activity (1.0 $\mu \mathrm{Ci}$ ) of a radionuclide in a unit (cubic or square centimeters) of an environmental compartment (air volume or ground surface). All DCFs used in this report were approved by DOE or by EPA (DOE 1988a; DOE 1988b; Beres 1990; EPA 1988; EPA 1993b).

\section{Comparison of Dose Levels}

Table A.2 presents a scale of dose levels, with an example of the type of exposure that may cause such a dose, or the special significance of such a dose. This information is intended to help the reader become familiar with a range of doses that various individuals may receive.

The maximally exposed person living near the ORR area could receive an annual EDE of about 4 mrem (0.04 mSv) from radionuclides released from the ORR during 1995.

\section{Dose from Cosmic Radiation}

The average annual dose equivalent to people in the United States from cosmic radiation is about $27 \mathrm{mrem}(0.27 \mathrm{mSv})$ (NCRP 1987). The average dose equivalent caused by cosmic radiation in Tennessee is about 45 mrem per year $(0.45 \mathrm{mSv}$ per year) (Tsakeres 1980). When shielding and the time spent indoors are considered, the dose for the surrounding population is reduced to $80 \%$, or about $36 \mathrm{mrem}(0.36 \mathrm{mSv})$ per year.

\section{Dose from Terrestrial Radiation}

The average annual dose from terrestrial gamma radiation is about $28 \mathrm{mrem}(0.28 \mathrm{mSv})$ in the United States but varies geographically across the country (NCRP 1987). Typical reported values are about $16 \mathrm{mrem}(0.16 \mathrm{mSv})$ on the Atlantic and Gulf coastal plains and about $63 \mathrm{mrem}(0.63 \mathrm{mSv})$ on the eastern slopes of the Rocky Mountains. The average external gamma exposure rate in the vicinity of the ORR is about $7.8 \mu \mathrm{R} / \mathrm{h}$, which results in an equivalent dose of about $51 \mathrm{mrem}$ per year $(0.51 \mathrm{mSv}$ per year).

\section{Dose from Internal Radiation}

The major contributors to the annual dose equivalent for internal radionuclides are the short-lived decay products of radon, which contribute an average dose of about $200 \mathrm{mrem}$ $(2.00 \mathrm{mSv})$ per year. This dose estimate is based on an average radon concentration of about $1 \mathrm{pCi} / \mathrm{L}(0.037 \mathrm{~Bq} / \mathrm{L})$ (NCRP 1987).

The average dose from other internal radionuclides is about 39 mrem $(0.39 \mathrm{mSv})$ per year, which is predominantly attributed to the naturally occurring radioactive isotope of potassium, ${ }^{40} \mathrm{~K}$. The concentration of radioactive potassium in human tissues is similar in all parts of the world (NCRP 1987). 
Table A.2. Comparison and description of various dose levels

\begin{tabular}{|c|c|}
\hline Dose level & Description \\
\hline 1 mrem & Approximate daily dose from natural background radiation, including radon \\
\hline $2.5 \mathrm{mrem}$ & Cosmic dose to a person on a one-way airplane flight from New York to Los Angeles \\
\hline 10 mrem & $\begin{array}{l}\text { Annual exposure limit set by EPA for exposures from airborne } \\
\text { emissions from operations of nuclear fuel cycle facilities, including power } \\
\text { plants, uranium mines, and mills }\end{array}$ \\
\hline 45 mrem & Average yearly dose from cosmic radiation received by people in the Paducah area \\
\hline 46 mrem & $\begin{array}{l}\text { Estimate of the largest dose any off-site person could have received from the } \\
\text { March 28, 1979, Three Mile Island nuclear accident }\end{array}$ \\
\hline 66 mrem & Average yearly dose to people in the United States from human-made sources \\
\hline 100 mrem & $\begin{array}{l}\text { Annual limit of dose from all DOE facilities to a member of the public who } \\
\text { is not a radiation worker }\end{array}$ \\
\hline 110 mrem & Average occupational dose received by U.S. commercial radiation workers in 1980 \\
\hline 244 mrem & Average dose from an upper gastrointestinal diagnostic $\mathrm{X}$-ray series \\
\hline 300 mrem & $\begin{array}{l}\text { Average yearly dose to people in the United States from all sources of natural } \\
\text { background radiation }\end{array}$ \\
\hline 1 to $5 \mathrm{rem}$ & $\begin{array}{l}\text { Level at which EPA Protective Action Guidelines state that public officials } \\
\text { should take emergency action when this is a probable dose to a member of the } \\
\text { public from a nuclear accident }\end{array}$ \\
\hline 5 rem & $\begin{array}{l}\text { Annual limit for occupational exposure of radiation workers set by the U.S. } \\
\text { Nuclear Regulatory Commission and DOE }\end{array}$ \\
\hline $10 \mathrm{rem}$ & $\begin{array}{l}\text { Estimated level at which an acute dose would result in a lifetime } \\
\text { excess risk of death from cancer } 0.8 \%\end{array}$ \\
\hline 25 rem & $\begin{array}{l}\text { EPA guideline for voluntary maximum dose to emergency workers for } \\
\text { non-lifesaving work during an emergency }\end{array}$ \\
\hline $75 \mathrm{rem}$ & $\begin{array}{l}\text { EPA guideline for maximum dose to emergency workers volunteering for } \\
\text { lifesaving work }\end{array}$ \\
\hline 50 to $600 \mathrm{rem}$ & $\begin{array}{l}\text { Level at which doses received over a short period of time produce } \\
\text { radiation sickness in varying degrees. At the lower end of this range, people } \\
\text { are expected to recover completely, given proper medical attention. At the top } \\
\text { of this range, most people will die within } 60 \text { days }\end{array}$ \\
\hline
\end{tabular}

Adapted from Savannah River Site Environmental Report for 1993, Summary Pamphlet, WSRC-TR-94-076, Westinghouse Savannah River Company, 1994. 


\section{Dose from Consumer Products}

The U.S. average annual dose to an individual from consumer products is about 10 mrem (0.10 mSv) (NCRP 1987); however, not all members of the U.S. population are exposed to all of these sources.

\section{Dose from Medical Sources}

Nuclear medicine examinations, which involve internal administration of radiopharmaceuticals, generally account for the largest portion of dose from human-made sources. However, the radionuclides used for specific tests are not distributed uniformly throughout the body. In these cases, the concept of EDE, which relates the significance of exposures of organs or body parts to the effect on the entire body, is useful in making comparisons. The average annual EDE from medical examinations is $53 \mathrm{mrem}(0.53 \mathrm{mSv})$, including 39 mrem $(0.39 \mathrm{mSv})$ for diagnostic $\mathrm{X}$ rays and $14 \mathrm{mrem}(0.14 \mathrm{mSv})$ for nuclear medicine procedures (NCRP 1989). The actual doses to individuals who receive such medical exams are much higher than these values, but not everyone receives such exams each year (NCRP 1989).

\section{Dose from Other Sources}

A few additional sources of radiation contribute minor doses to individuals in the United States. The dose to the general public from nuclear fuel cycle facilities, such as uranium mines, mills, fuel-processing plants, nuclear power plants, and transportation routes, has been estimated at less than 1 mrem $(0.01 \mathrm{mSv})$ per year (NCRP 1987).

A comprehensive U.S. Environmental Protection Agency report projected an average occupational dose to monitored radiation workers in medicine, industry, the nuclear fuel cycle, government, and miscellaneous industries to be $105 \mathrm{mrem}(1.05 \mathrm{mSv})$ per year for 1985 , down slightly from 110 mrem $(1.10 \mathrm{mSv}$ ) per year in 1980 (Kumazawa et al. 1984).

Small doses to individuals occur as a result of radioactive fallout from atmospheric atomic bomb tests, emissions of radioactive materials from nuclear facilities, emissions from certain mineral-extraction facilities, and transportation of radioactive materials. The combination of these sources contributes less than $1 \mathrm{mrem}(0.01 \mathrm{mSv})$ per year to the average dose to an individual (NCRP 1987). 
Appendix B: Chemicals 
-

-

- 


\section{Appendix B: Chemicals}

This appendix presents basic facts about chemicals. The information is intended to be a basis for understanding the dose or relative toxicity assessment associated with releases from the Oak Ridge Reservation (ORR), not a comprehensive discussion of chemicals and their effects on the environment and biological systems.

\section{PERSPECTIVE ON CHEMICALS}

The lives of modern humans have been greatly improved by the development of chemicals such as pharmaceuticals, building materials, housewares, pesticides, and industrial chemicals. Through the use of chemicals we can increase food production, cure diseases, build more efficient houses, and send people to the moon. At the same time we must be cautious to ensure that our own existence is not endangered by uncontrolled and overexpanded use of chemicals (Chan et al. 1992).

Just as all humans are exposed to radiation in the normal daily routine, humans are also exposed to chemicals. Some potentially hazardous chemicals do exist in the natural environment. In many areas of the country, soils contain naturally elevated concentrations of metals such as selenium, arsenic, or molybdenum, which may be hazardous to humans or animals. However, exposures to many more hazardous chemicals result from the direct or indirect actions of humans. Building materials used for the construction of homes may contain chemicals such as formaldehyde (in some insulation materials), asbestos (formerly used in insulations and ceiling tiles), and lead (formerly used in paints). Some chemicals are present as a result of application of pesticides and fertilizers to soil. Other chemicals may have been transported long distances through the atmosphere from industrial sources before being deposited on soil or water.

\section{PATHWAYS OF CHEMICALS FROM THE ORR TO THE PUBLIC}

Pathways refer to the route or way in which a person can come in contact with a chemical substance. Chemicals released to the air may remain suspended for long periods of time, or they may be deposited on plants, soil, and water. Chemicals may also be released as liquid wastes called effluents, which can enter streams and rivers.

People are exposed to chemicals by inhalation (breathing air), ingestion (eating exposed plants and animals or drinking water), or by direct contact (touching the soil or swimming in water). For example, fish in a river that receives effluents may take in some of the chemicals present. People eating the fish would then be exposed to the chemical. Less likely would be exposure by directly drinking from the stream or river.

The public is not normally exposed to chemicals on the ORR because access to the reservation is limited. However, chemicals released as a result of ORR operations can move through the environment to off-site locations, resulting in potential exposure to the public. 


\section{DEFINITIONS}

\section{Toxicity}

Chemicals have varying types of effects. Generally, when considering human health, chemicals are divided into two broad categories: chemicals that cause health effects but do not cause cancer (noncarcinogens) and chemicals that cause cancer (carcinogens). The potential health effects of noncarcinogens range from irritation to life-shortening. Carcinogens cause or increase the incidence of malignant neoplasms or cancers.

Toxicity refers to an adverse effect of a chemical on human health. Not all chemicals are toxic: every day we ingest chemicals in the form of food, water, and sometimes medications. Even those chemicals that are usually considered toxic are usually nontoxic or harmless below a certain concentration.

Concentration limits or advisories are set by government agencies for some chemicals that are known or thought to have an adverse effect on human health. These concentration limits can be used to calculate a chemical dose that would not harm even individuals who are particularly sensitive to the chemical.

\section{Dose Terms for Noncarcinogens}

\section{Reference Dose (RfD)}

An estimate (with uncertainty spanning an order of magnitude or greater) of a daily exposure level for the human population, including sensitive subpopulations, that is likely to be without an appreciable risk of deleterious effects during a lifetime. Units are expressed as milligrams per kilogram per day $\left(\mathrm{mg} \mathrm{kg}^{-1} \mathrm{day}^{-1}\right)$.

Values for RfDs are derived from doses of chemicals that result in no adverse effect or the lowest dose that showed an adverse effect on humans or laboratory animals. Because these doses are in most cases derived from animal studies, safety factors are added for application to humans. Safety factors range from 10 to 1000 (i.e., safe doses for humans are set at 10 to 1000 times lower than doses showing no effect or a non-life-threatening effect in animals). This is thought to protect the most sensitive individuals. The U.S.

Environmental Protection Agency (EPA) maintains the Integrated Risk Information System (IRIS) data base (EPA 1991), which contains verified RfDs and slope factors and up-to-date health risk and EPA regulatory information for numerous chemicals.

\section{Primary and secondary maximum contaminant level}

For chemicals for which RfDs are not available, national primary [maximum contaminant levels (MCLs)] and secondary drinking water regulation [secondary MCLs (SMCLs)] concentrations, expressed in milligrams per liter, are converted to RfD values by multiplying by $2 \mathrm{~L}$ (the average daily adult water intake) and dividing by $70 \mathrm{~kg}$ (the reference adult body weight). The result is a "derived" reference dose expressed in milligrams per kilogram per day $\left(\mathrm{mg} \mathrm{kg}^{-1} \mathrm{day}^{-1}\right)$.

\section{Dose Term for Carcinogens}

\section{Slope factor (SF)}

A plausible upper-bound estimate of the probability of a response per unit intake of a chemical over a lifetime. The slope factor is used to estimate an upper-bound probability of

\section{B-4 Appendix B: Chemicals}


an individual developing cancer as a result of a lifetime exposure to a particular level of a potential carcinogen. Units are expressed as risk per dose $\left(\mathrm{mg} \mathrm{kg}^{-1} \mathrm{day}^{-1}\right)$.

The SF converts the estimated daily intake averaged over a lifetime exposure to the incremental risk of an individual developing cancer. Because it is unknown whether a threshold (a dose below which no adverse effect occurs) exists for carcinogens, units for carcinogens are set in terms of risk factors. For potential carcinogens at the ORR, a specific risk of developing cancer over a human lifetime of 1 in $100,000\left(10^{-5}\right)$ was used to establish acceptable levels of exposure. That is, EPA estimates that a certain concentration in food or water could cause a risk of one additional cancer case for every 100,000 exposed persons.

\section{MEASURING CHEMICALS}

Environmental samples are collected in areas surrounding the ORR and are analyzed for chemical constituents that are most likely to be released from the ORR. Typically, chemical concentrations in liquids are expressed in terms of milligrams or micrograms of chemical per liter of water; concentrations in solids (soil and fish tissue) are expressed in terms of milligrams or micrograms of chemical per gram or kilogram of sample material.

The instruments used to measure chemical concentrations are very sensitive; however, they have limits, beyond which they cannot detect the chemicals of interest. Concentrations that are below the detection limits of the instruments are recorded as "less-than" $(<)$ values or with tildes $(\sim)$. Exposure calculations are given "less-than" values unless at least one sample exceeds the detection limit. The tilde indicates that estimated values and/or detection limits were used in estimating the average concentration of a chemical.

\section{RISK ASSESSMENT METHODOLOGY}

\section{Exposure Assessment}

To evaluate an individual's exposure by way of a specific exposure pathway, the intake amount of the chemical must be determined. For example, chemical exposure by drinking water and eating fish from the Clinch River is assessed in the following way. It is assumed that individuals outside the ORR boundary are exposed to statistically significant concentrations of contaminants. It is also assumed that they drink $2 \mathrm{~L}(0.53 \mathrm{gal})$ of water per day directly from the river, which amounts to $730 \mathrm{~L}$ (193 gal) per year, and that they eat $58 \mathrm{~g}(0.13 \mathrm{lb})$ of fish per day [21.2 kg $(46.7 \mathrm{lb})$ per year]. Estimated daily intakes or estimated doses to the public can be calculated by multiplying measured concentrations in water by $2 \mathrm{~L}$ or those in fish by $58 \mathrm{~g}$. These are conservative assumptions that in many cases result in higher estimated intakes and doses than an actual individual would receive.

\section{Dose Estimate}

Once the contaminant oral daily intake via exposure pathways is estimated, the dose can be determined. For chemicals, dose to humans is measured in terms of milligrams per kilogram per day $\left(\mathrm{mg} \mathrm{kg}^{-1} \mathrm{day}^{-1}\right)$. In this case, the "kilogram" refers to the body weight of an adult individual. When we calculate a chemical dose, the length of time an individual is exposed to a certain concentration is important. To assess off-site doses, it is assumed that the exposure duration occurs over a lifetime, which is defined as 70 years. Such exposures are called chronic in contrast to short-term exposures, which are called acute. 


\section{Calculation Methodology}

In previous annual environmental reports, the "calculated daily intakes," based on chemical concentrations in water or fish, were divided by the "acceptable daily intake," which was based on the RfD. Both intakes were expressed in milligrams per day by multiplying by $70 \mathrm{~kg}$ for body weight. Current risk assessment methodologies use the term hazard quotient (HQ) to evaluate noncarcinogenic health effects. Therefore, in this environmental report the HQ methodology is used. Because intakes are calculated in milligrams per kilogram per day in the HQ methodology, they are expressed in terms of dose. The HQ compares the estimated exposure dose $(I)$ to the $\mathrm{RfD}$ as follows:

$$
H Q=\frac{I}{R f D}
$$

where

$$
\begin{aligned}
H Q & =\text { hazard quotient (unitless) } \\
I & =\text { estimated dose }\left(\mathrm{mg} \mathrm{kg} \mathrm{day}^{-1}\right) \\
R f D & =\text { reference dose }\left(\mathrm{mg} \mathrm{kg}^{-1} \text { day }^{-1}\right)
\end{aligned}
$$

HQ values of less than 1 indicate an unlikely potential for adverse health effects, whereas HQ values greater than 1 indicate a concern for adverse health effects or the need for further study.

To evaluate carcinogenic risk, SFs are used instead of RfDs. In this report, we compare the estimated dose attributed from ingesting water or fish from rivers and streams surrounding ORR to the chronic daily intake (CDI) derived from assuming a human lifetime risk of developing cancer of $10^{-5}$ ( 1 in 100,000$)$. The SF is converted to a CDI as follows:

$$
C D I=\frac{1 \times 10^{-5}}{S F}
$$

where

$$
\begin{aligned}
C D I & =\text { chronic daily intake }\left(\mathrm{mg} \mathrm{kg}^{-1} \mathrm{day}^{-1}\right) \\
S F & \left.=\text { slope factor, oral (risk per } \mathrm{mg} \mathrm{kg}^{-1} \text { day }{ }^{-1}\right)
\end{aligned}
$$

In typical risk assessments risks are generally derived; however, in this report we assume $10^{-5}$ as the level of acceptable risk. To estimate the risk of inducing cancers, from ingestion of water and fish, relative to the risk of $10^{-5}$, the estimated dose $(I)$ is divided by the CDI. A ratio greater than 1 indicates a risk greater than $10^{-5}$. 
Appendix C: Air Permits 

Table C.1. Air permits at the Y-12 Plant

\begin{tabular}{|c|c|c|c|c|}
\hline $\begin{array}{c}\text { Y-12 Plant } \\
\text { source number }\end{array}$ & $\begin{array}{c}\text { Source reference } \\
\text { number }\end{array}$ & $\begin{array}{l}\text { Permit } \\
\text { number }\end{array}$ & Stack & Stack description \\
\hline \multicolumn{5}{|c|}{ Part 1 -operating permits at $Y-12$ Plant } \\
\hline \multirow[t]{4}{*}{ Y-9201-1-A } & $01-0020-15$ & $730303 \mathrm{P}$ & 582 & Weld booths sanders and grinders \\
\hline & & & 583 & Metal sanders and grinders \\
\hline & & & 584 & Plasma torch \\
\hline & & & 585 & Grinding room area exhaust \\
\hline \multirow[t]{2}{*}{ Y-9201-1-B } & $01-0020-59$ & $730310 \mathrm{P}$ & 586 & Tool grinding machine shop \\
\hline & & & 587 & Sand blaster exhaust \\
\hline \multirow[t]{2}{*}{ Y-9201-1-C } & $01-0020-17$ & $036057 \mathrm{P}$ & 278 & Graphite carbon machine shop \\
\hline & & & 279 & Graphite carbon machine shop \\
\hline \multirow[t]{2}{*}{ Y-9201-1-E } & $01-1020-92$ & $035050 \mathrm{P}$ & 00 & Lead machining operations \\
\hline & & & 6 & Welding shop sanding \\
\hline \multirow[t]{2}{*}{ Y-9201-1W-A } & 01-0020-99 & $036129 \mathrm{P}$ & 00 & Machine shop equipment \\
\hline & & & 272 & Grit blasting \\
\hline Y-9201-4-A & $01-1020-96$ & $032956 \mathrm{P}$ & 264 & Mercury flasking hood \\
\hline \multirow[t]{8}{*}{ Y-9201-5-H } & $01-0020-16$ & 026019P & 762 & Mixing process material \\
\hline & & & 763 & Setup and sample area \\
\hline & & & 764 & Vapor blaster \\
\hline & & & 765 & Nickel plating tank exhaust \\
\hline & & & 766 & Material handling \\
\hline & & & 767 & Material handling \\
\hline & & & 768 & Glovebox and blending station \\
\hline & & & 769 & Inspection house vacuum \\
\hline Y-9201-5-J & $01-0020-21$ & $730305 \mathrm{P}$ & 276 & Tool grinding machine shop \\
\hline \multirow[t]{4}{*}{ Y-9201-5E-B } & $01-0020-21$ & $730305 P$ & 273 & Electrochemical machine shop \\
\hline & & & 71 & Machining operations L5N \\
\hline & & & 72 & Vacuum inlets L5E machining \\
\hline & & & 73 & Palarite shop-Machine \\
\hline Y-9201-5N-A & $01-1020-18$ & $730314 \mathrm{P}$ & 67 & Machine shop exhaust \\
\hline \multirow[t]{8}{*}{ Y-9201-5N-B } & $01-0020-30$ & $030484 \mathrm{P}$ & 239 & Plating tanks and hoods \\
\hline & & & 240 & Plating tanks and hoods \\
\hline & & & 241 & Plating tanks and hoods \\
\hline & & & 242 & Incinerator \\
\hline & & & 243 & Grit blaster \\
\hline & & & 244 & Grit blaster and area exhaust \\
\hline & & & 245 & Process hoods \\
\hline & & & 454 & Plating hoods \\
\hline \multirow[t]{2}{*}{ Y-9201-5W-I } & $01-0020-24$ & $730305 \mathrm{P}$ & 00 & Machine shop equipment \\
\hline & & & 455 & Rubber-gel potting hood exhaust \\
\hline \multirow[t]{4}{*}{ Y-9202-A } & $01-0020-06$ & $031696 \mathrm{P}$ & 160 & Laboratory beryllium \\
\hline & & & 161 & Laboratory beryllium \\
\hline & & & 3 & Laboratory beryllium \\
\hline & & & 4 & Laboratory beryllium \\
\hline
\end{tabular}


Table C.1 (continued)

\begin{tabular}{|c|c|c|c|c|}
\hline $\begin{array}{l}\text { Y-12 Plant } \\
\text { source number }\end{array}$ & $\begin{array}{c}\text { Source reference } \\
\text { number }\end{array}$ & $\begin{array}{l}\text { Permit } \\
\text { number }\end{array}$ & Stack & Stack description \\
\hline \multirow[t]{12}{*}{ Y-9204-2-A } & $01-0020-46$ & $026107 \mathrm{P}$ & 301 & Storage tank \\
\hline & & & 302 & Storage tank \\
\hline & & & 303 & Storage tank \\
\hline & & & 304 & Storage tank \\
\hline & & & 305 & Storage tank \\
\hline & & & 306 & Storage tank \\
\hline & & & 307 & Storage tank \\
\hline & & & 308 & Storage tank \\
\hline & & & 309 & Storage tank \\
\hline & & & 310 & Storage tank \\
\hline & & & 311 & Storage tank/head tank \\
\hline & & & 312 & Storage tank \\
\hline \multirow[t]{9}{*}{$Y-9204-2-D$} & $01-1020-57$ & $730327 \mathrm{P}$ & 342 & Salvage vats \\
\hline & & & 343 & Storage tank \\
\hline & & & 344 & Lithium chloride crystallizer \\
\hline & & & 345 & Lithium chloride crystallizer \\
\hline & & & 346 & Neutralizer \\
\hline & & & 347 & Processor tank \\
\hline & & & 348 & Lithium chloride crystallizer \\
\hline & & & 349 & Processor tanks \\
\hline & & & 350 & Processor tank \\
\hline \multirow[t]{13}{*}{ Y-9204-2-E } & $01-1020-55$ & $730325 \mathrm{P}$ & 351 & Oven \\
\hline & & & 352 & Oven \\
\hline & & & 356 & Tungsten screener \\
\hline & & & 357 & Dry box vent \\
\hline & & & 358 & Material handling \\
\hline & & & 359 & Gloveboxes \\
\hline & & & 360 & Outgassing/annealing oven \\
\hline & & & 361 & Material handling \\
\hline & & & 362 & Gloveboxes \\
\hline & & & 363 & Reactor unloading station \\
\hline & & & 364 & Reactor unloading station \\
\hline & & & 365 & Metal ingot storage glovebox \\
\hline & & & 366 & New metal ingot storage glovebox \\
\hline \multirow[t]{3}{*}{ Y-9204-2-F } & $01-0020-51$ & $730309 \mathrm{P}$ & 368 & Classified \\
\hline & & & 369 & Classified \\
\hline & - & & 370 & Classified \\
\hline \multirow[t]{8}{*}{ Y-9204-2E-A } & $01-1020-91$ & $730312 \mathrm{P}$ & 202 & Positive ion accelerator \\
\hline & & & 436 & Oven \\
\hline & & & 439 & Hood exhaust \\
\hline & & & 441 & Hood \\
\hline & & & 442 & Hood \\
\hline & & & 443 & Perc degreaser \\
\hline & & & 444 & Chromic acid eletcropolish \\
\hline & & & 445 & Surface coating \\
\hline
\end{tabular}


Table C.1 (continued)

\begin{tabular}{|c|c|c|c|c|}
\hline $\begin{array}{l}\text { Y-12 Plant } \\
\text { source number }\end{array}$ & $\begin{array}{l}\text { Source reference } \\
\text { number }\end{array}$ & $\begin{array}{l}\text { Permit } \\
\text { number }\end{array}$ & Stack & Stack description \\
\hline Y-9204-3-A & 01-0020-89 & 018208P & 106 & Furnaces \\
\hline \multirow[t]{9}{*}{ Y-9204-4-B } & 01-0020-72 & $730313 P$ & 481 & Exhaust from machining operations \\
\hline & & & 482 & Exhuast from hood-reclamation \\
\hline & & & 484 & Rolling mill-1st floor \\
\hline & & & 485 & Exhaust from paint hood \\
\hline & & & 486 & Filtering exhaust from paint booths \\
\hline & & & 488 & Laboratory hoods-1st floor \\
\hline & & & 489 & Laboratory hoods-reclamation area \\
\hline & & & 490 & Assembly process-1st floor \\
\hline & & & 491 & Assembly process-1st floor \\
\hline \multirow[t]{4}{*}{ Y-9204-4-E } & $01-0020-33$ & 032932P & 258 & Plating equipment \\
\hline & & & 259 & Plating equipment \\
\hline & & & 260 & Plating equipment \\
\hline & & & 261 & Plating equipment \\
\hline Y-9206-A & 01-0020-48 & $012892 \mathbf{P}$ & 421 & Storage tank \\
\hline \multirow[t]{12}{*}{ Y-9206-B } & $01-0020-03$ & $731689 \mathrm{P}$ & 013 & South stack incinerator \\
\hline & & & 015 & West stack \\
\hline & & & 016 & Dissolving hood \\
\hline & & & 017 & Steam cleaning hoods \\
\hline & & & 115 & Reduction fluid bed \\
\hline & & & 135 & AEC scrubber stack \\
\hline & & & 136 & AEC consolidated stack \\
\hline & & & 208 & Conversion fluid bed \\
\hline & & & 209 & HF purge vent \\
\hline & & & 210 & Chemical makeup area \\
\hline & & & 211 & Hood 29 and 30 \\
\hline & & & 212 & DRY vacuum system \\
\hline \multirow[t]{2}{*}{ Y-9206-C } & $01-1020-24$ & $730316 \mathrm{P}$ & 12 & Classified \\
\hline & & & 14 & Uranium alloy production \\
\hline \multirow[t]{14}{*}{ Y-9212-A } & $01-1020-72$ & 036942P & 111 & Reduction fluid bed \\
\hline & & & 112 & Conversion fluid beds \\
\hline & & & 132 & Decontamination facility \\
\hline & & & 134 & B-Wing and C-1 Wing exhaust \\
\hline & & & 19 & FILT Exhaust \\
\hline & & & 21 & Centrifuges \\
\hline & & & 22 & Reduction salvage crusher \\
\hline & & & 24 & $\begin{array}{l}\text { Calciner and dry vacuum system } \\
\text { enclosure }\end{array}$ \\
\hline & & & 25 & $\begin{array}{l}\text { Denitrator area and fluid bed room } \\
\text { enclosure }\end{array}$ \\
\hline & & & 27 & D-Wing room 1010 hoods \\
\hline & & & 28 & Reduction shear and room \\
\hline & & & 33 & Headhouse equipment incinerator \\
\hline & & & 36 & East scrubber (C-1 wing) \\
\hline & & & 40 & B-1 sampling lab hood \\
\hline
\end{tabular}


Table C.1 (continued)

\begin{tabular}{|c|c|c|c|c|}
\hline $\begin{array}{l}\text { Y-12 Plant } \\
\text { source number }\end{array}$ & $\begin{array}{c}\text { Source reference } \\
\text { number }\end{array}$ & $\begin{array}{l}\text { Permit } \\
\text { number }\end{array}$ & Stack & Stack description \\
\hline & & & 42 & Chloride removal system (C-1) \\
\hline & & & 429 & Fluorine cylinder rack enclosure \\
\hline & & & 430 & HF dock cylinder/vaporizer \\
\hline & & & 431 & $\mathrm{~N}_{2} \mathrm{O}_{4}$ cylinder purge vent \\
\hline & & & 432 & Muffle furnaces (2) vent Room 229 \\
\hline & & & 50 & C-1 chip burner enclosure \\
\hline & & & 500 & Primary extraction vent \\
\hline & & & 501 & Secondary extraction vent \\
\hline \multirow[t]{4}{*}{ Y-9212-B } & 01-0020-02 & $730301 \mathrm{P}$ & 110 & U metal and U metal alloy \\
\hline & & & 38 & $U$ metal drying and briquetting process \\
\hline & & & 43 & Exhaust from chip washing \\
\hline & & & 48 & E-Wing machine shop \\
\hline \multirow[t]{9}{*}{$\mathrm{Y}-9212-\mathrm{C}$} & $01-0020-05$ & $025984 \mathrm{P}$ & 113 & Dissolver trays/scrubber \\
\hline & & & 114 & Shear and hacksaw hood \\
\hline & & & 128 & Precipitation process \\
\hline & & & 26 & $\begin{array}{l}\text { Drum receiving/sampling hood and } \\
\text { glovebox }\end{array}$ \\
\hline & & & 290 & Tube furnace/gas purge vent \\
\hline & & & 44 & Leaching and dissolving hoods \\
\hline & & & 45 & Muffle furnance dry hoods \\
\hline & & & 46 & Tray dissolver hoods \\
\hline & & & 47 & Dissolver tray hoods/room 1 \\
\hline Y-9215-A & $01-0020-37$ & $731839 \mathrm{P}$ & 3 & Machine shop hood exhaust \\
\hline \multirow[t]{4}{*}{ Y-9215-B } & $01-1020-51$ & $732125 \mathrm{P}$ & 1 & O-wing metal working operations \\
\hline & & & 2 & Turco pretreat spray hood \\
\hline & & & 4 & O-wing metal working operations \\
\hline & & & 6 & O-wing metal working operations \\
\hline \multirow[t]{4}{*}{ Y-9215-D } & $01-1020-53$ & $025966 \mathrm{P}$ & 10 & Roll mill exhaust \\
\hline & & & 11 & $\begin{array}{l}\text { Furnance/quench tank/conveyor } \\
\text { exhaust }\end{array}$ \\
\hline & & & 12 & Hydraulic shear exhaust \\
\hline & & & 9 & Rolling mill/ salt bath \\
\hline Y-9401-3-A & $01-1020-31$ & 034809F & 170 & Coal-fired boiler \\
\hline Y-9401-3-B & $01-1020-32$ & 034809F & 170 & Coal-fired boiler \\
\hline Y-9401-3-C & $01-1020-33$ & 034809F & 171 & Coal-fired boiler \\
\hline Y-9401-3-D & $01-1020-34$ & 034809F & 171 & Coal-fired boiler \\
\hline \multirow[t]{4}{*}{ Y-9404-11-A } & $01-1020-81$ & $28426 \mathrm{P}$ & 373 & Purification plant reator \\
\hline & & & 374 & Purification plant glovebox \\
\hline & & & 375 & Purification plant glovebox \\
\hline & & & 376 & Purification plant glovebox \\
\hline \multirow[t]{2}{*}{ Y-9404-5-A } & $01-0020-25$ & $012866 \mathrm{P}$ & 676 & Paint spray booth \\
\hline & & & 677 & Paint spray booth \\
\hline Y-9404-7-A & $01-1020-89$ & 034295P & 00 & Maintenance shop \\
\hline \multirow[t]{2}{*}{ Y-9404-9-C } & $01-1020-19$ & $730315 \mathrm{P}$ & 323 & Halar oven \\
\hline & & & 324 & Urethane warming oven \\
\hline
\end{tabular}


Table C.1 (continued)

\begin{tabular}{|c|c|c|c|c|}
\hline $\begin{array}{l}\text { Y-12 Plant } \\
\text { source number }\end{array}$ & $\begin{array}{c}\text { Source reference } \\
\text { number }\end{array}$ & $\begin{array}{l}\text { Permit } \\
\text { number }\end{array}$ & Stack & Stack description \\
\hline & & & 325 & Urethane oven \#3 \\
\hline & & & 326 & PVC oven \#4 \\
\hline & & & 327 & PVC oven \#5 \\
\hline & & & 328 & Steam autoclave \\
\hline & & & 329 & General use oven \\
\hline & & & 330 & Halar spray booth \\
\hline & & & 331 & Blue $\mathrm{M}$ oven \\
\hline & & & 332 & Drape forming equipment \\
\hline & & & 333 & Vacuum system \\
\hline & & & 336 & Despatch oven \\
\hline & & & 337 & Rubber preparation equipment \\
\hline & & & 338 & Lab hood \\
\hline & & & 339 & Despatch oven \\
\hline & & & 340 & Vacuum pumps \\
\hline & & & 341 & Plastics fume hood \\
\hline Y-9616-10-A & $01-1020-62$ & 029280P & 428 & Sulfuric acid storage tank \\
\hline Y-9616-7-A & $01-1020-80$ & $031254 \mathrm{P}$ & 271 & Vent from air stripper \\
\hline \multirow[t]{28}{*}{$Y-9616-7-B$} & $01-1020-74$ & 737019P & 459 & West end treatment storage \\
\hline & & & 460 & West end treatment storage \\
\hline & & & 461 & West end treatment storage \\
\hline & & & 462 & West end treatment storage \\
\hline & & & 463 & West end treatment vent reactor vessel \\
\hline & & & 464 & West end treatment storage \\
\hline & & & 465 & West end treatment vent degasifier unit \\
\hline & & & 466 & West end treatment storage \\
\hline & & & 467 & West end treatment storage \\
\hline & & & 468 & West end treatment storage \\
\hline & & & 469 & West end treatment vent lime silo \\
\hline & & & 470 & West end treatment storage \\
\hline & & & 471 & WETF laboratory hood \\
\hline & & & 472 & WETF sodium hydroxide tank \\
\hline & & & 473 & WETF clarifier (6-315) \\
\hline & & & 650 & Biological treatment tank \\
\hline & & & 651 & Biological treatment tank \\
\hline & & & 652 & Biological treatment tank \\
\hline & & & 653 & Biological treatment tank \\
\hline & & & 654 & Biological treatment tank \\
\hline & & & 655 & Biological treatment tank \\
\hline & & & 656 & Solids storage tank \\
\hline & & & 657 & Solids storage tank \\
\hline & & & 658 & Solids storage tank \\
\hline & & & 659 & Solids storage tank \\
\hline & & & 660 & Solids storage tank \\
\hline & & & 661 & Solids storage tank \\
\hline & & & 662 & Solids storage tank \\
\hline
\end{tabular}


Table C.1 (continued)

\begin{tabular}{|c|c|c|c|c|}
\hline $\begin{array}{c}\text { Y-12 Plant } \\
\text { source number }\end{array}$ & $\begin{array}{l}\text { Source reference } \\
\text { number }\end{array}$ & $\begin{array}{l}\text { Permit } \\
\text { number }\end{array}$ & Stack & Stack description \\
\hline & & & 665 & WETF-F-380A sludge settling \\
\hline & & & 666 & WETF-F-380B sludge settling \\
\hline & & & 667 & WETF-F-381A sludge concentrator \\
\hline & & & 668 & WETF-F-381B sludge denitrator \\
\hline & & & 669 & WETF-F-384 decant hold tank \\
\hline & & & 670 & WETF-F-382 decant tank/30 \\
\hline & & & 671 & WETF-F-385 decant tank/30 \\
\hline & & & 672 & WETF-F-390A calcium carbonate \\
\hline & & & 673 & WETF-F-390B calcium carbonate \\
\hline & & & 674 & WETF-F-390C calcium carbonate \\
\hline & & & 675 & WETF-F-400 F-401 slurry tank \\
\hline Y-9720-12-A & $01-1020-89$ & $034295 \mathrm{P}$ & 00 & Non-special nuclear material \\
\hline$Y-9720-25-A$ & $01-1020-89$ & $034295 \mathrm{P}$ & 00 & Drum storage warehouse \\
\hline Y-9720-28-A & $01-1020-89$ & 034295P & 00 & Drum storage warehouse \\
\hline Y-9720-31-A & $01-1020-89$ & $034295 \mathrm{P}$ & 00 & RCRA and mixed waste storage \\
\hline \multirow[t]{2}{*}{ Y-9720-32-A } & $01-0020-42$ & $032547 \mathrm{P}$ & 201 & Classified waste shredder \\
\hline & & & 435 & Classified paper incinerator \\
\hline Y-9720-44-A & $01-1020-89$ & 034295P & 00 & Low-level waste storage pad \\
\hline Y-9720-58-A & $01-1020-89$ & 034295P & 00 & PCB and RCRA staging and storage \\
\hline \multirow[t]{2}{*}{ Y-9720-6-A } & $01-0020-26$ & $012867 \mathrm{P}$ & 678 & Paint spray booth \\
\hline & & & 679 & Oven \\
\hline Y-9720-60-A & $01-1020-89$ & 034295P & 00 & DARA solids storage unit \\
\hline Y-9720-9-A & $01-1020-89$ & 034295P & 00 & PCB and RCRA hazardous waste \\
\hline \multirow[t]{5}{*}{ Y-9738-A } & $01-0020-14$ & $036776 \mathrm{P}$ & 576 & Sand blaster \\
\hline & & & 577 & Hood with fan \\
\hline & & & 578 & Sand blaster \\
\hline & & & 579 & Hood with fan \\
\hline & & & 580 & Hood with fan (removed) \\
\hline Y-9767-4-B & 01-0020-35 & $012877 \mathrm{P}$ & 00 & Chilled water circulating system \\
\hline \multirow[t]{6}{*}{ Y-9811-1-A } & 01-1020-95 & $731997 \mathrm{P}$ & 400 & Waste oil/storage bulk storage \\
\hline & & & 401 & Waste oil/storage bulk storage \\
\hline & & & 402 & Waste oil/storage bulk storage \\
\hline & & & 403 & Waste oil/storage bulk storage \\
\hline & & & 404 & Waste oil/storage bulk storage \\
\hline & & & 405 & Waste oil/storage bulk storage \\
\hline Y-9811-1-B & $01-1020-89$ & 034295P & 00 & Waste oil/solvent drum storage \\
\hline \multirow[t]{2}{*}{ Y-9811-6-A } & $01-1020-82$ & $029415 \mathrm{P}$ & 377 & Dry ash handling system \\
\hline & & & 378 & Dry ash handling system \\
\hline \multirow[t]{5}{*}{ Y-9811-8-A } & $01-1020-63$ & 032988P & 407 & Waste oil/solvent storage \\
\hline & & & 408 & Waste oil/solvent storage \\
\hline & & & 409 & Waste oil/solvent storage \\
\hline & & & 410 & Waste oil/solvent storage \\
\hline & & & 411 & Waste oil/solvent storage \\
\hline Y-9811-8-B & $01-1020-89$ & 034295P & 00 & Waste oil/solvent drum storage \\
\hline
\end{tabular}


Table C.1 (continued)

\begin{tabular}{|c|c|c|c|c|}
\hline $\begin{array}{c}\text { Y-12 Plant } \\
\text { source number }\end{array}$ & $\begin{array}{c}\text { Source reference } \\
\text { number }\end{array}$ & $\begin{array}{l}\text { Permit } \\
\text { number }\end{array}$ & Stack & Stack description \\
\hline \multirow[t]{6}{*}{ Y-9815-A } & $01-0020-11$ & $025895 \mathrm{P}$ & 780 & Vent from dissolvers \\
\hline & & & 781 & Nitric acid storage tank \\
\hline & & & 782 & Nitric acid storage tank \\
\hline & & & 783 & Storage tank $/ 4400 \mathrm{gal}$ \\
\hline & & & 784 & Storage tank $/ 1800 \mathrm{gal}$ \\
\hline & & & 785 & 2 storage tankS $/ 2200 \mathrm{gal}$ \\
\hline \multirow[t]{14}{*}{ Y-9818-A } & $01-0020-12$ & $025965 \mathrm{P}$ & 790 & Hot well seal tank \\
\hline & & & 791 & 10 storage tanks-nitric acid \\
\hline & & & 792 & Bioreactor tanks/ozonation \\
\hline & & & 793 & Basement exhaust \\
\hline & & & 794 & Nitric acid supply line vent \\
\hline & & & 795 & Calcium acetate storage tank \\
\hline & & & 796 & Nitric waste storage tank \\
\hline & & & 797 & Nitric waste storage tank \\
\hline & & & 798 & Nitric acid storage tank \\
\hline & & & 799 & Nitric acid storage tank \\
\hline & & & 800 & Ozone generator/area exhaust \\
\hline & & & 801 & Nitric acid waste tank \\
\hline & & & 802 & Caustic waste tank \\
\hline & & & 803 & Still condensers \\
\hline Y-9828-6-A & $01-1020-89$ & $034295 \mathrm{P}$ & 00 & Trash monitoring station \\
\hline Y-9983-74-A & $01-1020-89$ & 034295P & 00 & Old salvage yard \\
\hline \multicolumn{5}{|c|}{ Part II-construction permits at $Y-12$ Plant } \\
\hline \multirow[t]{4}{*}{ Y-9201-1-A } & $01-0020-15$ & $730303 \mathrm{P}$ & 582 & Weld booths sanders and grinders \\
\hline & & & 583 & Metal sanders and grinders \\
\hline & & & 584 & Plasma torch \\
\hline & & & 585 & Grinding room area exhaust \\
\hline \multirow[t]{2}{*}{ Y-9201-1-B } & $01-0020-59$ & $730310 \mathrm{P}$ & 586 & Tool grinding machines \\
\hline & & & 587 & Sand blaster exhaust \\
\hline Y-9201-5-J & $01-0020-21$ & $730305 P$ & 276 & Tool grinding machines \\
\hline \multirow[t]{4}{*}{ Y-9201-5E-B } & $01-0020-21$ & $730305 \mathrm{P}$ & 273 & Electrochemical machine \\
\hline & & & 71 & Machining operations L5N \\
\hline & & & 72 & Vacuum inlets LSE machining \\
\hline & & & 73 & Palarite shop-machine \\
\hline$Y-9201-5 N-A$ & $01-1020-18$ & $730314 \mathrm{P}$ & 67 & Machine shop exhaust \\
\hline \multirow[t]{2}{*}{ Y-9201-5W-I } & $01-0020-24$ & $730305 \mathrm{P}$ & 00 & Machine shop equipment \\
\hline & & & 455 & Rubber-gel potting hood exhaust \\
\hline \multirow[t]{7}{*}{ Y-9204-2-D } & $01-1020-57$ & $730327 \mathrm{P}$ & 342 & Salvage vats \\
\hline & & & 343 & Storage tank \\
\hline & & & 344 & Lithium chloride crystallizer \\
\hline & & & 345 & Lithium chloride crystallizer \\
\hline & & & 346 & Neutralizer \\
\hline & & & 347 & Processor tank \\
\hline & & & 348 & Lithium chloride crystallizer \\
\hline
\end{tabular}


Table C.1 (continued)

\begin{tabular}{|c|c|c|c|c|}
\hline $\begin{array}{l}\text { Y-12 Plant } \\
\text { source number }\end{array}$ & $\begin{array}{c}\text { Source reference } \\
\text { number }\end{array}$ & $\begin{array}{l}\text { Permit } \\
\text { number }\end{array}$ & Stack & Stack description \\
\hline & & & 349 & Processor tanks \\
\hline & & & 350 & Processor tank \\
\hline \multirow[t]{13}{*}{ Y-9204-2-E } & $01-1020-55$ & $730325 \mathrm{P}$ & 351 & Oven \\
\hline & & & 352 & Oven \\
\hline & & & 356 & Tungsten screener \\
\hline & & & 357 & Dry box vent \\
\hline & & & 358 & Material handling \\
\hline & & & 359 & Gloveboxes \\
\hline & & & 360 & Outgassing/annealing oven \\
\hline & & & 361 & Material handling \\
\hline & & & 362 & Gloveboxes \\
\hline & & & 363 & Reactor unloading station \\
\hline & & & 364 & Reactor unloading station \\
\hline & & & 365 & Metal ingot storage glovebox \\
\hline & & & 366 & New metal ingot storage glovebox \\
\hline \multirow[t]{3}{*}{ Y-9204-2-F } & $01-0020-51$ & $730309 \mathrm{P}$ & 368 & Classified \\
\hline & & & 369 & Classified \\
\hline & & & 370 & Classified \\
\hline \multirow[t]{8}{*}{ Y-9204-2E-A } & $01-1020-91$ & $730312 \mathrm{P}$ & 202 & Positive ion accelerator \\
\hline & & & 436 & Oven \\
\hline & & & 439 & Hood exhaust \\
\hline & & & 441 & Hood \\
\hline & & & 442 & Hood \\
\hline & & & 443 & Perc degreaser \\
\hline & & & 444 & Chromic acid electropolish \\
\hline & & & 445 & Surface coating \\
\hline \multirow[t]{9}{*}{ Y-9204-4-B } & $01-0020-72$ & $730313 P$ & 481 & Exhaust from machining operations \\
\hline & & & 482 & Exhaust from hood \\
\hline & & & 484 & Rolling mill \\
\hline & & & 485 & Exhaust from paint hood \\
\hline & & & 486 & Filtering exhaust from paint booths \\
\hline & & & 488 & Laboratory hoods \\
\hline & & & 489 & Laboratory hoods \\
\hline & & & 490 & Assembly process \\
\hline & & & 491 & Assembly process \\
\hline \multirow[t]{10}{*}{ Y-9206-B } & 01-0020-03 & $731689 \mathrm{P}$ & 013 & South stack incinerator \\
\hline & & & 015 & West stack \\
\hline & & & 016 & Dissolving hood \\
\hline & & & 017 & Steam cleaning hoods \\
\hline & & & 115 & Reduction fluid bed \\
\hline & & & 135 & AEC scrubber stack \\
\hline & & & 136 & AEC consolidated stack \\
\hline & & & 208 & Conversion fluid bed \\
\hline & & & 209 & $\mathrm{HF}$ purge vent \\
\hline & & & 210 & Chemical makeup area \\
\hline
\end{tabular}


Table C.1 (continued)

\begin{tabular}{|c|c|c|c|c|}
\hline $\begin{array}{c}\text { Y-12 Plant } \\
\text { source number }\end{array}$ & $\begin{array}{c}\text { Source reference } \\
\text { number }\end{array}$ & $\begin{array}{l}\text { Permit } \\
\text { number }\end{array}$ & Stack & Stack description \\
\hline & & & 211 & Hood 29 and 30 \\
\hline & & & 212 & Dry vacuum system \\
\hline \multirow[t]{2}{*}{ Y-9206-C } & $01-1020-24$ & $730316 \mathrm{P}$ & 12 & Classified \\
\hline & & & 14 & Uranium alloy production \\
\hline \multirow[t]{4}{*}{$\mathrm{Y}-9212-\mathrm{B}$} & $01-0020-02$ & $730301 P$ & 110 & $\mathrm{U}$ metal and U metal alloy \\
\hline & & & 38 & $\mathrm{U}$ metal drying and briquetting process \\
\hline & & & 43 & Exhaust from chip washing \\
\hline & & & 48 & E-wing machine shop \\
\hline $\mathrm{Y}-9215-\mathrm{A}$ & $01-0020-37$ & 731839P & 3 & Machine shop hood exhaust \\
\hline \multirow[t]{4}{*}{$Y-9215-B$} & $01-1020-51$ & $732125 \mathrm{P}$ & 1 & O-wing metal working operations \\
\hline & & & 2 & Turco pretreat spray hood \\
\hline & & & 4 & O-wing metal working operations \\
\hline & & & 6 & O-wing metal working operations \\
\hline \multirow[t]{17}{*}{ Y-9404-9-C } & 01-1020-19 & $730315 \mathrm{P}$ & 323 & Halar oven \\
\hline & & & 324 & Urethane warming oven \\
\hline & & & 325 & Urethane oven \#3 \\
\hline & & & 326 & PVC oven \#4 \\
\hline & & & 327 & PVC oven \#5 \\
\hline & & & 328 & Steam autoclave \\
\hline & & & 329 & General use oven \\
\hline & & & 330 & Halar spray booth \\
\hline & & & 331 & Blue $M$ oven \\
\hline & & & 332 & Drape forming equipment \\
\hline & & & 333 & Vacuum system \\
\hline & & & 336 & Despatch oven \\
\hline & & & 337 & Rubber preparation equipment \\
\hline & & & 338 & Lab hood \\
\hline & & & 339 & Despatch oven \\
\hline & & & 340 & Vacuum pumps \\
\hline & & & 341 & Plastics fume hood \\
\hline \multirow[t]{15}{*}{ Y-9616-7-B } & $01-1020-74$ & 737019P & 459 & West end treatment storage \\
\hline & & & 460 & West end treatment storage \\
\hline & & & 461 & West end treatment storage \\
\hline & & & 462 & West end treatment storage \\
\hline & & & 463 & West end treatment vent reactor vessel \\
\hline & & & 464 & West end treatment storage \\
\hline & & & 465 & West end treatment vent degasifier unit \\
\hline & & & 466 & West end treatment storage \\
\hline & & & 467 & West end treatment storage \\
\hline & & & 468 & West end treatment storage \\
\hline & & & 469 & West end treatment vent lime silo \\
\hline & & & 470 & West end treatment storage \\
\hline & & & 471 & WETF laboratory hood \\
\hline & & & 472 & WETF sodium hydroxide tank \\
\hline & & & 473 & WETF clarifier $(6-315)$ \\
\hline
\end{tabular}


Table C.1 (continued)

\begin{tabular}{|c|c|c|c|c|}
\hline $\begin{array}{c}\text { Y-12 Plant } \\
\text { source number }\end{array}$ & $\begin{array}{c}\text { Source reference } \\
\text { number }\end{array}$ & $\begin{array}{l}\text { Permit } \\
\text { number }\end{array}$ & Stack & Stack description \\
\hline & & & 650 & Biological treatment tank \\
\hline & & & 651 & Biological treatment tank \\
\hline & & & 652 & Biological treatment tank \\
\hline & & & 653 & Biological treatment tank \\
\hline & & & 654 & Biological treatment tank \\
\hline & & & 655 & Biological treatment tank \\
\hline & & & 656 & Solids storage tank \\
\hline & & & 657 & Solids storage tank \\
\hline & & & 658 & Solids storage tank \\
\hline & & & 659 & Solids storage tank \\
\hline & & & 660 & Solids storage tank \\
\hline & & & 661 & Solids storage tank \\
\hline & & & 662 & Solids storage tank \\
\hline & & & 665 & WETF-F-380A sludge settling \\
\hline & & & 666 & WETF-F-380B sludge settling \\
\hline & & & 667 & WETF-F-381A sludge concentrator \\
\hline & & & 668 & WETF-F-381B sludge denitrator \\
\hline & & & 669 & WETF-F-384 decant hold tank \\
\hline & & & 670 & WETF-F-382 decant tank/30 \\
\hline & & & 671 & WETF-F-385 decant tank/30 \\
\hline & & & 672 & WETF-F-390A calcium carbonate \\
\hline & & & 673 & WETF-F-390B calcium carbonate \\
\hline & & & 674 & WETF-F-390C calcium carbonate \\
\hline & & & 675 & WETF-F-400 F-401 slurry tank \\
\hline \multirow[t]{6}{*}{ Y-9811-1-A } & $01-1020-95$ & $31997 \mathrm{P}$ & 400 & Waste oil/storage bulk storage tank \\
\hline & & & 401 & Waste oil/storage bulk storage tank \\
\hline & & & 402 & Waste oil/storage bulk storage tank \\
\hline & & & 403 & Waste oil/storage bulk storage tank \\
\hline & & & 404 & Waste oil/storage bulk storage tank \\
\hline & & & 405 & Waste oil/storage bulk storage tank \\
\hline
\end{tabular}


Table C.2. ORNL air pollution emission sources permitted with the Tennessee Department of Environment and Conservation

\begin{tabular}{|c|c|c|c|}
\hline $\begin{array}{l}\text { Source } \\
\text { number }\end{array}$ & $\begin{array}{l}\text { Emission source } \\
\text { reference number }\end{array}$ & $\begin{array}{c}\text { TDEC } \\
\text { permit number }\end{array}$ & Source description \\
\hline$X-2519-1 / 5$ & $73-0112-03$ & $030284 \mathrm{P}$ & Steam plant \\
\hline $\mathrm{X}-2522-\mathrm{T} 1 \mathrm{~A}$ & $73-0112-10$ & $024114 \mathrm{P}$ & No. 2 fuel oil storage tank \\
\hline $\mathrm{X}-2525-\mathrm{SV}-11$ & $73-0112-49$ & $035026 \mathrm{P}$ & Electroplating \\
\hline$X-2547-01$ & $73-0112-27$ & $740817 \mathrm{P}$ & Surface coating spray booth \\
\hline $\mathrm{X}-3039$ & 73-0112-93 & 035494P & Off gas and hot cell ventilation \\
\hline $\mathrm{X}-3500-\mathrm{SV} 12$ & $73-0112-73$ & 036689P & Electric belt furnace \\
\hline$X-3502-01$ & $73-0112-05$ & $030881 \mathrm{P}$ & Spray booths (3) \\
\hline $\mathrm{X}-3502-09$ & $73-0112-94$ & $027194 \mathrm{P}$ & Hood gluing \\
\hline $\mathrm{X}-3502-\mathrm{SV} 1$ & $73-0112-39$ & 023808P & Oven curing \\
\hline $\mathrm{X}-3502-\mathrm{SV} 2$ & $73-0112-40$ & $023807 \mathrm{P}$ & Oven tempering \\
\hline $\mathrm{X}-3502-\mathrm{SV} 4$ & $73-0112-30$ & $036053 \mathrm{P}$ & Carpenter shop \\
\hline $\mathrm{X}-3544-\mathrm{SV} 1$ & $73-0112-70$ & $730468 \mathrm{P}$ & PWTP \\
\hline $\mathrm{X}-3587-\mathrm{SV} 1$ & $73-0112-56$ & 029830P & Printed circuit board facility \\
\hline$X-3608-01$ & $73-0112-37$ & $730489 \mathrm{P}$ & NRWTP air stripper column \\
\hline $\mathrm{X}-4508-\mathrm{SV} 8$ & $73-0112-61$ & $040077 \mathrm{P}$ & Acid etching process \\
\hline $\mathrm{X}-4508-S V 9$ & $73-0112-55$ & $024306 \mathrm{P}$ & Sandblaster \\
\hline$X-7002-04$ & $73-0112-08$ & $037231 P$ & Vehicle spray booth \\
\hline$X-7005-00$ & $73-0112-45$ & $037516 \mathrm{P}$ & Lead shop machining operation \\
\hline $\mathrm{X}-7005-3 / 7$ & $73-0112-26$ & $739585 \mathrm{P}$ & Five lead melting furnaces \\
\hline $\mathrm{X}-7007-1 / 2$ & 73-0112-09 & $030824 \mathrm{P}$ & Spray booth and cleaning booth \\
\hline$X-7021-00$ & $73-0112-58$ & $038357 \mathrm{P}$ & Grinding shop and sandblaster \\
\hline $\mathrm{X}-7057-S V 1$ & $73-0112-76$ & $030101 \mathrm{P}$ & Sandblaster \\
\hline $\mathrm{X}-7069-\mathrm{T} 1$ & 73-0112-60 NSPS & $730836 \mathrm{P}$ & Gasoline storage tank \\
\hline$X-7600-01$ & $73-0112-20$ & $017930 \mathrm{P}$ & Nuclear fuel reprocessing \\
\hline $\mathrm{X}-7602-01$ & $73-0112-24$ & $027090 \mathrm{P}$ & Boiler \\
\hline$X-7603-01$ & $73-0112-25$ & $740219 \mathrm{~F}$ & Steam-generating process \\
\hline$X-7667-0$ & $73-0112-0067-6$ & $73-0112-0067-6$ & Chemical detonation facility \\
\hline $\mathrm{X}-7830-\mathrm{SV} 1$ & $73-0112-71$ & $731010 \mathrm{P}$ & Liquid Waste Solidification Project \\
\hline $\mathrm{X}-7911-00$ & $73-0112-82$ & $034381 \mathrm{P}$ & HFIR \\
\hline $\mathrm{X}-7934-S V 2$ & $73-0112-53$ & 024912P & Silver recovery system \\
\hline $\mathrm{X}-7935-\mathrm{SV} 1$ & $73-0112-78$ & $027393 \mathrm{P}$ & Equipment cleaning facility \\
\hline $\mathrm{X}-\mathrm{FE}$ & 73-0112-97 & $029660 \mathrm{P}$ & Fugitive emission source \\
\hline $\mathrm{X}$-FLC & $73-0112-99$ & $034960 \mathrm{P}$ & Fluorescent lamp disposers \\
\hline
\end{tabular}


Table C.3. K-25 Site air permits

\begin{tabular}{|c|c|c|c|c|}
\hline $\begin{array}{l}\text { K-25 source } \\
\text { number }\end{array}$ & $\begin{array}{l}\text { Emission } \\
\text { source } \\
\text { reference } \\
\text { number }\end{array}$ & $\begin{array}{l}\text { Permit } \\
\text { number }\end{array}$ & Source description & $\begin{array}{l}\text { Permit } \\
\text { type }\end{array}$ \\
\hline K1037AVLISLAB & $73-1106-35$ & $935231 \mathrm{P}$ & $\begin{array}{l}\text { AVLIS Lab-metallothermic } \\
\text { reduction unit, chlorinator, } \\
\text { construct and oxide cell }\end{array}$ & $\begin{array}{l}\text { Permit to } \\
\text { construct }\end{array}$ \\
\hline K1037AVLISPRODCON & $73-1106-36$ & 935597P & $\begin{array}{l}\text { Products conversion } \\
\text { demonstration }\end{array}$ & $\begin{array}{l}\text { Permit to } \\
\text { construct }\end{array}$ \\
\hline K1095PS1234 & $73-0106-14$ & $734461 P$ & $\begin{array}{l}\text { Paint spray operation, one oven, } \\
\text { two spray booths, and one silk } \\
\text { screen degreaser }\end{array}$ & Operating \\
\hline K1202ST1 & $73-1106-20$ & $033203 \mathrm{P}$ & $\begin{array}{l}\text { Tank stores waste oils and } \\
\text { solvents for incinerator }\end{array}$ & Operating \\
\hline $\mathrm{K} 1202 \mathrm{ST} 2$ & $73-1106-41$ & $034392 \mathrm{P}$ & $\begin{array}{l}\text { Tank stores waste oils and } \\
\text { solvents for incinerator }\end{array}$ & Operating \\
\hline $\mathrm{K} 1420 \mathrm{~A} 1$ & $73-0106-82$ & 034619P & Flammable materials storage tank & Operating \\
\hline K1425WOSC & $73-0106-11$ & 029895P & $\begin{array}{l}\text { Waste oil and solvent storage } \\
\text { tanks }\end{array}$ & Operating \\
\hline K1425WOSA & $73-0106-11$ & 029895P & $\begin{array}{l}\text { Waste oil and solvent storage } \\
\text { tanks }\end{array}$ & Operating \\
\hline K1425WOSD & $73-0106-11$ & 029895P & $\begin{array}{l}\text { Waste oil and solvent storage } \\
\text { tanks }\end{array}$ & Operating \\
\hline K1425WOSB & 73-0106-11 & 029895P & $\begin{array}{l}\text { Waste oil and solvent storage } \\
\text { tanks }\end{array}$ & Operating \\
\hline K1435TSCAINCIN & 73-0106-78 & $032449 \mathrm{I}$ & TSCA Incinerator & Operating \\
\hline K1435CTANKFARM & $73-0106-75$ & $037460 \mathrm{P}$ & $\begin{array}{l}\text { Tank farm for hazardous liquid } \\
\text { wastes }\end{array}$ & Operating \\
\hline K1501BOILER4 & 73-0106-04 & $042076 \mathrm{~F}$ & Natural gas boiler & Operating \\
\hline K1501BOILER7 & 73-0106-17 & $042076 \mathrm{~F}$ & Gas/oil boiler & Operating \\
\hline K1501BOILER8 & $73-0106-12$ & $937114 \mathrm{~F}$ & Gas/oil boiler & Operating \\
\hline K1501BOILER9 & $73-0106-12$ & $937114 \mathrm{~F}$ & Gas/oil boiler & Operating \\
\hline K1407CNFAIRSTRIPPER & $73-0106-90$ & $939748 \mathrm{P}$ & $\begin{array}{l}\text { Air stripper for removing VOCs } \\
\text { at CNF }\end{array}$ & $\begin{array}{l}\text { Permit to } \\
\text { construct }\end{array}$ \\
\hline K25SITEFUGITIVEEMISSIONS & $73-1106-38$ & $043016 \mathrm{P}$ & $\begin{array}{l}\text { Number of sources logged into } \\
\text { permit }\end{array}$ & Operating \\
\hline
\end{tabular}




\section{Appendix D: Reference Standards for Water}


Table D.1. Reference standards for radionuclides in water (pCi/L)

\begin{tabular}{|c|c|c|c|}
\hline Parameter $^{a}$ & $\begin{array}{l}\text { National primary drinking } \\
\text { water standard }{ }^{b}\end{array}$ & $4 \%$ of $D_{C G}^{c}$ & $\mathrm{DCG}^{d}$ \\
\hline${ }^{241} \mathrm{Am}$ & & 1.2 & 30 \\
\hline${ }^{214} \mathrm{Bi}$ & & 24,000 & 600,000 \\
\hline${ }^{109} \mathrm{Cd}$ & & 400 & 10,000 \\
\hline${ }^{143} \mathrm{Ce}$ & & 1,200 & 30,000 \\
\hline${ }^{60} \mathrm{Co}$ & & 200 & 5,000 \\
\hline${ }^{51} \mathrm{Cr}$ & & 4,000 & 100,000 \\
\hline${ }^{137} \mathrm{Cs}$ & & 120 & 3,000 \\
\hline${ }^{155} \mathrm{Eu}$ & & 4,000 & 100,000 \\
\hline Gross alpha & 15 & & \\
\hline Gross beta & $50^{e}$ & & \\
\hline${ }^{3} \mathrm{H}$ & 20,000 & 80,000 & $2,000,000$ \\
\hline${ }^{131} \mathrm{I}$ & & 120 & 3,000 \\
\hline${ }^{40} \mathrm{~K}$ & & 280 & 7,000 \\
\hline${ }^{237} \mathrm{~Np}$ & & 1.2 & 30 \\
\hline${ }^{234 m} \mathrm{~Pa}$ & & 2,800 & 70,000 \\
\hline${ }^{238} \mathrm{Pu}$ & & 1.6 & 40 \\
\hline${ }^{239} 9240 \mathrm{Pu}$ & & 1.2 & 30 \\
\hline${ }^{226} \mathrm{Ra}$ & 5 & 4 & 100 \\
\hline${ }^{228} \mathrm{Ra}$ & 5 & 4 & 100 \\
\hline${ }^{106} \mathrm{Ru}$ & & 240 & 6,000 \\
\hline Sr, total rad & 8 & 40 & 1,000 \\
\hline${ }^{99} \mathrm{Tc}$ & & 4,000 & 100,000 \\
\hline${ }^{228} \mathrm{Th}$ & & 16 & 400 \\
\hline${ }^{230} \mathrm{Th}$ & & 12 & 300 \\
\hline${ }^{232} \mathrm{Th}$ & & 2 & 50 \\
\hline${ }^{234} \mathrm{Th}$ & & 400 & 10,000 \\
\hline Thorium, natural & & 2 & 50 \\
\hline${ }^{234} \mathrm{U}$ & & 20 & 500 \\
\hline${ }^{235} \mathrm{U}$ & & 24 & 600 \\
\hline${ }^{238} \mathrm{U}$ & & 24 & 600 \\
\hline Uranium, natural & & 24 & 600 \\
\hline Uranium, totaff & & 20 & 500 \\
\hline
\end{tabular}

${ }^{a}$ Only the radionuclides sought on the Oak Ridge Reservation are listed.

${ }^{b} 40$ CFR Part 141 National Primary Drinking Water Regulations, Subparts B and G, as amended.

'U.S. DOE Order 5400.5, Chapter III, Derived Concentration Guides for Air and Water.

${ }^{d}$ Four percent of the DCG represents the DOE criterion of 4 mrem effective dose equivalent from ingestion of drinking water.

${ }^{e}$ Regulatory guide for assessing compliance without further analysis.

$f_{\text {Minimum of uranium isotopes. }}$ 
Table D.2. Reference standards for chemicals and metals in water

\begin{tabular}{|c|c|c|c|c|c|c|}
\hline \multirow{3}{*}{ Parameter } & \multirow{2}{*}{\multicolumn{2}{|c|}{$\begin{array}{l}\text { National drinking } \\
\text { water standards }\end{array}$}} & \multicolumn{4}{|c|}{ Tennessee water quality criteria $^{c}$} \\
\hline & & & \multirow{2}{*}{$\begin{array}{l}\text { Domestic } \\
\text { water }\end{array}$} & \multirow{2}{*}{$\begin{array}{l}\text { Fish and } \\
\text { aquatic } \\
\text { life }\end{array}$} & \multicolumn{2}{|c|}{ Recreation } \\
\hline & Primary $^{a}$ & Secondary ${ }^{b}$ & & & Organisms & $\begin{array}{l}\text { Water and } \\
\text { organisms }\end{array}$ \\
\hline \multicolumn{7}{|c|}{ Anions $(m g / L)$} \\
\hline Chloride & & 250 & & & & \\
\hline Fluoride & 4 & 2 & & & & \\
\hline Nitrate & 10 & & & & & \\
\hline Nitrite & 1 & & & & & \\
\hline Sulfate, as $\mathrm{SO}_{4}$ & & 250 & & & & \\
\hline \multicolumn{7}{|c|}{ Base/neutral/acid extractable organics $(\mu g / L)$} \\
\hline $\begin{array}{l}\text { 1,2-Dichlorobenzene } \\
\text { 1,2,4-Trichlorobenzene }\end{array}$ & $\begin{array}{r}600 \\
70\end{array}$ & & & & 17,000 & 2,700 \\
\hline 1,3-Dichlorobenzene & & & & & 2,600 & 400 \\
\hline 1,4-Dichlorobenzene (para) & 75 & 5 & 75 & & 2,600 & 400 \\
\hline 2,4-Dinitrophenol & & & & & 14,000 & 70 \\
\hline 2,4-Dinitrotoluene & & & & & 91 & 1.1 \\
\hline 2,4,6-Trichlorophenol & & & & & 65 & 21 \\
\hline 2-Methyl-4,6-Dinitrophenol & & & & & 765 & 13.4 \\
\hline 3,4-Benzofluoranthene & & & & & 0.49 & 0.044 \\
\hline Benzo(k)fluoranthene & & & & & 0.49 & 0.044 \\
\hline Acenaphthylene & & & & & 2,700 & 1,200 \\
\hline Anthracene & & & & & 110,000 & 9,600 \\
\hline Benzo(a)anthracene & & & & & 0.49 & 0.044 \\
\hline Benzo(a)pyrene & 0.2 & & & 0.2 & 0.49 & 0.044 \\
\hline bis-(2-chloroethyl)ether & & & & & 14 & 0.31 \\
\hline bis-(2-ethylhexyl)phthalate & & & & & 59 & 18 \\
\hline Di-n-butyl phthalate & & & & & 12,000 & 2,700 \\
\hline Diethyl phthalate & & & & & 120,000 & 23,000 \\
\hline Dimethyl phthalate & & & & & $2,900,000$ & 313,000 \\
\hline Fluoranthene & & & & & 370 & 300 \\
\hline Fluorene & & & & & 14,000 & 1,300 \\
\hline Hexachlorobenzene & 1 & & & & 0.0077 & 0.0075 \\
\hline Hexachlorocyclopentadiene & 50 & & & & 17,000 & 240 \\
\hline Hexachloroethane & & & & & 89 & 19 \\
\hline Nitrobenzene & & & & & 1,900 & 17 \\
\hline Pentachlorophenol & 1 & & & 20 & 82 & 2.8 \\
\hline Pyrene & & & & & 11,000 & 960 \\
\hline \multicolumn{7}{|c|}{ Field measurements } \\
\hline Chlorine, $\mathrm{mg} / \mathrm{L}$ & & & & 19 & & \\
\hline Dissolved oxygen, mg/L & & & & 5 & & \\
\hline Temperature, ${ }^{\circ} \mathrm{C}$ & & & 30.5 & & 30.5 & \\
\hline $\begin{array}{l}\text { Turbidity, JTU } \\
\text { pH, standard units }\end{array}$ & 1 & $(6.5,8.5)$ & $(6.0,9.0)$ & $(6.5,8,5)$ & $(6.0,9.0)$ & \\
\hline \multicolumn{7}{|c|}{ Metals $(m g / L)$} \\
\hline Aluminum & & 0.2 & & & & \\
\hline Antimony & 0.006 & & & & 4.30 & 0.014 \\
\hline Arsenic & 0.05 & & 0.05 & 0.36 & 0.0014 & 0.00018 \\
\hline Barium & & & & & & \\
\hline Beryllium & 0.004 & & & & 0.0013 & \\
\hline Cadmium & 0.005 & & 0.005 & $0.0039^{f}$ & & \\
\hline Chromium, total & 0.1 & & 0.1 & & & \\
\hline Chromium (hexavalent) & & & & 0.016 & & \\
\hline Copper & $1.3^{8}$ & 1 & & $0.018^{f}$ & & \\
\hline Iron & & 0.3 & & & & \\
\hline
\end{tabular}


Table D.2 (continued)

\begin{tabular}{|c|c|c|c|c|c|c|}
\hline \multirow{3}{*}{ Parameter } & \multirow{2}{*}{\multicolumn{2}{|c|}{$\begin{array}{c}\text { National drinking } \\
\text { water standards }\end{array}$}} & \multicolumn{4}{|c|}{ Tennessee water quality criteria $^{c}$} \\
\hline & & & \multirow{2}{*}{$\begin{array}{l}\text { Domestic } \\
\text { water }\end{array}$} & \multirow{2}{*}{$\begin{array}{l}\text { Fish and } \\
\text { aquatic } \\
\text { life }\end{array}$} & \multicolumn{2}{|c|}{ Recreation } \\
\hline & Primary $^{a}$ & Secondary ${ }^{b}$ & & & Organisms & $\begin{array}{l}\text { Water and } \\
\text { organisms }^{d}\end{array}$ \\
\hline $\begin{array}{l}\text { Lead } \\
\text { Manganese }\end{array}$ & \multicolumn{2}{|l|}{$0.015^{8}$} & 0.005 & $0.082^{f}$ & & \\
\hline Mercury & \multicolumn{2}{|l|}{0.002} & 0.002 & 0.0024 & 0.00015 & 0.00014 \\
\hline Nickel & \multicolumn{2}{|l|}{$0.1^{h}$} & 0.1 & $1.418^{f}$ & 4.6 & 0.61 \\
\hline Selenium & 0.05 & & 0.050 & 0.02 & & \\
\hline Silver & \multicolumn{2}{|r|}{0.1} & & $0.004^{f}$ & & \\
\hline Thallium & \multirow{2}{*}{\multicolumn{2}{|c|}{0.002}} & \multirow[t]{2}{*}{0.002} & & & \\
\hline Zinc & & & & $0.117^{f}$ & 0.0063 & 0.0017 \\
\hline \multicolumn{7}{|c|}{ Others } \\
\hline Asbestos (fibers/L) & \multicolumn{6}{|l|}{$7,000,000$} \\
\hline Coliform bacteria (mL) & 0.01 & & & 0.01 & & \\
\hline Color (color units) & \multicolumn{3}{|l|}{0.01} & & & \\
\hline Cyanide (mg/L) & \multirow{2}{*}{\multicolumn{2}{|c|}{0.2}} & 200 & 0.022 & 220 & 0.7 \\
\hline Odor (T.O.N.) & & & & & & \\
\hline Total dissolved solids (mg/L) & \multicolumn{2}{|r|}{$\begin{array}{r}3 \\
500\end{array}$} & 500 & & & \\
\hline & & sticides/hert & cides/PCBs ( & $g / L)$ & & \\
\hline $\begin{array}{l}\text { 2,3,7,8-TCDD (Dioxin) } \\
\text { 2,4-D } \\
\text { 2,4,5-TP (Silvex) }\end{array}$ & $\begin{array}{l}0.0000 \\
70 \\
50\end{array}$ & & 0.000001 & & 0.000001 & \\
\hline $4,4^{\prime}-\mathrm{DDT}$ & & & & 1.1 & 0.0059 & 0.0059 \\
\hline $4,4^{\prime}-\mathrm{DDE}$ & & & & & 0.0059 & 0.0059 \\
\hline $4,4^{\prime}-\mathrm{DDD}$ & & & & & 0.0084 & 0.0083 \\
\hline Alachlor & 2 & & 2 & & & \\
\hline Aldicarb sulfoxide & 4 & & & & & \\
\hline Aldrin & & & & 3 & 0.014 & 0.0013 \\
\hline Atrazine & 3 & & 3 & & & \\
\hline Carbofuran & 40 & & 40 & & & \\
\hline Chlordane & 2 & & 2 & 2.4 & 0.0059 & 0.0057 \\
\hline Dalapon & 200 & & 200 & & & \\
\hline Dibromochloropropane & 0.2 & & 0.2 & & & \\
\hline Di(ethylhexyl)adipate & 400 & & 400 & & & \\
\hline Di(ethylhexyl)phthalate & 7 & & 6 & & & \\
\hline Dinoseb & 7 & & & & & \\
\hline Diquat & 20 & & & & & \\
\hline a-Endosulfan & & & & 0.22 & 159 & 74 \\
\hline b-Endosulfan & & & & 0.22 & 159 & 74 \\
\hline Endothall & 100 & & 100 & & & \\
\hline Endrin & 2 & & & 0.18 & 0.81 & 0.76 \\
\hline Ethylene dibromide & 0.05 & & 0.05 & & & \\
\hline Glyphosate & 700 & & 700 & & & \\
\hline Heptachlor & 0.4 & & 0.4 & 0.52 & 0.0021 & 0.0021 \\
\hline Heptachlor epoxide & 0.2 & & 0.2 & 0.52 & 0.001 & 0.0011 \\
\hline g-BHC (Lindane) & 0.2 & & 0.2 & 2 & 0.63 & 0.19 \\
\hline Methoxychlor & 40 & & 40 & & & \\
\hline Oxamyl (Vydate) & 200 & & 200 & & & \\
\hline PCB-1242 & & & & & 0.00045 & 0.00044 \\
\hline PCB-1254 & & & & & 0.00045 & 0.00044 \\
\hline PCB-1221 & & & & & 0.00045 & 0.00044 \\
\hline PCB-1232 & & & & & 0.00045 & 0.00044 \\
\hline PCB-1248 & & & & & 0.00045 & 0.00044 \\
\hline PCB-1260 & & & & & 0.00045 & 0.00044 \\
\hline PCB-1016 & & & & & 0.00045 & 0.00044 \\
\hline
\end{tabular}


Table D.2 (continued)

\begin{tabular}{|c|c|c|c|c|c|c|}
\hline \multirow{3}{*}{ Parameter } & \multicolumn{2}{|c|}{$\begin{array}{l}\text { National drinking } \\
\text { water standards }\end{array}$} & \multicolumn{4}{|c|}{ Tennessee water quality criteria $^{c}$} \\
\hline & \multirow[b]{2}{*}{ Primary ${ }^{a}$} & \multirow[b]{2}{*}{ Secondary $y^{b}$} & \multirow{2}{*}{$\begin{array}{c}\text { Domestic } \\
\text { water }\end{array}$} & \multirow{2}{*}{$\begin{array}{l}\text { Fish and } \\
\text { aquatic } \\
\text { life }\end{array}$} & \multicolumn{2}{|c|}{ Recreation } \\
\hline & & & & & Organisms & $\begin{array}{l}\text { Water and } \\
\text { organisms }^{d}\end{array}$ \\
\hline PCB, total & 0.5 & & 0.5 & & 0.00045 & 0.00044 \\
\hline Picloram & 500 & & 500 & & & \\
\hline Simazine & 4 & & 4 & & & \\
\hline Toxaphene & 3 & & 3 & 0.73 & 0.0075 & 0.0073 \\
\hline \multicolumn{7}{|c|}{ Volatile organics $(\mu g / L)$} \\
\hline 1,1,1-Trichloroethane & 200 & & 200 & & 170,000 & \\
\hline 1,1-Dichloroethene & 7 & & 7 & & 32 & 0.57 \\
\hline 1,1,2-Trichloroethane & 5 & & 5 & & 420 & 6 \\
\hline $1,1,2,2$-Tetrachloroethane & & & 5 & & 110 & \\
\hline 1,2-Dichloroethane & 5 & & 5 & & 990 & 3.8 \\
\hline 1,2-Dichloroethene & $70^{i}$ & & & & & \\
\hline cis-1,2-Dichloroethene & 70 & & 70 & & & \\
\hline trans-1,2-Dichloroethene & 100 & & 100 & & & \\
\hline 1,2-Dichloropropane & 5 & & 5 & & 39 & 0.52 \\
\hline cis-1,3-Dichloropropane & & & & & 1,700 & 10 \\
\hline trans-1,2-Dichloropropane & & & & & 1,700 & 10 \\
\hline Acrolein & & & & & 780 & 320 \\
\hline Acrylonitrile & & & & & 6.6 & 0.59 \\
\hline Benzene & 5 & & 5 & & 710 & 12 \\
\hline Bromodichloromethane & $100^{\circ}$ & & & & & \\
\hline Bromoform & $100^{j}$ & & & & 3,600 & 43 \\
\hline Carbon tetrachloride & 5 & & 5 & & 44 & 2.5 \\
\hline $\begin{array}{l}\text { Chlorobenzene } \\
\text { lat }\end{array}$ & 100 & & & & 21,000 & 680 \\
\hline Chloroethane & 200 & & & & & \\
\hline Chloroform & $100^{\circ}$ & & & & 4,700 & 57 \\
\hline Dibromochloromethane & $100^{j}$ & & & & 340 & 4.1 \\
\hline Ethylbenzene & 700 & & 700 & & 29,000 & 3,100 \\
\hline Methylene chloride & 5 & & 5 & & 16,000 & 47 \\
\hline Styrene & 100 & & 100 & & & \\
\hline Tetrachloroethene & 5 & & 5 & & 88.5 & 8 \\
\hline Toluene & 1,000 & & 1,000 & & 200,000 & 6,800 \\
\hline Trichloroethene & 5 & & 5 & & 810 & 27 \\
\hline Trihalomethanes, total & 100 & & & & 100 & \\
\hline Vinyl chloride & 2 & & 2 & & 5,250 & 20 \\
\hline Xylene, total & 10,000 & & 10,000 & & & \\
\hline
\end{tabular}

${ }^{a} 40$ CFR Part 141-National Primary Drinking Water Regulations, Subparts B and G, as amended.

${ }^{b} 40$ CFR Part 143-National Secondary Drinking Water Regulations, as amended.

${ }^{c}$ Rules of Tennessee Department of Environment and Conservation, Division of Water Pollution Control, Chapter 1200-4-3, General Water Quality Criteria, as amended.

dThese criteria, for the protection of public health, pertain to the consumption of water and organisms.

They are applied only to waters designated for both recreation and domestic water supply.

${ }^{e}$ JTU an NTU are roughly equivalent in the range of 25 to 1000 JTU.

${ }^{f}$ The standard is a function of total hardness. The values in this table correspond to a total-hardness value of $100 \mathrm{mg} / \mathrm{L}$.

${ }^{g}$ Action level, which is applicable to community water systems and non-transient, non-community water systems.

${ }_{h}$ EPA has deleted the MCL for nickel from the Code of Federal Regulations. The state of Tennessee retains a nickel MCL of $100 \mathrm{~g} / \mathrm{L}$ in its currently effective drinking water regulations.

iSee cis-Dichlorethene and trans-Dichloroethane.of uranium isotopes.

jLimit for total trihalomethanes (bromodichloromethane + bromoform + chloroform + dibromochloromethane). 


\section{Appendix E: Underground Storage Tank Data}


-

-

- 
Table E.1. Underground storage tanks (USTs) at the Y-12 Plant

\begin{tabular}{|c|c|c|c|c|c|c|c|c|c|}
\hline Location & $\begin{array}{c}\text { Tank } \\
\text { identification } \\
\text { number }\end{array}$ & $\begin{array}{l}\text { Installation } \\
\text { date }\end{array}$ & $\begin{array}{l}\text { Out-of- } \\
\text { service } \\
\text { date }\end{array}$ & $\begin{array}{l}\text { Capacity } \\
\text { (gallons) }\end{array}$ & Contents & Status & $\begin{array}{c}\text { Preliminary } \\
\text { investigation(s) }\end{array}$ & $\begin{array}{l}\text { Environmental } \\
\text { assessment } \\
\text { ( ) date to } \\
\text { regulatory } \\
\text { agency }\end{array}$ & $\begin{array}{c}\text { Corrective } \\
\text { action }\end{array}$ \\
\hline
\end{tabular}

\begin{tabular}{|c|c|c|c|c|c|c|c|c|c|}
\hline \multicolumn{10}{|c|}{ Petroleum USTS } \\
\hline $9722-6$ & $2312-U$ & 1987 & 1994 & 550 & Diesel & Inert filled 2/95 & CR (4/95) & NA & NA \\
\hline $9722-5$ & 2313-U & 1987 & 1994 & 550 & Diesel & Inert filled 2/95 & $\operatorname{CR}(4 / 95)$ & NA & NA \\
\hline $9999-7$ & 2316-U & 1986 & 1994 & 550 & Diesel & Inert filled $2 / 95$ & $C R(4 / 95)$ & NA & NA \\
\hline $9999-5$ & $2320-\mathrm{U}$ & 1986 & 1994 & 550 & Diesel & Removed 2/95 & CR (4/95) & NA & NA \\
\hline $9722-4$ & 2333-U & 1988 & 1994 & 550 & Diesel & Inert filled $3 / 95$ & CR (4/95) & NA & NA \\
\hline 9714 & 2334-U & 1987 & In use & 6,000 & Gasoline & Full compliance & Site check & NA & NA \\
\hline 9714 & 2335-U & 1987 & In use & 10,000 & Diesel & Full compliance & Site check & $N A$ & NA \\
\hline $9754-3$ & 2396-U & 1993 & In use & 10,000 & Diesel & Full compliance & NA & NA & NA \\
\hline $9754-3$ & 2397-U & 1993 & In use & 20,000 & Gasoline & Full compliance & NA & NA & $\mathbf{N A}$ \\
\hline 9712 & 0084-U & 1958 & 1988 & 500 & Used oil & Removed $6 / 88$ & CERCLA & TBD & TBD \\
\hline 92042 & 0134-U & 1966 & 1982 & 117 & Gasoline & Removed 8/88 & ISCR, FPRR & SIR $(3 / 92)$ & $\begin{array}{l}\text { EAR/CAP (8/92), } \\
\text { CAP approval } \\
\text { (5/93), CR (4/94), } \\
\text { SRF (1/95) }\end{array}$ \\
\hline $9754-2$ & 0439-U & 1978 & 1989 & 20,000 & Gasoline & Removed 9/89 & $\begin{array}{c}\text { IAR, ISCR, } \\
\text { FPRR }\end{array}$ & $\begin{array}{c}\text { SIR/CAP } \\
(3 / 91)\end{array}$ & $\begin{array}{l}\text { CAP (7/92), CAP } \\
\text { approval (5/93), } \\
\text { BMR (3/94), } \\
\text { SSSR (4/94) }\end{array}$ \\
\hline $9754-2$ & 0440-U & 1978 & 1989 & 10,000 & Diesel & Removed 9/89 & $\begin{array}{l}\text { IAR, ISCR, } \\
\text { FPRR }\end{array}$ & $\begin{array}{c}\text { SIR/CAP } \\
(3 / 91)\end{array}$ & $\begin{array}{l}\text { CAP (7/92), CAP } \\
\text { approval (5/93), } \\
\text { BMR (3/94), } \\
\text { SSSR (4/94) }\end{array}$ \\
\hline 9754 & 2073-U & 1944 & 1979 & 1,000 & Gasoline & Removed $10 / 93$ & SI & $\begin{array}{c}\text { SIR/CAP } \\
(3 / 91)\end{array}$ & $\begin{array}{l}\text { CAP (7/92), CAP } \\
\text { approval (5/93), } \\
\text { BMR (3/94), } \\
\text { SSSR (4/94) }\end{array}$ \\
\hline 9754 & 2074-U & 1944 & 1979 & 1,000 & Gasoline & Removed $10 / 93$ & SI & $\begin{array}{c}\text { SIR/CAP } \\
(3 / 91)\end{array}$ & $\begin{array}{l}\text { CAP (7/92), CAP } \\
\text { approval (5/93), } \\
\text { BMR (3/94), } \\
\text { SSSR (4/94) }\end{array}$ \\
\hline 9754 & $2075-\mathrm{U}$ & 1944 & 1979 & 1,000 & Diesel & Removed 10/93 & SI & $\begin{array}{c}\text { SIR/CAP } \\
\text { (3/9I) }\end{array}$ & $\begin{array}{l}\text { CAP (7/92), CAP } \\
\text { approval 5/93), } \\
\text { (BMR (3/94), } \\
\text { SSSR (4/94) }\end{array}$ \\
\hline 9754-1 & 1219-U & 1964 & 1988 & 12,000 & Diesel & Removed 12/89 & EA & SIR $(3 / 91)$ & $\begin{array}{l}\text { CAP (5/92), SRF } \\
\text { (2/94), SRF } \\
\text { approval (3/94), } \\
\text { SSSR (9/94), } \\
\text { SSSR revised (1/95) }\end{array}$ \\
\hline 9754-1 & $1222-\mathrm{U}$ & 1968 & 1988 & 12,000 & Gasoline & Removed $12 / 89$ & EA & $\operatorname{SIR}(3 / 91)$ & $\begin{array}{l}\text { CAP (5/92), SRF } \\
(2 / 94), \text { SRF } \\
\text { approval (3/94), } \\
\text { SSSR (9/94), } \\
\text { SSSR revised (1/95) }\end{array}$ \\
\hline $9720-15$ & 2068-U & 1968 & 1980 & 1,000 & Gasoline & Removed 2/90 & EA/FPRR & $\operatorname{SIR}(3 / 91)$ & $\begin{array}{l}\text { CAP }(5 / 92), \text { SRF } \\
\text { (2/94), SRF } \\
\text { approval (3/94), } \\
\text { SSSR (9/94), } \\
\text { SSSR revised (1/95) }\end{array}$ \\
\hline 9754-1 & $2082-U$ & 1981 & 1988 & 8,000 & Gasoline & Removed 12/89 & EA & $\operatorname{SIR}(3 / 91)$ & $\begin{array}{l}\text { CAP (5/92), SRF } \\
\text { (2/94), SRF } \\
\text { approval (3/94), } \\
\text { SSSR (9/94), } \\
\text { SSSR revised (1/95) }\end{array}$ \\
\hline PRW & $2310-U$ & 1975 & 1989 & 200 & Gasoline & Removed 11/89 & ISCR & $\begin{array}{c}\text { SIR/CAP } \\
(7 / 91)\end{array}$ & $\begin{array}{l}\text { EAR/CAP (3/93), } \\
\text { CAP approval } \\
(12 / 93), \text { OE } \\
(4 / 94,5 / 94) \\
\text { CR }(7 / 94)\end{array}$ \\
\hline $9201-1$ & 2331-U & 1973 & 1988 & 560 & Gasoline & Removed $12 / 88$ & ISCR, FPRR & $\operatorname{SIR}(3 / 92)$ & $\begin{array}{l}\text { EAR/CAP (7/92), } \\
\text { CAP approval } \\
\text { (12/93), BMR } \\
\text { (3/94), SRF (4/94), } \\
\text { SRF approval (5/94) }\end{array}$ \\
\hline $9401-3$ & $0713-\mathrm{U}$ & 1955 & 1988 & 10,500 & $\begin{array}{l}\text { No. } 2 \\
\quad \text { fuel oil }\end{array}$ & Removed 11/88 & NI & NA & NA \\
\hline
\end{tabular}


Table E.1 (continued)

\begin{tabular}{|c|c|c|c|c|c|c|c|c|c|}
\hline Location & $\begin{array}{c}\text { Tank } \\
\text { identification } \\
\text { number }\end{array}$ & $\begin{array}{l}\text { Installation } \\
\text { date }\end{array}$ & $\begin{array}{l}\text { Out-of- } \\
\text { service } \\
\text { date }\end{array}$ & $\begin{array}{l}\text { Capacity } \\
\text { (gallons) }\end{array}$ & Contents & Status & $\begin{array}{c}\text { Preliminary } \\
\text { investigation(s) }\end{array}$ & $\begin{array}{l}\text { Environmental } \\
\text { assessment } \\
\text { ( ) date to } \\
\text { regulatory } \\
\text { agency }\end{array}$ & $\begin{array}{l}\text { Corrective } \\
\text { action }\end{array}$ \\
\hline 9754 & $0836-U$ & 1944 & 1989 & 10,000 & Used oil & Removed 10/89 & RCRA & RCRA & RCRA \\
\hline $9204-3$ & 0928-U & 1966 & 1989 & 200 & Gasoline & Removed 5/89 & $\begin{array}{l}\text { RIR, closure } \\
\text { approved } \\
8 / 92\end{array}$ & NA & NA \\
\hline 9995 & $2078-U$ & 1965 & 1979 & 110 & Gasoline & Inert filled 1979 & CERCLA & TBD & TBD \\
\hline 9995 & $2079-U$ & 1965 & 1979 & 55 & Gasoline & Inert filled 1979 & CERCLA & TBD & TBD \\
\hline 9996 & $2080-U$ & 1971 & 1987 & 560 & Gasoline & Removed 12/88 & RIR & NA & NA \\
\hline 9212 & $2081-U$ & 1958 & 1970 & 280 & Gasoline & Removed 4/91 & ISCR & NA & $\mathrm{OE} / \mathrm{CR}(12 / 91)$ \\
\hline $9201-5$ & 2099.U & 1971 & 1989 & 560 & Gasoline & Removed 7/89 & $\begin{array}{l}\text { IAR, RIR, } \\
\text { closure } \\
\text { approved } \\
3 / 90\end{array}$ & NA & NA \\
\hline $9929-1$ & $2117-U$ & 1971 & 1983 & 550 & $\begin{array}{l}\text { No. } 2 \\
\quad \text { fuel oil }\end{array}$ & Removed 10/88 & NI & NA & NA \\
\hline $9204-4$ & $2130-U$ & 1960 & 1992 & 550 & Gasoline & Removed $12 / 92$ & RIR & NA & NA \\
\hline 9999 & $2293-U$ & 1954 & 1974 & 58 & Gasoline & Removed 1974 & NI & NA & NA \\
\hline 9999 & $2294 U$ & 1954 & 1974 & 58 & Gasoline & Removed 1974 & NI & NA & NA \\
\hline 9998 & $2305-U$ & 1956 & 1990 & 55 & Diesel & Removed 10/90 & $\begin{array}{l}\text { RIR, closure } \\
\text { approved } \\
\text { 1/95 }\end{array}$ & NA & NA \\
\hline PRE & $2315-U$ & 1960 & 1988 & 64 & Gasoline & Removed 11/89 & ISCR & $\begin{array}{c}\text { EAR/CAP } \\
(2 / 91)\end{array}$ & $\begin{array}{l}\text { OE/CAR (12/92), } \\
\text { closure } \\
\text { approval 1/95 }\end{array}$ \\
\hline 9769 & 2330-U & 1949 & 1988 & 5,000 & $\begin{array}{l}\text { No. } 2 \\
\text { fuel oil }\end{array}$ & Inert filled $4 / 88$ & NI & NA & NA \\
\hline $\begin{array}{c}\text { Chestmut } \\
\text { Ridge }\end{array}$ & $2336-U$ & 1981 & 1991 & 550 & Gasoline & Removed 5/91 & $\begin{array}{l}\text { RIR, closure } \\
\text { approved } \\
1 / 95\end{array}$ & NA & NA \\
\hline Buff. Mtn. & 2337-U & 1972 & 1990 & 250 & Gasoline & Removed 3/90 & LAR, ISCR & $\begin{array}{l}\text { SIR (5/91), } \\
\text { SIR Phase II } \\
(1 / 92)\end{array}$ & $\begin{array}{l}\text { Closure approval } \\
2 / 95\end{array}$ \\
\hline $9720-13$ & $2338-U$ & 1970 & 1984 & 200 & Used oil & Removed $7 / 90$ & RIR & $\mathrm{TBD}$ & TBD \\
\hline 9219 & $2395-U$ & 1964 & 1977 & 2,000 & $\begin{array}{l}\text { No. } 2 \\
\quad \text { fuel oil }\end{array}$ & Removed 6/93 & NI & NA & NA \\
\hline SYDD & 2063-U & 1959 & 1989 & 130 & Oilsolvent & Removed 7/89 & $\begin{array}{l}\text { IAR, ISCR/ } \\
\text { FPRR }\end{array}$ & CERCLA & CERCLA \\
\hline SYDD & $2328-U$ & 1959 & 1989 & 475 & Oil/solvent & Removed 7/89 & $\begin{array}{l}\text { IAR, ISCR/ } \\
\text { FPRR }\end{array}$ & CERCLA & CERCLA \\
\hline SYDD & $2329-U$ & 1959 & 1989 & 475 & Oilsolvent & Removed 7/89 & $\begin{array}{l}\text { IAR, ISCR/ } \\
\text { FPRR }\end{array}$ & CERCLA & CERCLA \\
\hline \multicolumn{10}{|c|}{ Hazardous Substance USTs } \\
\hline $9767-13$ & $2102-U$ & 1987 & 1992 & 7,500 & Methanol & Removed 1/93 & CR & NA & NA \\
\hline $9418-3$ & $2072-U$ & 1943 & 1960 & 45,000 & $\begin{array}{l}\text { Solid } \\
\text { uranium } \\
\text { oxide }\end{array}$ & Exempt & CERCLA & CERCLA & CERCLA \\
\hline $9825-1$ & $2129-U$ & 1984 & In use & 240,000 & $\begin{array}{l}\text { oxide } \\
\text { Solid } \\
\text { uranium } \\
\text { oxide }\end{array}$ & Exempt & NA & NA & NA \\
\hline
\end{tabular}

Notes

\begin{tabular}{|c|c|c|c|}
\hline BMR & baseline monitoring report & NA & not applicable \\
\hline CAP & corrective action plan & NI & not investigated \\
\hline CAR & corrective action report & $\mathrm{OE}$ & overexcavation \\
\hline CERCLA & $\begin{array}{l}\text { conducted under the Comprehensive Environmental } \\
\text { Response, Compensation and Liability Act }\end{array}$ & RCRA & $\begin{array}{l}\text { conducted under Resource Conservation and } \\
\text { Recovery Act, Subtitle C }\end{array}$ \\
\hline CR & closure report & RIR & release investigation report \\
\hline EA & environmental assessment & SIR & site investigation report \\
\hline EAR & environmental assessment report & SRF & site ranking form \\
\hline FPRR & free product remoyal report & SSSR & site-specific standard request \\
\hline IAR & initial abatement report & SYDD & salvage yard drum deheader \\
\hline ISCR & initial site characterization report & TBD & to be determined \\
\hline
\end{tabular}


Appendix F: NPDES Noncompliances 

Table F.1. Summary of Y-12 Plant NPDES excursions, 1995

\begin{tabular}{|c|c|c|c|c|}
\hline Date & Location & Excursion & Explanation & Corrective action \\
\hline $1 / 6 / 95$ & Outfall 99 & Oil Sheen & $\begin{array}{l}\text { Oil from a lathe that had been taken out of } \\
\text { service a couple of years ago seeped out of } \\
\text { the lathe pooling on the floor over a seal } \\
\text { floor drain. Over the years, the oil had } \\
\text { deteriorated the seal on the floor drain, }\end{array}$ & $\begin{array}{l}\text { All of the oil from the lathe was cleaned up } \\
\text { from the floor. The drain pipe was cut and } \\
\text { plugged. The floor drain was permanently } \\
\text { sealed with concrete. }\end{array}$ \\
\hline
\end{tabular}
deteriorated the seal on the floor drain, allowing the oil to seep into the pipe.

4/28/95 Outfall $160 \quad \begin{aligned} & \text { Unauthorized } \\ & \text { discharge }\end{aligned}$

A sump pump failure occurred at Building Repair the four sump pumps, two for the 9404-18, allowing the sump to overfill with east sump and two for the west sump. wastewater. The other three sump pumps at this facility were out of service for repairs. Consequently, there was no back-up pump, and the wastewater backed up into the building, out through the roll-up doors, and into the storm sewer drains located on either side of the building.

4/30/95 Outfall $163 \quad \begin{aligned} & \text { Unauthorized } \\ & \text { discharge }\end{aligned}$

The overhead line for the boiler blow down from the Steam Plant separated, allowing wastewater to be released to the paved are around the coal pile. As the wastewater entered into the storm sewer system, coal fines deposited around the storm sewer drain were also washed into the storm drain.

The overhead line has been repaired by reclamping the separated section with a Mueller clamp. When the line was hydrostatically tested, several more leaks were detected. Until such time that the overhead line can be completely replaced, the boiler blow down will be pumped to the Steam Plant Wastewater Treatment Facility using a diaphragm pump and a double-lined discharge hose.

Chlorine limit exceedance

$8 / 3 / 95$

Outfall 109

$12 / 4 / 95$

Monitoring

Chorine limit

Point 201 exceedance
Unauthorized discharge
A routine sample at Outfall 99 exceeded the NPDES Permit limit for chorine resulting in an excursion. The permit limit daily maximum for chlorine is $0.5 \mathrm{mg} / \mathrm{L}$, and this location is grab sampled once per quarter. Investigations into the cause resulted in the discovery of a source not previously identified as chlorinated water discharging to the outfall.

An unsaturated polyester resin containing styrene used in an in situ pipe relining operation was discharged to EFPC through Outfall 109 causing approximately 5,600 minnow-sized fish to die. An estimated five gallons or less of uncured resin material, which failed to harden during the curing process, flowed from the storm drain system into EFPC.

An elevated level of chlorine was recorded in EFPC at instream Monitoring Location 201 and exceeded the daily maximum permit limit of $0.019 \mathrm{mg} / \mathrm{L}$. The elevated level was determined to be related to temporary interruption of the System I dechlorinator chemical feed to the N/S pipe.
The concentration of sodium bisulfite was increased in the discharge line by installing an additional tablet dechlorinator.

Cleanup efforts were initiated immediately to remove the resins from the creek and storm drainage system. The procedure for conducting such sewer relining activities was modified to eliminate the discharge of resins to surface waters.

A chemical feed line blockage was removed, and the system was quickly restored with chlorine readings in EFPC returning to below detection within one hour of initial elevated readings. 
Table F.2. Summary of ORNL NPDES excursions, 1995

\begin{tabular}{cll}
\hline Date & \multicolumn{1}{c}{ Location } & Excursion \\
\hline $02 / 16 / 95$ & $\begin{array}{l}\text { X01 (Sewage Fecal coliform } \\
\text { Treatment } \\
\text { Plant) }\end{array}$ & $\begin{array}{l}\text { limit excursion } \\
\text { limesidual }\end{array}$ \\
$06 / 21 / 95$ & $\begin{array}{l}\text { X01 (Sewage } \\
\text { Treatment } \\
\text { Plant) }\end{array}$ & $\begin{array}{l}\text { Total resine limit } \\
\text { chlorion } \\
\text { excursion }\end{array}$
\end{tabular}

10/05/95 X01 (Sewage Fecal coliform Treatment limit excursion Plant)
06/28/95 X02 (Coal Oil and grease Yard Runoff limit excursion Treatment

On October 5, 1995 the ORNL Sewage Treatment Plant (STP) experienced an excursion of the fecal coliform bacteria limit. Rainfall occurred on October 5, 1995.

The specific cause of this o\&g nonconformance could not be ascertained. Operating conditions at the CYRTF were normal on June 28, 1995.
On February 16, 1995, the ORNL Sewage Treatment Plant (X01) experienced an exceedance of the fecal coliform permit and. Suspended solids, dissolved oxygen, February 16,1995 . STP staff were unable to action was developed.

An automatic valve that feeds chlorine to

The valve was switched to manualBuilding (Building 2643) malfunctioned.

The ORNL analytical lab was when instrument technicians consulted and indicated no STP effluent constituents that could have influenced the February 16, 1995 fecal coliform count. No specific cause was determined; therefore, no corrective recalibrated the control signal to the automatic control valve that feeds the chlorine. No impact on White Oak Creek species was observed.

Possible causes included routine maintenance taking place at the time of sample collection and sample compromised by rainfall intrusion. Procedural controls were put in place to address these issues.

A general plant project, Upgrade CYRTF, includes installation of an oil/water separator for the CYRTF. The upgrade was complete as of May 1996. This oil/water separator should help to preclude further o\&g noncompliance.

10/25/95 X02 (Coal Total suspended Yard Runoff solids limit Treatment excursion

9/13/95 $211 \quad$ Unpermitted discharge via an NPDES Outfall

On October 25, 1995 the ORNL Coal Yard Runoff Treatment Facility (CYRTF) experienced an excursion of the total suspended solids (TSS) limit. There was no indication of problems or unusual conditions during the time the composite sample was being collected.

No certain cause for the TSS excursion was determined. Therefore corrective actions have been developed. The CYRTF has undergone an upgrade project, which is expected to enhance the NPDES permit compliance capabilities of that facility.

A cloudy effluent was observed at NPDES Construction contractors tasked with Outfall 211 , a stormwater and cooling water sealing sanitary-sewer manholes had discharge pipe in the main ORNL plant inadvertently begun work in a storm complex. The source of the cloudy effluent, drain manhole. Work was stopped which flowed into White Oak Creek immediately until the mistake was (WOC), was determined to be in-situ resolved. No long-term environmental grouting work inside a storm drain manhole. effects resulted from this incident; A grout and sand mixture was in use. . schools of fish were observed in the creek soon after the cloudy release ceased.

Visible oil sheen During rainfall, a visible sheen was sighted ORNL spill response personnel were on White Oak Creek (WOC) as a result of able to capture a portion of the sheen stormwater runoff effluent from Outfall 207, at the bank of WOC using absorbent which conveys stormwater runoff from pads. The substance which caused the street and parking lot catch basins in the sheen had the appearance of a light oil ORNL 3500 Area. The sheen was visible on or fuel; total amount estimated to be the surface of WOC to a distance of less than 1 gallon. The release was of approximately 20 feet to 30 feet downstream from Outfall 207. very short duration. ORNL personnel traced the storm drain network but no source of the release was found. The sheen was attributed to surface residue being conveyed by rain runoff through Outfall 207. No evidence of adverse impact on aquatic species was found. 
Table F.2 (continued)

\begin{tabular}{|c|c|c|c|c|}
\hline Date & Location & Excursion & Explanation & Corrective Action \\
\hline $\begin{array}{l}\text { Calendar } \\
\text { Year } \\
1995\end{array}$ & $\begin{array}{l}\text { Category I\&II } \\
\text { Outfalls } \\
\text { (stormwater } \\
\text { runoff) }\end{array}$ & $\begin{array}{l}\text { I Total suspended } \\
\text { solids }\end{array}$ & $\begin{array}{l}20 \text { TSS limit excursions were measured at } \\
18 \text { outfalls during } 7 \text { storm sampling events. }\end{array}$ & $\begin{array}{l}\text { Eight of the exceedances were } \\
\text { corrected with minor improvements in } \\
\text { erosion controls. Four of the } \\
\text { exceedances will be or have been } \\
\text { corrected by physically removing the } \\
\text { outfall. Six of the exceedances were } \\
\text { not attributed to a specific cause and } \\
\text { are being watched for possible causes. } \\
\text { Two of the exceedances will be } \\
\text { corrected when the outfall pipe is } \\
\text { reconfigured so as to improve the } \\
\text { representativeness of future samples. }\end{array}$ \\
\hline
\end{tabular}


Table F.3. Summary of K-25 Site NPDES excursions, 1995

\begin{tabular}{|c|c|c|c|c|}
\hline Date & Location & Excursion & Explanation & Corrective action \\
\hline $2 / 16 / 95$ & Outfall 005 & $\begin{array}{l}\text { Sample } \\
\text { concentration } \\
(0.53 \mathrm{mg} / \mathrm{L} \\
\text { TRC) } \\
\text { exceeded } \\
\text { permit limit. }\end{array}$ & $\begin{array}{l}\text { The NPDES permitted limit for total } \\
\text { residual chlorine (TRC) was exceeded at } \\
\text { the K-1203 Sewage Treatment Plant. The } \\
\text { sample result was } 0.53 \mathrm{mg} / \mathrm{L} \text { and the daily } \\
\text { maximum NPDES limit is } 0.24 \mathrm{mg} / \mathrm{L} \text {. }\end{array}$ & $\begin{array}{l}\text { The K-1203 Sewage Treatment Plant is } \\
\text { equipped with a continuous TRC monitor } \\
\text { that measures and records TRC levels in the } \\
\text { effluent. The maximum TRC measurement } \\
\text { recorded from the continuous monitor for } \\
2 / 16 / 95 \text { was } 0.12 \mathrm{mg} / \mathrm{L} \text { which did not } \\
\text { exceed the permit limit. TRC concentrations } \\
\text { prior to and on subsequent days following } \\
\text { the elevated TRC measurement were well } \\
\text { below the permit limit. An investigation to } \\
\text { determine the cause for the discrepancies } \\
\text { between analytical results and values } \\
\text { measured by the continuous monitor was } \\
\text { inconclusive. }\end{array}$ \\
\hline $2 / 22 / 95$ & Outfall 005 & $\begin{array}{l}\text { Sample } \\
\text { concentration } \\
(31.9 \mathrm{mg} / \mathrm{L} \\
\text { BOD) } \\
\text { exceeded } \\
\text { permit limit. }\end{array}$ & $\begin{array}{l}\text { A biological oxygen demand (BOD) } \\
\text { concentration for a sample collected from } \\
\text { the K-1203 Sewage Treatment Plant } \\
\text { exceeded the permit limit. This sample } \\
\text { was } 31.9 \mathrm{mg} / \mathrm{L} \text { and the daily effluent } \\
\text { BOD limit is } 20 \mathrm{mg} / \mathrm{L} \text {. }\end{array}$ & $\begin{array}{l}\text { An investigation was conducted which } \\
\text { included discussions with other sewage } \\
\text { treatment plant operators, chemists, and the } \\
\text { State Operator Training Center in } \\
\text { Murfreesboro, Tennessee. The investigation } \\
\text { did not reveal a cause. }\end{array}$ \\
\hline $2 / 12 / 95$ & Outfall SD-120 & $\begin{array}{l}\text { Unpermitted } \\
\text { discharge }\end{array}$ & $\begin{array}{l}\text { As part of the Oak Ridge K- } 25 \text { Site Sewer } \\
\text { Upgrade Project, sections of the site sanitary } \\
\text { sewer system are isolated during relining } \\
\text { activities performed by Insitu Form. On } \\
2 / 23 / 95 \text {, a bypass pump failed at the low } \\
\text { point of the system causing sewage to back } \\
\text { up and to eventually overflow a manhole } \\
\text { near Building K-1007 and flow into a } \\
\text { nearby storm drain catch basin leading to } \\
\text { storm drain } 120 \text {. }\end{array}$ & $\begin{array}{l}\text { Immediate actions were taken to remove } \\
\text { any residual sewage remaining on the } \\
\text { parking area. The outlet of SD-120 was } \\
\text { inspected and no adverse impacts to the } \\
\text { environment were observed. In case of } \\
\text { bypass pump failure in the future, emergency } \\
\text { pumping operations will be initiated using } \\
\text { a preestablished backup pump. }\end{array}$ \\
\hline $5 / 1 / 95$ & $\begin{array}{l}\text { Outfall } \\
\text { SD-480/490 }\end{array}$ & $\begin{array}{l}\text { Visible oil } \\
\text { sheen }\end{array}$ & $\begin{array}{l}\text { On 5/1/95 a sheen was observed flowing } \\
\text { from SD-480/490 into the K-1007-P1 Pond. }\end{array}$ & $\begin{array}{l}\text { Oil absorbent booms and pads were utilized } \\
\text { to contain and remove the sheen. A } \\
\text { walkdown of the complete storm drain } \\
\text { system was initiated to find the source of } \\
\text { the discharge. No source was found. }\end{array}$ \\
\hline $12 / 4 / 95$ & Outfall SD-100 & $\begin{array}{l}\text { Sample } \\
\text { concentration } \\
(0.43 \mathrm{mg} / \mathrm{L} \\
\text { TRC) } \\
\text { exceeded } \\
\text { permit limit. }\end{array}$ & $\begin{array}{l}\text { A temporary dechlorination system being } \\
\text { used while a waterline break was being } \\
\text { repaired failed to function adequately. The } \\
\text { permit limit of } 0.14 \mathrm{mg} / \mathrm{L} \text { TRC was } \\
\text { exceeded. }\end{array}$ & $\begin{array}{l}\text { An investigation revealed that there was a } \\
\text { temporary. unexpected increase in flow } \\
\text { which dissolved dechlorination tablets at a } \\
\text { much higher rate than had previously been } \\
\text { experienced, rendering the dechlorination } \\
\text { system ineffective. Immediately upon } \\
\text { identifying the unexpected increase in flow, } \\
\text { additional dechlorination tables were added } \\
\text { to the system and the TRC concentration in } \\
\text { the effluent was brought back into } \\
\text { compliance with the NPDES Permit limit } \\
\text { for TRC. }\end{array}$ \\
\hline
\end{tabular}


Appendix G: Errata 
-

-

- 


\section{Appendix G: Errata}

The following corrections pertain to the Oak Ridge Reservation Annual Site Environmental Report for 1994 (Energy Systems 1994b).

Page

7-52, "Plant Perimeter"

line 1

line 2

line 2

$8-3$

The following table replaces Table 8.1.
For

gross beta activity $(17 \mathrm{pCi} / \mathrm{L})$ total radioactive strontium

$(6.8 \mathrm{pCi} / \mathrm{L})$

${ }^{3} \mathrm{H}$ concentrations $(320 \mathrm{pCi} / \mathrm{L})$
Read

gross beta activity $(460 \mathrm{pCi} / \mathrm{L})$ total radioactive strontium

$(180 \mathrm{pCi} / \mathrm{L})$

${ }^{3} \mathrm{H}$ concentrations $(86,000 \mathrm{pCi} / \mathrm{L})$

Table 8.1. QAQC results for the Oak Ridge Reservation, 1994

\begin{tabular}{|c|c|c|c|}
\hline \multirow{2}{*}{ Program } & \multirow{2}{*}{$\begin{array}{c}\text { Total number } \\
\text { of analytes }\end{array}$} & \multicolumn{2}{|c|}{ Acceptable } \\
\hline & & Total & Percentage \\
\hline EPA Contract Laboratory Program (CLP) ${ }^{a}$ & & & 90.0 \\
\hline $\begin{array}{l}\text { EPA Discharge Monitoring Report Quality } \\
\text { Assurance Study (DMR) }\end{array}$ & 94 & 88 & 93.6 \\
\hline $\begin{array}{l}\text { AIHA Environmental Lead Proficiency Analytical } \\
\text { Testing Program (ELPAT) }\end{array}$ & 124 & 120 & 96.8 \\
\hline $\begin{array}{l}\text { DOE Environmental Measurements Laboratory } \\
\text { (EML) }\end{array}$ & 170 & 159 & 93.5 \\
\hline $\begin{array}{l}\text { EPA Environmental Monitoring Systems } \\
\text { Laboratory at Las Vegas (EMSL-LV) } \\
\text { Intercomparison Radionuclide } \\
\text { Control Program }\end{array}$ & 212 & 183 & 86.3 \\
\hline $\begin{array}{l}\text { DOE Mixed Analyte Performance Evaluation } \\
\text { Program (MAPEP) }\end{array}$ & 145 & 136 & 93.79 \\
\hline $\begin{array}{l}\text { AIHA Proficiency Analytical Testing Program } \\
\text { (PAT) }^{c}\end{array}$ & 244 & 226 & 92.62 \\
\hline $\begin{array}{l}\text { Proficiency Environmental Testing Program } \\
\text { (PET) }\end{array}$ & 4371 & 4327 & 99.0 \\
\hline $\begin{array}{l}\text { Water Pollution Performance Evaluation QC } \\
\text { Program (WP) }\end{array}$ & 609 & 579 & 95.07 \\
\hline $\begin{array}{l}\text { Water Supply Laboratory Performance QC } \\
\text { Program (WS) }\end{array}$ & 477 & 458 & 96.01 \\
\hline
\end{tabular}

${ }^{a}$ The CLP Program scores its results on other factors besides quantitation. An average score was determined by averaging each site's average score from the CLP Program.

bIncludes toxicology data from the ORNL Environmental Sciences Division.

'Includes asbestos data from the K-25 Site Technical Division. 
Appendix H: Glossary 
-

-

- 


\section{Glossary}

AA - See atomic absorption spectrometry.

absorption - The process by which the number and energy of particles or photons entering a body of matter is reduced by interaction with the matter.

accuracy - The closeness of the result of a measurement to the true value of the quantity.

aliquot - The quantity of sample being used for analysis.

alkalinity - Alkalinity is a measure of the buffering capacity of water, and because $\mathrm{pH}$ has a direct effect on organisms as well as an indirect effect on the toxicity of certain other pollutants in the water, the buffering capacity is important to water quality.

alpha particle - A positively charged particle emitted from the nucleus of an atom having the same charge and mass as that of a helium nucleus (two protons and two neutrons).

ambient air - The surrounding atmosphere as it exists around people, plants, and structures.

analytical detection limit - The lowest reasonably accurate concentration of an analyte that can be detected; this value varies depending on the method, instrument, and dilution used.

analyte - A constituent or parameter that is being analyzed.

anion - A negatively charged ion.

aquifer - A saturated, permeable geologic unit that can transmit significant quantities of water under ordinary hydraulic gradients.

aquitard - A geologic unit that inhibits the flow of water.

ash - Inorganic residue remaining after ignition of combustible substances.

assimilate - To take up or absorb into the body.

atom - Smallest particle of an element capable of entering into a chemical reaction.

atomic absorption spectrometry (AA) - Chemical analysis performed by vaporizing a sample and measuring the absorbance of light by the vapor.

Atomic Energy Commission (AEC) - A federal agency created in 1946 to manage the development, use, and control of nuclear energy for military and civilian application. It was abolished by the Energy Reorganization Act of 1974 and succeeded by the Energy Research and Development Administration (now part of the U.S. Department of Energy and the U.S. Nuclear Regulatory Commission). 
base/neutral and acid extractables (BNA) - A group of organic compounds analyzed as part of Appendix IX of 40 CFR 264 and the EPA list of priority pollutants.

beta particle - A negatively charged particle emitted from the nucleus of an atom. It has a mass and charge equal to those of an electron.

biomass - The weight of any specific or general kind of organic matter, usually expressed per area or volume.

biota - The animal and plant life of a particular region considered as a total ecological entity.

blank - A control sample that is identical, in principle, to the sample of interest, except that the substance being analyzed is absent. In such cases, the measured value or signal for the substance being analyzed is believed to be a result of artifacts. Under certain circumstances, that value may be subtracted from the measured value to give a net result reflecting the amount of the substance in the sample. EPA does not permit the subtraction of blank results in EPA-regulated analyses.

calibration - Determination of variance from a standard of accuracy of a measuring instrument to ascertain necessary correction factors.

carcinogen - A cancer-causing substance.

cation - Positively charged ion.

CERCLA-reportable release - A release to the environment that exceeds reportable quantities as defined by CERCLA (Comprehensive Environmental Response, Compensation, and Liability Act).

chain-of-custody - A form that documents sample collection, transport, analysis, and disposal.

chemical oxygen demand - Indicates the quantity of oxidizable materials present in a water and varies with water composition, concentrations of reagent, temperature, period of contact, and other factors.

chlorocarbons - Compounds of carbon and chlorine, or carbon, hydrogen, and chlorine, such as carbon tetrachloride, chloroform, tetrachloroethylene, etc. They are among the most significant and widespread environmental contaminants. Classified as hazardous wastes, chlorocarbons may have a tendency to cause detrimental effects, such as birth defects.

closure - Control of a hazardous waste management facility under RCRA requirements.

compliance - Fulfillment of applicable requirements of a plan or schedule ordered or approved by government authority.

concentration - The amount of a substance contained in a unit volume or mass of a sample. 
conductivity - A measure of water's capacity to convey an electric current. This property is related to the total concentration of the ionized substances in water and the temperature at which the measurement is made.

confluence - The point at which two or more streams meet; the point where a tributary joins the main stream.

contamination - Deposition of unwanted material on the surfaces of structures, areas, objects, or personnel.

cosmic radiation - Ionizing radiation with very high energies, originating outside the earth's atmosphere. Cosmic radiation is one source contributing to natural background radiation.

count - The signal that announces an ionization event within a counter; a measure of the radiation from an object or device.

curie (Ci) - A unit of radioactivity. One curie is defined as $3.7 \times 10^{10}$ ( 37 billion) disintegrations per second. Several fractions and multiples of the curie are commonly used:

kilocurie $(\mathbf{k C i})-10^{3} \mathrm{Ci}$, one thousand curies; $3.7 \times 10^{13}$ disintegrations per second.

millicurie (mCi) $-10^{-3} \mathrm{Ci}$, one-thousandth of a curie; $3.7 \times 10^{7}$ disintegrations per second.

microcurie $(\mu \mathrm{Ci})-10^{-6} \mathrm{Ci}$, one-millionth of a curie; $3.7 \times 10^{4}$ disintegrations per second.

picocurie (pCi) $-10^{-12} \mathrm{Ci}$, one-trillionth of a curie; 0.037 disintegrations per second.

daughter - A nuclide formed by the radioactive decay of a parent nuclide.

decay, radioactive - The spontaneous transformation of one radionuclide into a different radioactive or nonradioactive nuclide, or into a different energy state of the same radionuclide.

dense nonaqueous phase liquid (DNAPL) - The liquid phase of chlorinated organic solvents. These liquids are denser than water and include commonly used industrial compounds such as tetrachloroethylene and trichloroethylene.

derived concentration guide (DCG) - The concentration of a radionuclide in air or water that, under conditions of continuous exposure for one year by one exposure mode (i.e., ingestion of water, submersion in air or inhalation), would result in either an effective dose equivalent of $0.1 \mathrm{rem}(1 \mathrm{mSv})$ or a dose equivalent of $5 \mathrm{rem}(50 \mathrm{mSv})$ to any tissue, including skin and lens of the eye. The guides for radionuclides in air and water are given in DOE Order 5400.5.

desorption - The process of removing a sorbed substance by the reverse of adsorption or absorption. 
dilution factor - The mathematical factor by which a sample is diluted to bring the concentration of an analyte in a sample within the analytical range of a detector (e.g., $1 \mathrm{~mL}$ sample $+9 \mathrm{~mL}$ solvent $=1: 10$ dilution, or a dilution factor of 10 ).

disintegration, nuclear - A spontaneous nuclear transformation (radioactivity) characterized by the emission of energy and/or mass from the nucleus of an atom.

dissolved oxygen - A desirable indicator of satisfactory water quality in terms of low residuals of biologically available organic materials. Dissolved oxygen prevents the chemical reduction and subsequent leaching of iron and manganese from sediments.

dose - The energy imparted to matter by ionizing radiation. The unit of absorbed dose is the rad, equal to 0.01 joules per kilogram in any medium.

absorbed dose - The quantity of radiation energy absorbed by an organ, divided by the organ's mass. Absorbed dose is expressed in units of rad (or gray) ( $1 \mathrm{rad}=0.01 \mathrm{~Gy}$ ).

dose equivalent - The product of the absorbed dose (rad) in tissue and a quality factor. Dose equivalent is expressed in units of rem (or sievert) $(1 \mathrm{rem}=0.01$ sievert).

committed dose equivalent - The calculated total dose equivalent to a tissue or organ over a 50-year period after known intake of a radionuclide into the body. Contributions from external dose are not included. Committed dose equivalent is expressed in units of rem (or sievert).

committed effective dose equivalent - The sum of the committed dose equivalents to various tissues in the body, each multiplied by the appropriate weighting factor.

Committed effective dose equivalent is expressed in units of rem (or sievert).

effective dose equivalent - The sum of the dose equivalents received by all organs or tissues of the body after each one has been multiplied by an appropriate weighting factor. The effective dose equivalent includes the committed effective dose equivalent from internal deposition of radionuclides and the effective dose equivalent attributable to sources external to the body.

collective dose equivalent/collective effective dose equivalent - The sums of the dose equivalents or effective dose equivalents of all individuals in an exposed population within a 50-mile $(80-\mathrm{km})$ radius, and expressed in units of person-rem (or person-sievert). When the collective dose equivalent of interest is for a specific organ, the units would be organ-rem (or organ-sievert). The 50-mile distance is measured from a point located centrally with respect to major facilities or DOE program activities.

dosimeter - A portable detection device for measuring the total accumulated exposure to ionizing radiation.

dosimetry - The theory and application of principles and techniques involved in the measurement and recording of radiation doses. Its practical aspect is concerned with using various types of radiation instruments to make measurements. 
downgradient - In the direction of decreasing hydrostatic head.

downgradient well - A well that is installed hydraulically downgradient of a site and may be capable of detecting migration of contaminants from a site.

drinking water standards (DWS) - Federal primary drinking water standards, both proposed and final, as set forth by EPA.

duplicate samples - Two or more samples collected simultaneously into separate containers.

duplicate result - A result derived by taking a portion of a primary sample and performing the identical analysis on that portion as is performed on the primary sample.

effluent - A liquid or gaseous waste discharge to the environment.

effluent monitoring - The collection and analysis of samples or measurements of liquid and gaseous effluents for purposes of characterizing and quantifying the release of contaminants, assessing radiation exposures of members of the public, and demonstrating compliance with applicable standards.

Environmental Restoration - A DOE program that directs the assessment and cleanup of its sites (remediation) and facilities contaminated with waste as a result of nuclear-related activities.

exposure (radiation) - The incidence of radiation on living or inanimate material by accident or intent. Background exposure is the exposure to natural background ionizing radiation. Occupational exposure is that exposure to ionizing radiation that takes place during a person's working hours. Population exposure is the exposure to the total number of persons who inhabit an area.

external radiation - Exposure to ionizing radiation when the radiation source is located outside the body.

fecal coliform - The coliform group comprises all of the aerobic, non-spore-forming, rod-shaped bacteria. The test determines the presence or absence of coliform organisms.

formation - A mappable unit of consolidated or unconsolidated geologic material of a characteristic lithology or assemblage of lithologies.

friable asbestos - Asbestos that is brittle or readily crumbled.

gamma ray - High-energy, short-wavelength electromagnetic radiation emitted from the nucleus of an excited atom. Gamma rays are identical to $X$ rays except for the source of the emission.

gamma spectrometry - A system consisting of a detector, associated electronics, and a multichannel analyzer that is used to analyze samples for gamma-emitting radionuclides. 
genotoxicology - The study of the effects of chemicals or radioactive contaminants on the genetics of individual animals or plants.

grab sample - A sample collected instantaneously with a glass or plastic bottle placed below the water surface to collect surface water samples (also called dip samples).

groundwater, unconfined - Groundwater exposed to the unsaturated zone.

half-life, biological - The time required for a biological system, such as that of a human, to eliminate by natural processes half the amount of a substance (such as a radioactive material) that has entered it.

half-life, radiological - The time required for half of a given number of atoms of a specific radionuclide to decay. Each nuclide has a unique half-life.

halogenated compound - An organic compound bonded with one of the five halogen elements (astatine, bromine, chlorine, fluorine, and iodine).

halomethane - Any compound that includes a methane group $\left(\mathrm{CH}_{3}\right)$ bonded to a halogen element (astatine, bromine, chlorine, fluorine, or iodine).

hardness - Water hardness is caused by polyvalent metallic ions dissolved in water. In fresh water, these are mainly calcium and magnesium, although other metals such as iron, strontium, and manganese may contribute to hardness.

heavy water - Water in which the molecules contain oxygen and deuterium, an isotope of hydrogen that is heavier than ordinary hydrogen.

herbaceous - Having little or no woody tissue.

hydrology - The science dealing with the properties, distribution, and circulation of natural water systems.

hydrogeology - Hydrolic aspects of site geology.

in situ - In its original place; field measurements taken without removing the sample from its origin; remediation performed while groundwater remains below the surface.

internal dose factor - A factor used to convert intakes of radionuclides to dose equivalents.

internal radiation - Internal radiation occurs when natural radionuclides enter the body by ingestion of foods, milk, and water, and by inhalation. Radon is the major contributor to the annual dose equivalent for internal radionuclides.

ion - An atom or compound that carries an electrical charge.

ion exchange - Process in which a solution containing soluble ions is passed over a solid ion exchange column that removes the soluble ions by exchanging them with labile ions 
from the surface of the column. The process is reversible so that the trapped ions are removed (eluted) from the column and the column is regenerated.

irradiation - Exposure to radiation.

isotopes - Forms of an element having the same number of protons in their nuclei but differing in the number of neutrons.

long-lived isotope - A radionuclide that decays at such a slow rate that a quantity of it will exist for an extended period (half-life is greater than 3 years).

short-lived isotope - A radionuclide that decays so rapidly that a given quantity is transformed almost completely into decay products within a short period (half-life is 2 days or less).

lower limit of detection (LLD) - The smallest concentration/amount of analyte that can be reliably detected in a sample at a $95 \%$ confidence level.

maximally exposed individual - A hypothetical individual who remains in an uncontrolled area and would, when all potential routes of exposure from a facility's operations are considered, receive the greatest possible dose equivalent.

mercury - A silver-white, liquid metal solidifying at $-38.9^{\circ} \mathrm{C}$ to form a tin-white, ductile, malleable mass. It is widely distributed in the environment and biologically is a nonessential or nonbeneficial element. Human poisoning from this highly toxic element has been clinically recognized.

microbes - Microscopic organisms.

migration - The transfer or movement of a material through the air, soil, or groundwater.

millirem (rem) - The dose equivalent that is one one-thousandth of a rem.

milliroentgen $(\mathbf{m R})-\mathrm{A}$ measure of $\mathrm{X}$-ray or gamma radiation. The unit is one-thousandth of a roentgen.

minimum detectable activity - The smallest activity of a radionuclide that can be distinguished in a sample by a given measurement system at a preselected counting time and at a given confidence level.

monitoring - Process whereby the quantity and quality of factors that can affect the environment and/or human health are measured periodically in order to regulate and control potential impacts.

natural radiation - Radiation arising from cosmic and other naturally occurring radionuclide sources (such as radon) present in the environment.

nuclide - An atom specified by its atomic weight, atomic number, and energy state. A radionuclide is a radioactive nuclide. 
outfall - The point of conveyance (e.g., drain or pipe) of wastewater or other effluents into a ditch, pond, or river.

parts per million (ppm) - A unit measure of concentration equivalent to the weight/volume ratio expressed as milligrams per liter.

parts per billion (ppb) - A unit measure of concentration equivalent to the weight/volume ratio expressed as grams per liter or nanograms per milliter.

person-rem - Collective dose to a population group. For example, a dose of 1 rem to 10 individuals results in a collective dose of 10 person-rem.

pH - A measure of the hydrogen ion concentration in an aqueous solution. Acidic solutions have a $\mathrm{pH}$ from 0 through 6 , basic solutions have a $\mathrm{pH}>7$, and neutral solutions have a $\mathrm{pH}=7$.

piezometer - An instrument used to measure the potentiometric surface of the groundwater. Also, a well designed for this purpose.

precision - The closeness of approach of a value of similar or replicate results to a common value in a series of measurements.

priority pollutants - A group of approximately 130 chemicals (about 110 are organics) that appear on a U.S. Environmental Protection Agency list because they are toxic and relatively common in industrial discharges.

process water - Water used within a system process.

process sewer - Pipe or drain, generally located underground, used to carry off process water and/or waste matter.

purge - To remove water prior to sampling, generally by pumping or bailing.

quality assurance (QA) - Any action in environmental monitoring to ensure the reliability of monitoring and measurement data.

quality control (QC) - The routine application of procedures within environmental monitoring to obtain the required standards of performance in monitoring and measurement processes.

quality factor - The factor by which the absorbed dose (rad) is multiplied to obtain a quantity that expresses, on a common scale for all ionizing radiation, the biological damage to exposed persons. It is used because some types of radiation, such as alpha particles, are more biologically damaging than others.

rad - The unit of absorbed dose deposited in a volume of material.

radioactivity - The spontaneous emission of radiation, generally alpha or beta particles or gamma rays, from the nucleus of an unstable isotope. 
radioisotopes - Radioactive isotopes.

radionuclide - An unstable nuclide capable of spontaneous transformation into other nuclides by changing its nuclear configuration or energy level. This transformation is accompanied by the emission of photons or particles.

reclamation - Recovery of wasteland, desert, etc., by ditching, filling, draining, or planting.

reference material - A material or substance with one or more properties that is sufficiently well established and used to calibrate an apparatus, to assess a measurement method, or to assign values to materials.

regression analysis - A collection of statistical techniques that serve as a basis for drawing inferences about relationships among quantities in a scientific system.

release - Any discharge to the environment. Environment is broadly defined as any water, land, or ambient air.

rem - The unit of dose equivalent (absorbed dose in rads $\times$ the radiation quality factor). Dose equivalent is frequently reported in units of millirem (mrem) which is one-thousandth of a rem.

remediation - The correction of a problem. See Environmental Restoration.

RFI Program - RCRA Facility Investigation Program; EPA-regulated investigation of a solid waste management unit with regard to its potential impact on the environment.

RFI/RI Program - RCRA Facility Investigation/Remedial Investigation Program; On the ORR, the expansion of the RFI Program to include CERCLA and hazardous substance regulations.

roentgen - $\mathrm{A}$ unit of exposure from $\mathrm{X}$ or gamma rays. One roentgen equals $2.58 \times 10^{-4}$ coulombs per kilogram of air.

screened interval - In well construction, the section of a formation that contains the screen, or perforated pipe, that allows water to enter the well.

seepage basin - An excavation that receives wastewater. Insoluble materials settle out on the floor of the basin, and soluble materials seep with the water through the soil column where they are removed partially by ion exchange with the soil. Construction may include dikes to prevent overflow or surface runoff.

self-absorption - Absorption of radiation by the sample itself, preventing detection by the counting instrument.

sensitivity - The capability of methodology or instruments to discriminate between samples with differing concentrations or containing varying amounts of analyte. 
settleable solids - Material settling out of suspension within a defined period.

settling basin - A temporary holding basin (excavation) that receives wastewater, which is subsequently discharged.

sievert (Sv) - The SI (International System of Units) unit of dose equivalent, $1 \mathrm{~Sv}=100 \mathrm{rem}$.

slurry - A suspension of solid particles (sludge) in water.

specific conductance - The ability of water to conduct electricity; this ability varies in proportion to the amount of ionized minerals in the water.

spike - The addition of a known amount of reference material containing the analyte of interest to a blank sample.

spiked sample - A sample to which a known amount of some substance has been added.

split sample - A sample that has been portioned into two or more containers from a single sample container or sample-mixing container.

stable - Not radioactive or not easily decomposed or otherwise modified chemically.

stack - A vertical pipe or flue designed to exhaust airborne gases and suspended particulate matter.

standard deviation - An indication of the dispersion of a set of results around their average.

standard reference material (SRM) - A reference material distributed and certified by the National Institute of Standards and Technology.

storm water runoff - Surface streams that appear after precipitation.

strata - Beds, layers, or zones of rocks.

substrate - The substance, base, surface, or medium in which an organism lives and grows.

surface water - All water on the surface of the earth, as distinguished from groundwater.

temperature - The thermal state of a body considered with its ability to communicate heat to other bodies.

terrestrial radiation - Ionizing radiation emitted from radioactive materials, primarily potassium-40, thorium, and uranium, in the earth's soils. Terrestrial radiation contributes to natural background radiation. 
total activity - The total quantity of radioactive decay particles that are emitted from a sample.

total dissolved solids - Dissolved solids and total dissolved solids are terms generally associated with freshwater systems and consist of inorganic salts, small amounts of organic matter and dissolved materials.

total organic halogens - A measure of the total concentration of organic compounds that have one or more halogen atoms.

total solids - The sum of total dissolved solids and suspended solids.

total suspended particulates - Refers to the concentration of particulates in suspension in the air irrespective of the nature, source, or size of the particulates.

transect - A line across an area being studied. The line is composed of points where specific measurements or samples are taken.

transmissive zone - A zone of sediments sufficiently porous and permeable to allow the flow of groundwater through the zone.

transuranic waste - Solid radioactive waste containing primarily alpha-emitting elements heavier than uranium.

transuranium elements - Elements with higher atomic weights than uranium; all 13 known transuranic elements are radioactive and are produced artificially.

trip blank - A sample container of deionized water that is transported to the well sample location, treated as a well sample, and sent to the laboratory for analysis; trip blanks are used to check for contamination resulting from transport, shipping, and site conditions.

tritium $\left({ }^{3} \mathbf{H}\right)$ - The hydrogen isotope with one proton and two neutrons in the nucleus. It emits a low-energy beta particle $(0.0186 \mathrm{MeV}$ maximum) and has a half-life of 12.5 years.

t-test - Statistical method used to determine if the means of groups of observations are equal.

turbidity - A measure of the concentration of sediment or suspended particles in solution.

unconsolidated zone - Soil zone located above the water table.

uncontrolled area - Any area to which access is not controlled for the purpose of protecting individuals from exposure to radiation and radioactive materials.

upgradient - In the direction of increasing hydrostatic head.

volatile organic compounds - Used in many industrial processes, the levels of these carcinogenic compounds must be kept to a minimum. They are measured by volatile 
organic analyses content. Common examples include trichloroethane, tetrachloroethylene, and trichloroethylene.

watershed - The region draining into a river, river system, or body of water.

wetlands - Lowland areas, such as a marshes or swamps, inundated or saturated by surface water or groundwater sufficiently to support hydrophytic vegetation typically adapted for life in saturated soils.

wind rose - A diagram in which statistical information concerning direction and speed of the wind at a location is summarized. 
References 
$\bullet$

-

- 


\section{References}

ANS, Glossary of Terms in Nuclear Science and Technology, American Nuclear Society, 1986.

Baker, D. A., and J. K. Soldat, Methods for Estimating Doses to Organisms from Radioactive Materials Released into the Aquatic Environment, PNL-8150, Pacific Northwest Laboratories, Richland, Wash., 1993.

Beres, D. A., The Clean Air Act Assessment Package-1988 (CAP-88): A Dose and Risk Assessment Methodology for Radionuclide Emissions to Air, Vols. 1-3, SC\&A, Inc., McLean, Va., 1990.

CDM Federal Programs, Inc., Feasibility Study of Best Management Practices for Non-Point Source Pollution Control at the Oak Ridge Y-12 Plant, Y/SUB/93B-99920C/1, 1993.

CDM Federal Programs, Inc., Union Valley Interim Study Remedial Site Evaluation, Y/ER-206/R1, 1995.

Chan, P. K., G. P. O'Hara, and A. W. Hayes, "Principles and Methods for Acute and Subchronic Toxicity," Principles and Methods of Toxicology, Raven Press, 1992.

City of Oak Ridge, City of Oak Ridge State Biosolids Management Report, Y/TS-1180/R1, Oak Ridge, Tenn., 1994.

Farnsworth, R. K., E. S. Thompson, and E. L. Peck, Evaporation Atlas for the Contiguous 48 United States, NOAA Technical Report NWS 33, National Weather Service, Office of Hydrology, Washington, D.C., 1982.

Geraghty \& Miller, Inc., A Study of Ground-Water Flow from the Chestnut Security Pits using a Fluorescent Dye Tracer, Y/SUB/90-00206C/6, prepared for Martin Marietta Energy Systems, Inc., 1990.

Hatcher, R. D., et al., Field Guide and Perspective on the Geology and Hydrology of the Oak Ridge Reservation, Oak Ridge National Laboratory/Univ. of Tennessee, Oak Ridge, Tenn., 1989.

International Commission on Radiological Protection (ICRP), Task Group on Reference Man, Publication 23, Pergamon Press, Oxford, 1975.

International Commission on Radiological Protection (ICRP), Recommendations of the International Commission on Radiological Protection, Publication 26, Pergamon Press, Oxford, 1977.

International Commission on Radiological Protection (ICRP), Recommendations of the International Commission on Radiological Protection, Publication 30, Pergamon Press, Oxford, 1978.

Kumazawa, S., et al., Occupational Exposure to lonizing Radiation in the United States: A Comprehensive Review for the Year 1980 and a Summary of Trends for the Years 1960-1985, EPA/520/1-8-005, U.S. Government Printing Office, Washington, D.C., 1984. 
Lockheed Martin Energy Systems, Inc., Stormwater Pollution Prevention Plan for the Oak Ridge Y-12 Plant, Y/TS-1180/R1, 1995.

Lockheed Martin Energy Systems, Inc., Tennessee-Part I, 1995 Groundwater Quality Data and Calculated Rate of Contaminant Migration, Y/TS-1435, 1996 a.

Lockheed Martin Energy Systems, Inc., Calendar Year 1995 Groundwater Quality Report for the Upper East Fork Poplar Creek Hydrogeologic Regime, Part 1, 1995 Groundwater Quality Data and Calculated Rate of Contaminant Migration, Y/TS-1436, Y-12 Plant, Oak Ridge, Tenn., 1996b.

Lockheed Martin Energy Systems, Inc., Calendar Year 1995 Groundwater Quality Report for the Bear Creek Hydrogeologic Regime, Part 1, 1995 Groundwater Quality Data and Calculated Rate of Contaminant Migration, Y/TS-1437, Y-12 Plant, Oak Ridge, Tenn., 1996b.

Martin Marietta Energy Systems, Inc., A Review of the Y-12 Plant Discharge of Enriched Uranium to the Sanitary Sewer (DEUSS), Y/TS-776, 1991.

Martin Marietta Energy Systems, Inc., Radiological Monitoring Plan for the Y-12 Plant Liquid Effluent Discharges to the Environment, Y/SUB/92-TK532C/1, 1992a.

Martin Marietta Energy Systems, Inc., Requirements for Quality Control of Analytical Data for the Environmental Restoration Program, ES/ER/TM-16, Oak Ridge, Tenn., $1992 \mathrm{~b}$.

Martin Marietta Energy Systems, Inc., Identification and Characterization of Wetlands in the Bear Creek Watershed, Y/TS-1016, 1993a.

Martin Marietta Energy Systems, Inc., Oak Ridge Reservation Annual Site Environmental Report for 1992, ES/ESH-31, Oak Ridge, Tenn., 1993b.

Martin Marietta Energy Systems, Inc., Evaluation of the Ambient Air Monitoring Program at the Oak Ridge Y-12 Plant, Y/TS-1157/R1, 1994a.

Martin Marietta Energy Systems, Inc., Oak Ridge Reservation Annual Site Environmental Report for 1993, ES/ESH-47, Oak Ridge, Tenn., $1994 \mathrm{~b}$.

Martin Marietta Energy Systems, Inc., Environmental Monitoring on the Oak Ridge Reservation: 1994 Results, ES/ESH-59, Oak Ridge, Tenn., 1995 a.

Martin Marietta Energy Systems, Inc., Oak Ridge Reservation Waste Management Plan, ES/WM-30, Oak Ridge, Tenn., 1995 b.

Moore, G. K., Concepts of Groundwater Occurrence and Flow Near Oak Ridge National Laboratory, Tennessee, ORNL/TM-11368, Oak Ridge, Tenn., 1988.

Myrick, T. E., et al., State Background Radiation Levels: Results of Measurements Taken During 1975-1979, ORNL/TM-7343, Oak Ridge, Tenn., 1981. 
NCRP, Ionizing Radiation Exposure of the Population of the United States, NCRP Report No. 93, National Council on Radiation Protection and Measurements, Washington, D.C., 1987.

NCRP, 1989 Exposure of the U.S. Population from Diagnostic Medical Radiation, NCRP Report No. 100, National Council on Radiation Protection and Measurements, Bethesda, Md., 1989.

Nuclear Regulatory Commission (NRC), National Register of Historic Places, Washington, D.C., 1969.

Nuclear Regulatory Commission (NRC), Calculation of Annual Doses to Man from Routine Releases of Reactor Effluents for the Purpose of Evaluating Compliance with 10 CFR 50, Regulatory Guide 1.109, App. I, Rev. 1, NRC Office of Standards Development, Washington, D.C., 1977.

Science Applications International Corporation (SAIC), Final Report of the Second Dye-Tracer Test at the Chestnut Ridge Security Pits, (Y/SUB/93-99928C/Y10/1), Y-12 Plant, Oak Ridge, Tenn., prepared for Martin Marietta Energy Systems, Inc., 1995.

Science Applications International Corporation (SAIC), Remedial Site Evaluation Report for K-901-A Holding Pond at the Oak Ridge K-25 Site, Oak Ridge, Tennessee, September 1995, DOE/OR/01-1386\&D1; K/ER-172, 1995.

Science Applications International Corporation (SAIC), Oak Ridge K-25 Site Groundwater Remedial Site Evaluation Report, K/ER-305, 1995.

Science Applications International Corporation (SAIC), Remedial Site Evaluation Report for K-901-A Holding Pond at the Oak Ridge K-25 Site, Oak Ridge, Tennessee, February 1996, DOE/OR/01-1386\&D2; K/ER-172, 1996a.

Shevenell, L. A., R. B. Dreier, and W. K. Jago, Summaryof Fiscal Years 1991 and 1992. Construction, Hydrologic, and Geologic Data Obtained from the Maynardville Limestone Exit Pathway Monitoring Program, Y/TS-814, Martin Marietta Energy Systems, Inc., Oak Ridge, Tenn., 1992.

Sutton, G. E., Jr., and S. M. Field, Distribution of Anthropogenic Fill Material Within the Y-12 Plant Area, Oak Ridge, Tennessee, Y/TS-1387, 1995.

Tennessee Valley Authority (TVA), Upper Bear Creek Experimental Project: A Continuous Daily-Streamflow Model, Research Paper No. 8, Division of Water Control Planning, Knoxville, Tenn., 1972.

Tennessee Valley Authority (TVA), Instream Contaminant Study, Task 4: Fish Sampling and Analysis. Report to U.S. Department of Energy, Oak Ridge Operations Office, Tennessee Valley Authority, Office of Natural Resources and Economic Development, Knoxville, Tenn., 1985.

Tsakeres, F. S., Radiological Assessment of Residences in the Oak Ridge Area, ORNL/TM-7392/V1, Oak Ridge National Laboratory, Oak Ridge, Tenn., 1980.

Tucci, P., Hydrology of Melton Valley at Oak Ridge National Laboratory, Tennessee, U.S. Geological Survey Waters Resources Investigations Report 92-4131, Nashville, Tenn., 1992. 
U.S. Department of Energy (DOE), External Dose-Rate Conversion Factors for Calculation of Dose to the Public, DOE/EH-0070, 1988a.

U.S. Department of Energy (DOE), Internal Dose Conversion Factors for Calculation of Dose to the Public, DOE/EH-0071, 1988b.

U.S. Department of Energy (DOE), Radioactive Decay Data Tables: A Handbook of Decay Data for Application to Radioactive Dosimetry and Radiological Assessments, DOE/TIC-11026, 1989.

U.S. Department of Energy (DOE), Environmental Regulatory Guide for Radiological Effluent Monitoring and Environmental Surveillance, DOE/EH-0173T, Washington, D.C., 1991.

U.S. Department of Energy, Oak Ridge Reservation Site Management Plan for the Environmental Restoration Program, DOE/OR-1001/R3, 1993.

U:S. Department of Energy (DOE), Third Annual Environmental Restoration Monitoring and Assessment Report for FY 1994 of the Oak Ridge National Laboratory, Oak Ridge, Tennessee, DOE/OR/01-1290\&D1, 1994.

U.S. Department of Energy (DOE), Environmental Monitoring Plan for the Oak Ridge Reservation, DOE/OR-1066/R1, 1995.

U.S. Department of Energy, Oak Ridge Reservation Site Management Plan for the Environmental Restoration Program, DOE/OR-1001/R4, 1995a.

U.S. Environmental Protection Agency (EPA), Limiting Values of Radionuclide Intake and Air Concentration and Dose Conversion Factors for Inhalation, Submersion, and Ingestion, Federal Guidance Report No. 11, EPA-520/1-88-020, 1988.

U.S. Environmental Protection Agency (EPA), Risk Assessments Methodology, Environmental Impact Statement, NESHAPs for Radionuclides, Background Information, Vol. 1, EPA/520/1-89-005, 1989.

U.S. Environmental Protection Agency (EPA), Environmental Radiation Data, Report No. 59 (JulySeptember 1989), EPA/520/5-90-003, 1990.

U.S. Environmental Protection Agency (EPA), Integrated Risk Information System (IRIS), Washington, D.C., 1991.

U.S. Environmental Protection Agency (EPA), Environmental Radiation Data Report 70, EPA-402-R-93-089, 1993a.

U.S. Environmental Protection Agency (EPA), External Exposure to Radionuclides in Air, Water, and Soil, Federal Guidance Report No. 12, EPA 402-R-93-081, $1993 \mathrm{~b}$.

U.S. Environmental Protection Agency (EPA), Exposure Factors Handbook-Draft, EPA/600/P95/002A, Office of Research and Development, U.S. EPA, June 1995. 
U.S. Environmental Protection Agency (EPA), 1996. J. Moyer, personal communication, Exposure Assessment Group, Office of Health and Environmental Assessment, U.S. EPA.

U.S. Fish and Wildlife Service, Preliminary Estimates of Waterfowl Harvest and Hunter Activity in the United States, 1995.

Personal communication with Ed Warr, Tennessee Wildlife Resources Agency, May 1996.

Webster, D. A., and M. W. Bradley, Hydrology of the Melton Valley Radioactive Waste Burial Grounds at Oak Ridge National Laboratory, U.S. Geological Survey Open File Report 87-686, Knoxville, Tenn., 1988.

Westinghouse Savannah River Company, Savannah River Site Environmental Report for 1993, Summary Pamphlet, WSRC-TR-076, Aiken, S.C., 1994. 
INTERNAL DISTRIBUTION

1. E. D. Aebischer

2. W. A. Alexander

3. T. B. Allen

4. L. J. Allison

5. G. E. Anderson

6. A. D. Arms

7. T. L. Ashwood

8. L. V. Asplund

9. J. B. Atwater

10. B. D. Barkenbus

11. J. H. Barker

12. F. P. Baxter

13. B. A. Berven

14. C. R. Bieber

15. T. J. Blasing

16. D. M. Borders

17. H. L. Boston

18. C. W. Broughton

19. A. W. Buttram

20. D. M. Buxbaum

21. R. B. Clapp

22. L. B. Cobb

23. L. H. Collins

24. D. E. Conrad

25. K. W. Cook

26. R. B. Cook

27. D. G. Cope

28. J. Culver

29. L. L. Cunningham

30. N. H. Cutshall

31. C. E. Daugherty

32. M. P. DeLozier

33. R. J. Devol

34. F. D. Dickens

35. J. G. Dorsey

36. K. M. Downer

37. R. C. Durfee

38. T. O. Early

39. J. M. Eaton

40. S. B. Edington

41. R. A. Evans

42. D. Everitt

43. H. L. Fellers

44. R. L. Fellows

45. C. J. Ford
46. J. M. Forstrom

47. M. W. Francis

48. D. W. Frazier

49. L. Frazier

50. C. E. Frye

51. C. T. Garten

52. R. W. Glass

53. H. A. Glovier, Jr.

54. C. D. Goins, Jr.

55. F. P. Gustavson

56. C. S. Haase

57. L. V. Hamilton

58. K. G. Hanzelka

59. J. G. Harris

60. R. E. Hawthorne

61. C. Hayes

62. J. N. Herndon

63. D. D. Herr

64. S. G. Hildebrand

65. C. C. Hill

66. R. L. Hinzman

67. D. K. Hoag

68. C. M. Horak

69. D. D. Huff

70. V. C. Huffstetler

71. R. A. Hummel

72. J. B. Hunt

73. L. D. Hyde

74. A. S. Icenhour

75. W. K. Jago

76. J. A. Johnston, Jr.

77. D. T. Kendall

78. S. B. Kerr

79. R. H. Ketelle

80. R. M. Keyser

81. B. L. Kimmel

82. H. L. King

83. R. H. Kingrea

84. C. R. Kirkpatrick

85. W. S. Koncinski

86. O. C. Kopp

87. E. H. Krieg, Jr.

88. L. A. Kszos

89. A. J. Kuhaida

90. J. M. Labauve 


\author{
91. C. M. Laborde \\ 92. S. Lankford \\ 93. R. R. Lee \\ 94. S. Y. Lee \\ 95. D. A. Levine \\ 96. J. M. Loar \\ 97. D. Y. Lu \\ 98. J. R. Lyons \\ 99. D. M. Mabry \\ 100. F. Maienschein \\ 101. R. C. Mason \\ 102. L. L. McCauley \\ 103. D. W. McDonald \\ 104. L. W. McMahon \\ 105. A. R. Medley \\ 106. A. R. Merrill \\ 107. L. J. Mezga \\ 108. D. Milan \\ 109. J. L. Miranda \\ 110. S. D. Morris \\ 111. T. W. Morris \\ 112. R. W. Morrow \\ 113. C. E. Mulkey \\ 114. J. B. Murphy \\ 115. M. E. Musolf \\ 116. F. R. O'Donnell \\ 117. J. P. O'Hearn \\ 118. R. W. Oliver \\ 119. P. T. Owen \\ 120. P. D. Parr \\ 121. M. J. Peterson \\ 122. T. L. Pierce \\ 123. L. G. Porter, Jr. \\ 124. J. E. Powell \\ 125. R. E. Pudelek \\ 126. L. Radcliffe \\ 127. RAPIC \\ 128. L. K. Rawlings \\ 129. J. S. Rayside \\ 130. R. M. Reed \\ 131. R. Richmond \\ 132. C. T. Rightmire \\ 133. J. G. Rogers \\ 134. P. S. Rohwer \\ 135. R. K. Roosa \\ 136. R. T. Roseberry \\ 137. H. H. Ross \\ 138. R. M. Rush \\ 139. L. B. Ryon \\ 140. E. M. Schilling
}

141. J. D. Shelton

142. L. G. Shipe

143. P. O. Simmons

144. C. S. Sims

145. E. D. Emith

146. W. E. Smith

147. M. L. Socolof

148. M. L. Sollenberger

149. G. R. Southworth

150. L. M. Sparks

151. M. I. Sparks

152. C. L. Stam

153. M. M. Stevens

154. A. J. Stewart

155. L. E. Stokes

156. J. E. Stone

157. J. D. Story

158. F. J. Sweeney

159. M. F. Tardiff

160. W. A. Thomas

161. P. B. Thompson

162. J. R. Trabalka

163. D. W. Turner

164. R. R. Turner

165. S. Turner

166. S. W. Vest

167. B. A. Walton

168. P. R. Wasilko

169. J. S. Wassom

170. J. L. Webb

171. R. W. Weigel

172. L. Welch

173. D. C. West

174. D. A. White

175. R. K. White

176. H. D. Whitehead, Jr.

177. M. C. Wiest, Jr.

178. S. W. Wiley

179. C. K. Williams, III

180. J. K. Williams

181. S. R. Wilson

182. S. L. Winters

183. A. K. Zava

184. Central Research Library

185. DOE K-25 Site Office

186. DOE Y-12 Site Office

187. ESD Library

188-190. ORNL Laboratory Records

191. ORNL Laboratory Records-RC 192. ORNL Patent Section 
193. ORNL Y-12 Technical Library

194. PGDP Library

195. PORTS Library

196. K-25 CEP Document Center

197. K-25 Site Library

198-204. Y-12 Site Audit Response Cen. 


\section{EXTERNAL DISTRIBUTION}

205. Office of Assistant Manager for Energy Research and Development, U.S. Department of Energy Oak Ridge Operations, P.O. Box 2001, Oak Ridge, TN 37831-8600.

206-207. Office of Scientific and Technical Information, P.O. Box 62, Oak Ridge, TN 37831.

208-258. This report is distributed widely by the Department of Energy's Oak Ridge Operations Office to local, state, and federal government agencies, the Congress, the public, and the news media. 